

\section{Taxation and the Financial Crisis}

This is an open access version of the publication distributed under the terms of the Creative Commons Attribution-NonCommercialNoDerivs licence (http://creativecommons.org/licenses/by-nc-nd/3.0/), which permits non-commercial reproduction and distribution of the work, in any medium, provided the original work is not altered or transformed in any way, and that the work is properly cited. For commercial re-use, please contact academic.permissions@oup.com 
This page intentionally left blank

This is an open access version of the publication distributed under the terms of the Creative Commons Attribution-NonCommercialNoDerivs licence (http://creativecommons.org/licenses/by-nc-nd/3.0/), which permits non-commercial reproduction and distribution of the work, in any medium, provided the original work is not altered or transformed in any way, and that the work is properly cited. For commercial re-use, please contact academic.permissions@oup.com 


\section{Taxation and the Financial Crisis}

Edited by

Julian S. Alworth and Giampaolo Arachi

\section{OXFORD}

UNIVERSITY PRESS

This is an open access version of the publication distributed under the terms of the Creative Commons Attribution-NonCommercialNoDerivs licence (http://creativecommons.org/licenses/by-nc-nd/3.0/), which permits non-commercial reproduction and distribution of the work, in any medium, provided the original work is not altered or transformed in any way, and that the work is properly cited. For commercial re-use, please contact academic.permissions@oup.com 


\section{OXFORD}

\section{UNIVERSITY PRESS}

Great Clarendon Street, Oxford ox2 6DP

Oxford University Press is a department of the University of Oxford.

It furthers the University's objective of excellence in research, scholarship, and education by publishing worldwide in

Oxford New York

Auckland Cape Town Dar es Salaam Hong Kong Karachi

Kuala Lumpur Madrid Melbourne Mexico City Nairobi

New Delhi Shanghai Taipei Toronto

With offices in

Argentina Austria Brazil Chile Czech Republic France Greece

Guatemala Hungary Italy Japan Poland Portugal Singapore

South Korea Switzerland Thailand Turkey Ukraine Vietnam

Oxford is a registered trade mark of Oxford University Press

in the UK and in certain other countries

Published in the United States

by Oxford University Press Inc., New York

(C) Oxford University Press 2012

Chapter 3 (C) European Union 2012

Chapter 5 (C) European Union 2012

Chapter 9 (C) Bank for International Settlements 2009

The moral rights of the authors have been asserted

Database right Oxford University Press (maker)

First published 2012

All rights reserved. No part of this publication may be reproduced, stored in a retrieval system, or transmitted, in any form or by any means, without the prior permission in writing of Oxford University Press, or as expressly permitted by law, or under terms agreed with the appropriate reprographics rights organization. Enquiries concerning reproduction outside the scope of the above should be sent to the Rights Department, Oxford University Press, at the address above

You must not circulate this book in any other binding or cover and you must impose the same condition on any acquirer

British Library Cataloguing in Publication Data

Data available

Library of Congress Cataloging in Publication Data

Library of Congress Control Number: 2012930325

Typeset by SPI Publisher Services, Pondicherry, India

Printed in Great Britain

on acid-free paper by

MPG Books Group, Bodmin and King's Lynn

ISBN 978-0-19-969816-5

10987665443221

This is an open access version of the publication distributed under the terms of the Creative Commons Attribution-NonCommercialNoDerivs licence (http://creativecommons.org/licenses/by-nc-nd/3.0/), which permits non-commercial reproduction and distribution of the work, in any medium, provided the original work is not altered or transformed in any way, and that the work is properly cited. For commercial re-use, please contact academic.permissions@oup.com 


\section{Acknowledgements}

This book originated in a conference held in Milan in April 2009 at Università Bocconi. We wish to thank Econpubblica-Università Bocconi and the Vice Rector for Research, Vincenzo Perrone, for financial support.

We received generous backing from Roberto Artoni, the EconpubblicaUniverisità Bocconi director, Alessandra Casarico, and Econpubblica research fellows. We would also like to thank Cecilia Caliandro and Federica Garlaschelli for editorial assistance in the preparation of the manuscript and index. 
This page intentionally left blank

This is an open access version of the publication distributed under the terms of the Creative Commons Attribution-NonCommercialNoDerivs licence (http://creativecommons.org/licenses/by-nc-nd/3.0/), which permits non-commercial reproduction and distribution of the work, in any medium, provided the original work is not altered or transformed in any way, and that the work is properly cited. For commercial re-use, please contact academic.permissions@oup.com 


\section{Contents}

List of Figures $\quad$ ix

List of Tables $\quad$ xi

List of Boxes $\quad$ xii

List of Contributors xiii

Abbreviations $\quad$ xviii

1. Introduction $\quad 1$

Julian S. Alworth and Giampaolo Arachi

2. Culprit, Accomplice, or Bystander? Tax Policy and the Shaping of the Crisis

Michael Keen, Alexander Klemm, and Victoria Perry

3. The Role of Housing Tax Provisions

Thomas Hemmelgarn, Gaetan Nicodeme, and Ernesto Zangari

4. The Role of Taxes in Compensation Schemes and

Structured Finance

Vieri Ceriani, Stefano Manestra, Giacomo Ricotti, and

Alessandra Sanelli

5. Can Tax Policy Help to Prevent Financial Crisis?

Thomas Hemmelgarn and Gaetan Nicodeme

6. Taxation and the Financial Sector

Douglas A. Shackelford, Daniel N. Shaviro, and Joel Slemrod

7. Income Tax Reform Implications of the Financial Crisis

Daniel N. Shaviro

8. Moving beyond the Crisis: Tax Policies for the Soundness

of Financial Markets

Geoff Lloyd

9. Government Debt Management at Low Interest Rates

Robert N. McCauley and Kazuo Ueda 
10. The Effects of Fiscal Consolidation on Short-Term Growth: A Review and Implications for the UK

Katarzyna Anna Bilicka, Michael P. Devereux, and Clemens Fuest

11. Regulation and Taxation: Economics and Politics

Donato Masciandaro and Francesco Passarelli

References

Author Index

291

Subject Index

viii

This is an open access version of the publication distributed under the terms of the Creative Commons Attribution-NonCommercialNoDerivs licence (http://creativecommons.org/licenses/by-nc-nd/3.0/), which permits non-commercial reproduction and distribution of the work, in any medium, provided the original work is not altered or transformed in any way, and that the work is properly cited. For commercial re-use, please contact academic.permissions@oup.com 


\section{List of Figures}

2.1. Effective average tax rates on owner-occupation (\%) 46

2.2. Debt ratios and the tax treatment of owner-occupation 48

3.1. Nasdaq Composite Index, 1993-2004 63

3.2. US Federal Reserve discount rate, 2000-9 64

3.3. US Capital and Financial Account 65

3.4. US Capital and Financial Account, components 65

3.5. Case-Shiller house price index 66

3.6. US prime and subprime mortgages $\quad 69$

$\begin{array}{lr}\text { 3.7. Adjustable rate mortgages } & 69\end{array}$

3.8. US interbank loans 72

3.9. Price-to-rent ratios 73

3.10. Effective average taxation of owner-occupation, Europe and the USA (\%) 78

$\begin{array}{ll}\text { 4.1. The securitization process } & 104\end{array}$

4.2. Collateralized debt obligations 105

4.3. Synthetic CDOs 105

4.4. Cash flows of a synthetic CDO 106

5.1. Share in tax revenue of EU Member States (addition-method FAT) 129

5.2. Share in tax revenue of selected EU Member States (broad-base FTT) 139

8A. Example of double-deduction management 198

8.1. Representative private equity fund structure 203

9A. Stylized monetary and debt management policy 216

9.1. BoE and Fed buyback announcements: ten-year government bond $\begin{array}{ll}\text { yields (\%) } & 218\end{array}$

9.2. Gross government debt and central bank assets (domestic currencies, as a percentage of GDP in 2008)

9.3. Three-month treasury bill and ten-year bond yields (\%) 221

9.4. Holdings/issuance of government bonds and notes 222

9.5. Bank credit and money growth (\%) 222

9.6. JGB issuance and BoJ purchases and holdings of JGBs 224

This is an open access version of the publication distributed under the terms of the Creative Commons Attribution-NonCommercialNoDerivs licence (http://creativecommons.org/licenses/by-nc-nd/3.0/), which permits non-commercial reproduction and distribution of the work, in any medium, provided the original work is not altered or transformed in any way, and that the work is properly cited. For commercial re-use, please contact academic.permissions@oup.com 
9B. Residual maturity of US Treasury debt and Federal Reserve holdings of Treasuries

9.7. Rating, duration, and average term to maturity of OECD sovereign domestic debt, 2007

10.1. UK deficit to GDP level, 2006-16

10.2. UK debt to GDP level, 2006-15

10.3. Debt-GDP ratio, country comparisons, 2011

10.4. Deficit-GDP ratio, country comparisons, 2011

10.5. Number of fiscal consolidations by size (CAPB measure) since 1994

10.6. Deficit levels versus CDS spreads, 2011

10.7. Debt levels versus CDS spreads, 2011

10.8. Monthly interbank three-month LIBOR, \% p.a., 2000-11, UK 


\section{List of Tables}

1.1. Financial levies and taxes in the European Union, 2011

2.1. Required post-CIT rates of return, 1990 and 2008

2.2. Marginal effective tax rates, selected countries, 2005 (\%) 36

2.3. Real cumulative house price inflation between 1998 and end 2007 (\%) 47

3.1. The taxation of owner-occupied housing in Europe and the USA, $2009 \quad 76$

5.1. Share of the financial sector in total value added 119

5.2. Return on equity in BIS reporting countries 120

5.3. Relative return of financial stocks $\quad 120$

5.4. Revenue estimates for the various forms of FAT (based on 2008 GDPs), tax rate $5 \%$

5.5. Estimated revenue from taxing shares, bonds, and derivatives (broad-base FTT) for countries where data were available, tax rate 0.1\%, 2006 (€bn)

5.6. Estimated revenue from taxing shares and bonds (narrow-base FTT), EU27 and Iceland, tax rate 0.1\%, 2008 (€mn)

5.7. Revenue from stamp duties on stocks and shares and other liable securities in the UK

9.1. Overview of three central bank policies to buy government bonds, 2009

10.1. Episodes of fiscal consolidation using method defined in Alesina and Ardagna (2010)

10.2. Episodes of fiscal consolidation using method defined in Guichard et al. (2007)

10.3. Summary of the empirical literature findings on the effects of fiscal consolidation on growth

10.4. Summary of the empirical literature findings on successful fiscal consolidations

10.5. Overview of OBR central fiscal forecast for UK, 2009-16 249

10.6. Total consolidation plans, UK, 2010-16 251

10.7. Contribution of primary expenditure and total revenue to fiscal consolidation, Alesina and Ardagna (2010) 251

10.8. Average debt to GDP levels during fiscal consolidation episodes 252

10.9. European Sovereign Credit Ratings as of 11 January 2011

This is an open access version of the publication distributed under the terms of the Creative Commons Attribution-NonCommercialNoDerivs licence (http://creativecommons.org/licenses/by-nc-nd/3.0/), which permits non-commercial reproduction and distribution of the work, in any medium, provided the original work is not altered or transformed in any way, and that the work is properly cited. For commercial re-use, please contact academic.permissions@oup.com 


\section{List of Boxes}

2.1. Taxation and the cost of capital 32

2.2. Taxation and asset prices $\quad 58$

3.1. A model of the housing market $\quad 74$

3.2. The methodology to compute the effective average tax rate 78

4.1. The tax treatment of employee stock options in the USA 95

8.1. Systems for taxing dividends at corporate and personal levels 196

8.2. Example of a common 'double-deduction' scheme using a hybrid entity 198

8.3. Tax arbitrage feedback theory in summary 200

9.1. Bond buying and debt management: a quantitative view 216

9.2. Operation Twist revisited 226

9.3. Japanese fifteen-year floating rate notes 227

xii

This is an open access version of the publication distributed under the terms of the Creative Commons Attribution-NonCommercialNoDerivs licence (http://creativecommons.org/licenses/by-nc-nd/3.0/), which permits non-commercial reproduction and distribution of the work, in any medium, provided the original work is not altered or transformed in any way, and that the work is properly cited. For commercial re-use, please contact academic.permissions@oup.com 


\section{List of Contributors}

Julian S. Alworth is Senior Partner at European Investment Consulting and research associate at Econpubblica-Università Bocconi. He holds an M.Sc. from the University of Maryland and a D.Phil. from Oxford University. He has taught at the Universities of Munich and Basel as well as at Bocconi University in Milan and the Saïd Business School (Oxford). His research interests include business taxation with a special focus on international issues, public policies towards financial markets and institutions, as well the modelling of retirement and pension decisions.

Giampaolo Arachi is Professor of Public Finance at the University of Salento and Research Fellow at Econpubblica-Università Bocconi. He is a graduate of the Bocconi University in Milan. Subsequently he received an M.Phil. in Economics from the University of Oxford and a Ph.D. in Public Finance from the University of Pavia. His research interests include the effects of taxes on business decisions and on financial markets as well as local public finance and fiscal federalism issues.

Katarzyna Anna Bilicka is a Research Fellow at the Oxford University Centre for Business Taxation. She received a B.Sc. in Mathematics and Economics and an M.Sc. in Economics and International Financial Economics from the University of Warwick. Her research interests include international monetary economics, fiscal policy, and competitiveness of tax systems.

Vieri Ceriani is Head of the Tax Department of the Banca d'Italia. He graduated in Economics in 1974, before attending a post-graduate programme in Economics at the University of Michigan. He joined Banca d'Italia in 1976, where he was assigned to the Public Finance Division of the Economic Research Department. From 1993 to 2001 he was Economic Adviser to a succession of finance ministers. He has represented the bank in several committees and groups at the ECB, the Ministry of the Economy, and private and public organizations in Italy and abroad. He is the author of numerous articles on public finance, in particular tax policy, fiscal federalism, and budget policy.

Michael P. Devereux is Director of the Oxford University Centre for Business Taxation, Professor of Business Taxation, and Professorial Fellow at Oriel College. He is Research Director of the European Tax Policy Forum, and Research Fellow of the Institute for Fiscal Studies, CESifo, and the Centre for Economic Policy Research. He is the elected Vice-President of the International Institute for Public Finance, and is Editor-in-Chief of International Tax and Public Finance, Assistant Editor (Economics) of the British Tax Review, and on the Editorial Board of the World Tax Journal. Professor Devereux is a member of the government multinational forum on tax, chaired by the Financial Secretary. He gained his Ph.D. in Economics at University College London. Prior to 
coming to Oxford, he was Professor and Chair of the Economics Departments at the Universities of Warwick and Keele. He has been closely involved in international taxpolicy issues in Europe and elsewhere, working with the OECD's Committee of Fiscal Affairs, the European Commission, and the IMF.

Clemens Fuest is Research Director of the Oxford University Centre for Business Taxation and Professor of Business Taxation. He is a research fellow of CESifo and IZA and Advisory Editor of the Canadian Journal of Economics. He is currently Chairman of the Academic Advisory Board of the German Federal Ministry of Finance and Member of the Academic Advisory Board of Ernst and Young AG, Germany. He has a Ph.D. in Economics from the University of Cologne. Prior to Oxford, he was a lecturer at the University of Munich and a professor of economics at the University of Cologne.

Thomas Hemmelgarn currently works as an economist for the European Commission's General Directorate for Taxation and Customs Union and for the German Federal Ministry of Finance. He holds a doctoral degree in Public Economics from the University of Cologne and a Master's in International Management from the Community of European Management Schools (CEMS). He is also a FiFo Policy-Fellow with the Cologne Centre for Public Economics (CPE) at the University of Cologne. He has studied at the University of Cologne, the Bocconi University in Milan, and Pennsylvania State University.

Michael Keen is Assistant Director in the Fiscal Affairs Department of the International Monetary Fund, where he was previously head of the Tax Policy and Tax Coordination divisions. Before joining the IMF, he was Professor of Economics at the University of Essex (UK), and Visiting Professor at Queen's University (Canada) and Kyoto University (Japan). He was the Elected President of the International Institute of Public Finance from 2003 to 2006, has served on the board of the National Tax Association, was a founding editor of International Tax and Public Finance, and has served on the editorial boards of many journals. He has led technical assistance missions on a wide range of issues in tax policy, and consulted for the World Bank, European Commission, the House of Lords, and the private sector. Recent publications appear in the American Economic Review, Economic Policy, the Journal of Public Economics, and the National Tax Journal; Michael is also is co-author of IMF books on The Modern VAT and Changing Customs.

Alexander Klemm works at the Fiscal Policies Division of the European Central Bank. He previously worked for five years at various departments of the International Monetary Fund, including the Fiscal Affairs Department, where the chapter published in this volume was prepared. Prior to that, he was employed by the Institute for Fiscal Studies in London, where he worked on research and policy advice, mostly on corporate tax issues. He was educated at the University of Bristol and the London School of Economics and holds a Ph.D. from University College London. He is broadly interested in public finances and macroeconomics. His publications include both academic and more policy-oriented articles, many of which are on tax policy.

Geoff Lloyd has substantial experience of UK and international tax policy and administration. He joined the UK Inland Revenue in 1986 as a tax inspector, responsible for negotiating tax liabilities with taxpayers ranging from small businesses 
to large foreign banks. He has since held a wide range of policy and senior management roles in HMRC, including as Director of Central Compliance, Director, Corporation Tax and VAT, and Director, Dispute Resolution. During a four-year secondment to the UK Treasury he was Head of EU Finance, and Acting Director, Europe. From 2009 to 2011 he was Senior Adviser to the OECD, with a special emphasis on tax and financial stability.

Robert N. McCauley is Senior Adviser in the Monetary and Economic Department of the Bank for International Settlements (BIS). Before October 2008 he served as the BIS Chief Representative for Asia and the Pacific in Hong Kong. Prior to joining the BIS, he worked for thirteen years for the Federal Reserve Bank of New York, leaving as head of the International Finance Department in research. He taught international finance and the multinational firm at the University of Chicago's Graduate School of Business in 1992.

Stefano Manestra is Senior Tax Analyst at the Tax Department of the Banca d'Italia. He graduated in 1990 and joined Banca d'Italia in 1995. He was first assigned to banking supervision. Since 1999 he has been working at the Tax Department of the bank, first as Tax Adviser in the Direct Tax Division, and subsequently as Senior Tax Analyst in the Tax Analysis Division. Currently, his main work and research fields are national and comparative business taxation, fiscal federalism, and the historical analysis of tax policies and tax laws.

Donato Masciandaro is Full Professor of Economics, Chair in Economics of Financial Regulation, at Bocconi University. Former Head of the Department of Economics, he is Director of the Paolo Baffi Centre on Central Banking and Financial Regulation. He is also Member of the Management Board of the Société Universitaire Européenne de Recherches Financières (SUERF). He served as Visiting Scholar at the International Monetary Fund (IMF) Institute, as well as Consultant at the United Nations. He is Associated Editor of the Journal of Financial Stability. His work has covered three main topics: central banking, financial regulation and supervision, and illegal financial markets.

Gaetan Nicodeme is head of the Taxing Capital and Consumption sector in the Economic Analysis, Evaluation and Impact Assessment Support Unit at the European Commission's General Directorate for Taxation and Customs Union. He is Lecturer at the Institute for European Studies and at the Solvay Brussels School of Economics and Management at the Free University of Brussels. He holds a Ph.D. in Economics and Management Sciences from the Solvay Brussels School of Economics and Management. His research focuses on corporate taxation, taxation of savings, and tax competition, with an emphasis on the European Union, and he has been published in top academic journals. He is a research affiliate of the Centre Émile Bernheim (CEB) at the Solvay Brussels School of Economics and Management and a non-resident fellow at the European Center for Advanced Research in Economics Statistics (ECARES) at the Université Libre de Bruxelles (ULB). He is also CESifo Research Network Affiliate. He has studied at Solvay Brussels School of Economics and Management, the Institute for European Studies at ULB, and the London School of Economics. 
Francesco Passarelli is Associate Professor of Economics at the University of Teramo and he teaches European Political Economy at Bocconi University, Milan. He is coordinator of the research area in European Affairs at the Italian Institute for Foreign Folicy Studies. His scientific interests include political economy, European integration, and cooperative game theory.

Victoria Perry is Division Chief of the Tax Policy Division of the Fiscal Affairs Department (FAD) at the International Monetary Fund. Since joining the IMF in 1993, she has provided technical assistance in tax policy and revenue administration to a wide variety of countries in East Africa, the former Soviet Union, Europe, and Asia. From 2002 to 2008 she served as Division Chief for Revenue Administration in FAD. Prior to joining the IMF, She was the Deputy Director of the Harvard University International Tax Program, teaching comparative income taxation and value-added taxation in the Harvard Law School and providing technical assistance in revenue policy through the Harvard Institute for International Development. She previously practised tax law with the Boston law firm of Hale and Dorr (now WilmerHale). She has served as the Chair of the Value Added Tax Committee of the American Bar Association Section of Taxation, and is currently President of the Board of Trustees of the American Tax Policy Institute. She received her J.D. from the Harvard Law School, and her B.A. from Yale University in Economics and Philosophy.

Giacomo Ricotti is Senior Tax Analyst at the Tax Department of the Banca d'Italia. He graduated in Business Administration in 1994 and joined Banca d'Italia in 1997, after three years in consulting. Currently, his main work and research fields are national, comparative, and international tax treatment of corporations, banks, financial products and investment vehicles, and quantitative analysis for assessing the impact of new tax laws on firms and banks. He has published research papers and articles on issues regarding the taxation of the banking and financial industries.

Raffaele Russo is a senior adviser at the OECD Centre for Tax Policy and Administration (CTPA), where he leads the work on aggressive tax planning. He has published extensively in the area of international taxation and is often a speaker at international tax conferences and seminars. He is a fellow lecturer at the Universities of Leiden (the Netherlands) and of Vienna (Austria).

Alessandra Sanelli is Senior Tax Analyst at the Tax Department of the Banca d'Italia. She graduated in Business Administration in 1993, and joined Banca d'Italia in 1994, after one year in private tax practice. Currently, her main work and research fields are tax treatment of financial products and investment vehicles, tax policies affecting financial income and business taxation, and national and international initiatives aimed at countering tax evasion. Between October 2003 and September 2004 she was at the OECD Centre for Tax Policy and Administration (CTPA) in Paris as Alessandro Di Battista Fellow, conducting a study on the economics of bank secrecy. She has published research papers and articles on the taxation of the financial sector and tax havens.

Douglas A. Shackelford is the Meade H. Willis Distinguished Professor of Taxation at the University of North Carolina, and director of the UNC Tax Center. His research and teaching address taxes and business strategy. Current areas of interest include the effects of shareholder taxes on equity prices, the taxation of multinationals, and the disclosure of 
corporate-tax information. He has published widely in accounting, economics, and finance journals. Dr. Shackelford is a research associate in public economics at the National Bureau of Economic Research in Cambridge, MA. He has held visiting faculty positions at Stanford University, Oxford University, and Universiteit Maastricht in the Netherlands. He received his Ph.D. from the University of Michigan and his B.S. from UNC-Chapel Hill.

Daniel N. Shaviro, the Wayne Perry Professor of Taxation at the New York University (NYU) Law School, is a graduate of Princeton University and Yale Law School. Before entering academia, he spent three years in private practice at Caplin \& Drysdale, a leading tax speciality firm, and three years as a Legislation Attorney at the Joint Congressional Committee on Taxation, where he worked extensively on the Tax Reform Act of 1986. In 1987, Shaviro began his teaching career at the University of Chicago Law School, and he joined the NYU Law School in 1995. Shaviro's scholarly work examines tax policy, budget policy, and entitlements issues.

Joel Slemrod is the Paul W. McCracken Collegiate Professor of Business Economics and Public Policy at the University of Michigan Economics Department, Director of the Office of Tax Policy Research at the Ross School of Business, and research associate at the National Bureau of Economic Research. Professor Slemrod received the A.B. degree from Princeton University in 1973 and a Ph.D. in Economics from Harvard University in 1980. He joined the Economics Department at the University of Minnesota in 1979. In 1983-4 he was a national fellow at the Hoover Institution and in 1984-5 he was the Senior Staff Economist for tax policy at the President's Council of Economic Advisers. He has been at Michigan since 1987, and was Chairman of the Business Economics Group from 1991 to 1992, and from 1995 to 1998. Professor Slemrod was Editor of the National Tax Journal from 1992 to 1998, the leading academic journal devoted to the theory and practice of taxation. He has been a consultant to the US Department of the Treasury, the Canadian Department of Finance, the New Zealand Department of Treasury, the World Bank, and the OECD, and Coordinator of the National Bureau of Economic Research project in international taxation. In 1993 he was an Invited Faculty Member at the US House Ways and Means Committee Annual Issues Seminar, and has testified before the Congress on domestic and international taxation issues.

Kazuo Ueda graduated from the School of Science, University of Tokyo, and received his Ph.D. from MIT. He has taught at the University of British Columbia, Osaka University, and the University of Tokyo. He served as a member of the Policy Board at the Bank of Japan during 1998-2005 and as Dean of the Faculty of Economics, University of Tokyo, from October 2005 to September 2007. His recent research focuses on the causes of the Japanese banking instability in the 1990s and on the Bank of Japan's monetary policy during the period 1995-2005.

Ernesto Zangari is Junior Economist at the Tax Department of the Banca d'Italia. After attaining his Ph.D. in Economics at the University of Turin, Ernesto joined the Banca d'Italia in 2006. He works at the Tax Department as a tax economist. His current research interests include corporate taxation, taxation of financial intermediation, and small-business taxation. He has published research papers in academic journals and central bank publications on issues relating to tax amnesties, VAT, corporate tax reforms, and taxation of the banking industry. 


\section{Abbreviations}

$\begin{array}{ll}\text { ABS } & \text { asset-backed security } \\ \text { ACE } & \text { allowance for corporate equity } \\ \text { ADR } & \text { American depositary receipt } \\ \text { AIG } & \text { American International Group } \\ \text { ARM } & \text { adjustable rate mortgage } \\ \text { ATP } & \text { Aggressive Tax Planning } \\ \text { BEIT } & \text { business enterprise income tax } \\ \text { BIS } & \text { Bank for International Settlements } \\ \text { BoJ } & \text { Bank of Japan } \\ \text { CAPB } & \text { cyclically adjusted primary budget balance } \\ \text { CBO } & \text { collateralized bond obligation } \\ \text { CBIT } & \text { comprehensive business income tax } \\ \text { CCCTB } & \text { common consolidated corporate tax base } \\ \text { CDO } & \text { collateralized debt obligation } \\ \text { CDS } & \text { credit default swap } \\ \text { CDS-IR } & \text { CDS Implied Ratings } \\ \text { CEB } & \text { Centre Émile Bernheim } \\ \text { CEMS } & \text { Community of European Management Schools } \\ \text { CEO } & \text { chief executive officer } \\ \text { CFC } & \text { controlled foreign corporation } \\ \text { CGT } & \text { capital gains tax } \\ \text { CLO } & \text { collateralized loan obligation } \\ \text { CIT } & \text { corporate income tax } \\ \text { CMBS } & \text { commercial MBS } \\ \text { CPE } & \text { Centre for Public Economics } \\ \text { CRA } & \text { Community Reinvestment Act } \\ \text { CTPA } & \text { DIT }\end{array}$

Xviii

This is an open access version of the publication distributed under the terms of the Creative Commons Attribution-NonCommercialNoDerivs licence (http://creativecommons.org/licenses/by-nc-nd/3.0/), which permits non-commercial reproduction and distribution of the work, in any medium, provided the original work is not altered or transformed in any way, and that the work is properly cited. For commercial re-use, please contact academic.permissions@oup.com 


\begin{tabular}{|c|c|}
\hline EATR & effective (average) tax rate \\
\hline $\mathrm{EC}$ & European Community \\
\hline ECARES & European Center for Advanced Research in Economics Statistics \\
\hline ECB & European Central Bank \\
\hline EEAG & European Economic Advisory Group \\
\hline EEC & European Economic Community \\
\hline EERP & Economic Recovery Plan for Growths and Jobs \\
\hline EESA & Emergency Economic Stabilization Act \\
\hline ETF & Exchange Traded Fund \\
\hline Fannie Mae & Federal National Mortgage Association \\
\hline FAD & Fiscal Affairs Department \\
\hline FAS & Financial Accounting Standard \\
\hline FASB & Financial Accounting Standards Board \\
\hline FASIT & financial asset securitization investment trust \\
\hline FAT & financial activities tax \\
\hline FATF & Financial Action Task Force \\
\hline FCRF & Financial Crisis Responsibility Fee \\
\hline FDIC & Federal Deposit Insurance Corporation \\
\hline Freddie Mac & Federal Home Loan Mortgage Corporation \\
\hline FSB & Financial Stability Board \\
\hline FSC & financial stability contribution \\
\hline FSF & Financial Stability Forum \\
\hline FTT & financial transaction tax \\
\hline GATS & General Agreement on Trade in Services \\
\hline GDP & gross domestic product \\
\hline Ginnie Mae & Government National Mortgage Association \\
\hline GSE & government-sponsored enterprise \\
\hline HFT & high-frequency trading \\
\hline HMRC & HM Revenue and Customs \\
\hline HNWI & high net worth individual \\
\hline IAS & International Accounting Standards \\
\hline IBFD & International Bureau of Fiscal Documentation \\
\hline IMF & International Monetary Fund \\
\hline IRAP & Imposta Regionale sulle Attività Produttive \\
\hline IRS & Internal Revenue Service \\
\hline ISO & incentive stock option \\
\hline
\end{tabular}


JGB Japanese government bond

LBO leveraged buyout

LDC less-developed country

MBS mortgage-backed security

METR marginal effective tax rate

MoF Ministry of Finance

NOL net operating loss

NPC notional principal contract

NQO non-qualified stock options

NYU New York University

OBR Office for Budget Responsibility

OECD Organization for Economic Cooperation and Development

OTC over the counter

PIT personal income tax

PV present value

REIT real estate investment trust

REMIC real estate mortgage investment conduit

RMBS residential MBS

SDRT stamp duty reserve tax

SF CDO structure finance CDO

SPE special purpose entity

SPV special purpose vehicle

SRE $\quad$ system risk externality

STT securities transaction tax

SUERF Société Universitarie Européenne de Recherches Financières

TARP Troubled Assets Relief Program

TED interest rate differential between T-bills and Eurodollar interbank loans

TRA97 Tax Relieve Act of 1997

TruPS trust preferred security

VAT value-added tax

WTO World Trade Organization

ZIRP zero interest rate policy

$\mathrm{XX}$

This is an open access version of the publication distributed under the terms of the Creative Commons Attribution-NonCommercialNoDerivs licence (http://creativecommons.org/licenses/by-nc-nd/3.0/), which permits non-commercial reproduction and distribution of the work, in any medium, provided the original work is not altered or transformed in any way, and that the work is properly cited. For commercial re-use, please contact academic.permissions@oup.com 


\title{
Introduction
}

\author{
Julian S. Alworth and Giampaolo Arachi
}

I believe that we should now build on the ideas that have emerged in the large financial centres and we should seek consensus on a co-ordinated approach over the coming months, building on four key elements.

First, that a levy on banks seems likely to be the most practical approach.

Second, that the levy should be designed to go with the grain of necessary regulatory reform not cut across or remove the need for it.

Third, that the levy should support globalisation and avoid doubletaxation of international banks.

And finally that proceeds should be for national governments to use, whether to put them aside in a dedicated insurance fund, to repay interventions or to reduce public debt.

Based on these four principles, we now need to work actively in the G20 to forge an internationally consistent approach.

(Gordon Brown, Speech on the Economy held a Canary Wharf, 10 March 2010)

[The International Monetary Fund is asked to] prepare a report for our next meeting June 2010 with regard to the range of options countries have adopted or are considering as to how the financial sector could make a fair and substantial contribution toward paying for any burden associated with government interventions to repair the banking system.

(G20 Press Communiqué, Pittsburgh Summit, September 2009)

\subsection{Introduction}

In the wake of the financial crisis, the taxation of the financial sector has become a very charged topic and the object of a number of international policy initiatives most notably that of the G20 (IMF 2010b). The outcome of

A previous version of this paper was presented at the ETPF/IFS conference "Tax policy in an uncertain world" held in London on 22 March 2010.

This is an open access version of the publication distributed under the terms of the Creative Commons Attribution-NonCommercialNoDerivs licence (http://creativecommons.org/licenses/by-nc-nd/3.0/), which permits non-commercial reproduction and distribution of the work, in any medium, provided the original work is not altered or transformed in any way, and that the work is properly cited. For commercial re-use, please contact academic.permissions@oup.com 
these initiatives and the extent to which they will be coordinated internationally remains unclear but there can be no doubt that the crisis has opened up a significant debate on the taxation of the financial sector including the tax treatment of individuals employed in the sector and the structure of incentive payments. ${ }^{1}$

This book originated from a conference held in Milan in April 2009. That conference addressed the issue of what lessons for tax policy could be drawn from the financial crisis. The papers presented at the conference (Chapters 2-6) examined whether tax arrangements in many countries and across jurisdictions may have influenced decision making and been a causal element in the crisis. The general conclusion from these papers was that the tax system had on balance played a minor role in triggering the crisis but that the crisis had served to underscore a number of weaknesses in existing tax systems.

Since then the debate has focused on a number of other issues many of which relate to the use of tax policy to address the problems in financial markets resulting from the crisis:

1. the manner in which the financial sector should 'pay' for its bailout but also the role of accumulated tax losses on financial institutions' behaviour (Chapter 5);

2. should taxes play a role in correcting the systemic externalities associated with 'too big to fail' and more generally the role of taxes in the regulation of the financial sector and their possible coordination with other domains (notably accounting and capital adequacy norms) (Chapter 11);

3. what types of tax are most appropriate for financial institutions and markets ('excess profits' versus 'financial transaction' taxes (Chapter 5);

4. the role of taxation in counter-cyclical and macroeconomic policies (Chapters 9 and 10).

This book attempts to provide a broad overview of these many disparate issues. Apart from certain clearly defined 'one-off' initiatives that have been passed into law, such as the bonus taxes and special levies on banks, the current debate has the character of a 'work in progress'. Because the understanding of what occurred in the run-up to the crisis is being constantly updated and policy proposals have not been finalized, our discussion in many ways is tentative ${ }^{2}$ and can be seen as taking stock of existing knowledge and as a very preliminary assessment of various positions that have been aired in numerous fora.

\footnotetext{
1 The IMF opened up a public consultation on the subject $<$ http://www.imf.org/external/np/ exr/consult/2009/index.htm>.

2 For example, a significant reassessment of the background to the Lehman bankruptcy has resulted from the Valukas (2010) report, which appeared on 11 Mar. 2010.
} 
This introduction summarizes the main themes that are raised in this book and highlights why the issue of how best to tax the financial sector will remain high on the agenda of future tax policy debates.

\subsection{Did tax policy contribute to the crisis?}

\subsubsection{Salient features of the crisis}

A long 'laundry list' of causal factors has been suggested as having caused the financial crisis or contributed to its character and severity, such as:

- the large global macroeconomic imbalances;

- the protracted period of low interest rates and credit boom in the USA and UK;

- the asset bubbles in the housing market in a number of countries;

- the concentration of risk in the financial sector;

- the leverage of households and financial intermediaries;

- the flaws in techniques to measure, price, and manage risk;

- the inadequacy of the regulation of the financial sector;

- the structure of compensation schemes encouraging managers to forsake long-run prospects for short-run return.

While these factors have often been country or jurisdiction specific, the financial crisis has been truly global in nature and has involved significant spillovers between financial institutions and across jurisdictions.

It is interesting to note that taxation and fiscal policy do not appear in the list of major culprits responsible for the financial crisis. There is a consensus that is reflected in the papers presented in Milan that the tax system appears to have played a secondary role, albeit a possibly decisive one in some circumstances, in determining the precise features of certain transactions. The most important appear to have been:

(a) the deductibility of mortgage interest by households;

(b) the aggressive use of debt financing in M\&A and private equity transactions;

(c) the use of hybrid financial instruments by financial institutions;

(d) the use of tax havens to structure tax-efficient securitization vehicles.

In assessing the importance of each of these tax drivers it is important to appreciate their role within the broader dynamic changes under way. In other words, the reason why these tax factors may have fostered a more unstable

This is an open access version of the publication distributed under the terms of the Creative Commons Attribution-NonCommercialNoDerivs licence (http://creativecommons.org/licenses/by-nc-nd/3.0/), which permits non-commercial reproduction and distribution of the work, in any medium, provided the original work is not altered or transformed in any way, and that the work is properly cited. For commercial re-use, please contact academic.permissions@oup.com 
financial environment depends heavily on other changes occurring in the financial environment.

\subsubsection{Household sector: indebtedness and tax}

The US housing bubble played a central role in the financial crisis. It is, therefore, not surprising that the first tax factor that came under scrutiny after the crisis was the tax treatment of residential housing.

The returns to owner-occupied housing, which include the value of using the property (the 'imputed rent') and any capital gains from house price appreciation, are very lightly taxed in most countries. Despite the low taxation of returns to housing, some costs, notably interest costs, are often deductible.

Mortgage interest tax relief encourages the build-up of (gross) housing debt, and there is evidence that countries offering more favourable tax treatment for home ownership do indeed have higher ratios of mortgage debt (Chapters 2 and 4). There is also evidence that mortgages fell significantly relative to home value (in the UK and USA) after reforms that reduced the value of mortgage interest relief. High levels of mortgage debt are also associated with very low savings rates of the household sector (Agell et al. 1995).

However, the provisions relating to mortgage interest tax relief do not appear sufficient to explain the timing and size of the increase in leverage of the personal sector and the geographical concentration of the increase in leverage across countries. This contrasts with the Nordic Countries' financial crisis in the early 1990s, where changes in the tax system coincided with a very significant decline in housing prices. ${ }^{3}$ A number of other policy developments as well as changes in the lending practices of financial intermediaries appear to have played a much more significant role in the current crisis, ${ }^{4}$ and any tax effect needs to take account of the complex interplay with these other developments (especially on the regulatory front) as well as some other subtle changes in tax provisions. Even in the Scandinavian case, where tax appears to have played a more significant role in the financial debacle, the build-up in debt by households was driven largely by a prolonged period of unprecedented financial liberalization.

\footnotetext{
3 Englund et al. (1995) suggest that demand for owner-occupied homes decreased by around $15 \%$ including the effects of the withdrawal of interest subsidies. They also estimated that shortrun impact on market prices of owner-occupied homes was between 10 and 15\%, or roughly half the fall in real prices recorded between 1990 and 1993.

4 Poterba and Sinai (2008) calculate the impact of interest deductibility on the user cost of housing in the USA and find that on average this provided a tax subsidy equivalent to around $19 \%$ of the user cost. While the subsidy is greatest for high-income households (since the deduction is taken at a higher marginal rate), it is nevertheless around $8 \%$ for those with low incomes.
}

This is an open access version of the publication distributed under the terms of the Creative Commons Attribution-NonCommercialNoDerivs licence (http://creativecommons.org/licenses/by-nc-nd/3.0/), which permits non-commercial reproduction and distribution of the work, in any medium, provided the original work is not altered or transformed in any way, and that the work is properly cited. For commercial re-use, please contact academic.permissions@oup.com 
Hemmelgarn et al. in Chapter 3 argue that the tax incentive for homeowners to take mortgages in the United States can be considered as a catalyst in a chemical reaction: the deductibility did not cause the bubble, but it may have favoured the run-up in prices. One example that may illustrate the interaction between taxes and the macroeconomic and regulatory framework is given by the housing policies enacted in 2004 and subsequent years, such as the American Dream Downpayment Act (see Chapter 3). These measures appear to have had a significant impact on US housing market dynamics, as low- and nodownpayment mortgages expanded very markedly. Chapter 3 suggests that the decrease of mortgage downpayments may have given rise indirectly to a tax break because of the asymmetric treatment of personal debt and equity: the cost of personal housing debt is deductible, whereas the opportunity cost of housing equity is not, so the consequence of lower- or no-downpayment mortgages may have been an abrupt decrease of the user cost of housing.

The spread of mortgages, in particular subprime loans, was also helped by more lax regulation of the financial sector and the development of new financial instruments. The technique of securitization, which consists of pooling the loans into an investment vehicle and then selling securities backed by payments for these loans, has received considerable attention in this respect (Chapter 4). This securitization process was itself helped by the emergence of a new class of derivatives that allowed the credit risk to be transferred to a third party: the credit default swaps (CDSs).

The role of tax in these securitizations is difficult to evaluate. However, it is clear that the existence of vehicles allowing for a full pass-through of mortgage payments unencumbered by tax was necessary for securitizations to prosper. As recently argued by Han et al. (2010), there is some evidence to suggest that the differential tax treatment of loans on banks' books (subject to corporation tax) and the exempt status of securitization vehicles may have been a factor for the growth of securitizations. While many vehicles were created on shore, the vast majority of securitizations traded internationally were issued through special purpose vehicles (SPVs) domiciled in offshore centres (Chapters 4 and 8), where tax conditions for structuring financial securities as well as market regulation were negligible (Eddins 2009).

\subsubsection{Corporate sector: leverage}

The role of taxes in corporate financing decisions has long been recognized: when interest payments are deductible against the corporate income tax (CIT) but returns to equity are not, then, all else being equal, firms will have an incentive to issue debt until the expected marginal tax benefit is just offset by the marginal increase in expected bankruptcy costs. These preferences for debt over equity can be mollified in the presence of personal taxes, but in practice

This is an open access version of the publication distributed under the terms of the Creative Commons Attribution-NonCommercialNoDerivs licence (http://creativecommons.org/licenses/by-nc-nd/3.0/), which permits non-commercial reproduction and distribution of the work, in any medium, provided the original work is not altered or transformed in any way, and that the work is properly cited. For commercial re-use, please contact academic.permissions@oup.com 
tax systems appear to favour debt over equity finance. This is particularly true if exempt investors tend to be the dominant source of external finance, as has been increasingly the case in recent years.

The tax advantage to debt appears to have been decreasing over time as a result of the generalized decline in inflation rates as well as statutory corporate tax rates across countries (Chapter 2). At the same time, other tax factors may have led to an increased reliance on this form of financing, such as the elimination of imputation systems in most European countries and the greater reliance on international capital markets where various forms of tax-exempt investors dominate bond markets. ${ }^{5}$ The extent to which these developments have mattered varies from country to country.

Changes in debt ratios of the non-financial corporate sector in the years immediately preceding the financial crisis do not show a clear pattern. According to some measures, the leverage of the non-financial corporate sector appears to have increased somewhat in the UK and the euro area in recent years (2005-8) following a period of stability in the 1990s (BIS 2009). By contrast, the leverage of the US corporate sector has remained unchanged. On the basis of these observations there is a broad consensus that the tax advantage afforded to debt did not contribute to the crisis.

However, there are two elements that deserve attention in assessing the importance of the tax advantage to debt in affecting the potential systemic weakness of the corporate sector. First, the absolute level of indebtedness, rather than changes in indebtedness, is what matters in terms of systemic risk. As highlighted in Chapter 2, when firms borrow, they are likely to internalize the expected bankruptcy costs they themselves incur but not the impact of their own failure and default on others (effects that are not present in the use of equity finance). ${ }^{6}$ As a consequence, debt ratios may be inefficiently high from the point of view of the society as a whole. These externalities are likely to be especially large for financial institutions, given their systemic importance and the (explicit or implicit) government's guarantees on bank deposits or other debt. While little is known on the magnitude of externalities from increased leverage, there is evidence that high leverage is correlated with greater output losses in bad times: Davis and Stone (2004) find that higher debt-equity ratios are associated with greater post-crisis output declines, and IMF (2008) that the cumulative output loss following periods of

\footnotetext{
5 Other factors such as cross-border arbitrage activity in equity markets suggest that the tax privilege of debt over equity may not be so significant.

${ }^{6}$ Chapter 2 also argues that there may also be strong effects on the balance of payments: preferential tax treatment of debt can provide an implicit subsidy to corporate and household borrowing, including from abroad, so increasing vulnerabilities through the capital account. The authors suggest that this might have happened in Latvia: the implicit corporate-level tax subsidy made the cost of investments financed by borrowing about 130 basis points lower than it would have been in the absence of tax.
}

This is an open access version of the publication distributed under the terms of the Creative Commons Attribution-NonCommercialNoDerivs licence (http://creativecommons.org/licenses/by-nc-nd/3.0/), which permits non-commercial reproduction and distribution of the work, in any medium, provided the original work is not altered or transformed in any way, and that the work is properly cited. For commercial re-use, please contact academic.permissions@oup.com 
financial stress tends to be larger the greater the run-up in non-financial corporate debt before the onset (see Chapter 2).

The second element of systemic relevance is that leverage ratios tend to be set to withstand external shocks based on historic experience. One area where such an approach may have given rise to potential problems in recent years is that of leverage buyouts, which rose to historic highs in the build-up to the crisis (see Chapter 2). The possibility of exploiting higher levels of leverage in target (and potential target) companies to achieve tax savings appears to have been in many instances a contributing motivation to the value of the transactions. The benefits of the tax shield depended on the assumption that revenues would grow in line with past experience.

In summary, while tax-induced behaviour of the non-financial corporate sector does not appear to have been one of the causes of the crisis, the high levels of indebtedness of some sectors may have exacerbated the real effects of the financial crisis. Keen et al. in Chapter 2 and Shaviro in Chapter 7 discuss several methods for eliminating debt bias, and more generally making the debt-equity choice tax neutral.

\subsubsection{Financial sector: regulatory and tax arbitrage}

Formally, the financial choices of financial institutions and non-financial corporations are affected by the tax system in the same way (Hanson et al. 2011). However, the high profitability of financial institutions in the years preceding the crisis increased the effective CIT rate, making the tax incentive to debt even stronger than for many non-financial corporations.

In the financial sector the tax bias to debt runs counter to regulatory objectives, which usually entail an implicit penalty to debt. Chapter 2 suggests that the tension between regulatory objectives and tax incentives has fostered the emergence of devices that enable debt-like instruments, attracting interest deduction, to be included in Tier 1 capital. ${ }^{7}$ Prominent among these are trust preferred securities (TruPS), which accounted for a large share of hybrid issues in the USA by both domestic and foreign financial intermediaries. There are two strategies to deal with this tension. The first is to introduce specific measures to close possibilities of this kind. However, if the underlying tax bias remains high, there will be a strong incentive to find other ways of achieving the same end. The second is to reduce the distance between tax and regulatory concepts and definitions.

\footnotetext{
7 Basel guidelines allow up to $15 \%$ of Tier 1 capital to be in the form of hybrid instruments that may attract interest deductions-in itself suggestive of the tax bias to debt finance that banks face (see Ch. 2).
}

This is an open access version of the publication distributed under the terms of the Creative Commons Attribution-NonCommercialNoDerivs licence (http://creativecommons.org/licenses/by-nc-nd/3.0/), which permits non-commercial reproduction and distribution of the work, in any medium, provided the original work is not altered or transformed in any way, and that the work is properly cited. For commercial re-use, please contact academic.permissions@oup.com 
Both strategies should be evaluated by taking into account that tax policy pursues objectives that are largely different from those of regulatory and accounting practices. There are obvious advantages in terms of administrative and compliance costs in applying common definitions and concepts for tax and accounting reporting, and corporate governance may also benefit if tax and book profits are more closely aligned (Desai et al. 2007). However, the most accurate measure of current income is not necessarily the best tax base. There may, for instance, be several good reasons for allowing accelerated depreciation or full expensing of investment for tax purposes, and provisioning may be best treated differently for accounting purposes than for those of assessing taxable income (see Chapter 2).

\subsubsection{New financial instruments and tax arbitrage}

The difficulties in measuring pricing and managing risk are greater for new financial instruments. Differential taxation of dividends, interest, and capital gains creates many inconsistencies in capital income taxation (see Chapter 7). Tax inconsistency can be exploited through the ability of derivatives to replicate a portfolio in a variety of ways and to expand the opportunities to tailor the nature of the payments to the tax preferences of the investor (transforming it into lightly taxed capital gains, for instance). ${ }^{8}$ However, most observers believe that tax played only a secondary role in encouraging the growth of the derivatives markets (Chapter 8). One important reason why tax planning may not have borne greater responsibility for the derivatives explosion, at least in the USA, is that tax law requires businesses that qualify as dealers in securities to use mark-to-market accounting with respect to all inventory items, and to treat all gains and losses on such items in a consistent way. In Chapter 7 Shaviro also notes that companies often used the same carefully structured derivatives transactions to achieve several objectives at the same time: minimize tax liabilities, manipulate reported earnings, avoid regulatory constraints, and minimize the effectiveness of investor oversight. In these circumstances, tax considerations, standing alone, may not have made a large difference, even though they clearly encouraged the underlying transactions.

A more direct connection between new financial instruments, tax, and the crisis has been suggested by Eddins (2009). He argues that collateralized debt obligations (CDOs) organized as pass-through entities became especially attractive because their owners entered into CDSs with sellers that could treat default losses as ordinary loss, while the CDO has pass-through tax treatment and therefore would have to treat defaults as capital losses. By

\footnotetext{
8 See Alworth (1998).
}

This is an open access version of the publication distributed under the terms of the Creative Commons Attribution-NonCommercialNoDerivs licence (http://creativecommons.org/licenses/by-nc-nd/3.0/), which permits non-commercial reproduction and distribution of the work, in any medium, provided the original work is not altered or transformed in any way, and that the work is properly cited. For commercial re-use, please contact academic.permissions@oup.com 
attaching the expected losses to the mark-to-market seller of the swaps, the CDO tranches allowed more tax offsets, thus providing a higher after-tax expected rate of return. The strategy was especially advantageous for the riskier tranches with higher expected default rates (Slemrod 2009). Ceriani et al. in Chapter 4 provide a detailed account of this tax arbitrage, highlighting the role played by CDSs. Further research is still needed to understand the real impact of the tax factors in the securitization process. While there is little denying that such arbitrage incentives may have existed, their importance appears difficult to assess in practice.

\subsubsection{Compensation schemes}

The dramatic rise in bonuses and stock option remuneration plans in the financial sector has been among the most debated aspects of the crisis. It is a common belief that stock options and other stock-based forms of remuneration are tax favoured compared to cash compensation. Tax rules for employee stock options are complex and vary substantially across countries and schemes. Ceriani et al. in Chapter 4 provide a detailed analysis of such provisions in OECD countries and come to the conclusion that there is no general tax preference for stock option plans once both employee and employer taxes are taken into account. Nevertheless, they argue that in the USA there is evidence of a preferential tax treatment on the employer's side, which, in conjunction with other factors, may have contributed to the success of stockbased remuneration plans. In other cases, it is possible that a tax preference emerged as a consequence of a unilateral perspective, with the favourable tax treatment at employee level prevailing over corporate tax considerations.

A somewhat different set of issues arises in the case of private equity and hedge fund managers, who receive most of their compensation as 'carried interest' ('performance fees'), subject, in some countries, only to relatively light taxation as dividends or long-term capital gains. Some have criticized this approach on the basis that it entails taxing managers at inappropriately low rates on what is effectively labour income(see Chapters 2 and 8). ${ }^{9}$ In the eyes of these same critics, the growth of 'hedge funds' and 'private equity' firms would appear to be driven in part by these tax considerations.

The basic argument used to support the recharacterization of income is that carried interest is compensation for performing a service. The sponsor (general partner or manager) is analogized to a money manager, who determines how best to invest a client's funds. Accordingly, the carried interest should be taxed

\footnotetext{
9 If this income were taxed as earnings, however, coherence would require that a corresponding deduction for payment of compensation be available to other partners-enabling an increase in the pre-tax remuneration of the fund managers.
}

This is an open access version of the publication distributed under the terms of the Creative Commons Attribution-NonCommercialNoDerivs licence (http://creativecommons.org/licenses/by-nc-nd/3.0/), which permits non-commercial reproduction and distribution of the work, in any medium, provided the original work is not altered or transformed in any way, and that the work is properly cited. For commercial re-use, please contact academic.permissions@oup.com 
similarly to risky returns given to other service providers, such as stock, stock options, or royalties. Indeed, investment advisors' fees are already taxed as ordinary income. This is the case, even if the fees are contingent on performance. For example, if investment advisors receive equity compensation, say in the company that employs them, typically either ordinary income-tax treatment or the principles governing options apply. According to this view, the funds remain the investor's funds. The investor gets taxed on the gains or losses in the funds and potentially can deduct the fees paid to the advisor (Bankman 2007).

According to others (Weisbach 2008), the structure of a private equity partnership does not perfectly fit this analogy. Typically, an investment advisor is not treated as owning the funds that are invested. Instead, the investment advisor is merely the agent for the investor. In a private equity partnership, the partnership is the owner of the funds and not merely an agent for the investors. An alternative way to view the activities of a sponsor of a private equity fund is as an entrepreneur who raises capital to make investments. The form used for raising capital is a limited partnership in which the sponsor is the general partner and the capital providers are limited partners. The limited partners are paid a market rate of return for their provision of capital and have no more involvement in partnership operations than any third-party provider of capital. Under US law, anyone who makes an investment and holds it as a capital asset, even if made with third-party capital, receives capital gain or loss on the investment. Accordingly, changing the tax treatment of general partners would have wider-ranging implications than simply affecting private equity. Another analogy used by supporters of the capital gains treatment of carried interest is that it is given to anyone buying shares through a margin account and profiting on the sale is using in part someone else's money and his or her own effort and ideas about stock valuations to make money.

The discussion of carried interest highlights two key problems in taxing capital income: the distortions to behaviour induced by differences in tax rates and the difficulty of distinguishing labour from capital income. In this as other areas, incentives to income shifting are unavoidable and give rise to complexity. As argued by Weisbach (2008), there is simply no general method of making this distinction, and attempts to do so are complex and give rise to other forms of tax avoidance.

\subsection{Implications for tax policy}

The fallout from the financial crisis and the impending budget deficits resulting from government bailout and counter-cyclical interventions has

This is an open access version of the publication distributed under the terms of the Creative Commons Attribution-NonCommercialNoDerivs licence (http://creativecommons.org/licenses/by-nc-nd/3.0/), which permits non-commercial reproduction and distribution of the work, in any medium, provided the original work is not altered or transformed in any way, and that the work is properly cited. For commercial re-use, please contact academic.permissions@oup.com 
prompted a series of policy initiatives that extend the remit of tax policy beyond mere revenue collection.

Three conceptually distinct areas have attracted the attention of policymakers:

1. special taxes on the financial sector to recover the costs incurred for the bailout;

2. taxes to correct for distortions (particularly of a systemic character) resulting from the safety net that applies to the financial sector;

3. problem areas with the taxation of the financial sector, which have been highlighted by the crisis (VAT on financial services, the interaction with accounting and regulatory definitions of income, anti-avoidance measures in particular with respect to tax arbitrage).

These topics are not disjointed, and in some instances potential policy prescriptions overlap with regulatory measures (see Chapters 5 and 11).

\subsubsection{Special levies on the financial sector}

Initially much of the policy debate was driven by the desire to placate public anger over the costs of the bailout measures. One response was to limit the bailout expenses by reappropriating windfall profits and rents in the financial sector. This approach is much in the same spirit (albeit with different implications) as the suggestions coming from the international supervisory and regulatory community. ${ }^{10}$ The main objective is to raise revenues from those institutions and their stakeholders that have benefited most from government intervention. ${ }^{11}$ These proposals have taken various forms.

\subsubsection{THE OBAMA PROPOSAL}

Some proposals attempt to achieve both efficiency and revenue objectives. The US government proposal for a Financial Crisis Responsibility Fee (FCRF) at a rate 0.15 per cent on financial firms' liabilities provides a prominent example. It has been presented both as a corrective device ${ }^{12}$ and as a means 'to compensate

10 'It is imperative that these profits be retained in financial institutions to rebuild capital ... The international supervisory and regulatory community is agreed that restricting dividend payments, share buybacks and compensation rates are appropriate means to these ends' (Financial Stability Board 2009: 2).

11 Some observers, in particular of the US package, have noted that a large number of the banks that are targeted for special tax treatment have already repaid the loans extended under the TARP programme and that a number of non-financial corporate entities should also in theory be subject to a special levy.

12 'As it would be based on an institution's size and exposure to debt, it would also further the Administration's financial reform goals by providing a check against the risky behavior that contributed to this crisis' (Office of Management and Budget 2011: 39).

This is an open access version of the publication distributed under the terms of the Creative Commons Attribution-NonCommercialNoDerivs licence (http://creativecommons.org/licenses/by-nc-nd/3.0/), which permits non-commercial reproduction and distribution of the work, in any medium, provided the original work is not altered or transformed in any way, and that the work is properly cited. For commercial re-use, please contact academic.permissions@oup.com 
taxpayers fully for the extraordinary support they provided'.$^{13}$ In essence, the fee would apply to the largest financial firms with consolidated assets exceeding $\$ 50$ billion. Under the initial proposal the base for the tax would be the firm's assets less Tier 1 capital and Federal Deposit Insurance Corporation (FDIC)assessed deposits. In essence, the tax would apply to financial firms' funding in wholesale markets, which in the view of many was the engine behind the build-up of leveraged risky portfolios. It also appears to be closely related to the ideas put forth by Paul Volcker to limit proprietary trading activities of commercial banks subject to the 'safety net' and more generally the systemic risks arising from maturity mismatches (Hanson et al. 2011).

A similar approach has been taken by the European Council. In March 2010 the Council agreed that 'Member States should introduce systems of levies and taxes on financial institutions to ensure fair burden-sharing and to set incentives to contain systemic risk' (European Council 2010: 6). By mid-2011 a number of special levies and taxes on financial institutions had been actually introduced in ten Member States (Table 1.1), and four other countries had announced the introduction of similar duties. However, no clear pattern can be detected in the European experiences, as tax rates and bases differ considerably.

\subsubsection{THE TAXATION OF BONUSES}

Other proposals aim mainly to achieve revenue and fairness objectives, as well as a means to support indirectly bank recapitalizations or a retroactive measure for banks that received state aid. These motivations were given for the tax on bonuses introduced in a coordinated move by the UK and France in 2009. The UK bank payroll tax applied to banking groups (including building societies) and was levied at a rate of 50 per cent on all discretionary and contractual bonus awards, to the extent that the bonus exceeded $£ 25,000$. It took effect from the time of the announcement, on 9 December 2009, until 5 April 2010. The French tax applied to bonuses, including deferred payments and awards of stock as well as cash.

Some interesting lessons can be learned from the UK and French bonus tax experiment. The first one is that the two governments were well aware of the potential consequences of the tax on the location of financial services as shown by the effort to coordinate their policies and by the one-off nature of the levy. ${ }^{14}$ The second is that the tax, while formally applying to labour income, appears in many instances to have been paid out of profits (via a grossing-up of pre-tax compensation). The tax appears to have raised revenue for $£ 2.5$ billion, an amount about five times larger than the government initial

13 Office of Management and Budget (2011: 39).

14 In the British case, the tax on bonus is only partly one off, as from 6 Apr. 2010 the top marginal rate of the personal income tax was raised from $40 \%$ to $50 \%$ for income above $£ 150,000$. 
Table 1.1. Financial levies and taxes in the European Union, 2011

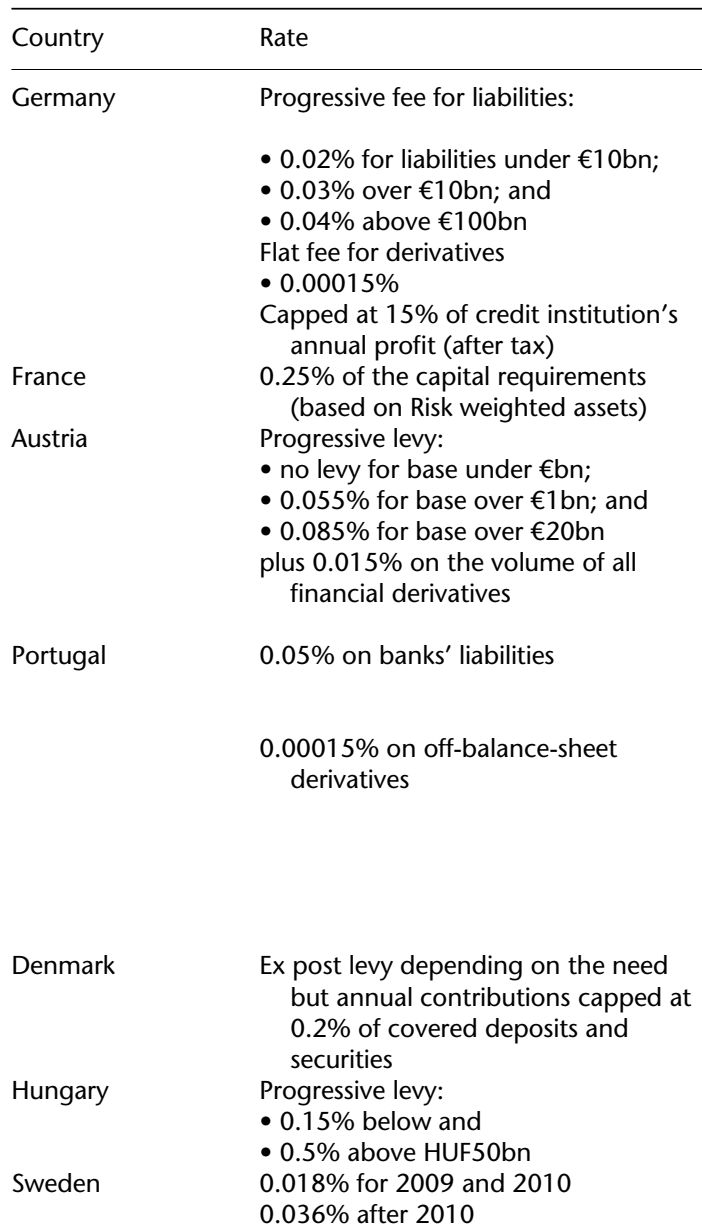

United Kingdom
1 Jan. 2011-28 Feb. 2011: 0.05\% for short-term chargeable liabilities and $0.025 \%$ for long-term chargeable equity and liabilities.

1 Mar. 2011-30 Apr. 2011: 0.1\% for short-term chargeable liabilities and $0.05 \%$ for long-term chargeable equity and liabilities.

1 May 2011-31 Dec. 2011: 0.075\%

for short-term chargeable liabilities and $0.0375 \%$ for long-term

chargeable equity and liabilities.
Base

- Liabilities excluding capital and deposits

- Derivatives (notional value)

Risk-weighted assets

Unconsolidated balance-sheet total excluding subscribed capital and reserves, secured deposits, and certain liabilities to banks, provided they are necessary to fulfil liquidity provisions plus add on for financial derivatives on trading book

(i) liabilities excluding Tier 1 and Tier 2 capital and insured deposits (only the amount effectively covered)

(ii) notional value of off-balance-sheet derivatives will also be 'levied' (excluding those used for hedging)

For both cases, the amount on which the levy will be calculated corresponds to the annual average of each end-of-month balance.

Covered deposits and securities

Balance-sheet total corrected for interbank loans

Liabilities excluding equity capital, debt securities included in the capital base, group internal debt transactions between those companies paying the fee, and debt issued under the guarantee programme

Liabilities excluding Tier 1 capital, insured deposits, policy holder liabilities, and assets qualifying for FSA liquidity buffer

This is an open access version of the publication distributed under the terms of the Creative Commons Attribution-NonCommercialNoDerivs licence (http://creativecommons.org/licenses/by-nc-nd/3.0/), which permits non-commercial reproduction and distribution of the work, in any medium, provided the original work is not altered or transformed in any way, and that the work is properly cited. For commercial re-use, please contact academic.permissions@oup.com 
Table 1.1. Continued

\begin{tabular}{|c|c|c|}
\hline Country & Rate & Base \\
\hline & $\begin{array}{l}1 \text { Jan. } 2012 \text { onwards: } 0.078 \% \text { for } \\
\text { short-term chargeable liabilities and } \\
0.039 \% \text { for long-term chargeable } \\
\text { equity and liabilities. }\end{array}$ & \\
\hline Latvia & $0.036 \%$ & $\begin{array}{l}\text { Liabilities excluding equity capital, } \\
\text { deposits subject to a deposit } \\
\text { guarantee scheme, mortgage } \\
\text { bonds, and subordinated liabilities } \\
\text { that are included in equity capital as } \\
\text { subordinated capital }\end{array}$ \\
\hline Cyprus & $\begin{array}{l}0.095 \% \text { on the overall level of deposits } \\
\text { in Cyprus (see base) for the years } \\
2011 \text { and } 2012 \text {. Capped at } 20 \% \text { of } \\
\text { credit institution's taxable income } \\
\text { for the two years } 2011 \text { and } 2012 \text {. }\end{array}$ & $\begin{array}{l}\text { Overall level of deposits (of residents } \\
\text { and non-residents) in Cyprus, } \\
\text { excluding the interbank deposits of } \\
\text { credit institutions operating in } \\
\text { Cyprus. The tax imposed for } 2011 \\
\text { will be calculated on the basis of } \\
\text { deposits at } 31 \text { Dec. } 2010 \text {. } \\
\text { Respectively for 2012, the tax } \\
\text { imposed will be calculated on the } \\
\text { basis of the deposits at } 31 \text { Dec. } \\
2011 \text {. }\end{array}$ \\
\hline
\end{tabular}

Source: Economic and Financial Committee (2011).

estimate. ${ }^{15}$ The high tax yield provides evidence of the choice of many banks to absorb the cost by 'grossing up' their bonus pools. ${ }^{16}$ The motivations for the 'tax shifting' in the UK appear to originate in the 'mobility' of skilled labour (Radulescu 2010). Shareholders appear to have borne the tax partly to reduce the impact of a higher top marginal tax on their globally mobile employees. This desire to maintain a UK presence may be suggestive of the existence of locational rents associated with a London presence. The nature of these and the extent to which they are durable over time are not clear.

Tax shifting raises two issues. The first one is related to the effect of the tax on bank capitalization. To the extent that the tax is borne by banks' profits through grossed-up bonuses, the levy may have a negative effect on bank capitalization, thereby running against the regulatory objective of strengthening the capital base of banks. The second is whether a direct levy on banks' profit may not be a more efficient way for allowing the financial sector to repay the cost of the bailout.

15 Brooke et al. (2010).

16 George and Megan (2010). There is also anecdotal evidence that some bank had planned to raise its base salaries for managing directors and others in order to make up for lower bonuses (Schaefer et al. 2009). The discussion about the extent of the tax revenue windfall does not appear to have taken account of the reduction in the corporate tax base associated with higher gross compensation. 


\subsubsection{EXCESS-PROFITS AND 'HIGH-PROFITS' TAXES}

A possible candidate in this respect is an excess-profits tax. There are several types of excess-profits taxes. In the USA an excess-profits tax was levied several times during wartime periods between 1917 and $1953 .{ }^{17}$ The various taxes implemented in this period may be classified in two broad families: the first, technically known as a war-profits tax, was designed to recapture the excess over standard profits that an individual corporation would have earned in the absence of defence- or war-induced expenditures; the second, frequently identified as a 'high-profits' tax, is based on the excess over some presumed reasonable standard rate of return on invested capital (Lent 1951). High-profits taxes are also similar to resource rent taxes such as the petroleum revenue tax in the UK or the Australian petroleum resource rent tax (Fraser 2002).

A high-profit tax may achieve the objectives of the bonus tax and the FCRF: it places the financial burden of the bailout on the institutions that have benefited most and is a means to tax 'rents' in the financial sector. To prevent the avoidance of the tax by the distribution of a high bonus, compensation above a given threshold should be added back to profit. Similar levies have recently been proposed by Keen et al. (2010) and by Kleinbard and Edgar (2010).

The effects of a high-profit tax on incentives depend on the manner in which it is implemented. There are two crucial issues. The first concerns whether the tax operates as an additional levy or as an allowance for corporate equity (ACE). In the former case, the excess-profit tax would apply only on profits in excess of a threshold amount, whereas the standard (normal) return on capital would be taxed at the general statutory rate. It is easy to show that this would leave existing incentives to capital structure unchanged, since at the margin debt equity decisions would be driven by the standard rate of tax on 'normal profit'. ${ }^{18}$ Furthermore, an additional levy might lead to greater risk taking if the excess return were not a pure rent but a return to risk taking (Kaplow 1994). By contrast, under an ACE the cost of debt and equity capital would be the same. This would favour the recapitalization of financial institutions and potentially offset the effects on greater risk taking resulting from the higher rates of tax on the excess returns.

In addition, an ACE tax could be aligned with bank regulation. To the extent that the standard rate of return is calculated on regulatory (that is, Tier 1) capital, the high-profit tax may provide a tax incentive to increase regulatory capital (see Chapter 2). A further advantage of an excess-profit tax

17 The first Canadian experiment with a corporation income tax, enacted in 1916, was also based on the high-profits principle.

18 A recent example of such an excess-profits tax was the Italian dual income tax (DIT). Under this arrangement, however, the normal return on equity was subject to a rate below the standard rate of tax. See Alworth and Lovisolo (1998) and Bordignon et al. (2001) for a discussion of the incentives in the context of cost of capital framework.

This is an open access version of the publication distributed under the terms of the Creative Commons Attribution-NonCommercialNoDerivs licence (http://creativecommons.org/licenses/by-nc-nd/3.0/), which permits non-commercial reproduction and distribution of the work, in any medium, provided the original work is not altered or transformed in any way, and that the work is properly cited. For commercial re-use, please contact academic.permissions@oup.com 
of the ACE type is that it could be implemented as a structural reform rather than a temporary or one-off measure and can be coordinated with a more general attempt to reduce the debt bias of the corporate tax.

Under current circumstances, the introduction of high-profit taxes or additional levies would need to take account of the stock of losses carried forward by many financial institutions (see Chapter 8). Taxpayers would benefit from a shift to an ACE the higher the excess-profit tax rate (relative to the ordinary rate) and the greater the size of the losses. ${ }^{19}$

\subsubsection{Correcting market failures}

Broadly speaking, the financial sector is prone to two types of problems requiring correction: (1) distorted incentive structures and undesired behaviour of economic agents (moral hazard) and/or (2) externalities within the financial sector (the failure of an institution propagates other financial intermediaries) and from the financial sector to the real economy (systemic risk). ${ }^{20}$ Corrective taxes are part of wider array of policy instruments, including banking supervision, the application of capital requirements and fees, typically to pay for deposit insurance, as well as general regulation of financial markets by both governments and financial intermediaries themselves (see Chapter 11). ${ }^{21}$

Proposals to utilize taxes to correct for moral hazard and externalities are relatively new and apply both to economic agents and to financial market transactions. They aim to correct different distortions but appear to have the overarching aim of reducing the importance of the financial sector (see Chapter 6). It is inevitable that such taxes may also provide important sources of revenue, and the border line between revenue collection and corrective objectives often tends to be blurred. ${ }^{22}$ Moreover, in this discussion the difference between 'user charges', capital requirements, and taxes is very tenuous, and typical revenue authorities may not ultimately be responsible for administering the 'tax'. Hence the role of corrective taxes cannot be divorced from other measures aimed at safeguarding the soundness and resilience of the financial system.

\subsubsection{PRUDENTIAL REGULATION}

Prudential regulation of financial institutions takes the form, on the one hand, of solvency or capital adequacy ratios, which aim through the imposition of minimum standards to prevent the failure of individual institutions

19 A solution to this issue would be to allow loss carry forwards at the pre-ACE statutory rate.

20 There are also many positive externalities resulting from well-functioning financial markets (Levine 1997).

21 For example, futures markets have a number of features, such as collateral arrangements (margin), that are meant to safeguard the clearing house against a default by one of its members.

22 This close connection was already apparent in the previous discussion regarding ACE. 
(Chapter 11). On the other hand, prudential regulation aims to prevent liquidity crises resulting from the mismatch between banks' assets and liabilities and the potential risk of bank runs; the most common instruments used for this purpose are implicit or explicit deposit guarantees, especially for retail deposits. Demand deposits are explicitly or implicitly insured in most countries up to some threshold amount per individual (or deposit account). In most cases, the capital in these deposit insurance funds is the reserve built up over time through the collection of insurance premiums from banks that receive the benefits of deposit insurance.

While the appropriate form of deposit insurance schemes has been the subject of long-standing debates, the financial crisis has highlighted the need for deposit insurance-related reforms that would improve the efficiency of the financial system. As shown by Pennacchi (2009) and Acharya et al. (2010), FDIC deposit insurance premiums in the USA have either been risk insensitive or relied only on individual bank failure risk. They have never focused on systematic and systemic risk.

Pennacchi (2009) argues that fair market deposit insurance premiums should contain a systematic risk premium in addition to expected losses. ${ }^{23}$ If a deposit insurer does not include a charge for systematic risk when setting premiums, insured deposits will be subsidized relative to other forms of uninsured funding. This leads to financial system distortions that excessively expand deposit insurance and encourage banks to make investments that have extreme systematic risk. ${ }^{24}$

\subsubsection{SYSTEMIC RISK: TAXES, USER CHARGES, CAPITAL REQUIREMENTS}

However, the charge for systematic risk that accounts only for the skewness in bank failure distribution is not sufficient to internalize the external effects of a single bank failure over the financial and economic system as a whole (systemic risk $^{25}$ ). As argued by Acharya et al. (2010) and Hanson et al. (2011), when a bank with insured deposits fails, the deposit insurance fund takes over the bank and sells it either as a going concern or piecemeal. During periods of

23 Pennacchi (2009) reviews empirical evidence that firms' actual credit spreads on uninsured debt contain, in addition to an expected loss component, a significant systematic risk premium. Thus, these uninsured debt holders, who can be viewed investing in default-free debt along with underwriting debt insurance, earn average returns greater than a holder of only default-free debt.

24 Duffie et al. (2003) and Falkenheim and Pennacchi (2003) provide techniques for estimating fair deposit insurance rates for privately held banks.

${ }^{25}$ Systemic risk is a negative externality and is defined by the extent of propagation of an initial shock (failure of one institution) through the financial system. Systemic risk is sometimes described as a form of (financial) pollution. However, the analogy with environmental externalities is imperfect, since the amount of systemic risk is endogenous to the reaction function of the public sector. In the financial sector, the bigger the accident, the higher are the chances to be rescued.

This is an open access version of the publication distributed under the terms of the Creative Commons Attribution-NonCommercialNoDerivs licence (http://creativecommons.org/licenses/by-nc-nd/3.0/), which permits non-commercial reproduction and distribution of the work, in any medium, provided the original work is not altered or transformed in any way, and that the work is properly cited. For commercial re-use, please contact academic.permissions@oup.com 
widespread bank failure, it is difficult to sell failed banks at attractive prices because other banks are also experiencing financial constraints.

In particular, the failures of large banks lead to greater 'fire sale ${ }^{26}$ discounts (Shleifer and Vishny 2011). Acharya et al. (2010) note that this event may generate a significant pecuniary externality with adverse contagion-style effects on other banks and the real economy. As a consequence, the resolution of large banks is more costly for the deposit insurance regulator, because the liquidation of large banks entails both higher direct losses and higher indirect losses owing to contagion effects. This suggests that higher premiums per dollar of insured deposit should be charged to large banks compared with that for small banks.

Finally, forbearance during systemic crisis creates a moral hazard problem as banks have an incentive to herd and become interconnected to increases their chance of a bailout. To discourage banks from excessive correlation in their investments the incentive-efficient premium should be higher than the actuarially fair premium and should increase in systemic risk (Acharya et al. 2010).

To summarize, the 'user charges' that can be used to correct for distorted incentives and for externalities can be decomposed into two components. The first is akin to the FDIC insurance fee and should cover the expected cost of failure for each single institution, where the expected cost takes also into account systematic risk. The second component should measure the external cost of failure and should also discourage moral hazard because of the implicit insurance to institutions that are deemed to be 'too big to fail'. This second component would be essentially Pigouvian, aimed at making banks internalize the negative systemic effects of their behaviour. Various alternative proposals are currently being debated.

\subsubsection{FEES BASED ON THE COMPOSITION OF LIABILITIES}

The development of the 2008 financial crisis has confirmed that the scale and speed of liquidity runs are the primary causes of propagation. Banks that rely excessively on short-term uninsured funding contribute to 'fire sales' and to contagion effects (Hanson et al. 2011). Perotti and Suarez (2009) propose a system of liquidity risk charges for correcting the negative externalities caused by banks' excessive reliance on short-term, 'uninsured' funding. As Pigouvian taxes they would complement deposit insurance charges, without creating any explicit commitment to liquidity support. A unit of short-term funding should pay a tax proportional to its marginal contribution to a bank's contribution to systemic vulnerability. A general approach would require the estimation of the systemic contribution of many bank characteristics (Adrian and Brunnermeier 2008).

26 The liquidation of securities by financial intermediaries at the same time as competitors.

This is an open access version of the publication distributed under the terms of the Creative Commons Attribution-NonCommercialNoDerivs licence (http://creativecommons.org/licenses/by-nc-nd/3.0/), which permits non-commercial reproduction and distribution of the work, in any medium, provided the original work is not altered or transformed in any way, and that the work is properly cited. For commercial re-use, please contact academic.permissions@oup.com 
An alternative approach discussed by Weder Di Mauro (2010) proposes that the tax base should be composed of all liabilities, excluding insured deposits (since they are already insured) and capital. The tax rate should vary with the size of the externality. The degree of systemic relevance could be estimated based on a series of indicators, which would include measures of size, interconnectedness, and complexity. These indicators could then be compressed (with a simple average of the ranks) into a risk score. Each risk score would be assigned a tax rate.

The tax rate should be set at such a level to eliminate the implicit subsidy to systemic institutions. There are several approaches that would help establish at least a range for the value of the subsidy. Weder di Mauro (2010) suggests measuring the subsidy by comparing the cost of the funding of small and large institutions before and after the 'too systemic to fail policy' was officially established. The idea is that the tax rate should eliminate extra profitability resulting from being able to tap capital markets with a 'too-systemic-to-fail' guarantee (see also Drehmann and Tarashev 2011).

\subsubsection{Transaction taxes}

The introduction of a financial transaction tax (FTT) as a tool to stabilize financial markets and improve their functioning is one of the policy options that are being discussed for correcting potential market imperfection (Chapter 5 and Matheson 2010) In the most recent discussions on proposals for an FTT, it is argued that such tax could solve three problems at the same time:

1. stabilize the financial markets by reducing speculative and technical trading, especially in the derivatives market by increasing transaction costs;

2. raise substantial tax revenue while creating only small distortions in the real economy;

3. serve as a contribution of the financial sector to the financing of bailout costs caused by the financial crisis.

FTTs have existed for a long time in various guises and represent a significant source of revenue in many countries (especially in Latin America). Discussion of their use as an instrument to correct for 'distortions' in the financial markets, especially after economic downturns, started with Keynes's reflections (1936) on stock markets following the Great Depression. The idea of an FTT is also linked to the proposal of James Tobin on an international uniform tax on all spot currency conversions. Tobin $(1974,1978)$ argued that the increased mobility of private financial capital-especially after the end of the Bretton Woods system-might lead to excessive shifts of funds that create real

This is an open access version of the publication distributed under the terms of the Creative Commons Attribution-NonCommercialNoDerivs licence (http://creativecommons.org/licenses/by-nc-nd/3.0/), which permits non-commercial reproduction and distribution of the work, in any medium, provided the original work is not altered or transformed in any way, and that the work is properly cited. For commercial re-use, please contact academic.permissions@oup.com 
economic costs for national governments and economies. Tobin reasoned that the tax would increase the effectiveness of domestic monetary policy.

The proponents of an intervention argue that the tax could improve the functioning of financial markets by reducing speculative short-term activities, which they consider as a reason for price volatilities and price bubbles (Chapter 5 and Matheson 2010). It is argued that potentially harmful financial activities with a high amount of transactions per day would be reduced even by a very low tax rate, but long-run investments would not be distorted by such a low tax rate because of the low frequency of such transactions. Hence the debate on FTTs has generally narrowed down to the question of the influence that transaction costs on trade volume, and price volatility, and if they can serve as a corrective device to reduce the number of allegedly harmful short-term traders.

The theoretical literature does not provide clear-cut answers. The various empirical studies fail to detect a strong relationship between an increase in transaction costs (via either taxes or other means) and the functioning of markets. Most studies find that trade volume is reduced, but the effects on volatility and prices are less clear, even though results based on panel data and estimation approaches that better identify transaction cost effects seem to find unexpectedly a positive relationship between transaction costs and volatility.

As argued above, a general transaction tax is advocated not only as a means for correcting market failure, but also as an efficient way to raise revenue. Schulmeister, Schratzenstaller, and Picek (2008) estimate that in Europe revenues from an FTT at a rate of 0.01 per cent would lie between 0.59 per cent and 0.78 per cent of GDP, an amount roughly similar to the estimated loss in revenue that is due to the exemption of financial services from VAT. ${ }^{27} \mathrm{How}$ ever, as noted by Matheson (2010), the argument that an FTT would cause little distortion because it would be levied at a very low rate on a very broad base is not persuasive once account is taken of the potential incidence of the tax. A tax levied on transactions at one stage 'cascades' into prices at all further stages of production.

The international experience also shows that tax design is crucial both for the effect of the tax on the functioning of the market and for revenues (Chapter 5 and Matheson 2010).

Finally, as noted in Chapter 11, the setting of transaction taxes is affected by the nature of the political process, which can lead to outcomes that are far from the optimal level of tax rates.

27 They estimate a revenue loss from financial services VAT exemption of about $0.7 \%$ of GDP, assuming a share of the financial sector in overall value added of $3.5 \%$ and an average VAT rate of $20 \%$. 


\subsubsection{Redesigning the taxation of financial institutions}

The financial crisis has highlighted the distinctive features of the financial sector raising the issue of whether financial institutions deserve a special tax treatment because of the peculiar nature of their activities or whether their taxation should be subsumed under general principles applying to income and consumption taxation. Possible reforms can be grouped into two distinct sets: (1) piecemeal revisions of existing taxes or (2) more radical reform of the taxation of the financial sector.

\subsubsection{FINANCIAL AND TAX ACCOUNTING}

Despite the fact that banks are generally subjected to the same general tax provisions as non-financial companies, existing tax rules acknowledge the specific nature of their activities by allowing several differential tax treatments and exceptions to the rules that apply generally to business income. Banks are unique in that interest income and expenses represent the core of cash flows, depreciation allowances for fixed assets are relatively minimal, and the valuation of complex financial transactions (such as activities in the foreign exchange markets, trading in securities, and operations in derivative products) is recurrent. High degrees of leverage also typically characterize banking activity. The valuation of assets and liabilities is also subject to different criteria depending on whether the assets and liabilities are held in trading or investment portfolios. Trading portfolios are typically marked to market, but also investment portfolios are being increasingly subject to 'fair-value' rules.

The conformity of financial accounting and tax accounting (book-tax conformity) is of great importance for banks. Financial accounting standards and tax laws frequently provide specific, and often different, rules for how to report income for book and tax purposes, even though both income reports are based on the same underlying fundamental transactions.

\subsubsection{MARKING TO MARKET}

The taxation of gains (or losses) only when realized, rather than as they accrue, can create significant distortions, creating an incentive to defer the realization of gains and accelerate that of losses. Not surprisingly, marking gains and losses to market and treating them as current have gained in acceptance as a general policy principle. The principle also means that financial institutions are neutral in respect of transactions that involve simultaneous gains and losses such as wash sales.

There are some potential pitfalls in marking to market. Taxation on fair market value may induce the sale of assets to finance the accruing liability, though there is little sign that this has been a significant problem in the financial sector. Schizer (2000) has argued that the extent to which marking

This is an open access version of the publication distributed under the terms of the Creative Commons Attribution-NonCommercialNoDerivs licence (http://creativecommons.org/licenses/by-nc-nd/3.0/), which permits non-commercial reproduction and distribution of the work, in any medium, provided the original work is not altered or transformed in any way, and that the work is properly cited. For commercial re-use, please contact academic.permissions@oup.com 
to market has been used for tax purposes may have led dealers to become 'accommodation parties' for other taxpayers in transactions that artificially defer income for one party while accelerating losses for another. It has also been suggested that extensive use of marking to market in the taxation of financial institutions may increase the volatility of revenue.

\subsubsection{PROVISIONING FOR LOAN LOSSES}

The crisis has also drawn attention to difficulties in the tax treatment of loan losses (Chapters 6 and 8). Losses are an inevitable cost that banks incur in providing credit and are recognized as an expense for financial, regulatory, and tax purposes. The principal issues surrounding the treatment of loan losses concern the timing and manner in which expenses are recognized. These may differ depending on the different objectives pursued by auditors, regulators, and the tax authorities.

Three constraints affect the level of provisioning and the amount of write-offs that a bank may decide to make. First, company law lays down what banks are required to disclose in their balance sheets and profit and loss accounts. Secondly, supervisors are concerned to see that banks follow a prudent and responsible approach to making provisions. In the past, general reserves, which have not been earmarked, have been included in bank capital, whereas specific provisions have been excluded from such calculations. Finally, the tax authorities set out specific guidelines as to what they regard as allowable deductions against profits. One of the problems in understanding provisioning and its possible effects is that each of these various types of valuation may differ markedly within a single country.

For financial and regulatory accounting purposes, banks may set aside either specific or general provisions to reflect the possible deterioration in the value of their assets. In the first instance it falls to the banks to decide what they consider to be the correct value of their assets and, consequently, to choose the appropriate level of provisioning that should be made. Specific provisions (or reserves) are made against clearly identifiable problems, which can be expected to occur in connection with the affairs of a particular customer or group of customers. General provisions permit a blanket cover against all possible expected future as well as current losses. For financial accounting purposes (IAS 2002), general provisions relating to losses that are present in existing portfolios of loans but have not been identified specifically are treated as an expense. However, provisions relating to future losses are accounted as appropriations of reserves.

Provisioning is materially assisted by the possibility of an offset against tax for the annual charge that is made in the profit and loss account. Decisions on tax deductions are made by the fiscal authorities and need not be consistent with regulatory and supervisory requirements.

This is an open access version of the publication distributed under the terms of the Creative Commons Attribution-NonCommercialNoDerivs licence (http://creativecommons.org/licenses/by-nc-nd/3.0/), which permits non-commercial reproduction and distribution of the work, in any medium, provided the original work is not altered or transformed in any way, and that the work is properly cited. For commercial re-use, please contact academic.permissions@oup.com 
Tax accounting practices do not generally conform to financial accounting practices and prudential regulation. The broad objective of both tax and financial accounting is measuring income. However, the objective of financial and especially prudential accounting is conservatism-that is, to delay income and anticipate expenses. Tax accounting is designed to ensure that income is not understated. Nonconformity gives rise to timing differences.

The tax treatment varies widely across countries. There are broadly two approaches. The so-called charge-off method recognizes a tax deduction only when loans become worthless. Countries that follow this approach are the United States, Australia, Korea, Malaysia, and the Philippines. The tax authorities in most other countries for which information is available tend to allow specific provisions but differ widely in terms of the degree of conformity with financial and accounting for loan losses, the required evidence regarding the deterioration in asset values, and in some instances the maximum amount of loan losses allowed in a single year. The most favourable countries from this standpoint appear to be France, Germany, and the Netherlands. Finally a few countries (for example, Germany and Singapore) also allow general provisions (as a percentage of qualifying loans), but these are subject to limitations.

Provisioning rules can have several effects on the international activities of banks of different nationalities and the allocation of banks' assets across financial centres. First, banks may decide to allocate their loans in centres where provisioning is most generous. Second, generous provisioning policy can be an implicit subsidy to banking relative to other forms of financial intermediation and can affect interest rates charged on differing forms of financing. Generous provisioning may allow certain financial institutions to shield a sizeable part of their income from tax and thereby obtain a competitive advantage. Third, where accounting and fiscal definitions of income do not broadly coincide, banks may be unwilling to set aside an appropriate level of provisions unless the tax authorities permit tax deductibility. Finally, different tax-provisioning policies can affect the character of risk taking by banks and the distribution of their profits over time. The treatment of claims on problem debtor countries was one area where differing tax provisioning rules led banks to adopt diverse behaviour. $^{28}$ In those countries where tax provisioning for such claims was limited, there was an incentive for banks to realize losses outright, through

\footnotetext{
28 One of the clearest examples of the subtle tax distinctions between various nationality groups of banks occurred at the time of the Mexican financing package (1990) put together under the Brady debt relief initiative. Under that scheme banks agreed to convert their rescheduled credits (amounting to about 85\% of Mexico's external debt) into bonds at a reduced face value (65\%) and market interest rates (LIBOR $+13 / 16)$, into bonds having the same face value but a reduced and fixed interest rate (6.25\%), or to provide new loans equal to $25 \%$ of banks' exposure. A survey of the major banks involved indicated that tax considerations together with regulatory and business strategies with Mexico were the major factor determining the decision of which instrument to choose (Hay and Paul 1991).
}

This is an open access version of the publication distributed under the terms of the Creative Commons Attribution-NonCommercialNoDerivs licence (http://creativecommons.org/licenses/by-nc-nd/3.0/), which permits non-commercial reproduction and distribution of the work, in any medium, provided the original work is not altered or transformed in any way, and that the work is properly cited. For commercial re-use, please contact academic.permissions@oup.com 
sales of their loans in secondary markets or by establishing losses through specially authorized loan sales. ${ }^{29}$ By contrast, the possibility of tax deductions for provisions encouraged banks in some countries to allocate large amounts of their capital to less-developed countries (LDCs), possibly inhibiting the disposal of their assets on the secondary market for country loans. ${ }^{30}$

Though there are important overlaps, the objectives of tax policy need to be recognized as distinct from those of regulatory and accounting practices if all are to be well aligned with one another. Tax policy towards financial decisions is appropriately charged with raising revenue without creating excessive distortions. Any remaining non-tax distortions to financial decisions are then best left to regulatory policy. Clearly there are monitoring and compliance advantages in applying common definitions and concepts for tax and accounting purposes, and there has been substantive discussion of possible corporate governance advantages in closely aligning tax and book profits. But the ideal tax base is not necessarily the most accurate measure of current income. There are, for instance, and as will be seen, potential advantages in allowing full expensing of investment for tax purpose. And even where, or if, marking to market were felt to be inappropriate for financial accounting purposes, a strong tax rationale for doing so-as much to avoid distortions as it is to fine-tune the measurement of income or wealth-would remain.

Issues concerning the tax treatment of provisions for bad loans would be raised by moving towards dynamic provisioning. Dynamic provisioning would include a systematic and mandatory counter-cyclical element of general provisioning, raising questions as to their tax treatment. To the extent that dynamic provisioning would be analogous to depreciation allowances for physical assets that reflect their expected reduction in value (or sometimes more, if accelerated depreciation is allowed), deductibility could be argued to be appropriate. Other approaches would be appropriate if the CIT were to be fundamentally reformed.

\subsubsection{Other issues}

\subsubsection{REVISITING HARD-TO-TAX AREAS}

More recent discussions appear to have taken the direction of suggesting that financial institutions and market should be subjected to special tax treatment.

\footnotetext{
${ }^{29}$ In the United States the value of a tax deduction depends in part on whether it is applied against domestic or foreign source income. Since many banks have only limited potential liabilities in respect of foreign source income by virtue of the tax credits from double taxation relief, tax deductions against foreign source income reduce the value of these tax credits.

${ }^{30}$ In Japan, where tax deductibility for provisions against loans to problem debtor countries has until recently been limited, losses realized on loan sales in the secondary market have generally not been recognized. However, in some instances these restrictions have been waived and Japanese banks have been able to sell exissssting loans to a factoring company set up jointly by the major banks.
} 
While many of the proposals overlap with the topics already covered in the previous sections, mention should also be made of proposals to change the VAT status of financial institutions. These proposals that have been suggested only informally ${ }^{31}$ may be seen as an alternative to corrective taxes, as a manner to reduce the excessive size of the sector as well as a means to raise revenues in a relatively efficient way by reaping the rents of the sector.

\subsubsection{THE TREATMENT OF TAX HAVENS}

Tax havens have been the object of intense scrutiny in the 2000s. The focus has been on both the lax tax regimes of these jurisdictions as well as the often weak regulatory framework particularly in respect of hedge funds and various types of SPVs. Often, the centres are said to facilitate criminal activities, since some centres do not comply with the Financial Action Task Force (FATF) rules in respect of anti-money laundering regulations.

The crisis has coincided with a step-up in a generalized clampdown on undeclared offshore accounts, which had been building up over the previous decade. A number of very publicized episodes have involved the transfer to the tax authorities of the names of holders of offshore accounts. Individual financial institutions have been held responsible for encouraging unlawful activity and faced significant fines. The authorities appear to have exploited the wave of anti-bank feeling to extend their extra-territorial powers and step up international cooperation to push through further anti-evasion measures.

A different set of issues is raised by the exploitation of regulatory and tax arbitrage involving offshore centres. The use of offshore centres to create corporate or other types of vehicle is often driven by the absence of adequate onshore forms of intermediation, particularly for foreign investors. This may be due to delays in creating enabling legislation and uncertainty in respect of the nature of domestic legislation.

\subsection{The tax policy and the macroeconomy}

During the crisis the governments implemented several measures to avoid the collapse of the financial system and to alleviate the economic consequences of the crisis on the real economy. The direct effect of these policy measures has been a sharp deterioration of public budgets. In the EU the average publicsector deficits increased from 0.9 per cent of GDP in 2007 to 6.8 per cent in 2010 and over the same period the public sector debt jumped from below 60 to above 80 per cent of GDP (Chapter 5).

31 This suggestion appears implicitly in IMF (2009a).

This is an open access version of the publication distributed under the terms of the Creative Commons Attribution-NonCommercialNoDerivs licence (http://creativecommons.org/licenses/by-nc-nd/3.0/), which permits non-commercial reproduction and distribution of the work, in any medium, provided the original work is not altered or transformed in any way, and that the work is properly cited. For commercial re-use, please contact academic.permissions@oup.com 
Government debt management and fiscal consolidation will certainly remain crucial issues in the public policy debate for several years. In Chapter 9 McCauley and Ueda notice that government debt management is often discussed with reference to the question of whether central banks should proceed to extraordinary buying of government bonds. There are other relevant issues, such as how treasury debt management can contribute to maintaining the growth of bank assets, lowering the long-term bond yields or reducing net government interest payments, which are rarely analysed, despite the relevance they have in the post-crisis scenario. Based on the experience of the United States in the 1930s and Japan in the 2000s, McCauley and Ueda suggest that governments may indeed benefit from issuing long-term debt with interest rates tied to short-term bill rates in the confidence that monetary policy will keep yields low. As long as short-term rates remain low, treasuries will benefit from interest cost savings. When the economic activity quickens and interest rates rise again, they will benefit from higher taxes in compensation for higher servicing costs.

Chapter 10 addresses the crucial question of whether fiscal consolidation may have a contractionary or expansionary effect. According to the conventional 'Keynesian' approach, a public deficit reduction, achieved either through a cut in government expenditure or through an increase in taxes, brings about a decline in aggregate demand and depresses the rate of growth of GDP. Fiscal consolidation may curb the recovery with the risk of pushing the economy back into recession. In recent years the Keynesian view has been challenged by several papers on both theoretical and empirical grounds. Bilicka et al. in Chapter 10 present a survey of the theoretical literature and a critical evaluation of the empirical evidence. They identify several factors that seem to increase the probability of a fiscal consolidation being expansionary and use them to attempt an evaluation of the possible impact of UK fiscal consolidation announced in 2010. However, the authors highlight a number of weakness in the empirical literature, which include the lack of very clear identification of both fiscal consolidations episodes and expansionary effects.

\subsection{Conclusions}

While there is little conclusive evidence that the tax system played a major role in triggering the tax crisis, there is growing support for making taxes play a prominent role in policy responses. A number of special taxes have been introduced and proposed to recover the cost of the 'bailout'. These have involved both special taxes on financial institutions as well as taxes on bonuses. The revenues of these special taxes have been quite significant, but the ultimate

This is an open access version of the publication distributed under the terms of the Creative Commons Attribution-NonCommercialNoDerivs licence (http://creativecommons.org/licenses/by-nc-nd/3.0/), which permits non-commercial reproduction and distribution of the work, in any medium, provided the original work is not altered or transformed in any way, and that the work is properly cited. For commercial re-use, please contact academic.permissions@oup.com 
incidence of these measures remains uncertain. It is also unclear whether these measures will continue in the future.

The ongoing debate has also highlighted that taxation may be used as a corrective instrument to complement prudential regulation of the banking sector. Some corrective tax proposals aim to curtail activity in the financial sector ('Tobin taxes'), on the grounds that a large number of transactions are either speculative or of no social use. No international consensus has emerged to date as to the most appropriate approach. Without some of global coordination, such measures would inevitably create competitive distortions across countries and market segments, as suggested by numerous past experiences.

The crisis has also drawn attention to a number of well-known weaknesses in the taxation of the banking sector, particularly in respect of loan loss provisioning, the relationship between financial and tax accounting, markto-market accounting, and value-added taxation. These issues are by no means new. The crisis has added saliency to finding longer-term solutions. Unfortunately, after renewed attention to these questions, the political climate no longer appears propitious to address the needed structural reforms.

This is an open access version of the publication distributed under the terms of the Creative Commons Attribution-NonCommercialNoDerivs licence (http://creativecommons.org/licenses/by-nc-nd/3.0/), which permits non-commercial reproduction and distribution of the work, in any medium, provided the original work is not altered or transformed in any way, and that the work is properly cited. For commercial re-use, please contact academic.permissions@oup.com 


\title{
Culprit, Accomplice, or Bystander? Tax Policy and the Shaping of the Crisis
}

\author{
Michael Keen, Alexander Klemm, and Victoria Perry
}

\subsection{Introduction}

This chapter considers channels by which tax distortions are likely to have contributed to excessive leveraging and other financial market problems that came to the forefront during the financial crisis, and what this may mean for sensible directions of future tax reform.

This is an ambitious task. Economists are likely to be unpacking the financial crisis for years to come, and this may well lead to better understanding-relative, it must be said, to quite a low base-of the impact of taxation on the performance of modern financial markets. The discussion here ${ }^{1}$ is simply a first pass on the issue in the wake of the crisis: a health check on the most obvious possible channels of effect. Several such come to mind and are examined here. These include the corporate tax bias towards the use of debt finance (considered in Section 2.2), tax distortions in housing markets (Section 2.3), and a range of effects through the development of complex financial instruments and structures, including extensive use of low-tax jurisdictions, ${ }^{2}$ and on risk taking,

This is a revised version of IMF (2009a), previously published as Keen, Klemm, and Perry (2010). We have benefited greatly from the comments and advice of Alan Auerbach, Carlo Cottarelli, Geoffrey Lloyd, Gareth Myles, John Norregaard, Jeffrey Owens, Joel Slemrod, and Peter Birch Sørensen, as well as those of many colleagues at the IMF and seminar audiences in Milan and Toronto. Views expressed are ours alone, and should not be attributed to the International Monetary Fund, its Executive Board, or its management.

1 This chapter is based on IMF (2009a), which was prepared, in early 2009, for the Executive Directors of the IMF. An account of their views is at <http://www.imf.org/external/np/sec/pn/2009/ pn0976.htm $>$. For other discussions of tax issues raised by the crisis, see Lloyd in Chapter 8 and Slemrod (2009).

${ }^{2}$ The terms 'tax haven' and 'low-tax jurisdiction' are not used here synonymously: the former having come to be associated with illegal concealment of income, we use the latter term to

This is an open access version of the publication distributed under the terms of the Creative Commons Attribution-NonCommercialNoDerivs licence (http://creativecommons.org/licenses/by-nc-nd/3.0/), which permits non-commercial reproduction and distribution of the work, in any medium, provided the original work is not altered or transformed in any way, and that the work is properly cited. For commercial re-use, please contact academic.permissions@oup.com 
including through executive compensation (Section 2.4). The chapter also considers the activist use of tax policy to impact on asset prices (Section 2.5).

A central conclusion is that tax distortions do not appear to have triggered the crisis: there are, for instance, no obvious tax changes that explain rapid increases in debt in some parts of affected economies in recent years. But tax distortions may have made the crisis more painful, by, for example, leading to levels of debt higher than would otherwise have been the case. Early alleviation of these distortions could have helped offset the factors that over the last few years led to higher leverage and other financial market problems-and would reduce exposure to future crises. Though not a culprit in the sense of having been a proximate cause of the crisis, tax policy was also no innocent bystander: an accomplice for sure, if an unwilling one.

The chapter describes that complicity and broad lessons for structural tax reform, to be undertaken once more pressing concerns have subsided, arguing for firmer action on long-standing (and deep-rooted) distortions. These distortions have mostly long been recognized, but few countries have acted on them decisively. There remains much to learn, but one lesson of the crisis may be that the benefits from mitigating them are far greater than previously thought.

The benchmark for the analysis is taken to be neutrality in the tax treatment of alternative financial arrangements. Financial markets are marked by extensive informational asymmetries and other imperfections, so there may in principle be scope for corrective taxation. Some would argue, for example, that non-tax factors create an inherent tendency towards excessive leverage and that the tax system ought, therefore, actively to disfavour debt. But there is no consensus on the precise nature and magnitude of such inefficiencies, or on the relative merits of tax and regulatory responses in addressing them. Neutrality of tax arrangements thus remains a core benchmark for policy evaluation and design in this, as in other areas of tax design. Of course, neutrality and efficiency considerations in tax design need to be tempered by distributional concerns, administrative and compliance capacity, and other considerations likely to vary substantially across countries. The importance of neutrality is as a benchmark relative to which differential treatments may be evaluated, providing a check on special pleading and inadvertent side effects (from, for example, the use of tax measures to pursue objectives for which spending measures are better targeted).

highlight the perfectly legal avoidance opportunities that low tax rates (and/or narrow bases) may create: see Section 2.4.2. 


\subsection{Debt bias and other key tax distortions to corporate finance}

Tax is one of many determinants of corporate financial policies. In a world of complete markets, perfect information, and no taxation, the parcelling of returns between equity and debt claims has no real consequence. Informational imperfections, however, introduce considerations that can lead to a determinate choice. Issuing debt, for instance, can help constrain managers in their self-interested use of free cash flow (though there may be other bettertargeted incentive structures to achieve that). But tax considerations are also critical: with interest payments deductible against the corporate income tax (CIT) while equity returns are not, firms have an incentive to issue debt until the expected tax benefit is just offset by the increase in expected bankruptcy costs. While the focus in what follows is on the debt bias this can create, taxation can distort other margins of financial choice too-such as whether and when to realize capital gains or losses - and some of the issues this creates are also considered.

\subsubsection{Assessing tax distortions to financial policies}

The heart of the issue is the almost ubiquitous practice of allowing interest payments, but not the cost of equity finance, as a deduction against CIT. ${ }^{3}$ Leveraged buyouts (LBOs) are a prominent instance of the use of interest deductibility, but the potential tax incentive to debt finance applies more generally. The consequent bias towards debt finance is greater the higher is the effective CIT rate, since this means that more tax is saved as a result of the deduction. It will thus be lower, for example, for firms that are, or expect to be, in a tax loss position: since losses are not carried forward with interest, any future reduction in tax liabilities has lower present value (PV) than an immediate deduction.

Levels of corporate indebtedness appear to have increased in recent years. In the UK, bank lending to non-financial companies increased from the mid-1990s from around 20 to nearly 40 per cent of GDP in 2007 (Bank of England 2008), and the aggregate ratio of debt to the replacement value of capital for non-financial corporations rose from around 30 per cent at the turn of the century to about 50 per cent in 2006 (Bank of England 2007). In the eurozone, the ratio of nonfinancial corporate debt to GDP rose from around 50 per cent to 66 per cent between 1998 and 2006 (ECB 2006). Debt-equity ratios appear to have been more stable in the USA - where they also tend, historically, to be lower than in other

\footnotetext{
3 The original rationale for this was a legalistic one, the view being that the corporation is so entwined with its shareholders that payments to them should not be deductible, whereas payments on debt are to true third parties and so should be. In economic terms, of course, both kinds of payment represent a return to capital, and it is their combined treatment at corporate and personal levels that matters. Shaviro (2009a) discusses further.
}

This is an open access version of the publication distributed under the terms of the Creative Commons Attribution-NonCommercialNoDerivs licence (http://creativecommons.org/licenses/by-nc-nd/3.0/), which permits non-commercial reproduction and distribution of the work, in any medium, provided the original work is not altered or transformed in any way, and that the work is properly cited. For commercial re-use, please contact academic.permissions@oup.com 
countries ${ }^{4}$ - at around 40 per cent since 2003 (Board of Governors of the Federal Reserve System 2008). Many financial institutions, of course, took on very high leverage prior to the crisis, with investment banks, for example, commonly operating with equity only 3-4 per cent of assets (and in some cases much lower).

LBOs, marked by especially heavy use of interest deductions, increased substantially up to mid-2007. Post-acquisition interest deductions under these schemes can be so large as to eliminate CIT payments for several years. There is also likely to have been an indirect effect in encouraging other firms to increase their borrowing to defend against possible LBOs. Many LBOs cross national borders, moreover, and so are characterized by complex structuring intended to minimize tax liability and in some cases exploit opportunities for 'double dipping'. ${ }^{5}$ Between 2003 and 2006, the amount raised by private equity funds, ${ }^{6}$ which arrange most LBOs, increased about fivefold, to around $\$ 230$ billion (UK House of Commons, Treasury Committee 2007); and between 2000 and 2007 their share of merger and acquisition activity in the USA rose from 3 to nearly 30 per cent (US Government Accountability Office 2008).

Personal taxes on interest, dividends, and capital gains may also affect the choice between debt and equity finance (with a distinction, in the latter case, between finance by retaining earnings and by selling new shares). Box 2.1 provides a detailed discussion of the tax factors affection financing decisions. ${ }^{7}$ The key conclusions are as follows:

- The taxation of interest income at personal level offsets to some degree the tax advantage at corporate level.

- Finance by retained earnings, since it leads to an appreciation of the share price, is less attractive the higher is the effective rate of capital gains tax (CGT). Commonly, however, the effective CGT rate is low, largely because gains are typically taxed when they are realized rather than as they accrue, so that the tax liability can be reduced in present value by deferring realization (the 'lock-in' effect). ${ }^{8}$

\footnotetext{
${ }^{4}$ Davis and Stone (2004), for example, report a ratio of debt to the market value of equity ratio of $28 \%$ for the non-financial corporate sector in the USA in 1999, relative to a G7 median of 59\%. Reflecting the magnitude of corporate liabilities, however, the ratio of corporate debt to GDP in the USA, at $46 \%$, is close to the G7 median of 0.50 .

5 That is, taking multiple interest deductions: by, for instance, borrowing in a (high-tax) country to acquire equity in a subsidiary located in a low-tax jurisdiction that then lends to another subsidiary in a third country (see Mintz 2004).

6 Private equity and hedge funds are partnerships, so are taxed not at entity level but by 'flowthrough' to the partners (raising issues related to the tax treatment of the general managers that are discussed in Section 2.4.4). Hedge funds typically do not push debt down to corporations, so this leverage issue does not arise.

7 For a more complete treatment, see, e.g., Auerbach (2002).

8 In addition, capital gains are often charged at a lower statutory rate the longer assets are held (as in the USA, and until 2008 in the UK and Germany); and, in the USA, CGT can be avoided by holding assets until death.
}

This is an open access version of the publication distributed under the terms of the Creative Commons Attribution-NonCommercialNoDerivs licence (http://creativecommons.org/licenses/by-nc-nd/3.0/), which permits non-commercial reproduction and distribution of the work, in any medium, provided the original work is not altered or transformed in any way, and that the work is properly cited. For commercial re-use, please contact academic.permissions@oup.com 


\section{Box 2.1. TAXATION AND THE COST OF CAPITAL}

The after-corporate tax rate of return $\rho$ that a company needs to earn in order to generate the post-tax return required by those investing in it, when the gross interest rate is $R$, dependson the marginal source of finance, as follows:

Debt finance. Interest deductibility means that to pay lenders interest of $R$ the company need earn only an after-CIT return of

$$
\rho=\left(1-T_{C}\right) R
$$

where $T_{C}$ is the rate of CIT.

Retention finance. As shown in the appendix to this chapter, the company needs to earn

$$
\rho=\left(\frac{1-T_{R}}{1-T_{G}}\right) R
$$

where $T_{R}$ is the shareholder's personal tax rate on interest income (relevant because their alternative to leaving money in the firm is to lend it out) and $T_{G}$ the effective rate of CGT (relevant because of the gain that retaining earnings will generate).

New equity finance. As also shown in the appendix, in this case:

$$
\rho=\left(\frac{1-T_{R}}{1-T_{D}}\right) R
$$

where $T_{D}$ is the rate of tax on dividends at personal level.

In practice, a key margin of choice is that between borrowing and retaining earnings. Comparing (1.1) and (1.2), borrowing will be tax-preferred to retention if $1-T_{C}<\left(1-T_{R}\right) /\left(1-T_{G}\right)$, or

$$
T_{C}>\left(T_{R}-T_{G}\right) /\left(1-T_{G}\right) .
$$

For instance, at a CIT rate of 30\%, and with interest taxed at $40 \%$ and CGT at $20 \%$, debt is preferred. Retentions would be preferred, however, if gains were taxed at $14 \%$ or less.

- Dividend taxation raises the cost of new equity finance. It does not in principle affect that of retention finance: in a choice between (1) retaining current profits and distributing them later, and (2) distributing them now, the dividend tax has to be paid in either case, and so-though it reduces shareholders' net income-does not affect the relative attractions of the two. The dividend tax matters for new equity finance, however, since the funds to be invested are not already trapped within the corporation. Many countries allow some integration of personal and corporate taxes to mitigate this effect, by providing an explicit credit (as under imputation systems $)^{9}$ or charging a lower rate than is applied to interest income.

\footnotetext{
9 These were common in Europe, but have become less so in recent years, partly because of complexities in dealing with cross-border investments but also as decisions of the European Court
} 
While high-income individuals may prefer equity finance, for others-including tax-exempt institutions and non-residents-the corporate-level tax advantage to debt dominates. Tax-exempt investors-pension funds, charitable foundations, and, in many cases, sovereign wealth funds ${ }^{10}$ - clearly prefer debt finance: for them indeed there is a clear arbitrage gain in lending to tax-paying corporations and taking the interest untaxed. In addition, for non-resident investors, not liable to domestic personal taxes, the deductibility of debt finance is critical. Tax exempts are quantitatively important. In the UK, pension funds and insurance companies held around 30 per cent of all equities in 2006, and non-residents-probably subject only to withholding taxes-held 40 per cent. Direct holdings by resident individuals, in contrast, were only 13 per cent. Some put the comparable figure for tax-exempt equity holdings in the USA at around 50 per cent. The scale and active management of the tax exempts may give their tax interests heavy weight in corporate financial decisions.

These distortions ${ }^{11}$ create advantages to the use of debt measurable in hundreds of basis points. Table 2.1 shows, for G7 members, the costs of the three sources of corporate finance in 1990 and 2008; the upper panel relates to investors facing top marginal tax rates and the lower to tax-exempt investors-the two extremes. It shows the proportion of the gross market interest rate available to investors that a company needed to earn, after CIT, to meet the after-tax return required by those investors. At a 10 per cent interest rate, for instance, in 1990 a Japanese corporation needed to earn 6.25 per cent after CIT to finance borrowing (if its marginal shareholder paid at the highest marginal rate) but 8.42 per cent on retained earnings. Even for top-rate taxpayers, debt is cheaper than new equity finance in almost all cases, and, except in Canada, Germany, and the UK, it was cheaper than retention finance too. For tax-exempt investors, of course, debt is always tax preferred.

Table 2.1 also suggests that the tax advantage to debt finance has in most cases fallen since 1990 . The trend reduction in statutory CIT rates-the

of Justice have suggested that the Community's non-discrimination rules require member states to provide credit for CIT paid in other member states. Australia and New Zealand retain full imputation, and Canada partial.

${ }^{10}$ While practice varies, sovereign wealth funds are generally exempted on their passive investments.

${ }^{11}$ Analyses of the kind above leave unclear how equilibrium is reached in financial markets, since incentives for tax arbitrage-borrowing infinitely large amounts to pay infinitely large dividends, for example-will remain unless tax rates happen to meet particular 'knife-edge' conditions for all investors. Elements of an answer (which also revolve around the nature of any equilibrium, given, for instance, the likely non-unanimity of shareholders with different tax positions as to the best policy for the firm to pursue) include non-linearities in marginal tax rates (progressivity of the personal tax as stressed in M. H. Miller (1977), and the effective rate of corporate tax falling as more debt is issued, for example), heterogeneity of risk attitudes across investors, and legal and other constraints on short-selling (analysed, e.g., in Auerbach and King 1982).

This is an open access version of the publication distributed under the terms of the Creative Commons Attribution-NonCommercialNoDerivs licence (http://creativecommons.org/licenses/by-nc-nd/3.0/), which permits non-commercial reproduction and distribution of the work, in any medium, provided the original work is not altered or transformed in any way, and that the work is properly cited. For commercial re-use, please contact academic.permissions@oup.com 
Table 2.1. Required post-CIT rates of return, 1990 and 2008 (in \% of the interest rate)

\begin{tabular}{|c|c|c|c|c|c|c|}
\hline \multirow[t]{2}{*}{ Countries } & \multicolumn{3}{|c|}{1990} & \multicolumn{3}{|c|}{2008} \\
\hline & Debt & $\begin{array}{l}\text { Retained } \\
\text { earnings }\end{array}$ & $\begin{array}{c}\text { New } \\
\text { equity }\end{array}$ & Debt & $\begin{array}{l}\text { Retained } \\
\text { earnings }\end{array}$ & $\begin{array}{l}\text { New } \\
\text { equity }\end{array}$ \\
\hline & \multicolumn{6}{|c|}{ Top-rate personal investor } \\
\hline Canada & 62.0 & 58.5 & 78.5 & 62.0 & 56.9 & 70.5 \\
\hline France & 63.0 & 45.0 & 66.7 & 66.7 & 76.1 & 100.0 \\
\hline Germany & 64.0 & 47.0 & 64.0 & 75.0 & 55.0 & 71.0 \\
\hline Italy & 64.0 & 70.0 & 82.4 & 72.5 & 75.4 & 83.4 \\
\hline Japan & 62.5 & 84.2 & 100.0 & 70.0 & 84.2 & 88.9 \\
\hline UK & 65.0 & 66.7 & 75.0 & 72.0 & 62.8 & 80.0 \\
\hline \multirow[t]{2}{*}{$\mathrm{USA}^{\mathrm{a}}$} & 66.0 & 77.4 & 100.0 & 65.0 & 67.5 & 76.5 \\
\hline & \multicolumn{6}{|c|}{ Tax-exempt investor } \\
\hline Canada & 62.0 & 100.0 & 100.0 & 62.0 & 100.0 & 100.0 \\
\hline France & 63.0 & 100.0 & 100.0 & 66.7 & 100.0 & 100.0 \\
\hline Germany & 64.0 & 100.0 & 100.0 & 75.0 & 100.0 & 100.0 \\
\hline Italy & 64.0 & 100.0 & 100.0 & 72.5 & 100.0 & 100.0 \\
\hline Japan & 62.5 & 100.0 & 100.0 & 70.0 & 100.0 & 100.0 \\
\hline UK & 65.0 & 100.0 & 100.0 & 72.0 & 100.0 & 100.0 \\
\hline$U_{S A}{ }^{a}$ & 66.0 & 100.0 & 100.0 & 65.0 & 100.0 & 100.0 \\
\hline
\end{tabular}

${ }^{a}$ Federal taxes only.

Source: Authors' calculation.

(weighted) OECD average has fallen by nine percentage points since 1990has raised the cost of debt finance. Changes in personal tax rates, however, have had more mixed effects, and the overall impact for top-rate taxpayers varies across countries: in both the UK and the USA, the relative tax advantage of debt for top-rate taxpayers has been reduced; in France it has increased. While developments in the tax advantage to debt in itself are thus mixed, the increasing importance of tax exempts-for which the tax advantage of debt, though it has fallen, remains substantial-and the growth in the use of complex financial arrangements, including through low-tax jurisdictions, may well have meant more aggressive exploitation of those tax incentives to high leverage.

The empirical evidence suggests that tax distortions have caused leverage to be substantially higher than it would have been under a neutral tax system. Surveying the empirical literature, Weichenrieder and Klautke (2008) conclude that a 10-point increase in the CIT rate increases the debt-asset ratio by 1.4 to 4.6 points. As a rough order of magnitude, the debt bias from a CIT at 20 per cent (ignoring personal taxes) would then be to increase a debt-equity ratio that would otherwise be 40 per cent, up to between 45 and 60 per cent. The effect may thus be far from negligible.

Significant tax policy effects on leverage have been found in studies differing in country coverage and methodology. For the USA, MacKie-Mason (1990)

This is an open access version of the publication distributed under the terms of the Creative Commons Attribution-NonCommercialNoDerivs licence (http://creativecommons.org/licenses/by-nc-nd/3.0/), which permits non-commercial reproduction and distribution of the work, in any medium, provided the original work is not altered or transformed in any way, and that the work is properly cited. For commercial re-use, please contact academic.permissions@oup.com 
finds that, as the arguments above imply, the probability of issuing debt is comparatively low for firms with large losses carried forward and for unprofitable firms with large investment tax credits. Recent work on a panel of European medium-sized enterprises (Cheng and Green 2008) finds that tax policy has a significant impact on debt ratios. Reviewing the evidence, Graham (2003) comes to the same conclusion, while Auerbach (2002) also reads it as confirming an impact at firm level. Tax effects on the debt-equity ratios of subsidiaries of multinationals are particularly strong. For US multinationals, Desai et al. (2004) find that leverage is higher in high-tax countries: a 10 per cent increase in the tax rate boosts the debt-asset ratio by 2.6 per cent. Very similar results have been obtained for European multinationals (Mintz and Weichenrieder 2005; Büttner et al. 2006; Huizinga et al. 2008). At a more aggregate level, Devereux et al. (2006) note that the proportion of inward direct investment taking the form of debt is greater the higher the statutory CIT rate.

Little is known, however, of the welfare costs of these distortions. Weichenrieder and Klautke (2008) estimate a deadweight loss from tax distortions to financial decisions of 0.05-0.15 per cent of invested capital (at an interest rate of 5 per cent). This, though, reflects only the loss relative to what would otherwise be the firm's optimal financing choice, so ignores any consequences external to the firm itself. Importantly, even small tax distortions can have large welfare effects if they act on large pre-existing inefficiencies, reflecting, for instance, adverse externalities from the use of debt.

These distortions imply a marginal subsidy to debt-financed investment if the tax system provides accelerated depreciation allowances for physical assets, as it commonly does. Leaving personal taxes aside, a corporate tax system that allowed deduction of both financing costs and true economic depreciation would have no effect on investment decisions, since it would enable full recovery of all costs over the lifetime of a project. Tax would then be levied only on supernormal profits: the marginal effective tax rate (METR) ${ }^{12}$ would be zero. Allowing more than true economic depreciation along with interest deductibility costs thus amounts to a (marginal) subsidy: at the margin, unprofitable projects can become profitable, purely for tax reasons, if financed with debt. Equity-financed investments, enjoying no corporate-level deduction, are tax discouraged. Table 2.2 reports METRs on alternatively financed investments, showing that these effects have been sizeable. In France, for instance, debt finance received a 36 per cent subsidy at the margin while equity-financed investment faced a 20 per cent tax.

12 Defined, more precisely, as the proportion by which the pre-tax return on a project that the investor just finds worthwhile exceeds the post-tax return he or she requires.

This is an open access version of the publication distributed under the terms of the Creative Commons Attribution-NonCommercialNoDerivs licence (http://creativecommons.org/licenses/by-nc-nd/3.0/), which permits non-commercial reproduction and distribution of the work, in any medium, provided the original work is not altered or transformed in any way, and that the work is properly cited. For commercial re-use, please contact academic.permissions@oup.com 
Table 2.2. Marginal effective tax rates, selected countries, 2005 (\%)

\begin{tabular}{lccccr}
\hline Source of finance & France & Germany & Italy & UK & USA \\
\hline Equity & 20 & 29 & 19 & 20 & 24 \\
Debt & -36 & -37 & -48 & -28 & -46 \\
\hline
\end{tabular}

Source: Devereux et al. (2002); updated data available at <http://www.ifs.org >.

The distinction between debt and equity, however, has become blurred. A focus of financial innovation has been constructing instruments with many features of equity but enough features of debt to attract interest deduction. Hybrids of this kind (such as convertible bonds and preferred securities ${ }^{13}$ ) have come to play a large part in corporate financing, ${ }^{14}$ exploiting the intrinsic difficulty of making firm distinctions between the two. ${ }^{15}$ To the extent that such hybrids enable what is really equity to attract the same treatment as debt, they may ease the inefficiencies created by differential tax treatment of the two. But this comes at some cost: a loss of CIT revenue, and increased complexity and opacity of financial arrangements.

While much of the literature in this area has had non-financial institutions in mind, if only implicitly, financial institutions face qualitatively the same tax considerations in balancing equity and debt finance (including deposits). Banks have traditionally been able to sustain high debt ratios by virtue of having relatively safe assets, and implicit or explicit deposit guarantees reinforce this. Moreover, the high profitability of financial institutions in recent years will have made debt more attractive for them than for many nonfinancials, since the low probability of tax exhaustion it implies means a high effective CIT rate.

The tax bias to debt runs counter to regulatory objectives in the financial sector. Banks face both an explicit tax advantage of debt and, through regulatory requirements, an implicit penalty-with evident risk of policy incoherence. Tax incentives towards high leverage may have undercut the effectiveness of regulatory requirements.

This tension is reflected in the emergence of devices that enable debt-like instruments, attracting interest deduction, to be included in Tier 1 capital. Basel guidelines allow up to 15 per cent of Tier 1 capital to be in the form of

\footnotetext{
13 The former give the holder the option to convert to equity (and sometimes the issuer the option to call the bond); the latter pay distributions at a fixed rate but allow the issuer to defer payment.

${ }^{14}$ Devereux et al. (2006) report a survey of finance officers as indicating that anti-avoidance legislation adopted in the UK in 2005 has substantially reduced the use of hybrid entities and instruments.

15 Shaviro (2009a) notes, for instance, that the US Congress instructed the Treasury to issue comprehensive regulations setting out the tax distinction between the two in 1969: but, not for want of trying, it has been unable to do so.
} 
hybrid instruments that may attract interest deductions-in itself suggestive of the tax bias to debt finance that banks face. Beyond this, moreover, devices have emerged by which banks can include as Tier 1 capital what is arguably closer to debt. Prominent among these is the trust preferred security (TruPS), which has accounted for a large share of hybrid issues in the USA. ${ }^{16}$ Measures can be conceived to close specific possibilities of this kind (in the case of TruPS, for example, by appropriate consolidation rules to look through the trust) and the crisis itself may have restored the appeal of simple equity—but so long as the underlying tax bias remains so too will an incentive to find other ways of achieving the same end.

\subsubsection{Possible policy responses}

The concerns raised by potential debt bias are clear. Issues also arise at the interface of tax, regulation, and accounting.

\subsubsection{ALLEVIATING DEBT BIAS}

Given the potentially large macroeconomic damage from excess leverage, it is hard to see why debt finance should be systematically tax favoured. Microtheory results on the probable inefficiencies of financial markets-whether there will be too much borrowing or too little-are model specific. ${ }^{17}$ The impact of externalities operating at a more macro-level, however, seems clear-cut: when firms borrow, they are likely to internalize the expected bankruptcy costs they themselves incur but not the impact of their own failure and default on others (effects that are not present in the use of equity finance). These externalities are likely to be especially large for financial institutions, given their systemic importance. Some aspects of government policy exacerbate these concerns, as with guarantees (explicit or implicit) on bank deposits or corporate debt. There may also be strong effects on the balance of payments: preferential tax treatment of debt can provide an implicit subsidy to corporate and household borrowing, including from abroad, so increasing vulnerabilities through the capital account. This may have happened in Latvia, to give just one example, where-though other factors were probably the major sources of external imbalances-the implicit corporate-level tax subsidy made investment financed by borrowing

\footnotetext{
16 Preferred securities are treated as Tier 2 capital if issued directly by the bank. If issued, however, by a trust in which the bank has an interest, which then makes a loan to the bank, the interest is deductible to the bank, while Basel guidelines allow inclusion of the bank's equity interest in Tier 1 capital.

17 Stiglitz and Weiss (1981) and de Meza and Webb (1987), for instance, derive contrasting results from different assumptions on the joint distribution of projects' probability of success and return if successful.
}

This is an open access version of the publication distributed under the terms of the Creative Commons Attribution-NonCommercialNoDerivs licence (http://creativecommons.org/licenses/by-nc-nd/3.0/), which permits non-commercial reproduction and distribution of the work, in any medium, provided the original work is not altered or transformed in any way, and that the work is properly cited. For commercial re-use, please contact academic.permissions@oup.com 
(including from abroad) something like 130 basis points cheaper than it would have been in the absence of tax. ${ }^{18}$ Externalities from increased leverage are hard to quantify, but there is evidence that high leverage is associated with greater output losses in bad times. ${ }^{19}$ These macro-externalities raise the question of whether taxation should actively discriminate against debt finance. Current knowledge, however, does not allow a definitive view on this. Most important for present purposes is that there is no compelling reason why debt should be actively tax favoured-movement towards neutrality would thus be seen as desirable even by those who would wish to go further and tilt the playing field against debt.

Fundamental but conceptually straightforward reforms to the CIT-for which there are some encouraging precedents—can eliminate the debt bias at corporate level. Levelling the treatment of debt and equity costs can be done in either of two broad ways.

One approach is to limit the extent of interest deductibility:

- Thin capitalization rules deny deductibility for interest payments in excess of some level. Such rules have become more common in recent years. But they are essentially ad hoc, failing to capture all avoidance-related transactions and to acknowledge the differing debt capacities of different enterprises.

- A comprehensive business income tax (CBIT, see US Department of the Treasury 1992) would deny interest deductibility altogether (while retaining depreciation allowances broadly unchanged).

- 'Cash-flow' forms of CIT would allow investment to be deducted in full (rather than depreciated over time), while giving no deduction for interest. One such approach-for example, the 'S-base' of Meade (1978) - would be to tax net distributions to shareholders (so that, while banks would have no deduction for interest paid, interest received would not in itself be taxable). Since the PV of net distributions is the PV of the firm's fundamental value, such a tax-and all other cash-flow taxes, to which it is equivalent-is non-distorting not only for financing but also for real investment decisions.

The CBIT and cash-flow routes, however, involve transitional difficulties in dealing with pre-existing debt. And if adopted unilaterally they run the risk of multinationals being unable to claim foreign tax credits in their home

\footnotetext{
18 There are no data on corporate leverage in Latvia during this period, though the financial and real estate sectors did become highly leveraged.

19 Davis and Stone (2004), for instance, find that higher debt-equity ratios are associated with larger post-crisis output declines, and IMF (2008) that the cumulative output loss following periods of financial stress tends to be larger the greater the run-up in non-financial corporate debt before the onset.
}

This is an open access version of the publication distributed under the terms of the Creative Commons Attribution-NonCommercialNoDerivs licence (http://creativecommons.org/licenses/by-nc-nd/3.0/), which permits non-commercial reproduction and distribution of the work, in any medium, provided the original work is not altered or transformed in any way, and that the work is properly cited. For commercial re-use, please contact academic.permissions@oup.com 
country, since interest deductibility is often taken as a necessary condition for any tax to be regarded as a creditable income tax. (This will be less of a concern for multinationals whose home countries operate a territorial system.) A CBIT would also require somewhat complex treatment of banks.

The alternative is to keep interest deductibility but also allow a deduction for a notional cost of equity finance: the allowance for corporate equity (ACE) form of CIT. Under an ACE, corporations deduct not only interest on debt but also a notional return to shareholders' equity. ${ }^{20}$ Tax is thus ultimately levied only on profits in excess of investors' required return, so that the ACE is fully neutral. Several countries have already experimented with the ACE (or variants), and with some success. Croatia implemented an ACE from 1994 to 2001, and it has recently been adopted in Belgium and Latvia. A variant is applied in Brazil, and partial ACEs were applied in Austria and Italy. Although some ACE experiments were terminated-with changes of government, and in some cases a cut in the headline CIT rate-technical assessments of these experiences have been broadly positive, with evidence that movement towards an ACE is indeed associated with reduced debt-equity ratios. ${ }^{21}$ There are certainly important practical issues in the implementation of an ACE. Prominent among these is the choice of notional rate of return, there being a strong argument for the use of some proxy for a risk-free rate of return: so long as the availability of a future tax reduction is perfectly certain-which requires appropriate arrangements in the event, for example, of the firm ceasing operationsthe associated cash flow is appropriately discounted as risk free. ${ }^{22}$

For banks, an ACE would essentially mean giving a tax deduction for a notional return on Tier 1 capital. Its adoption would thus send a strong and clear signal that accumulating capital reserves is no longer to be tax penalized.

Restricting the deduction for interest to the same notional rate for debt as well as equity — an extended form of ACE-would also eliminate the problems associated with hybrids. ${ }^{23}$ This might appear to ride roughshod over the traditional legal distinctions between straightforward debt and equity claims: but the argument set out above in the case of the 'equity-only' ACE suggests that the use of a risk-free rate as the marker for deductibility is appropriate for both forms of finance. Uniform treatment would not be a necessary feature of ACE adoption, but would eliminate the need to make the inherently

20 This and other issues in implementing an ACE are discussed in Griffith et al. (2010).

21 See Klemm (2007); for Croatia, Keen and King (2002); for Italy, Bordignon et al. (2001) and Staderini (2001), the latter finding reduced debt-equity ratios consequent on movement to the partial ACE.

22 See Bond and Devereux (2003). The use of a single notional rate, rather than one varying by firm or sector, clearly also has the merit of simplicity.

23 A 'uniform cost of capital allowance' of this kind is proposed and discussed further by Kleinbard (2007b). 
problematic distinction between debt and equity for tax purposes, and also limit the narrowing of the tax base.

The principal difficulty with the ACE is the reduction in revenue it can imply. Moving to an ACE narrows the tax base: it may have reduced CIT revenue in Croatia by one-third. ${ }^{24}$ Raising the statutory CIT rate to recover this lost revenue is problematic if done unilaterally, as it would risk increased profit shifting to lower tax jurisdictions. The risk of revenue loss can be overstated, however. To the extent that the pre-existing CIT led to a marginal subsidy to debt-financed investment, movement to neutrality would actually lead to an increase in revenue-an effect ignored in standard revenue calculations. The immediate revenue impact can be mitigated, moreover, by providing relief only in respect of equity built up after some initial date (with antiavoidance provisions to prevent recharacterization of 'old' equity as new).

Importantly for both its distributional and revenue impact, much of the efficiency gain from moving towards an ACE would probably benefit labour, not equity-holders. In an economy open to capital movements, much of the real burden of a source-based tax on the normal return to capital will be passed on by internationally mobile capital to immobile factors, notably labour: if the required after-CIT return to capital is fixed on world markets, then taxing that normal return must lead to a higher before-tax return; and the only way this can happen is if the return to immobile factors falls. Emerging evidence suggests that this effect may be substantial. ${ }^{25}$ This implies-though no doubt not an easy political sell-that eliminating a tax on the normal return to capital would lead labour income to increase by enough for revenue to be recovered through taxing labour explicitly and still leave labour better off. ${ }^{26}$

Adopting an ACE or cash-flow CIT would not eliminate all distortions to financial decisions, for which changes to personal taxation would also be needed. But both would remove normal profits from the CIT base. This would be consistent with a range of approaches to achieving a more neutral tax treatment of alternative forms of capital income. It could readily be integrated into a broader expenditure tax. Or it could be part of a more traditional income tax, with neutrality between the alternative forms of finance achieved by taxing interest and dividend income at the same rate while exempting capital gains on corporate stock. ${ }^{27}$ That, in turn, could be done either as part of a comprehensive income tax (treating capital and labour

24 Simulation results in De Mooij and Devereux (2009) suggest that unilateral movement to an ACE by EU members would reduce corporate tax revenues by an average of $44 \%$.

25 Arulampalam et al. (2008) and Hassett and Mathur (2008).

26 If, on the other hand, the normal return is subsidized (which, as noted above, may well be the case for debt-financed investments), eliminating the distortion would increase tax revenue by more than labour income falls: taxes could be cut so as to leave labour better off and tax revenue ultimately no lower.

27 Since, given the dividend tax, not doing so would amount to double taxation.

This is an open access version of the publication distributed under the terms of the Creative Commons Attribution-NonCommercialNoDerivs licence (http://creativecommons.org/licenses/by-nc-nd/3.0/), which permits non-commercial reproduction and distribution of the work, in any medium, provided the original work is not altered or transformed in any way, and that the work is properly cited. For commercial re-use, please contact academic.permissions@oup.com 
income identically) or as part of a 'dual' income tax (applying a progressive tax to labour income and a flat tax to all forms of capital income). The choice of accompanying measures would evidently be key in shaping the overall distributional impact of the reform.

Fundamental change in the CIT treatment of debt and equity would probably be too unsettling for some while, but movement to an ACE or cash-flow system is in this respect likely to be the less problematic route. Removing interest deductibility—even if only for 'new' debt-would risk amplifying financial distress. The alternative route of extending deductibility to equity finance, however, would have the opposite effect, and might make recapitalization of banks, for instance, more attractive than under current rules. The revenue impact, however, remains a concern, not least given the very deep fiscal challenges, amplified by the financial crisis and response to it, that many advanced countries now face. ${ }^{28}$

\subsubsection{TAX, REGULATORY, AND ACCOUNTING LINKAGES}

The crisis has drawn attention to difficulties in the regulatory treatment of financial institutions' tax losses. The reduction in future tax liabilities implied by accumulated tax losses can, under certain circumstances, be included in Tier 1 capital. The requirement for inclusion is that such deferred tax assets have a reasonable prospect of being realized in the near future-within the following year, under US rules. On occasion, however, tax losses have apparently been valued for these purposes far above their likely PV.

Increased use of marking to market (fair value accounting) in taxing financial institutions may increase the volatility of revenue, but is the right direction for tax policy. The lock-in effect of levying CGT on realization rather than accrual, noted earlier, creates an incentive to defer realizing gains and accelerate realizing losses. ${ }^{29}$ Even if taxed at the same nominal rate, capital gains thus become inherently more favourably treated than other forms of capital income, such as interest. This creates opportunities for tax arbitrage-a significant concern at personal level (where taxation on realization remains the norm) as well as corporate. As banks have expanded their trading books, increased use of marking to market in assessing their tax liability-in this area tax rules generally follow accounting treatment-will have made revenue more volatile (albeit in the direction of strengthening the automatic stabilizers that other tax developments over recent years may have weakened). A potential difficulty is that taxation on fair market value may induce the sale of assets simply to finance the accruing liability. There is though little sign that this has been a significant problem in the financial sector. It is possible, moreover, to

28 These are stressed and discussed in Cottarelli and Viñals (2009).

29 As Slemrod (2009) notes, this latter 'lock-out' effect may be of some importance at present.

This is an open access version of the publication distributed under the terms of the Creative Commons Attribution-NonCommercialNoDerivs licence (http://creativecommons.org/licenses/by-nc-nd/3.0/), which permits non-commercial reproduction and distribution of the work, in any medium, provided the original work is not altered or transformed in any way, and that the work is properly cited. For commercial re-use, please contact academic.permissions@oup.com 
design schemes that tax on realization but mimic taxation on accrual, and there is some practical experience with them. ${ }^{30}$ Greater neutrality in taxing capital income is likely to require more rather than less marking to market.

Though there are important overlaps, the objectives of tax policy need to be recognized as distinct from those of regulatory and accounting practices if each is to serve its proper purpose. Clearly, there are monitoring and compliance advantages in applying common definitions and concepts for tax and accounting purposes, and some see corporate governance advantages in closely aligning tax and book profits: this can create a helpful tension between the temptations to overstate profits for financial accounting purposes and to understate them for tax purposes. But the ideal tax base is not necessarily the most accurate measure of current income. For instance, valuing depreciation at (some reasonable approximation of) true economic rates is generally appropriate for financial accounting, but there can be a case for encouraging investment by allowing faster depreciation-or even full expensing-for tax purposes. It may also be appropriate to treat provisioning for bad debt differently for accounting and tax purposes.

Recent proposals to move towards dynamic provisioning (as in the Turner Review (FSA 2009) and IMF 2009b, for instance)—meaning a systematic and mandatory counter-cyclical element of general provisioning-raise issues concerning the tax treatment of provisions for bad loans. The most common approach is to allow tax deductions only for specific provisions (related to the impairment of particular assets), not general. To the extent that dynamic provisioning would be analogous to depreciation allowances for physical assets that reflect their expected reduction in value (or sometimes more, if accelerated depreciation is allowed), deductibility could be argued to be appropriate. Other approaches might be needed if the CIT were to be fundamentally reformed. ${ }^{31}$

\subsection{Housing}

Housing is commonly subject to special tax treatment that may have increased household leverage and house prices. Taxation does not explain

30 One such scheme, developed in Auerbach (1991), effectively charges tax on the excess of the actual sale value not over the acquisition price but over what that price would have been had the asset earned the risk-free rate, in effect taxing only the normal return while leaving the realization decision undistorted; Auerbach and Bradford (2004) describe a more general class of schemes achieving the same effect. Alworth et al. (2003) describe experience in Italy with schemes intended to mimic the effects of taxation on accrual.

31 An incidental advantage of an ACE, for instance, is that tax incentives to overstate specific provisions would in principle be eliminated, since any increased deduction from doing so would be offset in PV by a reduction in Tier 1 capital and hence in the future imputed tax allowance on equity.

\section{2}

This is an open access version of the publication distributed under the terms of the Creative Commons Attribution-NonCommercialNoDerivs licence (http://creativecommons.org/licenses/by-nc-nd/3.0/), which permits non-commercial reproduction and distribution of the work, in any medium, provided the original work is not altered or transformed in any way, and that the work is properly cited. For commercial re-use, please contact academic.permissions@oup.com 
the widespread house price boom-that occurred in countries with very different tax systems-and there are no obvious tax changes that might have triggered its collapse. But taxation does create substantial distortions in a market of central macroeconomic importance.

\subsubsection{The tax treatment of housing}

Within a comprehensive income tax, fully neutral taxation of owner-occupation would require full taxation of imputed rents and capital gains on housing, and deductibility of mortgage interest payments. Consider the alternative of, for instance, renting instead and investing in fully taxed assets: taxation of imputed rents - the consumption value of housing services-is needed to match the payment of market rents from taxed income; taxation of capital gains is needed to match the CGT liability on other financial assets; and deductibility of mortgage interest is needed to match the taxation of the interest available from investing in other assets.

In practice, imputed rents and capital gains on primary residences are rarely taxed, creating a general bias towards housing that mortgage interest reliefwhere it remains-is likely to reinforce. Very few countries bring imputed rents into the income tax (the Netherlands and Switzerland being exceptions). ${ }^{32}$ Some tax capital gains on owner-occupied housing, but typically more lightly than other income or only beyond a high threshold (or both). Even in the absence of distortions on the financing side, these features would tax-favour owner-occupation relative to renting. And mortgage interest costs attract tax relief, subject to limits, in a number of countries (including Denmark, France, Italy, Spain, Italy, France, and the USA). Since borrowing to acquire other assets is generally not deductible, this makes investment in housing even more favoured.

Mortgage interest relief would not tax-favour mortgage finance if the alternative to borrowing were investing less in fully taxed assets and other interest were also deductible - but that is commonly not the case. If alternative investments were fully taxed, mortgage interest deductibility would mean that the opportunity costs of acquiring housing by borrowing and by running down other assets would in each case be the after-tax interest rate-so mortgage finance would not be tax favoured. Many countries, however, tax other forms of saving (such as pensions) at reduced rates. In that case, if the return on those assets matches the pre-tax interest rate on mortgage debt, there is an arbitrage gain from leveraging against housing and investing own-funds in the non-housing asset. And, while interest on loans used to finance

32 Several countries charge VAT on first sales of residences, which-to the extent that house prices are the present value of housing services-amounts to an implicit tax on imputed rents, though one that is not tailored to household circumstances in the same way that income tax is.

This is an open access version of the publication distributed under the terms of the Creative Commons Attribution-NonCommercialNoDerivs licence (http://creativecommons.org/licenses/by-nc-nd/3.0/), which permits non-commercial reproduction and distribution of the work, in any medium, provided the original work is not altered or transformed in any way, and that the work is properly cited. For commercial re-use, please contact academic.permissions@oup.com 
consumption is generally not deductible, home equity loans have provided (within limits) just such a tax-favoured way to borrow and spend.

The distributional impact of mortgage interest relief can be complex, but deductibility probably favours the better off. On the one hand, higher-income individuals may be more likely to face constraints on their access to taxfavoured assets (since this is often subject to caps), so that their opportunity cost of investing in housing is the after-tax return. This creates an argument for some tax relief to ensure that the less well off also pay an after-tax rate. Against this, however, deductions are typically worth more to the better off, as they take them against a higher marginal rate of tax. The latter effect would be avoided if relief were provided-as many countries do-not as a deduction but as a credit (reducing tax paid, rather than the income taxed).

Ownership/occupation and transaction taxes are also important elements in the tax treatment of housing. Recurrent taxes based on ownership or occupation have potential appeal both as serving as user charges reflecting the value of local public services-and as such they are often allocated to lower-level governments-and, to the extent that these and other features are location specific, as being less vulnerable to interjurisdictional tax competition than the CIT and other taxes on more mobile bases. There is indeed evidence that such taxes (along with consumption taxes) have significantly less adverse effects on growth than income taxation (Johansson et al. 2008). Housing transactions themselves are often subject to tax, sometimes in significant amounts (up to 9 per cent in Ireland).

\subsubsection{Impact on prices and leverage}

Tax policy can affect two key aspects of housing markets: house prices and households' leverage. These are interrelated, as high house prices encourage removing equity through increased borrowing, the availability of cheap loans drives up house prices, and the expectation of price increases raises the expected return on borrowing to acquire housing. ${ }^{33}$

\subsubsection{HOUSE PRICES}

Favourable tax treatment is likely to be capitalized in house prices, may be reflected in the rate of house price inflation, and can also increase housing price volatility. In the short run, when the physical stock of housing is virtually fixed, most taxes (or tax subsidies) will be fully capitalized in housing prices, with the incidence mainly on the seller (though the effect may be mitigated by changes in the supply of housing offered for sale). A reduction

\footnotetext{
33 Taxation also affects other features of the housing market, not considered here-including the share of housing in the aggregate capital stock.
} 
in the rate of CGT on housing, for instance, would be expected to increase house prices (with some offset as sellers enter the market to realize deferred gains). It might also lead to a slower-not, as one might expect, a faster-rate of house price appreciation (because a lower pre-tax gain is needed to yield the required post-CGT return). ${ }^{34}$ In the longer term, supply responses will ease price effects, but marked effects can remain. Importantly too, distortions affecting most directly prices in one segment of the market (the greater value of mortgage interest deductions for high-income taxpayers, for example) will generate substitution effects that then feed price effects through to others. There is also evidence that more favourable tax treatment of housing is associated with greater volatility of its price (van den Noord 2005).

Tax effects can substantially reduce the user cost of - and hence increase the demand for-housing. Poterba and Sinai (2008) find, for the USA, that mortgage interest deductibility and other tax features on average provided a tax subsidy equivalent to around 19 per cent of the user cost. ${ }^{35}$ This means that, for households facing a user cost of capital of, say, 10 per cent, the favourable tax treatment of housing was equivalent to a reduction of 235 basis points, a substantial amount by the usual standards of monetary policy discussions. The reduction is greatest for high-income households (since they take the mortgage interest deduction at a higher marginal rate), but it is nevertheless around 8 per cent for those with low incomes.

Effective tax rates on housing vary enormously across countries, and with the circumstances of the investor and investment. An effective (average) tax rate (EATR) on housing can be calculated as the ratio of the PV of total taxes over an expected holding period to the sum of the PV of imputed rent and capital gains. EATRs can be very high-sometimes more than 100 per centwhen investors keep a house for a short period and are subject to high transaction taxes. They can also be negative-for example, in countries that allow mortgage interest deductions but do not tax imputed rents and alternative assets.

Figure 2.1 shows calculated EATRs for ten countries, a mix of small and large, industrialized and emerging economies, and booming and flat housing markets. These assume a property purchased for $\$ 250,000$, held for ten years, 80 per cent mortgage financed, and appreciating in value by 5 per cent per year-and then track how EATRs vary across countries as each of these assumptions is changed. Such changes affect the ranking of countries, but: Spain, France, and to a lesser extent Denmark have relatively high tax rates across a range of assumptions; Ireland and the USA have low EATRs. Italy

34 See Box 2.2.

35 The comparison is with an idealized personal income tax of the type described above.

This is an open access version of the publication distributed under the terms of the Creative Commons Attribution-NonCommercialNoDerivs licence (http://creativecommons.org/licenses/by-nc-nd/3.0/), which permits non-commercial reproduction and distribution of the work, in any medium, provided the original work is not altered or transformed in any way, and that the work is properly cited. For commercial re-use, please contact academic.permissions@oup.com 

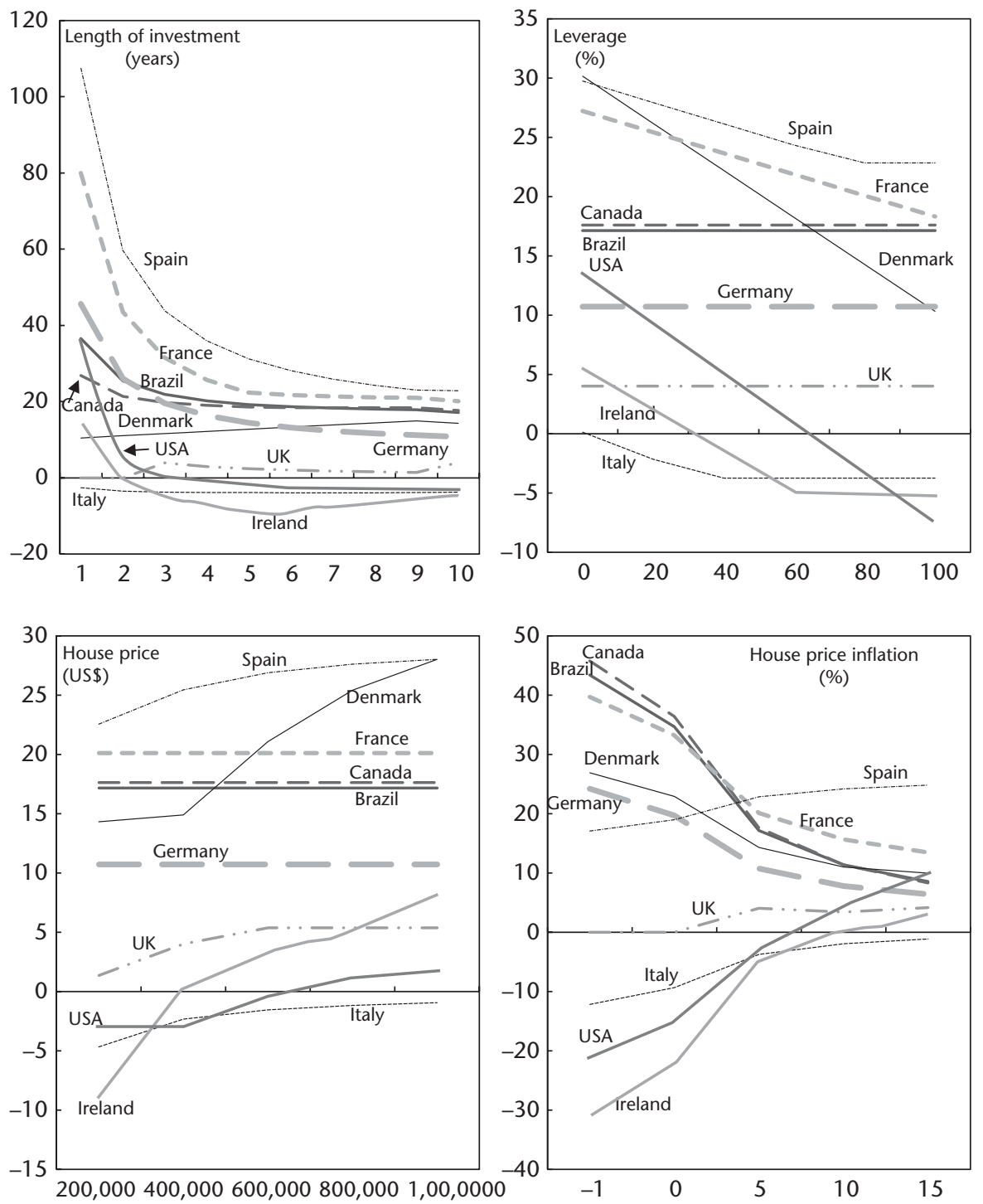

Figure 2.1. Effective average tax rates on owner-occupation (\%) Source: Authors' calculation.

stands out as a country with an almost consistently negative tax rate, reflecting very low taxation combined with interest deductibility.

These EATRs show a number of interesting patterns. Virtually all countries show a falling tax rate as the investment period increases: this is the result of transaction taxes, which are relatively more important for short investments. In countries offering tax relief for mortgage interest, the EATR falls as leverage

46

This is an open access version of the publication distributed under the terms of the Creative Commons Attribution-NonCommercialNoDerivs licence (http://creativecommons.org/licenses/by-nc-nd/3.0/), which permits non-commercial reproduction and distribution of the work, in any medium, provided the original work is not altered or transformed in any way, and that the work is properly cited. For commercial re-use, please contact academic.permissions@oup.com 
Table 2.3. Real cumulative house price inflation between 1998 and end 2007 (\%)

\begin{tabular}{|c|c|c|c|c|c|c|c|c|c|}
\hline \multicolumn{3}{|c|}{ High-tax countries } & \multicolumn{4}{|c|}{ Medium-tax countries } & \multicolumn{3}{|c|}{ Low-tax countries } \\
\hline Spain & France & Denmark & Brazil & Canada & Germany & UK & USA & Ireland & Italy \\
\hline 110.9 & 105.9 & 75.7 & n.a. & 65.2 & -18.0 & 124.1 & 45.3 & 108.5 & 56.4 \\
\hline
\end{tabular}

Note: n.a. $=$ not available.

Source: Authors' calculation based on data from OECD (2008a).

increases. This effect is strongest for the USA, reflecting the very high upper limit for mortgage interest deduction (on debt of up to $\$ 1,000,000$ ). Other countries have much lower limits (Ireland, Italy, and Spain) or allow deduction only against capital income, which is taxed at a lower rate (Denmark). Higher house prices increase taxation in some countries, reflecting progressive elements of ownership or transaction tax rates, or capital gains tax imposition if a threshold is exceeded. House price inflation has different effects across countries.

Special vehicles-not captured in these calculations-may have created further tax biases towards housing. Real estate investment trusts (REITs) provide CIT exemption for corporations whose main business is property investment (subject to fulfilling certain criteria, notably distributing a large share of profits to shareholders); dividends are taxed at shareholder level, potentially at low rates. This makes investing in property through REITs tax favoured relative to doing so directly (which would attract tax, and deductions, at ordinary income-tax rates). Further, in the USA a substantial proportion of the required cash distributions from REITs is typically in the form of non-taxable return of capital, as the earnings and profits of the REIT are frequently reduced by high leverage and depreciation.

Taxation does not appear, however, to have been the main driver of house price developments since 1990. Strong price increases occurred in all countries examined above, including in the high-tax group (see Table 2.3). The same conclusion flows from the diverse experience of local markets: in the USA, for example, booming property markets in coastal cities went with more stagnant developments inland, despite relatively small inter-state variation in tax rates. Nor are there changes in tax rules that clearly account for housing price movements over the period. Some commentators attach importance, for instance, to a substantial increase in the CGT exemption for housing in the USA in 1997, something of an inflection point for house prices. The impact of this change is not clear-cut, however, since it also eliminated rollover relief, ${ }^{36}$ which for some taxpayers was a marked reduction in generosity.

36 This provided that any gain on disposal of a house would not be taxed if the proceeds were reinvested in another property: so no tax liability arose as long as taxpayers traded up with each move. 


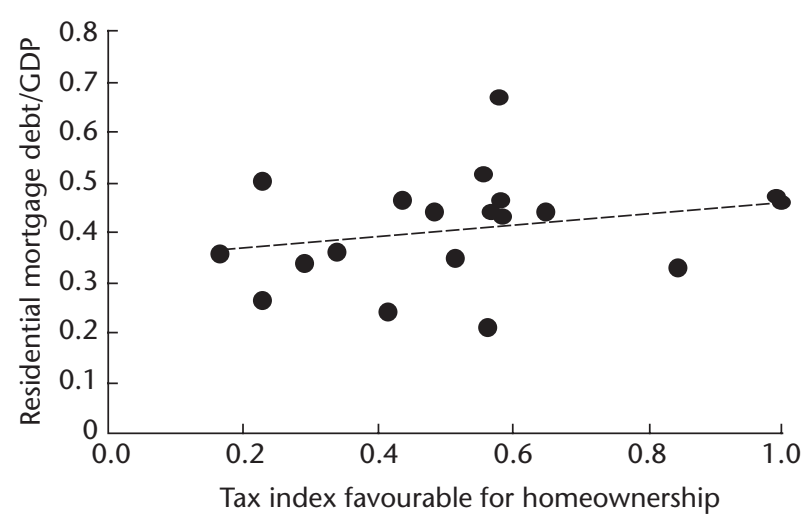

Figure 2.2. Debt ratios and the tax treatment of owner-occupation Source: Cardarelli et al. (2008).

\subsubsection{MORTGAGE DEBT}

Mortgage interest tax relief encourages the build-up of (gross) housing debt if alternative investments are less than fully taxed, which, as noted above, is often the case because, all else being equal, the after-tax return on other investments then exceeds the cost of mortgage-backed borrowing.

There is evidence that countries offering more favourable tax treatment for home ownership do indeed have higher ratios of mortgage debt (see Figure 2.2). Analyses for the UK (Hendershott et al. 2003) and the USA (Dunsky and Follain 2000) confirm that mortgages fell significantly relative to home value after reforms reducing the value of mortgage interest relief. Of course, other factors are also at work, notably regulatory limits on maximum loan-to-value ratios of realistic appraisals. As a result, even some countries without mortgage relief-such as the UK, since 2000-have experienced substantial growth in housing debt and housing price bubbles.

\subsubsection{Possible policy responses}

Alleviating tax distortions to housing markets would improve efficiency and help avoid macroeconomic imbalances-but timing is important. The social objectives underlying these distortions-realizing the beneficial externalities from owner-occupation for which there is some evidence-can be achieved through better-targeted measures (such as outright grants): Glaeser and Shapiro (2002), for example, note that, while mortgage interest deduction does appear to increase the amount spent on housing in the USA, home-ownership rates have been broadly stable, despite large changes in the tax subsidy. To the extent

This is an open access version of the publication distributed under the terms of the Creative Commons Attribution-NonCommercialNoDerivs licence (http://creativecommons.org/licenses/by-nc-nd/3.0/), which permits non-commercial reproduction and distribution of the work, in any medium, provided the original work is not altered or transformed in any way, and that the work is properly cited. For commercial re-use, please contact academic.permissions@oup.com 
that they are capitalized in house prices, existing tax subsidies do not even help first-time buyers. Some reforms towards greater tax neutrality, however, would probably reduce house prices and/or construction activity, and so be inappropriate during times of recession.

Policy thus requires balancing the needs of short-term recovery and those for ultimate structural improvement in the taxation of housing. Transaction taxes can be easy to collect, but scaling them back would remove an impediment to efficient trading, increase prices, and speed up clearance of any excess stock of unsold houses. It would also be helpful for labour mobility. When housing markets regain robustness, other distortions should be addressed. Since housing tax regimes vary widely, so too should reform priorities. Possibilities - to be coordinated with both each other and any wider changes in the tax system-include:

- Taxing imputed rents (perhaps proxied from market values) and capital gains on housing. The former in particular goes to the heart of the bias towards housing (and would be appropriate under both income- and expenditurebased approaches to personal taxation).

- If imputed rents remain untaxed, phasing out mortgage interest relief, where it remains. Experience in the UK indicates that this can be done without undue controversy or adverse impact. ${ }^{37}$

- Fully taxing first sales of residences under the VAT (or other sales tax). This is structurally attractive irrespective of the income-tax treatment of housing - since anything else distorts consumption decisions to no obvious purpose-but may also serve as a proxy for income taxation of imputed rents. It would raise (tax-inclusive) house prices, including of existing houses, but (by reducing the tax-exclusive price on new sales) adversely affect construction activity.

- Raising ownership taxes. As well as providing a relatively efficient revenue source, this would go some way towards implicitly taxing imputed rentsbut would probably require improved valuation practices in many countries.

The desirability of many of these reforms has long been recognized; the question is whether experience with the costliness of housing market distortions will increase willingness to address them.

37 The UK phased out mortgage interest relief gradually. From 1983 the upper limit (of $£ 30,000$ ) was frozen and hence slowly eroded by inflation. In 1991 relief was restricted to the basic rate, then reduced to 20\% (1994), 15\% (1995), and 10\% (1998), before finally being abolished in 2000.

This is an open access version of the publication distributed under the terms of the Creative Commons Attribution-NonCommercialNoDerivs licence (http://creativecommons.org/licenses/by-nc-nd/3.0/), which permits non-commercial reproduction and distribution of the work, in any medium, provided the original work is not altered or transformed in any way, and that the work is properly cited. For commercial re-use, please contact academic.permissions@oup.com 


\subsection{Complexity, low-tax jurisdictions, and risk taking}

This section considers the tax treatment of innovative financial instruments, the presence of low-tax jurisdictions, and other tax provisions, including in relation to executive compensation. It concludes that tax has through these channels contributed to the opacity of financial arrangements, but the direct impact on risk taking has been less clear-cut.

\subsubsection{Financial innovation}

Financial innovation has been driven primarily by the search for new ways to allocate risk-but also by tax considerations. These can be a matter essentially of manipulating legal form (as with hybrid instruments), but may also be achieved by creating substantively new instruments: swaps, for instance, may be used solely to avoid withholding taxes. Generically, the ability to replicate a portfolio in a variety of ways expands opportunities to tailor the nature of the payments to the tax preferences of the investor (transforming it into lightly taxed capital gains, for instance).

Tax policy has in some cases facilitated, and even encouraged, securitizationpotentially increasing the attraction of subprime lending, for instance-but has not driven it. It is not always clear how innovative transactions will be taxed. The creation in the USA, for instance, of the Real Estate Mortgage Investment Conduit in 1986 and Financial Asset Securitization Investment Trust in 1997 provided clear and neutral tax treatment for the issuance of mortgage and debt-instrument-backed securities, respectively. ${ }^{38}$ Subtler considerations suggest, however, that this element of neutrality can set the scene for exploiting distortions in the taxation of capital gains and other income in ways that are more attractive for risky original loans ${ }^{39}$ - which consequently become easier to finance.

Lack of clarity in the tax treatment of new instruments can lead to further complexities through the use of strategies aimed at assuring tax minimization: one way of trying to ensure that special purpose vehicles (SPVs) themselveswhich are just intermediating receipts ${ }^{40}$-are not subject to an additional layer of tax, for example, is by locating them in low-tax jurisdictions.

38 Tax issues raised by securitization include: whether any gains on assets placed in the SPV by the originator are taxable; whether the special purpose vehicle (SPV) itself is taxable; and whether payments to holders of the securitized assets will be taxed as interest or dividends.

39 Investors paying tax on interest income at a rate higher than that at which they can offset capital losses benefit by pooling assets to pay interest at a rate that reflects the expected losses. Investors facing the same rate on both, on the other hand, do not care about the mix of interest and gains. Bringing the two types together creates scope for tax arbitrage from which both can benefit, with a role too for the use of CDSs. Eddins (2009) develops this argument.

40 Neutrality argues against taxing intermediation of this kind. A coherent approach is to treat the SPV itself on a flow-through basis, taxing instead at the level of the originator and security-holder. 


\subsubsection{POSSIBLE POLICY RESPONSES}

Complex financial instruments exploit tax distortions-differential treatment across types of income, investors, and jurisdictions-that are deeply embedded in current practice. Little is known, however, of when financial innovation has the beneficial effect of reducing the social cost of underlying tax and other distortions and when, on the contrary, it amplifies them-or of the practical importance of such effects. What is clear is that tax arbitrage opportunities, and hence scope for creative ways to exploit them, will remain unless all forms of capital income are taxed at a single marginal rate-internationally as well as domestically. One aspect of at least moderating such distortions is likely to be further movement towards levying CGT on accrual rather than realization, whether by marking to market or equivalent realizations-based schemes.

\subsubsection{Low-tax jurisdictions}

The availability of low rates on capital income in some jurisdictions creates opportunities for tax arbitrage, including through high leverage-leading to further opaqueness of financial arrangements. For instance:

- The exemption of foreign profits-either permanently or until repatriation-creates an incentive to lend from low-tax jurisdictions to high (taking interest deductions at a high rate and paying tax at a low rate)—making debt finance in high-tax countries even more attractive. ${ }^{41}$

- Complex corporate structures, including through the use of hybrid entities, ${ }^{42}$ can reinforce this effect still further by enabling interest to be deducted (possibly twice or more) without offsetting taxation of the interest receipt.

- Other profit-shifting devices can be used, for example, manipulating transfer prices and locating intangible property rights and corporate headquarters judiciously.

- In countries using a residence-based tax system, further complications arise as funds are routed so as maximize the benefits from double-tax agreements.

\footnotetext{
41 Controlled foreign corporation (CFC) rules aim to preclude this by bringing passive income into tax even if not repatriated.

42 These are entities treated as a corporation in one country but as a branch or partnership (rather than subsidiary) in another. For instance, a parent company can then locate in a low-tax jurisdiction a hybrid that the home country treats not as a corporation (and hence is not subject to its CFC rules) but as a branch of a corporation located in some third, high-tax jurisdiction. The parent then injects equity into the hybrid, which lends to the high tax affiliate. This generates interest deductions in the high-tax country, but the interest received by the affiliate is not taxed by the home country until repatriated.
}

This is an open access version of the publication distributed under the terms of the Creative Commons Attribution-NonCommercialNoDerivs licence (http://creativecommons.org/licenses/by-nc-nd/3.0/), which permits non-commercial reproduction and distribution of the work, in any medium, provided the original work is not altered or transformed in any way, and that the work is properly cited. For commercial re-use, please contact academic.permissions@oup.com 
Tax-induced complexity in how and where financial assets are held may hamper financial supervision, even when the motivation for complex arrangements is tax avoidance rather than circumventing supervision.

Low tax rates in some jurisdictions may have increased their own vulnerability, and contributed to high levels of leverage elsewhere. There were no systematic changes in the tax treatment or practice of low-tax jurisdictions that would explain the onset of the crisis. Some low-tax jurisdictions may, however, have increased their own exposure by attracting capital inflows vulnerable to reversal: there is evidence that reducing the rate of CIT, for instance, leads to a temporary but significant capital inflow (Keen and Syed 2006).

\subsubsection{POSSIBLE POLICY RESPONSES}

Recent developments in relation to 'tax havens' focus on evasion concerns, not opportunities for legal arbitrage. The OECD reports that all eighty-four countries that it monitors have now committed to the principles of its harmful tax practice project, the essence of which is willingness to exchange taxpayer information on request (as set out in Article 26 of the OECD's model tax treaty). Such information exchange is intended to prevent residents of countries operating the residence principle from evading tax by depositing funds in lower-tax jurisdictions and failing to declare the proceeds. This is likely to be efficiency improving, and to increase revenue in residence countries both directly and by reducing the incentive for other countries to set low tax rates. It does not, however, address the legal use of low-tax jurisdictions for any of the tax-reducing purposes described above. There may be a dampening effect through reduced availability of finance from investors willing to accept a lower return because they are not tax compliant. Even with full information exchange, however, distortions from cross-country divergence in tax rates will remain.

Addressing the distortions associated with low-tax jurisdictions would require a substantial, controversial, and challenging increase in tax cooperation, as well perhaps as policy action by high-tax countries. Two distinct but related issues arise. One is the downward pressure on tax rates associated with international tax competition: all could lose from this, even though ultimately all end up with the same tax rate. The second is the opportunity for tax arbitrage created by differences in tax rates. Acting on either would require unprecedented tax cooperation, the challenge being to develop a firmer consensus on what constitutes harmful tax practices. There are clear sovereignty concerns. And there are intellectual ones too. Some see tax competition as providing a beneficial constraint on government size, for instance, and it may ease credibility problems in taxing capital income. ${ }^{43}$ Prohibiting differentially

\footnotetext{
43 Pros and cons of international tax competition are reviewed in Wilson (1999) and Keen (2008).
} 
low tax rates that are 'ring-fenced' from the domestic economy-a possibility raised at the outset of the OECD project (OECD 1998)-might worsen tax competition by requiring low tax rates to apply domestically too. ${ }^{44}$ Importantly, opportunities for international tax arbitrage are to a large degree contingent on practices in high-tax countries. ${ }^{45}$ Movements towards exemption, as sometimes mooted, could increase the attractions of low-tax jurisdictions by eliminating any tax on repatriation (Mullins 2006). It would be conceivable, indeed, for residence countries to eliminate the deferral that is a key reason for the use of low-tax jurisdictions. These and other international tax issues are likely to require closer attention.

\subsubsection{Risk taking and tax losses}

There are important non-tax distortions to risk taking. Limited liability itself creates an inherent bias towards more risk taking, since shareholders enjoy the upside of risky investments but are protected against the downside. ${ }^{46}$ Accounting rules can also play a role. In the USA, for example, the cost of stock options shown in the financial accounts may be lower than the tax deduction generated. To the extent that non-tax distortions lead to excessive risk taking, a case can be made that taxation should be structured to counter this.

Proportional taxation of investment returns (with full relief for losses) can lead to higher investment in risky assets-but progressivity reduces this effect. A fully symmetric tax system reduces the variance of after-tax returns by dampening both positive returns in good outcomes and negative ones in bad outcomes (by reducing other tax liabilities or providing a rebate). If the tax is applied uniformly to all assets (so leaving their relative expected returns unaffected), this encourages risk-averse investors to hold more of the risky asset. ${ }^{47}$ Progressive taxation (a higher average tax rate when the outturn is good than when it is bad) mitigates this effect. It could be that this check to risk taking has become weaker as income-tax systems have become less progressive over recent years.

Imperfect loss offset-a form of progressivity-tends to discourage risk taking. ${ }^{48}$ Under most CITs, the government shares in positive profits but not in losses. Instead, losses are carried forward and deducted against future profits, typically without any adjustment for either inflation or the reduction

${ }^{44}$ See Keen (2001) and Janeba and Smart (2003).

45 This is the case, for instance, with the potential inconsistencies that make possible the hybrid entity (explained in the appendix to this chapter).

46 As argued forcefully by Sinn (2008), for example.

${ }^{47}$ In the simplest case, the investor ends up bearing the same after-tax risk, with increased holding of the asset offset by the reduced riskiness of its post-tax return.

${ }^{48}$ If denial of loss offset is used to reduce the tax rate, the increased after-tax return in good states makes the effect ambiguous.

This is an open access version of the publication distributed under the terms of the Creative Commons Attribution-NonCommercialNoDerivs licence (http://creativecommons.org/licenses/by-nc-nd/3.0/), which permits non-commercial reproduction and distribution of the work, in any medium, provided the original work is not altered or transformed in any way, and that the work is properly cited. For commercial re-use, please contact academic.permissions@oup.com 
in the value of the tax allowance from its deferral. In addition to discouraging risk taking, this creates opportunities for tax arbitrage ${ }^{49}$ and may disadvantage new entrants.

Standard tax treatment of losses can impede corporate restructuring. The usual principle is that tax losses may not be transferred to the successor entity if the ownership or nature of the enterprise's activity substantially changes. But acquiring a distressed bank, for instance, may be much more attractive if its accumulated tax losses can be used, as experience during the crisis has highlighted: a change in an Internal Revenue Service (IRS) ruling ${ }^{50}$ significantly eased the takeover of troubled banks, enabling Wells Fargo, for example, to use $\$ 19.4$ billion of tax losses that it acquired (for $\$ 15$ billion) with Wachovia.

\subsubsection{POSSIBLE POLICY RESPONSES}

Refunding tax losses, permitting their sale, or carrying them forward at interest would facilitate efficient restructuring and ease a potential entry barrier. But it would be costly in revenue terms, increase the potential bias towards risk taking noted above, and worsen debt bias (by preserving the value of interest deductions even when the firm has no current taxable income against which to use it). Addressing this last, as discussed in Section 2.2, would limit the risks in easing some of the more arbitrary restrictions on the use of tax losses, including in the context of mergers and acquisitions. Easing these restrictions may be especially appealing in relation to banks, both for restructuring and in warranting substantial inclusion of tax losses in regulatory capital. And the alternative to allowing the transfer of losses may be bank failure, and an expensive and damaging call on deposit insurance.

\subsubsection{Executive compensation}

The level and form of executive compensation have attracted considerable attention, but the question here is whether tax policy has distorted them. The central issue is the balance between salary and performance-related pay, the latter (which has come to account for more than half of all executive compensation) in the form of bonuses, stock options, and the like. A key difference between them is that stock options, in particular, generally increase in their value to the executive with the riskiness of the actions they take (and hence of the underlying share price), whereas salary does not. The general considerations

\footnotetext{
49 Leasing, for instance, can be a way for companies effectively to trade in tax losses, with taxpaying firms taking investment-related deductions that are then shared by leasing to tax-exhausted companies.

50 Subsequently reversed, though not retroactively.
} 
of the previous subsection suggest that taxation may affect the balance between the two, even if neither is intrinsically tax favoured: they suggest that tax consideration may encourage larger performance-related components. Tax distortions may also affect other components of executive compensation, including golden parachutes and carried interest of fund managers.

Tax rules for employee stock options are complex and vary substantially across countries and schemes-but in many cases offer only limited benefit relative to salary. Employers choose between (1) paying salary now (with deduction at corporate level and taxation at personal level) and (2) granting the right to exercise an option later, with the employer then taking the difference between market and exercise price as a deduction and the executive paying personal tax on the same. ${ }^{51}$ The main difference is that in the latter case funds accumulate free of personal tax within the corporation, whereas in the former the executive is liable for taxation on his or her own holdings. The advantage of (2) is thus one of deferral, which may be small: for the USA, Hall and Liebman (2000) put this at only around 4 per cent of compensation cost. In some cases (as in Germany, for example) restrictions on deductibility of option costs at corporate level have meant that options are actually tax disfavoured.

Importantly, tax rules in the USA have clearly encouraged performancerelated pay. Since 1993, the deductibility of non-performance-related executive salaries has been limited to $\$ 1$ million-a strong incentive to use more incentivized pay schemes.

Golden parachutes generally do not receive special tax treatment. They are usually generally taxed as other earned income-and in the USA are actually tax penalized, with certain payments subject to a 20 per cent excise and not deductible against CIT.

Private equity and hedge fund managers receive most of their compensation as 'carried interest', subject, in several countries, only to relatively light taxation as dividends or long-term capital gains. ${ }^{52}$ Critics see this as taxing managers at inappropriately low rates on what is effectively labour income. If this income were taxed as earnings, however, coherence would require that a corresponding deduction for payment of compensation be available to other partners-enabling an offsetting increase in the pre-tax remuneration of the fund managers. Many fund investors, however, are tax exempt and so could not use the deduction: taxing as earned income would then result in increased partnership tax payments. The remuneration arrangements for fund managers are in any event likely to encourage risk taking, since only a fixed fee is

51 The tax treatment described here is not universal, but is quite common.

${ }^{52}$ This is the case, for instance, in Belgium, Denmark, Finland, France, Germany, Ireland, Italy, Spain, Sweden, the USA, and the UK. 
received until some target rate of return is realized: light taxation of carried interest once that return is realized may amplify this effect.

\subsubsection{POSSIBLE POLICY RESPONSES}

Practice varies widely, but major tax biases to the form of executive remuneration do not appear to have been endemic. Some country-specific action may be needed simply to achieve greater neutrality-for instance, removing caps on deductibility limits on ordinary salary (dealing with any equity concerns through progressivity of the general income tax). If it were felt necessary to go further and actively discourage the use of stock options-and a tax argument might be made that they reinforce the tendency to excess risk taking implied by limited liability (and implicit government guarantees)—such measures as denial of CIT deductibility (perhaps above some threshold) could be considered.

The carried interest issue turns on the fundamental distortion introduced by taxing capital gains and dividend distributions differently from labour income-which almost all tax systems are likely to retain. The fairness concern is a real one, but no fully satisfactory solution has yet been found.

\subsection{Taxation and financial asset prices}

Asset prices reflect expected future returns, and hence expected future tax payments. Recognizing this, tax policy can be used, and has been, to affect asset prices. The expectation that future capital gains will be taxed, for example, can in principle make bubbles less likely. Several countries indeed used tax measures to this end during the housing boom: the Republic of Korea, for instance, introduced in 2005 a national-level property tax charged at progressive rates on the combined value of all housing and land over a threshold value (with an exemption for one-person households), and from 2007 reinforced a progressive CGT structure for housing. Ireland introduced an antispeculative yearly ownership tax of 2 per cent of the market value of homes other than primary residences. In other cases, tax measures have been used, at least in part, to support asset prices. One benefit some anticipated from the 2003 dividend tax cut in the USA, for example, was a substantial increase in equity prices and consequent wealth effects. And in the present crisis, a number of countries have used tax measures to bolster house prices: Ireland, for example, removed stamp duty on first-time buyers (of relatively inexpensive properties) and extended mortgage interest relief.

Such asset price effects can be substantial. Poterba (2004) estimates, for example, that the 2003 cuts in dividend taxation and CGT in the USA increased share prices by around 6 per cent; ex post, Amromin et al. (2006)

This is an open access version of the publication distributed under the terms of the Creative Commons Attribution-NonCommercialNoDerivs licence (http://creativecommons.org/licenses/by-nc-nd/3.0/), which permits non-commercial reproduction and distribution of the work, in any medium, provided the original work is not altered or transformed in any way, and that the work is properly cited. For commercial re-use, please contact academic.permissions@oup.com 
find the aggregate effect to have been muted, but with a substantial impact for high-dividend-paying firms. And there is evidence that announcements of reductions in stamp duty on share transactions in the UK have led to greater price increases for more frequently traded stocks. ${ }^{53}$

Tax effects on asset prices, however, can be complex and hard to predict. Three aspects of price behaviour are potentially important: level, rate of increase, and volatility. Tax measures can affect all three, and in ways that may be difficult to anticipate:

- A higher rate of CGT may cause the price of an asset to fall but its rate of appreciation to increase (in order to continue yielding the after-tax return available on other assets; see Box 2.2 for details). It is even possible for a higher CGT rate to be associated with higher asset prices (because any capital loss attracts a larger tax break).

- Reducing dividend taxes may have no effect on equity prices if the marginal shareholder is non-resident (and so not subject to the tax).

- Preferential tax treatment of the return on some asset can increase the volatility of its price (implying a relatively high variance of returns, as discussed in Section 2.3.3 above).

- Transaction taxes, sometimes recommended as a way to decrease price volatility, have been found in some cases actually to increase it (by thinning the market). ${ }^{54}$

Ad hoc tax policy measures are unlikely to be the best way to deal with unwelcome asset price developments. Compounding the uncertainties of effect just noted is the risk of creating unintended distortions and avoidance opportunities: for instance, lowering CGT in the attempt to support asset prices can create an incentive to transform interest income into capital gains. Gaps between announcement and implementation (or even the expectation of tax changes) can distort financial decisions (the anticipation of a reduction in stamp duty in the UK during 2008, for example, was reported to have led to some delaying of transactions). And lags in the adoption of tax changes can cause unwelcome pro-cyclical effects: tax increases on land holdings intended to quell the bubble in Japan, for instance, did not come into effect until after it had burst (Morinobu 2006). Tax measures can be attractive for their asset specificity and, in some circumstances, relative speediness. But they are no substitute for counter-cyclical policies, both monetary and potentially fiscal (applied across a range of instruments and maintaining tax

53 See Bond et al. (2005), who examine the effects on share prices of reductions in stamp duty announced in 1984, 1986, and (though ultimately not implemented) 1990.

${ }^{54}$ See, e.g., Westerholm (2003). 


\section{Box 2.2. TAXATION AND ASSET PRICES}

In a world of perfect certainty, the price of a share-like financial asset would evolve according to the arbitrage condition

$$
r V_{t}=\left(1-T_{D}\right) D_{t}+\left(1-T_{G}\right) \dot{V}_{t}
$$

where $V_{t}$ denotes the price of the asset of interest at time $t, r$ the (fixed and unchanging) after-tax return on some alternative asset, $D$ the dividend, taxed at rate $T_{D}$, and $T_{G}$ the (accrual-equivalent) CGT rate. (There are new equity issues, for simplicity.)

That a higher CGT rate may lead to faster price appreciation can be seen by taking the special case in (2.1) in which the current dividend is zero: the proportional price increase is then $\dot{V} / V=r /\left(1-T_{G}\right)$.

Solving (1.1), with limiting condition $\lim _{t \rightarrow \infty} D_{t} \exp \left(-r t /\left(1-T_{G}\right)=0\right.$, gives the asset price as:

$$
V_{0}=\left(\frac{1-T_{D}}{1-T_{G}}\right) \int_{0}^{\infty} D_{t} \exp \left(-r t /\left(1-T_{G}\right)\right) d t
$$

An increase in the dividend tax rate thus clearly lowers the asset price. The effect of a higher CGT rate, however, is ambiguous. On the one hand, it reduces the present value of future dividends because of the additional tax payable as the asset price rises to reflect them; it also, however, cushions the present value cost of any future reduction in the asset price. Differentiating in (1.2), the balance between these two effects can be seen to depend on the duration of the asset (that is, on the average length of time until dividends are received): a higher CGT rate reduces the current asset price if and only if duration is sufficiently long. The likelihood of a higher CGT rate leading, counterintuitively, to increasing asset prices may be less in practice than this algebra suggests, however, both because opportunities for loss offset may be limited and because the taxation on realization rather than accrual provides an opportunity for asset-holders to lessen the price impact.

neutrality properties). These would properly operate in part through effects on asset prices. Targeted regulatory actions are surer and better-focused instruments for dealing with particular assets, with structural tax policy best guided by the core objective of neutrality across assets and over time.

\subsection{Conclusions}

Tax distortions are likely to have encouraged excessive leveraging and other financial market problems evident in the crisis. These effects have been little explored, but are potentially powerful enough to have effects of macroeconomic significance. Taxation can result, for example, in a net subsidy to borrowing of hundreds of basis points, raising debt-equity ratios and vulnerabilities from capital inflows. 
This chapter has reviewed the main channels by which tax distortions can significantly affect financial markets, drawing implications for tax design once the crisis has passed. Tax rules vary widely across countries, but some general conclusions emerge:

- Corporate-level tax biases favouring debt finance, including in the financial sector, are pervasive, often large-and are hard to justify given the potential impact on financial stability. There is a strong case for dealing more decisively with this bias; for example, by also allowing a deduction of an imputed equity cost (which for regulated financial institutions would be akin to an allowance for Tier 1 capital).

- Continued favourable treatment of housing in many countries has supported high housing prices, while mortgage interest relief-where it remains - may have encouraged heavy household leverage. The risks in distorting a market so central to financial stability reinforce long-standing efficiency and equity arguments for more neutral taxation.

- The development and use of complex financial instruments is generally driven by non-tax considerations, but is in part a response to, and shaped by, underlying tax distortions (such as relatively favourable treatment of capital gains, and cross-country tax differentials). Moreover, securitization and other devices can amplify the economic costs of those tax distortions (for example, by reducing the cost of subprime financing), and their use to secure favourable tax treatment contributes to opaque financial arrangements. Solutions are not simple, given the profundity of the underlying tax distortions.

- Divergences in national tax rates, bases, and practices create substantial opportunities for international tax arbitrage, further increasing opacity and reinforcing tax biases to debt. Progress on 'tax havens' addresses issues of evasion but not fundamental ones of tax avoidance. Measures to address the latter that are both politically acceptable and technically coherent are hard to identify, but need to be explored further.

- Tax measures can have significant effects on asset price dynamics, but are unlikely to be the best way to deal with bubbles.

Almost all these issues have long been recognized in the public finance literature. Their importance, however, may not have been fully appreciated.

This is an open access version of the publication distributed under the terms of the Creative Commons Attribution-NonCommercialNoDerivs licence (http://creativecommons.org/licenses/by-nc-nd/3.0/), which permits non-commercial reproduction and distribution of the work, in any medium, provided the original work is not altered or transformed in any way, and that the work is properly cited. For commercial re-use, please contact academic.permissions@oup.com 


\section{APPENDIX}

\section{Taxes and the cost of corporate finance}

This appendix explains the tax effects on the costs of retention and new equity finance reported in Box 2.1 and discussed in the text.

For retention finance, note first that, if the company retains an additional $\$ 1$ of aftertax income, this costs the shareholder $\$\left(1-T_{D}\right)$ as forgone after-tax dividend, where $T_{D}$ denotes the rate of tax on dividends at personal level. This could have been lent out to generate interest income $R$ that would have been taxed at rate $T_{P}$. The net income forgone is thus $\$\left(1-T_{D}\right)\left(1-T_{R}\right) R$. Against this, the additional internal funds generate a capital gain (taxed at rate $T_{G}$ ) that reflects additional future net income $\rho$, which will generate dividends (taxed at $T_{D}$ ). The net benefit to retaining an additional $\$ 1$ is thus

$$
-\left(1-T_{D}\right)\left(1-T_{R}\right) R+\left(1-T_{G}\right)\left(1-T_{D}\right) \rho .
$$

Setting this to zero gives (1.2).

For new equity, (1.3) in Box 2.1 follows from a similar argument ${ }^{55}$ except that the initial cost is in terms of funds already in the shareholders' hands, and so is not mitigated by the dividend tax, and there are no capital gains consequences (since the share is purchased at a price reflecting the future earnings). Optimality thus requires

$$
-\left(1-T_{R}\right) R+\left(1-T_{D}\right) \rho=0,
$$

which gives (1.3). Imputation schemes of the kind mentioned in the text provide a shareholder-level credit for corporate-level taxes charged at some rate $C$, so that $1-T_{D}=\left(1-T_{R}\right) /(1-C)$; if $C$ is set at the CIT rate-'full' imputation-the cost of new equity is the same as that of debt finance.

55 The marginal cost of any form of finance today typically depends on the marginal source in the future: the latter is assumed throughout this analysis to be retentions.

60

This is an open access version of the publication distributed under the terms of the Creative Commons Attribution-NonCommercialNoDerivs licence (http://creativecommons.org/licenses/by-nc-nd/3.0/), which permits non-commercial reproduction and distribution of the work, in any medium, provided the original work is not altered or transformed in any way, and that the work is properly cited. For commercial re-use, please contact academic.permissions@oup.com 


\title{
The Role of Housing Tax Provisions
}

\author{
Thomas Hemmelgarn, Gaetan Nicodeme, and Ernesto Zangari
}

\subsection{Introduction}

The 2008 financial crisis hit the world economy severely. While taxes are not considered a proximate cause of the crisis, some aspects of tax policy may have led to increased risk taking and indebtedness (see Chapter 2). Tax incentives may indeed have exacerbated the behaviour of economic agents, leading them to wrong economic decisions. Among the tax factors, the widespread tax-induced bias to homeownership has attracted considerable attention, because excessive demand in the housing market, combined with lax lending practices, may have contributed to the speculative bubble in real estate prices.

This chapter proposes a detailed account of the manner in which tax provisions relating to the housing market may have led to the banking crisis. Monetary and regulatory policies opened up the possibility for a housing bubble that eventually burst and created a credit crunch because of a lack of confidence between actors on financial markets. Governments reacted by a combination of capital and liquidity injections, regulatory measures, and fiscal stimulus.

In most narratives of the financial crisis, the dynamics of the US housing market play a decisive role: in fact, the problems started with the housing market and the financial structure that was built on it. Not surprisingly, many commentators have found fault with some tax provisions that may have contributed to an overheated housing market. In particular, attention has

\footnotetext{
The authors thank Jean-Pierre De Laet, Vieri Ceriani, Stefano Manestra, David Pitaro, Giacomo Ricotti and Alessandra Sanelli for useful comments. This chapter was written by Mr Gaetan Nicodeme (European Commission, Université Libre de Bruxelles, CEPR and CESifo), Mr Thomas Hemmelgarn (European Commission), and Mr Ernesto Zangari (Banca d'Italia). The views expressed in this chapter are those of the authors and do not necessarily reflect the official positions of the respective institutions with which the authors are affiliated.
}

This is an open access version of the publication distributed under the terms of the Creative Commons Attribution-NonCommercialNoDerivs licence (http://creativecommons.org/licenses/by-nc-nd/3.0/), which permits non-commercial reproduction and distribution of the work, in any medium, provided the original work is not altered or transformed in any way, and that the work is properly cited. For commercial re-use, please contact academic.permissions@oup.com 
been focused on the tax treatment of residential housing capital gains and on the deductibility of interest expenses on mortgages.

Some commentators argue that the quasi repeal of residential housing capital gains taxation in 1997 may have fuelled the housing bubble. On the other hand, neither the OECD nor the IMF believe that this factor has played a significant role; ${ }^{1}$ moreover, the academic research that has analysed the dynamics of the US housing market tends to have reached the same conclusion (see also Chapter 2).

The role of the mortgage interest deductibility in the crisis is also controversial. There was no relevant change in the US tax rules on this tax break in the 2000s; the housing boom did not take place evenly across the country, although the federal tax system has a nationwide coverage. Housing prices went up both in countries where interest on mortgages was deductible and in countries where it was not or where it was deductible only within limits. Nevertheless, this tax break can be thought of as a catalyst in a chemical reaction: the deductibility did not cause the bubble, but it may have accelerated the run-up in prices. It remains true that the US regime is one of the most generous in an international comparison; while all other countries allow interest deductibility only for acquisition or renovation of residential buildings, the US tax code extends this allowance to other purposes ('home equity loan'); moreover, the relatively generous limits to the benefit are capped on the amount of the mortgage, not on the amount of interest payments (as in all other countries). Since it is proportional to debt, the tax break is more relevant for riskier mortgages with higher interest rates and may have contributed to trigger 'gambles' on housing, especially in the context of 'exuberant' price expectations.

A meaningful comparison can be made between the 2008 financial crisis and the 1990s Scandinavian banking crises. In the late 1980s Norway, Sweden, and Finland experienced large credit and asset upswings, followed by severe downturns after the burst of asset prices. As in the recent US and world financial crisis, so in the Scandinavian banking crises: deregulatory measures, expansionary monetary policy, and lax risk analysis interacted and paved the way for a rapid credit expansion and increases in asset prices; ${ }^{2}$ an important role was played by the housing market dynamics, which in turn were probably affected by housing tax provisions; and the asset bubbles burst when interest rates started to increase. ${ }^{3}$ An interesting case in regard to the relationship between housing tax rules and financial crisis is Sweden: here the housing tax rules may have contributed indirectly to the price upswings

\footnotetext{
1 See IMF (2009a) and OECD (2009a).

2 See Englund (1999: 80).

3 The increase of interest rates was due not only to a change in the stance of monetary policy, but also to the effects of German reunification (Englund 1999: 89).
} 
(the 'catalyst' argument) and directly to the bursting of the price bubble, through the 1990-1 tax reform, which substantially reduced the benefit stemming from the deductibility of interest payments, increasing the real cost of borrowing. ${ }^{4}$ With respect to the Scandinavian banking crises, the US financial crisis seems to have been even more related to the housing market developments; another distinctive and important feature of the current crisis regards the role of securitization (see below).

This chapter is organized as follows. Section 3.2 provides an introduction to developments of the 2008 financial crisis. Section 3.3 offers a reflection on whether specific tax provisions may have aggravated the crisis by encouraging homeownership and risky behaviour. Section 3.4 contains some final remarks.

\subsection{The build-up to the 2008 financial crisis}

\subsubsection{General economic conditions before the crisis}

The events leading to the financial and economic crisis that began in 2008 are heavily debated and the dust has not yet settled on the real causes of the crisis. The arguments set out in this chapter are, therefore, somewhat speculative and subject to debate, and they will eventually be judged by history. Yet, a majority of commentators point to several elements that have facilitated an easing of credit and an increase in risk taking.

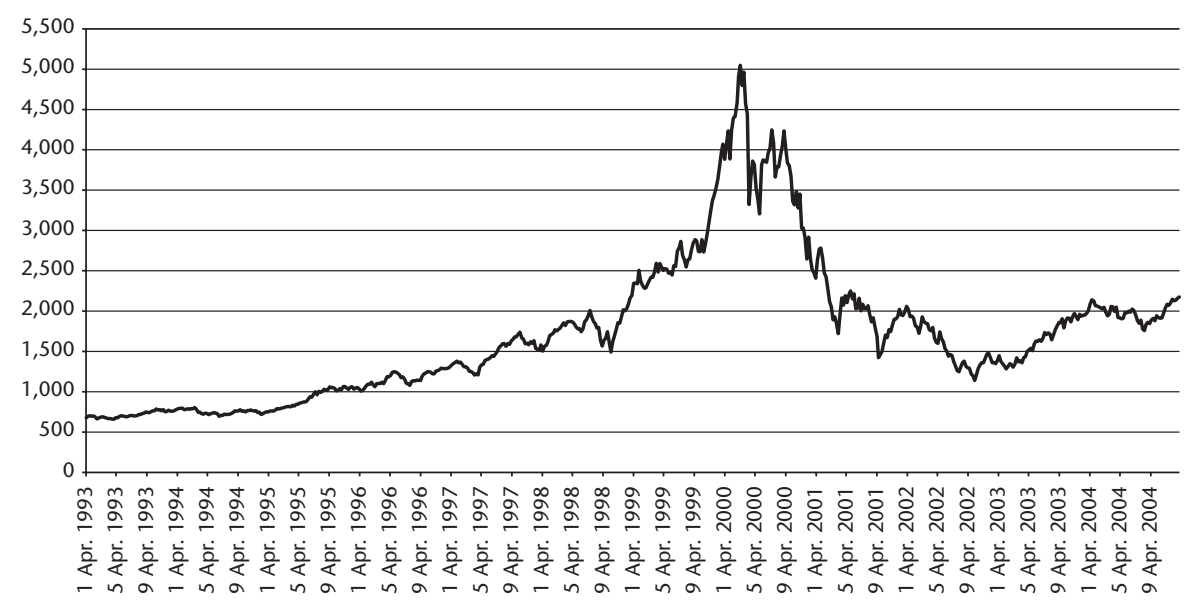

Figure 3.1. Nasdaq Composite Index, 1993-2004

Source: Yahoo! Finance.

${ }^{4}$ See Agell et al. (1995) and Englund et al. (1995).

This is an open access version of the publication distributed under the terms of the Creative Commons Attribution-NonCommercialNoDerivs licence (http://creativecommons.org/licenses/by-nc-nd/3.0/), which permits non-commercial reproduction and distribution of the work, in any medium, provided the original work is not altered or transformed in any way, and that the work is properly cited. For commercial re-use, please contact academic.permissions@oup.com 


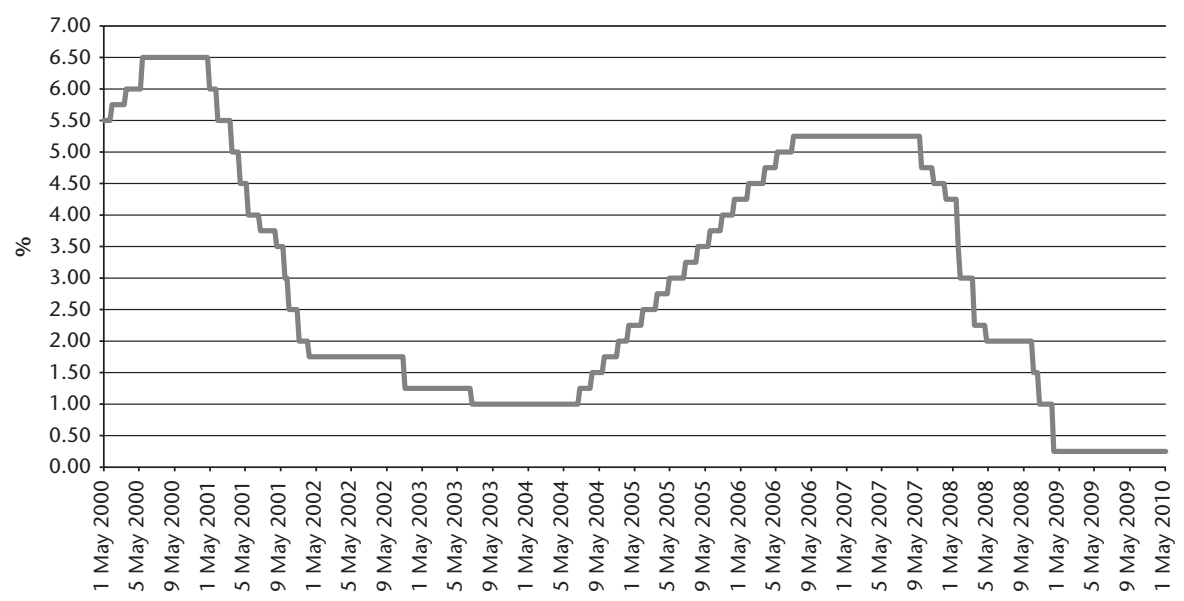

Figure 3.2. US Federal Reserve discount rate, 2000-9

Source: Federal Reserve.

The economic conditions in the early 2000s were characterized by the bursting of the dot-com bubble, which peaked in March 2000 and led to a pronounced decline in world stock-market indices in the following years (see Figure 3.1). The reaction of the Federal Reserve to this stock-market decline and the steady worsening of economic conditions were to reduce interest rates. Accordingly, the US Primary Credit Discount Rate was progressively lowered from 6.5 per cent at the peak of the bubble in mid-2000 to 1 per cent by mid-2003 (see Figure 3.2). ${ }^{5}$

A second characteristic of the world economy in the early 2000s was massive inflows of capital on international financial markets. The US Capital and Financial Account is illustrative of this phenomenon (see Figure 3.3). ${ }^{6}$ Between 1995 and 2000 it increased from 1.54 per cent to 4.25 per cent of GDP and continued to rise in the first half of the 2000s to peak at 6.10 per cent of GDP in 2006. The main driver of this expansion was net portfolio investment, which grew from $\$ 42.7$ billion in 1998 to over $\$ 807$ billion in 2007 -a twentyfold increase over nine years (see Figure 3.4). As a result, in the first half of the 2000s the US economy was characterized by a rapid recovery in a lowinterest-rate environment, despite a high degree of risk aversion in stock markets, following the tech bubble burst.

\footnotetext{
5 Note that the Federal Reserve most certainly also tried to combat the economic consequences of the 11 Sept. 2001 terrorist attacks. The US economy was also in a context of low inflation, if not of deflation risk, which facilitated an ease in monetary policy.

6 The Capital and Financial Account is composed of the net capital transfers, the change in the domestically owned assets abroad, and the change in foreign-owned assets at home. It mirrors the current account (which is composed of the trade balance and the net unilateral current transfers).
} 


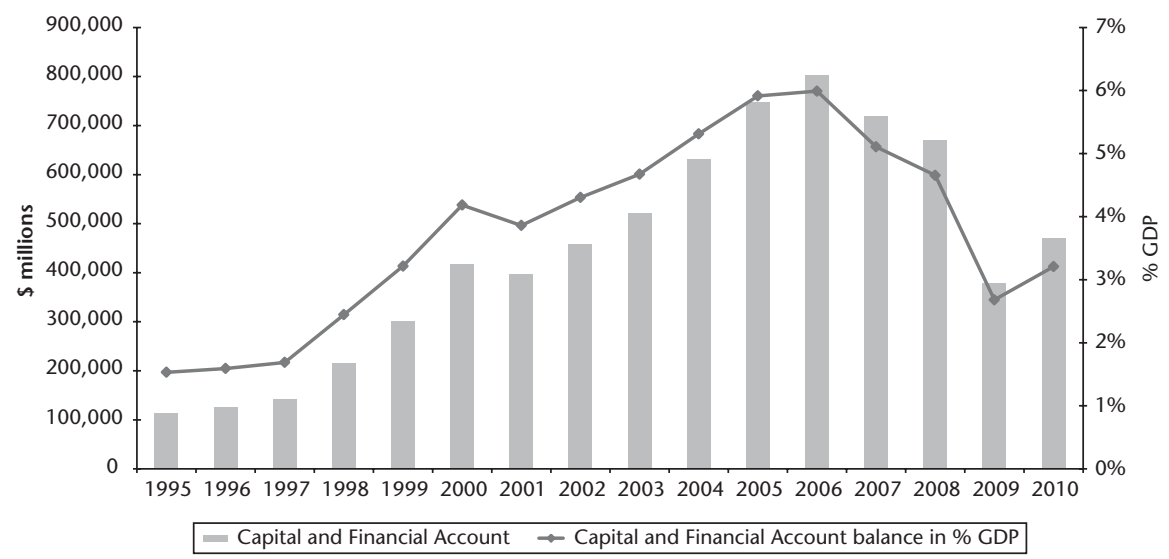

Figure 3.3. US Capital and Financial Account

Source: US Bureau of Economic Analysis.

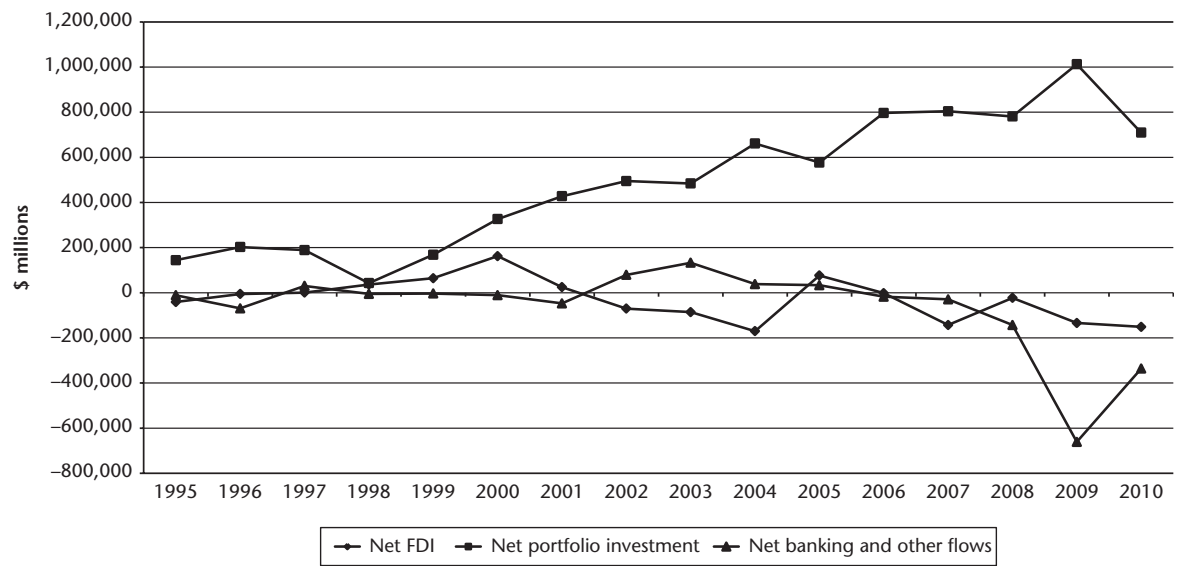

Figure 3.4. US Capital and Financial Account, components Source: US Bureau of Economic Analysis.

\subsubsection{Promotion of homeownership, deregulation, and subprime credits}

In their search for new places in which to invest, many economic agents saw property as a safe and more profitable haven. The conditions were consequently slowly put in place for a housing bubble. Between 2001 and 2005 in the United States the number of houses sold increased by 41.3 per cent and the average Case-Shiller price index rose by 57.8 . per cent and 43.1 per cent in

This is an open access version of the publication distributed under the terms of the Creative Commons Attribution-NonCommercialNoDerivs licence (http://creativecommons.org/licenses/by-nc-nd/3.0/), which permits non-commercial reproduction and distribution of the work, in any medium, provided the original work is not altered or transformed in any way, and that the work is properly cited. For commercial re-use, please contact academic.permissions@oup.com 


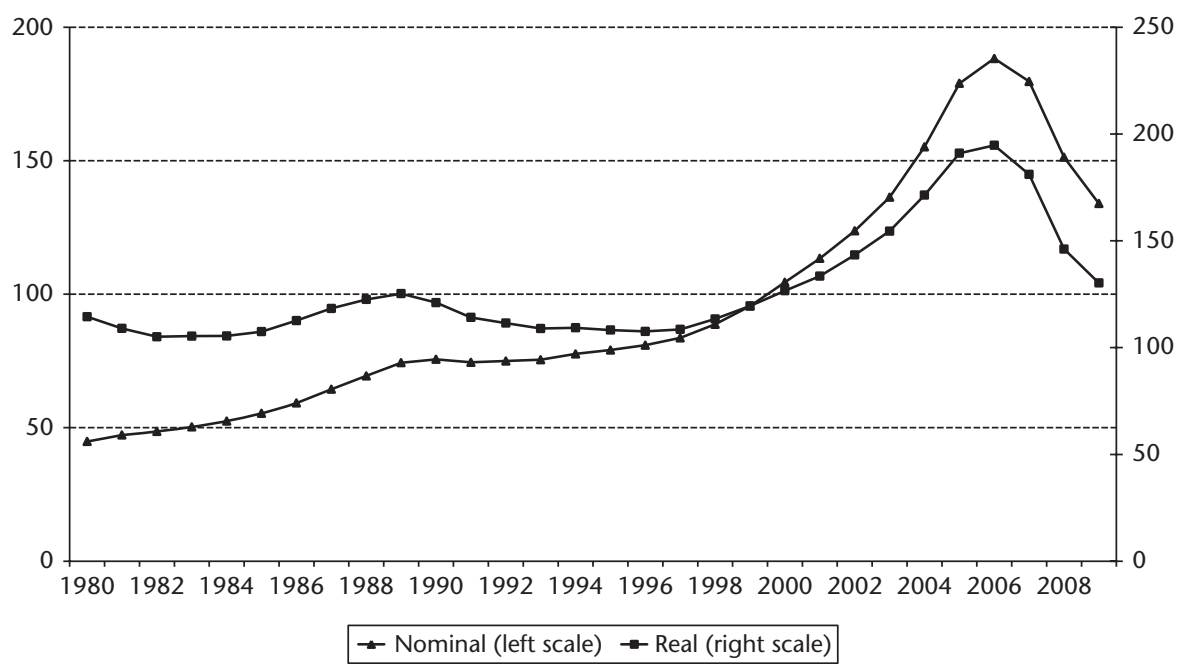

Figure 3.5. Case-Shiller house price index

Source: Shiller (2005). See <http://www.irrationalexuberance.com $>$.

nominal and real terms, respectively (see Figure 3.5$).^{7}$ In addition to favourable economic conditions (low interest rates, large inflow of capital that needed to be recycled in the economy, and cold feet of investors towards stock markets), several regulatory measures also created incentives towards homeownership.

First, politicians wanted to expand homeownership, especially for poorer families. Two institutions played a particular role in this policy: Fannie Mae and Freddie Mac. The Federal National Mortgage Association (Fannie Mae) was created in 1938 under the Roosevelt administration to purchase and securitize mortgages in order to ensure enough liquidity for lending institutions. It became an independent body - albeit with implicit government guarantee-in 1968 and was complemented in 1970 by a competitor, the Federal Home Loan Mortgage Corporation (Freddie Mac), which achieved similar functions on this secondary mortgage market. The role of Fannie Mae and Freddie Mac was to purchase loans from mortgage sellers such as banks and other financial institutions, securitize them into mortgage-backed bonds, and resell them on the secondary market, guaranteeing the principal and interest of the loan in exchange for a fee. This mechanism proved to be a powerful instrument to refinance lending institutions with fresh cash and subsequently allow them to engage in additional lending

\footnotetext{
7 See $<$ http://www.census.gov $>$ for data about house sales. For a description of the Case-Shiller index, see $<$ http://www.standardandpoors.com/indices/sp-case-shiller-home-price-indices $>$.
} 
activities. The US administrations also used these agencies to expand housing credit to middle- and low-income families as well as in distressed areas. ${ }^{8}$

Second, the US tax system contained several incentives for homeowners to increase their use of mortgages. For example, the 1986 Tax Reform Act disallowed consumers to deduct interest payments on consumer loans (car loans, credit card loans, and so on). This created a perverse incentive for homeowners to use or refinance their home mortgages-whose interest payments were tax deductible - to pay off their other debts or to extract cash for personal expenses. This incentive became increasingly larger because of the wealth effect of ever-rising home values. In addition, the 1997 Taxpayer Relief Act simplified the tax treatment of housing capital gains and increased in many cases the tax exemption for these incomes-giving further incentives to buy houses. The effects of the Low Income Housing Tax Credit and the 2004 American Dream Downpayment Act provided further fiscal and support measures in favour of homeownership. ${ }^{9}$

In this context, financial institutions reacted by opening the credit tap, helped by more lax regulations. The 1999 Gramm-Leach-Bliley Act repealed some of the provision of the 1933 Glass-Steagall Act, which disallowed financial institutions to combine commercial, insurance, and investment activities and this might have led to more risk-prone attitudes from the part of commercial banks. ${ }^{10}$ Risk taking was also encouraged by relaxed rules on capital adequacy and new accounting standards. The decision on 28 April 2004 by the Securities and Exchange Commission to loosen the capital rules for large financial institutions (following their request) and to let computer models of those investment companies determine the level of risk of investment (that is, de facto self-monitoring) may have led to a sharp increase in the leverage of the main US financial institutions. ${ }^{11}$ This trend was also facilitated by the

\footnotetext{
${ }^{8}$ See the 1977 Community Reinvestment Act (CRA), which was extended by the 1992 Federal Housing Enterprises Financial Safety and Soundness Act and scrutinized by the 1995 New Community Reinvestment Act, or the decision of the Department of Housing and Urban Development in 2000 to order Fannie Mae to devote half of its business to poorer families, which was increased to a $56 \%$ goal in 2004.

9 The Low Income Housing Tax Credit was part of the 1986 Tax Reform Act and provides developers with tax credit for equity investment when investing in low-income units in a housing project. The 2004 American Dream Downpayment Act provided downpayment grants of a maximum of $\$ 10,000$ or $6 \%$ of the purchase price of the house (whichever amount was larger) to first-time homebuyers with annual incomes that do not exceeded $80 \%$ of the area median income. See also Gale et al. (2007).

${ }^{10}$ See Lloyd in Chapter 8.

11 See <http://securities.stanford.edu/news-archive/2004/20040428_Headline08_Drawbaugh. htm>; <http://www.nytimes.com/2008/10/03/business/03sec.html>. Between 2003 and 2007 the leverage of the top five US financial institutions evolved as follow: Lehman Brothers from $22.7 \%$ to $29.7 \%$, Bear Stearns from $27.4 \%$ to $32.5 \%$, Merrill Lynch from $15.6 \%$ to $30.9 \%$, Goldman Sachs from $17.7 \%$ to $25.2 \%$, and Morgan Stanley from 23.2\% to 32.4\%. In 2007, their total debt amounted to $\$ 4.1$ trillion, a third of US GDP (sources: Wikipedia using annual reports <http://www.lehman.com/annual/2007/fin_highlights >; <http:/www.bearstearns.com/
}

This is an open access version of the publication distributed under the terms of the Creative Commons Attribution-NonCommercialNoDerivs licence (http://creativecommons.org/licenses/by-nc-nd/3.0/), which permits non-commercial reproduction and distribution of the work, in any medium, provided the original work is not altered or transformed in any way, and that the work is properly cited. For commercial re-use, please contact academic.permissions@oup.com 
Basel-II agreements, which entered into force in 2008 and gave more scope for financial institutions to assess their risks, as well as by the introduction of the International Accounting Standards in 2005, which forced companies to register gains and losses on financial assets immediately, possibly leading to more stock volatility.

In this context, the proportion of subprime mortgages ${ }^{12}$ soared from 7.2 per cent of the total in 2001 to over 20 per cent in 2005 and 2006 (see Figure 3.6). Gambling was also at play, as some studies pointed out that over a third of the houses bought were for investment or second-residence purposes, and those specific acquisitions were made with the hope that continued price increases would allow buyers to resell with profit. Accordingly, a third of the loans made in 2002 were either interest only (where only interest is repaid) or negative amortization loans (where less than the interest is paid during a first period and the accrued unpaid interest is added to the outstanding amount of the loan). ${ }^{13}$ Moreover, an increasing number of loans were granted as adjustable rate mortgages (ARMs) ${ }^{14}$ between 2001 and 2004 -mostly for the two pre-cited types of loans-and this despite stabilizing interest rates, which possibly indicates an increasing number of credit-constrained borrowers (see Figure 3.7).

sitewide/investor_relations/sec_filings/proxy/index.htm $>$; $\quad<$ http://ir.ml.com/sec.cfm?DocType= Annual\&Year=2008 >; $<$ http://www2.goldmansachs.com/our-firm/investors/financials/current/ annual-reports/revised-financial-section-2007.pdf $>$; $<$ http://www.morganstanley.com/about/ ir/shareholder/10k2007/10k11302007.pdf $>$ ).

12 By definition, a subprime loan is a loan that does not meet the 'prime' standards and is consequently risky. There may be various elements that make the loan fail the 'prime' test (e.g., length, structure, etc.). In this context, it is the profile of the borrower and/or the difference between the loan and the value of the house or the collateral. Loans are usually classified based on the guidelines of government-sponsored enterprises (GSEs). When a credit fulfils the GSE's criteria, it is labelled 'conventional'. When the loan fulfils all guidelines but the amount of the credit (usually loans above $\$ 300,000$ ), it is labelled as 'jumbo'. In those two cases, the creditworthiness of the borrower is not questioned and both loans are 'prime' loans. Non-prime loans can be Alternative A, when, for instance, the borrower has income that is difficult to assess (e.g., selfemployed), a high debt-to-income ratio, little documentation, or several mortgaged houses. In this case, the creditworthiness is not questioned, but there is a higher risk. Non-prime loans can also be home-equity loans, which is a heterogeneous category of second- and first-lien mortgages with high loan-to-value ratios, home improvement loans, and revolving home-equity lines of credits. Finally, non-prime loans also includes the subprime loans with low-credit-quality borrowers (Fabozzi 2005).

13 The Economist (2005).

${ }^{14}$ For subprime mortgages, the proportion of fixed-rate mortgages dropped from $33.2 \%$ in 2001 to $18.6 \%$ in 2005 , while the bulk of the loans were of hybrid nature (i.e., with a fixed rate during an initial period of 2-3 years and then adjustable based on a reference rate) and not pure ARM. From 2005 the share of balloon mortgages in subprime mortgages jumped to reach $25-30 \%$. Those mortgages require a large final payment. Note also that $55-60 \%$ of subprime mortgages were originated to extract cash, while only $30-40 \%$ of the loans were to buy a house (Demyanyk and Van Hemert 2009).

This is an open access version of the publication distributed under the terms of the Creative Commons Attribution-NonCommercialNoDerivs licence (http://creativecommons.org/licenses/by-nc-nd/3.0/), which permits non-commercial reproduction and distribution of the work, in any medium, provided the original work is not altered or transformed in any way, and that the work is properly cited. For commercial re-use, please contact academic.permissions@oup.com 


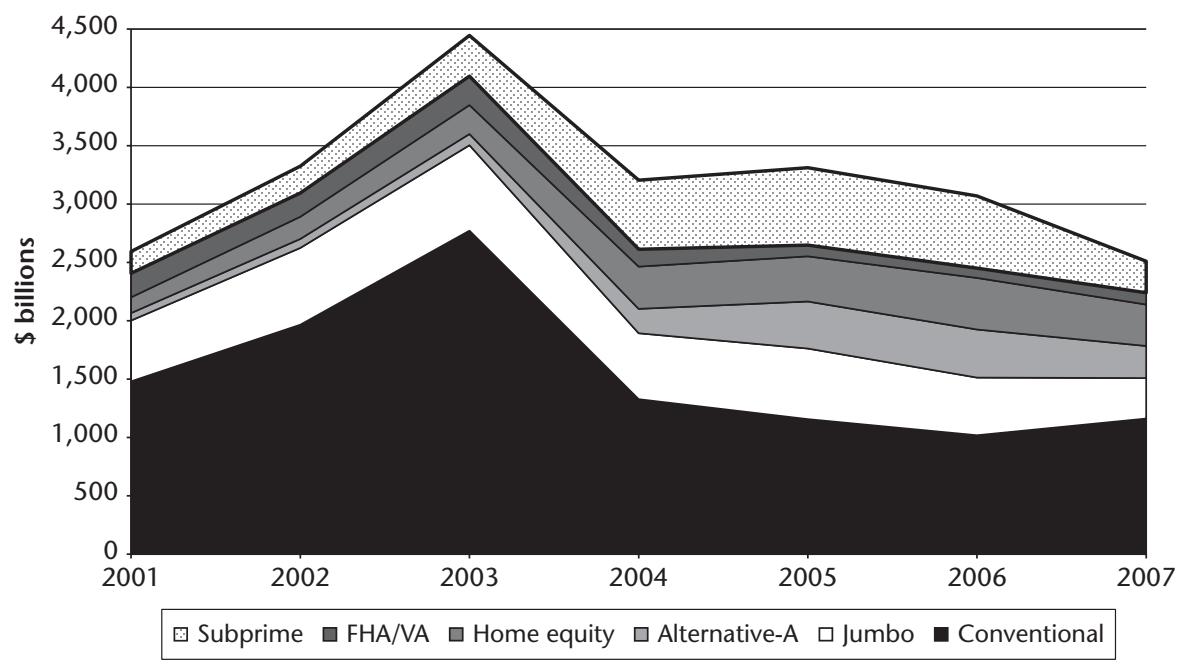

Figure 3.6. US prime and subprime mortgages

Source: Joint Center for Housing Studies at Harvard University (2008).

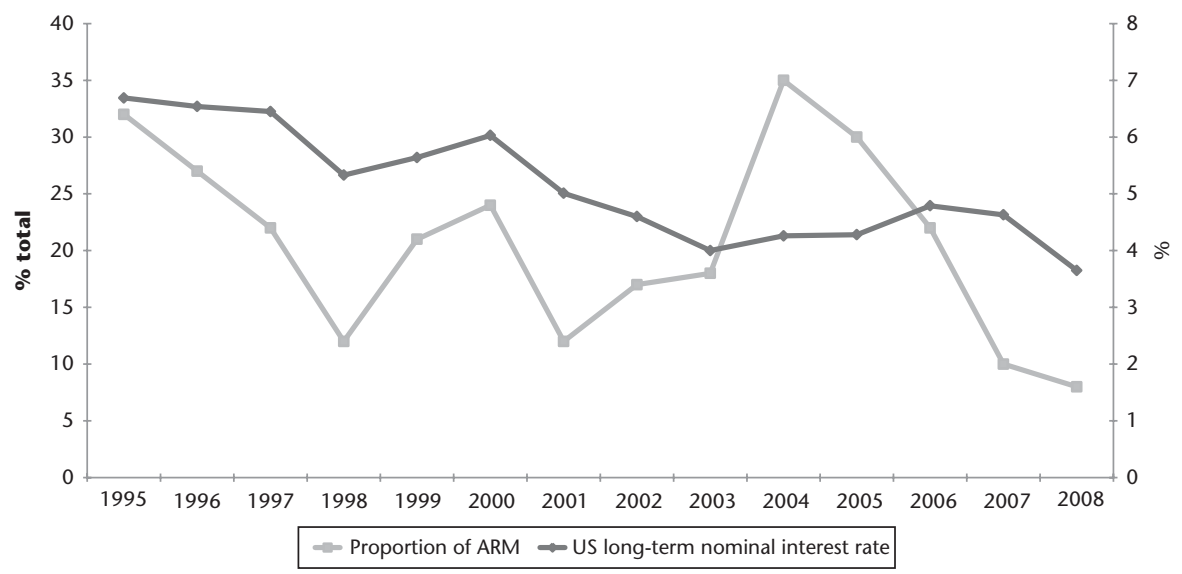

Figure 3.7. Adjustable rate mortgages

Source: AMECO and Joint Center for Housing Studies at Harvard University $(2008,2009)$.

Note: Central government benchmark bond of ten years.

\subsubsection{The securitization of mortgages}

The spread of mortgages, in particular subprime loans, was largely helped by the development of new financial instruments, in particular the technique of securitization, which consists of pooling loans into an investment vehicle and then selling securities backed by payments for these loans. In the case of mortgages, those financial instruments are mortgage-backed securities

This is an open access version of the publication distributed under the terms of the Creative Commons Attribution-NonCommercialNoDerivs licence (http://creativecommons.org/licenses/by-nc-nd/3.0/), which permits non-commercial reproduction and distribution of the work, in any medium, provided the original work is not altered or transformed in any way, and that the work is properly cited. For commercial re-use, please contact academic.permissions@oup.com 
(MBS). Typically, the financial institution will buy the claims of thousands of mortgages and pool them into a so-called special purpose vehicle (SPV), a legal entity outside the balance sheet of a financial institution and hence not subject to capital requirements. The securities are separated in several tranches-senior, mezzanine (or junior), and equity (non-investment grade) with a sequential preference for the claims (that is, the senior tranche has preferred claim on the proceeds over the other two and the mezzanine tranche has preference over the equity tranche). By doing so, financial institutions are able to rearrange the risk of the pool and to redistribute it across investors with different preferences. ${ }^{15}$ This, in turn, lowers the cost of lending and extends credit to borrowers with a lower credit quality.

An important development has been the issue of collaterized debt obligations (CDOs), a family of asset-based securities that is backed by diversified debt obligations such as mortgage-backed securities, corporate bonds, bank loans, credit-card debt, and so on. ${ }^{16}$ While an MBS is backed by mortgage payments, a CDO is backed by mortgage-based securities within a portfolio and therefore represents a resecuritization (Baily et al. 2008). The advantage of a CDO is that it allows financial institutions to rearrange the securities into new compartments within the $\mathrm{CDO}$ and to transform low-rated mortgagebased securities into high-rated CDOs. According to Baily et al. (2008), CDO issuances went from virtually zero in 1995 to over $\$ 500$ billion in 2006 and virtually all CDOs issued after 2006 were backed by low-rated subprime MBS.

This securitization process was itself helped by the emergence of a new class of derivatives that allowed the transfer of credit risk to a third party: the credit default swaps (CDS). These are common instruments, representing 73 per cent of the \$2.3 trillion credit derivative products in 2002 ( $\mathrm{O}^{\prime}$ Kane 2005). The principle is that a third party agrees to assume the default risk of a specific asset in exchange for an income. This process allows the CDO issuer to shield from the risk and to increase the rating of its bonds. The CDS market has developed mainly outside organized markets (that is, they were over-thecounter operations) and grew exponentially from virtually zero in 2001 to about \$15 trillion in 2005 and over \$60 trillion in 2007 (Baily et al. 2008).

\subsubsection{The bubble burst}

With US inflation rising from 1.6 per cent in 2002 to 2.3 per cent in 2003, 2.7 per cent in $2004,3.4$ per cent in 2005 , peaking at 4.3 per cent in June $2006,{ }^{17}$ the Federal Reserve gradually raised interest rates from 1 per cent to

15 See Fabozzi (2005) for a description of these instruments and Baily et al. (2008) for an account description of the processes.

16 See Fabozzi (2005: chs 30 and 31). $\quad 17$ See <http://www.inflationdata.com>.

This is an open access version of the publication distributed under the terms of the Creative Commons Attribution-NonCommercialNoDerivs licence (http://creativecommons.org/licenses/by-nc-nd/3.0/), which permits non-commercial reproduction and distribution of the work, in any medium, provided the original work is not altered or transformed in any way, and that the work is properly cited. For commercial re-use, please contact academic.permissions@oup.com 
5.25 per cent (see Figure 3.2) and the first cracks appeared in the housing market. Some borrowers, especially those with ARMs, started feeling the pain and eventually could not repay their mortgages. The number of foreclosures increased exponentially from 885,000 in 2005 to $1,259,118$ in 2006, $2,203,295$ in 2007 , and 3,157,806 in $2008 .{ }^{18}$ The number of houses sold declined, and prices levelled off before plunging.

Financial institutions started to be hit, as they were heavily indebted and exposed via mortgage-backed securities, whose value are based on mortgage payments and house values. HSBC announced in February 2007 that it was writing down $\$ 10.5$ billion of subprime MBS. This event was followed in April by the bankruptcy of New Century Financial, the largest US subprime lender. In July, the collapse of two hedge funds run by Bear Stearns because of subprime losses was another alarming sign of deterioration, as were the announcements of heavy losses in other financial institutions, which put some of them on the verge of bankruptcy (for example, Bear Stearn)—with in some cases bank runs (for example, Northern Rock in the $\mathrm{UK}^{19}$ ). The near collapse of the banking system happened in September 2008. On 7 September, ailing government-sponsored enterprises Fannie Mae and Freddy Mac were urgently nationalized. On 14 September, Merrill Lynch saw itself close to illiquidity and was sold to the Bank of America. The next day, Lehman Brothers filed for bankruptcy, and the day after, American International Group (AIG), one of the largest $\mathrm{CDS}^{20}$ providers, avoided bankruptcy only thanks to a $\$ 85$ billion loan from the Federal Reserve. ${ }^{21}$ The uncertainty about external positions and liquidity or solvency of financial institutions led to a sharp drop in confidence among financial market participants. This led in turn to a sharp increase in the TED Spread-an indicator of perceived credit risk-which went over 300 basis points on 17 September $2007^{22}$ and to a sharp fall in the interbank lending activities (see Figure 3.8). These financial problems spread into the real economy via a credit crunch, creating a drop in available funds for private investment.

The banking crisis also quickly spread to stock markets. The S\&P-500 index started to decline from its peak of 1565.15 points on 9 October 2007 to

18 See <http://www.realtytrac.com $>$ for data sources.

19 Northern Rock asked and received liquidity support from the Bank of England in September 2007 and was eventually nationalized in Feb. 2008.

20 Credit default swaps (CDSs) are 'insurance' contracts through which the buyer of the CDS hedges the risk of default of an investment in a financial asset (the reference instrument). The buyer of the CDS provides the seller with payments in the form of fees or premiums, and, in exchange, the seller provides the buyer with a payoff if the reference instrument suffers a credit event (e.g., default of the counter-party).

21 See Wibaut (2008) for an excellent description of the events.

22 The TED spread is the difference in basis points between the short-term interbank rate (i.e., the LIBOR) and the three-month US treasury rate. Its historical fluctuation is between 10 and 50 basis points. On 10 October 2008 it reached a record 465 basis points <http://www. tedspread.com>.

This is an open access version of the publication distributed under the terms of the Creative Commons Attribution-NonCommercialNoDerivs licence (http://creativecommons.org/licenses/by-nc-nd/3.0/), which permits non-commercial reproduction and distribution of the work, in any medium, provided the original work is not altered or transformed in any way, and that the work is properly cited. For commercial re-use, please contact academic.permissions@oup.com 


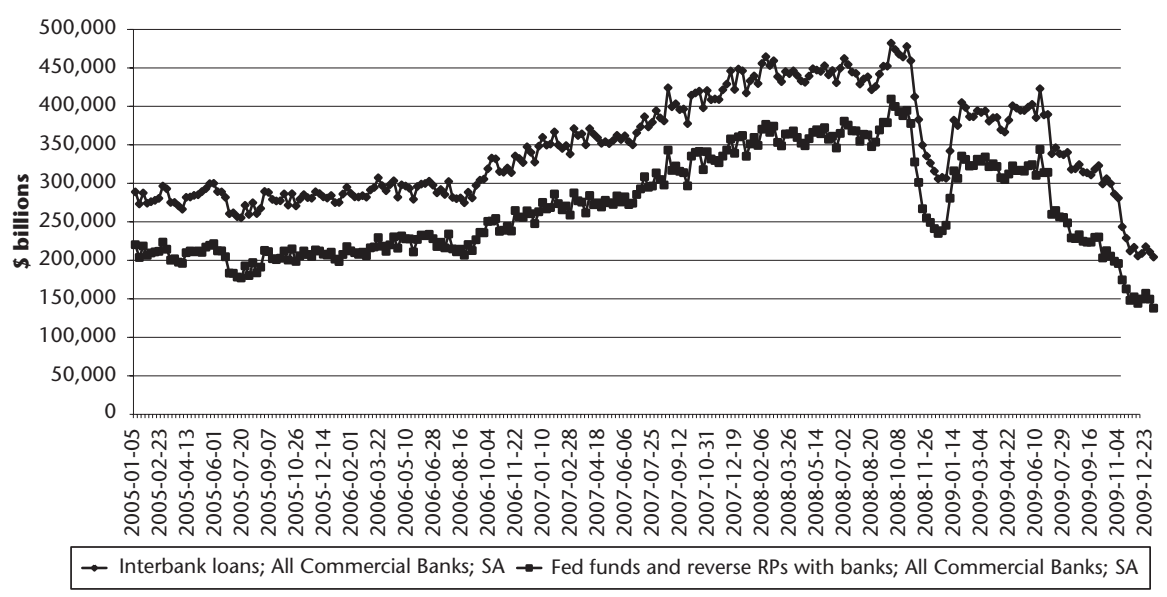

Figure 3.8. US interbank loans

Source: Board of Governors of the Federal Reserve System (2011).

1251.70 points on 12 September 2008, a decline of more than 20 per cent in less than a year. On 15 and 17 September, amid turmoil in large financial institutions, it lost twice an additional 4.71 per cent. The descent into hell was not over yet, with stock crashes of 8.8, 7.6, 9.0, and 8.9 per cent on 29 September, 9 October, 15 October, and 1 December, respectively. On 9 March 2009, the S\&P-500 index reached its lowest point: 676.53 points, only 43.2 per cent of its value fifteen months earlier.

\subsection{Did taxes on housing contribute to the crisis?}

The end of the speculative price bubble in the US housing market has been identified as an important trigger for the financial crisis. In Europe, Ireland and Spain faced similar price bubbles, and, when the international crisis hit, this led to a severe downturn in these two countries, which had formerly shown some of the best economic performance in the eurozone. Other European countries such as the UK, France, Sweden, and the Netherlands had experienced similar increases in house prices since the mid-1990s, albeit to a lesser extent. ${ }^{23}$

While real house prices rose in many countries, the same was true for the price-to-rent ratio, which is defined as the nominal housing price index divided by the rent component of the consumer price index. This is an indicator of the relative attractiveness to own a house versus renting it; it can be interpreted also as an indicator of the over- or undervaluation of the

23 See Hilbers et al. (2008).

72

This is an open access version of the publication distributed under the terms of the Creative Commons Attribution-NonCommercialNoDerivs licence (http://creativecommons.org/licenses/by-nc-nd/3.0/), which permits non-commercial reproduction and distribution of the work, in any medium, provided the original work is not altered or transformed in any way, and that the work is properly cited. For commercial re-use, please contact academic.permissions@oup.com 


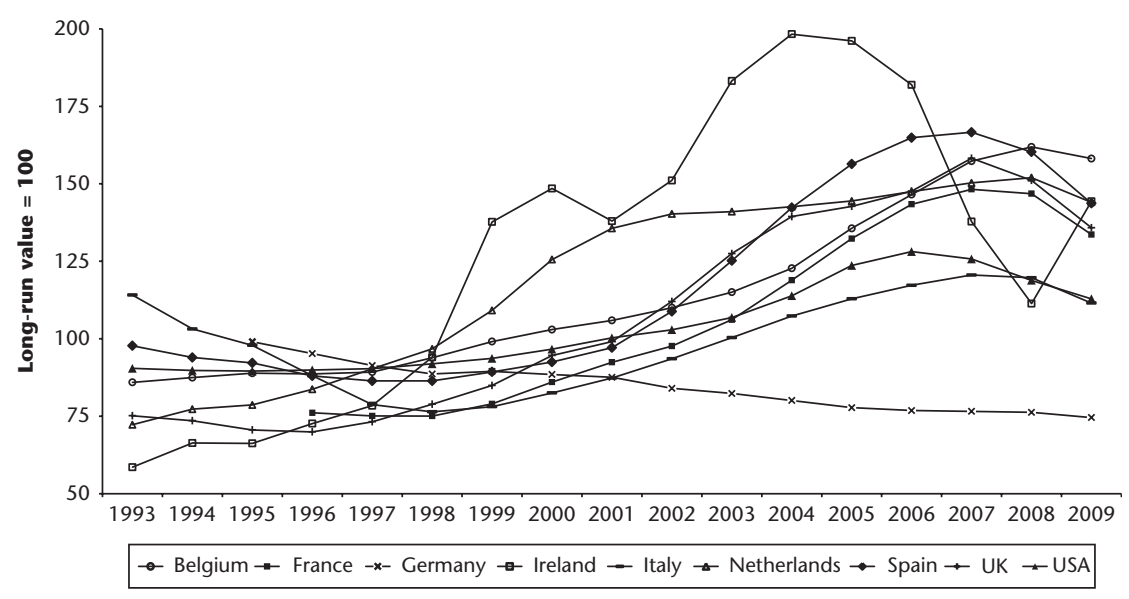

Figure 3.9. Price-to-rent ratios

Source: OECD (2010b).

housing market. As seen in Figure 3.9, since the mid-1990s the price-to-rent ratio has increased significantly in many countries, especially Ireland and Spain. Ireland also faced the most dramatic decrease after the peak had been reached in 2005. These dynamics point to an overvaluation of the housing market in the years prior to 2008 in several countries.

Given these observations, the question arises how taxes might influence house prices and price-to-rent ratios. To answer this question, we first recall the main results stemming from a very simple economic model of the housing market, which provides a basis for discussion of the effects of some basic housing tax provisions. Second, we compare the tax systems of different countries with respect to the US system. Finally, we discuss the possible role of housing tax provisions in the financial crisis.

\subsubsection{The economic analysis of the housing sector}

The decision to buy a house entails two economic dimensions: a consumption decision and an investment-production decision. ${ }^{24}$ The first facet is related to the decision of households to consume housing services, which is mainly related to the quality of the house. The household decides what type of house and in which location it would like to consume. The investmentproduction decision is related to the potential value increase of the property, as households take into account that owning a house is also an investment.

${ }^{24}$ A detailed analysis of the functioning of the housing market can be found in Pozdena (1988).

This is an open access version of the publication distributed under the terms of the Creative Commons Attribution-NonCommercialNoDerivs licence (http://creativecommons.org/licenses/by-nc-nd/3.0/), which permits non-commercial reproduction and distribution of the work, in any medium, provided the original work is not altered or transformed in any way, and that the work is properly cited. For commercial re-use, please contact academic.permissions@oup.com 
Housing is a durable good that can potentially be sold at a higher price, even after years of use. This makes the decision to buy a house more complex than consumption decisions for other goods that are based mainly on the price and on the consumer's budget constraint.

A simple and quite general demand-supply model of the housing market (see Box 3.1) predicts that:

\section{Box 3.1. A MODEL OF THE HOUSING MARKET}

The standard economic analysis of the housing sector moves from the observation that the housing market actually consists of two interrelated markets: one for the existing stock of houses, which determines their price, and one for the new flow of construction, which determines residential investment. ${ }^{a}$

The equilibrium on the market of existing houses requires that owners, as investors, earn the same return on the housing investment as on alternative investments:

$$
R_{H}=\left[\left(1-\tau^{P I T}\right) i^{M}+\delta+\beta+m+\tau^{P}-\left(1-\tau^{\complement G}\right) E\left(\pi^{H}\right)\right] P_{H}
$$

where $R_{H}$ denotes the marginal value of rental services per period, $\tau^{P I T}$ the relevant personal income tax rate, ${ }^{\mathrm{b}} i^{M}$ the financing cost (for simplicity assumed equal to the investor's opportunity cost of funds), ${ }^{c} \delta$ the depreciation of the stock of existing houses, $\beta$ the risk premium required by the investor to be owner rather than tenant, $m$ the maintenance cost per unit value, $\tau^{P}$ the property tax rate, $\tau^{\complement G}$ the housing capital gains tax rate, $E\left(\pi^{H}\right)$ the expected housing price appreciation, and $P_{H}$ the price of existing houses. ${ }^{d}$ The above equation can also be interpreted as follows: in the long run the cost of owning a house should be equal in equilibrium to the cost of renting it, with $R_{H}$ representing the annual cost of renting and the quantity in square brackets representing the user cost of housing or ownership (or 'imputed rent'). ${ }^{\mathrm{e}}$

Assuming that the rental value $R_{H}$ is decreasing in the stock of houses $\mathrm{H}$ (i.e., $d R_{H} / d H<0$ ), and that the user cost of housing is positive, equation (1.1) can be interpreted as a (downward-sloping) demand function, whose slope is steeper the lower is the user cost.

A housing supply function can be easily derived assuming a positive relationship between (net) residential investment and the ratio of house prices over building costs $\left(C_{H}\right){ }^{f}$ Formally:

$$
H_{t}-H_{t-1}=\Delta H_{t}=\phi\left(P_{H, t} / C_{H, t}\right)-\delta H_{t}
$$

The short-run price elasticity of housing supply is equal to $\phi$; the long-run elasticity is larger and equal to $\phi / \delta$. In this simple model house prices play the same role of the value of the firm's stock in Tobin's $q$ dynamic investment model.

\footnotetext{
a Standard references are Kearl (1979), Topel and Rosen (1988), and Poterba (1984, 1991, 1992).

b Without loss of generality, we assume the case of mortgage interest deductibility, as in the USA.

c See Poterba (1984: 732); see also Poterba (2008).

d See Van den Noord (2005).

e See Hilbers et al. (2008: 8).

f See Poterba (1991).
}

This is an open access version of the publication distributed under the terms of the Creative Commons Attribution-NonCommercialNoDerivs licence (http://creativecommons.org/licenses/by-nc-nd/3.0/), which permits non-commercial reproduction and distribution of the work, in any medium, provided the original work is not altered or transformed in any way, and that the work is properly cited. For commercial re-use, please contact academic.permissions@oup.com 
- since housing supply is basically fixed in the short run, the housing market is subject to price overshooting in the face of demand shocks; the housing market is therefore intrinsically volatile;

- the deductibility of mortgage interests, by reducing the user cost of ownership, decreases the demand elasticity; it therefore increases the volatility of the housing market; ${ }^{25}$

- the increase in volatility could have negative effects, especially if agents form expectations (also partially) in an extrapolative manner, inducing prolonged price upswings or downswings not linked to 'fundamentals'; ${ }^{26}$ in the best-case scenario, the choices of households and firms could be temporarily distorted; in the worst-case scenario, a price bubble may form;

- rise in expectations on housing price appreciation and more generous tax breaks on housing (for example, lower capital gains tax rates) may generate, in principle and under some conditions, unsustainable dynamics in the housing market. ${ }^{27}$

\subsubsection{The taxation of housing in Europe and the USA}

There is a great diversity of housing tax regimes across countries. ${ }^{28}$ International comparisons are difficult to carry out because of the complexity of tax codes (in terms of deductions, exceptions, threshold limits, and so on).

Table 3.1 summarizes the information concerning the tax treatment of mortgage interest expenses and imputed income for owner-occupied housing, capital gains on first-home selling, and property taxes on owner-occupied dwellings for a set of countries comprising Belgium, France, Germany, Ireland,

25 In general, the price sensitivity of demand for housing tends to fall with the extent of preferential tax treatment for housing and with the expected rate of housing price appreciation (see Van den Noord 2005).

26 For the USA, see Case and Shiller (1988). See also the general discussion in Poterba (1991).

27 The model sketched in Box 3.1 can easily account for disequilibria dynamics. Suppose, for example, that, for whatever reason, the user cost of ownership becomes equal to zero. This can happen because of: either a decrease in the (net) mortgage interest rate (for instance, because of more generous interest deductibility and/or lower monetary policy interest rates), given expected housing price appreciation; or a sudden increase of the expectations of housing price appreciation; or a decrease of taxes on housing capital gains; or a combination of the previous factors. The right-hand side of equation (1.1) in Box 3.1 becomes equal to zero. The left-hand side can be equal to zero only when the demand for housing is infinite. With very strong demand for housing there will pressure on prices in the short run (given the low short-run supply elasticity). Regardless of how expectations are formed, agents will anticipate higher prices, and this would push the user cost into negative territory, with a further increase in demand, and so on. Here we have a vicious cycle-a price bubble processwhich can be rationalized even by a very simple model, with very general assumptions.

28 For a review of housing tax regimes in Europe, see Hilbers et al. (2008). See also ECB (2003) and Van den Noord (2005). By comparing the information in these papers with ours, it is possible to get a picture of how housing taxation changed in the decade prior to 2007 .

This is an open access version of the publication distributed under the terms of the Creative Commons Attribution-NonCommercialNoDerivs licence (http://creativecommons.org/licenses/by-nc-nd/3.0/), which permits non-commercial reproduction and distribution of the work, in any medium, provided the original work is not altered or transformed in any way, and that the work is properly cited. For commercial re-use, please contact academic.permissions@oup.com 
Table 3.1. The taxation of owner-occupied housing in Europe and the USA, 2009

\begin{tabular}{|c|c|c|c|c|}
\hline Country & $\begin{array}{l}\text { Taxation of } \\
\text { imputed rents }\end{array}$ & Mortgage interest tax relief & $\begin{array}{l}\text { Capital gains } \\
\text { taxation }\end{array}$ & Property tax \\
\hline Belgium & Yes $^{a}$ & Tax deductibility with a limit ${ }^{\mathrm{b}}$ & No & $\mathrm{No}^{\mathrm{a}}$ \\
\hline France & No & Tax credit for the first five years with a limit & No & $\begin{array}{l}\text { Taxe d'habitation and Taxe } \\
\text { foncière }\end{array}$ \\
\hline Germany & No & No & No & Grundsteuer \\
\hline Ireland & No & Tax credit for the first seven years with a limit ${ }^{d}$ & No & No \\
\hline Italy & No & Tax credit with a limit & No & No \\
\hline The Netherlands & $\mathrm{Yes}^{\mathrm{e}}$ & Tax deductibility without limit & No & Onroerende-zaakbelasting $(O Z B)$ \\
\hline Spain & No & Tax credit with a limit on the amount of housing costs & $\mathrm{No}^{\mathrm{f}}$ & Impuesto sobre bienes inmuebles \\
\hline UK & No & 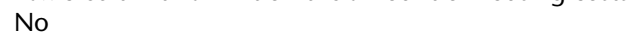 & No & Council Tax \\
\hline USA & No & $\begin{array}{l}\text { Tax deductibility } \\
\text { with a limit on the amount of mortgage principal ( } \$ 1 \\
\text { million) }\end{array}$ & $\begin{array}{l}\text { No } \\
\text { (if CG }<\$ 500,000 \text { ) }\end{array}$ & $\mathrm{Yes}^{\mathrm{g}}$ \\
\hline
\end{tabular}

${ }^{a}$ In Belgium the imputed rent is a 'cadastral income', which was last reviewed in 1975 and has been indexed to inflation since 1990. In the case of owner-occupation, the deemed income (after the deduction of some deemed expenses) is not subject to income tax, but only to an 'immovable withholding tax' (precompte immobilier), with a rate that depends on the region where the property is located (see Haulotte et al. 2010). Taking into account the municipal surcharges, the effective tax rate of the immovable withholding tax ranges from $18 \%$ to $50 \%$ (IBFD 2009 ). In the computations of the effective tax rate in Figure 3.10 we assume an immovable withholding tax rate of $34 \%$ (the average between $18 \%$ and $50 \%$ ).

${ }^{b}$ The deduction pour habitation propre et unique refers to mortgage interest, mortgage capital, and to particular insurance premiums regarding the loan (Haulotte et al. 2010: 29). The limit to the deduction is $€ 2,770$ for the first ten years and $€ 2,080$ thereafter.

${ }^{c}$ France also levies a net wealth tax with specific rules for owner-occupied houses. More precisely, the impôt de solidarité sur la fortune is an annual tax on the excess of the overall value of assets over a certain threshold, with a $30 \%$ reduction of the value of the owner-occupied house (see Borselli et al. 2010).

${ }^{\mathrm{d}}$ Since 1 May 2009 in Ireland the interest relief has been restricted to the first seven years of the mortgage. In 2010 Ireland started to phase out mortgage interest relief: the tax break will be abolished from 2018; for new loans the relief will be gradually reduced (see IBDF 2010).

${ }^{\mathrm{e}}$ In the Netherlands the imputed income is calculated as a percentage (until 2008 up to $0.55 \%$ ) of the market value of the property (since 2009 there has been no maximum imputed income (see IBFD 2009)).

${ }^{\mathrm{f}}$ In Spain full rollover relief is available for the sale of the primary residence. Moreover, housing capital gains are exempt when realized by a taxpayer aged 65 or more.

${ }^{9}$ The state and local real estate taxes are deductible against the federal personal income tax.

Sources: IBDF (2009); Borselli et al. (2010).

This is an open access version of the publication distributed under the terms of the Creative Commons Attribution-NonCommercialNoDerivs licence (http://creativecommons.org/licenses/by-nc-nd/3.0/), which permits non-commercial reproduction and distribution of the work, in any medium, provided the original work is not altered or transformed in any way, and that the work is properly cited. For commercial re-use, please contact academic.permissions@oup.com 
Italy, the Netherlands, Spain, the USA and the UK (an overview of the property tax regimes can be found in the appendix to this chapter). ${ }^{29}$

From a theoretical point of view, under a comprehensive income tax, a fully neutral taxation of owner-occupation requires the taxation of imputed rents and capital gains of housing and the deductibility of mortgage interests. ${ }^{30}$ Real-world tax systems are anything but neutral. In fact, owner-occupancy is tax favoured with respect to renting in many countries, and with respect to most forms of return on personal savings: with only a few exceptions, imputed rents and capital gains on owner-occupied housing are not taxed; the tax relief on mortgages' interest further reinforces the tax bias towards housing.

Table 3.1 shows that only Belgium and the Netherlands tax the imputed rent on owner-occupancy. Mortgage interest costs attract tax relief in all countries except Germany and the UK. In the Netherlands, Belgium, and the United States interest expense is deductible from the tax base (but in Belgium the deduction is capped at a given amount of interest payments, while in the USA the cap refers to the amount of mortgage principal), so the tax advantage depends on the marginal tax rate of the owner. In the other countries the tax relief for financing costs mainly takes the form of a tax credit, often with limited duration. ${ }^{31}$ Basically, no country in our set taxes capital gains on owner-occupied housing. Finally, with regard to property taxes, only Belgium, Ireland, and Italy do not tax the owneroccupied property; notice that in the USA it is possible to deduct state and local real estate taxes against the federal personal income tax.

To get an idea of the quantitative effects of the personal income-tax rules regarding imputed income, mortgage interests and capital gains, and the fiscal burden of the property taxes, we compute the effective average tax rate on owner-occupied housing using a simplified version of the IMF methodology, which does not consider transaction taxes ${ }^{32}$ (see Box 3.2 for a description of the methodology). The results of these computations are shown in Figure 3.10 (see the appendix to this chapter for the assumptions regarding property taxation). ${ }^{33}$

29 Tax information refers to the 2009 tax codes reported in IBFD (2009). See also Borselli et al. (2010).

30 See Van den Noord and Heady (2001: 30) and IMF (2009a: 17).

31 For example: in Spain, taxpayers are allowed to set off $15 \%$ of the costs incurred for acquisition or renovation of a primary residence against their income-tax liability, up to €9,015 (i.e. the maximum credit is $€ 1,352$ ); in Ireland, for first-time buyers, the relief-given at source with the effect of reducing the borrower's interest payments-takes the form of a tax credit at a rate of $25 \%$ for years 1 and 2, 22.5\% for years 3, 4, and 5, 20\% for years 6 and 7 (the interest relief is restricted to an interest payment of $€ 20,000$ for a couple); in France, interest on loans for purchase or the construction of the principal residence entitles the taxpayer to a $20 \%$ tax credit for the initial five-year period of the loan (40\% for the first twelve months), up to $€ 7,500$ per year for a couple (i.e., the maximum credit is $€ 3,000$ in the first year and $€ 1,500$ for the remaining four years); in Italy, interest on mortgage loans taken to build or buy the principal residence entitles the taxpayer to a $19 \%$ tax credit up to $€ 4,000$ (i.e., maximum credit equal to $€ 760$ ).

32 Which can arguably be substantial for some countries (see IMF 2009a).

33 For Belgium, as Van den Noord (2005: 36), we assume that the imputed income is the same fraction of the value of the unit of housing as in the Netherlands $(0.55 \%)$. To take into account the

This is an open access version of the publication distributed under the terms of the Creative Commons Attribution-NonCommercialNoDerivs licence (http://creativecommons.org/licenses/by-nc-nd/3.0/), which permits non-commercial reproduction and distribution of the work, in any medium, provided the original work is not altered or transformed in any way, and that the work is properly cited. For commercial re-use, please contact academic.permissions@oup.com 


\section{Box 3.2. THE METHODOLOGY TO COMPUTE THE EFFECTIVE AVERAGE TAX RATE}

The IMF methodology considers the purchase of a house at a predetermined price $(\$ 250,000)$, with a holding period of ten years, an investor in the top-income tax bracket, no repayment of principal, and proceeds of home sales used to buy another house. The effective tax rate is computed as the ratio of the present value of all taxes paid during the holding period to the present value of house incomes. ${ }^{\text {a }}$ The yearly housing income is the sum of the imputed rent and the capital gain, assumed to be equal to $4 \%$ and $5 \%$ of the house price, respectively. As in the IMF study, we use a mortgage interest rate of $6 \%$ and a discount rate of $5 \%$, and we assume that the purchase is $80 \%$ mortgage financed. In contrast with the IMF study, the price of the house in our computations is set at $€ 500,000$; this permits the highest possible tax relief to be obtained in all the countries where the tax allowance for mortgage interest is limited.

${ }^{a}$ For an early approach, which relies on the cost of capital to compute effective marginal tax rates, see, e.g., the analyses in Jorgenson and Landau (1993).

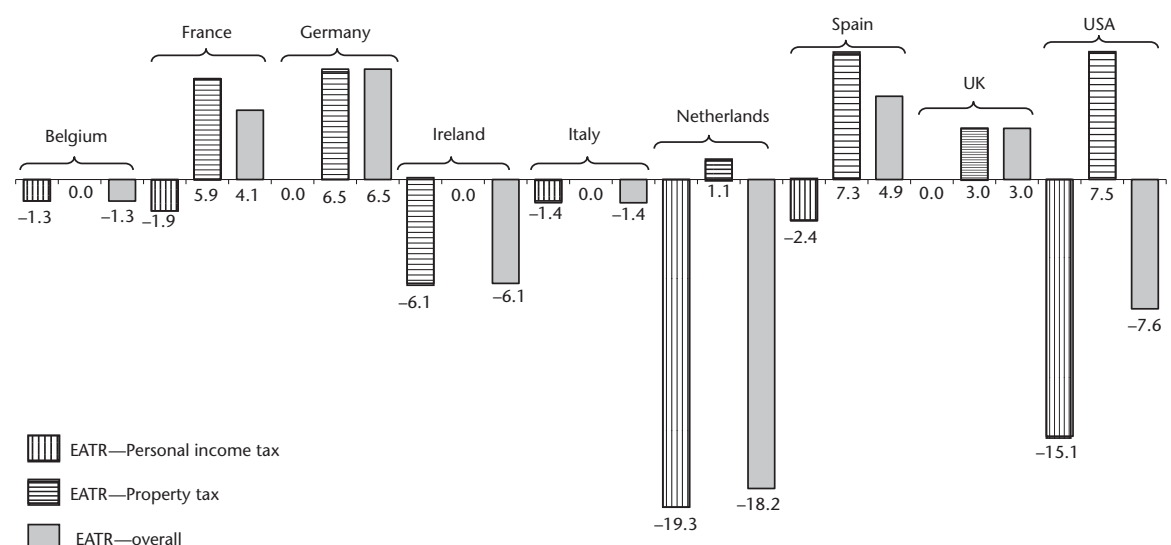

Figure 3.10. Effective average taxation of owner-occupation, Europe and the USA (\%) Source: our calculations. Data: IBFD (2009). Methodology: IMF (2009).

In all the countries the personal tax system provides incentives to owneroccupation: since the effective average personal tax rates are negative in all countries save Germany and the UK, housing investment is subsidized by the personal income-tax system. Owner-occupancy is tax favoured de facto by the

difference between the two tax systems, in contrast with Van den Noord's analysis, we consider a 'fiscal value' of the house lower than the market value. We assume a 33\% cut of the market value of the house. Moreover, we assume that the Belgium 'fiscal' imputed income grows at the rate of $2 \%$ (rather than at 5\%, as in the Netherlands). For the sake of comparison, assuming no cut of the market value and a 5\% growth rate for the 'fiscal' imputed income, the effective tax rate on housing would be $-0.4 \%$ (rather than $-1.3 \%$ of Figure 3.10 ); assuming a $50 \%$ cut of the market value and a $2 \%$ growth rate for the imputed income, the effective tax rate would instead be $-1.6 \%$.

This is an open access version of the publication distributed under the terms of the Creative Commons Attribution-NonCommercialNoDerivs licence (http://creativecommons.org/licenses/by-nc-nd/3.0/), which permits non-commercial reproduction and distribution of the work, in any medium, provided the original work is not altered or transformed in any way, and that the work is properly cited. For commercial re-use, please contact academic.permissions@oup.com 
personal tax system also in Germany and the UK, since the effective average tax rate (equal to zero) is generally lower than the tax rates on alternative investments.

The implicit tax subsidy stemming from the personal income-taxation rules is particularly strong in the Netherlands and in the USA, where mortgage interest is deductible basically with no limits. ${ }^{34}$ The subsidy is also strong in Ireland; but notice that Ireland started to phase out this tax relief in 2009.

As regards property taxation, the fiscal burden is comparatively higher in the USA, Spain, Germany, and France than in the UK and the Netherlands (as noted above, Belgium, Ireland, and Italy do not tax owner-occupied property).

By considering the overall effective tax rate, the tax subsidy for owneroccupied housing is found to be the largest in the Netherlands, the USA, and Ireland.

When the international comparison refers, not only to interest tax relief, taxation of imputed rents and capital gains, and taxes on property, but also to transaction taxes, ${ }^{35}$ as in the IMF's analysis, the results show large differences across countries. ${ }^{36}$ However, as regards the United States, the results are consistent with the IMF's: overall, the USA stands out as having low taxes on owneroccupied housing (see Section 3.3.3.2 for a brief discussion on the cross-country correlation between measures of effective taxation and house prices).

\subsubsection{Housing taxation and the financial crisis}

The main direct cause of the financial crisis lies in the bursting of the US housing bubble, so, in assessing responsibility for the financial crisis, it is natural to begin by examining the structure and the dynamics of the US housing market, particularly its demand side. The focus here is on the possible role of the 'tax factor' in the US housing market dynamics. ${ }^{37}$

The IMF and the OECD do not consider tax rules as the main reason for the housing bubble: housing prices increased in countries with different tax systems, and there were no tax breaks clear and big enough to explain the

\footnotetext{
${ }^{34}$ In the countries where the tax allowance related to mortgage interest is limited, the EATR of the personal income-tax system depends on the value of the house: once the limit of the tax break is reached, the EATR increases with the value of the house, and it has an upper bound that depends on the overall housing (personal) tax regime. For instance, if the imputed income is not taxed, the EATR is negative and will tend to zero as the housing income increases. This happens because the tax break becomes less relevant as (the present value of) the total housing income gets higher. If we assume an initial house price equal to $€ 250,000$, and we keep all the remaining assumptions used in the main text, the EATR of the personal income-tax system would be $-0.8 \%$ for Belgium (against $-1.3 \%$ of Figure 3.10 ), $-3.7 \%$ for France (against $-1.9 \%$ ), $-7.3 \%$ for Ireland (against $-6.1 \%$ ), $-2.7 \%$ for Italy (against $-1.4 \%$ ), and $-4.9 \%$ for Spain (against $-2.4 \%$ ). Notice that the ranking of the countries is basically unaffected by the change of the assumption regarding the house price.

35 Which can arguably be substantial for some countries (see IMF 2009a).

36 See IMF (2009a: 20-1a).

37 For in-depth analyses of the dynamics of the US housing market, see Case and Shiller (2004); Glaeser et al. (2005); Himmelberg et al. (2005); and Shiller (2005).
} 
price dynamics that were observed. ${ }^{38}$ At the same time, many commentators have found fault especially with the tax treatment of housing capital gains and mortgage interest deductibility. Let us consider each of them in turn.

\subsubsection{CAPITAL GAINS TAXATION}

Since the bursting of the US housing bubble, it has been asserted that the housing policies pursued in the USA since the mid-1990s are partly to blame for the financial crisis, particularly the policies aimed at increasing homeownership through access to mortgage loans for first-time buyers with low and variable incomes. ${ }^{39} \mathrm{~A}$ tax measure in the same vein is the repeal of capital gains taxation on home selling with the Tax Relief Act of 1997 (henceforth TRA97).

TRA97 generated a change in the tax treatment of housing capital gains. Previously, housing capital gains had been taxed when homeowners sold their houses, unless they resorted to the 'rollover rule' or to the '55-age rule'. The rollover rule allowed homeowners to postpone the taxation, provided they bought a house of equal or higher value within two years. The 55-age rule allowed sellers aged 55 or more to claim a one-time exclusion of $\$ 125,000$ against the capital gains tax. TRA97 abolished both rules and allowed homeowners to claim $\$ 500,000$ exclusion ( $\$ 250,000$ for singles) against the capital gains tax as often as every two years. Since the ownership and use tests to claim the exclusion are not very strict, it was often possible to get the tax benefit for a second home (Shan 2008).

The repeal of capital gains taxation may have had an important impact on the effective taxation on housing: using the same IMF methodology and the same assumptions as above, ${ }^{40}$ it can be demonstrated that, following TRA97, the effective average tax rate on housing decreased from $-6.37 \%$ to $-17.12 \% .{ }^{41}$ However, the overall effects of TRA97 on the US housing market are theoretically ambiguous, ${ }^{42}$ and the existing empirical evidence does not offer clear-cut answers. ${ }^{43}$

38 See IMF (2009a) and OECD (2009a).

39 See Katz (2009).

40 In the computations we use the highest marginal tax rate in 1996 and 1997, which was equal to $39.6 \%$. The capital gains tax rate applied for 1996 is $28 \%$ (see Shan 2008).

${ }^{41}$ The average tax rate in $1996,-6.37 \%$, is the average between the tax rate for homeowners aged 55 years or more at the time of selling $(-8.23 \%)$ and the tax rate for homeowners aged less than 55 years at the time of selling who decide to buy after ten years $(-4.51 \%)$.

${ }^{42}$ For example, TRA97 also lowered all long-term capital gains tax rates, which were further reduced in 2001 and 2003 (see Shan 2008). The reduction of the capital gains tax rate with the TRA97 may have had effects on the market for rental properties (where the rents are determined), then indirectly affecting the market for owner-occupied houses (see Box 3.1, equation (1.)). The lower long-term capital gains tax rates may have allowed the building of rental projects in which landlords could also break even with lower rents. And lower rents could have eased the demand pressure on the market for owner-occupied houses, contrasting the possible demand pressure coming from the repeal of capital gains taxation on first-home selling.

${ }^{43}$ See Bier et al. (2000); Cunningham and Engelhardt (2008); Biehl and Hoyt (2008); Shan (2008); and Quayes (2010). 
Some commentators observe a structural break in the time series of US house prices between 1997 and 1998 (see Figure 3.5) and associate it with the repeal of capital gains taxation. In subsequent years, other factors became important: the rise in house prices, drawing investors' attention; the end of the stock-market boom following the peak in March 2000; the attempt by the Federal Reserve to avoid a severe recession in 2001 by pumping liquidity into the system; the public policies aimed at increasing the homeownership rate. However, the new provisions on capital gains taxation of 1997 may have contributed to the house-price boom, 'fuelling the mother of all housing bubbles', 44 playing the role of a precipitating factor. Their effects were then amplified by mechanisms involving investor confidence and expectations of market performance (besides the other factors mentioned above); adaptive or extrapolative expectations may have played a role in these amplification mechanisms. ${ }^{45}$

Other commentators hold that the repeal of the capital gains taxation did not play a significant role in the genesis of the financial crisis. The IMF considers the role of the 1997 measures unclear, since the elimination of rollover relief may have resulted in worse tax treatment for some taxpayers, and since house prices did not increase everywhere, which implied that other factors were at work. ${ }^{46}$ More importantly, perhaps, many scholars assign no significant role in the price boom to the 1997 break. $^{47}$

\subsubsection{MORTGAGE INTERESTS DEDUCTIBILITY}

In the USA it is possible to deduct interest costs on mortgages taken to buy, build, or improve a house (so-called home acquisition debt), up to $\$ 1$ million. ${ }^{48}$

In general, mortgage interest deductibility, particularly when unlimited (as in the Netherlands) or with mostly non-binding limits (as in the USA), decreases the cost of ownership and tends to tilt households' decisions whether to rent or buy a house towards ownership; it also encourages people to spend too much on housing, and it may actually end up subsidizing wealthier homeowners, who have higher marginal tax rates, and the construction

${ }^{44}$ See Smith (2007); Bajaj and Leonhardt (2008); and Gjerstad and Smith (2009).

${ }^{45}$ See Shiller (2005: 69).

${ }^{46}$ See IMF (2009a).

47 See Case and Shiller (2004); Glaeser et al. (2005); Himmelberg et al. (2005); and Shiller (2005). Burman (2008) argues that the new capital gains tax rules were unimportant with respect to the bubble, stressing that the previous rules raised little revenue.

${ }^{48}$ Mortgage interest is an itemized deduction. In the US system, most taxpayers can choose to deduct either the total amount of itemized deductions or a standard deduction; the latter depends on the filing status of the taxpayer. In general, itemized deductions are chosen by wealthier taxpayers (Glaeser and Shapiro 2002).

This is an open access version of the publication distributed under the terms of the Creative Commons Attribution-NonCommercialNoDerivs licence (http://creativecommons.org/licenses/by-nc-nd/3.0/), which permits non-commercial reproduction and distribution of the work, in any medium, provided the original work is not altered or transformed in any way, and that the work is properly cited. For commercial re-use, please contact academic.permissions@oup.com 
industry. ${ }^{49}$ Moreover, since the benefit is proportional to debt, the deduction is basically a subsidy to 'gambles on housing', ${ }^{50}$ and this could lead to excessive risk taking. ${ }^{51}$

As regards risk taking, since the second half of the 1990s, credit-scoring methods have been widely used in the USA to price lending. This has probably facilitated the access to credit for many high-risk borrowers. Obviously, given the amount of debt, the riskier the borrower, the higher the interest rate charged, and the greater the tax benefits from deduction. Unlike countries that cap the deduction at a given amount of interest, the United States establishes the cap to the mortgage principal, and this implies a tax favour to riskier borrowers. ${ }^{52}$

In contrast with other countries, ${ }^{53}$ in the USA it is possible to claim a deduction for interest on mortgage loans taken out for purposes other than house purchase-for example, to buy a car or pay for college tuition, up to $\$ 100,000$ (so-called home equity loan). Home equity—-the difference between the market value of the house and the loans secured by the value of the house-can be used as collateral.

Home equity loans may have played an indirect role in leading up to the financial crisis. In fact, the run-up in US housing prices, along with the rise in home acquisition debt fuelled by 'bull' price expectations, may have directly fed the growth of home equity loans, thereby providing part of the mortgage raw materials for the strong growth of the securitization industry (see Section 2.3). This process may have been magnified by the deductibility of mortgage interests.

The deductibility of interest on home equity loans clearly creates a bias to personal debt, encouraging people to prefer borrowing against home equity to other forms of borrowing, and to extract the equity from their home for personal and business reasons.

The lowering over time of personal income-tax rates in the USA has reduced the size of the tax benefit stemming from the mortgage interest deductibility, ${ }^{54}$ which nevertheless remains substantial by international standards (see Figure 3.10).

${ }^{49}$ See Glaeser (2009). $\quad{ }^{50}$ See Glaeser (2009) and Sullivan (2005).

${ }^{51}$ One could argue that there could be positive externalities associated with homeownership and housing consumption that might be worth subsidizing through mortgage interest deductibility. These externalities are, however, very difficult to measure, and, moreover, interest deductibility appears to have been ineffective in promoting homeownership in the USA (see Glaeser and Shapiro 2002 and the references therein).

52 The same holds true in countries, such as the Netherlands, where there are no limits to interest deductibility.

${ }^{53}$ In the Netherlands it was possible to claim interest deductions on equity withdrawals until 1996.

${ }^{54}$ See Poterba (1992).

\section{2}

This is an open access version of the publication distributed under the terms of the Creative Commons Attribution-NonCommercialNoDerivs licence (http://creativecommons.org/licenses/by-nc-nd/3.0/), which permits non-commercial reproduction and distribution of the work, in any medium, provided the original work is not altered or transformed in any way, and that the work is properly cited. For commercial re-use, please contact academic.permissions@oup.com 
However, the role of tax deductibility alone with respect to the recent bubble is unclear because of conflicting evidence. If we consider our set of countries (see Section 3.3.2), it is true that the Netherlands, the other country with strong interest deductibility and providing substantial tax benefits according to our computations, belongs to the 'fast-lane' set of countries, according to the IMF ranking based on the house price increases in the 1990s and 2000s. ${ }^{55}$ On the other hand, the UK was also a 'fast-lane' country, basically without having provision for any interest tax relief for most of the recent boom period. ${ }^{56}$ More importantly, as far as the USA is concerned, there was no break in the tax relief for interest expense to explain the housing boom. Moreover, the price dynamics in the USA differed across states and regions, although there are no interstate differences in interest deductibility.

A possible indirect role of the interest deductibility for the US housing market dynamics may be related to the large increase in low- and no-downpayment mortgages during the second part of the price boom period, ${ }^{57}$ which was probably facilitated by the housing policies enacted in 2004 and subsequent years. ${ }^{58}$ Given the asymmetric treatment of personal debt and equity, the decrease of mortgage downpayments may have given rise indirectly to a tax break: since the cost of personal housing debt is deductible, unlike the opportunity cost of housing equity, the consequence of the increase of lower- or no-downpayment mortgages may have been an abrupt fall in the user cost of housing. ${ }^{59}$

Despite the inconclusive evidence based on simple time-series and crosssection comparisons, it is very likely that the interest tax relief may have somehow contributed to housing price inflation in the USA, ${ }^{60}$ along the

55 See Hilbers et al. (2008).

56 The UK phased out interest deductibility over the period 1974-99. First, a ceiling on the mortgage principal eligible for deduction was introduced. Then, the rate at which it was possible to claim the deduction was gradually lowered to zero (OECD 2000: 151).

57 According to the surveys conducted by the National Association of Realtors, in 2003 the median downpayment for first-time homebuyers was equal to $6 \%$, a figure that fell to $2 \%$ in the period 2004-7. The median downpayment for repeat homebuyers also declined starting in 2004, although to a lesser extent (see $<$ www.realtor.org $>$ ).

58 On 16 Dec. 2003 the American Dream Downpayment Act was signed into law, with a view to assisting low-income first-time homebuyers by providing downpayment. Among other things, the Act expanded the supply of no-downpayment mortgages for first-time homebuyers (US Department of Housing and Urban Development 2005).

${ }^{59}$ As an example, using the highest marginal tax rate of the federal income tax in 2003 and 2004 (35\%), and assuming a downpayment to buy the house equal to 5\% in 2003 and 0\% in 2004, the effective average tax rate computed with the IMF methodology (see Section 3.2) would decrease from $-17.97 \%$ to $-18.92 \%$. Since the reduction of downpayments referred especially to lowincome first-time buyers, it is reasonable to compute the change of the effective taxation also with the lowest income-tax rate (10\%); in this case the effective average tax rate would decrease from $-5.13 \%$ to $-5.41 \%$. Of course, it is hard to say whether and to what extent these changes in the economic advantageousness of the housing investment may have been statistically significant at the margin for housing market dynamics.

60 See Sullivan (2008) and Surowiecki (2009).

This is an open access version of the publication distributed under the terms of the Creative Commons Attribution-NonCommercialNoDerivs licence (http://creativecommons.org/licenses/by-nc-nd/3.0/), which permits non-commercial reproduction and distribution of the work, in any medium, provided the original work is not altered or transformed in any way, and that the work is properly cited. For commercial re-use, please contact academic.permissions@oup.com 
lines of a catalyst in a chemical reaction. The simple and very general economic model sketched above predicts that tax relief of the kind provided in the USA can contribute to the volatility of the housing market; and that mortgage interest tax relief can be a contributing factor of instability if it is coupled with low financing costs and/or 'exuberant' housing price expectations.

In conclusion, tax incentives may have played a role in the development of the housing bubble, but the size of this role is difficult to assess, although the odds are that this role has been secondary to monetary policy and credit markets developments.

\subsection{Conclusions}

The 2008 financial crisis has already proved to be the worst economic crisis since the Second World War. The burst of a housing bubble in the United States led to a stop in confidence of investors towards all mortgage-based assets that had flourished in previous years and to uncertainties with regards to the financial exposure and liquidity of world major financial institutions. This banking crisis eventually spread to a stock-market crash and to a credit crunch in the real economy. The rapid expansion of credit and the increasing degree of indebtedness and risk-taking behaviour of financial institutions was a striking characteristic of the build-up to the crisis.

In this context, one important policy question is whether tax systems may have created negative incentives, favouring risk. Several tax provisions in favour of homeownership may have led to increased purchases of houses in several countries. However, the available evidence is mixed when it comes to assessing whether different tax treatments have led to different price developments, suggesting that lax monetary policy and increased risk taking by lenders are more powerful explanations for the housing bubble. In turn, this risk-taking behaviour may have been exacerbated by tax provisions on the treatment of executive compensation and by tax arbitrage possibilities across different types of investors. Chapter 4 discusses these issues in depth.

Countries have implemented strong policy responses to the crisis. In particular, many countries have taken tax measures as part of broader fiscal stimulus packages. They have, however, come short of changing tax systems. Two issues have attracted some attention and are evaluated in Chapter 5: the idea of a financial transaction tax and/or a financial activities tax to collect more revenues from the financial sector and to correct for negative externalities.

This is an open access version of the publication distributed under the terms of the Creative Commons Attribution-NonCommercialNoDerivs licence (http://creativecommons.org/licenses/by-nc-nd/3.0/), which permits non-commercial reproduction and distribution of the work, in any medium, provided the original work is not altered or transformed in any way, and that the work is properly cited. For commercial re-use, please contact academic.permissions@oup.com 


\section{APPENDIX}

\section{Property taxation on owner-occupied housing}

\section{Belgium}

There is no real estate taxation.

\section{France}

The property tax (taxe foncière) is a local tax due by the legal owner of the house. It is based on the notional rental value of the property (valeur locative cadastrale). The tax is calculated by multiplying half of the latter value by coefficients determined by the local councils. In 2008 the average municipal rate was 17.76\% (see Borselli et al. 2010).

The dwelling tax (taxe d'habitation) is a local tax owed by the person who occupies a dwelling. As the property tax, it is assessed on the deemed rental value of the property. In 2008 the average municipal rate was equal to $13.85 \%$; in special cases, state government adds a surtax (0.2\% for principal residence) (see Borselli et al. 2010). Tax reductions are generally granted to taxpayers with dependants, for the principal residence.

The last general revision of the valeur locative cadastrale was made in 1974 (and based on data for 1970) and updated in 1980. Every year the cadastral values are revised to reflect the changes of the characteristics of the properties; to some extent the annual revisions should reflect also the changes of the market values (Lefebvre 2010a: 626).

\section{Germany}

The real estate tax (Grundsteuer) is levied annually by the municipalities on immovable properties. The tax is calculated by applying a federal tax rate of $0.35 \%$ to the fiscal value of the property (Einheitswert). The result is then multiplied by a municipal coefficient (Hebesatz). On average the final effective tax rate is equal to 1.9\% (see IBFD 2011). The real estate tax is not deductible for income-tax purposes in case of owner-occupation. The fiscal value of the property is generally much lower than the market value (about $20-50 \%$ of the market value; see Mayer 2006).

This is an open access version of the publication distributed under the terms of the Creative Commons Attribution-NonCommercialNoDerivs licence (http://creativecommons.org/licenses/by-nc-nd/3.0/), which permits non-commercial reproduction and distribution of the work, in any medium, provided the original work is not altered or transformed in any way, and that the work is properly cited. For commercial re-use, please contact academic.permissions@oup.com 


\section{Ireland}

There is no real estate taxation.

\section{Italy}

There is no real estate taxation on owner-occupation (since 2008).

\section{The Netherlands}

The real estate tax (Onroerendezaakbelasting) is levied annually by the municipalities on immovable properties. The tax base is the fair market value for fiscal purposes (Wet waardering onroerende zaken (WOZ)) issued every year by the municipalities. On average the tax rate is equal to $0.1 \%$ (see $<$ http://www.cijfernieuws.nl/ozbd.html $>$ ). The tax is not deductible for income-tax purposes in case of owner-occupation.

\section{Spain}

The real estate tax (impuesto sobre bienes inmuebles (IBI)) is levied annually by the municipal authorities on the possession of immovable property. The tax base is the cadastral value of the property (valor cadastral). The tax rate ranges between $0.4 \%$ and $1.1 \%$ (see Borselli et al. 2010). The tax is not deductible for income-tax purposes in case of owner-occupation. The cadastral value is revised with reference to the market values according to several procedures. The general revision is made at least every ten years (see Lefebvre 2010b: 1598; see also <http://www.catastro.meh.es/esp/procedimientos/ Renovaciones $>$ ).

\section{UK}

The council tax is an annual tax on domestic property levied by local authorities. It is primarily a property tax; it is also a charge on local services users, since the payment is related to household size. Each property is assigned to one of eight bands (from A to H), according to its assessed capital value in 1991. Every year, each local council decides the bill for band D; the bills for the other bands are charged at a fixed proportion of the band D bill. On average, in 2008-9 the council tax per dwelling was equal to $£ 1,145$; the tax bill increased at an annual rate of 5\% over the period 2004-9 (see $<$ http://www.communities. gov.uk>).

\section{USA}

Property taxes are imposed by local municipalities and counties in each US state. The tax liability is generally calculated by multiplying a tax rate by an assessment ratio (the part of the value of the property that is taxed) by the market value of the property. On average, in 2009 the tax bill was $1.04 \%$ of home value (see <http://www.

\section{6}

This is an open access version of the publication distributed under the terms of the Creative Commons Attribution-NonCommercialNoDerivs licence (http://creativecommons.org/licenses/by-nc-nd/3.0/), which permits non-commercial reproduction and distribution of the work, in any medium, provided the original work is not altered or transformed in any way, and that the work is properly cited. For commercial re-use, please contact academic.permissions@oup.com 
taxfoundation.org/research/topic/89.html>). The state and local real estate taxes are deductible for the purposes of income taxation.

\section{Assumptions used in the computations of the EATR for property taxes}

It is well known that cadastral values are usually lower than market values. Hence, in countries where property taxes are based on cadastral values (as in France, Spain, and Germany), the burden of these taxes is usually lower than in countries where these taxes are more closely related to market values (as in the Netherlands and the USA). To consider these differences, for the countries where property taxes are based on cadastral values, we assume that at the beginning of the holding period the fiscal value of the property is lower than the market value by a given percentage; then we keep the property taxes constant in real terms over the holding period (we assume a 2 per cent inflation rate).

More precisely, we assume an initial 65 per cent cut of the market value in Germany (see Mayer 2006) and a 33 per cent cut in France (for which we do not have more precise information). For Spain we assume an initial fiscal value equal to the market value (since the cadastral values are more updated than in other countries; see $<$ http://www. catastro.meh.es/esp/procedimientos/Renovaciones $>$ ).

For the UK, we use actual data on the council tax. More precisely, we use the average council tax bill per dwelling for 2008-9 and we let it grow at a 5 per cent rate over the holding period (source: $<$ http://www.communities.gov.uk $>$ ).

For the Netherlands and the USA, property taxes are computed with reference to the market value of the properties.

This is an open access version of the publication distributed under the terms of the Creative Commons Attribution-NonCommercialNoDerivs licence (http://creativecommons.org/licenses/by-nc-nd/3.0/), which permits non-commercial reproduction and distribution of the work, in any medium, provided the original work is not altered or transformed in any way, and that the work is properly cited. For commercial re-use, please contact academic.permissions@oup.com 


\title{
The Role of Taxes in Compensation Schemes and Structured Finance
}

\author{
Vieri Ceriani, Stefano Manestra, Giacomo Ricotti, and Alessandra Sanelli
}

\subsection{Introduction}

This chapter develops the thoughts initially presented at a conference on 'Tax Policy and the Financial Crisis' held in April 2009 at the Bocconi University in Milan, where we tentatively grappled with the possible effects of the tax system on the economic factors that had triggered the 2008 financial crisis. Did any features of the tax system influence the build-up of the crisis, and, if so, how?

We try to identify cases in which the fiscal regime interacted with other factors and reinforced them. We do not provide a comprehensive answer, but highlight some of the observations, doubts, and evidence that have been put forward so far. Our starting point is that taxation is an important factor, but usually not the most important driver of economic trends.

We do not deal with the tax biases that favour debt finance and are inherent in corporation tax systems. This issue, highlighted by the IMF (2009a) and others, has triggered some proposals for reforming the corporation tax through the introduction of an allowance for corporate equity (ACE): that is, a deduction for a notional return on own capital. Nor do we examine the taxation of residential housing and the deductibility of mortgage interest: the dynamics of the US housing market and the financial structure that was built on it, which seem to have played a decisive role in most narratives of the financial crisis, are analysed in this book in the contribution of Hemmelgarn, Nicodeme, and Zangari (Chapter 3).

The views expressed in this chapter are those of the authors and do not in any way commit the Banca d'Italia. Although the work is the product of a joint effort, V. Ceriani wrote Sections 4.1 and 4.5, A. Sanelli Section 4.2, G. Ricotti Sections 4.3, 4.4.1, and 4.4.2, and S. Manestra Section 4.4.3.

This is an open access version of the publication distributed under the terms of the Creative Commons Attribution-NonCommercialNoDerivs licence (http://creativecommons.org/licenses/by-nc-nd/3.0/), which permits non-commercial reproduction and distribution of the work, in any medium, provided the original work is not altered or transformed in any way, and that the work is properly cited. For commercial re-use, please contact academic.permissions@oup.com 
In the following sections we concentrate on two more specific fields. In Section 4.2 we review the taxation of stock options and other performance-based remuneration forms (Section 4.2.1); we also illustrate how the favourable tax treatment provided for 'carried interest' in many countries may have reinforced the trend towards aggressive highly leveraged private equity transactions with little regard to employment issues or the long-term prospects of firms (Section 4.2.2.). Section 4.4 shows the role of taxation in facilitating the development of structured finance; in particular, we describe how the growth of the securitization (Sections 4.4.1 and 4.4.2) and credit default swap markets (Section 4.4.3), namely in the United States, may have been reinforced by some features of the tax system and by the interaction between the tax systems of different countries, including tax havens. Section 4.5 provides some concluding remarks.

\subsection{Performance-based remuneration and taxes}

\subsubsection{Stock options and other stock-based remuneration schemes}

It is generally acknowledged that equity-based and other performance-related compensation plans at large financial institutions were one of the factors that led to ever greater risk taking and thus contributed to the financial crisis that began in 2007.

The 1990s and the 2000s have seen an enormous rise in executive remuneration. In the United States, between 1990 and 2008 the average pay of the chief executive officer (CEO) of a large corporation rose from 100 to nearly 400 times that of the average worker. A similar though less marked pattern can be found in Europe. The chief factors responsible for this huge gap are the various forms of performance-based compensation, most notably bonuses and stock options.

Finance began influencing firms' governance in the early 1990s. The idea of creating 'shareholder value' rested on the assumption that markets could evaluate executives' performances better than human judgement. Various forms of stock-based compensation became very popular, first in the United States and then in other developed countries, on the theory that they could motivate employees to act in the interest of the firm's shareholders and align the interests of senior executives with the general interest of the firm. Many large firms paid a significant portion of total compensation in stock or similar instruments, with the stock-based portion typically greater, the higher the position of the employee. The increased use of stock-based remuneration gave rise to ever greater incentives to risk taking that were not counterbalanced by employees' exposure to losses in the event of poor corporate performance, since other factors were in place. In fact, although vesting and other restrictions required employees to hold some newly granted stock for significant periods of time, the sensitivity of equity prices to short-term corporate 
performance and shareholders' frequent tendency to focus on short-term results spurred employees, and especially executives, to aim at maximizing stock-price increases in the short term rather than the firm's long-term growth. ${ }^{1}$ The same factors also led employees to underestimate possible future downside risks.

The incentive to risk taking arising from stock-based remuneration was particularly strong in the financial sector. Given the structure of financial markets in most developed countries, banks and other financial firms can change their desired mix of risk/return much more easily and quickly than non-financial firms. For financial firms, then, large bonuses linked mainly to short-term profits regardless of the possible long-term risks may have induced managers to choose an ever higher level of risk in order to achieve higher returns, leading to the systemic excessive risk taking that severely threatened the global financial system.

Compensation practices at large financial institutions have generally been counted as one of the sources of the system of distorted incentives that led to the financial crisis. Here the question is: did tax rules favour remuneration schemes that rewarded high risk taking or those that focused on short-term performance?

It is a common belief that stock options and other stock-based forms of remuneration are tax favoured compared with cash compensation. If this is true, then the tax system could be held responsible for contributing to the crisis through its pro-cyclical effects by reinforcing a structure of incentives that led to excessive risk taking.

Stock options are financial instruments that give the owner (usually the firm's executives and other employees) the right to buy a certain asset (usually the company's shares) at a specified price (strike price or exercise price) at any time during a predetermined period or at the end of that period. Over the life of a stock option four different events can be identified: grant, when the stockoption right is granted to employees; vesting, the expiring of the minimum holding period required to exercise the option (usually 3-5 years); exercise, when the employee actually exercises the option right and acquires the stock; and disposal, the sale of the shares received through option exercise. ${ }^{2}$

The tax treatment of stock options is linked to a number of issues, such as the qualification of income (employment income or capital income), the

\footnotetext{
1 Financial Stability Forum (2009). The theoretical literature has tried to explain the shortcomings of stock options in terms of the information asymmetries between managers and shareholders. In this view, stock options are a form of managerial 'rent extraction' from the firm at the expense of shareholders: the assumption here is that executive compensation programmes are usually developed by insiders (the executives themselves) rather than by shareholders and will thus reflect executives' preferences. In this reading, stock options contribute to the corporate governance problems instead of solving them. See OECD (2005).

2 See OECD (2005).
} 
applicable taxes and charges (income tax, capital gains tax, and social-security contributions), the timing of taxation (grant, exercise, or disposal of shares), and the treatment at corporate level (whether or not the cost can be deducted from corporate income). As a benchmark we assume a tax treatment that ensures neutrality between stock options and cash salary, which would require equal treatment of the two forms of remuneration at personal level and the deductibility of stock-option costs from corporate tax (OECD 2005). ${ }^{3}$

Against this benchmark, a cross-country analysis of the tax treatment of stock options offers a mixed picture. According to an OECD study carried out in 2005 using legislation in force in 2002, tax rules vary substantially from country to country, but in most cases stock options enjoy only limited benefits compared with a cash salary. Since stock options are considered a form of deferred compensation, in most OECD countries their benefits are treated as ordinary income for employees and taxed at progressive income-tax rates. Taxation is usually applied at the time of exercise. The tax base is the increase in stock value accrued until exercise-that is, the difference between the market price of the shares at the exercise date and the strike price. By contrast, the subsequent gain arising from disposal of the shares-that is, the difference between the selling price and the market price of the shares at the exercise date-is usually taxed at the capital gains tax rates (but is exempt in countries where capital gains are not taxed).

Under given conditions (so-called concessionary schemes) stock options enjoy a preferential tax treatment at the employee level. The preferential treatment may consist in the possibility of deferring taxation until the disposal of the shares (Canada, Denmark, France, Iceland, Ireland, Italy, the Slovak Republic, the UK, and the USA) and/or in tax-rate reductions. The latter often consist in the lower capital gains tax rates being applied not only to the gain accruing after exercise, but also to previous gains arising between the grant date and the exercise date, which would otherwise be taxed as ordinary income (Denmark, Iceland, Ireland, Italy, Japan, Spain, the UK, and the USA). Other countries give tax relief in determining the tax base. ${ }^{4}$ In many countries (including Denmark, France, Ireland, Italy, Japan, Spain, the UK, and the USA) preferential regimes also include exemption from social-security contributions. ${ }^{5}$

3 This neutrality condition also applies under uncertainty if taxation takes place at exercise or applies at grant on the basis of the option's fair market value.

4 For example, in Austria a part of the gain (up to 50\%) is exempt; in Canada and in Spain the taxable base is respectively 50 and $70 \%$ of the employee benefit. In Luxembourg the employee benefit is reduced for tax purposes by $5 \%$ each year (up to a maximum of $20 \%$ ).

5 Some countries also exempt stock-option benefits arising from standard plans from employee and employer social-security contributions.

This is an open access version of the publication distributed under the terms of the Creative Commons Attribution-NonCommercialNoDerivs licence (http://creativecommons.org/licenses/by-nc-nd/3.0/), which permits non-commercial reproduction and distribution of the work, in any medium, provided the original work is not altered or transformed in any way, and that the work is properly cited. For commercial re-use, please contact academic.permissions@oup.com 
At the corporate level, stock options usually give the right to a tax deduction on the difference between the market price of the shares at the exercise date and the strike price-that is, for an amount exactly mirroring that taxed as personal income for the employee. In many countries (Denmark, Germany, Greece, Iceland, Luxembourg, the Netherlands, Portugal, Sweden, Switzerland, Turkey, the UK, and the USA) the deduction is granted, at least for some plans, even if the firm has not incurred an actual cash outflow (that is, when employees are given newly issued shares). In others (including France, Italy, Japan, Spain, and the USA) or for some plans, the economic cost of stock options (the dilution in stock value when newly issued shares are assigned to employees) is a non-deductible item. Finally, in some countries (Austria, Belgium, Hungary, Ireland, New Zealand, Poland, and the Slovak Republic) deduction of stock-option costs is never allowed. Consequently, from the point of view of companies, stock options can be tax disadvantaged compared with cash salary.

Each country can provide for a different combination of employee and employer tax treatment of stock-option plans, depending on the specific characteristics of the plans-that is, on whether or not they fulfil the requirements of concessionary schemes. As a result, different tax provisions can combine in a number of ways in each country, giving rise to an overall tax wedge on stock-option benefits that can vary from plan to plan.

The OECD report calculates marginal tax wedges on the different types of stock-option plans in OECD countries and compares them with tax wedges on ordinary salaries. The calculation takes into account both employee- and employer-level taxation and social-security contributions. The results show that in some countries (for example, Australia, Austria, Canada, and Japan) the tax wedge on stock options, at least for certain schemes, is greater than that on ordinary salary. In many countries (for example, Germany, Luxembourg, Sweden, Switzerland, and Turkey) the tax treatment of stock options and cash salary is the same and so are the effective tax rates for both average and higher levels of income. In some cases (including Denmark, Greece, Italy, the UK, and the USA) neutrality between stock options and ordinary salary obtains only for schemes for which deductibility from the corporate income-tax base is allowed.

Under certain conditions or for certain schemes, a number of countries (including Australia, Canada, Denmark, France, Italy, Japan, Korea, Portugal, Spain, and the UK) grant preferential tax treatment of stock options at the personal level while also allowing deductibility at the corporate level. In these countries, stock options are tax favoured compared with ordinary salary; often, the tax advantage of stock options increases with income. For highincome taxpayers, the tax advantage seems especially great for certain concessionary schemes in Belgium (more than 22 percentage points), Denmark

This is an open access version of the publication distributed under the terms of the Creative Commons Attribution-NonCommercialNoDerivs licence (http://creativecommons.org/licenses/by-nc-nd/3.0/), which permits non-commercial reproduction and distribution of the work, in any medium, provided the original work is not altered or transformed in any way, and that the work is properly cited. For commercial re-use, please contact academic.permissions@oup.com 
(58.5 points), France (26.5 points), Italy (42.8 points), Spain ( 48.9 points), and the UK (30 points). ${ }^{6}$

Other countries (for example, Canada, Finland, Japan, Spain, and the USA) combine a preferential tax treatment at the employee level with nondeductibility at corporate level. Depending on individual cases, the tax wedge on stock options can be higher or lower than that on ordinary salary. However, at high levels of income, stock options tend to be tax favoured in these countries.

Although the preferential tax treatment of stock-option benefits can lower dramatically the tax burden on equity-based remuneration, the importance of tax advantages is often limited by the conditions that must be fulfilled in order to qualify for these benefits. For example, in order to enjoy preferential tax treatment, an employee may need to hold the shares for some time after exercise (at least one year in the USA); in addition, the concessionary schemes quite often cap the amount of stock-option benefits that can enjoy the favourable tax treatment. ${ }^{7}$ Although these caps are sometimes high, in conjunction with other conditions they often result in concessionary plans being used mainly by start-up firms or in limited cases.

In the light of the foregoing facts and considering the more neutral or even disadvantaged tax treatment of standard stock-option plans compared with ordinary salary, the common belief that stock options enjoy a tax advantage over cash-based remuneration is not confirmed in general. Basing their conclusions on a comparison of the relative tax treatment of cash-based and standard stock-option compensation plans in the USA, the UK, Germany, and France, Fehr et al. (2004) find that the latter are often tax disadvantaged; ${ }^{8}$ a tax preference for stock options arises only from large differences between personal and capital gains tax rates (as in France) or from tax discrimination of cash compensation (as in the USA).

The empirical evidence on the supposed tax preference of stock options, mostly referring to the United States, is also mixed (OECD 2005). Some studies (e.g., Hall and Murphy 2003) argue that the widespread use of stock-option plans in the USA during the 1990s can be partly explained by a combination of tax and accounting rules. Hall and Liebman (2000), examining the relative tax treatment of stock options and cash salary in the USA in the 1980s and 1990s,

\footnotetext{
${ }^{6}$ OECD (2005: 73-6, table 2.7).

7 For instance, under the UK concessionary scheme known as the Company Share Option Plan, the total value of shares an employee can receive under option must not exceed $£ 30,000$. Another UK concessionary scheme, the Enterprise Management Incentive option, is targeted to companies with gross assets of less than $£ 30$ million, and provides for a maximum of $£ 100,000$ stock-option benefit to each employee. In the USA, the preferential treatment for Incentive Stock Options is subject, among other conditions, to the value of the shares underlying stock-option benefits not exceeding \$100,000.

${ }^{8}$ Like the OECD, this study considers both employee- and firm-level taxation.
} 
find only a moderate tax advantage of 'non-qualified stock options' over a cash salary, because the tax advantages to the executives of deferring taxes until exercise were largely offset by the tax disadvantages to the company of not being able to deduct option expenses from taxable profits until the time of exercise. ${ }^{9}$ In general, however, they find little evidence that changes in the tax treatment of stock options during the 1980s and the 1990s have played a major role in the dramatic explosion of executive stock-option pay. Other factors (such as changes in corporate governance) appear to have had more influence.

In spite of the controversial results of economic analysis and the inconclusive empirical evidence, it is nonetheless possible that tax considerations actually do play a role in the choice between ordinary salary and stock options. For instance, stock options could be tax preferred to cash remuneration from a unilateral perspective-that is, on the basis of solely employee or employer taxation: in given circumstances, one of the two levels of taxation could dominate the other in the determination of remuneration policies. This could happen, for instance, because of shortcomings in the corporate governance mechanisms regulating the firm's remuneration policies. In the case of large, widely held corporations, it is quite likely that executives' remuneration policies are decided by executives themselves, since boards tend to be dominated by CEOs and senior executives of other firms rather than by individual shareholders. These board members have an interest in keeping executive compensation high. Under these circumstances, it is very likely that employees' taxes outweigh corporate tax considerations. ${ }^{10}$ An alternative explanation, put forward by some studies (Murphy 2002; Hall and Murphy 2003) could be that decisions over stock-option grants are made on the basis of the 'perceived cost' rather than the real economic cost of the options. The 'perceived cost' of an option is lower than the economic cost, because it takes into account only the actual cash flow for the firm and not the opportunity cost, equal to what an outside investor would pay for the option (OECD 2005). Finally, in some countries tax incentives to use stock options instead of ordinary salary may arise from specific features of the tax system or from the interaction between tax law and other rules, and not just from the tax treatment of stock options. ${ }^{11}$

\footnotetext{
9 They found also a moderate advantage of non-qualified stock options over incentive stock options (ISOs), because of the fact that option expenses cannot be deducted for ISOs.

${ }^{10}$ Smith and Huston (2009) find that individual-level tax incentives also outweigh corporate tax incentives in employees' decisions whether to sell the shares immediately after exercise or to hold them in view of future price increases.

11 Another potentially important issue is cross-country option ownership. Many executives and other highly qualified employees paid with stock options transfer their tax domicile to low-tax countries during the holding period. This enables them to reduce their tax burden, even if the tax rules of the employer's country do not provide for a favourable tax treatment of stock options.
}

This is an open access version of the publication distributed under the terms of the Creative Commons Attribution-NonCommercialNoDerivs licence (http://creativecommons.org/licenses/by-nc-nd/3.0/), which permits non-commercial reproduction and distribution of the work, in any medium, provided the original work is not altered or transformed in any way, and that the work is properly cited. For commercial re-use, please contact academic.permissions@oup.com 


\section{Box 4.1. THE TAX TREATMENT OF EMPLOYEE STOCK OPTIONS IN THE USA}

The US tax code provides for two possible tax treatments of stock options:

1. In the case of standard stock-option plans, referred to as non-qualified stock options (NQOs), employees are taxed at the exercise date and at personal progressive rates on the difference between the market value at the same date and the exercise price. Any subsequent gain realized upon sale of the shares is taxed at the lower capital gains rates. ${ }^{a}$ As far as the employer is concerned, NQOs have the advantage of allowing a tax deduction at the same time and in the same amount as the ordinary compensation paid to the employee, even when there is no actual cost to the firm (unlike cash remuneration).

2. If stock-option plans satisfy given criteria, set out by the tax code, they are called incentive stock options (ISOs). ${ }^{\mathrm{b}}$ ISOs allow employees to defer taxation on the gain emerging at the exercise date until the stock is sold and have it taxed at the lower capital gains rates. ${ }^{c}$ On the other hand, the employer gets no tax deduction for ISOs.

For both types of plan, there is scarcely any tax favour by comparison with cash-based remuneration. In fact, the only tax advantage of NQOs may consist in the possibility of a corporate tax deduction, even if there is no actual cash outflow. For the employee, apart from the deferment of taxation from grant to the exercise date, NQOs do not have any particular tax advantage over cash remuneration, except where the employee does not sell the shares immediately after exercise, since all subsequent gains are taxed at the lower capital-gains tax rates. On the other hand, under ISOs employees are taxed on their stock-option income at the lower capital-gains tax rates, but at the same time companies forfeit their stock-option corporate deductions.

Taking into account both employee and employer tax considerations, ISOs are preferred to NQOs if under the latter the additional taxation on the employee exceeds the value of the deduction to the employer. For employees facing high personal tax rates, ISOs may be better than NQOs in the case of companies with low tax rates, such as start-ups or companies with net operating losses. ${ }^{\text {d }}$ Start-ups, with low taxable profits, tend to use ISOs, as they would face liquidity constraints if they had to pay high salaries to attract executives and other highly qualified employees. On the other hand, since the value of their stock may increase dramatically over time, the use of incentive stockoption plans is quite common. ${ }^{\mathrm{e}}$ In short, in the case of ISOs, employee tax considerations tend to predominate. By contrast, in the case of NQOs, used mostly by large, profitable companies, especially for senior executive compensation packages, since the tax advantage depends on the value of the shares at the exercise date and on the company tax rate, company tax considerations tend to prevail. ${ }^{f}$

\footnotetext{
a Provided the shares are held for at least one year after exercise.

b Section 422 of the Internal Revenue Code. Stock obtained under an ISO cannot be disposed of within two years of the grant date nor within twelve months after exercise. ISOs cannot be granted with an exercise price below the stock price at grant date, and the aggregate stock value covered by the ISOs is limited to $\$ 100,000$ per year per employee.

c Both benefits are allowed provided that the shares are held for at least one year after exercise. If the employee sells the shares before that period, ordinary personal tax rates apply.

$d$ Although the possibility of corporate deduction linked to NQOs may have a value for corporations with net operating losses, since the US tax code allows them to carry the losses back (for two years) or forward (for up to twenty), for these corporations the relative weight of the corporate tax deductibility of stockoption costs is likely to be lower, in practice, than the favourable employee tax treatment.
}

(continued)

This is an open access version of the publication distributed under the terms of the Creative Commons Attribution-NonCommercialNoDerivs licence (http://creativecommons.org/licenses/by-nc-nd/3.0/), which permits non-commercial reproduction and distribution of the work, in any medium, provided the original work is not altered or transformed in any way, and that the work is properly cited. For commercial re-use, please contact academic.permissions@oup.com 


\section{Box 4.1. CONTINUED}

e In the context of venture capital, stock options have often been used to overcome capital and liquidity constraints. The foreseeable increase in value of stock options on the shares of young, high-growth companies creates incentives not only for executives, but also for other qualified employees, to work for such companies even if the cash salaries are less attractive than those offered by larger companies. This argument has found empirical support, and has often been used by policy-makers to justify tax policies that allow for a favourable tax treatment of stock options in the context of venture-capital-financed firms. However, in many cases tax incentives have been ill-focused, making benefits available to a much greater number of entities than those actually suffering from liquidity constraints.

${ }^{f}$ Empirical evidence on the role of taxes in the choice between ISOs and NQOs is somewhat mixed. On an aggregate level, over time the relative use of ISOs and NQOs has changed consistently with changes in the personal, corporate, and capital-gains rates. Hite and Long (1982) show that firms switched from ISOs to NQOs after the Tax Reform Act of 1969 lowered the top rates for individuals. However, Madeo and Omer (1994) report that firms that switched from ISOs to NQOs following the 1969 tax reform tended to have low tax rates, whereas in theory it should have been the high-tax firms switching. Balsam et al. (1997) report that after the Tax Reform Act of 1986 NQO usage increased relative to ISOs because the top individual rate was set below the top corporate rate, and the capital-gains rate was set equal to the tax rate on ordinary income.

The USA offers the chief example of interaction between tax and other rules. As with other countries, analysis of the general tax treatment of stock-option plans in the USA does not reveal a general tax bias in their favour (see Box 4.1).

While the tax advantage for employees may help explain the large use of ISOs in start-up companies, to understand the widespread use of NQOs in large companies ${ }^{12}$ other tax factors and a combination of tax and accounting rules must be taken into account. First, in 1993 a powerful incentive came from the newly enacted rule that introduced a $\$ 1$ million cap on 'non-performance-based' compensation that a corporation could deduct from its taxes, since the cap did not apply to stock-option plans. And, until 2004, US accounting rules allowed companies to issue stock options to employees and, unlike any other type of compensation, report a zero compensation expense on their books. ${ }^{13}$ Moreover, since 1969 the US tax code (Section 83) has allowed corporations issuing NQOs to deduct from their taxable income, on the exercise date, the difference between what the employee paid to exercise the option and the market value of the stock received. This amount exactly mirrors the amount that is taxed as personal income of the employee. This combination of accounting rules permitting corporations to grant huge NQOs 'free of charge'-that is, without having to register any cost in their

12 Jaquette et al. (2003) estimate that in the late 1990s and early 2000s $89 \%$ of options granted in the United States where NQOs.

${ }^{13}$ This happened so long as, on the grant date, the stock options were 'at the money', i.e. their exercise price was not lower than the stock price at grant date. More precisely, since 1973 companies could avoid recording any expense on granted options in their financial statements. However, from 1995 onwards they had to disclose the use of stock options and options' fair value in the notes to their financial statements. See Bulow and Shoven (2005). 
financial accounts-and tax rules allowing corporations to deduct the stockoption income of the employee in the year of exercise, even when there was no actual cost to the firm (as in the case of newly issued shares), gave companies an incentive to issue huge stock-option grants, because stock options made possible a large tax deduction that could dramatically lower their taxes without affecting the profits shown on their books. ${ }^{14}$

In 2005, in the wake of huge corporate financial scandals such as Enron and WorldCom, not to mention the dot-com tech boom and subsequent bust, a new Financial Accounting Standard (FAS 123R) issued by the Financial Accounting Standards Board (FASB) became mandatory for all publicly traded corporations. FAS $123 \mathrm{R}$ requires all companies to record a compensation expense equal to the fair value on grant date of all stock options provided to an employee in exchange for the employee's services. ${ }^{15}$ Thus, since 2005 accounting rules have required companies to expense stock options at the grant date, ${ }^{16}$ while tax rules still allow deduction of stock-option expenses at the exercise date. Although the gap has been reduced and there is some evidence of a shift from stock options to restricted stock in large firms' compensation plans (Carter et al. 2007), ${ }^{17}$ the accounting incentives to grant large high stock-option benefits to executives are still large, particularly when stock prices are rising. ${ }^{18}$ On the other hand, given the current mismatch between accounting and tax rules, stock options that are granted and vested but never exercised by the holder (for example, in case of a subsequent price drop) produce a corporate book expense but no tax deduction. ${ }^{19}$ Overall, then, the US tax and accounting rules tend to have pro-cyclical effects.

The wave of corporate financial scandals in which executives received huge amounts through the exercise of stock options prompted a revision of stock-

14 The lack of a requirement to report stock-option expenses in companies' financial statements probably also helps explain the fraudulent practice of 'backdating' stock options that many companies resorted to in the 1990s and early 2000s according to investigations by the Securities and Exchange Commission. Executives were awarded stock options backdated to a point at which the company's stock prices were lower, so that the exercise price could be set at a lower level.

${ }^{15}$ The International Accounting Standard Board (IASB) implemented a similar approach effective 1 Jan. 2005.

${ }^{16}$ The fair value is amortized over the vesting period. That is, compensation expense is recognized prior to the tax deduction (which arises when the employee exercises the NQO), generating a temporary difference and thus a deferred tax asset in each year of the vesting period (Scholes et al. 2008).

${ }_{17}$ Restricted stock grants are equivalent to call options with an exercise price of zero. Unlike stock options, they have always had to be reported on companies' financial statements, thereby reducing corporate net income at year's end.

18 Data from tax returns of US companies for tax years 2004-7 show that stock-option compensation expenses permitted companies huge tax savings and were one of the chief factors in the difference between book and tax income reported by US corporations. The bulk of this difference was concentrated in a relatively small number of corporations that awarded substantial stock options to their executives. See Levin (2009).

19 Only if a stock option never vests can previously booked expenses be recovered. See Levin (2009). 
option regulations aimed at making remuneration policies more transparent, improving the structure of incentives for managers so as to reduce excessive risk taking, and reducing inequalities between different classes of employees. In April 2009, in the wake of action to counter the main factors responsible for the 2007-8 financial crisis, the Financial Stability Forum (FSF)—now the Financial Stability Board (FSB)-released a set of 'Principles for Sound Compensation Practices ${ }^{20}$ meant to apply to significant financial institutions, especially large, systemically important ones and aimed at reducing incentives to excessive risk taking that might arise from the structure of compensation schemes. In this approach, compensation regimes must be viewed in the broader context of sound corporate governance and effective risk management; implementation of the principles at national level will ensure that compensation structures are consistent with firms' long-term goals and prudent risk taking. ${ }^{21}$ Similar principles have been endorsed by the European Commission. ${ }^{22}$

Although neither the FSB nor the European Commission mentioned tax rules among the reforms needed to discourage remuneration practices that lead to excessive risk taking, at national level the tax treatment of bonuses and stock options became part of this debate. In the United States, changes to the combination of accounting and tax rules that distort firms' choices between stock options, other forms of equity-based compensation, and ordinary salary have been under discussion for several years. During the Bush administration, the Senate Finance Committee examined a number of bills to raise the taxation of stock options and private equity managers' remuneration. Similar proposals have been presented since President Obama took office. ${ }^{23}$ However,

20 Financial Stability Forum (2009).

21 The FSF principles identified several lines of action aimed at ensuring that compensation structures are consistent with firm's long-term goals and prudent risk taking. Specifically, firms' boards of directors must play an active role in the design, operation, and evaluation of compensation schemes. Compensation, particularly bonuses, must properly reflect risk; and the timing and composition of payments must be sensitive to the time horizon of risks. Stakeholders, including shareholders, should be adequately and timely informed on compensation policies in order to exercise effective monitoring; an annual non-binding shareholder advisory vote on executive compensation is also recommended. For their part, regulators will have to assess firms' compensation policies. With regard to risk management, the FSF identified three key principles. First, compensation must be symmetric with risk, linking the size of the bonus pool to the overall performance of the firm; employees' incentive payments should be linked to the contribution of the individual and business unit to such performance. Bonuses should diminish or disappear in the event of poor firm, divisional, or business unit performance. Second, compensation payout schedules must be aligned with the time horizon of risks. Third, the mix of cash, equity, and other forms of compensation should be consistent with the risk stemming from employee activities. The FSF principles were followed in 2009 by a set of specific proposals in key areas, including pay structure. In 2010 a first Peer Review Report on compensation found significant progress in the regulatory framework in FSB member states, as well as in implementation by financial institutions. However, the report also showed a need of further work to align pay schemes with risk.

22 See European Commission (2009a, 2009b).

23 See, e.g., the bill filed in July 2009 by Senator C. Levin: Ending Excessive Corporate Deductions for Stock Options Act (Levin 2009). 
none of these proposals has been approved. Some limited measures have been adopted in connection with the crisis. The Emergency Economic Stabilization Act (EESA) of 2008 tightened the tax rules for non-qualified deferred compensation schemes involving tax-exempt foreign vehicles ${ }^{24}$ and restricted the deductibility of executive compensation for financial institutions selling troubled assets to the Treasury. ${ }^{25}$

In Europe, the May 2008 EU Council of Economic and Finance Ministers condemned overly generous pay and benefit packages for corporate executives and cited changes to preferential tax rules as one of the possible tools to address the issue. Since then, some limited measures have been taken at national level. In 2008 Italy repealed the favourable stock-option rules providing for lower capital gains taxation (12.5 per cent) at disposal of the whole gain accrued since grant; the lower capital gains tax rate is now applied only for the taxation of the gain accrued between exercise and disposal, while previously accrued gains (that is, between grant and exercise) are now once again subject to ordinary income tax. ${ }^{26}$ In 2009 Austria repealed the partial tax exemption available under a concessionary scheme for stock-option benefits not exceeding $€ 36,400$ at the time of grant. Denmark also abolished one of the concessionary stock-option schemes. The Netherlands enacted new tax rules on 'excessive remuneration schemes' leading to the application of progressive personal income tax to many forms of deferred compensation. However, it is unclear whether these limited restrictions of stock-option concessionary schemes are aimed at tightening the rules on executives' pay or instead reflect national budgetary needs.

A more explicit link to the distortions arising from remuneration policies in the financial sector seems to have inspired the temporary bonus taxes introduced between the end of 2009 and the beginning of 2010 by some European governments. At the end of 2009 the UK and France introduced a one-off tax on discretionary bonuses in the banking sector, aimed at encouraging change in the remuneration practices that had contributed to excessive

24 The new section 457A added to the Internal Revenue Code requires non-qualified deferred compensation paid by a non-qualified entity (i.e. a non-resident tax-transparent vehicle) to be taxed as part of the recipient's income as soon as there is no longer a substantial risk of forfeiture. The provision was introduced mainly as a response to perceived abuses by hedge funds. Under previous legislation, the deferred compensation was taxed only in the year of receipt, and not in the year it was earned. In addition to the immediate taxation, a penalty tax of $20 \%$ of the deferred compensation has also become payable.

${ }^{25}$ As part of the Troubled Assets Relief Program (TARP) enacted in the Emergency Economic Stabilization Act of 2008, Congress tightened existing rules on the tax treatment of executive compensation and golden parachute payments made by financial institutions that sell troubled assets to the Treasury as part of the TARP. For institutions selling more than $\$ 300$ million in troubled assets, the existing $\$ 1$ million limit on the deductibility of non-performance-based compensation paid to the five most highly compensated employees (including the CEO) was reduced to $\$ 500,000$.

${ }^{26}$ At the same time, a specific tax exemption for investments in start-ups was introduced.

This is an open access version of the publication distributed under the terms of the Creative Commons Attribution-NonCommercialNoDerivs licence (http://creativecommons.org/licenses/by-nc-nd/3.0/), which permits non-commercial reproduction and distribution of the work, in any medium, provided the original work is not altered or transformed in any way, and that the work is properly cited. For commercial re-use, please contact academic.permissions@oup.com 
risk taking and at developing sustainable long-term remuneration policies that take greater account of risk and facilitate the build-up of loss-absorbing capital. ${ }^{27}$ In both countries stock-option plans were excluded from the tax, provided their structure allowed sufficient links to medium-term corporate performance. The tax was intended as a temporary measure paving the way for better remuneration policies. In both governments' view, in the longer term remuneration practices should change as a result of corporate governance and regulatory reforms. Another purpose of the tax was to recover part of the government subsidies paid to financial institutions and to prevent government-financed banks from paying excessive remuneration while they still needed to strengthen their capital base. A similar initiative has been taken by Portugal, with the introduction of a 50 per cent 'punitive tax' on bonuses paid in 2010 to managers and board directors of financial-sector institutions. $^{28}$

In 2010 Italy, where banks had not received government subsidies, introduced a 10 per cent surcharge on stock options and variable bonuses paid to financial-sector CEOs and directors. However, unlike the British and French measures, the Italian levy, which applies to variable remuneration exceeding three times fixed earnings, is permanent and also applies to stock options. ${ }^{29}$

The measures on the taxation of bonuses are part of the wider debate about the possible remedies to the crisis and about who should bear the cost of past bailouts or future bank failures. At the international level, both the IMF and the European Commission have analysed two possible forms of financial sector taxation: a financial activity tax applied to the value added of the banking and financial sector, and a stability levy, a tax on some balance-sheet items of banks and other financial institutions, possibly used to finance a special anti-crisis fund. Several countries (including the USA, ${ }^{30}$ the UK, France, Germany, and Sweden) have already introduced or are introducing stability

27 The one-off tax applies only to bonuses paid in 2009 in the case of France, and to bonuses paid between 9 December 2009 and 5 April 2010 for the UK. In both countries the tax rate is $50 \%$ and stock options are excluded from the tax base. In the UK the tax applies to bonuses exceeding $£ 25,000$; in France the exempt amount is $€ 27,500$.

${ }^{28}$ The tax applies if the bonus represents more than $25 \%$ of the annual salary and exceeds $€ 27,500$.

${ }^{29}$ Permanent tax measures affecting the variable salary components (or bonuses) in the financial sector have been proposed in Luxembourg and Switzerland. In Luxembourg, a bill submitted to parliament in May 2010 introduces restrictions on the deductibility of excessive bonuses and golden handshakes in the banking sector and for multinationals. In Switzerland, according to a proposal of the Federal Council presented in April 2010, bonuses that depend on company profits paid by banks and insurance companies should no longer be treated as business expenses for tax purposes, but as profit distribution and therefore should be taxable as corporate profits.

${ }^{30}$ In January 2010 the Obama administration introduced a plan for a $0.15 \%$ Financial Crisis Responsibility Fee to be applied to businesses that had received TARP money. The fee would be levied on the debts of financial firms with more than $\$ 50$ billion in consolidated assets. See Office of the Press Secretary (2010). 
levies. A penalty tax on bank bonuses is often considered an appropriate supplementary measure. However, the temporary levies on bonuses have proved to be of limited effectiveness: in most cases banks and financial institutions have preferred to bear all or part of the cost of the tax, leaving the net amount of bonuses almost unaffected. In some cases, banks active at the international level have chosen to spread the cost of the tax over all employees, not just those in the countries directly affected by the levy.

In conclusion, although analysis of the tax treatment of employee stockoption plans, made taking into account both employee- and employer-level taxes, does not confirm a general tax preference for stock-option plans over cash remuneration, it is possible that a tax preference for stock-option plans has emerged as a consequence of the favourable tax treatment at employee level outweighing corporate tax considerations (or vice versa). In addition, in some countries, notably the USA, the dramatic growth of stock-based remuneration plans may have been fostered by specific tax provisions, or by a combination of tax and other rules. Overall, economic analysis suggests that the key to eliminating improper incentives to risk-taking and improving the neutrality of the tax system towards different forms of remuneration is to be found in country-specific measures rather than in general policy guidelines for the abolition of concessionary schemes.

Moreover, better to align the incentives of managers with those of the firm and to generate positive synergies with the ongoing reforms of corporate governance affecting remuneration policies, the tax treatment of stock-option plans should aim to ensure tax neutrality only to plans that meet given conditions (minimum vesting periods, prohibition of renegotiation in case of falling stock prices, and so on). Those not meeting the conditions should be taxed more heavily than ordinary salary.

\subsubsection{Venture capital, private equity, hedge funds: the 'carried-interest' controversy}

In the second half of the 2000s, high investor demand and cheap loan finance led many private equity funds to engage in aggressive highly leveraged corporate restructurings aimed at maximizing the fund's short-term performance but often paying little heed to the firms' long-term prospects and resulting in staff redundancies, wage reductions, and so on. The growth of private equity transactions prompted ever greater risk-taking and highly leveraged deals.

Among the tax factors that might have reinforced this trend-including the possibility to shift debt acquired to finance the deals onto target companies, which could deduct debt interest, or the tax-haven location of many private equity and hedge funds, permitting zero taxation at fund level and opportunities for evasion for high-wealth investors-the tax treatment of 
private equity and hedge fund managers' remuneration attracted much attention.

Managers of venture capital and private equity funds receive most of their compensation in the form of 'carried interest' - that is, as a share of the funds' realized profits on its investments above a certain threshold. ${ }^{31}$ In several countries, notably those with the most private equity funds (the UK and the USA), the carried interest is taxed at preferential capital gains rates rather than ordinary income-tax rates. In several cases the favourable tax treatment also applies to managers of hedge funds, whose remuneration structure often follows that of private equity funds. It has been argued that this tax treatment is inappropriate, since it taxes as dividends or capital gains what is effectively labour income. Since remuneration based on carried interest is likely to encourage risk taking, the favourable tax treatment of carried interest may have reinforced this effect. From a purely economic viewpoint, it is hard to justify taxing risky compensation at lower rates than other compensation. And, to the extent that carried interest can be qualified as service or labour income, taxing it more favourably than other forms of compensation for risktaking activities can hardly be justified on grounds of efficiency and equity. ${ }^{32}$ On the contrary, taxing carried interest on a par with other, economically equivalent forms of income would yield tax equity and efficiency at the same time, and probably limit aggressive risk taking by private equity managers.

31 A venture capital or private equity fund manager is usually the general partner in a fund partnership, and is typically rewarded with a $2 \%$ management fee and $20 \%$ share of the realized profits on investments above a certain threshold. This $20 \%$ profit share is known as 'carried interest', because the financial capital underpinning it is provided or 'carried' by investors, who are limited partners, even though the management expertise, or 'sweat equity', which also contributes to the profit, is provided by the fund manager.

32 Critics of the capital gains tax treatment of carried interest observe that there are two key reasons to conclude that carried interest ought to be categorized as compensation for services, and not as capital gains. First, private equity fund managers are not putting their own financial capital at risk. A basic standard for establishing whether income constitutes capital gains would seem to be whether the individual receiving the income had capital at stake. General partners of private equity partnerships get the $20 \%$ in return for management services, not because they put $20 \%$ of the money in the investment pot. Managers do sometimes make a small contribution of capital to the fund. When this occurs, a small share of the carried interest could be considered a financial investment. But the amount managers contribute is typically between $1 \%$ and $5 \%$-not $20 \%-$ and the carried interest income attributable to it can be separated out and treated differently under the tax code. Second, private equity managers are performing a service, for which the carried interest is clearly compensating them. Unlike limited partners, they are responsible for making investment decisions and managing investments. The main argument that has been offered in defence of treating carried interest as capital gains is that it entails a lot of risk. However, the character of carried interest income should not depend on whether the compensation is performance based. A wide range of performance-based compensation, including arrangements in which service providers accept the entirety of the risk of the success or failure of the enterprise, is effectively labour income and taxed as ordinary income for services. See the Statement of Peter R. Orszag before the Committee on Finance of the United States Senate, The Taxation of Carried Interest, 11 July 2007.

This is an open access version of the publication distributed under the terms of the Creative Commons Attribution-NonCommercialNoDerivs licence (http://creativecommons.org/licenses/by-nc-nd/3.0/), which permits non-commercial reproduction and distribution of the work, in any medium, provided the original work is not altered or transformed in any way, and that the work is properly cited. For commercial re-use, please contact academic.permissions@oup.com 
In response to criticism of the excessive remuneration of private equity fund managers, since 2007 several European countries have tightened the tax rules on carried interest. In 2008 the UK repealed the tax advantage for carried interest, which had been subject to a capital gains tax of 10 per cent, introducing a general rate of 18 per cent for all capital gains, including carried interest. Germany reduced the exempt percentage of carried interest from 50 to 40 per cent and introduced more specifically targeted tax rules for venture capital and private equity. In 2009 the Netherlands made many forms of deferred compensation, including carried interest, subject to progressive income tax, in the context of the new rules on the 'excessive remuneration schemes' recalled above.

The debate on limiting the tax benefits for carried interest has also been lively in the United States, particularly following the biggest buyout boom in history in 2007, when firms including Blackstone Group LP and Och-Ziff Capital Management Group raised their profiles through public stock listings. Bills were presented in Congress, but no legislative change ensued. In February 2010 President Obama presented the 2011 budget proposal, containing provisions to treat carried interest as ordinary income. This would boost the tax rate, starting in 2011, to 39.6 per cent for most executives, from the current 15 per cent capital gains tax rate.

\subsection{The development of structured finance}

It is generally acknowledged that structured finance played a key role in the financial crisis. The spread of asset-backed securities (ABSs) and credit derivatives, designed to transfer and reduce (or increase) exposure to credit risk, paved the way for the diffusion of toxic assets and the rise of a shadow banking system' (Onado 2009).

Structured finance's chief objective is the transfer of risk between financial intermediaries and investors; it is based on securitization technique. There are several definitions of securitization. ${ }^{33}$ Broadly speaking, the securitization process transforms a financial relationship into a market transaction. More specifically, an 'asset securitization' is composed of two stages (see Figure 4.1): (1) transfer of a pool of assets from the original owner (the originator) to a finite-lived, stand-alone special vehicle (special purpose entity (SPE), or special purpose vehicle (SPV)); (2) issuance of securities by the SPV, in order to finance the purchase of the assets. ${ }^{34}$

\footnotetext{
33 For a more detailed discussion of securitization and structured finance, see Scott (2004); BIS (2005); Fabozzi and Khotari (2007); Lucas et al. (2007); and Duffie (2008).

34 This analysis does not consider the legal issues of securitization, i.e. the 'true sale' of the assets and the 'bankruptcy remoteness' of the SPV; on these issues, see Johnsen and Eagan (2003) and Fabozzi and Khotari (2007).
} 


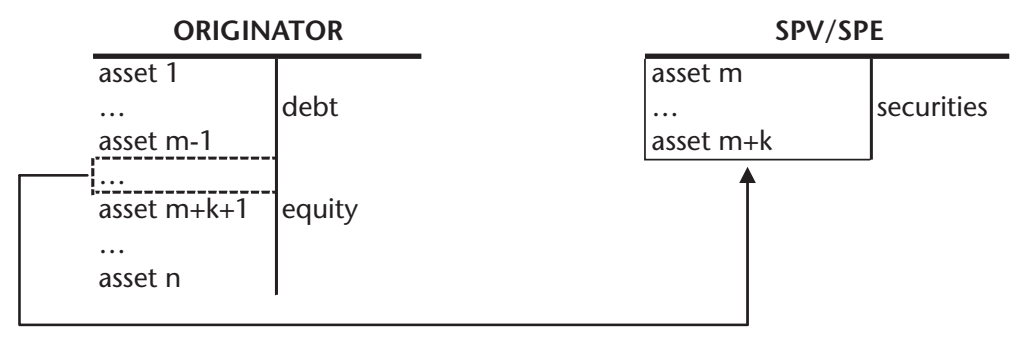

Figure 4.1. The securitization process

The repayment of principal and interest of securities issued by the SPV is ensured by the cash flow deriving from the assets sold by the originator. As regards SPV structures, there are 'pass-through SPVs' and 'pay-through SPVs'. In the former, the SPV issues securities representing an undivided right to a pro-rata share of the cash flows deriving from the originator assets; in the latter, the SPV reconfigures the cash flows deriving from the originator's assets, in order to issue several classes of securities, each one with different seniority and distinct risk-return profiles, ranging from AAA bonds to equity. This permits investors seeking higher yields to have a wider choice on the financial market. The securities issued by the SPV are generally called ABSs (asset-backed securities). ${ }^{35}$

The SPV can be created not by an originator but by a financial intermediary, who buys assets (loans or bonds) on the market and puts them in an SPV; in this case, the securitization process creates securities called collateralized debt obligations $\left(\mathrm{CDOs}^{36}\right)$, issued in several tranches with different levels of risk; the SPV is often referred to as a CDO (see Figure 4.2). A CDO usually has fewer financial instruments as collateral than an ABS. ${ }^{37}$

35 There are several kinds of ABSs, depending on the type of asset sold by the originator. The most important are mortgage-backed securities (MBSs), which can be divided between commercial MBSs (CMBSs), secured by commercial and multifamily properties, and residential MBSs (RMBSs). ABSs are backed also by home equity loans, car loans, consumer loans, and credit-card receivables. Most mortgage-backed securities are issued by US government agencies, such as the Government National Mortgage Association (Ginnie Mae), the Federal National Mortgage Association (Fannie $\mathrm{Mae}$ ), and the Federal Home Loan Mortgage Corporation (Freddie Mac), which began mortgage securitization in late 1970s. The first non-agency mortgage securitization was set up by Bank America in 1977 (Johnsen and Eagan 2003).

36 CDOs collateralized by bonds are called CBOs; if loans are the collateral, we have CLOs. CDOs can be backed by ABSs and MBSs too, usually by mezzanine tranches: in this case we have structured finance CDOs (SF CDOs). CDOs collateralized by other CDOs are called CDOs squared.

${ }^{37}$ For a fuller description of the differences between CDOs and ABSs, see Mason and Rosner (2007).

This is an open access version of the publication distributed under the terms of the Creative Commons Attribution-NonCommercialNoDerivs licence (http://creativecommons.org/licenses/by-nc-nd/3.0/), which permits non-commercial reproduction and distribution of the work, in any medium, provided the original work is not altered or transformed in any way, and that the work is properly cited. For commercial re-use, please contact academic.permissions@oup.com 


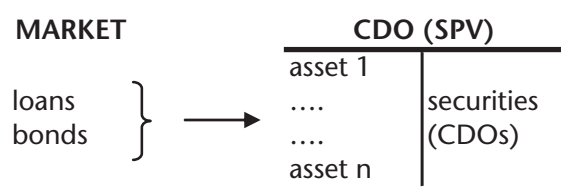

Figure 4.2. Collateralized debt obligations

A synthetic $\mathrm{CDO}$ is a $\mathrm{CDO}$ whose underlying portfolio consists mainly not of bonds but of credit default swaps (CDSs). CDSs are contracts intended to protect a party (the protection buyer) against credit risk (see Figure 4.3). ${ }^{38}$

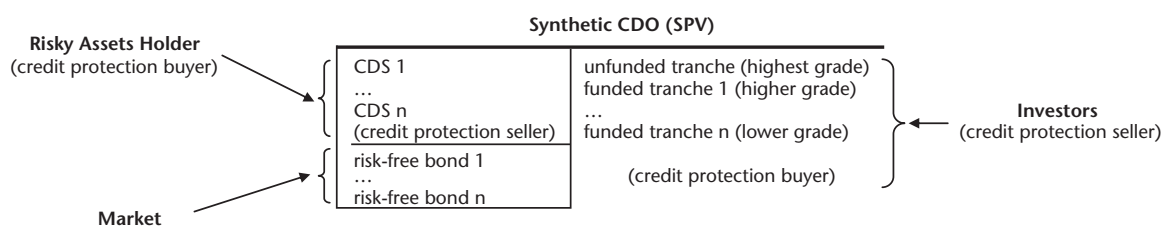

Figure 4.3. Synthetic CDOs

In this case, the SPV sells protection against credit risk via CDSs; at the same time, by selling tranches of synthetic CDOs to investors, it buys protection from them. In this way, synthetic CDOs create credit exposures for investors (Adelson 2004; Remolona and Shim 2008). In other words, with synthetic CDOs 'credit risk exposure is transferred via CDS rather than the transfer of ownership of corporate debt obligations' (Lucas et al. 2007).

Compared with CDOs or ABSs, a synthetic CDO works differently (see Figure 4.4). In fact, tranches may be funded or unfunded. The investor pays an amount to subscribe a CDO's funded tranche, in order to receive interests, in addition to the premium linked to the CDSs' risks. If the investor subscribes an unfunded tranche, he subscribes the CDS contracts alone, without investing any capital, and receives a periodic premium; in other words, subscribing an unfunded tranche is the equivalent of subscribing a CDS on the whole underlying portfolio of the synthetic CDO. The unfunded tranche has the highest grade (that is, it is the least risky) and may have to make a payment to the synthetic CDO only in the event that the portfolio's losses are not covered by the funded tranches' principal.

Obviously, ABSs, CDOs, and synthetic CDOs can be linked to get more sophisticated structures. Imagine, for example, a bank that securitizes

\footnotetext{
38 More specifically, a CDS is a contract where one party buys credit protection on a reference entity (bonds, loans, etc.) from the other party. The credit protection buyer pays a fee during the term of the contract unless and until a credit event (bankruptcy, default, etc.) regarding the reference entity occurs; in this case the credit protection seller must refund the buyer's loss.
}

This is an open access version of the publication distributed under the terms of the Creative Commons Attribution-NonCommercialNoDerivs licence (http://creativecommons.org/licenses/by-nc-nd/3.0/), which permits non-commercial reproduction and distribution of the work, in any medium, provided the original work is not altered or transformed in any way, and that the work is properly cited. For commercial re-use, please contact academic.permissions@oup.com 


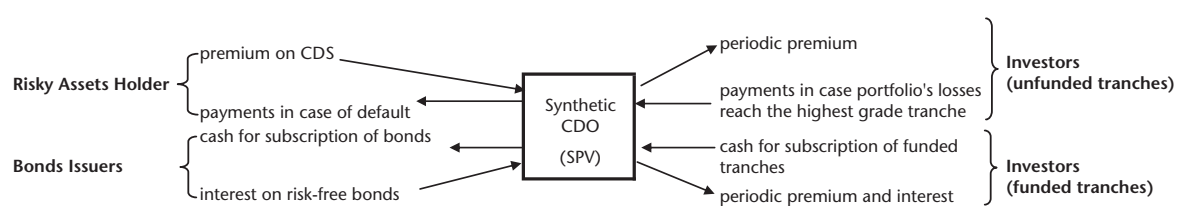

Figure 4.4. Cash flows of a synthetic CDO

mortgages in an SPV that issues MBSs; the MBSs become collateral of a CDO; the risk of CDOs is insured by a synthetic CDO, and so on.

Summing up, there is structured finance when three main features are present: (1) asset pooling; (2) issue of several classes of liabilities; (3) an SPV, which breaks the link between the credit risk of the asset pool and the credit risk of the original asset-holder (BIS 2005).

There are many reasons for using securitizations: for example, reducing funding costs; diversifying funding sources; managing corporate risks; achieving off-balance-sheet financing; lowering the cost of capital; removing assets from balance sheets; converting illiquid assets into marketable securities; for CDOs, also increasing asset management activity and profitability (Adelson 2004; Fabozzi and Khotari 2007). These incentives can explain the rapid growth of ABSs and CDOs and the demand of banks for new 'raw materials' (loans, also of subprime quality). According to some authors (Onado 2009; Shin 2009), because of the advantages of securitizations, the growth of subprime mortgages is due more to a loan supply excess from banks than to a loan demand excess from subprime borrowers.

In the next section we point out the role of taxation in this escalation, referring in particular to the US tax rules.

\subsection{The role of taxation in the development of securitization}

It has been pointed out that 'tax planning in the securitization area is generally defensive rather than offensive. Transactions are undertaken for non-tax reasons...' (Peaslee and Nirenberg 2001: 8). In other words, 'the potential [tax] abuses in the securitization area appear ... to be a pimple on the back of an elephant' (Peaslee and Nirenberg 2001: 8). Nevertheless, even if there is no direct tax advantage for the originator or the intermediary, a securitization may have important indirect tax advantages.

\subsubsection{The tax advantages of pooling}

One of the main advantages of securitization is the possibility of pooling assets with different maturity and income characteristics, in order to issue

This is an open access version of the publication distributed under the terms of the Creative Commons Attribution-NonCommercialNoDerivs licence (http://creativecommons.org/licenses/by-nc-nd/3.0/), which permits non-commercial reproduction and distribution of the work, in any medium, provided the original work is not altered or transformed in any way, and that the work is properly cited. For commercial re-use, please contact academic.permissions@oup.com 
securities without any link to the collateralized asset. From a tax point of view, the assets pooled bear interest and capital gains/losses that could not be taxed at the same rate (for example, in the USA individuals are taxed at the ordinary personal income-tax rates on interest income and at special-lower-rate on capital gains/losses) and at the same time. So, reconfiguring assets also means mixing interest and losses; in this way, the value of a capital loss is greater than before securitization, because losses can be offset not only with capital gains (saving an amount of capital gains tax), but also with interest (saving a higher amount of taxes). In other words, securitization moves the taxable event from individual positions (interest and gains/losses on single assets, received from each asset) to the overall result of the pool of assets (the sum of interest, gains, and losses from all assets), reducing the expected tax liability (Eddins 2009). Moreover, the timing structure of flows received from securities issued by the SPV produces a tax advantage in terms of tax deferral: offsetting between interest and losses makes it possible to defer the taxation of the revenues until the SPV distributes incomes on the securities it has issued (or the securities issued by the SPV are sold and capital gains realized).

To reach these goals, it is essential to avoid taxation of the SPV. In fact, only in this case is it possible (1) to eliminate the tax otherwise due if assets remained in the original asset-holder's balance sheet, and (2) to shift the taxable event from the taxation of principal and interest stemming from the original assets to the taxation of flows received on the securities issued by the SPV.

\subsubsection{The US tax treatment of special purpose vehicles}

Taxation of an SPV can be avoided if the SPV is considered a conduit for US tax purposes or a tax-free offshore entity. ${ }^{39}$ Conduit status for tax purposes is achieved through the 'check-the-box' regulation or compliance with the requirements established for some securitization vehicles: real estate mortgage investment conduit (REMIC), for MBSs; financial asset securitization investment trust (FASIT), for ABSs. ${ }^{40}$

Initially, amendments to tax rules were designed to remove hurdles to the growth of the securitization market development. The introduction of the REMIC regime in 1986, of the FASIT regime in 1996, and of the check-the-box regulation in 1997 allowed greater flexibility in designing securitizations and made market development easier (Nomura 2006). ${ }^{41}$ According to Peaslee and

39 CDOs are usually issued by offshore SPVs, in order to escape taxation on corporate income (Lucas et al. 2007).

40 These vehicles are not subject to federal corporate tax, but may be subject to state taxes.

41 REMICs were introduced by the Tax Reform Act of 1986. The FASIT regime, created under the Small Business Job Protection Act of 1996 and effective from 1997, was subsequently repealed and has not been enforceable since 1 January 2005.

This is an open access version of the publication distributed under the terms of the Creative Commons Attribution-NonCommercialNoDerivs licence (http://creativecommons.org/licenses/by-nc-nd/3.0/), which permits non-commercial reproduction and distribution of the work, in any medium, provided the original work is not altered or transformed in any way, and that the work is properly cited. For commercial re-use, please contact academic.permissions@oup.com 
Nirenberg (2001: 6), 'the advent of the REMIC rules has led to a blossoming of financial engineering in the mortgage-backed securities area' ${ }^{42}$ Under these rules a SPV is considered a conduit for tax purposes, but, at the same time, in order to preclude tax avoidance, limits are set on allowable securities, substitution of mortgages, cash contributions to the SPV, and so on.

As housing prices began to decline in 2006 and it became clear that a substantial portion of subprime residential adjustable-rate mortgages would not survive the interest-rate resets, efforts were begun to renegotiate the terms of these loans in order to avoid a surge of defaults. These efforts were hampered by the fact that the mortgages had been packaged into REMICs or other investment trusts, where the ability to modify mortgages is severely limited by tax rules designed to ensure that the investment trust maintains a substantially fixed pool of mortgages. Modifying mortgages held by a REMIC can make the vehicle subject to severe penalties, including a 100 per cent prohibited-transaction tax or even possible loss of REMIC or investment trust status altogether.

As the financial crisis made it necessary to renegotiate mortgage loans, the Internal Revenue Service (IRS) issued tax guidance ${ }^{43}$ providing a safe-harbour list of permitted modifications in REMICs (Beeman 2009).

In some circumstances, avoiding the taxation of SPV may have contributed to the growth of securitization. Because of the corporate taxation of bank income, some banks may have an incentive to sell loans, and this incentive is an increasing function of the corporate income-tax rate (Han et al. 2010).

At least other three tax issues may play an important role in securitization (Peaslee and Nirenberg 2001; Johnsen and Eagan 2003). The first is the characterization of the originator's transfer of assets to the SPV, which for tax purposes may be treated as either a sale of assets (the originator recognizes gains or losses on the transfer) or a loan secured (without any transfer of tax ownership). The second issue regards the tax characterization of securities issued by the SPV as debt or equity; if an investor is treated as an equity owner, he could be taxed on the SPV's residual taxable income emerging in any period (so-called phantom income ${ }^{44}$ ). The third issue concerns the tax treatment of credit default swaps (CDSs), which we analyse below.

\footnotetext{
42 Owing to temporal mismatching between proceeds from assets held by the vehicle and payments on the securities it issues, in some periods taxable income exceeding economic income may have to be recognized. The excess-i.e. the difference between taxable income and economic income-is called phantom income and constitutes ordinary taxable income for holders of equity interests in a REMIC. For more information, see Lupo (2008).

43 IRS rev. proc. 2007-72, 2008-28, 2008-47. Initial attempts to relax these rules had been made in 2004 and 2005.

44 See n. 42.
}

This is an open access version of the publication distributed under the terms of the Creative Commons Attribution-NonCommercialNoDerivs licence (http://creativecommons.org/licenses/by-nc-nd/3.0/), which permits non-commercial reproduction and distribution of the work, in any medium, provided the original work is not altered or transformed in any way, and that the work is properly cited. For commercial re-use, please contact academic.permissions@oup.com 


\subsubsection{The taxation of credit default swaps}

The taxation of CDSs has enhanced the development of structured finance through two mechanisms:

- a tax arbitrage, created by asymmetries and inconsistencies in the tax treatment of the parties to the CDS contract (the credit protection 'seller' and the credit protection 'buyer'), which in turn give rise to uncertainties in the qualification of CDSs for tax purposes;

- a de facto exemption from withholding tax (or insurance excise tax) on CDS premium received by non-residents, complementing the tax arbitrage mechanism.

The tax treatment of CDSs in the USA is a matter of debate. ${ }^{45}$ The IRS issued a notice requesting information from market participants and experts in 2004, but did not issue specific tax guidance on the matter; meanwhile, recent developments in the market of CDSs (standardization, significant upfront payments, and so on) have increased the complexity of tax issues (see Munro 2010: passim). Taxpayers can only rely on the opinion of tax experts, who do not even agree on the approach to analysing the problem and propose two different methods:

- the analogy approach, with CDSs held to be analogous to other derivatives and the same tax treatment applied;

- the analytical approach, with the tax treatment of CDSs derived by analysing single elements of the transactions-for example, the nature of the reference obligation, the nature of parties, and so on.

The literature has paid little attention to the analytical approach, perhaps because tax rules operate first 'by characterizing a financial contract as a type of financial instruments... and then by taking context into account ${ }^{\prime}{ }^{46}$ By contrast, the analogy approach has been extensively pursued and ultimately turned into four different theories: a CDS has been compared to a guarantee, an insurance contract, a notional principal contract (NPC), or a (put) option. This list has been considered exhaustive in the absence of 'similar breadth and depth of tax law for other potential analogies' (that is, letter of credit). ${ }^{47}$

\footnotetext{
45 'The current state of taxation of financial instruments is a mess...Credit default swaps present a case study of much that is wrong with the extant method of rule promulgation ... the tax treatment of financial innovation continues to be regulated in ... a haphazard "cubbyhole" approach' (Brunson 2008: 2, 10).

${ }_{46}$ New York State Bar Association Tax Section (2005: 566).

${ }^{47}$ New York State Bar Association Tax Section (2005: 567).
} 
Analyses have substantially rejected the first two hypotheses, underlining significant and detailed differences between a CDS and a guarantee ${ }^{48}$ or an insurance contract; ${ }^{49}$ in general, CDSs-like all financial derivatives-have latu sensu a guarantee/insurance function, but this does not necessarily imply that they are legally equated with those operations. Most opinions (and recommendations) qualify CDSs as NPCs or options, but there is still debate on which of these definitions is more appropriate. An NPC, ${ }^{50}$ like a CDS, is a financial instrument providing payments at specified intervals, by reference to a specified index on a notional amount and in exchange for specified consideration or a promise to pay a similar amount; but the payments to the credit protection seller should be taxed/deducted over the life of NPC, whereas the life of a CDS cannot be known in advance. An option, like a $\mathrm{CDS}$, is a continuing offer plus an agreement to leave the offer open, but the condition for exercise is the occurrence of a default and not a mere decision of the credit protection buyer. ${ }^{51}$

Following the general rules on the taxation of securities, the tax treatment of an operation with CDSs depends on two major variables:

- characterization either as capital gains or losses, taxed or deductible at 15 per cent, or as ordinary income, taxable or deductible at 35 per cent for corporations and at the ordinary income-tax rates for individuals;

- timing, with the different options of taxation on a cash basis, for mere investors, an accrual (mark-to-market) basis, for dealers and traders in securities.

Usually, the credit protection buyer is an investor and his credits are capital assets, while the seller is a dealer or a trader. Accordingly, a loss incurred on a credit by a non-corporate credit protection buyer will be treated as a capital loss deductible at 15 per cent and netting will be allowed primarily within ' 15 per cent group' gains; ${ }^{52}$ the refund the credit protection buyer receives from the seller must be treated in the same way as the loss.

48 In CDSs the buyer is not required to hold the reference obligation, has no right of subrogation in a case of default, and his payment obligation is always directed to the seller, not to a third party. In addition, CDSs are traded, generic, and standard, while guarantees are usually non-traded and specific.

49 In a CDS, (a) the credit event is not triggered by a 'fortuitous event'; (b) the loss lacks the classical elements of loss in insurance contracts (timing, quantification in advance, no insurable interest if the buyer does not hold the reference obligation, absence of pooling and dilution of risk); (c) sector regulations permit banks but not insurance companies to engage in CDSs.

50 The definition of NPC encompasses interest-rate swaps, basis swaps, currency swaps, interestrate caps, interest-rate floors, equity swaps, and equity index swaps; options are excluded.

51 For a discussion on replacing "the customary definition of options in terms of the "rights" of the parties with a definition that better reflects the true economics of options', see Brandes (2008: esp. $80 \mathrm{ff}$.).

52 Further netting is allowed within ' 25 per cent group' and, finally, ' 28 per cent group' capital gains.

This is an open access version of the publication distributed under the terms of the Creative Commons Attribution-NonCommercialNoDerivs licence (http://creativecommons.org/licenses/by-nc-nd/3.0/), which permits non-commercial reproduction and distribution of the work, in any medium, provided the original work is not altered or transformed in any way, and that the work is properly cited. For commercial re-use, please contact academic.permissions@oup.com 
As for timing, the credit protection buyer will always account for the loss only when it is realized, on a cash basis, whereas the seller is a mark-to-market operator and is taxed on an accrual basis, including the gains or losses in its income subject to corporate income tax.

If we qualify CDSs as guarantees or insurances, the buyer will treat the refund of loss received from the seller as a capital income (15 per cent); the seller will treat all the payments made or received as ordinary income or expense (35 per cent). As for timing rules, while the buyer has only the option for realization, the loss of the seller may be treated through a baddebt deduction (guarantee) or an estimated loss (insurance).

If CDSs are equated with NPCs, the tax characterization of payments made and received by the buyer and the seller are in principle the same as in guarantees or insurance contracts. As regards timing, both the buyer and the seller must account for the payment of premiums on an accrual basis, but the seller can also mark CDSs to market.

CDS options are deemed to be a capital asset under section 1234 of the US tax code, so all payments made and received by the buyer are not ordinary income or expense, but capital losses/gains, deductible or taxable at the expiration of the option. The seller has no capital gain or loss but only ordinary income or expense and marks CDSs to market.

Summing up, the tax treatment of operations involving CDSs is characterized by asymmetries and inconsistencies, because of the differences between buyers and sellers in respect of the tax characterization of items and the timing of taxation. The different views on the nature of CDSs do not eliminate these problems: for example, if a CDS is qualified as a NPC for hedging, the same tax treatment can be applied to buyers and sellers, but an asymmetry remains for the buyer between the loss and the refund. Including CDSs in the general tax treatment of securities, the qualification by analogy always creates room for tax arbitrage.

Eddins (2009) has developed a theory ('tax arbitrage feedback theory') about how these tax arbitrage opportunities have been exploited. Simplifying the situation described above, he identifies three different players: 'traditional buy and hold investor', with interest taxed as ordinary income and losses deductible as capital items at a different rate; 'mark-to-market business trader', with interest and losses accounted for as ordinary income, at the same rate; and 'non-taxable investor' (such as pension funds).

The asymmetric tax treatment of interest versus losses creates a tax penalty for traditional investors. Since this tax asymmetry does not exist for mark-tomarket operators (and non-taxable investors), the premium paid for CDSs includes this tax penalty and the mark-to-market operator is able to extract and retain this tax penalty, transforming a tax loss deductible at 15 per cent 
into a loss deductible at 35 per cent. The 'Credit Default Swap Tax Arbitrage Equation' is the following:

$$
\text { TaxPenalty }=\beta \times(1-R) \times \frac{\left(T_{\text {Interest }}-T_{\text {Losses }}\right)}{1-T_{\text {Interest }}}
$$

where $\beta$ is the annualized bankruptcy risk, $R$ the expected recovery rate, and $T_{\text {Interest }}$ and $T_{\text {Losses }}$ are, respectively, the tax rates on interest and losses of a traditional investor. The arbitrage profit depends primarily on the difference between the tax rates, but it also increases as $\beta$ and $R$ increase: the higher the risk, the greater the profit. Therefore, the 'tax penalty' represents the arbitrage profit of the mark-to-market operator. 'And because this arbitrage is tax-based, instead of price-based, it cannot be eliminated by price moves' (Eddins 2009: 19).

The profit opportunity has a feedback: to exploit it operators need CDSs, and CDSs need low-grade credit. The consequence is a multiple boost affecting different markets: loans increase to supply the raw materials of the chain, CDSs increase to extract risk from loans in exchange for protection, and CDOs increase to buy from investors the protection sold through CDSs. As Eddins (2009: 19) observes:

this particular tax arbitrage does not exist for high-grade credit because the odds of default are so low that there is hardly any tax benefit to arbitrage. Therefore, the creation of low-grade credit was a requirement to fuel the arbitrage. The extreme profitability of these businesses to Wall Street provided powerful feedback to induce the creation of lots of low-grade debt. Unrecognized was the fact that increasing the quantity of low-grade credit within the financial system also increased the systematic risk of default. This set off a chain reaction that spread far and wide.

There only remains a final point to analyse, one not mentioned by Eddins: as the arbitrage profit is extracted by the mark-to-market operator via the CDS premium (which is equal to the tax penalty), can the taxation of the CDS premium compensate for (or at least reduce) the arbitrage profit?

As noted by the IRS (2004), taxpayers are also concerned about the treatment of payments from a credit protection buyer in the USA to a non-resident credit protection seller. The question is whether these payments are subject to taxation in the USA, either through a withholding tax or through an excise tax on insurance premiums. ${ }^{53}$

Let us recall that non-residents are taxed on US source income only if it is effectively related to a US trade or business (that is, a regular, continuous, and considerable business); unrelated income is taxed if particular conditions obtain. ${ }^{54}$

53 For a deeper discussion, see Peter (2006).

54 The income is US source and falls under section 861 or was allocated by regulations to sources within the USA or is allocated by comparison and analogy; income must be fixed, determinable, annual, or periodic. 
If we consider the four possible characterizations of CDSs, we find that these instruments are subject to virtually no form of taxation in the USA when the recipient is a non-resident.

We have already shown why CDSs appear quite different from guarantees. But, even if they were comparable, this would not lead to the taxation of payments to a non-resident: a guarantee is not necessarily subject to withholding tax, because it is not necessarily related to a US trade or business (and this is even more likely for a CDS); the IRS does not cite guarantees among US source items, and it is an open question whether the proceeds of a guarantee can be equated with payment of interest.

Even if the definition of insurance does not appear to apply to CDSs, let us consider CDSs as insurance contracts: if the seller is not an insurance firm, then it is not engaged in an insurance activity; consequently, the US source premium is not US source income and is not subject to withholding tax. In respect of the excise tax of 4 per cent on the premiums paid by a US insured party to a non-US insurer and levied when the risk is located wholly or partly within the USA, CDS contracts may provide that the buyer be indemnified against the risk of paying excise tax via a premium increase. In this case, again, non-residents are not taxed.

We have shown that CDSs appear to fit the definition of NPCs; as income from NPCs is not mentioned in the sourcing rules of the US tax code and the IRS defines the source of such income on the basis of the taxpayer's residence, the income is not taxable in the USA if the credit protection seller is a foreigner. Again, the CDS payments received by the seller are tax exempt in the USA.

CDSs could be considered as options. Again, income from option premiums is not mentioned in the sourcing rule; the IRS has not ruled on it, so no withholding tax is levied. Consequently, such income is US source income non-taxable in the USA.

To conclude: it is an open question whether a CDS guarantee should be subject to withholding tax. It is possible that a CDS insurance holder could also be exempted de facto from the excise tax. A CDS-NPC holder can escape the withholding tax. Finally, it is almost certain that no tax is levied on premiums received from a CDS option. The tax arbitrage described above is accompanied by a de facto exemption of CDS premiums received by non-residents.

\subsection{Conclusions}

Although taxation was not the paramount factor in the 2008 financial crisis, a number of features of national tax systems-and, in some cases, the interaction among them-may have contributed to reinforce the economic factors 
that triggered the financial crisis. In several instances, tax provisions created opportunities for tax arbitrage and extra-profits for financial intermediaries.

In this chapter we have examined two specific cases, regarding the tax treatment of performance-based remuneration of managers and venture capital fees and the tax provisions applying to the securitization and CDS markets.

The dramatic rise in bonuses, stock-option plans, and other performancebased remuneration forms in the financial sector has been singled out as playing an important role in triggering the crisis because it tends to overemphasize short-term profitability compared with longer-term goals. As the Financial Stability Forum (now Financial Stability Board) has pointed out, this feature is particularly unwelcome in the financial sector, where higher returns may quite easily (more easily than in other sectors) be pursued in a trade-off against higher risks.

The analysis of the tax treatment of stock-option plans, made taking into account both employee- and employer-level taxes, does not confirm a general tax preference for these plans over cash remuneration. However, in some countries, notably the USA, the dramatic growth of stock-based remuneration plans may have been fostered by specific tax provisions, or by a combination of tax and other rules. In other cases, it is possible that a tax preference emerged as a consequence of a unilateral perspective, with the favourable tax treatment at employee level prevailing over corporate tax considerations. Overall, economic analysis suggests that the key to eliminating improper incentives to risk-taking and improving the neutrality of the tax system towards different forms of remuneration is to be found in country-specific measures rather than in general policy guidelines for the abolition of concessionary schemes. Moreover, better to align the incentives of managers with those of the firm and to generate positive synergies with the ongoing reforms of corporate governance affecting remuneration policies, the tax treatment of stock-option plans should aim to ensure tax neutrality only to plans that meet given conditions (minimum vesting periods, prohibition of renegotiation in case of falling stock prices, and so on).

In a vein similar to that of stock-option plans and other performance-based remuneration, also the preferential tax treatment provided by many countries for 'carried interest' earned by managers of venture capital and private equity funds (taxation at preferential capital gains rates rather than at ordinary incometax rates) might have contributed to the explosive growth of aggressive private equity transactions through highly leveraged corporate restructurings aimed at maximizing the fund's short-term performance but often paying little heed to the firms' long-term prospects and resulting in staff redundancies, wage reductions, and so on. The favourable tax treatment of 'carried interest' reinforced other tax factors that might have favoured this trend, including the possibility to shift debt acquired to finance the deals onto target companies, which could

This is an open access version of the publication distributed under the terms of the Creative Commons Attribution-NonCommercialNoDerivs licence (http://creativecommons.org/licenses/by-nc-nd/3.0/), which permits non-commercial reproduction and distribution of the work, in any medium, provided the original work is not altered or transformed in any way, and that the work is properly cited. For commercial re-use, please contact academic.permissions@oup.com 
deduct debt interest, or the tax haven location of many private equity and hedge funds, permitting zero taxation at fund level and opportunities for evasion for high-wealth investors.

The securitization process, allowing the risks assumed by a company to be passed on and diluted in the market, played a fundamental role in shifting risk from financial firms to the whole system and thus in making the crisis systemic. Taxation also appears to have been a factor in securitization. Although the intermediaries involved did not seek preferential tax treatment or pursue tax-avoidance schemes, securitization created opportunities for tax arbitrage and reduction of the overall tax wedge paid by the originator, the special purpose vehicle (SPV) and the final investor. The SPV must be a tax-free vehicle (either a conduit recognized as exempt under domestic tax law or a foreign entity located in a jurisdiction with no direct taxation). In this case, by combining different incomes (interest, capital gains and losses), the SPV makes it possible to pool and offset incomes that are ordinarily taxed at different rates (hence permitting preferential deductibility of capital losses); furthermore, it allows the taxation of the revenues generated by the underlying original assets to be deferred until the SPV distributes incomes on the securities it has issued (or the securities issued by the SPV are sold and capital gains are realized).

The expansion of credit default swaps has greatly assisted the securitization process, creating a sort of insurance on the credit risk of the underlying assets. Their tax treatment has also spurred the growth of securitization: in fact, it created further possibilities of tax arbitrage and provided for a de facto exemption from withholding tax on CDS premium received by non-residents.

In conclusion, taxation has not been the main component of the securitization process, but it certainly has not created disincentives; indeed, it has created opportunities for tax arbitrage and extra-profits for financial intermediaries able to internalize these opportunities.

This is an open access version of the publication distributed under the terms of the Creative Commons Attribution-NonCommercialNoDerivs licence (http://creativecommons.org/licenses/by-nc-nd/3.0/), which permits non-commercial reproduction and distribution of the work, in any medium, provided the original work is not altered or transformed in any way, and that the work is properly cited. For commercial re-use, please contact academic.permissions@oup.com 


\title{
5
}

\section{Can Tax Policy Help to Prevent Financial Crisis?}

\author{
Thomas Hemmelgarn and Gaetan Nicodeme
}

\subsection{Introduction}

Following a year of progressive worsening of the subprime crisis, the collapse of Lehman Brothers on 15 September 2008 marked a halt in interbank lending and plunged the world into a severe economic and financial crisis. Governments were immediately forced to respond to avoid the collapse of the whole financial system and to alleviate the economic consequences of the crisis on the real economy. This response took the form of specific measures aimed at banks and measures to stimulate the economy. In the European Union, between October 2008 and May 2010, Member States individually committed to a total of about $€ 3$ trillion (that is about 26 per cent of their combined GDP) in various measures to support the financial sector (for example, recapitalization of financial institutions, guarantees on bank liabilities, relief of impaired assets), albeit the effective use is about $€ 1.5$ trillion, including measures outside schemes (European Commission 2010a; Stolz and Wedow 2010). This aid was framed by several communications adopted by the European Commission between October 2008 and July 2009, setting out how it would apply state aid rules to government measures aimed at supporting the banking sector in the context of the economic crisis. In the US, the Emergency Economic Stabilization Act of October 2008 launched the Trouble Asset Relief Program (TARP), which provided the US Treasury with $\$ 700$ billion to purchase 'trouble assets'.

This chapter was written by Mr Gaetan Nicodeme and Mr Thomas Hemmelgarn, DirectorateGeneral for Taxation and Customs Union (C) European Union, 2011. The views expressed in this chapter are those of the authors and do not necessarily reflect the official position of the European Commission.

This is an open access version of the publication distributed under the terms of the Creative Commons Attribution-NonCommercialNoDerivs licence (http://creativecommons.org/licenses/by-nc-nd/3.0/), which permits non-commercial reproduction and distribution of the work, in any medium, provided the original work is not altered or transformed in any way, and that the work is properly cited. For commercial re-use, please contact academic.permissions@oup.com 
In terms of stimulus packages, the European Commission issued the European Economic Recovery Plan for Growths and Jobs (EERP) in November 2008, which provides a mix of tax and expenditure measures to support the real economy and to boost confidence of $€ 200$ billion (that is, 1.5 per cent of EU GDP). For 2009 and 2010, the expansionary stimulus measures amounted to 1.5 per cent and 1.4 per cent of EU27 GDP respectively (European Commission 2010b: 20). Consequent to these policy measures and to the economic downturn, EU27 average public deficits increased from 0.9 per cent of GDP in 2007 to a 6.4per cent in 2010, and public debt jumped from below 60 per cent of GDP in 2007 to above 80 per cent for the years to come (European Commission 2010c: 5).

In addition, there is a wide perception that the financial sector bears a major responsibility for the occurrence and the extent of the crisis. In particular, the financial sector may be too large and take too much risk because of actual or expected state support (resulting in moral hazard), information asymmetries, and remuneration structures, which, together with macroeconomic developments, contributed to the recent crisis (FSA 2009; High Level Group on Financial Supervision in the EU 2009; Hemmelgarn and Nicodeme 2010; Ceriani et al. in Chapter 4 this volume).

Finally, the financial sector has been relatively profitable in the 1990s and 2000s, and there is a desire to ensure that the financial sector makes a fair and substantial contribution to public finances. Taken together, these elements constitute rationales for opening a debate as whether additional or increased taxes on the financial sector could help with consolidation and increased efficiency and stability of financial markets.

In October 2009, the European Council agreed that a coordinated strategy for existing stimulus policies was needed for when the recovery was secured and invited the Commission to examine innovative financing at a global level. The Staff Working Document (European Commission 2010d) assesses the potential of innovative financing-new ways of raising public revenues, or of complementing them by leveraging private finance, as well as new approaches to already existing fiscal instruments-at a global level to raise revenues for addressing the consolidation, development aid, and climatechange mitigation challenges in order to narrow down the range of options to the most promising ones. The analysis suggests that some instruments, notably certain forms of contributions from the financial system, can bring a 'significant "double dividend" of both raising revenues and improving market efficiency and stability could be reaped. In particular, schemes aimed at pricing leverage and risk-taking in the financial sector could raise substantial revenues while limiting undesirable behaviour by financial institutions and could be administered at a reasonable cost' (European Commission 2010d: 5). 
In March 2010, the European Parliament adopted a resolution requesting the Commission to carry out an assessment on a financial transaction tax. The Parliament also recommended the use of innovative finance instruments in the context of a report on the impact of the financial and economic crisis on developing countries.

In parallel, an increasing international debate has started at the G20 level, where leaders asked for the IMF to 'prepare a report for our next meeting [June 2010] with regard to the range of options countries have adopted or are considering as to how the financial sector could make a fair and substantial contribution toward paying for any burden associated with government interventions to repair the banking system'. The IMF (2010a) proposes two possible forms of contribution from the financial sector, serving distinct purposes: (1) a 'financial stability contribution' (FSC) linked to a credible and effective resolution mechanism, ${ }^{1}$ and (2) a 'financial activities tax' (FAT) levied on the sum of the profits and remuneration of financial institutions if additional revenues are needed for consolidation purposes.

Finally, the European Commission (2010e, 2010f) put forward a twofold approach in October 2010. The Commission supports further exploration and development of a financial transaction tax (FTT) at the global level and will promote an agreement with the most relevant partners. At EU level, the Commission sees potential in a financial activities tax (FAT), as, if carefully designed and implemented, an EU FAT could generate significant revenues and help to ensure greater stability of financial markets, without posing undue risk to EU competitiveness.

In the light of these debates, this chapter assesses two potential instruments to raise additional tax revenues from the financial sector and potentially to correct for its externalities. ${ }^{2}$ It is organized as follows. The second section sheds some light on the current tax treatment of the financial sector. The third and fourth sections respectively assess the advantages and drawbacks of a financial transaction tax and a financial activities tax, including the issues raised by a possible introduction at the EU level only if no agreement is reached at G20 level. The analysis shows that both instruments could be candidates for a tax on the financial sector (FAT) or on financial markets

\footnotetext{
${ }^{1}$ With regard to this, the Commission has proposed the establishment of national resolution funds which would be financed by bank levies (COM(2010) 254 final). This topic is not covered in this chapter. Other instruments have also been discussed, decided, or already enacted in several Member States, but will not be discussed here. They include bonus taxes, surcharges to the CIT for the financial sector, currency transaction levies (CTL), and so on.

2 Note that this issue as to whether and how taxes may have fuelled a speculative bubble is not part of this analysis. It is reviewed by Hemmelgarn, Nicodeme, and Zangari in Chapter 3, this volume, in the context of the housing bubble. More generally, models show that higher capital gains taxes may fuel a bubble, because speculative assets are subject to an arbitrage condition with other assets, and that a higher tax forces a higher required return (Kunieda 2011).
}

\section{8}

This is an open access version of the publication distributed under the terms of the Creative Commons Attribution-NonCommercialNoDerivs licence (http://creativecommons.org/licenses/by-nc-nd/3.0/), which permits non-commercial reproduction and distribution of the work, in any medium, provided the original work is not altered or transformed in any way, and that the work is properly cited. For commercial re-use, please contact academic.permissions@oup.com 
(FTT). An important difference between the two instruments is that the FAT seeks to target the value added by the financial sector, while the FTT is directed at the transactions executed on financial markets.

\subsection{Taxation of the financial sector}

The debate on the fair contribution of the financial sector to fiscal consolidation is closely related to the issue of whether the existing tax systems result in over- or under-taxation with respect to the non-financial sector. For Europe, the main taxes to be considered are the corporate income tax (CIT) and VAT.

\subsubsection{Corporate income taxation}

The financial sector accounted for a substantial share of corporate tax revenues before the crisis. The EU27 GDP-weighted average share of the contribution by the financial sector to total corporate tax collection was around 20 per cent in both 2006 and 2007 (European Commission 2010f). It decreased to 17 per cent in 2008 as a result of the crisis, and this share will most probably decrease further in the coming years due to the fact that the accumulated losses during the crisis will reduce future tax payments via loss carry-forward. ${ }^{3}$ The values for the EU27 are similar to those for many non-EU G20 countries, as collected by the IMF for its report to the G20. For example, between 2006 and 2008, the share of the financial sector in total corporate tax collection was around 18 per cent for the United States, 23.5 per cent for Canada, and around 15 per cent in Brazil and Australia. ${ }^{4}$

Table 5.1. Share of the financial sector in total value added

\begin{tabular}{lccccc}
\hline Year & USA & Euro area & EU27 & UK & Germany \\
\hline 1980 & 4.91 & 4.74 & - & - & - \\
1990 & 5.86 & 5.52 & - & 6.1 & - \\
1995 & 6.64 & 5.46 & - & 5.8 & 4.4 \\
2000 & 7.54 & 4.99 & 4.7 & 5.1 & 3.9 \\
2005 & 7.97 & 6.32 & 5.2 & 7.0 & 4.3 \\
2006 & 8.05 & 6.16 & 5.3 & 7.6 & 4.1 \\
2007 & 7.90 & 5.89 & 5.3 & 8.2 & 3.6 \\
2008 & 8.02 & 5.84 & 5.3 & 9.3 & 3.4 \\
2009 & 8.08 & - & 5.8 & - & - \\
\hline
\end{tabular}

Sources: USA and euro area: BIS (2010: 77); for EU, UK, and Germany: Eurostat Annual Sectoral Account.

\footnotetext{
3 The issue of the tax risks involving bank losses is discussed in Chapter 8.

${ }^{4}$ It should be stressed, however, that the CIT share concerns incorporated companies only and is, therefore, not directly comparable to the shares in value added, which also include unincorporated companies.
}

This is an open access version of the publication distributed under the terms of the Creative Commons Attribution-NonCommercialNoDerivs licence (http://creativecommons.org/licenses/by-nc-nd/3.0/), which permits non-commercial reproduction and distribution of the work, in any medium, provided the original work is not altered or transformed in any way, and that the work is properly cited. For commercial re-use, please contact academic.permissions@oup.com 
Table 5.2. Return on equity in BIS reporting countries

\begin{tabular}{lcccc}
\hline Entities & $1995-2009$ & $1995-2000$ & $2001-7$ & $2008-9$ \\
\hline Banks & 12.2 & 13.3 & 12.8 & 3.2 \\
Non-bank financials & 11.2 & 12.3 & 11.4 & 5.4 \\
Non-financials & 11.7 & 10.9 & 12.8 & 9.8 \\
\hline
\end{tabular}

Note: Return on equity is defined as net income over total shareholder funds. Median values across years and institutions. Source: BIS (2010: 75).

Table 5.3. Relative return of financial stocks

\begin{tabular}{lrrrr}
\hline Country & $1970 \mathrm{~s}$ & $1980 \mathrm{~s}$ & $1990 \mathrm{~s}$ & $2000 \mathrm{~s}$ \\
\hline Canada & 2.25 & -0.39 & 2.48 & 5.70 \\
Germany & 1.82 & 3.29 & 4.10 & -6.65 \\
UK & -1.10 & -4.03 & 2.66 & -6.34 \\
Japan & -7.17 & 2.80 & -5.06 & -0.25 \\
USA & -1.58 & -1.33 & 4.42 & 0.07 \\
\hline
\end{tabular}

Note: Average return on financial stocks minus that on non-financial stocks, annualized in \%.

Source: BIS (2010: 76).

The 20 per cent share in the total CIT collected in EU27 is much larger than the share of the sector in total employment, which is around 3 per cent and total value added, which was slightly above 5 per cent at the outset of the crisis (see Table 5.1). The high share in corporate taxes can, however, be explained by a profitability that was relatively high.

There is indeed some evidence that the financial sector has been more profitable than the non-financial sector in the 1990s and 2000s. ${ }^{5}$ The question arises as whether the high profitability of the sector could result in economic rents that could be captured either by managers in the form of higher remuneration or by shareholders in the form of higher returns. For example, the financial sector could be different from other sectors because of the perception of an implicit or explicit public protection.

Current available data are unfortunately scarce and patchy. Table 5.2 seems to indicate that return on equity in the financial sector has broadly been at par with that of the non-financial sector. However, these median values hide large variations across institutions, years, and countries. For example, the BIS (2010) reveals that German financial companies have posted higher return on their stocks than German non-financial companies since the 1970s up to the financial crisis, but the same cannot be said, for example, for UK companies except in the 1990s (see Table 5.3). ${ }^{6}$ Turning to remuneration, there is some piecemeal evidence that would suggest that remuneration in the financial

\footnotetext{
5 See, e.g., Devereux, Griffith, and Klemm (2004), who analyse the corporate tax revenue structure for the UK and find a higher profitability of the financial sector.

${ }^{6}$ Higher performance of stocks also partly reflects higher risk (measured by volatility).
} 
sector is or has been higher than in other sectors. Philippon and Reshef (2009) found that, starting in the 1990s, 30-50 per cent of the wage differential between the financial and non-financial sectors in the USA is due to rents.

In conclusion, it is not clear whether financial sector was under- or overtaxed under the CIT before the crisis.

\subsubsection{Value-added taxation}

If statutory provisions of corporate tax systems do not seem to differentiate between the financial sector and the non-financial activities in the EU, the same is not true for value-added taxation (VAT). Since the adoption of the Sixth VAT Directive in 1977, the EU's common value-added tax system has generally exempted mainstream financial services including insurances and investment funds. Article 135(1) of the VAT Directive provides a compulsory exemption from VAT for most financial and insurance services, but, at the same time, the Directive allows Member States to grant taxable persons the option of taxing financial services, to the extent that this is technically possible. Around twothirds of all financial services are margin based, which makes the implementation of the invoice-credit VAT system very difficult in this respect (Kerrigan 2010).

The question of whether applying VAT to the financial sector would raise additional tax revenues and-consequently-whether the exemption constitutes an under-taxation case for the financial sector is an unsettled empirical question. Indeed, the exemption means that, as the financial sector does not charge VAT on most of its output, it cannot deduct the VAT charged on its inputs. This is known as the 'irrecoverable VAT problem'. Based on case studies, PricewaterhouseCoopers (2006) found that VAT recovery rates in the financial sector varied from 0 per cent to 74 per cent. The variations in recovery rates could be explained by differences in the way in which the Member States interpret the scope of the exemption and the option to tax. ${ }^{7}$

The VAT exemption for the financial sector has the probable consequence that, assuming that some input VAT is irrecoverable and passed through into prices, the price of financial services for business users is higher than it would be under a VAT system with deductible output VAT, while the price of financial services for final (individual) users is lower than it would be if VAT were applied. For the latter, this also means that sales from the financial sector are under-taxed compared to sales from non-financial sectors. Finally, the exemption also

\footnotetext{
7 The data are not available at the sector level. The accounting practice for non-recoverable VAT is to subsume it in the general cost structure of an enterprise, and, no matter how significant the figures are, there is no practice or requirement that would give rise to their appearance in published reports. In comparison with income taxes, where reporting standards mandate detailed rules for the computation and disclosure of CIT liabilities, there are no equivalent obligations for VAT liabilities.
} 
distorts prices of exported financial services. Under a VAT system, exports are zero rated. Because of the irrecoverable VAT, assuming a similar costs structure, the exemption system possibly puts the export of services of the exempted financial sector at a competitive disadvantage compared to foreign competitors when the VAT rate that applies to input is higher than the one applied in the foreign country.

Two questions arise from this exemption. The first one is how the profits of the financial sector would compare under a VAT system and the current exemption. The second question is whether the exemption leads to VAT losses for tax authorities. Both are empirical questions. There have been a few attempts in the economic literature to quantify the VAT losses deriving from exemption for financial services, and most studies point to a net revenue loss (Genser and Winker 1997; Huizinga 2002; De la Feria and Lockwood 2009). This advantage is estimated to be around 0.15 per cent of GDP (Huizinga 2002), which for the EU27 translates into close to €20 billion.

In some countries, financial institutions are subject to specific tax measures designed to compensate for the VAT exemption. For example, New Zealand applies VAT to general insurance (but not to life insurance, creditor protection policies, and other financial intermediation services), Singapore taxes agency services, Australia includes financial agency services and non-life insurance and provides input credits for financial services, and Israel and Quebec apply the addition method (Poddar 2003). France and Denmark also apply compensation taxes that are close to the financial activities tax described further.

In conclusion, even though the CIT does not seem to tax the financial sector more lightly than other sectors, the VAT exemption of financial services might lead to a favourable tax treatment of the sector despite the fact that input VAT is not deductible for the sector.

\subsection{The financial activities tax}

Within its G20 report, which focuses on making the financial sector pay for public interventions, the IMF is proposing introducing a financial activities tax (FAT).

In its simplest form, a FAT is a tax targeted to the financial sector and whose base is the sum of profit and remunerations in the sector. One rationale behind this base is the fact that, should a rent occur, it will go either to shareholders in terms of higher profit (dividends or capital gains) or to workers (via higher remuneration). One additional feature of the FAT is that, in accounting terms, the sum of profit and remunerations represents the value added of the sector. With adequate design, a FAT could therefore mimic expost the value added that is difficult to assess on a transaction basis and could then be a proxy for VAT.

This is an open access version of the publication distributed under the terms of the Creative Commons Attribution-NonCommercialNoDerivs licence (http://creativecommons.org/licenses/by-nc-nd/3.0/), which permits non-commercial reproduction and distribution of the work, in any medium, provided the original work is not altered or transformed in any way, and that the work is properly cited. For commercial re-use, please contact academic.permissions@oup.com 
Besides compensating for VAT exemption and tackling possible rents in the sector, a FAT could also try to address two additional policy objectives. First, because it represents an additional burden on the sector, which could translate into prices of financial services, a FAT could decrease the size of the financial sector. Second, a FAT could try to reduce risk taking by targeting the profit generated by risky activities. This relies, however, on the assumption that risk is correlated with high return. In that case, taking the return to factors above their 'normal' level would achieve the objective.

\subsubsection{FAT alternative forms}

A FAT can take several possible forms, depending on how profit and remunerations are defined: the addition-method FAT, the rent-taxing FAT, and the risk-taxing FAT.

In the addition-method FAT, profit can be defined in two possible ways. It can first be defined in the same way as for CIT purpose. Profit is generally computed by taking income from sales and deducting several items: material costs, remunerations, provisions for various risks, interest paid (for most countries), depreciation, losses carried forward (or backward), and so on, and by including the net revenue from exceptional operations. Importantly, this definition of the tax base can include specific tax provisions that have the purpose of removing or alleviating the tax bias towards debt. This is, for example, the case of an allowance for corporate equity (ACE) or a comprehensive business income tax (CBIT). Many of these rules differ across countries. This is the case, for example, for tax provisions for depreciation and rules for carrying losses. Therefore, unless a common tax base for corporate taxation is chosen, such a definition will lead to differences across countries.

Such tax can be a source-based tax such as a conventional CIT with a (full or partial) exemption system for foreign-source income or can be a residencebased tax such as a conventional CIT with a (direct or indirect) foreign tax credit system. Both definitions of the base do tax the full return to equity. A source-based tax can also tax the full return to capital by disallowing interest deductibility. This is the case of a CBIT. Alternatively, it can tax rents only by allowing for the deductibility of a (notional or actual) amount for the remuneration of equity. This is the case of an ACE.

The profit part of the base can also be defined in cash-flow terms. Cash-flow taxes have been subject to a relatively rich amount of economic literature, starting with the recommendations of the Meade Committee (1978) in the UK. ${ }^{8}$ In its simplest definition, a cash-flow tax at the corporate level would tax

\footnotetext{
8 See, e.g., Grubert and Newlon (1997); Bond and Devereux (1995, 2003); Bradford (2000, 2004); OECD (2007b); or Auerbach and Devereux (2010).
} 
corporations on the difference between the sales of goods and services and the purchases of goods and services from other businesses and from employees. This makes two major differences compared to a classical CIT: (1) assets are immediately expensed rather than capitalized and depreciated; (2) sales and purchases are accounted for on a cash basis and not on an accrual basis (Bradford 1986). A cash-flow tax would include all real (R) transactions. Because of the nature of the activities of the financial sector, it shall also include all financial (F) transactions (for example, changes in financial reserves, interest paid or received, amounts borrowed or loaned). This is the so-called $(\mathrm{R}+\mathrm{F})$ base (that is, real plus financial). ${ }^{9}$ There are three main ways of designing an $(\mathrm{R}+\mathrm{F})$ cash-flow tax for the profit part (see Devereux and Sørensen 2006).

- A first option is to design a source-based cash-flow tax. This tax would be levied on the net cash-flow from domestic production. The base would, therefore, be the cash-flow from domestic and foreign sales minus the cash disbursements on purchasing domestic and imported inputs (including capital goods) and minus labour costs.

- A second option is to design a full destination-based cash-flow tax. This tax would be levied only on domestic sales (from domestic or foreign companies). The base would therefore be the cash-flow from domestic sales minus the cash disbursements on the inputs (material, capital, and labour) used for the production of the goods and services sold domestically.

- A third option is to design a VAT-type destination-based cash-flow tax. This tax would be levied on sales to domestic customers (from domestic and foreign companies). The base would be the cash-flow from domestic sales minus the cash disbursements from domestic purchases and minus labour costs. Also like VAT, export sales would not be taxed, but all imports would be. The base is equivalent to the VAT base minus labour costs. Although all types of addition-method FAT using a cash-flow definition of profit would come close to mimicking VAT, this option is the one that comes the closest to this objective.

Remuneration is defined in its broad sense. It includes wages and salaries, bonuses and other performance-related pay schemes, as well as non-financial advantages (for example, company cars, company phones, and so on).

The rent-taxing FAT aims at taxing the rents accruing to the financial sector while leaving untaxed the normal return to capital and labour factors. Such

\footnotetext{
9 Note that a positive (negative) net result implies a cash flow to (or from) stockholders. There is, therefore, an equivalence between the ' $\mathrm{R}+\mathrm{F}$ ' base and the ' $\mathrm{S}$ ' base, which consists of net payments to stockholders (dividends or sales and purchases of shares) (see Bradford 1986: $120 \mathrm{ff}$.).
} 
version of the FAT could be designed in the following way: for the profit part, the normal return to capital can be exempted by one of these two designs:

- using a definition of the base similar to the one used for the CIT and allowing for an ACE;

- using a definition of the base in terms of cash-flow. All three designs discussed above (residence based, full destination base, VAT-type destination based) would have the requested property. This is because any cash-flow tax allows for an immediate expense of investment. As a consequence, the present value of future cash-flows from a marginal investment equals the initial expense of the investment, and the marginal effective tax rate is zero. A cash-flow tax is, therefore, non-distortionary and falls only on pure rents.

As for the wage part, the normal return to labour can be exempted by providing an allowance for 'normal' remuneration. Such 'normal' remuneration per employee could, for instance, be defined as the average remuneration in other non-financial sectors, possibly correcting for the type of functions. This version of the FAT is the one that best achieves the objective of targeting rents in the sector.

The risk-taxing FAT takes into account an allowance that is supposed to take into account the risk premium that will be paid to factors of productions. It can be given to shareholders and/or to workers. In both cases, the base would be identical to the rent-taxing FAT, except for this additional allowance. This is the version of the FAT that could best achieve a reduction in excessive risk.

\subsubsection{The economics of FAT}

As it targets the sum of profit and remuneration of a financial institution, the FAT is not transaction based but relies instead on items of the financial statements of financial institutions. The FAT's effects on financial activities may take several aspects.

First, in terms of its effects on market structures and risk taking, the additionmethod FAT would not directly alter the market structures where financial institutions are active, since it taxes profits independently from how they are earned. In this sense, it does not discriminate between different products nor depend on the level of turnover. For all versions of the FAT, however, by making financial services more expensive, it would decrease the size of the financial sector. The rent-taxing FAT would not be distortive. If the financial sector earns economic rents and if the policy goal is to reduce those in order to correct for the potentially distorted size and behaviour of the financial sector, this tax offers a solution. The risk-taxing FAT attempts to tax excess return that is due to unduly risky activities. Such a tax would directly target the harmful 
effects of excessive risk taking. This would be done by applying a relatively high tax rate (so as to discourage risk) on returns above a defined level. This FAT therefore introduces some elements of progressivity. For capital, the interest rate on risk-free investments could be taken and increased by return on risk component. The latter is, of course, difficult to estimate. For wages, the average wages in other sectors could serve as a proxy. This would, however, not account for structural differences in sectors that might lead to different wage structures in addition to potentially untaxed rents. In addition, this FAT cannot distinguish between high returns that are due to unduly risky behaviour or to skills and efforts. This makes the threshold somewhat arbitrary.

Second, all versions of the FAT would be designed to be neutral vis-à-vis financing and investment decisions, and hence not to distort the activities of the financial sector while still reducing its size. This can be achieved by the application of either an ACE or a definition of profit based on cash-flow. Third, any version of the FAT could lead to differences in treatment between financial institutions subject to such a tax and quasi-financial institutions outside its scope. The implementation of a FAT should, therefore, cover as large as possible a range of financial institutions.

Fourth, all versions of the FAT can be seen as a tax on the profits from net transactions and other financial-sector business. This is an important difference compared to the FTT, which would tax gross transactions and have a cumulative effect. As such, the tax take is independent of the risk characteristics of the product traded and instead a function of the number of times the product is traded. Fifth, in the technical design of the risk- and rent-taxing FAT, important parameters deriving from 'normal' profit rates or wage levels would need to be determined, which illustrates the potential practical complexity of such taxes.

\subsubsection{Revenue estimates of FAT}

Turning to revenues, the potential of the FAT depends on the type of FAT that is chosen and, obviously, on the underlying assumptions. An appropriate estimation of revenues would require comprehensive firm-level data, as, with aggregate data, profits of some companies are compensated by losses of others, blurring the picture. In addition, the estimation of a VAT-type destination-based FAT would require data on the location of transactions. Using aggregate data and specific assumptions (for example, profits are defined as gross operating surplus and mixed income in the financial intermediation sector), the IMF reports that the tax base for the addition-method FAT varies from 2.5 per cent of GDP in Sweden to 8.4 per cent of GDP in Ireland and even 23.2 per cent of GDP in Luxembourg. The sample's GDP-weighted average is 4.14 per cent of GDP. For the rent-taxing FAT and the risk-taxing FAT, the GDP-weighted averages would be 1.78 per cent and 0.79 per cent per cent of GDP respectively.

This is an open access version of the publication distributed under the terms of the Creative Commons Attribution-NonCommercialNoDerivs licence (http://creativecommons.org/licenses/by-nc-nd/3.0/), which permits non-commercial reproduction and distribution of the work, in any medium, provided the original work is not altered or transformed in any way, and that the work is properly cited. For commercial re-use, please contact academic.permissions@oup.com 
Hence, applying a low FAT rate of 5 per cent and extrapolating the results from the sample of fifteen Member States collected by the IMF (2010c) - and representing 91 per cent of EU27 GDP-to the EU27 for the three methods provide broad orders of magnitude for tax revenues of respectively $€ 25.9$ billion, €11.1 billion, and $€ 4.9$ billion. Table 5.4 gives an overview of the country values.

For the twenty-two developed economies-representing about 62 per cent of world GDP-considered in the IMF report to the G20, a 5 per cent rate of the addition-method FAT would create revenue corresponding to an arithmetic average of 0.28 per cent of GDP (IMF 2010c). Using the country-level estimates for the share in GDP to calculate absolute figures, this would translate into total revenue for the twenty-two countries of roughly $€ 75$ billion for the addition-method FAT. The revenue for other FAT versions would be $€ 35$ billion for the rent-taxing FAT and €10 billion for the risk-taxing FAT.

In terms of their geographical distribution, the potential tax revenues would - by and large-mirror the share of Member States in the activities of the financial sector (which is more diversified than their share in trading places). Figure 5.1 presents the distribution for the addition method.

\subsubsection{Implementation}

Because it relies on items that are easily identified, a FAT is theoretically easy to introduce. The easiest version would be the addition-method FAT, as the other two versions require the determination of some normal or risk-adjusted return and wage payments. A FAT could potentially add to the existing incentives to shift profit via relocating profit or remuneration that derive from differences in current CIT and personal income tax (PIT) systems. The unilateral introduction of a FAT triggers relocation and competitive disadvantage risks, as in the case of the FTT, but, given the nature of the base and the need for financial companies generally to operate for their basic activities where consumers reside, the risk of relocation can be assumed to be lower than in the case of the FTT. Technical developments may, however, increase the mobility of the financial sector. For example, in the field of retail banking the development of Internet banking may provide opportunities for avoidance.

Another important issue is the inequality of treatment across sectors that a FAT would create. This issue may potentially conflict with legislation or general tax practices in some countries. On the other hand, a FAT could arguably also be seen as a tax surcharge that aims at correcting inequalities of treatment across sectors (for example, VAT exemption).

In principle, because it relies on existing items of the balance sheet, both the technical difficulties and the administrative costs of implementing and collecting the FAT could be limited. However, given the different accounting rules in Member States, a creation of a coherent framework might be difficult.

This is an open access version of the publication distributed under the terms of the Creative Commons Attribution-NonCommercialNoDerivs licence (http://creativecommons.org/licenses/by-nc-nd/3.0/), which permits non-commercial reproduction and distribution of the work, in any medium, provided the original work is not altered or transformed in any way, and that the work is properly cited. For commercial re-use, please contact academic.permissions@oup.com 
Table 5.4. Revenue estimates for the various forms of FAT (based on 2008 GDPs), tax rate $5 \%$

\begin{tabular}{|c|c|c|c|c|c|c|c|c|c|}
\hline \multirow{2}{*}{$\begin{array}{l}\text { Member } \\
\text { States }\end{array}$} & \multicolumn{3}{|c|}{ Addition method FAT } & \multicolumn{3}{|c|}{ Rent-taxing FAT } & \multicolumn{3}{|c|}{ Risk-taxing FAT } \\
\hline & $\begin{array}{l}\text { Tax base } \\
\text { (\% GDP) }\end{array}$ & $\begin{array}{l}\text { Tax } \\
\text { revenue } \\
(\% \text { GDP) }\end{array}$ & $\begin{array}{l}\text { Tax } \\
\text { revenue } \\
(€ \mathrm{mn})\end{array}$ & $\begin{array}{l}\text { Tax base } \\
(\% \text { GDP) }\end{array}$ & $\begin{array}{l}\text { Tax } \\
\text { revenue } \\
(\% \text { GDP) }\end{array}$ & $\begin{array}{l}\text { Tax revenue } \\
(€ \mathrm{mn})\end{array}$ & $\begin{array}{l}\text { Tax base } \\
\text { (\% GDP) }\end{array}$ & $\begin{array}{l}\text { Tax } \\
\text { revenue } \\
(\% \text { GDP) }\end{array}$ & $\begin{array}{l}\text { Tax revenue } \\
(€ \mathrm{mn})\end{array}$ \\
\hline $\mathrm{BE}$ & 4.2 & 0.2 & 724 & 1.8 & 0.1 & 310 & 1.5 & 0.1 & 259 \\
\hline BG & n.a. & n.a. & n.a. & n.a. & n.a. & n.a. & n.a. & n.a. & n.a. \\
\hline $\mathrm{CZ}$ & n.a. & n.a. & n.a. & n.a. & n.a. & n.a. & n.a. & n.a. & n.a. \\
\hline $\mathrm{DK}$ & 4.0 & 0.2 & 466 & 1.8 & 0.1 & 210 & 0.7 & 0.0 & 82 \\
\hline $\mathrm{DE}$ & 3.6 & 0.2 & 4,492 & 1.5 & 0.1 & 1,872 & 0.5 & 0.0 & 624 \\
\hline $\mathrm{EE}$ & n.a. & n.a. & n.a. & n.a. & n.a. & n.a. & n.a. & n.a. & n.a. \\
\hline IE & 8.4 & 0.4 & 764 & 5.7 & 0.3 & 518 & 1.8 & 0.1 & 164 \\
\hline $\mathrm{EL}$ & n.a. & n.a. & n.a. & n.a. & n.a. & n.a. & n.a. & n.a. & n.a. \\
\hline ES & 3.5 & 0.2 & 1,905 & 1.7 & 0.1 & 925 & 0.9 & 0.0 & 490 \\
\hline FR & 3.3 & 0.2 & 3,215 & 0.9 & 0.0 & 877 & 0.8 & 0.0 & 779 \\
\hline IT & 3.6 & 0.2 & 2,822 & 1.6 & 0.1 & 1,254 & 0.4 & 0.0 & 314 \\
\hline $\mathrm{CY}$ & n.a. & n.a. & n.a. & n.a. & n.a. & n.a. & n.a. & n.a. & n.a. \\
\hline LV & n.a. & n.a. & n.a. & n.a. & n.a. & n.a. & n.a. & n.a. & n.a. \\
\hline $\mathrm{LT}$ & n.a. & n.a. & n.a. & n.a. & n.a. & n.a. & n.a. & n.a. & n.a. \\
\hline $\mathrm{LU}$ & 23.2 & 1.2 & 456 & 15.3 & 0.8 & 301 & 5.7 & 0.3 & 112 \\
\hline $\mathrm{HU}$ & 3.6 & 0.2 & 190 & 2.0 & 0.1 & 106 & 0.9 & 0.0 & 47 \\
\hline MT & n.a. & n.a. & n.a. & n.a. & n.a. & n.a. & n.a. & n.a. & n.a. \\
\hline $\mathrm{NL}$ & 4.9 & 0.2 & 1,460 & 2.0 & 0.1 & 596 & 0.6 & 0.0 & 179 \\
\hline $\mathrm{OE}$ & 4.0 & 0.2 & 564 & 1.7 & 0.1 & 240 & 1.8 & 0.1 & 254 \\
\hline PL & n.a. & n.a. & n.a. & n.a. & n.a. & n.a. & n.a. & n.a. & n.a. \\
\hline PT & 4.8 & 0.2 & 413 & 2.6 & 0.1 & 223 & 0.5 & 0.0 & 43 \\
\hline RO & n.a. & n.a. & n.a. & n.a. & n.a. & n.a. & n.a. & n.a. & n.a. \\
\hline SI & n.a. & n.a. & n.a. & n.a. & n.a. & n.a. & n.a. & n.a. & n.a. \\
\hline SK & n.a. & n.a. & n.a. & n.a. & n.a. & n.a. & n.a. & n.a. & n.a. \\
\hline $\mathrm{FI}$ & 1.9 & 0.1 & 175 & 0.9 & 0.0 & 83 & 0.2 & 0.0 & 18 \\
\hline SE & 2.5 & 0.1 & 418 & 0.9 & 0.0 & 150 & 0.7 & 0.0 & 117 \\
\hline UK & 6.1 & 0.3 & 5,537 & 2.7 & 0.1 & 2,451 & 1.1 & 0.1 & 998 \\
\hline Sample & 4.14 & 0.21 & $23,600.9$ & 1.78 & 0.09 & $10,116,1$ & 0.79 & 0.04 & $4,479.4$ \\
\hline EU27 & & & $25,920.7$ & & & $11,110.5$ & & & $4,919.7$ \\
\hline
\end{tabular}

Note: The estimates assume no behavioural response. For the rent-taxing and the risk-taxing FAT, the IMF takes $40 \%$ of the wage differential between the top $25 \%$ earners in the financial secto and the top $25 \%$ earners in other sectors. This 'surplus' is $12 \%$ of wage costs. For the risk-taxing FAT, the benchmark for the return on average equity above which profit would be taxed is $15 \%$. See IMF (2010c) for other assumptions and details. Note that the IMF applies an R+F base by subtracting capital formation from profit. The EU27 figures are retrieved by taking the GDP-weighted average values of the sample for the tax base and applying them to EU27 GDP for 2008.

Sources: IMF (2010b) and own calculations.

This is an open access version of the publication distributed under the terms of the Creative Commons Attribution-NonCommercial-

NoDerivs licence (http://creativecommons.org/licenses/by-nc-nd/3.0/), which permits non-commercial reproduction and distribution of

the work, in any medium, provided the original work is not altered or transformed in any way, and that the work is properly cited. For

commercial re-use, please contact academic.permissions@oup.com 


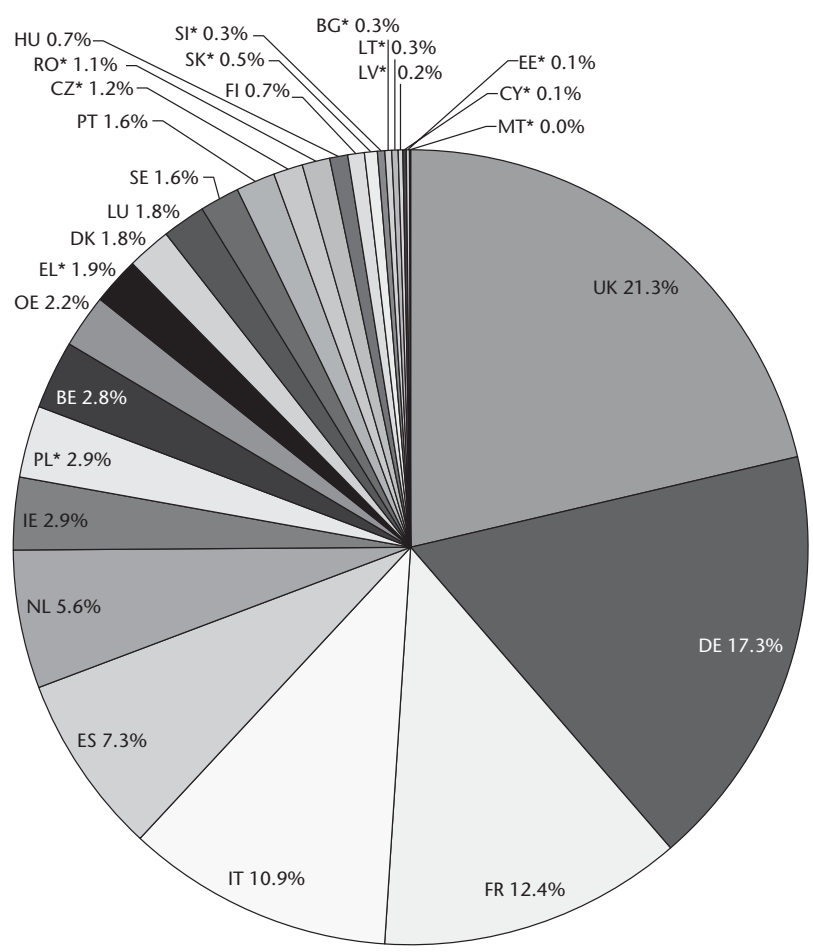

Figure 5.1. Share in tax revenue of EU Member States (addition-method FAT)

Note: Member States for which data are missing in Table 5.4 are assumed to raise tax revenues in percentage of GDP in the same proportion as the sample's GDP average. The sign $\left(^{*}\right)$ indicates the countries concerned.

Finally, in the context of the European Union, the compatibility with the VAT directive, in the light of the existing jurisprudence (e.g. Case C-475/03) would need to be verified, given that its base proxies value added. For the same reason, the FAT would require several adjustments to make it interact with the invoicecredit VAT. These adjustments, discussed by the IMF, include the absence of input VAT crediting against the FAT and vice versa, border adjustments in the case of the addition-method FAT, a mimicking of zero rating for operations with clients outside the EU, and, to mitigate the absence of crediting, a FAT rate that is lower than the standard VAT rate. These are non-trivial technical issues.

\subsubsection{Experiences with FATs}

In 1968, France introduced a payroll tax (taxe sur les salaires ${ }^{10}$ ), which is levied on employers who are not liable for VAT or who have not been liable for VAT on at

10 Covered by articles 231 to 231 bis R and 1679, 1679A, and 1679 bis of the General Tax Code.

This is an open access version of the publication distributed under the terms of the Creative Commons Attribution-NonCommercialNoDerivs licence (http://creativecommons.org/licenses/by-nc-nd/3.0/), which permits non-commercial reproduction and distribution of the work, in any medium, provided the original work is not altered or transformed in any way, and that the work is properly cited. For commercial re-use, please contact academic.permissions@oup.com 
least 90 per cent of their turnover during the previous year. These include bank and insurance companies. The tax base is defined as gross remunerations, prior to the deduction of the employee's national insurance contribution, including benefits in kind. The measure is therefore not a FAT per se, but the underlying concept is the same. For employers who are partly liable to VAT, the payroll tax is due in proportion of the exemption. Remunerations paid by public administrations are exempted as long as this does not create distortions in competition. Remunerations paid to apprentices are fully or partially exempted, depending on the number of employees. A limited number of remunerations are also exempted. These are paid mainly in the context of training of workers and incentives to hire unemployed. Businesses with a turnover that does not exceed a defined threshold (€80,000 for sales of goods and $€ 32,000$ for services) are also exempted. The tax rate is 4.25 per cent. It is increased to 8.5 per cent for individual annual pay between $€ 7,491$ and $€ 14,960$ and to 13.6 per cent for individual annual pay above $€ 14,960$. There is a reduced rate of 2.95 per cent for overseas territories. The tax is not due if its annual total amount is under $€ 840$. If the tax due is between $€ 840$ and $€ 1,680$, the tax is reduced by an amount representing three-quarters of the difference between $€ 1,680$ and the tax originally due. Non-profit associations are eligible to a tax credit of $€ 5,890$ per year. The payroll tax is deductible from the CIT or the personal income tax. In 2008, the annual tax revenues amounted to $€ 11.3$ billion. This is about 0.55 per cent of GDP (European Commission 2010g). About 85 per cent of this amount would be levied from financial institutions (IMF 2010).

In 1990, Denmark introduced a duty on wage and salary costs (Lønsumsafgift ${ }^{11}$ ) for businesses engaged in certain activities that are exempted from VAT. The tax base is generally the sum of labour costs and taxable profit. ${ }^{12}$ For several sectors, including financial activities, the tax base is defined as labour costs plus a supplement of 90 per cent. The general tax rate is 3.08 per cent. Specific rates apply to various sectors. For financial services, the rate is 5.08 per cent of labour costs plus an additional 4.5 per cent of 90 per cent of labour costs (that is, an effective rate of $9.13 \%\left(5.08+90 \% \%^{*} 4.5 \%\right)$ ). This rate will be increased to 10.5 per cent, but this measure will not be effective before 2013. In 2008, the annual revenues amounted to DKK4,668.7 million (that is, about $€ 650$ million) or 0.26 per cent of GDP (European Commission 2010g). About 70 per cent of this amount would be raised from the financial sector (IMF 2010).

Italy introduced in 1997 a regional tax on productive activities (Imposta Regionale sulle Attività Produttive $\left.(I R A P)^{13}\right)$. This regional tax is applied to

${ }^{11}$ Covered by the law on tax on labour costs (lov om afgift af lønsum mv.).

12 In case of losses, these are deducted from the labour costs. The system is, therefore, symmetric.

13 Covered by D. Lg. N446 of 15 December 1997 and L no. 244/2007. 
taxpayers engaged in commercial business. The tax base is the value of the net production, which is accounting profit plus most remuneration. Several exemptions apply for unit trusts, pension funds, European Economic Interest Groupings, and some small taxpayers. Deductions are allowed for contributions for labour insurances, expenses related to junior clerks, disabled persons, and R\&D. In addition, there is a $€ 1,850$ deduction for each employee (with a maximum of five) to enterprises with income below $€ 400,000$, and certain regions apply a €9,200 deduction for each employee. The base is allocated across regions based on the number of workers in each region. The basic rate is 3.90 per cent, and it can be increased by regions up to 1 percentage point. However, since 2008, the rates increased by regions must be multiplied by a coefficient of 0.9176 . In 2008, the annual tax revenues amounted to $€ 36$ billion or 2.3 per cent of GDP (European Commission 2010g).

\subsection{Financial transaction tax}

The 2008 crisis indeed showed that, possibly in part because of lax regulation, financial markets did not work properly in some areas. Since then the discussion on how to correct potential market imperfection has gained momentum, and the introduction of a financial transaction tax as a tool to stabilize financial markets and improve their functioning is one of the policy options being discussed. The FTT was debated at the G20 level ${ }^{14}$ and has received attention from the European Parliament, ${ }^{15}$ the European Council, and a number of Member States.

In the discussions on proposals for an FTT, it is argued that such tax could solve three problems at the same time:

- It could stabilize the financial markets especially in the derivatives market by increasing transaction costs. The proponents of an intervention argue that a low-rate tax (for example, 0.1 per cent) could improve the functioning of financial markets by reducing potentially harmful financial activities like short-term speculation and technical trading with a high amount of transactions per day. On the other hand, long-run investments would not be distorted by such a low tax rate because of their low frequency of transactions.

14 The IMF report on a fair and substantial contribution of the financial sector came to the conclusion that the tax should not be dismissed on the grounds of administrative problems.

${ }^{15}$ The European Parliament's Resolution of 10 Mar. 2010 asks the Commission and Council to look at how the tax could be used to finance development cooperation and help developing countries to combat climate change, as well as how the tax could contribute to the EU budget. In March 2011, the European Parliament passed a resolution calling for an FTT at global level and possibly at EU level if the latter failed to be implemented.

This is an open access version of the publication distributed under the terms of the Creative Commons Attribution-NonCommercialNoDerivs licence (http://creativecommons.org/licenses/by-nc-nd/3.0/), which permits non-commercial reproduction and distribution of the work, in any medium, provided the original work is not altered or transformed in any way, and that the work is properly cited. For commercial re-use, please contact academic.permissions@oup.com 
- It could raise substantial tax revenue, while creating only small distortions in the real economy. The administrative costs of collecting an FTT could also be very low compared to other taxes. ${ }^{16}$

- It could serve as a contribution of the financial sector to the financing of bailout costs caused by the financial crisis.

However, opponents argue that the FTT would not address the harmful effect of excessive risk taking seen in the run-up to the crisis, since it does not address-or only in an indirect way-the underlying market failures-for example, the misaligned incentives in the financial sector.

\subsubsection{The theoretical literature on FTT}

Financial transaction taxes have long been discussed, especially after economic downturns, starting with Keynes's reflections in 1936 on stock markets following the Great Depression. He argued that a 'substantial government transfer tax on all transactions might prove the most serviceable reform available with a view to mitigating the predominance of speculation over enterprise in the United States' (Keynes 1936: 160). The rationale for his statement was that firms would concentrate on short-term performance rather than long-run prospects because of speculation. On the other hand, Keynes also pointed out that, 'if individual purchases of investments were rendered illiquid, this might seriously impede new investment, so long as alternative ways in which to hold his savings are available to the individual. This is the dilemma' (Keynes 1936: 160). This illustrates admirably the debate that has taken place ever since about the role of trade volume and liquidity and its effects on price volatility and on the efficiency of financial markets.

The idea of an FTT is also linked to the proposal of James Tobin on an international uniform tax on all spot currency conversions. Tobin (1974, 1978) argued that the increased mobility of private financial capitalespecially after the end of the Bretton Woods system-might lead to excessive shifts of funds that create real economic costs for national governments and economies. Tobin reasoned that the tax would increase the effectiveness of domestic monetary policy. Eichengreen et al. (1995) argue that a transaction tax on currency exchange could create some scope for differences in national

16 Data from the UK show that the collection cost for the stamp duty is around 0.11 pence per pound collected, to be compared with 1.59 pence for income tax (Bond, Hawkins, and Klemm 2004). 
tax rates. This, in turn, would allow national monetary policy to react better to domestic macroeconomic needs. ${ }^{17}$ With the introduction of the euro, the discussion on speculation in currency markets became less important for Europe, since the single currency made such speculations impossible within the euro area. Currency crises in the 1990s in Russia and Asia led nevertheless to renewed discussions on the potential benefits of such a currency transaction tax. In this context, it was primarily seen as a penalty on short-term currency speculations. At the time, such tax became increasingly popular among non-governmental organizations, which saw it as a device for raising revenue to finance development aids or similar projects while at the same time reducing the size and improving the performance of financial markets. The idea of such a 'double dividend' can still be found in current discussions.

While Keynes (1936) focused on stock markets and Tobin $(1974,1978)$ on currency transactions, the idea of a general and uniform financial transaction tax is to levy a tax on a wider range of financial transactions. The idea of a more general securities transaction tax was put forward by Stiglitz (1989) and Summers and Summers (1989) after the October 1987 stock-market crash. They argued that noise traders drive stock prices away from fundamentals, which might lead to higher volatility and price bubbles. Similar to the proponents of the currency transaction tax, they argued that higher transaction costs would reduce the amount of speculative trading and in turn give more room to trading based on fundamental economic data. Stiglitz (1989) argues that the private return of gathering information in order to respond more quickly to market changes is higher than the social return of this activity. ${ }^{18}$ Levying a tax on these activities would improve economic efficiency of the market by reducing the incentives for this sort of rent seeking. ${ }^{19}$

However, subsequent theoretical literature gave a mixed picture of the potential effects of financial transaction taxes. Dooley (1996) argues that the

17 Garber and Taylor (1995) present a sceptical note on this argument.

18 The empirical analysis of some of these trading forms, notably high-frequency trading in currency markets, has so far not shown strong detrimental as such. Chaboud, Chiquoine, Hjalmarsson, and Vega (2009) analyse the effect on FX markets and find rather positive effects. Nevertheless, there are also concerns raised, for example, by the European Central Bank (ECB) that this high-frequency trading could create negative effects ('ECB Warns of High-Speed Trading Risks', Financial Times, 24 Feb. 2011). In a reply to public consultation of the European Commission, the ECB stated: 'In the last few years, automated trading, and in particular High-Frequency Trading (HFT), has experienced strong growth. Such a development may trigger a number of risks for orderly trading and for financial stability' (see < http://www.ecb.int/pub/pdf/other/ecpublicconsultationreviewmifideurosystemcontribution201102en. pdf $>$ for the full text).

19 When discussing the potential side effects of such a tax, he assumes that price volatility in the financial market is not increased but instead decreased. This is a critical assumption. As shown below, the question of how volatility is influenced by such a tax is central to its evaluation.

This is an open access version of the publication distributed under the terms of the Creative Commons Attribution-NonCommercialNoDerivs licence (http://creativecommons.org/licenses/by-nc-nd/3.0/), which permits non-commercial reproduction and distribution of the work, in any medium, provided the original work is not altered or transformed in any way, and that the work is properly cited. For commercial re-use, please contact academic.permissions@oup.com 
assumption that the tax falls differentially on different types of investors is invalid, and it is not clear that investors who base their decisions on fundamentals have longer holding periods than pure speculators. Mixed results can be found in Subrahmanyam (1998), who finds that transaction taxes do indeed reduce market liquidity but also reduce rent-seeking behaviour for obtaining private information-an element also pointed out by Stiglitz (1989). Schwert and Seguin (1993) surveyed the arguments for and against transaction taxes. They conclude that there is little evidence that the potential beneficial effects of a transaction tax outweigh the potential costs that are due to tax avoidance and unclear tax incidence.

\subsubsection{The empirical literature on FTT}

Theoretical studies have not led to conclusive results mainly because results usually depend on the authors' assumption about the functioning of the market. It is, therefore, interesting to check whether empirical evidence gives a clearer picture. At first glance, the various empirical studies leave the reader with the impression that the empirical relationship between an increase in transaction costs (via either taxes or other means) and market functioning is equally inconclusive. Since the 1990s, a number of empirical studies have been conducted to measure the effect of changes in transaction costs, and many of them lead to opposite results. However, a closer look at these studies shows that the quality of the data and the estimation techniques differ substantially. Many papers based on time series face problems in identifying increases in transaction costs and in disentangling those from other potential effects on trade volume and volatility (Umlauf 1993; Saporta and Kan 1997).

More recent papers have improved this by using panel data and an estimations technique that allow market-wide volatility to be separated from volatility caused by transaction-cost changes. Hau (2006) shows that transaction costs increase volatility using panel data from the Paris Stock Exchange. The effect of stamp duties on prices was analysed for the UK by Bond et al. (2005). The paper uses a natural-experiment approach, which allows them to use fixed effects in their estimations in order to capture otherwise unobservable effects and identify the change of transaction costs. ${ }^{20}$ A similar approach with difference-in-differences estimation was taken by Jones and Seguin (1997) for data on the reduction of commission fees at the

\footnotetext{
${ }^{20}$ Natural experiments were first used in labour economics in the 1970s. The concept was later applied to tax reforms in order to isolate tax effects from other influences on economic decisions. The idea of this approach is that reforms often generate two groups of individuals: a 'control group', which is not affected by the tax change, and a 'treatment group', which faces different taxation after a reform. By comparing the behavioural differences of the two groups after a reform, one can measure the influence of the tax change.
} 
New York stock exchange. Since this reduction was not the same for all markets, they could set up a treatment and a control group to estimate the effects. Their results reject the hypothesis that a decrease of transaction costs increases volatility. ${ }^{21}$

Two other recent papers using time series show that results can indeed be conflicting. Baltagi et al. (2006) use data from stock exchanges in China and show that stamp tax rate increases from 0.3 per cent to 0.5 per cent led to a trading volume decrease by a third. This translates into an elasticity of turnover with respect to a stamp tax of -0.5 . They also find that volatility increases significantly. On the other hand, Liu and Zhu (2009) find that the relationship between transaction costs and price volatility is negative in Japan, a result in line with the argumentations of Stiglitz (1989) and Summers and Summers (1989). The authors cannot use the estimation approach of Jones and Seguin (1997), since the reduction of transaction was for the whole Japanese market. They therefore have to create what they call 'second-best control portfolios' in order to identify the cost effect. Their results are contradicted by Hayashida and Ono (2011), who study the impact of the repeal of the Japanese stock transaction tax in 1999 and the decrease in the capital gains tax in 2003. In both cases, the tax reform led to a decrease in volatility.

More recent research based on experimental economics as well as some theoretical work points to the fact that the effects of such a tax depend on the market structure. ${ }^{22}$ For the European discussion and further research on this topic, it is necessary to evaluate the market structure in the different financial centres in Europe. If this structure is heterogeneous, the tax might affect the markets in question very differently. The empirical literature comes thus to different results when evaluating the effects of transaction taxes. While most studies find that trade volume is reduced, the effects on volatility and prices is less clear, even though results based on panel data and estimation approaches that better identify transaction-cost effects more often seem to find a positive relationship between transactions costs and volatility. For the discussion of the financial transaction tax in Europe, one should keep in mind the importance of analysing the structure and functioning of the single national financial markets. The effects of the tax might be varying, depending on the products traded and the way dealers and brokers interact in the market.

\footnotetext{
21 Note that proponents of the tax usually argue that studies that concentrate on short-term volatility are irrelevant, since the medium-term volatility is the relevant variable that is driven by technical traders. The problem, however, is that it is not clear whether or not the influence of technical trading on this medium-term volatility is also driven by the business cycle and other factors that drive prices. Therefore concentrating on short-term volatility is probably the best proxy available for econometric analysis. There is also no theoretical model that could explain why shortterm trading is indeed increasing medium-term volatility.

22 See Hanke et al. (2007) and Pelizzari and Westerhoff (2007).
} 
To summarize, the evaluation of an FTT depends largely on the underlying assumptions about the functioning of the financial market and whether the potential market failure can be corrected using a transaction tax. In general, the proponents of the tax argue that the tax would reduce the number of noise traders and consequently of technical trading. Furthermore, the tax would decrease price volatility and unproductive short-term speculation, since investors would concentrate on the long-run return of projects. Last but not least, the proponents argue that the tax would lead to substantial tax revenue. The opponents of the tax argue that it would increase transaction costs. This increase in transaction costs would reduce liquidity of markets and therefore market efficiency. It would decrease stock prices and increase the cost of capital companies, leading to less investment. They also argue that such a tax would shift transactions away to other markets in countries that do not apply an FTT.

\subsubsection{Revenue estimates of FTT}

The broad-base variant of the FTT would tax stocks, bonds, and derivatives transactions carried on exchange places as well as over the counter (OTC) ${ }^{23}$ For stocks and bonds, the spot value of the transaction constitutes the tax base, while for derivatives the notional (or underlying) value of the contract is taken. ${ }^{24}$ This variant has a very broad tax base because of the inclusion of derivatives. In general, the tax base is defined as the total value of the transaction. This is the case for spot transactions such as stocks, bonds, and currency exchanges. For derivatives, the determination of the transaction value is more complex. In principle, one could argue that the value of the notional value could be the tax base. Given the high leverage of some derivatives, this would create a very large tax base, and the tax payment would be large compared to the actual price paid for the contract. While taxing these instruments could potentially reduce companies' leverage, it would also increase the costs for

\footnotetext{
23 The OTC transactions include derivative transaction as well as foreign-exchange spot transactions.

24 The notional value of the asset is defined as the value of a derivative's underlying assets at the spot price. In the case of options or futures contracts, this is the number of units of the asset underlying the contract, multiplied by the spot price of the asset. The notional value is used to take into account the (sometimes substantial) leverage of financial instruments, like derivatives. The use of the notional value could, however, lead to substantial problems. Since the real cash flows connected to the purchase of the derivative are much smaller than its notional value, the tax burden differs significantly across derivative products. In cases where margins are very small, the actual tax rate might be much higher than the above-mentioned rates. This leads to the problem that the real burden of the tax is very high, changing between products and increasing the cost of hedging activity for companies.
} 
companies that hedge risk. It might also lead to double taxation if the underlying is traded (and taxed) at the spot market when the option is executed. Instead of taxing the notional value, an alternative could be to tax only the actual premium. ${ }^{25}$ However, this would reduce the tax base significantly. The narrow-base variant is based on the conservative assumption that only bonds and stock transactions would be taxed.

For the broad-base FTT, Schulmeister et al. (2008) estimated the potential revenue of a general FTT for 2006 and found that, at a rate of 0.1 per cent, the tax could raise between $\$ 177$ billion (about $€ 145$ billion) and $\$ 467$ billion (about $€ 370$ billion) in Europe, depending on the assumptions of the decrease in trading volume. ${ }^{26}$ The lion's share of these substantial amounts (between 80 per cent and 90 per cent of the revenue, depending on the assumptions about the reduction of transactions) would be collected from taxing derivatives on organized exchanges or on over-the-counter (OTC) markets. These estimates suffer, however, from several uncertainties. First, it is unclear whether some of the categories used are based on flows or on outstanding amounts (that is, stocks). In this latter case, the real flows can be a fraction of the stocks, if, for example, a derivative contract runs over several periods. In fact, many swaps can extend to fifty years, and are counted in full for each year in the inventory data. Second, the data used display the gross amounts of derivative contracts. Many of these contracts cancel out economically, since market participants close open positions with new contracts. Hence, the estimates might underestimate the fact that many of these contracts could be netted off in case a tax is introduced. It is reported that, in some market segments, the netting is only a few percentage of the total. Third, they are based on the assumption that the notional value of the traded derivatives would constitute the tax base. The idea is to tax the leverage of the products. As discussed above, the economic case for using the underlying may not be well funded.

These estimates assume a strong decrease in turnover measured in notional amounts. However, there might be additional structural effects on markets, which could change the way these businesses are conducted significantly, leaving essentially no substantial tax base. These are very difficult to predict and should be kept in mind when assessing the revenue potential. Given these issues, Table 5.5, with the potential revenue for some EU countries, should be interpreted with caution.

25 This is possible for derivatives only where a premium is actually paid. This is not the case for all types of derivatives, notably interest rate swaps.

26 Note that Switzerland and Norway are included in this estimate.

This is an open access version of the publication distributed under the terms of the Creative Commons Attribution-NonCommercialNoDerivs licence (http://creativecommons.org/licenses/by-nc-nd/3.0/), which permits non-commercial reproduction and distribution of the work, in any medium, provided the original work is not altered or transformed in any way, and that the work is properly cited. For commercial re-use, please contact academic.permissions@oup.com 
Table 5.5. Estimated revenue from taxing shares, bonds, and derivatives (broad-base FTT) for countries where data were available, tax rate $0.1 \%, 2006$ (€bn)

\begin{tabular}{lccccccc}
\hline Country & BE & DE & FR & IT & OE & NL & UK \\
\hline Projected receipts & 3.3 & 35.5 & 15.0 & 5.1 & 1.6 & 5.1 & 162.8 \\
\hline
\end{tabular}

Source: Schulmeister et al. (2008).

Using the narrow-base version of the FTT, the tax revenue from spot transactions on exchanges would be between $\$ 72$ (about $€ 57$ ) billion and $\$ 80$ (about €64) billion or 0.15 per cent and 0.17 per cent of global GDP. Applied in the EU27 and Iceland exchanges, the tax revenue estimates are around $€ 18$ billion for 2008 (see Table 5.6).

For various reasons, these potential revenues might actually be in the high end of estimates. First, the reference years of 2006 and 2008 were years of high

Table 5.6. Estimated revenue from taxing shares and bonds (narrow-base FTT), EU27 and Iceland, tax rate $0.1 \%, 2008(€ \mathrm{mn})$

\begin{tabular}{|c|c|c|c|c|}
\hline Exchange & $\begin{array}{l}\text { Share } \\
\text { trading }\end{array}$ & $\begin{array}{l}\text { Bond } \\
\text { trading }\end{array}$ & $\begin{array}{l}\text { Revenue } \\
\text { shares }\end{array}$ & $\begin{array}{l}\text { Revenue } \\
\text { bonds }\end{array}$ \\
\hline Athens (EL) & 77,282 & 28 & 62 & 0 \\
\hline BME Spanish (ES) & $1,639,054$ & $4,650,178$ & 1,311 & 3,255 \\
\hline Borsa Italiana (IT) & $1,019,484$ & 175,458 & 816 & 123 \\
\hline Bratislava SE (SK) & 14 & 23,049 & 0 & 16 \\
\hline Bucharest SE (RO) & 1,601 & 46 & 1 & 0 \\
\hline Budapest SE (HU) & 20,877 & 1,613 & 17 & 1 \\
\hline Bulgarian SE (BG) & 1,261 & 125 & 1 & 0 \\
\hline Cyprus SE (CY) & 1,397 & 15 & 1 & 0 \\
\hline Deutsche Börse (DE) & $3,181,146$ & 123,943 & 2,545 & 87 \\
\hline Irish SE (IE) & 55,695 & 24,944 & 45 & 17 \\
\hline Ljubljana SE (SL) & 1,589 & 255 & 1 & 0 \\
\hline London SE (UK) & $4,264,020$ & $4,465,192$ & 3,411 & 3,126 \\
\hline Luxembourg SE (LU) & 1,299 & 57 & 1 & 0 \\
\hline Malta SE (MT) & 48 & 435 & 0 & 0 \\
\hline $\begin{array}{l}\text { NASDAQ OMX Nordic } \\
\text { Exchange } \\
\text { (DK, EE, FI, IS, LV, LT, SE) }\end{array}$ & 909,832 & $1,991,782$ & 728 & 1,394 \\
\hline $\begin{array}{l}\text { NYSE Euronext (BE, FR, } \\
\text { NL, PT) }\end{array}$ & $2,999,217$ & 33,099 & 2,399 & 23 \\
\hline Prague SE (CZ) & 29,880 & 22,685 & 24 & 16 \\
\hline Warsaw SE (PL) & 47,253 & 702 & 38 & 0 \\
\hline Wiener Börse (OE) & 71,177 & 800 & 57 & 1 \\
\hline Total & $14,322,128$ & $11,514,404$ & 10,025 & 8,060 \\
\hline
\end{tabular}

Note: The (simple) assumption made here is a reduction in trade volumes of only $30 \%$ for bonds and $20 \%$ for shares and a tax rate of $0.1 \%$. Note that some exchanges cover more than one country. The data do not provide a split to separate transactions between those countries that share exchanges.

Source: World Federation of Exchanges and own calculations. 


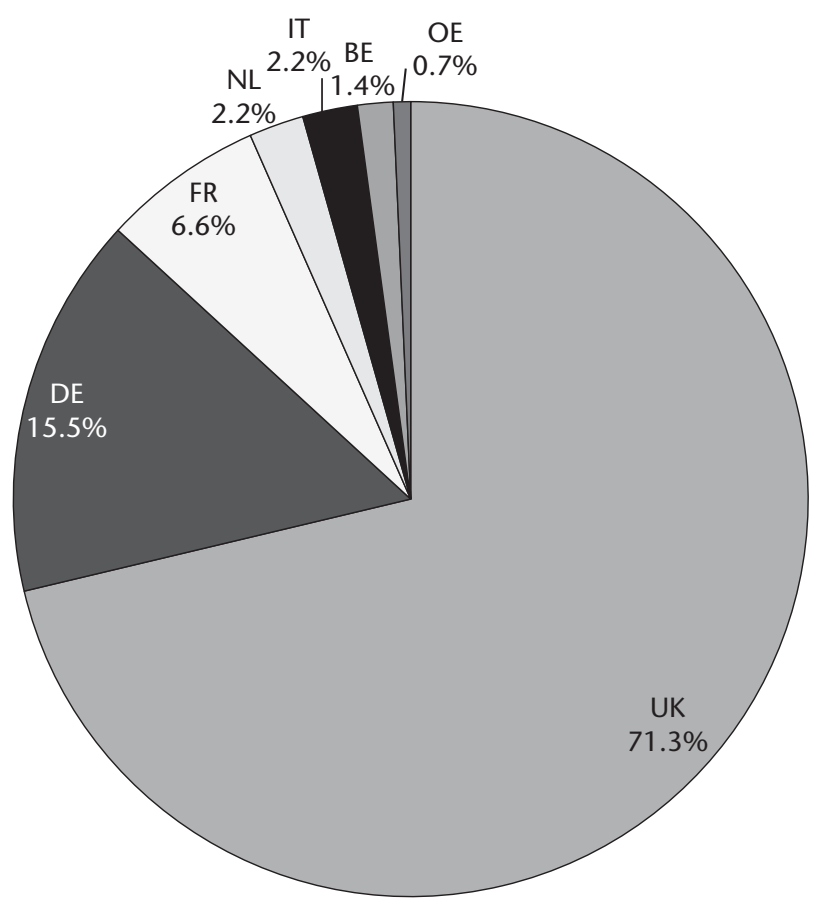

Figure 5.2. Share in tax revenue of selected EU Member States (broad-base FTT)

Source: Schulmeister et al. (2008). Note that data are not available for all Member States for these estimates. However, it is reasonable to assume that the revenue for most Member States not listed in the graph is marginal, since their financial sectors are in most cases relatively small compared to the countries included.

levels of trading, and exchanges could have fallen ever since. Second, these estimates may underestimate tax avoidance that is due to relocation and migration to non-taxed products. Third, it is not clear whether all transactions volumes used in the estimates can actually be taxed according to the assumptions. This is especially the case for the taxation of derivatives, which account for the largest part of the revenue estimates in the broad-base FTT. In conclusion, the revenue estimates have to be interpreted with caution and are there to provide order of magnitude. ${ }^{27}$

The potential tax revenues would be very uneven from a geographical point of view, because trading is currently concentrated in a few places (even more when derivatives are accounted for; see Figure 5.2). Nevertheless, in terms of incidence, the economic burden might be at least partly transferred to international investors (even though the tax would be collected in a few markets).

\footnotetext{
27 For a critical review of revenue collection from transaction taxes, see also Honohan and Yoder (2010).
}

This is an open access version of the publication distributed under the terms of the Creative Commons Attribution-NonCommercialNoDerivs licence (http://creativecommons.org/licenses/by-nc-nd/3.0/), which permits non-commercial reproduction and distribution of the work, in any medium, provided the original work is not altered or transformed in any way, and that the work is properly cited. For commercial re-use, please contact academic.permissions@oup.com 
Table 5.6 shows that, for the narrow-base FTT, most revenues are also collected in larger European exchanges such as the UK, Spain, and Germany. One might argue that, while all countries introduce the tax and carry some of its burden, the benefit of the tax in terms of revenue is located in only a few countries with large financial centres. However, the economic distortions in terms of reduction in trade volumes and risk of relocation of financial transactions due to the tax might also be strongest in countries with large financial centres. In conclusion, the uneven revenue collection might be of less importance if the tax is an effective device to improve market efficiency to the benefit of all investors, domestic and foreign. If the goal of the tax is to raise revenue, this would raise the question as to who should receive the revenues and whether or not an agreement to share revenues internationally should be envisaged, since otherwise benefits will be distributed unevenly.

\subsubsection{Experiences with transaction taxes}

The UK stamp duty on transfers of securities consists of two instruments: (1) a stamp duty charged on instruments of transfer and (2) a stamp duty reserve tax (SDRT) charged on underlying agreements to transfer securities where an instrument is not executed. The two duties go hand in hand. Stamp duties in the UK are collected on documents used to effect the sale and transfer of ownership in shares and other securities of UK-based companies. In order to collect duties on transactions carried out through electronic share-dealing systems, the stamp duty reserve tax (SDRT) was introduced in 1986. Stamp duties are levied on the underlying value of the transferred good at a standard rate of 0.5 per cent. The SDRT taxes transactions in shares where no instrument of transfer is executed and which are therefore outside the scope of the 'standard' stamp Duty. In this sense, it is a transaction tax, levied on agreements to transfer chargeable securities, while the 'standard' stamp duty is charged upon documents. SDRT accounts for the majority of revenue collected on share transactions effected through the UK's exchanges. Both SDRT and standard stamp duty are levied on share transactions in UK incorporated companies, taxed at 0.5 per cent of the purchase price of shares. It is charged whether the transaction takes place in the UK or overseas, and whether either party is resident of the UK or not. Securities issued by companies overseas are not taxed. This means that the tax is paid by foreign and UK-based investors who invest in UK incorporated companies. To put it differently, the tax is connected to the location of headquarters.

Revenues from duties on the transfer of stocks and shares have increased over the 2000s. After the economic downturn in 2001-2, revenue declined for

This is an open access version of the publication distributed under the terms of the Creative Commons Attribution-NonCommercialNoDerivs licence (http://creativecommons.org/licenses/by-nc-nd/3.0/), which permits non-commercial reproduction and distribution of the work, in any medium, provided the original work is not altered or transformed in any way, and that the work is properly cited. For commercial re-use, please contact academic.permissions@oup.com 
Table 5.7. Revenue from stamp duties on stocks and shares and other liable securities in the UK

\begin{tabular}{lrcccc}
\hline Year & $\begin{array}{c}\text { SDRT } \\
(€ \mathrm{mn})\end{array}$ & $\begin{array}{c}\text { Standard stamp } \\
\text { duty }(€ \mathrm{mn})\end{array}$ & $\begin{array}{l}\text { Stamp duties } \\
\text { total revenue } \\
(€ \mathrm{mn})\end{array}$ & $\begin{array}{c}\text { Over total tax } \\
\text { revenue }(\%)\end{array}$ & $\begin{array}{l}\text { Over } \\
\text { GDP (\%) }\end{array}$ \\
\hline $1995-6$ & n.a. & n.a. & 1,810 & 0.59 & 0.20 \\
$1996-7$ & n.a. & n.a. & 1,966 & 0.60 & 0.20 \\
$1997-8$ & n.a. & n.a. & 3,033 & 0.73 & 0.25 \\
$1998-9$ & n.a. & n.a. & 3,696 & 0.79 & 0.28 \\
$1999-2000$ & n.a. & n.a. & 5,617 & 1.10 & 0.40 \\
$2000-1$ & n.a. & n.a. & 7,383 & 0.77 & 0.46 \\
$2001-2$ & 4,218 & 367 & 4,586 & 0.69 & 0.28 \\
$2002-3$ & 3,669 & 455 & 4,124 & 0.65 & 0.24 \\
$2003-4$ & 3,280 & 418 & 3,698 & 0.77 & 0.23 \\
$2004-5$ & 3,454 & 548 & 4,001 & 0.77 & 0.28 \\
$2005-6$ & 4,105 & 961 & 5,067 & 0.82 & 0.28 \\
$2006-7$ & 4,767 & 745 & 5,511 & n.a. & 0.30 \\
$2007-8$ & 5,372 & 716 & 6,091 & & 0.22 \\
$2008-9$ & 3,673 & 349 & 4,022 & & \\
\hline
\end{tabular}

Source: HM Revenue and Customs and own calculations.

two years in a row, but from 2004-5 onwards revenue steadily increased, despite the fact that the tax rate remained unchanged at 0.5 per cent. There are three main reasons for this development. First, share prices increased significantly in recent years as a consequence of the economic boom. Second, volume of traded shares also increased, since the number of incorporated companies increased. Last, turnover also augmented, since shares have become important products for medium- and short-term investments. However, revenue declined also for this category in 2008-9 because of the financial crisis. This observation suggests that revenue from stamp duties is pro-cyclical. In fact, revenue from stamp duties on transfers of financial assets was more than 30 per cent lower in 2008-9 compared to 2007-8.

Table 5.7 shows the revenue data for both types in the first and second columns. $^{28}$ The third column shows the total revenue from the two sources. The peak is in 2000-1 just before the end of the Internet bubble. Columns 4 and 5 show tax revenues in relation to total tax revenues and GDP. The stamp duty was on average about 0.7 per cent of total tax revenue. In terms of GDP and total tax revenue, the highest values were reached during the boom years at the turn of the century, notably in 2000-1. For 2008-9 the value is back to the level of the mid-1990s, which is around 0.2 per cent of GDP. On average almost 90 per cent of revenues actually stem from the SDRT.

28 The split between the two levies is available only from 2001 onwards. Note that small differences between values single and sums occur because of rounding when converting revenues in sterling pound to euro.

This is an open access version of the publication distributed under the terms of the Creative Commons Attribution-NonCommercialNoDerivs licence (http://creativecommons.org/licenses/by-nc-nd/3.0/), which permits non-commercial reproduction and distribution of the work, in any medium, provided the original work is not altered or transformed in any way, and that the work is properly cited. For commercial re-use, please contact academic.permissions@oup.com 
Given the existence of the tax, one should observe that investors discount higher future transaction costs when trading shares. These costs should be capitalized in lower share prices. In fact, empirical studies show that the stamp duty influences the share prices negatively. More frequently traded shares are more affected than low-turnover shares. For firms that rely on equity as a marginal source of finance, this may increase capital costs. There are no estimates on the effects on trading volumes and price volatility of the stamp duties in the UK. Given results from empirical studies on the effect of transaction costs on trade volumes, it is likely that stamp duties reduce trade volumes significantly. Whether or not this increases price volatility is disputed, however, as recent studies tend to find a positive correlation between trade volumes and price volatility (see Section 5.4.2).

While it is possible to avoid stamp duty by executing and retaining the instrument outside the UK, in practice the need to register the change in ownership, combined with various restrictions on the use of unstamped instruments, means that most instruments of transfer are presented for stamping. The SDRT is difficult to avoid, because the vast majority of UK company shares are held in the CREST settlement system, which automatically debits SDRT when they are transferred. Nevertheless, two mechanisms can be used legally to avoid the SDRT: (1) the American depositary receipts (ADRs) and (2) the exchange traded fund (ETF). Many UK companies have ADR programmes that enable them to market themselves in the USA. Shares are issued to a US depositary bank, which issues ADRs. These receipts rather than the underlying shares are traded on the US markets. Such trading is exempted from the standard 0.5 per cent SDRT transfer charges, but, as compensation, there is a charge, paid only once at the rate of 1.5 per cent, when the shares are issued to the depositary bank. Placing shares into an ADR system is not regarded as avoidance. The second option is to use an overseas collective investment scheme that lists on a UK exchange (an ETF) and qualifies for exemption from SDRT provided that it is not centrally managed and controlled in the UK or has a UK share register. The exemption was introduced in 2007 to encourage overseas ETFs to list in the UK. However, owners of an ETF share do not legally own the shares in the fund. If investors want to have voting rights, the ETF cannot be used to avoid stamp duty.

The Swedish experience with FTT is often put forward by its opponents. ${ }^{29}$ In the 1980s Sweden experienced strong growth of the financial sector, which was accompanied by significant increases in the salaries of professionals in this sector. It was argued that the financial sector's contribution to the

29 The description of the Swedish experience is based on Umlauf (1993) and Campbell and Froot (1993). Sweden levied transaction taxes on stock-exchange and stock options, fixed interest securities, and the connected derivatives.

This is an open access version of the publication distributed under the terms of the Creative Commons Attribution-NonCommercialNoDerivs licence (http://creativecommons.org/licenses/by-nc-nd/3.0/), which permits non-commercial reproduction and distribution of the work, in any medium, provided the original work is not altered or transformed in any way, and that the work is properly cited. For commercial re-use, please contact academic.permissions@oup.com 
economy and the society was small compared to the resources it used. Furthermore, excessive financial transactions were seen as destabilizing the economy and as promoting disproportionate wage differentials between sectors. The latter point was politically of great importance. Despite the resistance of the Ministry of Finance, Sweden introduced a 50 basis points tax on the purchase or sale of equity securities in January 1984. A round trip transaction (purchase and sale) resulted therefore in a 100 basis points tax. The tax applied to all equity security trades in Sweden using local brokerage services as well as to stock options. The fact that only local brokerage services were taxed is seen in the literature as the main design problem of the Swedish system. Avoiding the tax only required using foreign broker services. In July 1986, the tax rate was increased to 100 basis points. In 1987, the tax base was extended, and half the normal rate was also applied to transactions between dealers. In January 1989, the tax base was widened again, and a tax on fixed-income securities was introduced. The tax rate was considerably lower than on equities, as low as 0.2 basis points for a security with a maturity of ninety days or less. On a bond with a maturity of five years or more, the tax was 3 basis points. Only fifteen months later, on 15 April 1990, the tax on fixed-income securities was abolished. In January 1991, the rates on the remaining taxes were cut by half, and by the end of the year they were also abolished completely.

There are various reasons for the abolishment of the tax. First of all, the revenues from the taxes were disappointing. The revenues from the tax on fixed-income securities were expected to amount to 1,500 million Swedish kroner per year, but the average was only around 50 million a year. Furthermore, since trading volumes fell, the capital gains tax became less and less applicable, and revenue declined. The increase in revenue from equity transaction taxes was almost entirely offset by this reduction in capital gains taxes. The net budget effect was accordingly close to zero. An additional reason for the decline in revenue from capital gains taxes was the decline in share prices that accompanied the introduction of the transaction tax. The day the tax was announced, share prices fell by 2.2 per cent. Taking into account possible trading based on insider information in the weeks before the official announcement, the price decline is estimated to have amounted to 5.35 per cent. These declines were in line with the net present value of tax payments on future trades. Investors discounted the future payments, and prices for equity decreased, driving up capital costs accordingly.

Next to the low revenue generated from the tax, relocation became a serious problem in Sweden. Sixty per cent of the trading volume of the eleven most actively traded Swedish share classes moved to the UK after the announcement in 1986 that the tax rate would double. Thirty per cent of all Swedish equity trading moved offshore. By 1990, more than 50 per cent of all Swedish trading had moved to London. Foreign investors reacted to the tax by moving 
their trading offshore, while domestic investors reacted by reducing the number of their equity trades.

Even though the tax on fixed-income securities was much lower than that on equities, the impact on the traded volume was much more dramatic. During the first week after the introduction of the tax, the volume of bond trading fell by 85 per cent, even though the tax rate on five-year bonds was only 3 basis points. The volume of futures trading fell by 98 per cent, and the options trading market disappeared. Trading in money market securities, which faced a tax as low as 0.2 basis points, fell by 20 per cent. This reaction was due in large part to the existence of a wide variety of non-taxed substitutes. Once the taxes had been eliminated, trading volumes returned and grew substantially in the 1990 s.

A prominent example of a transfer tax outside the EU is Switzerland. A transfer tax (Umsatzabgabe) is levied on the transfer of domestic or foreign securities where one of the parties is a Swiss security broker. Swiss brokers include banks and bank-linked financial institutions as defined by Swiss banking law. In addition, companies that own taxable securities of a book value in excess of CHF10 million qualify as security brokers. A broker who acts as a party to the transaction must pay one half of the transfer tax for himself and another half on behalf of each party who is not a broker. If the broker merely acts as an intermediary, he is required to pay only one half of the transfer tax on behalf of each party who is not a broker. If a Swiss security broker deals at a foreign stock exchange in securities that are subject to Swiss transfer tax, the part of the tax allocated to the other party to the transaction is not levied. The taxable base is equal to the consideration paid; if there is no consideration, the taxable base is the fair market value of the security. The duty is levied at a rate of 0.15 per cent for domestic securities and 0.3 per cent for foreign securities. Eurobonds, other bonds denominated in a foreign currency and the trading stock of professional security brokers are exempt. Certain types of transactions are also exempt. The revenue of the Swiss transfer tax was CHF1.9 billion in 2007. This corresponds to 0.37 per cent of GDP.

Another example of a country with transaction taxes outside the EU is Taiwan. The securities transaction tax (STT) is imposed upon gross sales price of securities transferred, and the tax rates are 0.3 per cent for share certificates issued by companies and 0.1 per cent for corporate bonds or any securities offered to the public that have been duly approved by the government. However, trading of corporate bonds and financial bonds issued by Taiwanese issuers or companies are temporarily exempt from STT, beginning 1 January 2010. The Taiwanese government argued that this 'would enliven the bond market and enhance the international competitiveness of Taiwan's

This is an open access version of the publication distributed under the terms of the Creative Commons Attribution-NonCommercialNoDerivs licence (http://creativecommons.org/licenses/by-nc-nd/3.0/), which permits non-commercial reproduction and distribution of the work, in any medium, provided the original work is not altered or transformed in any way, and that the work is properly cited. For commercial re-use, please contact academic.permissions@oup.com 
enterprises' ${ }^{30}$ The legal taxpayer is the seller of the securities, and tax is collected by the broker or sales agent or the transferee in cases of direct transactions.

Since 1998, Taiwan has also levied a stock index futures transaction tax on both parties to the transaction based on the contracted amount. The transaction tax is levied per transaction at a rate of not less than 0.01 per cent and not more than 0.06 per cent, based on the value of the futures contract. Revenue from the securities transaction tax and the futures transaction tax was about $€ 2.4$ billion in 2009. The major part of this revenue came from the taxation of bonds and stocks ( 96.5 per cent). The taxation of stock index future shares was 3.5 per cent. In total, this corresponds to 0.8 per cent in terms of GDP.

\subsubsection{Implementation}

A prerequisite for a global or a unilateral introduction at EU level is a relatively high degree of coordination of tax bases and rates. To reduce incentives for shifting to markets with lower tax rates and smaller product coverage, the coverage of financial products and the tax rates should be the same in all countries. There might also be a need to find agreements with financial centres outside Europe in order to reduce the migration of transactions. Although some third countries use such taxes, as illustrated in the previous section, the tax coverage is usually narrow and allows certain exemptions that might create possibilities for relocation.

The discussion of the Swedish experience with transaction taxes has shown that, if evasion and relocation are easy and cheap, market effects can be dramatic. In such a case, legal security could be a means to decrease the potential for relocation, as, for example, in the UK, which applies a stamp duty that covers only transactions in securities of UK-registered corporate companies and seems to be rather resistant to relocation (even though some studies indicate that 20 per cent of transactions have relocated, which is a large number per se). The risk for relocation might be mitigated for exchanges trading domestic stocks and bonds. It is less clear whether this would also be possible for foreign stocks and bonds traded domestically and derivatives. The increased use of registration duties could help to reduce this problem. Network externalities or agglomeration rents are often seen as reasons why relocation could be mitigated. The idea is that a very low tax rate would not lead to relocation, given the advantage from concentration in one marketplace. This argument has its merits, but it is difficult to evaluate in practical terms. The effect could be very diverse for different product classes. Furthermore, while in

\footnotetext{
${ }^{30}$ See <http://www.ey.gov.tw/ct.asp?xItem=65822\&ctNode=1334\&mp=11> for the press release.
} 
the short term agglomeration might be considered as an immobile asset of a region, this is not necessarily the case once new investment opportunities and market structures evolve. Another possibility to reduce relocation incentives would be the use of differentiated tax rates. Tax rates could vary for different markets and products according to their mobility, both geographical and cross products (a form of Ramsey taxation). This would decrease the potential relocation but would also reduce tax revenue and increase administrative costs. Also, it would be difficult in practice to determine the exact crosselasticities as to fine-tune the taxes. The differentiated tax rates might create distortions between the uses of various products. Finally, if the FTT is meant as a corrective device, differentiated tax rates set according to the mobility of financial products might undermine this function.

The administrative costs of collecting an FTT could be relatively low. Data from the UK show that the collection cost of the stamp duty is only 0.21 pence per pound collected. The main reason is that the vast majority of UK company shares are held in the CREST settlement system, which automatically debits the duty when shares are transferred. In contrast to that, for income tax, the value is 1.24 pence, and 0.76 pence for corporation tax. ${ }^{31}$ However, this levy is a pure securities transaction tax, and does not tax a wider range of nonsecurities transactions, such as lending or depositing, for which administrative costs might be higher.

Legal aspects have to be considered as well. In relation to the original proposal by Tobin for a currency transaction tax, likely legal obstacles need to be taken into account, regarding its compatibility with free movement of capital and payments between Member States and between Member States and third countries. These concerns might also apply to derivatives. Similarly, the compatibility of such a levy with Article XI of the General Agreement on Trade in Services (GATS), which provides that World Trade Organizatin (WTO) members cannot apply any restrictions on international transfer and payments for current transactions relating to their specific commitments, would have to be further assessed. ${ }^{32}$ The introduction of a tax on financial transactions might also require changes to Council Directive 2008/7/EC. ${ }^{33}$

31 See the Departmental Autumn Performance Report 2009 of HM Revenue and Customs $<$ http://www.official-documents.gov.uk/document/cm77/7774/7774.pdf $>$.

32 See also the innovative financing at a global level, Commission Staff Working Document, SEC (2010) 409 final (1 Apr. 2010), on this issue.

33 Council Directive 2008/7/EC of 12 Feb. 2008 concerning indirect taxes on the raising of capital, Official Journal L 46/11 of 21.02.2008.

This is an open access version of the publication distributed under the terms of the Creative Commons Attribution-NonCommercialNoDerivs licence (http://creativecommons.org/licenses/by-nc-nd/3.0/), which permits non-commercial reproduction and distribution of the work, in any medium, provided the original work is not altered or transformed in any way, and that the work is properly cited. For commercial re-use, please contact academic.permissions@oup.com 


\subsection{Conclusions}

The 2008 financial and economic crisis has left deep strains on public finances and has shed light on various excesses of the financial sector. These facts have raised the question of whether additional or increased taxes on the financial sector would be justified and advisable. This debate is particularly relevant in the context of the European Union, as the VAT Directive exempts the sector, arguably leading to its under-taxation.

Two specific taxes have attracted policy attention. The financial transaction tax, whose origins date from Tobin (1978), would tax financial transactions of various types on organized or over-the-counter markets. For its proponents, its attractiveness lies in both its alleged stabilizing effects and its high revenues potential. Both features are, however, uncertain, as several empirical studies show increased volatility following the introduction of financial transaction taxes, and revenues estimates are based on disputed assumptions and sources. A financial activity tax offers an interesting alternative. Besides interesting revenues potentials, the tax could be designed as a proxy for value added and is designed to target economic rents.

This is an open access version of the publication distributed under the terms of the Creative Commons Attribution-NonCommercialNoDerivs licence (http://creativecommons.org/licenses/by-nc-nd/3.0/), which permits non-commercial reproduction and distribution of the work, in any medium, provided the original work is not altered or transformed in any way, and that the work is properly cited. For commercial re-use, please contact academic.permissions@oup.com 


\title{
6
}

\section{Taxation and the Financial Sector}

\author{
Douglas A. Shackelford, Daniel N. Shaviro, and Joel Slemrod
}

\subsection{Introduction}

A looming global catastrophe-daunting problems in measuring the marginal social damage caused by significant economic activities-international cooperation undermined by divergent national interests-concerns that tax-based solutions will undermine economic growth-accusations of self-serving experts misrepresenting, or even doctoring, the evidence 1.1.1.

But enough about global warming. Although the topic of this chapter is the role of taxation in restructuring the financial sector, many of the same issues arise (with the possible exception of the last). Moreover, a long tradition of examining tax instruments for addressing pollution externalities, as a substitute for or supplement to regulation, can be brought to bear in assessing how taxation of the financial sector should respond to the dangerous spillover effects that, as the 2008 crisis made all too clear, can result from failure by particular firms. It is only since the first decade of the twenty-first century that academics and policy-makers have given serious attention to the possible role of tax instruments in the financial than the environmental realm, reflecting direct regulation's predominant role in addressing financial-sector issues. Indeed, the public economics literature's engagement with this sector, whether one looks for theoretical modelling or detailed empirical study, is startlingly sparse.

Tax policy has already reacted to the financial crisis in several disparate ways. A number of countries enacted stimulus packages that included tax cuts. In some countries, these were coupled with tax-rate increases, designed to address already-large fiscal imbalances that the financial crisis had only

This chapter was originally published as Shackelford et al. (2010).

This is an open access version of the publication distributed under the terms of the Creative Commons Attribution-NonCommercialNoDerivs licence (http://creativecommons.org/licenses/by-nc-nd/3.0/), which permits non-commercial reproduction and distribution of the work, in any medium, provided the original work is not altered or transformed in any way, and that the work is properly cited. For commercial re-use, please contact academic.permissions@oup.com 
made worse. ${ }^{1}$ The UK enacted a one-time 50 per cent tax on bankers' bonuses, rationalized partly on the ground that it would induce banks to build up capital rather than paying excessive compensation to insiders. There have also been a number of significant proposals. For example, in the US, the Obama administration proposed in 2010 a bank fee on non-depository liabilities in excess of $\$ 10$ billion, characterized as a way to help cover the direct fiscal cost of the Troubled Assets Relief Program (TARP) bailout. The Group of 20 Finance Ministers and Central Bank Governors (the G20) asked the International Monetary Fund (the IMF) to issue a report on 'the range of options countries have adopted or are considering as to how the financial sector could make a fair and substantial contribution toward paying for any burden associated with government interventions to repair the banking system'. ${ }^{2}$

In this chapter, we examine the role of taxation in the financial sector. We first look backwards, at the role of the tax system in bringing about the 2008 financial crisis, and at proposals to penalize institutions or individuals who may have contributed to the crisis. Then we look forward to the tax system's potential role in a restructured financial system. Here, going beyond the focus of the Obama administration and the G20 on simply paying for the specific cost of past or potential future bailouts, we examine what might be the features of an optimal Pigouvian corrective tax system that addresses market failures giving rise to externalities. Relatedly, we address the possible trade-offs between pure Pigouvian taxation and seeking revenue from the financial sector, such as to endow a resolution fund to be used in future crises. Along the way, we discuss the crucial differences between the well-studied case of pollution externalities and the much less-studied application of corrective externality taxation to the financial sector. We close by briefly examining several alternative tax proposals that have recently been enacted or proposed. An appendix to the chapter discusses an accounting legacy of the crisis that may affect financial firms' propensity to repeat the risk-seeking behaviour that gave rise to the crisis in the first place.

\subsection{Looking backwards}

\subsubsection{Did income-tax systems help cause the 2008 crisis?}

As Acharya and Richardson (2009: 195) note, 'there is almost universal agreement that the fundamental cause of the [2008 financial] crisis was a combination of a credit boom and a housing bubble'. During the boom-and-bubble

\footnotetext{
1 Hemmelgarn and Nicodeme (2010) list the EU27 countries' tax-cut and tax-increase measures.

2 Pittsburgh Summit (2009), item 16, 'Strengthening the International Financial Regulatory System'. See also an interim report at IMF (2010b).
} 
period, numerous financial firms placed huge, highly leveraged bets against a sector-wide decline in housing prices. ${ }^{3}$ This left them facing potential or actual insolvency when housing prices collapsed, with effects that were transmitted to the broader world economy by mechanisms that we discuss below.

In assessing why the boom and bubble occurred and why financial firms made such risky bets, most observers have agreed—-though with a few dissenting voices-that income-tax systems ${ }^{4}$ were not a major proximate cause (IMF 2009a; Shaviro 2009e; Slemrod 2009; Hemmelgarn and Nicodeme 2010; Lloyd in Chapter 8). Instead, more promising lead suspects include the following:

1. mortgage originators who had no stake in the borrowers' ability to pay;

2. borrowers who accepted easy credit, such as through back-loaded subprime mortgages that financed home purchases they could not afford;

3. opaquely structured securitization that neither sellers, buyers, nor rating agencies fully understood;

4. the rating agencies' eagerness to make money by offering AAA ratings to risky issuances by paying clients;

5. the existence of 'heads we win, tails you lose' incentive structures for financial firms and their managers;

6. capital-adequacy regulations that were riddled with loopholes that financial firms increasingly learned to exploit;

7. financial institutions' use of derivative financial instruments to ramp up and concentrate, rather than offload and diversify, their downside risk exposure; and

8. failed risk-management models that underweighted the possibility and impact of a national decline in US real estate prices.

The general consensus that taxation did not play a primary role in causing the crisis exists, even though, in many respects, 'the tax system's "fingerprints" [were] all over the "crime scene"' (Shaviro 2009e: 3). For example, in many countries, albeit in varying degrees, income-tax rules may have encouraged both excessive corporate leverage and highly leveraged homeownership. Income taxes may also have contributed to pervasive governance problems in publicly traded companies, and to the proliferation of non-transparent financial instruments that played a key role in prompting the crisis.

\footnotetext{
${ }^{3}$ As the federal civil case against Goldman Sachs highlights, others placed large bets on such a decline.

${ }^{4}$ We focus on income taxation, but note that financial institutions pose challenging problems for a value-added tax (VAT) as well, such that they invariably receive special treatment that is generally preferential and always non-neutral. Whether these distortions also pushed in the wrong direction, with respect to making a financial crisis more likely, has not been explored.
} 
A key reason for not discerning greater income-tax causation of the crisis is that these flaws have generally existed for decades, and the timing of the crisis cannot be linked to any notable expansion of them. Hence, there is not only no 'smoking gun', but little broader reason to believe that income taxation's causal role went beyond pushing in the wrong direction by generally exacerbating biases that existed in any event. This observation does not, however, rule out the possibility that the tax biases served, in effect, as extra gasoline intensifying the explosion once other causes had lit the match. For example, declining real estate prices would not have created such widespread mortgage default risk had not loan-to-value ratios been so high (often reflecting tax incentives for leverage).

Whether taxation's background role in intensifying the financial crisis was great or small, however, its already well-known flaws take on new importance if they affirmatively point in the wrong direction, rather than merely departing from the usual tax policy prescription of neutrality. Corporate debt bias, for example, though typically criticized for inducing increased bankruptcy costs or distorting firms' responses to asymmetric information problems (Shaviro 2009a: 92-4), may be worse than was previously thought if publicly traded firms would be prone to adopting excessive leverage, from a social standpoint, even in the absence of tax considerations. Moreover, the widespread bias in favour of owner-occupied housing (often with additional incentives for leverage) looks even worse from the perspective of 2010 and afterwards than it did before. Risk externalization may also have been effectively encouraged by an incoherent system of taxing capital income that creates tax arbitrage opportunities, often exacerbated by derivatives, while regulatory responses may have been undermined by tax regimes that draw strong distinctions between financial institutions that are classified either as banks, insurance companies, or dealers even when they perform overlapping functions (Kleinbard 2003).

As we discuss below, a number of potentially complicated and ambitious new taxes on the financial sector have been discussed. While the 2008 financial crisis shows how important it is to consider whether such instruments might help to improve incentives, reform efforts should not unduly focus on the exotic and new at the expense of the familiar and old. Addressing undesirable incentives within the existing income tax may be as or more important as creating new tax instruments.

\subsubsection{Should those responsible pay up?}

We turn now from the relatively abstract question of how structural aspects of countries' income-tax rules may have contributed to the financial crisis, to the very tangible and emotionally salient question of whether particular ongoing 
business enterprises, or even flesh-and-blood individuals, should be blamed and punished for what happened during the crisis or how they profited unduly in the run-up to the crisis. Sentiments of blame, retribution, or the assignment of responsibility for past harm are widespread in the political environment, and have been expressed by leaders and experts-not just, say, in the popular press.

Thus, President Obama, in announcing his administration's bank fee proposal, emphasized that his 'commitment is to recover every single dime the American people are owed', and said his 'determination to achieve this goal is only heightened when I see reports of massive profits and obscene bonuses at the very firms who owe their continued existence to the American people...' (Office of the Press Secretary 2010). Likewise, Columbia University's Jeffrey Sachs, in expressing his support for a financial transaction tax, told a UK audience that the so-called Robin Hood tax would properly burden a financial sector that was 'under-taxed', 'out of control', and enjoying huge profits at the expense of the general public. As things stood, he argued, 'bankers are brazenly smirking as they pocket large amounts of our money' (L. Elliott 2010).

A number of different motives may underlie seeking to punish (or at least to scale back the rewards enjoyed by) those who are considered responsible for the financial crisis. Retribution, or at least making wrongdoers pay for the harm they caused, may be considered good in itself. Or it may be thought to provide an instructive lesson that might help to restrain similar misbehaviour in the future. Finally, widespread public perceptions that banks and bankers have unduly guided and profited from recovery measuresreflecting that, as Illinois Senator Richard Durbin put it, they 'are still the most powerful lobby on Capitol Hill' and 'frankly own the place' (Yakabuski 2010)—can harm confidence in public institutions, acceptance of needed policies, and the political careers of incumbents. Addressing such perceptions is, therefore, potentially a high political priority, arguably for reasons both good and bad.

While some of these issues lie outside our areas of expertise, we offer three comments. First, for individuals whose actions, while working in the financial sector, may have helped cause the crisis, punishment for wrongdoing other than breaking specific laws that were in existence at the time is generally unlikely, given legal bars and social norms against ex post facto punishment. This lack of punishment is not entirely to be regretted, given how the political power to impose ex post facto punishment could potentially be misused.

Second, using nominally prospective taxes to punish wrongdoing institutions (or, rather, the people associated with such institutions) for past acts runs into two distinct types of difficulties under the theory of tax incidence. In illustration, suppose that a bank fee like that proposed by the Obama

This is an open access version of the publication distributed under the terms of the Creative Commons Attribution-NonCommercialNoDerivs licence (http://creativecommons.org/licenses/by-nc-nd/3.0/), which permits non-commercial reproduction and distribution of the work, in any medium, provided the original work is not altered or transformed in any way, and that the work is properly cited. For commercial re-use, please contact academic.permissions@oup.com 
administration, or a financial transaction tax like that proposed by Jeffrey Sachs, is enacted, not just to address market actors' incentives on a forwardlooking basis-although, as we will discuss below, this is an important rationale for both proposals-but also in response to banks' past wrongdoing. In either case, banks would have to remit money to the government that-all else being equal—would reduce their profitability, and thus the value of their shares.

Suppose initially that the banks actually bear this tax in the form of reduced profitability (until the banking sector shrinks), rather than being able to pass it on to transactional counter-parties such as their customers. This would adversely affect the value of the banks' shares, imposing a transition loss on their shareholders at the time when the tax was announced (or became more fully anticipated). These, however, may not be the same shareholders as those who benefited from the earlier run-up in stock prices that may have resulted from the banks' increasing their profits through socially reckless 'heads we win, tails you lose' bets or other misconduct.

Alternatively, some or the entire incidence of the new tax might fall on the banks' transactional counter-parties after it has taken effect. For example, depositors might face higher fees or lower interest returns, or customers of the banks' stock dealer businesses might face higher transaction costs. Even if this was appropriate in terms of properly aligning people's incentives, it would clearly have no retributive rationale. The precise nature of the tax will affect who ends up bearing its burden. For example, a tax levied only on large domestic financial institutions is more likely to be borne by these institutions' shareholders, as this set of institutions will be less likely successfully to recoup the tax liability by raising its prices, given that competitors (small domestic and foreign) do not face the same tax.

Third, a tax that, as a political matter, was most easily rationalized or sold on retributive grounds (especially given banks' political power) might independently prove to have desirable features from an efficiency standpoint. Properly aligning incentives is only one example of how this could happen. Purely backward-looking taxes are inherently non-distorting with regard to future decisions, ${ }^{5}$ other than to the extent that they influence perceptions of future policy-admittedly, an important potential consideration. Moreover, if it were to turn out that existing financial firms enjoy rents, a tax on those rents is in principle non-distorting (and would be borne by the firms' shareholders, though not necessarily those on hand when any earlier wrongdoing occurred).

\footnotetext{
5 Backward-looking taxes are, however, not the least distortionary way to raise revenue in comparison to an appropriately designed Pigouvian tax.
} 


\subsection{Looking forwards}

\subsubsection{Lessons of the financial crisis}

Whether or not income taxation played a significant role in causing or exacerbating the 2008 financial crisis, new tax instruments might conceivably be part of the regulatory response to lessons learned about how to reduce the chance of future crises. To evaluate this possibility, it is useful to begin by reviewing how the financial sector's economic and regulatory structure may have contributed to events.

As noted above, the financial crisis emerged as a consequence of numerous financial firms' potential or actual solvency when housing prices collapsed at the end of the boom-and-bubble period, leaving these firms with huge losses on their highly leveraged bets against such a decline. In the case of a different set of firms, this might have mattered only to their shareholders, creditors, and employees. However, because of the important role that financial firms play in the United States and world economy, the distress ended up being transmitted far more broadly. Accordingly, an enquiry into the possible tax-policy implications of lessons learned requires the examination of two distinct questions: why the firms made these risky bets (and conceivably might do so again), and why the systemic effects of their losses proved so large and widespread.

\subsubsection{Incentive problems in the financial sector}

Varying explanations have been offered for financial firms' so widely following 'nickels in front of a steamroller' strategies, under which one earns extranormal returns most of the time but occasionally experiences dramatic losses (Duarte et al. 2005). For example, some have blamed irrational exuberance and herd behaviour, arguably key components of asset price bubbles, as discussed, for example, by Shiller (2005). Whatever role such factors played, however, it is clear that key actors also had economic incentives to behave as they did.

With limited liability at the entity level, shareholders of financial firms could potentially benefit from placing risky bets on the real estate market under which they would capture profits on the upside but escape bearing losses on the downside. For example, AIG, by writing tens of billions of dollars' worth of insurance against mortgage defaults that would occur in large numbers if and only if housing prices steeply declined, 'guaranteed that the very problem being insured against-a systemic decline-would prevent the underwriters of the insurance from making good when the problem materialized' (Acharya and Richardson 2009: 206). This potentially created expected firmlevel profits even if the bets, analysed properly in the light of the tail risk, had a 
negative expected return. And this is true even without factoring in the chance of some kind of government bailout in the event of a steep housingmarket decline.

Making things worse, financial firms' managers frequently had economic incentives to follow the 'nickels in front of a steamroller' strategy, even if the expected return to shareholders was negative. Reflecting the widespread quest for 'alpha', the ability to generate extraordinary expected returns, and the rarity of true alpha, firms designed high-powered incentive compensation schemes that in practice rewarded the creation of 'fake alpha' -investments that earned apparently extraordinary returns in normal circumstances but that bore substantial tail risk (Rajan 2008).

Thus, in the period leading up to the financial crisis, 'bankers were increasingly paid through short-term cash bonuses based on volume and on markedto-market profits, rather than on the long-term profitability of their bets' (Acharya and Richardson 2009: 206-7). Managers could also anticipate not being held personally liable for the consequences of making bad decisions, so long as one could claim that they reflected a defensible business judgement. These incentives were evidently so compelling that, even as the housing market began to decline in mid-2006, many financial firms kept on placing multi-billion-dollar bets on the real estate market that generated millions of dollars in immediate bonuses for the managers who were placing them.

The incentive problems associated with limited liability and high-powered yet overly short-term and otherwise poorly designed executive compensation packages are not, of course, limited to the financial sector. However, three key factors appear to have made the social payoff here especially toxic. First, financial firms may have technological 'advantages' over others in placing huge, negative-return bets on which others bear much of the downside. Especially in the modern financial world with its wide range of multi-billiondollar, unregulated derivatives markets, and with the spread of techniques for evading regulatory oversight, such firms are well positioned to place huge bets, with only limited capital, that are difficult for others to observe, much less understand and evaluate.

Second, for reasons we discuss below, the downside of insolvency from the realization of tail risk was often not as bad for financial firms and their managers as in other sectors of the economy. Banks with federal deposit insurance, and other financial firms that had implicit insurance from the prospect of being bailed out, if necessary, such as on the ground that they were 'too big to fail', could take undue risks with the knowledge that, if they become insolvent, they might have their capital replenished and be allowed to continue operating.

Third, if proper incentives were fully in place, banks and other financial firms would probably be more cautious than other types of firms in accepting 
tail risk, not less. As we discuss next, their fundamental business model can make even the mere suspicion, among investors and other counter-parties, that they face insolvency risk potentially a self-fulfilling prophecy. This danger creates both firm-level and industry-wide sensitivity to risk that is not generally matched in other sectors of the economy. Since this is tied to their broader role in the economy, we discuss it further in the next section.

\subsubsection{Broader economic role of the financial sector}

When managers of publicly traded companies make costly errors, such as by placing risky bets that end up generating huge losses, it is always bad news for somebody. For example, a given firm's shareholders, creditors, employees, and customers may be adversely affected if managerial recklessness leads to insolvency. Often, though, the broader macroeconomic harm is limited. Moreover, many of the adversely affected parties may have some ability and incentive to protect themselves, thus further limiting the need for government intervention.

Financial firms are in some respects different, however, reflecting their broader economic role and the consequent harm that they can do even to people who are not in a contractual relationship with them. Ex post, this can lead to the compelling policy reasons for financial rescue that helped to motivate the massive government interventions of 2008 and 2009. It also greatly matters ex ante, however, because it is desirable to minimize the chance that neither costly bailouts nor the macroeconomic harm that they seek to contain will ever be realized.

Fundamentally, banks-and increasingly, other financial firms that are legally classified as dealers, traders, or insurance companies-supply the liquidity that both consumers and businesses need, by providing payment systems that are generally needed for non-cash transactions to occur. They do so by intermediating between two distinct groups with mismatched preferences (D. J. Elliott 2010b). The first consists of investors with savings that they want to invest in a safe and highly liquid manner, permitting them to withdraw cash whenever they like. The second consists of businesses that want to use this pool of savings to fund investment projects that may be riskier and are more long term, requiring a relatively illiquid commitment of funds.

Without the intermediating function, 'depositors would have to accept the near-zero or even negative return that [otherwise] would be available' (D. J. Elliott 2010b: 2). Business investors, meanwhile, would face relative capital scarcity and have to pay much higher interest rates 'if the only funding sources were pension plans and others with truly long-term investment horizons' (D. J. Elliott 2010b: 2). But, at least in the short run, banks' role in supplying payment systems is potentially even more important. A wide range

\section{6}

This is an open access version of the publication distributed under the terms of the Creative Commons Attribution-NonCommercialNoDerivs licence (http://creativecommons.org/licenses/by-nc-nd/3.0/), which permits non-commercial reproduction and distribution of the work, in any medium, provided the original work is not altered or transformed in any way, and that the work is properly cited. For commercial re-use, please contact academic.permissions@oup.com 
of ordinary business and consumer transactions rely on these systems, and potentially will not take place if they are disrupted.

To perform their intermediating role between depositors and business investors, financial firms must be able to meet the depositors' ongoing cash demands, despite having loaned funds that therefore are not readily available in the short term (and may require fire sales to access). Keeping a reasonable amount of capital on hand helps, and can ensure that, under normal conditions, both random and specifically predictable variations in investors' daily cash withdrawal demands will pose no problem for a given financial firm. Even the best-managed bank in the world, however, makes promises of immediate cash access to its investors that it simply cannot keep if too many of them act on these promises at the same time.

This phenomenon is known, of course, as a run on the bank. While it should never happen to any well-managed bank with adequate capital in hand under ordinary circumstances, it can happen to any bank, anywhere and at any time, if something triggers a sudden flood of investor withdrawal requests. For example, a run may result from the spread of concern among investors that a given bank has lost money on its investments and might face long-term insolvency even when it is able to realize the cash value of its investments. What is more, an investor need not believe that the bank is long-term insolvent in order to have reason for demanding immediate liquidity. All she needs to believe is that enough other investors will believe it is potentially insolvent-or, like her, will anticipate others believing this (or believing that it will be believed). ${ }^{6}$ An externality among investors-the race to the bank that triggers the run on the bank-thereby potentially triggers the broader external harm from disappearing liquidity to a national or world economy.

Against this background, two seemingly contradictory facts about the risk of bank runs (or the need for similarly disruptive fire sales) hold simultaneously. First, there is no surer way to trigger a bank run than by generating large losses that become publicly known - such as by reason of having made huge and risky bets involving tail risk that is realized when an asset bubble collapses. Second, even a sound and well-managed firm may be subject to a bank run, while even one that is unsound-if it can conceal its losses and keep on bringing in new investors-may indefinitely postpone the day of reckoning.

6 The potential for infinite regress brings to mind Keynes's famous comment about the stock market as a beauty contest in which one is rewarded for predicting whom others will pick as the most beautiful, leading to a situation 'where we devote our intelligences to anticipating what average opinion expects the average opinion to be' (Keynes 1936: 156). The run-on-the-bank reverse beauty contest looks for anticipation of failure, rather than success, and is only an exceptional, rather than a regular, phenomenon given that it has no effect on investment returns under ordinary circumstances.

This is an open access version of the publication distributed under the terms of the Creative Commons Attribution-NonCommercialNoDerivs licence (http://creativecommons.org/licenses/by-nc-nd/3.0/), which permits non-commercial reproduction and distribution of the work, in any medium, provided the original work is not altered or transformed in any way, and that the work is properly cited. For commercial re-use, please contact academic.permissions@oup.com 
Bernard L. Madoff Investment Securities LLC might be (seemingly) flourishing to this day if the financial crisis had not triggered cash demands from its investors that exceeded its on-hand liquid capital.

To clarify thinking about this, suppose initially that there were just one financial firm, with transparent finances, supplying liquidity for the entire world economy. If this firm failed, the resulting economic harm would go beyond the specific cash loss to creditors (such as depositors) to include the lost surplus from transactions that depended on the liquidity it had been supplying - potentially leading to the vast welfare loss associated with a global recession or depression. Given the assumed transparency, a bank run would be triggered as soon as the firm incurred losses—or perhaps even risked incurring them-but otherwise would probably require some other sort of extraordinary triggering event (for example, a currency crisis).

Add non-transparent company finances and a multiplicity of financial firms, and the problem gets a lot more difficult. Now beliefs about firm solvency that could trigger a bank run are potentially more volatile, and new information about one firm may affect beliefs about others. For example, if one firm's losses come to light, investors may conclude-with considerable reason, though it would not matter even if they were wrong-that others are likely to have suffered losses as well, whether from following similar strategies or from counter-party risk in their transactional interrelationships.

In short, there is substantial potential for inter-firm contagion. However, the determinants of such contagion (both who spreads it and who contracts it) are complex and multifaceted. Relevant factors may include firm liquidity, actual and apparent solvency and riskiness, the complexity or opacity of a given firm's financial positions, its size or market share, its interconnectedness with other firms, and beliefs about its managers (including about their acumen, honesty, and political clout).

Explicit deposit insurance, and softer expectations that important (such as 'too big to fail') financial firms will be rescued out if necessary, help to reduce bank runs and the associated harms, but do so in exchange for worsening the firms' investment incentives by making losses less painful to the managers and shareholders. The prospect of rescue conditioned on the risk of major economic distress may also cause firms actually to prefer large prospective calamities to small ones. As Weder di Mauro (2010) points out, 'a driver does not have an incentive to be involved in a big accident [rather than a small one], a financial institution does'.

Even where these government backups are operating, however, substantial harm beyond the bailout cost may result when financial firms suffer losses, both from interim uncertainty about the scope of coverage and delay in restoring lost liquidity. If, at the same time, perceived wealth and therefore consumer demand are independently plunging, because of the collapse of the

This is an open access version of the publication distributed under the terms of the Creative Commons Attribution-NonCommercialNoDerivs licence (http://creativecommons.org/licenses/by-nc-nd/3.0/), which permits non-commercial reproduction and distribution of the work, in any medium, provided the original work is not altered or transformed in any way, and that the work is properly cited. For commercial re-use, please contact academic.permissions@oup.com 
same asset bubbles that triggered the financial firms' losses, the liquidity shock may end up doing even greater harm than it would have done otherwisealthough it may also end up being mistakenly over-blamed for the jointly caused macroeconomic harm.

\subsubsection{Optimal government response to financial firm externalities: available tools and the role of taxation}

As we saw above, excessive and unwise risk taking by financial firms triggered large losses that had huge negative externalities that extended not only to the federal government's bailout costs, but to the massive social costs of triggering or worsening a global recession. Financial firms that were crippled by the realization of tail risk imposed these costs on society not just directly but through a process of contagion that undermined the financial sector generally. Looking forward, one would like to prevent current and future financial firms and their managers from similarly imposing harm on the rest of society.

The good news is that we have sharp theoretical tools for analysing the optimal social response to externalities, deployed most prominently in the economic literature concerning environmental externalities from pollution and climate change. In environmental policy, no less than government intervention in the financial sector, the traditional approach was regulatory command, in the form of requiring or banning particular behaviour by private actors. This approach came to be criticized, however, by economists who, building on the work of Arthur Pigou (1928), argued that it made too little use of market mechanisms that could improve efficiency in the achievement of regulatory objectives.

In theory, regulatory command can achieve optimal results if regulators have the right incentives and sufficient information. Thus, suppose they could design limits on pollution emission that ensured that firms would pollute only when the correctly measured benefits of doing so, compared to all alternatives, exceeded the social harm. In practice, however, even if centralized regulators have the right incentives to seek optimal rules, they often lack the particularized information about firms' alternatives that would be needed to prescribe by general rule the socially optimal decision in each case. Firms are likely to have better information about their own choices, and thus may be expected to do a better job of optimizing if a mechanism can be found for properly aligning their incentives. Hence the above makes the case for using another tool, Pigouvian taxation, when it can be properly designed.

Suppose that regulated firms know much more about the costs of changing pollution than does the regulator. Ordinarily, they may have incentives not to reveal that information. If, however, they are charged a pollution tax, equal to the expected marginal harm that they cause through their actions (Kaplow

This is an open access version of the publication distributed under the terms of the Creative Commons Attribution-NonCommercialNoDerivs licence (http://creativecommons.org/licenses/by-nc-nd/3.0/), which permits non-commercial reproduction and distribution of the work, in any medium, provided the original work is not altered or transformed in any way, and that the work is properly cited. For commercial re-use, please contact academic.permissions@oup.com 
and Shavell 2002), they will use that information to optimize pollution decisions that the regulator would have got wrong by reason of its being effectively 'compelled to treat firms the same when in fact they differ' in dimensions that it cannot observe (Christiansen and Smith 2009: 2).

Thus, consider global warming. An enforceable carbon tax, set properly and applying globally, would give businesses the incentive to set carbon emissions at exactly the right level, given the tradeoff between the value consumers place on the associated economic production and the costs imposed by changing the world's climate. Obviously, in practice, even if all countries (and the relevant political actors in each country) were willing to cooperate fully, setting the tax price properly would be extremely difficult. ${ }^{7}$ In principle, however, assuming a particular answer to the set of valuation questions, there is a 'correct' carbon tax per unit of carbon emission, applying uniformly across the world because all carbon is identical.

A perfectly functioning carbon tax of this kind eliminates all need for the use of regulatory command with respect to carbon emissions. Unfortunately, however, things are not always so simple (or, rather, the complications are not always confined to valuing an output that is at least globally uniform). Consider alcohol consumption, which at moderate levels may 'be fairly harmless while heavy drinking by some individuals generates large and progressivelyincreasing externalities' (Christiansen and Smith 2009: 6). Thus, a uniform tax per unit of alcohol consumed would fail to generate the Pigouvian optimum. Moreover, while in principle one could try to differentiate the tax appropriately, applying non-linear taxes (even to the same consumer) based on a full assessment of the broader circumstances, in practice this might be infeasible or overly costly to implement. These difficulties may cause the use of regulatory command, such as restrictions on where and when alcohol can be sold, to be preferable to attempting full reliance on Pigouvian taxation.

\subsubsection{Pigouvian taxation of the financial sector}

In principle, this analysis clearly applies to a financial firm that makes investments with significant downside risk. Thus, it is worth asking what costs an optimal Pigouvian tax would require the firm to take into account. Relevant items would include the expected costs to (1) uninsured counter-parties from firm insolvency, (2) taxpayers and beneficiaries of government programmes,

\footnotetext{
7 The obstacles to setting the carbon tax properly would include (1) the broad empirical uncertainty in climate models, (2) the difficulty of measuring the welfare cost even of determinate climate effects, and (3) questions of how to make trade-offs between the welfare of individuals in very different circumstances (such as people in rich versus poor or advanced versus underdeveloped countries, or the members of current versus future generations), if any distributional effects are not offset by any other policy, including tax, changes.
}

This is an open access version of the publication distributed under the terms of the Creative Commons Attribution-NonCommercialNoDerivs licence (http://creativecommons.org/licenses/by-nc-nd/3.0/), which permits non-commercial reproduction and distribution of the work, in any medium, provided the original work is not altered or transformed in any way, and that the work is properly cited. For commercial re-use, please contact academic.permissions@oup.com 
present and future, who would be worse off to the extent the government offered explicit or implicit insurance coverage, and (3) anyone else directly or indirectly affected by the heightened prospect of runs on the bank (at the same firm or elsewhere) and/or of the negative economic consequences from the associated harm to the liquidity function that banks and other financial firms serve in facilitating transactions that generate surplus.

Unfortunately, an optimal Pigouvian tax on financial firms could not, like an optimal carbon tax, simply apply a simple flat rate to a distinct output. There is no single activity whose aggregate sum equals expected harm. Indeed, many distinct aspects of financial institutions' activities may have negative externalities, including those that affect:

- liquidity (the lack of which may lead to fire sales);

- solvency;

- riskiness;

- complexity (opacity);

- size or market share;

- interconnectedness.

Thus, both the activities of a firm and various aspects of its relations with other firms may matter. ${ }^{8}$ And, even once an activity is identified, the optimal corrective tax (or subsidy) is unlikely to be uniform. Rather, it seems likely to be, not only firm-activity specific and firm-size specific, but also state specific.

If the insurance protection that the government offered was so certain, comprehensive, and instantaneous as to eliminate the associated harms that were discussed above (such as lost liquidity from bank runs that spread outwards via contagion), a correctly priced insurance fee might come close to being a full Pigouvian tax. However, any gaps, delays, or uncertainties in the coverage that caused runs on the bank still to be possible would mean that the fee fell short of covering all the social harm from risky investments. In addition, even if bank runs and liquidity loss were now impossible, inter-firm contagion would permit one firm's actions to affect the expected cost to the government of providing insurance coverage to other firms. ${ }^{9}$

\footnotetext{
${ }^{8}$ Some recent work has tried to quantify the marginal damage, but the formulas are too complicated to offer a plausible basis for actual legislation; see, e.g., Adrian and Brunnermeier (2008).

${ }^{9}$ Even if the social harm could be reduced to the fiscal cost of supplying insurance protection, the government would hold a risky position, as the insurer of all financial firms, if its various investment risks (such as from betting against a downturn in real estate prices) were correlated. Thus, even with an actuarially fair fee, the insurance fund would have a large positive balance when tail risk was realized less frequently than expected, and would leave the government with financial exposure under the opposite scenario. Governments that, like the United States, face long-term fiscal gaps that raise serious questions about long-term policy sustainability (see, e.g., Shaviro 2007; Auerbach and Gale 2009), and that are otherwise also taking 'long' betting positions on the performance of their national economies through their tax and transfer systems, might
}

This is an open access version of the publication distributed under the terms of the Creative Commons Attribution-NonCommercialNoDerivs licence (http://creativecommons.org/licenses/by-nc-nd/3.0/), which permits non-commercial reproduction and distribution of the work, in any medium, provided the original work is not altered or transformed in any way, and that the work is properly cited. For commercial re-use, please contact academic.permissions@oup.com 
In practice, the precise downside risk attributes of a particular financial firm's overall investment position are unlikely to be fully observable by tax authorities. Thus, an actuarially fair risk-adjusted fee structure not only would fall short of giving financial firms the right social incentives at the margin when they make investment choices, but is unlikely to be entirely feasible. Therefore, the key incentive problem that gave rise to the 2008 financial crisis-excessive risk-taking by firms and managers that did not face the entire downside-will probably remain even if a fairly well-designed tax instrument is adopted.

For two distinct reasons, therefore, the tool of regulatory command is likely to continue being necessary, in addition to any tax instruments that are adopted. First, expected social harm, other than the purely pecuniary to the government as insurer, is multidimensional and difficult to measure. Second, even that pecuniary harm cannot be measured entirely accurately through a risk-adjusted fee. Thus, the classic tax-or-regulation debate is surely beside the point with respect to financial institutions, because regulation of the financial sector both is not going away, and should not. In particular, capital-adequacy regulations will surely continue to be necessary (D. J. Elliott 2010a), and indeed must presumably be improved and made harder to avoid given their failure in many cases during the period leading up to the financial crisis. Given, however, the multidimensional character of systemic risk, multiple tax and/or regulatory instruments are likely to be needed.

A risk-adjusted tax or fee for government insurance coverage, even if imperfect, clearly can play a positive role within this framework of multidimensional response, by addressing one of the central externalities when such coverage is provided. It might improve financial firms' incentives to a degree if it tended to go up when they increased riskiness in observable ways. Moreover, setting the fee at the right (average) level for financial firms as a whole, even if it was not correct at the margin case by case, would have the advantage of eliminating the net subsidy to the sector that otherwise would exist by reason of the insurance coverage. All else being equal, this net subsidy otherwise would cause the financial sector to be too large. ${ }^{10}$

The following are some key principles to keep in mind when designing such a tax or fee:

- It should recognize the wide variety of activities that come under the umbrella of the financial sector. Otherwise, financial firms could

reasonably consider this a detriment, unless fully reflected in the pricing for the insurance coverage.

${ }^{10}$ Note that many, such as Krugman (2010a), argue that the financial sector is too large for reasons wholly apart from the subsidy.

This is an open access version of the publication distributed under the terms of the Creative Commons Attribution-NonCommercialNoDerivs licence (http://creativecommons.org/licenses/by-nc-nd/3.0/), which permits non-commercial reproduction and distribution of the work, in any medium, provided the original work is not altered or transformed in any way, and that the work is properly cited. For commercial re-use, please contact academic.permissions@oup.com 
use excluded activities to impose downside pecuniary risk on the government.

- It should be derivative proof, so that its intended incentive effects could not be skirted by the creation of derivative products that constructed the same financial positions while avoiding its application.

- Its applicability should not depend on the arbitrary designation of what type of institution was undertaking an action-an important design element, given that financial institutions with different designations often perform overlapping functions and sell overlapping products. Thus, to the extent that it is feasible, it should be activity based but not institution based, applying automatically to any firm that performed the banking-type functions (time intermediation and providing payment systems) that give rise to the need for insurance protection.

- Relatedly, it would properly address predominantly non-financial firms with financial units, such as GMAC Financial Services (now Ally Financial), GE Finance, or GE Capital.

- The link between firms paying the tax and those getting government insurance coverage need not be absolute. Suppose that a given predominantly non-financial firm that also conducts financial activities is not expressly covered, but to a degree performs banking functions. This role might cause it to have implicit government insurance coverage if bailout was a possibility, and also might cause its failure, if permitted to occur, to yield the same negative externalities as a bank run at a covered institution.

- International coordination is desirable, since negative externalities can easily cross borders. ${ }^{11}$ Given the realities of international politics, however, the instrument should be robust to imperfect international coordination.

- With multiple tools being used to address financial-sector externalities, any evaluation of the consequences of new tax legislation must be made in the light of the regulatory environment, which is itself in flux. ${ }^{12}$

\footnotetext{
11 In this regard, think of Iceland, whose financial institutions are (actually were) large and imposed costs that crossed the ocean.

12 If the quantity regulation of an activity that generates a negative externality is set optimally, then any tax set at a rate less than or equal to the marginal social damage will raise revenue, but will not alter behaviour from the social optimum. Such a tax is attractive because it raises revenue with no distortion rather than because of its Pigouvian incentives. A tax set at a rate in excess of the marginal social damage collects further revenue, but at the cost of moving the equilibrium from the social optimum, with too little of the externality-generating activity. If the quantity regulation is set too laxly, a tax at a rate below the implicit marginal social damage implied by the regulation will raise revenue with no marginal effect, while a tax in excess of that amount (but not greater than the actual marginal social damage) will both raise revenue and affect activity in the right direction. If
}

This is an open access version of the publication distributed under the terms of the Creative Commons Attribution-NonCommercialNoDerivs licence (http://creativecommons.org/licenses/by-nc-nd/3.0/), which permits non-commercial reproduction and distribution of the work, in any medium, provided the original work is not altered or transformed in any way, and that the work is properly cited. For commercial re-use, please contact academic.permissions@oup.com 
For example, a tax aimed at large institutions must be evaluated in the light of regulations designed to limit firm size.

- The cyclical-counter or pro-nature of any state-specific tax is potentially important. All else being equal, the tax or fee should be designed so as not to trigger liabilities that sap funds just when the financial firms, and the system as a whole, are most fragile.

- Given negative externalities apart from the pecuniary cost to the government of providing insurance coverage, the amount raised by a well-designed tax or fee could exceed expected payouts under the coverage. Moreover, if the government creates a resolution fund to make insurance payouts as needed and decides to credit that fund with the revenues received, it should not cease to collect the tax even if the fund reaches a predetermined size that is considered big enough to meet any expected obligations. The need to address financial firms' risk-taking incentives is ongoing and entirely separate from that of whether, in the aggregate, they are paying for the full expected value of their insurance coverage.

Given that even imperfect Pigouvian taxation could improve incentives to a degree, in so far as it was able to put a price on some aspects of externalityimposing behaviour, we next examine several alternative tax proposals that have recently been made or discussed regarding the financial sector.

\subsection{Tax proposals}

In this section we apply the preceding analysis to assess recent proposals for new taxes on financial institutions or certain financial activities. We focus on four proposals: a financial transaction tax, a tax on bonuses, and two types of taxes on financial institutions: an excise-tax-like levy that might fall on excess profits, and the financial activities tax (FAT) discussed by the IMF in its preliminary response to the G20 request noted in Section 6.1.

Before we get to the details, a few words of background are in order. First, the proposals generally have multiple motivations and objectives. Thus, although the effect on the incentives of financial institutions and other market participants are of concern (à la Pigouvian taxes), revenue-raising and retributive motivations are also apparent. Second, although in theory (meaning absent administration, implementation, and political economy issues) an appropriate

the quantity regulation is set too strictly, a tax raises revenue without affecting behaviour; neither would a subsidy offset the suboptimal level of activity, although it would incur a revenue loss.

This is an open access version of the publication distributed under the terms of the Creative Commons Attribution-NonCommercialNoDerivs licence (http://creativecommons.org/licenses/by-nc-nd/3.0/), which permits non-commercial reproduction and distribution of the work, in any medium, provided the original work is not altered or transformed in any way, and that the work is properly cited. For commercial re-use, please contact academic.permissions@oup.com 
Pigouvian tax would be highly complex, in practice only relatively simple policies are on the table.

\subsubsection{Financial transactions tax (FTT)}

The idea of a tax on some set of financial transactions has been around for a while, and certainly pre-dates the policy reform agenda triggered by the 2008 financial crisis. In a world without derivatives, the tax base would be the amounts for which specified financial assets were sold. Modern versions of the proposal also include in the tax base the notional value or spot price of the assets referenced in transactions involving derivative securities.

Some proponents of an FTT eye the revenue potential, which looks large relative to the required rates of tax. The economic arguments in support of imposing such a tax centre instead on its ability, by increasing the costs of financial asset transactions, to reduce speculative and technical trading that increases financial markets' volatility and susceptibility to bubbles. These issues are certainly related to the financial crisis, and are therefore worth taking seriously. Although a comprehensive review of the literature is beyond the scope of this chapter, we think it fair to say that theoretical studies have not led to conclusive results about the veracity of the claimed benefits, and that the empirical literature also does not support the claim that an increase in transaction costs (through higher taxes or other mechanisms) generally improves market functioning (Hemmelgarn and Nicodeme 2010). Instead, its main effects may include (1) raising the costs of capital for entities issuing new securities, (2) through its downward effect on trading volume, reducing liquidity and price discovery, while also potentially increasing short-term price volatility, and (3) displacing securities trades from taxed to untaxed venues (Matheson 2010: 29).

An FTT is an unlikely candidate as a retributive tax, given its uncertain incidence, as well as its likely ineffectiveness at retrospectively targeting those who caused, or profited from, the 2008 financial crisis. Thus, in the end its principal appeal may lie in the large amount of revenue it can raise, relative to the tax rate, if not so widely avoided (such as by using derivatives or moving securities trades to untaxed venues) that even in this respect it ends up being merely a 'damp squib' (Honohan and Yoder 2010: 23).

To say that an FTT (if sufficiently airtight) might raise substantial revenue, relative to its tax rate, is merely another way of saying that its tax base is at least nominally large. Supporters often tie this feature to the oft-quoted tax policy mantra favouring 'broad-based, low-rate' taxes over narrow-base, highrate taxes. But the logic behind this mantra does not apply to any and all broad-base taxes, regardless of their underlying efficiency properties. Thus, for example, economically well-informed proponents of retail sales taxes 
generally agree that 'broadening' the base by including business-to-business sales, rather than just those to consumers, and thus creating a gross receipts (or turnover) tax, would reduce, rather than increase, economic efficiency, by generating a cascading tax on economic production by multiple nonintegrated firms.

The FTT similarly imposes a cascading tax, largely on business-to-business sales. While the cascading base allows a lower rate to raise more revenue than would an equal-rate tax on, say, income, that is simply because it penalizes the use of separate firms. We thus are sceptical that the case for an FTT is any stronger than that for a gross receipts tax, ${ }^{13}$ although we note that the latter instrument has come back in fashion as a revenue-raising tool for certain US states.

\subsubsection{Bonus Tax}

Both the United Kingdom and France introduced temporary taxes on bonus payments to employees in the financial sector. Under the British levy, called the Bank Payroll Tax, bonus payments in excess of $£ 25,000$ were taxed at a rate of 50 per cent on a temporary basis; the measure expired as of 5 April 2010. The French tax was similar in rate and threshold, and applied to bonuses paid during the 2009 accounting year. In May of 2010, Senator Jim Webb (D-VA) offered an amendment to the US financial reform bill under debate that would impose a one-time, 50 per cent tax on bonuses of more than $\$ 400,000$ paid to executives of Fannie Mae, Freddie Mac, and other financial institutions that got at least $\$ 5$ billion from the Troubled Asset Relief Program Congress approved in 2008. The proposed bonus tax would apply to income generated for work in 2009 and paid in 2010.

If expected to recur, a tax on bonuses is an invitation to avoidance, given the difficulty of ascertaining and monitoring what part of compensation is in fact a 'bonus'. This is, of course, not an issue for a tax applied retroactivelythat is, before the characterization had tax-liability implications. As a onetime, ex post measure, it has the economic advantage of being non-distorting. Of more political salience but uncertain economic accuracy, it could be perceived as exacting a penalty from those individuals whose mistakes helped precipitate the crisis and who nevertheless profited in its build-up and from the taxpayer-financed bailouts that accompanied it. However, a retrospective tax on bonuses is certainly a blunt instrument for assessing a tax on this kind of culpability.

13 One could possibly argue for some kind of FTT as a form of presumptive tax on tax-noncompliant businesses in the informal sector, especially if it is creditable against income tax or VAT liability. But this is a separate objective from those that we address in this chapter.

This is an open access version of the publication distributed under the terms of the Creative Commons Attribution-NonCommercialNoDerivs licence (http://creativecommons.org/licenses/by-nc-nd/3.0/), which permits non-commercial reproduction and distribution of the work, in any medium, provided the original work is not altered or transformed in any way, and that the work is properly cited. For commercial re-use, please contact academic.permissions@oup.com 
The retrospective nature of the British and French bonus taxes made the placement of the obligation to remit the amount due critical to its incidence, as there can be no ex post adjustment of market prices in reaction to a one-time tax. Because both the British and French bonus taxes were to be remitted by the employer, the burden would be likely to be borne by shareholders, rather than by the employees who received the bonuses, ${ }^{14}$ and thus did not assign penalties across individuals according to culpability, even if one assumes that receiving a bonus is a good proxy for culpability.

\subsubsection{Levies on financial institutions}

On 14 January 2010, the Obama administration proposed a levy of 0.15 per cent on a base equal to liabilities, excluding deposits subject to assessments by the Federal Deposit Insurance Corporation (for banks) and certain liabilities related to insurance policies. The fee would apply only to firms with consolidated assets that exceed $\$ 50$ billion, of which there were about sixty firms in 2010. The administration estimated that such a fee would collect $\$ 90$ billion from 2011 to 2020, which would go into general revenues to offset the estimated cost of the 2008 bailout fund, and then expire. The Senate bill initially contained a provision collecting $\$ 50$ billion from financial firms and setting the money aside to fund future bailouts. On 31 March 2010, the German government announced plans to introduce a levy on banks with a base of liabilities excluding capital and deposits, and a rate that depends on some measure of systemic risk; details of the risk-varying premium have not yet been released. In contrast to the US proposal, the revenue from the levy would be paid into a stability fund that would finance a resolution regime for systemically relevant banks. The French government has announced it will soon release its own plan, and on 1 April 2010 German Chancellor Merkel said that Germany and the United Kingdom would work together to propose a bank levy to the G20 countries. However, news reports suggest that there is substantial opposition to such a levy, including from Australia, Brazil, Canada, and Japan (Davis 2010). In addition, there are proposals before the US Congress for a systemic dissolution fund, facilitating the liquidation of large and significant financial institutions that become insolvent, and funded by a variable assessment fee. The rate would depend on several factors, possibly reflecting some measure of risk, but the relevant details have not yet been settled or announced.

${ }^{14}$ We assume that the employment contracts between affected financial firms and the employees who received bonuses did not provide that compensation would be adjusted to reflect new firm-level taxes such as the bonus tax. 
These proposals differ on a number of dimensions:

- Is the base uninsured liabilities, or does it also include insured deposits? The former base provides a disincentive for banks to fund risky lending and investments with less stable funding. Insured deposits presumably are safe in this respect, but, on the other hand, one still does not want banks to make risky bets with these funds based on a 'heads we win, tails you lose' rationale.

- Is the rate risk weighted or flat? If it is risk weighted, what are the risk factors and how are they measured? The Pigouvian logic supports the use of risk weighting to measure flexibly the marginal social damage of the activities of a financial institution. But here the devil is in the details, and the difficulty of measuring risk factors accurately and transparently.

- Is the tax remitted entirely ex ante, or are there also ex post clawbacks within the resolution process? The former would reduce the pro-cyclicality of the levy, except to the extent that any risk weighting triggers higher tax liability just when financial institutions are most fragile.

- Are the revenues paid into a resolution fund, or do they go into general revenues? If the former, do the revenues effectively constrain the size of future bailouts? This is not relevant to the incentive effects and efficiency properties of the tax unless the designation of such a fund affects the credibility of a bailout. More crucial is whether the premiums need not be paid once the fund reaches a certain amount. This would almost certainly be inappropriate, as the social cost of risky behaviour does not go to zero when the fund reaches an essentially arbitrary size.

- How does a liability tax interact with mandated regulatory capital? Maintaining regulatory capital is costly because it limits the amounts of funds that the bank can invest. Moreover, the amount of required capital is increasing in the riskiness of the bank. Similarly, a tax on the bank's liabilities is a tax on invested funds and it can be structured to be increasing in the riskiness of the bank-for example, exempting insured deposits is an example of taking the bank's risk into account in determining the base for the liability tax. Thus, raising the amount of required regulatory capital and levying a liability tax are substitutes for reducing bank risk and should be coordinated.

The IMF (2010b) report proposes a new tax on financial institutions, called a financial activities tax (FAT), whose base is profits (in excess of a 'normal' return) plus worker compensation above a per-employee threshold. ${ }^{15}$ The report argues that this would approximate taxing rents, and therefore invokes

15 Kleinbard and Edgar (2010) suggested a similar levy, with a similar justification. 
the efficiency arguments for rent taxation. ${ }^{16}$ Kleinbard and Edgar (2010) stress that the recent extraordinary profits in the financial sector must have been due either to luck or to temporarily successful risk taking, and that either account would suggest the identification of a low-distortion tax base. ${ }^{17}$ They argue that such an excess profits tax would also mitigate risk taking that is socially excessive because, as discussed earlier, the losses from bad outcomes are often borne by people other than shareholders. ${ }^{18}$ In effect, apparently extraordinary profits serve as a proxy for identifying inappropriate tail risk. From this perspective the FAT could be considered as a backup, for flaws in the regulations designed to limit risk taking. To the end of 2010, however, as stressed elsewhere in this chapter, the optimal coordination of tax and regulatory policies had not been adequately addressed.

IMF (2010b: 20) notes several non-trivial issues of implementation that would need to be worked out before a FAT is introduced. To these we might add the difficulty of establishing a 'perimeter' for its application. Predominantly non-financial corporations with significant financial operations would presumably not be subject to the FAT, in order to minimize the administrative and compliance costs. However, leaving similar activities out of the FAT base would encourage migration of these activities to 'non-financial' firms, thus distorting the structure of the true financial sector and potentially undermining advancement of the regulatory aims.

\subsection{Conclusions}

Multiple motives underlie the post-crisis flurry of proposals to levy new taxes on financial institutions or their transactions:

1. a desire for retribution or recompense from parties deemed to have caused, and/or profited from, the 2008 crisis;

16 They also argue that, appropriately designed, it could offset the usually favourable treatment afforded financial institutions under VAT. While this argument does not directly apply to the United States, which does not have VAT, the consumption value of financial services (such as those provided on low-interest, low-fee personal checking accounts) typically also escapes income taxation, both in the United States and elsewhere.

17 This argument addresses the fact that a tax on pure profits or rents in any sector has desirable efficiency properties, but in practice it is difficult to separate pure profits or rents from the normal return to capital, and so designing a non-distorting tax is difficult. If one can assert that most of the observed return in a given sector is rent or pure profit, then the potential distorting effect per dollar raised is arguably low.

18 In view of the argument of Domar and Musgrave (1944), such a tax would reduce risk taking only given that the tax treatment of losses is punitively asymmetric. Otherwise, a tax on profits might induce decision-makers to increase pre-tax risk positions in order to restore the after-tax positions they had in absence of the tax. Note also that ex post increases in the generosity of the tax treatment of losses is a form of taxpayer bailout.

This is an open access version of the publication distributed under the terms of the Creative Commons Attribution-NonCommercialNoDerivs licence (http://creativecommons.org/licenses/by-nc-nd/3.0/), which permits non-commercial reproduction and distribution of the work, in any medium, provided the original work is not altered or transformed in any way, and that the work is properly cited. For commercial re-use, please contact academic.permissions@oup.com 
2. a desire to align private incentives with the social cost of activities that demonstrably have potentially catastrophic external contagion effects, so as to reduce the likelihood of future crises; and

3. a desire to raise revenue to offset the government fiscal imbalances exacerbated by the cost of dealing with the financial crisis and subsequent recession.

The appropriate tax scheme greatly differs depending on the motive, although most proposals seek to serve more than one.

Economic analysis can clarify what design elements are more likely to achieve which goals. The theory of incidence is relevant for ascertaining whether the burden of new taxes will actually fall on those intended to bear the burden, and cautions that-political rhetoric aside-burdens are not borne by legal entities such as corporations, but by people. Backward-looking taxes cannot be shifted, and thus the remitter of the tax is crucial, but for forward-looking taxes the scope of the tax matters as well as the alternatives the market participants have to the taxed activity. The large literature on Pigouvian taxation is helpful, but has mostly been applied to environmental externalities, which are different in important ways from the type of negative externalities generated by financial activity. For example, the latter are likely to be institution specific and state specific. Measuring the marginal cost is difficult-although perhaps no more so than in the case of climate changeand thus the theoretically optimal Pigouvian levy is difficult to calculate, may be difficult to administer and monitor, and is difficult to implement in a transparent and explainable way. Simple versions of the theoretical optima should perhaps be designed, but they are likely to be imperfect.

It is true that taxes, as opposed to most regulations, raise revenue, and many countries affected by the financial crisis are in a dire long-term fiscal situation. Yet taxes on financial institutions and activities are not the only way to raise revenue. Thus, as usual, the issue is whether these ways of raising revenue are less damaging (or even more supportive) to the economy, with more favourable equity consequences, than likely alternatives.

We conclude that, with regard to financial transactions taxes, the answer to this question is no. The efficiency cost is likely to be high relative to the revenue raised, given the lack of any good evidence that it improves incentives or addresses externalities in any clearly identifiable respect. The allure of its low rate relative to revenue potential is illusory, and its incidence is uncertain.

One-time, backward-looking taxes on bonuses above a threshold have minimal efficiency costs, and might even be approximately on the mark in assessing a retributive penalty if collected from employees rather than firms. Forward-looking bonus taxes would be difficult to administer, however, and the case that they would improve incentives is hard to make. 
A graduated tax on the uninsured bank liabilities of large financial institutions would potentially provide a socially desirable disincentive for risky investment backed by less stable funding. Penalizing larger corporations would be desirable in so far as they pose larger systemic risks to the economy, although the relationship between size and such risk is not entirely clear. Such a tax would probably be borne by shareholders and other constituencies of the larger institutions at the time when enactment first became generally expected. Loosely tying the revenue from such a tax to a resolution fund would not necessarily add substantiality to the credibility of pledges about how and when to make use of such a fund (for example, if rescue was expected in any event), and could be damaging if it led to dismantling of the tax once the fund had reached an arbitrarily determined size.

A tax on financial firms' profits in excess of a normal return (plus worker compensation above a per-employee threshold) has potential appeal despite historical scepticism in the literature concerning the general merits of excess profits taxes. In this setting, an excess profits tax could be rationalized either as primarily reaching rents or as indirectly indicating the presence of tail risk that is an externality from the firms' (or their employees') standpoint. However, the merit and applicability of these arguments remain uncertain, and imposing such a tax would also pose various design challenges, including whether and how to apply it to what are effectively financial firms nestled inside larger firms outside the recognized financial sector.

Future research should be directed towards sharpening the applicability of the Pigouvian framework to the case of financial-sector externalities. In particular, the optimal coordination of regulation and corrective taxation should be explored in more depth. US Treasury Secretary Geithner describes the administration's proposed fee as being designed to 'complement' regulatory policies (Geithner 2010), and the IMF (2010b: 2) remarks that any new tax should 'reflect and be coordinated with' regulation, recommending a 'more holistic approach' (IMF 2010b: 22). How these unexceptionable goals are best achieved should be high on the research agenda.

This is an open access version of the publication distributed under the terms of the Creative Commons Attribution-NonCommercialNoDerivs licence (http://creativecommons.org/licenses/by-nc-nd/3.0/), which permits non-commercial reproduction and distribution of the work, in any medium, provided the original work is not altered or transformed in any way, and that the work is properly cited. For commercial re-use, please contact academic.permissions@oup.com 


\section{An accounting legacy of the crisis}

Even if income taxes were not a major proximate cause of the financial crisis, they will play a key role going forward in the decisions of most financial institutions because many of the tax deductions associated with the losses during the crisis have yet to result in any cash tax savings. The realized tax losses of many such firms were large enough to offset fully all profits in the year generated and the carry-back years. Such losses now are being carried forward to potentially offset tax liability in future profitable years.

Besides reducing future tax payments, these net operating loss carry-forwards can strengthen the financial institution's current balance sheet and regulatory capital. The carry-forwards create deferred tax assets that are included on the balance sheet and in the computation of Tier 1 capital, the key measure used by regulators to assess a financial institution's capital adequacy. ${ }^{19}$ Furthermore, expenditures and losses, which have been expensed for book purposes but not yet deducted for tax purposes, also qualify as deferred tax assets. Of particular note for tax purposes, the bad-debt reserve for the portion of a US bank's loan portfolio that it does not expect to collect is not deductible (because a tax deduction is permitted only when a specific loan is deemed uncollectible and removed from the portfolio), but, instead, the product of the bad-debt reserve and the tax rate is recorded as a deferred tax asset. The logic is that the bank will pay fewer taxes in the future when the uncollectible loans are charged off.

However, to the extent that a firm is not expected ever to realize the tax savings represented by the deferred tax asset, a valuation allowance must be established. The valuation allowance is a 'contra-asset', which reduces the balance of the gross (or total) deferred tax assets. If the firm cannot establish that it anticipates future taxable income from one of four sources, ${ }^{20}$ then a valuation allowance is required. The valuation allowance can be costly for financially constrained companies, the very firms for which future taxable income is uncertain, because it reduces the firm's net deferred tax assets, accounting earnings, and equity.

Therefore, financially constrained companies face incentives to minimize their valuation allowance. Among the four sources of income that can enable a firm to avoid a valuation allowance, generating expected future taxable income is the most important

\footnotetext{
19 See Graham et al. (2010) for a detailed discussion of deferred tax assets and other aspects of the accounting for income taxes.

20 The four sources are (1) future reversals of existing taxable temporary differences, (2) future taxable income, (3) taxable income in carry-back periods, and (4) the existence of tax planning strategies.
}

\section{2}

This is an open access version of the publication distributed under the terms of the Creative Commons Attribution-NonCommercialNoDerivs licence (http://creativecommons.org/licenses/by-nc-nd/3.0/), which permits non-commercial reproduction and distribution of the work, in any medium, provided the original work is not altered or transformed in any way, and that the work is properly cited. For commercial re-use, please contact academic.permissions@oup.com 
means of establishing that the firm will eventually utilize the tax deductions and thus does not need to establish a valuation allowance. One way to increase expected future taxable income and thus reduce the valuation allowance is to shift to riskier investments. Because of the limits on the refundability of losses, riskier investments with the same expected income generate more expected taxable income, enabling the corporation to book a smaller valuation allowance. By booking a smaller valuation allowance, the firm boosts current accounting earnings, assets, and equity. In summary, the accounting rules encourage many of the banks that suffered the greatest losses from the financial crisis (and thus have the largest deferred tax assets) to take more risks than they would without financial reporting incentives.

Regulators provide even stronger incentives for weak financial institutions to engage in excessively risky undertakings, because they further restrict the use of deferred tax assets as a source of regulatory capital. Regulators accept deferred tax assets, net of the valuation allowance, as Tier 1 capital, but banks can use future taxable income only to the extent that taxable income is expected in the next twelve months. This restriction for regulatory capital purposes can be important. Lindo (2009) reports that a study by the Federal Reserve Board found that, for financial accounting purposes, most banks do not require a valuation allowance to be invoked if they anticipate taxable income in the next two to six years, and some banks accept taxable income within ten years as sufficient to avoid recording a valuation allowance. Thus, the more restrictive twelvemonth rule for regulatory capital purposes means that some banks avoid the valuation allowance for book purposes but nonetheless have the deferred tax assets disallowed for regulatory purposes. Furthermore, regulators do not permit deferred tax assets to exceed 10 per cent of Tier 1 capital. Accordingly, even if taxable income is anticipated within the next twelve months, deferred tax assets will be disallowed to the extent they exceed 10 per cent of Tier 1 capital. Finally, if the 10 per cent of Tier 1 capital rule is binding, any action that reduces Tier 1 capital (for example, repaying TARP funds) has an additional adverse impact on Tier 1 capital because it also reduces the permitted deferred tax assets.

Not surprisingly, banks have repeatedly lobbied the Federal Reserve Board to lift or limit these two additional regulatory restrictions, as yet to no avail. ${ }^{21}$ Given that these bank holding companies can enhance their regulatory capital simply by qualifying their deferred tax assets for inclusion in Tier 1 capital, it seems plausible that rearranging their affairs, including shifting to riskier investments, will be an attractive, relatively low-cost means of capital enhancement for years to come for many US banks. The impact of inducing the largest US banks (whose risky endeavours contributed to the financial crisis) to engage in riskier behaviour than they might otherwise have preferred, owing to the financial reporting and regulatory incentives surrounding the deferred tax assets, merits attention from policy-makers.

21 However, in December 2009, state life insurance regulators did relax their treatment of deferred tax assets by shifting from a twelve-month taxable income requirement to a thirty-sixmonth taxable income requirement, and from a limit of 10 per cent of capital and surplus to a limit of 15 per cent of capital and surplus. The immediate impact was to boost the capital of life insurers by $\$ 11$ billion by permitting previously disallowed deferred tax assets to count for regulatory purposes. 


\title{
Income Tax Reform Implications of the Financial Crisis
}

\author{
Daniel N. Shaviro
}

\subsection{Introduction}

Gore Vidal once stated that the four sweetest words in the English language are 'I told you so'. Can tax experts, despite not having predicted the great financial crisis and economic downturn that broke out in 2008, nonetheless properly indulge in the pleasure of saying these words? The rationale would be that defects in countries' income-tax rules, long emphasized by the experts but without prompting any policy response, helped bring about or worsen the crisis.

In favour of the above proposition, a number of different tax rules seem clearly to have pushed in the wrong direction at crucial margins where damage ended up being done. For example:

- Excess leverage contributed to the financial crisis, and income-tax systems around the world typically encourage corporate debt finance relative to equity finance.

- The emergence and collapse of housing bubbles also played a crucial role, and in many countries, such as the USA, income-tax systems provided strong tax preferences for homeownership that, at a minimum, distorted investment patterns and may also have specifically fuelled the bubbles.

\footnotetext{
This chapter is based on a talk prepared for the conference on Tax Policy and the Financial Crisis at Bocconi University, Milan, on 30 April 2009. I have benefited from conversations with Sam Eddins, Michael Keen, Geoff Lloyd, Yoram Margalioth, Alex Raskolnikov, and Joel Slemrod. I am also grateful to Julian Alworth and Giampaolo Arachi for detailed comments on an earlier draft, and to the D'Agostino-Greenberg Fund for financial support.
}

This is an open access version of the publication distributed under the terms of the Creative Commons Attribution-NonCommercialNoDerivs licence (http://creativecommons.org/licenses/by-nc-nd/3.0/), which permits non-commercial reproduction and distribution of the work, in any medium, provided the original work is not altered or transformed in any way, and that the work is properly cited. For commercial re-use, please contact academic.permissions@oup.com 
- Pervasive governance problems with respect to publicly traded companies played a crucial role, and income-tax rules may in some settings have exacerbated these problems.

- The proliferation of non-transparent financial instruments also helped trigger the crisis, and tax considerations often encouraged, or at least provided a convenient rationale, for the use of such instruments.

In short, the tax system's 'fingerprints' are all over the 'crime scene' of the 2008 financial crisis. Suggestive though this may be, however, the actual strength of the causal relationship between the two remains unclear, and is thought by most observers to be relatively small. For example, in some cases the tax biases may have been less important than other independent reasons for behaviour that helped prompt the crisis. It is also noteworthy that differences in countries' income-tax rules do not always seem to have been associated with differences in outcome, as one might have expected if tax were playing a key causal role. For example, housing bubbles were not limited to countries with large tax preferences for homeownership.

Finally, at least one important tax distortion arguably should have leaned against the crisis. Tax systems with graduated marginal rates or loss nonrefundability can notoriously discourage risk taking. Even if this is not generally desirable, one might think that it would have helped discourage the excess risk taking that contributed to the crisis, if tax considerations had generally been playing a central role. Yet there is little evidence that nonrefundability or graduated rates mattered greatly to the managers who were taking absurd risks on behalf of publicly traded companies-although this partly reflects the exact design of the tax rules' risk discouragement, as distinct from the overall importance of tax considerations.

Even if one accepts that tax distortions did not play a dominant role in causing or exacerbating the crisis, the fact that they frequently pointed in the wrong direction is important. One cannot be sure that they will not play a greater role the next time around. Moreover, any causal role whatsoever suggests that the underlying distortions are potentially even more economically damaging than tax experts had previously recognized. Thus, I offer here a very brief review of the main areas in which the tax system's fingerprints appear near the 2008 crime scene, and of how this association might affect subsequent tax policy thinking.

This chapter is organized as follows. Section 7.2 discusses the tax law distinction between debt and equity. Section 7.3 discusses risk taking and the financial crisis. Section 7.4 discusses the taxation of derivatives. Section 7.5 discusses corporate governance. Section 7.6 discusses the taxation of housing. Section 7.7 offers brief concluding remarks. 


\subsection{Tax law distinction between debt and equity}

\subsubsection{The underlying issue}

Tax law, in common with accounting, insists on shoehorning a broad range of financial instruments, potentially with multiple continuously varying features, into the twin categories of debt and equity. The key differences in tax treatment are twofold. First, payouts by corporate issuers to holders generally are deductible as interest expense if the instruments are classified as debt, but are non-deductible dividends if the instruments are classified as equity. Second, for debt but not equity, periodic payouts may be imputed for tax purposes even if they are not actually made, leading to mandatory annual inclusion by holders (and potential deductibility by issuers). ${ }^{1}$

Thus, equity-financed corporate earnings are potentially taxed twice, although (1) taxpayers can control the timing of the second tax or even avoid it permanently, ${ }^{2}$ and (2) the shareholder-level tax may bear a reduced rate or receive other benefits such as imputation credits. ${ }^{3}$ Debt-financed corporate earnings generally are taxed only once, and at the holder's rather than the corporate issuer's marginal rate.

These rules are commonly described as creating an income-tax bias in favour of debt over equity. However, while frequently true, this statement needs to be qualified. Suppose a given tax system has marginal tax rates for high-income individuals that exceed the top corporate rate, and that such individuals can avoid paying the shareholder-level tax with respect to their corporate equity holdings. For such individuals, equity rather than debt is tax preferred, as it permits them to pay tax on their returns to corporate investment at the lower corporate rate rather than at their own rates (M. H. Miller 1977).

One further tax advantage of debt, given interest payments' deductibility, applies to cross-border investment. A multinational corporate group can use debt to shift net taxable income from high-tax to low-tax countries, both by having affiliates in the former countries do most of the group's borrowing and through the judicious use of intra-group debt-as in the case where a high-tax affiliate injects equity into a low-tax affiliate and then borrows the money back. ${ }^{4}$

For debt's frequently more favourable tax treatment to matter economically, the debt label must correlate with some underlying substance. If taxpayers can

\footnotetext{
1 Original issue discount rules that have this effect are perhaps most elaborate in the USA, but exist in numerous other countries as well. See Ault and Arnold (2004: 251-7).

2 In the USA, for example, shares of corporate stock that are held until death can then be redeemed for their fair market value without generating capital gain. See US Internal Revenue Code, section 1014.

3 See Ault and Arnold (2004: 329) (describing dividend relief provisions in various countries).

4 Even intra-group borrowing, while not increasing the multinational group's overall position as a net debtor, may affect a borrowing affiliate's other creditors (including not just other lenders but, for example, trade creditors, workers, and tort claimants).
} 
simply marry the preferred economic characteristics of financial arrangements to whichever tax label (debt or equity) they prefer-a situation that increasingly prevails although still not entirely-then the problem is simply one of making aggressive tax planning too easy, rather than of distorting economic decisions (Shaviro 2009a: 52-4).

In cases where the choice really does matter economically, as where a company decides to issue either classic fixed-rate debt or common stock, the frequent tax bias in favour of debt can matter for a number of different reasons. Most pertinently to the financial crisis, it can increase bankruptcy risk. Or it can lead companies to make the wrong choice, from a pre-tax standpoint, in using financial instrument design to mitigate agency costs in the use of investors' funds. Debt financing, for example, can encourage risky 'heads we win, tails you lose' investment choices by managers that the prospective suppliers of funds may find difficult to monitor. While debt also has potential advantages-for example, it permits prospective investors to limit their enquiry into a given investment's economic prospects to the issue of potential default-creating a tax bias in either direction can undermine pretax optimization of the agency problem.

Thus, there would be a strong case for eliminating debt bias, and more generally making the debt-equity choice tax neutral, even if the excessive leverage that contributed to the financial crisis did not make the bias seem especially pernicious. However, addressing debt bias, or more generally advancing tax neutrality in financial instrument choice, could take a number of different forms.

\subsubsection{Corporate integration methods of addressing debt bias}

For decades, academics have proposed (and countries have in varying degrees attempted) corporate integration, a term referring to a suite of alternative reform proposals all of which would move towards causing equity-financed corporate investment to be taxed, in effect, just once. ${ }^{5}$ At its most ambitious (but not in all versions), corporate integration would create tax neutrality not just between debt and equity, but also regarding the use of corporate versus non-corporate entities, the timing of corporate distributions, and the form of such distributions (for example, as between dividends and share repurchases) (Shaviro 2009a: 152-3). The forms that corporate integration could take include the following:

\footnotetext{
5 For this purpose, equity-financed corporate investment is viewed as having been taxed just once, even if tax revenues are collected at both the entity and the owner levels, so long as the overall net tax liability is similar to that which would arise if there were only one collection point.
}

This is an open access version of the publication distributed under the terms of the Creative Commons Attribution-NonCommercialNoDerivs licence (http://creativecommons.org/licenses/by-nc-nd/3.0/), which permits non-commercial reproduction and distribution of the work, in any medium, provided the original work is not altered or transformed in any way, and that the work is properly cited. For commercial re-use, please contact academic.permissions@oup.com 
- Dividend exemption. Permitting shareholders to receive dividends tax free would address debt bias, but would not achieve tax neutrality in financial instrument choice when there are tax-rate differences between corporations and shareholders. Thus, under dividend exemption one would expect shareholders with high marginal rates (compared to the applicable corporate rate) to prefer equity from a tax standpoint, while those with low marginal rates preferred debt. The net result might often be tax discouragement of holding debt if, as is true in many countries though not, at present, the USA, the corporate rate was significantly below the top individual rate. This would not be the case, however, if the marginal investors were tax-exempt entities, such as universities and pension funds.

- Dividend imputation. Under an imputation system, dividends are taxed to shareholders, but their amount is grossed up by the corporate tax payment attributed to the distributed earnings, and the shareholder receives a tax credit in the amount of the gross-up. Thus, suppose the corporate rate was 25 per cent, the shareholder rate was 35 per cent, and that a given shareholder received a $€ 75$ dividend (€100 with the gross-up). For tax purposes, the shareholder would have $€ 100$ of income and a $€ 25$ tax credit, and therefore would owe a further $€ 10$ of tax. ${ }^{6}$ Imputation goes further than exclusion towards the creation of tax neutrality between debt and equity, because it causes the shareholder rather than the corporate rate ultimately to apply for equity, just as it does (to the extent of deductible interest payments) for debt. It does not appear to be the wave of the future, however. Among the countries that moved away from it in the 2000s, in response both to complexity concerns and to European Community (EC) legal issues regarding non-resident investors, are France, Germany, and the UK (Ault and Arnold 2004: 327).

- Comprehensive business income tax (CBIT). In 1992, the US Treasury Department released a comprehensive tax-reform plan under which the tax treatment of debt and equity would largely be conformed, by denying corporate interest deductions and making the receipt of both dividends and corporate interests tax free to investors. In effect, this would have been dividend exemption plus changing the tax treatment of debt to be like that for equity. The proposal was never seriously considered by the US political system.

If CBIT had been seriously considered, key problems would have included transition (for example, how to treat pre-existing debt) and the question of

\footnotetext{
6 In a relatively pure imputation system, such as that applied in Australia, imputation credits are refundable if in excess of the shareholder's overall income-tax liability, including upon receipt by a tax-exempt shareholder.
} 
how to treat shareholder capital gain upon selling equity. The obvious solution would be to exempt the gain, for reasons of consistency with dividend exemption. This, however, would risk creating tax-avoidance problems. Suppose, for example, that a taxpayer was planning to sell an appreciated building, and that this ordinarily would lead to a taxable capital gain. Without anti-avoidance rules, all the taxpayer would need to do, in order to avoid the tax, is incorporate the building and sell the newly created shares. Obviously, special rules could be devised to address such scenarios, but they would add to the complexity of the CBIT approach and probably leave residual tax-planning opportunities.

In the international setting, the CBIT approach has the advantage of preventing the use of debt by domestic companies to reduce domestic source taxable income. Yet it arguably errs in centring tax liability at the entity level, rather than the investor level. In an era of high and rising worldwide capital mobility, many expect corporate tax rates to face continuing and eventually substantial downward pressure. The tax rates paid by individuals-at least as to active business income that is currently consumed ${ }^{7}$-are not under similar downward pressure, however, in so far as people remain relatively immobile and cannot easily hide their income (for example, reflecting international information exchange agreements between governments). This suggests that, even if one agrees that the tax treatment of debt and equity ought to be conformed, it may be preferable to use the debt model, in which the investor's tax rate ends up applying, rather than the equity model with its reliance on the entity's tax rate (Shaviro 2009a: 163).

- Allowance for corporate equity (ACE). Under an ACE system, corporations are permitted an interest-like deduction with respect to their equity. This may be accompanied, as under the business enterprise income tax (BEIT) proposed by Edward Kleinbard (2007a), by requiring shareholders to include the notional return to equity even if no dividends have been paid (in keeping with the common tax treatment of debt, which may accrue annual taxable income even if interest is not being currently paid). This not only advances tax neutrality between debt and equity, but causes the shareholder (rather than the corporate) rate to apply to normal rates of return on corporate investment. A further advantage is that it makes the tax system's cost recovery rate for corporate investments effectively irrelevant, ${ }^{8}$ thereby promoting inter-asset tax neutrality and reducing the importance

\footnotetext{
7 Tax rates on capital income that individuals earn on their savings is, however, frequently tax exempt at the entity as well as the investor level, reflecting the widespread use of tax-exempt institutions (such as pension funds) and the use of tax rules (such as those in the USA for individual retirement accounts) that permit individuals to save for retirement without paying current income $\operatorname{tax}$.

${ }^{8}$ Swifter cost recovery reduces the value of corporate equity on which the ACE deduction is computed. Or, to put it the other way around, slower cost recovery is offset by the allowance of
}

This is an open access version of the publication distributed under the terms of the Creative Commons Attribution-NonCommercialNoDerivs licence (http://creativecommons.org/licenses/by-nc-nd/3.0/), which permits non-commercial reproduction and distribution of the work, in any medium, provided the original work is not altered or transformed in any way, and that the work is properly cited. For commercial re-use, please contact academic.permissions@oup.com 
of cross-border variations between systems (Jacobs 1997). ACE systems were enacted but swiftly abandoned in Austria, Croatia, and Italy, and continue to exist in Belgium and Brazil (Klemm 2007). The BEIT has not as yet received serious political consideration anywhere, though I have argued elsewhere that it merits serious consideration (Shaviro 2008).

\subsubsection{Other methods of addressing debt bias}

Given the lack of a clear causal relationship between the tax system's predominant debt bias and the financial crisis, the adoption of corporate integration in response to the crisis seems unlikely (even if the case for it has been modestly strengthened). Thus, it is worth considering other possible responses to debt bias. Three in particular are worth noting, especially as they have independent advantages from a tax-policy standpoint.

- Lower corporate rates. Since the mid-1990s, numerous countries, in the European Union and elsewhere, have reduced their statutory corporate tax rates, often to significantly below top marginal rates for individuals. The motivating force has presumably been tax competition, reflecting that companies' locational investment decisions are generally more tax responsive than individuals' national residence choices. ${ }^{9}$ Yet, even though addressing excess corporate leverage seems unlikely to have motivated creation of the tax-rate differentials, the effect on tax incentives for leverage is potentially significant. Raising the differential increases the pool of investors who find equity investment tax preferable because it lowers the initially applicable tax rate. Thus, corporate rate cuts have the potential to move the overall system from one in which debt is predominantly tax-preferred towards one in which debt and equity simply have different investor clienteles.

- Stronger thin capitalization rules. Many countries have thin capitalization rules, limiting interest deductions either in general or for interest paid to non-residents, if some comparative measure (such as the taxpayer's debt-equity ratio) suggests that the taxpayer's level of debt is excessive. The two principal purposes these rules serve are to limit tax-base-eroding payments to non-residents, and to prevent avoidance of the double corporate tax by reason of having only minimal equity. While both of these concerns sound purely in tax policy, rather than macroeconomic

additional interest-like deductions on the unrecovered equity, thus compensating the taxpayer for the effect of deferral on the deduction's time value.

9 Individuals' mobility in response to national tax-rate differences may be on the rise, however. See, e.g., Kleven et al. (2010) (finding that European soccer players who are superstars, but not players of more ordinary ability, respond significantly to national tax rates in their decisions regarding where to play).

This is an open access version of the publication distributed under the terms of the Creative Commons Attribution-NonCommercialNoDerivs licence (http://creativecommons.org/licenses/by-nc-nd/3.0/), which permits non-commercial reproduction and distribution of the work, in any medium, provided the original work is not altered or transformed in any way, and that the work is properly cited. For commercial re-use, please contact academic.permissions@oup.com 
concern about the potential impact of excess leverage, thin capitalization rules could easily be designed to address the latter concern more forcefully. This might require making them significantly tougher, and generally counting borrowing from tax-paying residents as well as non-residents.

- Worldwide interest allocation rules for multinationals. Since international tax planning creates an important incentive for the extensive use of debt by large multinational companies, arguably it should be addressed distinctively, as a way of using the tax system to combat excess leverage, even if thin capitalization rules are revised (where necessary) to apply equally to payments to residents and non-residents. One possible mechanism is the source rules that all income -tax systems use to determine what portion of a given taxpayer's income arose domestically.

Nearly all countries-with the important exception of the USA-generally treat domestic borrowing as reducing domestic taxable income, and foreign borrowing as reducing foreign taxable income, without regard to where the borrowing occurred. Thus, suppose a multinational company borrows $€ 100$ million in a country with a 30 per cent tax rate, in order to invest the funds in a country with a 15 per cent tax rate. Suppose the interest rate is 8 per cent (or $€ 8$ million per year) and that the investment earns profits at only 7 per cent (or $€ 7$ million per year). While the investment loses money before tax, it is actually profitable after tax if-as most countries' tax rules would permitthe taxpayer can deduct its outlay at a 30 per cent rate while including its receipt at only a 15 per cent rate. ${ }^{10}$

The USA attempts to limit this incentive, though just for resident US corporations, by applying complicated 'worldwide-allocation' rules to domestically incurred interest expense that may result in allocating it pro rata to foreign assets. These rules have been criticized on various grounds, including their complexity and asymmetric treatment of foreign borrowing (which cannot give rise to domestic interest expense). ${ }^{11}$ Unfortunately, the underlying problem has no good solution, given that the fungibility of money impedes ascertaining how a given loan was actually used at the margin (in the sense of what outlay would have been forgone if not for the loan). ${ }^{12}$ For present purposes, it is enough to note that, while the US interest allocation rules are aimed at a tax-policy concern-protecting the domestic tax base-they can in practice reduce overall tax incentives for excessive leverage.

${ }^{10}$ Deducting $€ 8$ million at a 30\% rate would reduce the annual outlay to $€ 5.6$ million after tax, while including $€ 7$ million at a $15 \%$ rate would reduce the annual receipt to $€ 5.95$ million.

${ }^{11}$ See generally Shaviro (2001).

12 What is more, even if a given country's interest allocation rules 'correctly' allocated interest expense, inconsistency between its rules and those of other countries could cause some of a multinational's interest expense to be deducted either more than once or not at all, yielding peculiar incentive effects.

This is an open access version of the publication distributed under the terms of the Creative Commons Attribution-NonCommercialNoDerivs licence (http://creativecommons.org/licenses/by-nc-nd/3.0/), which permits non-commercial reproduction and distribution of the work, in any medium, provided the original work is not altered or transformed in any way, and that the work is properly cited. For commercial re-use, please contact academic.permissions@oup.com 


\subsection{Risk taking and the financial crisis}

Excess leverage was merely one input into a fundamental cause of the financial crisis, which was excessive risk taking by a wide range of large public companies. Failed or bailed-out companies from the 2008 crisis, such as AIG, are widely viewed as having followed a well-known strategy under which one 'earns small positive returns most of the time, but occasionally experiences dramatic losses... [causing it to be known as] picking up nickels in front of a steamroller' (Duarte et al. 2006). This strategy gave them years of high profitability, followed by socially costly collapses when, for example, housing or stock prices finally stopped rising steeply.

The popularity of the 'nickels in front of a steamroller' strategy reflected, not just irrationality, bubble psychology, and herd behaviour, but badly misdirected incentives outside the tax realm. At the entity level, limited liability and the 'too big to fail' scenario made risky bets by large public companies potentially worth making, from the shareholders' standpoint, even if they had negative expected social payoffs. At the managerial level, executives with highly earnings-sensitive compensation arrangements knew that the business judgement rule (protecting them from liability for almost any arguably reasonable business decision) meant that they could take 'heads I win, tails you lose' bets with the shareholders' money. In addition, the expectation that they could move swiftly from one company to another often gave them extremely short-time horizons, and the income effect of being able to earn so much in a short time often meant that they did not count on having decades-long successful careers. A couple of big years might set one up financially for life, even if the 'steamroller' hit one's former company a few years later.

All this is a non-tax story, of course. In so far as the tax system affected incentives for publicly held financial institutions to take on risk, it seemingly pointed in the right direction (given the above problems) by discouraging it. Given loss non-refundability, companies that win their gambles and have positive taxable income pay tax at the statutory rate, but those that end up with negative taxable income do not thereby generate negative tax liability (that is, a right to be paid by the government based on the statutory rate). Instead, they are limited to claiming net operating losses (NOLs) against positive taxable income in other years, generally with very limited (if any) loss carry-backs and more extensive loss carry-forwards. Where losses are carried forward, at a minimum the present value of the tax saving from them ends up being reduced, and in some cases they end up never being used.

Leaving aside concerns about excessive risk taking that came to light in the financial crisis, this asymmetrically adverse treatment of losses has only one possible justification. It reduces the scope for companies to drain revenues 
from the government by creating artificial tax-shelter losses. As things stand, tax-shelter losses that survive legal scrutiny, or else are not properly challenged on audit, can eliminate a company's positive tax liability (including for other years, through the use of NOLs), but at least they cannot generate net refunds from the government. However, if one were confident that taxpayers reporting tax losses genuinely had economic losses, the main effects of asymmetrically adverse treatment of losses would include (1) discouraging risky investments that might have a positive expected pre-tax return, and (2) encouraging otherwise inefficient mergers between companies so that those with positive taxable income could absorb the losses created by unsuccessful gambles.

Given, however, concern about excessive risk taking, should we conclude that the tax system's loss limits pointed in the right direction in this regard, and accordingly that limits on using NOLs ought if anything to be made stricter? As it happens, in the USA prior to the 2008 crisis, effective corporate tax rates were rising, largely because tax losses were becoming more frequent (Altshuler et al. 2009), ${ }^{13}$ implying that non-refundability mattered. The problem, however, is that it arguably was misdirected in so far as the 'nickels in front of a steamroller' strategy is concerned. That strategy may have excellent short-term odds of generating a profit, whereas the eventual loss when the 'steamroller' hits may not matter to executives with short-time horizons who may be long gone by that point.

This suggests that increasing risk neutrality by making the tax treatment of NOLs more favourable-for example, by lengthening carry-over periods or allowing the amount carried forward to grow at an annual interest ratemight not greatly worsen the problems of excessive risk taking in large public companies that contributed to the 2008 crisis. Two further considerations should be kept in mind, however. First, lengthening loss carry-forwards while limiting their transferability (as many countries do) can create a 'zombie firms' problem, in which failing companies that cannot produce efficiently are kept alive because of the value of their tax attributes. Second, the case for greater tax neutrality with respect to risk taking does not mean that lengthening NOL carry-overs, with retroactive application to pre-existing losses, is good tax or macroeconomic policy in response to a down business cycle. The retroactive loosening of loss limits is misdirected in so far as risk taking incentives going forward are concerned and, considered as fiscal stimulus, may amount to ill-directed 'stimulus for losers', since companies that have been making money derive no benefit from it.

13 The greater frequency of US corporate tax losses in the years before 2008 resulted largely from a decline in average profitability, rather than from greater variance (Altshuler et al. 2009).

This is an open access version of the publication distributed under the terms of the Creative Commons Attribution-NonCommercialNoDerivs licence (http://creativecommons.org/licenses/by-nc-nd/3.0/), which permits non-commercial reproduction and distribution of the work, in any medium, provided the original work is not altered or transformed in any way, and that the work is properly cited. For commercial re-use, please contact academic.permissions@oup.com 


\subsection{Taxation of derivatives}

Huge markets in complex derivatives are widely viewed as having helped trigger the financial crisis. They enabled companies to place huge bets cheaply (often pursuant to the 'nickels in front of a steamroller' strategy), while hindering investor and regulatory oversight and creating webs of counterparty risk that ended up transmitting credit problems across the world economy like a fast-travelling flu virus.

Derivatives are also good for tax planning, because they permit taxpayers to increase the degree of separation between the economic fundamentals of their positions, on the one hand, and the tax system's interpretation of what they are doing, on the other. To illustrate, suppose one wants the economic consequences of owning a particular stock, but does not want to be treated as the owner for tax purposes. Derivatives permit one to achieve much or all of the former without the latter. Thus, by the late 1990s, numerous non-US investors who wanted to hold stocks in dividend-paying US companies without being subject to US withholding tax on the dividends learned that they could achieve this by purchasing total return swaps.

Economically, the swaps gave these taxpayers economic positions that were identical (counter-party risk aside) to holding the stock directly with debt financing at, say, the LIBOR rate. As a matter of US tax law, however-at least as interpreted by sellers of the swaps, without timely pushback from the Internal Revenue Service-they permitted avoidance of the withholding tax, based on the fact that US tax law generally treats income from swaps held by foreign investors as foreign source income. Use of the swaps became sufficiently pervasive to prompt the Chief of Staff of the US Congressional Joint Committee on Taxation to refer to a widespread view that 'only fools pay withholding taxes on dividends today' (see Shaviro 2009b).

More generally, derivatives create three main types of problems for the tax system. The first is asymmetry in the treatment of counter-parties, as in the case where a periodic time value return can be deducted on one side without being included on the other. The second is inconsistency in the treatment of a given economic arrangement, depending on how it is structured (as in the total return swaps example). The third is imbalance in the tax treatment of gains and losses, as in the case where one can readily realize an ordinary loss, but in the event of a gain can either defer it indefinitely or else ensure that it is capital gain, taxable at less than the ordinary income rate (Raskolnikov 2008).

Despite special cases, such as the pervasive use of total return swaps to avoid US withholding tax, most observers believe that tax played only a secondary role in encouraging the growth of the derivatives markets that, in some key

This is an open access version of the publication distributed under the terms of the Creative Commons Attribution-NonCommercialNoDerivs licence (http://creativecommons.org/licenses/by-nc-nd/3.0/), which permits non-commercial reproduction and distribution of the work, in any medium, provided the original work is not altered or transformed in any way, and that the work is properly cited. For commercial re-use, please contact academic.permissions@oup.com 
cases, spectacularly collapsed in $2008 .^{14}$ One important reason why tax planning may not have borne greater responsibility for the derivatives explosion, at least in the USA, is that US tax law requires businesses that qualify as dealers in securities to use mark-to-market accounting with respect to all inventory items, and treat all gains and losses on such items as ordinary. Consistent mark-to-market accounting by both sides to a transaction eliminates any problems of asymmetry, inconsistency, and imbalance.

Even in cases with a non-dealer on at least one side, where tax considerations may often have encouraged the use of derivatives, the marginal impact may not have been great. In practice, companies often used the same carefully structured derivatives transactions to minimize tax liabilities, manipulate reported earnings, avoid regulatory constraints, and minimize the effectiveness of investor oversight. In these overdetermined circumstances, tax considerations, standing alone, may not have made a large difference, even though they clearly encouraged the underlying transactions.

Given the underlying incoherence of realization-based income taxation, in particular when it relies on formalistic categories such as discrete 'debt' and 'equity', the tax rules for derivatives are hard to improve in more than a piecemeal fashion that targets particular transactions. Broader progress might require expanding the mark-to-market rules' range of application. This, however, would raise administrative questions about how to value assets that are not publicly traded, along with probable political concerns about taxpayer liquidity to pay tax on unrealized asset appreciation.

\subsection{Corporate governance}

One clear lesson of the financial crisis was that corporate governance problems proved considerably worse than many academics had previously believed-not just in the 1990s heyday of the 'Chicago school' era, but perhaps even in the aftermath of the wave of accounting scandals (pertaining, for example, to Enron, Parmalat, and Tyco) that had abounded in the first few years of the twenty-first century. Managerial incentives to overstate earnings and create short-term profits, at the price of serious long-term downside economic risk (Bebchuk and Fried 2004), often proved beyond the disciplinary capacity of market forces. The problems were especially great with respect to financial firms, given the far greater difficulty of accurately assessing, say, AIG's economic performance than GM's.

14 However, an important exception to this widespread view is Eddins (2009), who argues that the growth and collapse of the collateralized debt obligation (CDO) market relied crucially on an underlying tax arbitrage play that required high risk in order to generate positive after-tax returns.

This is an open access version of the publication distributed under the terms of the Creative Commons Attribution-NonCommercialNoDerivs licence (http://creativecommons.org/licenses/by-nc-nd/3.0/), which permits non-commercial reproduction and distribution of the work, in any medium, provided the original work is not altered or transformed in any way, and that the work is properly cited. For commercial re-use, please contact academic.permissions@oup.com 
Tax considerations contributed to the corporate governance crisis in various ways. For one, tax-sheltering opportunities offer a rationale for reduced transparency that managers can then exploit to siphon resources from their firms without being observed by regulatory authorities, shareholders, or investors (Desai and Dharmapala 2008). For another, at least in the USA, tax considerations may encourage the use of incentive compensation. In particular, such compensation can be used to avoid an ill-conceived $\$ 1$ million ceiling on deductible annual salary payments to top executives at publicly traded companies. ${ }^{15}$ In addition, executives can often defer their US income-tax liability on the receipt of valuable property such as stock options. ${ }^{16}$ While this deferral may yield no overall tax benefit, since generally the employer's deduction is deferred as well, ${ }^{17}$ it has the optical benefit (from the managers' standpoint) of permitting compensation packages to appear smaller, as they need not be grossed up to achieve after-tax equivalence with payments that are currently taxable to them and deductible by the employer. Although incentive compensation is commonly rationalized as improving executive performance, it arguably backfired, both by encouraging an overly short-term focus (along with outright manipulation of reported earnings), and by reducing executive compensation's transparency (Bebchuk and Fried 2004).

Standard tax-reform principles would suggest treating different types of executive compensation neutrally, rather than inducing greater use of incentive compensation. One could even argue, however, for tilting the tax rules against at least poorly designed incentive arrangements. Thus, suppose one believes that poor design of executives' incentive compensation packages is too deeply rooted in current practice and institutional arrangements for even the shock of the financial crisis to induce the adoption of adequate changes. ${ }^{18}$ If one, therefore, supports a regulatory response to the problem, the tax system offers one possible vehicle. For example, rather than affirmatively requiring or barring particular types of compensation arrangements, one could use differences in tax treatment as a non-compulsory thumb on the scales. This might involve imposing modest tax penalties (including the

15 US Internal Revenue Code section 162(m).

16 See US Internal Revenue Code section 83(a) (generally permitting deferral where the property is subject to a 'substantial risk of forfeiture').

17 See US Internal Revenue Code section 83(h). If employer and employee marginal tax rates are the same, this makes deferral tax neutral, and thus seemingly irrelevant if the parties would respond to immediate taxation by grossing up the nominal option value so as to compensate the employee for it. Managers at publicly traded companies may none the less prefer deferral for optical reasons, because the gross-up makes their compensation packages appear to be larger.

18 The arguably suboptimal typical design features of typical executive compensation packages include failing to require retention of one's financial interest in the employer for a sufficiently long period (encouraging short-term thinking), and rewarding stock-prices increases even when they are shared with the stock market, or one's industry as a whole, rather than reflecting distinctive company performance. See, e.g., Bebchuk and Fried (2004).

This is an open access version of the publication distributed under the terms of the Creative Commons Attribution-NonCommercialNoDerivs licence (http://creativecommons.org/licenses/by-nc-nd/3.0/), which permits non-commercial reproduction and distribution of the work, in any medium, provided the original work is not altered or transformed in any way, and that the work is properly cited. For commercial re-use, please contact academic.permissions@oup.com 
denial of tax benefits such as deferral on the employee side) for compensation packages that were viewed as departing from best practices.

A second area in which tax-policy responses to corporate governance problems have recently been discussed pertains to the relationship between taxable income and financial accounting income. Managers of publicly traded companies notoriously attempt, in many cases, to shelter taxable income, on the one hand, while inflating reporting earnings, on the other, leading some commentators to suggest that closer relationships between the two income measures be mandated (Desai 2005; Shaviro 2009c). One of the main countervailing concerns, however, is that this might lead to the politicization of accounting standards, as legislatures that care more about the tax base expanded their accounting interventions in response to the linkage (Hanlon et al. 2005). ${ }^{19}$

\subsection{Taxation of housing}

Tax-policy experts have long argued against income-tax preferences for housing. The chief argument is the standard efficiency point that tax favouring one form of consumption over others leads to deadweight loss, as assets are shifted to tax-favoured uses, even when this reduces their pre-tax yield. Tax preferences for housing, and in particular homeownership, are none the less widespread, albeit not universal. This presumably reflects political considerations, as well as the administrative difficulty (or perhaps simply the counter-intuitive character) of taxing homeowners on their imputed rental income.

When exclusion of imputed rental income is accompanied by generally permitting home mortgage interest to be deducted, as under the US incometax rules, the problems caused may go beyond societal over-investment in homes relative to other assets. Taxpayers with limited net saving are effectively encouraged to hold a risky, undiversified asset with substantial leverage. If the tax rules also (as in the USA) provide a substantial exclusion for gain realized upon the sale of a home, while generally taxing other capital gains, the inducement to neglect elementary principles of investment diversification is greater still.

Provisions of this kind clearly would be expected to promote over-investment in real estate, along with the prospect that, in a down market for real estate, there could be extensive defaults and a serious impact on many households' net

19 In the European Community (EC), substantial progress towards developing a depoliticized common consolidated corporate tax base (CCCTB) might pose the question of whether to re-establish the close relationship between the tax and accounting income bases that existed in much of the EC until accounting standards began to be internationalized (Shaviro 2009d).

This is an open access version of the publication distributed under the terms of the Creative Commons Attribution-NonCommercialNoDerivs licence (http://creativecommons.org/licenses/by-nc-nd/3.0/), which permits non-commercial reproduction and distribution of the work, in any medium, provided the original work is not altered or transformed in any way, and that the work is properly cited. For commercial re-use, please contact academic.permissions@oup.com 
retirement saving. It is a somewhat different question, however, whether such provisions should be expected to (or in the early 2000s did) promote the emergence and collapse of a bubble market in real estate. Market bubbles remain an ill-understood dynamic phenomenon, whereas stable tax preferences might affect only the equilibrium. What is more, the emergence of housing bubbles, and their collapse in 2008, do not appear to have been limited to countries with substantial tax preferences for homeownership. In Chapter 3 of this volume, Hemmelgarn, Nicodeme, and Zangari conclude that 'the available evidence is mixed' regarding the relationship between tax rules and price developments, 'suggesting that lax monetary policy and increased risk taking by lenders are more powerful explanations of the housing bubble'.

Nonetheless, the 2008 financial crisis arguably strengthened, in two main respects, the already well-understood case for more neutral treatment of housing. First, the crisis dramatically illustrated the dangers of under-diversification and highly leveraged homeownership. Second, while tax-preferring homeownership is sometimes justified on the ground that it has positive externalities (for example, by encouraging residents to invest in neighbourhood quality), the recent fallout suggests that it may also have negative externalities. For example, the higher transaction costs of moving when one is a homeowner, rather than a renter, may slow economic adjustment when jobs disappear in some regions and arise in others. This may adversely affect, not just the homeowners themselves, but prospective employers and social-welfare systems.

\subsection{Conclusions}

Tax rules encouraging excessive debt, complex financial transactions, poorly designed incentive compensation for corporate managers, and highly leveraged homeownership may all have contributed to the financial crisis, but do not appear to have been among the primary causes. Even without a strong causal link, however, the pre-existing case for tax reform at all these margins is arguably strengthened by the 2008 financial crisis, which suggests that tax rules not only fell short of classic neutrality benchmarks but generally leaned in precisely the wrong direction. With respect to excessive risk taking, while the tax system arguably leaned in the 'right' direction by treating gains and losses asymmetrically, this seems unlikely to have mattered much to corporate managers who were pursuing short-term profits via the 'nickels in front of a steamroller' strategy.

In most of the above areas, increasing tax neutrality has much to recommend it, even apart from any impact on the likelihood of repeat financial crises in the future. With respect to corporate governance, however, if greater regulatory oversight is deemed necessary, the tax system provides a possible

This is an open access version of the publication distributed under the terms of the Creative Commons Attribution-NonCommercialNoDerivs licence (http://creativecommons.org/licenses/by-nc-nd/3.0/), which permits non-commercial reproduction and distribution of the work, in any medium, provided the original work is not altered or transformed in any way, and that the work is properly cited. For commercial re-use, please contact academic.permissions@oup.com 
vehicle for intervention that would rely on shaping incentives through nonneutral rules (for example, requiring that incentive compensation be appropriately designed if it is to receive favourable tax treatment, such as deferral). Even if this is not done, however, tax rules that treat even poorly designed incentive compensation more favourably than cash salary are clearly inappropriate and should be eliminated.

With respect to the effect of loss non-refundability on risk taking, allowing greater use of pre-existing NOLs would not improve incentives going forward. In addition, it might be criticized as misdirected 'stimulus for losers', and should not be structured in such a way as to encourage the perpetuation of 'zombie firms' that would otherwise be liquidated.

In addressing the non-neutral tax rules that pointed in the wrong direction in 2008, the chief obstacle is political choice. Expert views favouring greater neutrality were well known, but were not heeded. In the aftermath of the crisis, the lack of a strong causal link suggests that this state of affairs may be unlikely to change much. However, the one case in which discernible political trends may arguably end up pointing in the right direction concerns the tax system's debt bias, which could be significantly reduced if corporate rates continue declining relative to top individual rates.

This is an open access version of the publication distributed under the terms of the Creative Commons Attribution-NonCommercialNoDerivs licence (http://creativecommons.org/licenses/by-nc-nd/3.0/), which permits non-commercial reproduction and distribution of the work, in any medium, provided the original work is not altered or transformed in any way, and that the work is properly cited. For commercial re-use, please contact academic.permissions@oup.com 


\title{
Moving beyond the Crisis: Tax Policies for the Soundness of Financial Markets
}

\author{
Geoff Lloyd
}

\subsection{Introduction}

It is widely accepted that tax was not among the root causes of the 2008 financial crisis. But tax measures may have contributed in exacerbating nontax incentives to greater leverage, greater risk taking, and a lack of transparency (see Chapters 2-4).

Most countries' tax systems contain long-standing systemic biases in favour of corporate debt financing, even after allowing for a compensating bias favouring dividends or capital gains from equity investment over interest income. Changes in investment patterns and cross-border financial flows brought about by the twin forces of globalization and financial innovation may have significantly increased the impact of this bias in the first decade of the new century. A bias to debt finance raises financial stability concerns, because of the relative fragility of highly indebted companies, and because of the systemic impact of a credit crunch when the banking sector is exposed to substantial counterparty risk (Hanson et al. 2011). There is considerable anecdotal evidence of the tax bias to debt encouraging higher levels of gearing by companies, and banks have tended not only to gear up to the levels of debt allowed under regulatory capital rules but also to issue hybrid, equity-like, forms of debt, rather than ordinary share capital, where that satisfied both the regulators and the conditions for a tax deduction.

The common tax preference for investment returns in the form of capital gains creates a further bias in favour of investment in risky assets, where returns are likely to come largely in the form of appreciation. The fact that preferential tax treatment for capital gains is matched by limited tax relief

This is an open access version of the publication distributed under the terms of the Creative Commons Attribution-NonCommercialNoDerivs licence (http://creativecommons.org/licenses/by-nc-nd/3.0/), which permits non-commercial reproduction and distribution of the work, in any medium, provided the original work is not altered or transformed in any way, and that the work is properly cited. For commercial re-use, please contact academic.permissions@oup.com 
for capital losses reduces this bias only if investors actually consider the possibility of price declines. The same bias favours the relatively risky activities of private equity and hedge funds, whose managers are typically taxed at preferential capital gains tax rates, even where there is no risk of capital loss.

Systemic biases in favour of both debt financing and risky assets may each be exacerbated by increased tax arbitrage activity, again facilitated by globalization and financial innovation.

This chapter examines how the debt biases and the incentives to pursue returns in the form of capital appreciation may have contributed to the financial crisis. It focuses in particular on the use of complex securitization vehicles and tax havens to achieve complex forms of risk transfer that relied heavily on tax arbitrage strategies. While these biases may in part have disappeared as a result of the significant losses incurred by financial institutions, other tax-related asymmetries may come to dominate behaviour. The response of tax and regulatory authorities has been to extend and improve the domain of controls; this new regulatory environment has potentially a number of tax-related implications.

The remainder of this chapter examines first the root causes of the crisis and the nature of the regulatory response that followed immediately thereafter. It then looks at potential interactions between tax policy and the soundness of financial markets focusing on tax biases to corporate leverage, incentives to tax arbitrage, the role of securitization techniques, private equity and hedge funds, and the importance of tax havens. An appendix to this paper discusses the impact of the crisis on tax revenues with a particular focus on the tax implications arising from the loss position of many financial institutions.

\subsection{The financial crisis, its causes, and the regulatory response}

It is now widely accepted that the root causes of the financial crisis can be identified at two levels: global liquidity policies (low interest rates in particular nurturing a strong credit expansion with cheap leverage and bubble tendencies in asset prices); plus a poor regulatory framework, which not only failed to prevent the growth of asset bubbles but actually contributed to their growth and concentration into the specific areas, such as mortgage securitization, where the credit bubble eventually burst with such damaging consequences.

More immediate causes of the crisis can be categorized as follows (BIS 2009, 2010):

- the boom in credit and asset prices;

- a high appetite for yield and a high tolerance of risk;

- lack of transparency;

- inadequate regulation;

- inadequate governance. 
Particular shortcomings in the regulatory framework that have been commonly linked with the crisis include weak controls on securitizations and other off-balance-sheet transactions; lack of rigour on the part of credit-rating agencies; inadequate capital adequacy supervision; poor risk modelling; lapses in corporate governance; and poor levels of consumer and investor protection.

The banking business model facilitated by this regulatory environment has been characterized by a focus on short-term share-price growth rather than long-term soundness of banks' balance sheets and has been especially evident in the USA. Banks found ways of increasing profits by using derivatives to insure against high levels of credit and market risk while reducing their borrowing costs by ring-fencing liabilities in off-balance-sheet conduit subsidiaries. Bank employees were encouraged to seek short-term profits through bonuses based on fee income and up-front revenue, rather than on sustainable lending. The same banking model became prominent in other investment banking centres such as Switzerland, Germany, and the UK, and the same incentives, as well as market-share pressures, meant that the drive to greater leverage and off-balance-sheet activity was widely copied around the world, both in the financial sector and beyond.

Many of the defining elements of the pre-crisis financial sector were global in scope. The main root causes of the crisis-cross-border debt balances, exploitation of differences in regulation and in market prices (known as arbitrage), and the market for the highest-yielding investments-were all also global. Yet there is a fundamental tension between global integration of markets and nationally based regulation. In a globally competitive market, it is inevitable that market players will seek the most advantageous regulatory environment for financial transactions, and, where necessary, exploit differences in national regulations. Out of this tension between national regulation and global market integration emerged what has become known as the 'shadow banking system'. ${ }^{1}$

The shadow banking system consists of non-bank financial institutions that, like banks, borrow at short term in liquid forms, and lend or invest at long term in less liquid assets. Many 'shadow bank' institutions and vehicles emerged in US and European markets, between the years 2000 and 2008, and came to play an important role in providing credit across the global financial system. These included special purpose vehicle (SPV) companies, conduits, money market funds, monoline insurers, investment banks, hedge funds, and other non-bank financial institutions. Like commercial banks, these institutions are subject to

\footnotetext{
1 The term 'shadow banking system' is attributed to Paul McCulley of PIMCO, who in 2007 defined it as 'the whole alphabet soup of levered up non-bank investment conduits, vehicles, and structures' (<http://www.pimco.com/EN/Insights/Pages/GCBF\%20August-\%20September $\% 202007 . \operatorname{aspx}>)$.
} 
market risk, credit risk, and especially liquidity risk, since their liabilities are short term while their assets are more long term and illiquid. This creates a potential problem in that they are not depositary institutions and do not have direct or indirect access to a central bank's lender-of-last-resort support. Therefore, during periods of market illiquidity, they could go bankrupt if unable to refinance their short-term liabilities.

Investment strategies pursued by shadow banking entities can be regarded in many cases as destabilizing and corrosive of efficient and productive activity. For example, some of the 'absolute return' techniques of hedge funds-designed to secure profits for their investors even if market prices went down rather than up-could be used aggressively to force share prices deliberately down. High levels of leverage were able to be used in private equity fund takeovers to take profits out of the target company, and this led to a rise in leverage in potential target companies too, as they geared up to avoid takeover. The profits available to shadow banking entities through regulatory and market arbitrage opportunities offered by derivatives resulted in part from a diversion of financial and intellectual capital away from productive activity and into ultimately unproductive and destabilizing financial transfers. A by-product of this was a phenomenal growth in derivatives markets, to the point where the nominal value of derivative contracts outstanding was many times higher than the value of the underlying securities they might have hedged or insured. ${ }^{2}$

Some of the arbitrage opportunities made possible through the shadow banking system stemmed from the location of the funds or other entities in secrecy jurisdictions that lack transparency and are not prepared to exchange information on cross-border tax abuses. For tax-haven jurisdictions, the offering in terms of no or low tax and light touch regulation may have been seen as much as an expression of their own sovereignty as the tax regimes of other countries, and in an integrated global market it is inevitable that jurisdictions will compete for mobile financial business by offering regulatory and tax benefits, just as others offer benefits of infrastructure and political stability.

There has, of course, been a contraction/consolidation of the financial sector in the wake of the crisis, and the shadow banking system is the area in which financial-sector contraction has been greatest. There may, at least for a time, be some natural wariness of off-balance-sheet and offshore-based activity, as market players have had their fingers so badly burned. On its own, though, this trend is unlikely to persist, which is why governments may look for ways of permanently reining back the shadow banking system in the future and ensuring that financial-sector activity is suitably regulated wherever it arises.

\footnotetext{
2 See BIS Triennial and Regular OTC Derivatives Market Statistics <http://www.bis.org/publ/ otc_hy1011.htm>).
} 
Against that background, key elements of the coordinated regulatory response to the financial crisis endorsed by G20 leaders at the London summit of 2 April 2009 were as follows:

- the creation of a new Financial Stability Board (FSB) to provide early warning of financial risks and the actions needed to address them;

- extension of regulation and oversight to all systemically important financial institutions, instruments, and markets, including hedge funds; hedge funds or their managers will be required to disclose information, including on their leverage, necessary for assessment of the systemic risks they pose individually or collectively, and supervisors will require institutions that have hedge funds as their counter-parties to have effective risk management;

- the implementation of Financial Stability Forum (FSF) pay and compensation and corporate social responsibility principles;

- future improvements to bank capital adequacy regulation, which will prevent excessive leverage-specifically, that risk-based capital requirements should be supplemented with a simple, transparent non-risk-based measure to help to contain the build-up of leverage in the banking system, such as an overall, unweighted, minimum capital requirement;

- action against non-cooperative jurisdictions, including tax havens (covered in more detail below);

- call for improved accounting standards on valuation and provisioning (including strengthening of accounting recognition of loan-loss provisions and off-balance-sheet exposures), and generally towards a single set of global accounting standards;

- extension of regulation and oversight to Credit Rating Agencies.

In the first half of 2009, there was significant progress in the adoption of OECD exchange of tax information standard by a wide range of jurisdictions. All eighty-four countries monitored by the Global Forum on Transparency and Exchange of Information have now endorsed international tax transparency and exchange of information standards. This will reduce the attractiveness of structured finance products in tax-haven jurisdictions at least for nontax-compliant investors.

At the London summit, the G20 in addition:

- called for all countries and jurisdictions to adopt the international tax information exchange standard;

- agreed to develop a toolbox of effective countermeasures against jurisdictions that do not meet the tax transparency standard.

This is an open access version of the publication distributed under the terms of the Creative Commons Attribution-NonCommercialNoDerivs licence (http://creativecommons.org/licenses/by-nc-nd/3.0/), which permits non-commercial reproduction and distribution of the work, in any medium, provided the original work is not altered or transformed in any way, and that the work is properly cited. For commercial re-use, please contact academic.permissions@oup.com 


\subsection{Potential interaction between tax policies and the soundness of financial markets}

Tax considerations influence virtually all economic decisions and may have exacerbated other forces at work in the current crisis. Of particular interest are the taxation issues around securitization, the proliferation of collateralized debt obligations (CDOs), and the extraordinary boom in credit default swap (CDS) contracts, which played such a central role in the 2008 banking crisis. There are also more long-standing issues that deserve serious consideration as background influences, such as debt versus equity.

\subsubsection{A bias to corporate debt/leverage}

One long-standing issue is that there is an overall bias in many countries' tax systems encouraging corporate leverage. Changes in investment patterns and cross-border financial flows brought about by the twin forces of globalization and financial innovation may have significantly increased the impact of this bias in recent years. From a financial stability point of view, the key problem with high levels of leverage is that this makes companies more vulnerable to economic shocks and increases the probability of bankruptcy. Specifically, highly leveraged companies are particularly susceptible to volatility in profits (since they will be required to make interest payments irrespective of profitability) and-unless they have hedged-to volatility in currency or interest rates. Systemically, if leverage levels become unsustainable and lead to a credit crunch, firms and households are left without access to the credit they need, leading to a collapse in demand.

While banking operations are by their nature highly leveraged, for the most part the leverage has in the past been considered sustainable because banks rely on most depositors' desire to keep their deposits with the bank, together with a cushion of more permanent capital (as required for regulatory purposes), to be able to service claims for repayment of the bank's borrowing. However, leverage raises particular financial stability issues for banks, given the short-term nature of their borrowing and the fact that the regulatory capital 'cushion' consists to a large degree in retained earnings, which are the result of financial profits, which are volatile in that they are tied to the variations in stock markets, and (as recent experience has shown) highly susceptible to a collapse in asset values.

A systemic bias in favour of corporates financing themselves with debt (as opposed to equity) results from treating interest as a business cost in arriving at corporate profits, and so deductible for tax purposes against annual corporate profits, while treating returns to equity finance as a distribution of corporate 


\section{Geoff Lloyd}

profits, and not deductible in computing those. As a result, profits may be taxed both at corporate and personal level when they are distributed as dividends (see Box 8.1).

The tax bias in favour of debt is certainly a key factor in corporate financing decisions. Market disciplines may work to align the interests of various corporate stakeholders (that is, shareholders, creditors, and managers) as regards exposure to risk of individual enterprises. But the overall result may be more leverage than is desirable from a systemic point of view.

For the regulated financial sector, capital adequacy rules operate to limit the debt component of a company's capital, but even there the tax deduction for interest acts as an incentive for firms to maximize debt financing within the limits allowed by the regulators. A feature of the Basel capital adequacy regime for banks is that regulatory capital that takes the form of debt (much Tier

\section{Box 8.1. SYSTEMS FOR TAXING DIVIDENDS AT CORPORATE AND PERSONAL LEVELS}

\section{Systems with no double taxation}

- Full imputation (full taxation at corporate level, full credit at personal level): Australia, Mexico, New Zealand

- No personal taxation of dividends (profits taxed only at corporate level): Greece,Slovak Republic

\section{Systems with double taxation of economic rents only}

- Dividends taxedabove a deemed normal level at the corporate and individual level: Norway, Belgium.

\section{Systems involving double taxation}

- Classical (full taxation at both corporate and personal levels): Austria, Czech Republic, Germany, Iceland, Ireland, Netherlands, Switzerland ${ }^{a}$

o Modified classical (classical system but preferential taxation at personal level): Denmark, Japan, Poland, Portugal, Spain, United States

o Partial imputation (full taxation at corporate level, partial credit at personal level): Canada, Korea, United Kingdom

- Partial inclusion (taxation at corporate level, partial exclusion at personal level): Finland, France, Italy, Luxembourg, Turkey

- Split rate (dividends taxed higher than retained earnings at corporate level): None

- Schedule relief (dividends taxed but at a lower flat rate than progressive income tax): Hungary

a Some cantons use a modified classical system.

Source: OECD. 
2 capital and so-called innovative Tier 1 capital) can qualify for a tax deduction, further reducing the cost of capital. Such instruments work to ensure stable funding, but the debt-servicing arising from them remains a claim on the shareholders' income. There may be a case for tax systems not to encourage Tier 1 capital to be issued in the form of debt-like instruments (which in regulatory terms are functioning as equity).

Opportunities also exist for non-financial firms to reduce their cost of equity capital by issuing hybrid securities that function as equity for regulatory purposes but which for tax purposes are treated as debt. To qualify as debt for tax purposes, the securities are likely to be less permanent, and give the investor greater rights to dividends/interest, than ordinary share capital. Global issues of this form of 'cheap equity' — subsidized by the tax deduction they attracted-reached almost $\$ 180$ billion in 2007. Although its status as equity is clearly a matter for regulators, it is likely that the tax benefits of these hybrids encouraged a substantial take-up of less secure forms of capital than would otherwise have been the case.

The greatest tax distortions in favour of debt financing will be in situations where there is no compensating increase in taxation at the level of the investor, compared with the taxation of dividends or capital gains on shares. Such a compensating increase could in theory arise if tax systems systematically compensated for the bias to corporate debt through reduced taxation of dividends and capital gains on shares. In practice, the distortion is greatest when the investor is tax exempt, or when tax is evaded (for example, a nonresident evading his country's tax on income not subject to effective information exchange, particularly with respect to income not subject to withholding tax by the source country), or when hybrid structures ${ }^{3}$ are used to achieve either a double deduction ('double dip') for the interest expense or relief for the interest expense with no corresponding taxation. These issues are covered more fully below.

\subsubsection{The impact of international tax arbitrage}

As long as there are differences in and between national tax systems, there will be opportunity for tax arbitrage, and to a certain extent governments do and will continue to accept that this is a given fact in today's global economy. Specifically, there is wide scope for taxpayers to exploit international asymmetries relating to the tax treatment of debt financing, through arbitrage of

\footnotetext{
3 Hybrid structures are entities, transactions, or transfers that are treated as giving rise to debt for tax purposes in one jurisdiction or regime and simultaneously giving rise to equity for tax purposes in another. Tax benefits can be achieved by playing the benefits of these differences off against each other-known as tax arbitrage.
} 
the tax treatment of both corporate structures and financial instruments, or to shift income through stock lending or repurchase agreements in order to gain access to tax credits for tax withheld at source. Common tax arbitrage structures (see Box 8.2) provide incentives for both increased leverage and the taking-on of more risky investment (as marginally unviable projects become

\section{Box 8.2. EXAMPLE OF A COMMON 'DOUBLE-DEDUCTION' SCHEME USING A HYBRID ENTITY}

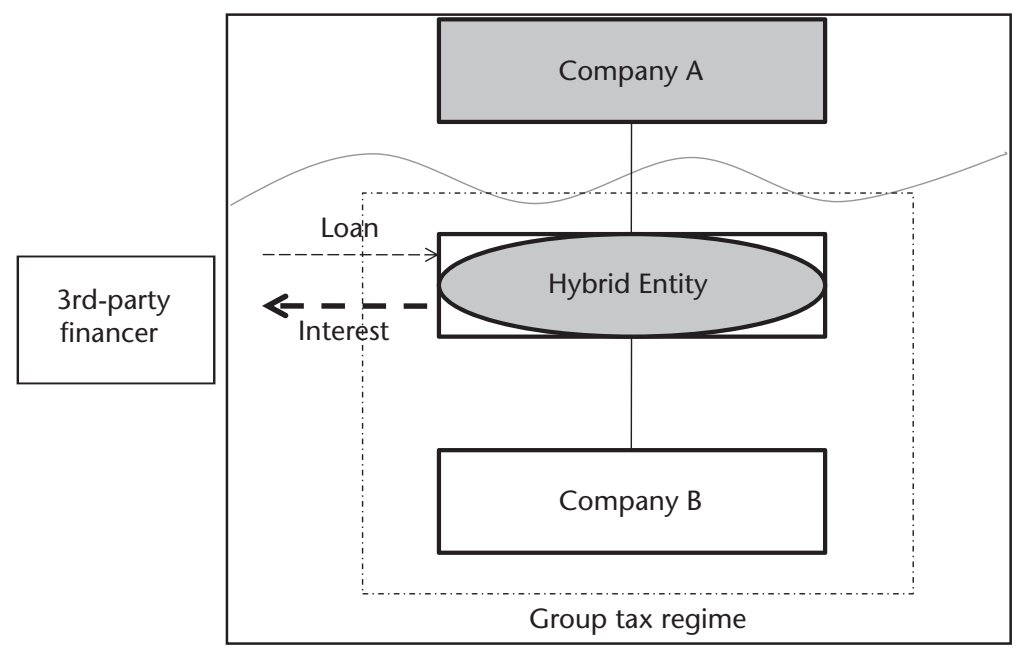

Figure 8A. Example of double-deduction management

Company A has a subsidiary (Company B) in country B, owned by an intermediate, hybrid, entity that uses third-party borrowing to finance $B$ Co. If the hybrid entity is regarded as tax transparent by country $\mathrm{A}$, its owner, $\mathrm{A}$ Co, will get a tax deduction in country A for interest paid on the hybrid entity's third-party loan, and, if the hybrid is at the same time regarded as tax opaque by country $B$, it will also get a tax deduction for that interest in country B, which B Co will also benefit from under the applicable group tax/fiscal consolidation regime in country $B$. The effect of this 'double-dip' arrangement is that there is an added benefit for leveraging A Co's investment in B Co with bank debt, and as such it adds further to a presumed existing bias for debt financing.

Similar double deductions (and incentive to leverage) can be obtained through hybrid instruments (treated as debt at one end of the transaction and as equity at the other) or through a combination of a hybrid entity and hybrid instrument. And, in some circumstances, highly structured arbitrage using hybrid structures and instruments allows a third-party lender to access a foreign tax credit that would not otherwise have been available, and that in effect encourages leverage by providing an unintended subsidy for cheap cross-border lending at the expense of the lender's home state exchequer.

This is an open access version of the publication distributed under the terms of the Creative Commons Attribution-NonCommercialNoDerivs licence (http://creativecommons.org/licenses/by-nc-nd/3.0/), which permits non-commercial reproduction and distribution of the work, in any medium, provided the original work is not altered or transformed in any way, and that the work is properly cited. For commercial re-use, please contact academic.permissions@oup.com 
viable due to the ability to finance them more cheaply by exploiting tax arbitrage benefits).

Arbitrage in capital markets can generally be beneficial, in tending to improve the efficiency of capital allocation through the removal of asymmetries in response to arbitrage. This is not the case for tax arbitrage, as the fixed legal parameters giving rise to the asymmetry do not get arbitraged away, however large the volume of transactions. This makes tax arbitrage potentially damaging in economic terms, as it encourages a growth in financial derivative transactions far in excess of the financing required for real investment. This diversion of productive activity, the encouragement of leverage, plus the fact that each derivative transaction necessarily introduces a counter-party credit risk, all potentially adds to financial instability.

\subsubsection{Capital gains versus income and securitization}

Often for good policy reasons, tax systems commonly contain a preference for investment returns in the form of capital gains. But this can create a bias in favour of investment in risky assets, where returns are likely to come largely in the form of appreciation. The fact that preferential tax treatment for capital gains is matched by limited relief for capital losses reduces this bias only if investors actually consider the possibility of price declines. The same bias favours the relatively risky activities of private equity and hedge funds, whose managers are typically taxed at preferential capital gains rates, even where there is no risk of capital loss. It could also provide an important motivation for securitization, benefiting investors who face higher taxes on their interest income than they can recover in the event of credit default losses.

For investors, securitizations offer access to a much wider range of risk/yield investment preferences than would be available from investing either directly in corporate shares or bonds or through a traditional collective investment vehicle. This is achieved through a combination of a 'pay-through' securitization structure (where the incoming interest and principal cash flows from securitized receivables can be reconfigured to give a different mix of interest and principal cash flows going out to investors), ${ }^{4}$ a multi-tranche capital structure for the securitization financing vehicle (giving a choice of different risk/yield exposures over the portfolio of securitized cash flows), and credit enhancement through the use of derivatives (in particular CDSs).

\footnotetext{
4 This is the case for mortgages in the United States where the 1986 Tax Act created real estate mortgage investment conduits (REMICs) as vehicles that are not themselves subject to tax but pass the tax liabilities through to investors much as a partnership does. It shifts the basis for taxation from the principal and interest received by the REMIC to the form in which it is paid to investors.
}

This is an open access version of the publication distributed under the terms of the Creative Commons Attribution-NonCommercialNoDerivs licence (http://creativecommons.org/licenses/by-nc-nd/3.0/), which permits non-commercial reproduction and distribution of the work, in any medium, provided the original work is not altered or transformed in any way, and that the work is properly cited. For commercial re-use, please contact academic.permissions@oup.com 
However, research by Samuel Eddins (2009) has highlighted the extent to which the 'pay-through' features of a securitization may provide potential tax benefits to investors who face higher taxes on their interest income than they can recover as capital losses in the event of credit default losses. The availability of these tax benefits to investors allows banks to reduce their borrowing costs, and can be magnified using a tax arbitrage through which banks and insurers can in effect sell their ability to take full tax deductions for credit losses to non-financial sector investors, by writing CDSs. This arbitrage is at its most profitable in relation to the lowest-quality/highest credit risk receivables, and is limited only by the level of available savings to invest and the amount of low-quality credit on the market. As such, this might have provided a substantial tax-driven incentive for the creation and securitization of the very kind of subprime debt bubble that was at the heart of the causes of the crisis, as a result of which tax may have contributed to or exacerbated the underpricing of credit risk (see Box 8.3).

\section{Box 8.3. TAX ARBITRAGE FEEDBACK THEORY IN SUMMARY}

Providers of capital seek to invest where risk-adjusted after-tax returns are the highest.

Free markets are available to all comers and therefore offer the same terms and prices to any and all investors.

The real world has many investor types subject to different tax rates and rules, depending on their status and the nature of their investment, but all competing within the same markets.

For example:

- a 'traditional' (individual or corporate) non-financial sector investor is likely to be taxed at income-tax rates on interest income, but will be taxed (and get tax relief, if at all) at-lower-capital-gains tax rates on gains (and losses) on the principal invested;

- a financial sector investor is likely to be taxed (and get tax relief) at income-tax rates on all profits and losses, without distinction between interest and principal;

- a tax-exempt (or non-compliant) investor will not be taxed (or get tax relief) at all;

- a high-yielding bond subject to relatively high risk of credit default will, therefore, be subject to a higher tax wedge for a 'traditional' investor than a lower-yielding/ lower-risk bond.

Up to a point, this difference can be alleviated through a 'pay-through' securitization in which the investor holds bonds issued by the securitization SPV. Overall, a pool of low credit quality receivables may, for example, yield only $95 \%$ of expected principal repayments, but $10 \%$ interest. But this mix can be transformed within the SPV by paying a $5 \%$ coupon on the bonds, and using the balance of income to meet $100 \%$ of principal repayments. The 'traditional' investor can, therefore, receive the same cash flows but in a more tax-efficient way-fully offsetting the underlying capital loss against the incometax receipt in a way that would not have been permitted with a direct investment. 
But substantially greater tax geared benefits can be achieved by arbitraging the tax position of the 'traditional' investor against that of a financial-sector investor, whosubject to sufficient tax capacity - can in any event set losses of principal off against income receipts. This can be done by the SPV enhancing the creditworthiness of the collateral for its bonds in the form of the securitized receivables by entering into a CDS with a bank, hedge fund, or insurer, in return for a fee. Tax-paying non-financial-sector investors will be prepared to finance this fee, through lower yields, in return for achieving a lower expected tax wedge on their return. For the financial institutions writing the CDS, this is a pure profit opportunity, financed by the expected tax saving achieved by the non-financial-sector investors. And the financial institutions in turn could lay off some or all of the credit risk taken on (while retaining all or some of the tax benefit) by entering into further mirrored credit derivative transactions with other counter-parties.

Profits available to financial institutions underwriting CDOs in this way are at their highest when the credit default risk is highest-since it is here that non-financial-sector investors face the greatest tax wedge compared with financial-sector investors-and are limited only by the supply of available savings and the supply of low-grade securitized debt.

It is not necessary for the market players concerned to appreciate that this arbitrage is essentially founded on the differential tax treatment of income and capital, on the one hand, and of the financial and non-financial sector, on the other-the profit opportunities emerge simply from the pricing of credit protection in the market. None the less, it provides a potent tax-driven incentive for a surge in low-grade securitized credit and for banks to switch from old-fashioned lending activity into the pure profits enabled by a government-financed tax arbitrage.

Eddins argues that an arbitrage incentive is created by tax treatment of interest and credit default losses that is symmetric for financial institutions, while many taxable 'buy and hold' investors face higher taxes on their interest income than they can recover in the event of losses. This means that insurance against default is worth more to the buy and hold investor than to the financial institution selling the insurance. The price of the insurance determines how the difference is shared between the buyer and seller, and Eddins believes that the market for such insurance was so large that the financial institutions writing the swaps were able typically to get most of the benefit. And, since the derivatives contracts allow the credit risk to be separated from the time value of the money component of the contractual interest rate on the security itself, the CDS is a very efficient instrument, as it requires essentially no capital, since there is no need to pay for the underlying security.

The empirical weight that should be placed on this argument is not clear, since linking the impact of the CDS through to the ultimate 'buy and hold' investors who would benefit from the arbitrage is not straightforward. Nevertheless, it is clear that significant investment into securitized subprime mortgage debt was made by hedge funds, which would have been able to pass those benefits onto individual investors in the form of higher after-tax returns. More generally, incentives become embedded in prices, even if no one has a full 
overview of the forces at work, and, since tax rates are fixed legal parameters, differentials do not get arbitraged away, however large the volume of transactions becomes.

\subsubsection{Leveraged buy-outs/private equity}

Low investment yields resulting in part from the surplus of global funds in the run-up to the crisis opened up arbitrage opportunities for companies and investors to buy higher yielding assets. Private equity firms took up these opportunities on a significant scale to use leverage to buy higher yielding corporate assets in the listed equity market, to take companies private and augment returns further. The strong growth of capital available to private equity resulting from strong investor demand, together with readily available and cheap loan finance, increased the pressure to move into increasingly high-risk and leveraged deals. Leveraged buyouts resulted in target companies being geared up with high levels of debt, compared with norms for publicly owned corporates, with a knock-on effect for potential target companies as they took on more debt to stave off a hostile takeover. This in turn will have significantly eroded corporate tax receipts. Private equity fund structures may also in some cases exploit international tax arbitrage opportunities to give a double tax deduction or 'double dip' for the interest expense (see Figure 8.1).

In a typical cross-border private equity structure, as set out in Figure 8.1, a local holding company is inserted that will initially borrow funds, supplementing the equity stakes of the limited partners in the private equity fund, to acquire the target. It will be part of a fiscal consolidation/tax group with the target company itself, so enabling interest deductions for its borrowings to be offset against target profits for corporate tax purposes, before then pushing debt down into the target itself through refinancing (and in the process securing early repayment of some of the limited partners' initial investment).

In some cases tax deductions may also be given for shareholder debt, as thin capitalization rules often provide only a weak protection against extraction of corporate profits by shareholders in the guise of interest, even though that is what these rules are designed to do.

The usual 'carried interest' ${ }^{5}$ tax treatment of private equity fund managers means that rewards to fund managers are taxed at preferential capital gains rates rather than as income. On one point of view, this is the 'right' result in

A private equity fund manager is usually the general partner in a fund partnership, and is typically rewarded with a $2 \%$ management fee and $20 \%$ share of the realized profits of the fund on its investments above a certain threshold. This $20 \%$ profit share is known as 'carried interest', because the financial capital underpinning it is provided or 'carried' by investors, who are limited partners, even though the management expertise, or 'sweat equity', which also contributes to the profit is provided by the fund manager.

This is an open access version of the publication distributed under the terms of the Creative Commons Attribution-NonCommercialNoDerivs licence (http://creativecommons.org/licenses/by-nc-nd/3.0/), which permits non-commercial reproduction and distribution of the work, in any medium, provided the original work is not altered or transformed in any way, and that the work is properly cited. For commercial re-use, please contact academic.permissions@oup.com 


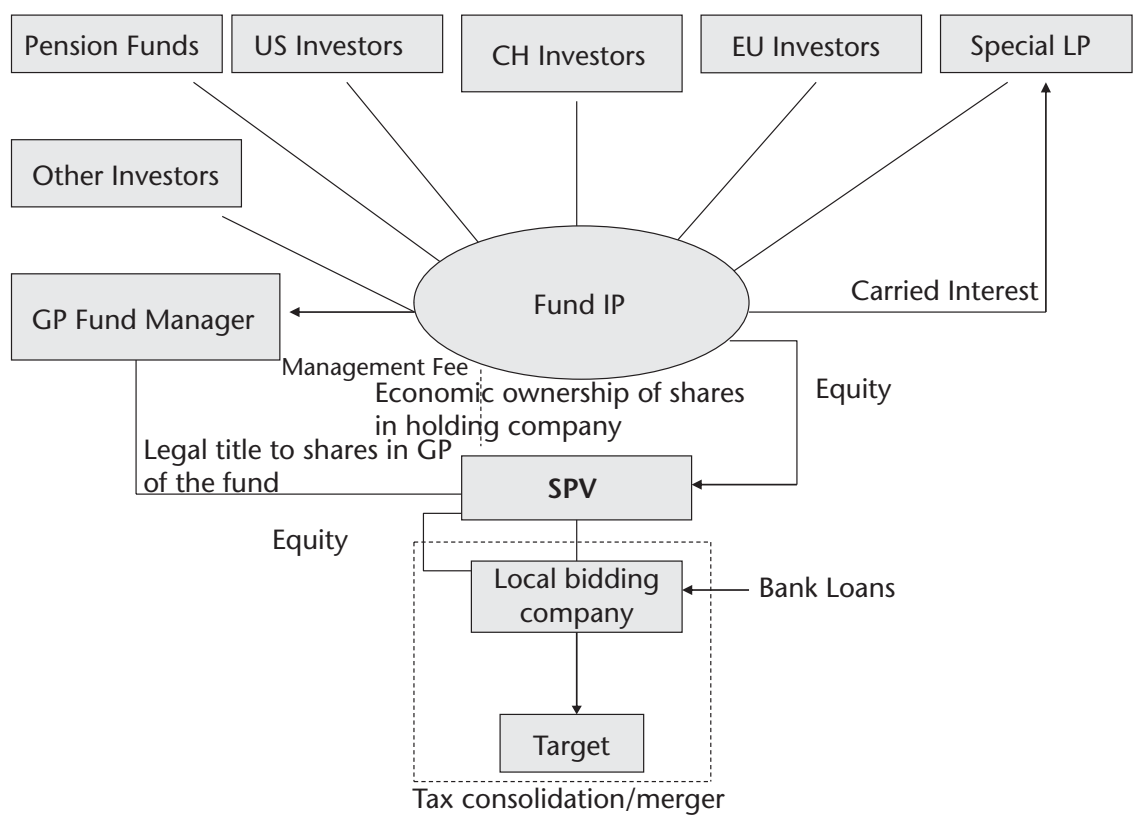

Figure 8.1. Representative private equity fund structure

policy terms, equating the tax treatment of fund managers with that of the so-called sweat equity introduced into a company by an owner-manager. An alternative view is that the manager's returns are akin to professional fees/ employment income, and should be taxed at marginal income-tax rates, matched by a tax deduction at the level of the fund (or for its investor partners) for the fees paid to the fund manager. The no-tax status of many private equity fund investors, however, offers a tax arbitrage under which a capital gains tax treatment of the fund manager's reward is always likely to be beneficial.

For a non-compliant investor, a lack of effective information provision to tax authorities on the income and gains of private equity fund investors could add to the potential incentives to invest via cross-border private equity funds; however, the proportion of high net worth individual (HNWI) investment in private equity funds appears to have been relatively minor.

\subsubsection{Hedge funds}

The 'absolute return' strategies pursued by many hedge funds-designed to make profits out of differences or changes in market prices, whether these go up or down-are likely to have been fuelled by tax arbitrage as well as non-tax arbitrage opportunities. Through borrowing and selling 'short', a fund on

This is an open access version of the publication distributed under the terms of the Creative Commons Attribution-NonCommercialNoDerivs licence (http://creativecommons.org/licenses/by-nc-nd/3.0/), which permits non-commercial reproduction and distribution of the work, in any medium, provided the original work is not altered or transformed in any way, and that the work is properly cited. For commercial re-use, please contact academic.permissions@oup.com 


\section{Geoff Lloyd}

behalf of its investors is able to profit from reductions in the market price of bonds or shares that would have given rise to a capital loss had the investor held the securities directly, and, by structuring investments through a limited company fed by an investment 'feeder' partnership, investors are able to benefit from taxation of what are essentially financial trading transactions at preferential capital gains tax rates.

Hedge fund managers also benefit from similar tax-privileged 'carriedinterest' treatment as private equity fund managers. And for non-compliant investors, offshore/untransparent structures ${ }^{6}$ and a lack of effective information provision to tax authorities at an investor level may have provided taxrelated incentives for non-compliant HNWIs to invest via hedge funds, where the proportion of private investors has traditionally been somewhat larger than for private equity funds.

\subsubsection{Tax havens and SPVs}

The interplay between tax and regulation appears to have contributed to the widespread use of tax havens as jurisdictions for the special purpose vehicles (SPVs) at the centre of the crisis.

For example, restrictions on credit quality applied to the underwriting standards of mortgages that could be securitized in the United States are fairly high. These restrictions could be avoided by the use of SPVs in tax havens, and the (higher) tax benefits of securitizing lower-quality mortgages could be obtained. Since certain tax havens levy no business income tax, SPVs offering CDOs can be structured there as limited liability companies without incurring any tax liabilities at the level of the SPV. For mortgage investors, this replicated the tax benefits of real estate mortgage investment conduits (REMICs) across a wider range of mortgages. For investors in private equity and hedge funds carrying out active management of businesses they have purchased onshore, this provided access to passive income without any tax complications arising from business activity. In particular, non-US and tax-exempt US private equity and hedge fund investors avoided the need to file returns or pay tax on a share of 'effectively connected income' or 'unrelated business taxable income' that the partnership structure of US-based SPVs would have required.

Non-tax reasons for using such jurisdictions to create SPVs include circumventing restrictions on transfers of shares and using equity structures not permitted in home countries. These would not have played an important role, however, with fixed interest structured products that accounted for most of the financing at the heart of the crisis.

\footnotetext{
${ }^{6}$ Some estimates suggest that as much as $70 \%$ of these funds operate out of the Cayman Islands.
}

This is an open access version of the publication distributed under the terms of the Creative Commons Attribution-NonCommercialNoDerivs licence (http://creativecommons.org/licenses/by-nc-nd/3.0/), which permits non-commercial reproduction and distribution of the work, in any medium, provided the original work is not altered or transformed in any way, and that the work is properly cited. For commercial re-use, please contact academic.permissions@oup.com 
More generally, the tax-neutral environment of tax havens means they can facilitate the conversion of income to capital or the deferral of income, which will generate higher after-tax yields or lower after-tax costs of capital through tax arbitrage, increasing incentives to leverage and distorting the allocation of resources. A lack of effective exchange of information for tax purposes also provides a draw for non-tax-compliant investors safe in the knowledge that high returns from their investment will not be disclosed to home tax authorities. This applies not only to non-residents, but also to resident businesses and individuals who are able to route their investments through an offshore haven to take advantage of the generally more advantageous tax benefits reserved for non-residents.

\subsection{Conclusion}

Tax was not among the root causes of the financial crisis. But tax measures may have contributed in exacerbating non-tax incentives to greater leverage, greater risk-taking, and a lack of transparency.

This chapter has examined how the greatest distortions in favour of debt finance have arisen from the asymmetry between taxation of the debtor and creditor-for example, if the creditor is exempt from tax, or if hybrid structures or instruments are used to exploit international differences such as through getting a double dip for interest relief. Arbitrage in capital markets can generally be beneficial, tending to improve the efficiency of capital allocation by arbitraging away asymmetries in pricing. This is not the case for tax arbitrage, since fixed tax parameters mean the distortion remains and can be exploited semi-permanently. This can lead to lost government revenues, wasted resources, increases in borrowing to finance the arbitrage, increased complexity, through use of financial derivatives to carry out the arbitrage (which in turn introduces new counterparty credit risks), and ever more complex tax measures introduced to protect tax revenues from arbitrage. Revenue authorities have evidence of attempted tax arbitrage by multinational companies on a significant scale, although some of this affects only transactions within groups of companies and so will not necessarily lead directly to increased leverage.

Differences in the tax situations of different investors encourage the formation of tax clientèles, where investors' choices depend on their particular tax situation. As well as limiting efficient risk diversification, this opens up opportunities for tax arbitrage that distort efficient market pricing. The collateralization of subprime debt through securitizations and associated CDS activity may have provided incentives for just this kind of arbitrage. Investors subject to capital gains tax (and restricted capital loss relief) were able to share in the 
high yields from low-grade debt as a result of the 'slice and dice' repackaging within securitization SPVs and from entering into CDSs with financial traders who could get full tax relief for default losses. This arbitrage among different tax clienteles was potentially most advantageous for the riskiest debt with the highest expected default rates.

Tax havens have been at the heart of the shadow banking system, which in turn has been at the heart of the high levels of leverage and risk taking at the root of the crisis. They are home to many of the conduits (SPVs and the like), money funds, hedge funds, and other non-bank financial institutions through which the pre-crisis bubble was inflated. The tax-neutral environment of havens means they can facilitate the conversion of income to capital or the deferral of income that will generate higher after-tax yields or lower after-tax costs of capital through tax arbitrage, increasing incentives to leverage and distorting allocation of resources. A lack of effective exchange of information for tax purposes also encourages non-compliance, as investors are aware that information will not be disclosed to their home tax authorities.

The OECD has achieved substantial progress in addressing risks of tax evasion through exchange of information, with over 100 member countries of the Global Forum on Transparency and Exchange of Information endorsing international tax transparency and exchange of information standards. ${ }^{7}$ This will reduce the attractiveness of structured finance products in tax-haven jurisdictions at least for non-tax-compliant investors.

To date there has been less coordinated action by governments to address potential systemic distortions caused by tax preferences for debt financing and for capital gains, partly because of the lack of hard evidence of the actual impact of such distortions, and partly because of the diversity of national tax systems and tax policy preferences in which these financial stability issues are just one element.

As part of an overall strategic response to the financial crisis, priorities in this area could be to raise awareness of the incentives to financial instability caused inadvertently by common features of national tax systems, to evaluate the impact of these incentives, and to identify whether there are well-targeted reforms that might reduce or remove tax distortions to excessive leverage, excessive risk taking, and lack of transparency in future.

7 <http://www.oecd.org/document/44/0,3746,en_21571361_43854757_47572780_1_1_1_1,00. html>. 
APPENDIX

\section{Addressing Tax Risks Involving Bank Losses ${ }^{8}$}

\section{Potential scale/fiscal cost of banks' tax losses}

The effects of the 2008 financial and economic crisis on bank profits worldwide have been phenomenal, with reported write-downs and losses of $\$ 1.3$ trillion up to January 2010 either directly related to the financial crisis, or coming from effects throughout the banking sector. Industry-wide returns on equity fell from 17.9 per cent in 2006 to 3.2 per cent in 2008 (Dayal et al. 2010). Of the 4,500 banks worldwide monitored by The Banker, around 200 incurred pre-tax losses of $\$ 5$ million or more in 2008 , totalling around $\$ 400$ billion (Lambe 2009). The largest commercial losses arose in those banks directly exposed to the collapse of the property market, which was the immediate trigger for the financial crisis. These were banks involved as originators of subprime mortgages, issuers of collateralized debt obligations (CDOs) linked to property assets, investors in asset-backed securities, or any combination of the three. These large commercial losses can be regarded as the flip side of large profits made in the years prior to the crisis, which in part were due to a combination of increased bank leverage coupled with asset valuations that underpriced risk, and a regulatory arbitrage involving transfer of assets to off-balance-sheet conduits that required only a fractiontypically less than 20 per cent-of the regulatory capital otherwise needed.

Reliable information on the likely extent and fiscal cost of banks' tax losses is not publicly available. However, the growth over time in published balance-sheet figures of net deferred tax assets can be taken as a broad proxy of what a bank believes is the growth in the stock of realized and unrealized tax losses carried forward, which the bank thinks it probable it can utilize. On these assumptions, and as a rough calculation, the stock of realized and unrealized tax losses at the end of 2009 may have been at least $\$ 700$ billion, with a potential fiscal cost of some $\$ 230$ billion. ${ }^{9}$ There are indications that it may take between three and eight years for this overall stock of bank tax losses to be utilized, with some banks remaining in a loss position for many more years to come.

\footnotetext{
8 This section has been prepared with Raffaele Russo. It summarizes the principal results of OECD (2010a).

9 Authors' calculations derived from The Banker database <http://www.thebankerdatabase. com>.
}

This is an open access version of the publication distributed under the terms of the Creative Commons Attribution-NonCommercialNoDerivs licence (http://creativecommons.org/licenses/by-nc-nd/3.0/), which permits non-commercial reproduction and distribution of the work, in any medium, provided the original work is not altered or transformed in any way, and that the work is properly cited. For commercial re-use, please contact academic.permissions@oup.com 


\section{Relevant country tax rules for recognizing and relieving losses}

Country rules differ in the extent to which write-downs and losses on banks' loans and securities are recognized for tax purposes. There are also wide variations in country rules giving relief for overall tax losses. This gives rise to potential international tax planning opportunities.

Tax loss relief rules are complex, and differ from country to country, giving rise to further potential tax risks for both business and revenue bodies. Sideways loss relief is available in most countries, while others ring-fence loss relief to particular types of income or profits. Group taxation regimes of one kind or another are available in many countries, although cross-border group taxation regimes exist in only a small number of countries. Carry-over of losses (forward or backward) is a feature of all tax systems, though here too there are marked differences between countries, with only a minority allowing the carry-back of losses, and most imposing a time limit on loss carry-forward. There are also different restrictions to the carry-over of losses triggered by a change in the ownership and/or the activity of the loss-making company, and the definitions of these terms also vary between countries. These restrictions may not apply in some countries on internal reorganizations within a group of companies, if there is no tax avoidance, or if there are specific exceptions to facilitate commercial rescue/restructuring plans. From a cross-border perspective, whether losses of foreign branches are relieved depends generally on whether double taxation relief is provided by way of a tax credit or exemption, while losses of foreign subsidiaries are generally not deductible in the country of the parent company (though there are some exceptions). 'Double-dip' reliefs for losses are expressly ruled out in some countries.

\section{Main issues for banks}

Losses give rise to various tax risks from the perspective of banks, which for the most part relate to certainty. Banks would normally not expect revenue bodies to revisit valuations signed off by auditors and more generally would like tax to follow accounts write-off treatment. Banks also expect revenue bodies to apply domestic and international tax rules consistently to both profits and losses. In addition, banks have a key non-tax interest in ensuring that they receive full tax relief for commercial losses, as tax losses can in some circumstances count towards regulatory capital available to support their business. Certain banks have indicated that revenue body support-in real timefor tax loss claims has directly influenced regulators in accepting tax losses as available to contribute to regulatory capital. Without this, the banks would have needed to issue new capital, repay borrowings, and/or reduce their lending activity, and this may have affected their recovery strategy.

\section{Main issues for revenue bodies}

Revenue bodies are concerned with ensuring the right amount of tax is paid at the right time, and will pay particular attention to the incentives that may affect that outcome one way or the other. Banks in many countries sustained substantial commercial losses, 
and revenue bodies will want to ensure that relief for those losses is given in accordance with the applicable law. However, revenue bodies are also concerned at the potential risk to tax systems posed by the extent to which banks might use aggressive tax planning schemes to extend relief for losses beyond what is due. To some extent, there are factors that potentially mitigate this concern, at least in the short term. The value of tax losses to banks as a source of regulatory capital in many countries may in some cases reduce incentives for banks to seek to sell those losses to unrelated parties. Beyond that, a contraction of the structured finance activity in the wake of the crisis may have temporarily reduced opportunities for aggressive tax planning involving structured finance products. Even so, the scale of the stock of tax losses, and the potential regulatory capital, profitability, and cash-flow benefits for banks able to convert them to cash, mean that revenue bodies are alert to potential compliance risk in a number of areas.

\section{Transfer pricing}

Transfer pricing is a key risk area in international taxation in general and may trigger particular attention in the case of loss-making banks or loss-making affiliates within profit-making banking groups. In the banking sector, the allocation of risks within a group has a very important and distinct role in profit/loss allocation, and revenue bodies are monitoring whether losses are allocated where the risks related to them belong. Particular attention will be devoted to the consistency of the transfer pricing policy of banks with the business models adopted over time. Revenue bodies are concerned that in some cases loss-making financial assets may be allocated to relatively high-tax jurisdictions, through non-arm's length transactions or dealings. Transfer pricing concerns have also been identified in relation to financial transactions-for example, non-arm's length prices for guarantee fees, related party interest rates, and split hedges.

\section{Corporate reorganizations}

A further potential compliance risk involves transfer of losses/profits through reorganizations. Tax rules do not always provide for symmetrical treatment of profits and losses, particularly where that might encourage tax-driven distortions, and revenue bodies are alert to techniques that frustrate necessary restrictions, including techniques that anticipate likely losses or that exploit CFC rules to import losses. Revenue bodies (in particular those where real-time working is the norm) are already examining the tax consequences of changes of ownership and reorganizations to ensure that the rules are being complied with. Techniques that raise concerns from the perspective of revenue bodies are, for example, the acquisition of a loss-making company for the only purpose of merging it into a tax group with profit-making companies, thereby reducing the taxable profits of other group companies by the losses of the acquired company. In other cases, revenue bodies have noticed an increase in the acquisition of loss-making companies towards the end of a tax year, before losses materialize for tax purposes. This may be due to the fact that restrictions on the carry-over of losses or on different forms of group taxation regime rarely apply in relation to parts of a tax period. Revenue bodies 
have also encountered cases where, in the course of corporate reorganizations, banking entities with loss-making activities have been allocated highly mobile income (such as income from financing or licensing of intangibles) so as to be able to offset their losses against the related income, despite the fact that they were not carrying out the economic activity giving rise to this income.

\section{Profit shifting using financial instruments}

The use of financial instruments as means of shifting profits or losses among different taxpayers is another potential area of concern for revenue bodies. Potential tax risks that have been identified in this area are the use of call/put options to transfer profits or losses for tax purposes, and the purported transfer of risks through swaps, other derivatives, and debt waivers. Some revenue bodies have identified back-to-back transactions that are primarily or exclusively motivated by the willingness to transfer or optimize the use of tax losses. There may also be cases where instruments that are in economic terms a loan or deposit to the bank are instead structured in a way that they qualify for tax purposes as shares giving rise to dividends. More generally, revenue bodies are alert to new tax planning techniques involving financial instruments that take advantage of the tax exhaustion of banks, as opposed to the (more traditional) techniques designed to shield profits from taxation.

\section{Loss carry-over rules}

Circumvention of loss carry-over rules is another area of potential compliance risk. The possibility of carrying back or forward losses against the income of other group companies is a particular concern in relation to group reorganizations. Country variations in loss relief rules may themselves create an incentive for tax planning. Countries allowing loss carry-back may attract tax planning aimed at releasing tax paid by companies reporting profits in previous years. Similarly, countries that provide for short loss carry-forward expiry dates may be particularly exposed to tax planning aimed at acceleration of loss utilization or loss refreshing, while other countries may be particularly exposed to planning aimed at loss importation. Examples of attempted loss-refreshing schemes that have been identified by revenue bodies include a bank's transfer of its perpetual loan obligation to a subsidiary at a value below its nominal amount, for which it claims to realize profits against which it can set off its expiring losses, in return for a potential future loss in the subsidiary.

\section{Loss recognition rules}

There is also concern regarding possible manipulation of bank loss recognition rules. In some countries different items of income are treated differently for tax purposes, and profits/losses from each type cannot be offset against each other. There is a risk that taxpayers try to circumvent these rules in order to obtain upfront relief for their losses. This includes, for example, the opportunities arising because of the different tax treatment of loans and securities, which in some instances are taxed on a realization 
basis and in others on an accrual basis, as banks are potentially able to control when they recognize a loss by deferring sales or bringing forward sales as needed.

\section{Double dips}

Another area of potential concern for revenue bodies is the multiple deduction of what is economically the same loss, generally through the use of hybrid mismatch arrangements. An increasing number of countries have rules dealing with schemes whose aim is to exploit the arbitrage possibilities that are due to the existence of differences in the applicable tax rules. In some cases these rules are based on a linking principle, according to which the domestic tax treatment is linked to the tax treatment in the foreign country, therefore preventing, for example, the deduction in more than one country of what is economically the same loss.

\section{Tools available to revenue bodies to address compliance risk}

Revenue bodies have a number of tools to help manage potential compliance risks, starting with encouraging responsible tax reporting through cooperation and dialogue. Initiatives aimed at establishing a fruitful and effective dialogue with the taxpayer are considered to be very useful in addressing the main compliance issues from the perspective of the revenue bodies, and these also carry important benefits for the taxpayer in terms of the greater certainty that comes from real-time working with the tax authority. Even where a dispute will be resolved through litigation, dialogue can help to clarify the positions taken by each party, and to reduce the costs to each party of the dispute being unnecessarily protracted. Real-time intelligence gathering on industry developments, the use of questionnaires, taxpayer alerts, hiring experts, and related staff training ensure that dialogue between the tax authority and banks is on a 'commercially aware' footing. Requests for rulings and clearances from revenue bodies also play an important role in gathering relevant information about banks' intentions and risk appetite. Disclosure rules also serve as an early warning system and may put aggressive tax planners on notice that the revenue body will want to analyse certain transactions in detail. For all countries, audits constitute an important tool to detect aggressive tax planning behaviour, and are clearly a key backstop to real-time dialogue and intervention. International cooperation among revenue bodies is particularly relevant in order fully to understand the details of taxpayers' activities, particularly in the area of complex financial instruments involving multiple countries. Joint audits may also play a useful role in this respect, since they allow revenue bodies to obtain relevant information in an efficient manner. Cooperation between revenue bodies and local regulators may also be an effective tool, since banks are required continuously to monitor their own risks, including their tax risks.

\section{Way forward}

There are differences in the experiences of different countries in relation to the taxation of bank losses, as well as differences in administrative, legal, and cultural frameworks. 
Against that background, OECD (2010a) makes a number of recommendations for revenue bodies and banks. These recommendations are set out in full below.

\section{Recommendations for revenue bodies}

To improve commercial awareness in order better to understand, assess, and respond to tax risks, while facilitating sustainable business activity, revenue bodies should work constructively with the banking sector and regulatory bodies to gain a shared understanding of the commercial context and the links between tax and regulatory reporting, building on the engagement that has underpinned this report. This could involve joint training, secondments, seminars, and workshops, including on a multilateral basis where appropriate.

To encourage transparent tax compliance and improve detection of aggressive tax planning, revenue bodies should:

- encourage real-time engagement and open and transparent relationships between banks and revenue bodies;

- consider with regulatory bodies how the transparency of financial accounts in relation to provisions for tax exposures might be improved;

- consider the use of disclosure rules for aggressive tax planning involving losses;

- remain alert to and actively monitor potential compliance risks involving bank losses; in this regard, revenue bodies could use deferred tax asset statements as a tool for better understanding banks' incentives for tax planning involving losses.

To reduce tax risks arising from complexities and uncertainties in the operation or interaction of country rules, revenue bodies should:

- consider the adequacy of their guidance for banks on how national loss relief rules apply and, where possible, to offer real-time discussion and resolution of issues;

- bring to the attention of their government tax policy officials those situations that may potentially raise policy issues, and in particular those where the same tax loss is relieved in more than one country as a result of differences in tax treatment between jurisdictions, in order to determine whether steps should be taken to eliminate that arbitrage/mismatch opportunity.

To benefit fully from international and domestic cooperation, revenue bodies should:

- share intelligence and information on aggressive tax planning involving banks' losses, including through an international network of revenue body officials and by contributing to the OECD Aggressive Tax Planning (ATP) Directory non-taxpayer-specific information on schemes involving tax losses, including on bank tax losses;

- share experience and best practices on how to identify and where possible address cases of multiple deduction of the same economic loss; 
- take opportunities to work closely with national regulatory bodies in addressing aggressive planning to maximize the use of losses for tax purposes, including in cases where that tax planning is intended to produce non-tax, regulatory, benefits.

To encourage earlier certainty, revenue bodies should:

- consider an enhanced relationship approach, where appropriate to a country's circumstances, based on the benefits to both taxpayers and revenue bodies; in this regard, revenue bodies should recognize the importance for banks' business activity in securing early certainty on the availability of tax losses within the applicable tax rules, and give appropriate priority to the resolution of potential disputes over tax losses.

\section{Recommendations for banks}

In order to reduce their tax risks involving losses, banks can contribute in the following ways:

- Banks have a key role in supporting a better commercial understanding of their business by revenue bodies, and could encourage that through dialogue, joint training, secondments, seminars and workshops.

- Banks should be open and transparent with revenue bodies in their planning involving tax losses, whether or not that is primarily tax or non-tax driven.

- Banks' boards should ensure appropriate corporate governance processes are in place around tax risk management, including resourcing internal audit activities, as a means to confirm that such policies are adhered to.

- Banks should highlight areas of uncertainty in the operation of current country loss recognition and loss relief rules, thus allowing revenue bodies and their tax policy officials to address that uncertainty in a timely manner.

- Consistent with the OECD (2010c, 2010d), banks are encouraged to support the way they have allocated tax losses to a particular jurisdiction with appropriate documentation, as this may reduce substantially the potential for disputes.

- In setting their business strategy, banks should consider the benefits of an enhanced relationship with revenue bodies, including early certainty, reduced compliance costs, and reduced reputational risk.

This is an open access version of the publication distributed under the terms of the Creative Commons Attribution-NonCommercialNoDerivs licence (http://creativecommons.org/licenses/by-nc-nd/3.0/), which permits non-commercial reproduction and distribution of the work, in any medium, provided the original work is not altered or transformed in any way, and that the work is properly cited. For commercial re-use, please contact academic.permissions@oup.com 


\title{
Government Debt Management at Low Interest Rates
}

\author{
Robert N. McCauley and Kazuo Ueda
}

\subsection{Introduction}

The advisability of central banks' extraordinary buying of government bonds is much debated. However, the question of how treasury debt management can contribute to maintaining the growth of bank assets, lowering long-term government bond yields, or reducing net government interest payments is rarely posed. The Bank of England's and Federal Reserve's March 2009 announcements of outright purchases of gilts and Treasury bonds drew more attention than the respective treasuries' announcements of large issues of bonds around the same time. Inattention to debt management in the context of proposals to alter the duration of government debt in private hands is puzzling. After all, the government balance sheet tends to bulk large in relation to that of the central bank. As a result, a substantial change in the central bank's assets can be offset by a small change in government liabilities.

This chapter first discusses the objectives of debt management and monetary policy and the complementarities and tensions between them, especially at low interest rates. It then reviews the interaction of central bank purchases of government bonds and debt management in the United States in the 1930s and Japan in the late 1990s and the 2000s. A discussion of initiatives undertaken in the United Kingdom, Japan, and the United States follows.

The authors thank Naohiko Baba, Claudio Borio, Brendan Brown, Michael Cross, Jacob Gyntelberg, Richard Koo, Kenneth Kuttner, Hiroshi Nakaso, Akira Otani, and Frank Packer for discussions, and Jhuvesh Sobrun for assistance. Any errors remain those of the authors. Authors' views are not necessarily shared by the Bank for International Settlements. This chapter was originally published as McCauley and Ueda (2009).

This is an open access version of the publication distributed under the terms of the Creative Commons Attribution-NonCommercialNoDerivs licence (http://creativecommons.org/licenses/by-nc-nd/3.0/), which permits non-commercial reproduction and distribution of the work, in any medium, provided the original work is not altered or transformed in any way, and that the work is properly cited. For commercial re-use, please contact academic.permissions@oup.com 


\subsection{Interactions between debt management and monetary policy}

A government with sizeable financial obligations must choose its debt composition: fixed-rate or short-term/variable rate; domestic or foreign currency; nominal or price indexed. These choices comprise debt management. Nowadays, debt management generally aims to minimize cost, to limit variability of interest payments and bunching of cash flows, to offset variation in taxes and spending, or to achieve some combination of these. Not so long ago, debt management was given a role in stabilizing the economy, alongside, or even as a part of, monetary policy.

Monetary policy seeks to stabilize prices and economic activity by influencing spending by firms and households. When activity strains an economy's capacity, policy restrains spending. When activity falls short, policy attempts to stimulate spending. In many countries, monetary policy had come to focus on hitting an inflation objective by setting a short-term interest rate.

The goals and conduct of debt management and monetary policy can complement each other, but can also give rise to tensions. The traditional view was that the cost of debt service was secondary to the need to 'fund' the debt-that is, to issue fixed-rate debt so long dated that banks would not hold it (or it would not serve as near money for non-banks). Structurally, skilful debt management aids monetary policy in producing a deep, liquid, and resilient market for operations. However, debt management aimed only to minimize costs might create tensions with monetary policy by relying on short-term debt (given the normal upward slope of the yield curve). Over the business cycle, debt management can 'get in the way' of monetary policy, for instance, if bonds are issued heavily when the central bank is easing.

The scope for interaction and even tensions depends on how the economy works and how monetary and debt management policies are implemented. In terms of the economy's functioning, this scope is minimal if the mix of bills and bonds does not matter for the shape of the yield curve or the economy at large. Private investors may treat treasury bills and bonds as perfect substitutes, pricing bonds as an average of expected bill yields over the bond's life. In this case, the mix of bills and bonds will not affect yields. ${ }^{1}$ For the scope for interaction to be minimal, debt composition must also not affect firm and household spending through its effect on broad money (Box 9.1).

\footnotetext{
1 For a recent discussion of the case of perfect substitutability, see Clouse et al. (2003), and the evidence in Baba et al. (2005) and Oda and Ueda (2007). For imperfect substitutability, see Bernanke et al. (2004) and Kuttner (2006).
}

This is an open access version of the publication distributed under the terms of the Creative Commons Attribution-NonCommercialNoDerivs licence (http://creativecommons.org/licenses/by-nc-nd/3.0/), which permits non-commercial reproduction and distribution of the work, in any medium, provided the original work is not altered or transformed in any way, and that the work is properly cited. For commercial re-use, please contact academic.permissions@oup.com 


\section{Box 9.1. BOND BUYING AND DEBT MANAGEMENT: A QUANTITATIVE VIEW}

Following Congdon (2003), this box simplifies the economy's balance sheet to show the quantitative differences among various operations that can be carried out at very low interest rates. The upshot is that a central bank's purchase of government bonds can be seen as a compound of quantitative easing, defined as the central bank injecting funds into the banking system, and a debt management exchange of treasury bills for treasury bonds. This graphical 'T-account' exercise is consistent with King's emphasis (2009) on the purchase of gilts from the 'wider economy', and not just banks, as well as the Bank of England's purchase of gilts of five to twenty-five years' residual maturity, usually held by non-banks.

In the initial situation (Figure 9A, top left-hand panel), the government has a mix of bill and bond liabilities. The bills are held by the central bank and the commercial banking system. The non-bank private sector holds bonds and deposits in the banking system. Cash holdings are abstracted away, so that bank deposits comprise the stock of money. The corporate and household sectors as borrowers from banks and issuers of bonds are also abstracted away.

In this simple schema, one can represent quantitative easing as an operation between the central bank and the commercial banking system (Figure 9A, upper right-hand panel). The central bank buys treasury bills with its liabilities, and bank reserves increase. Not much happens: the banks hold fewer treasury bills paying essentially no interest but

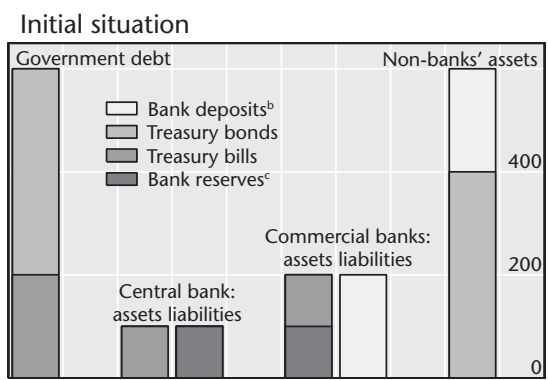

Quantitative easing: central bank buys bills ${ }^{a}$

Debt management: bills swapped for bonds ${ }^{d}$
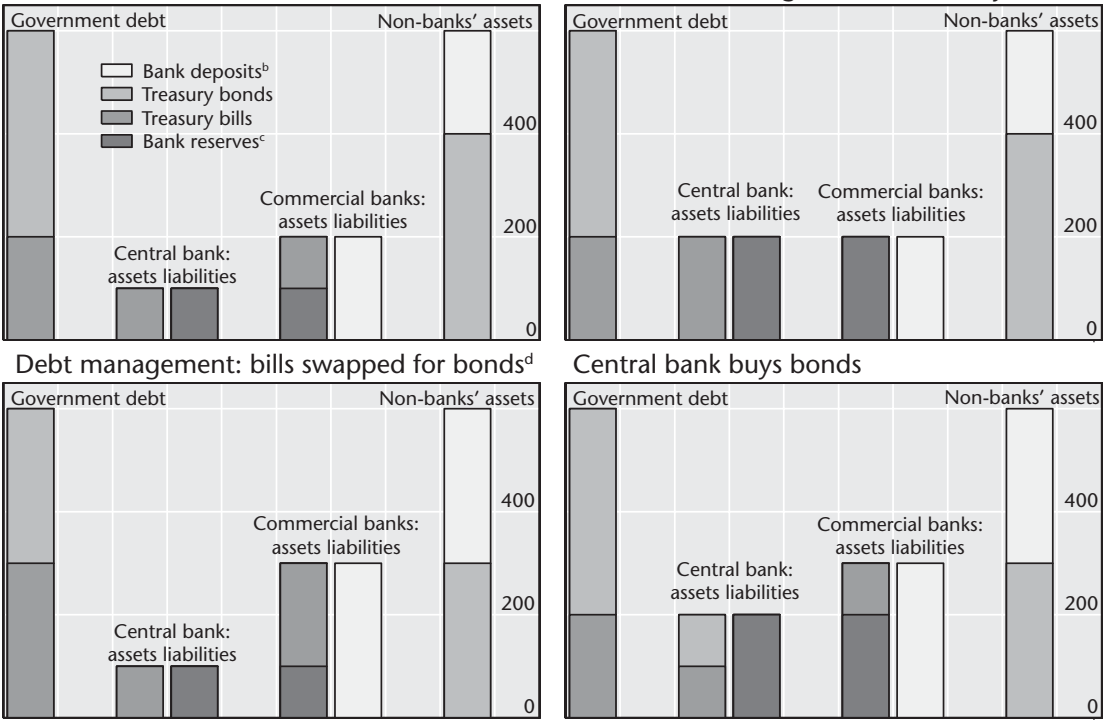

Central bank buys bonds

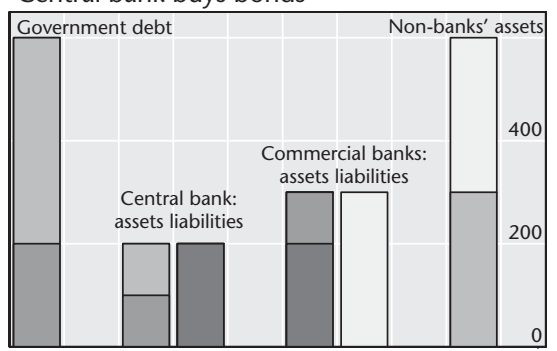

Figure 9A. Stylized monetary and debt management policy

a The central bank buys 100 bills from commercial banks. Their cash reserves increase by 100 .

b Held by the private sector.

' Commercial banks' deposits with central bank.

${ }^{d}$ The government sells 100 in bills to the commercial banks and buys 100 in bonds.

Sources: Congdon (2003); authors' adaptation.

\section{6}

This is an open access version of the publication distributed under the terms of the Creative Commons Attribution-NonCommercialNoDerivs licence (http://creativecommons.org/licenses/by-nc-nd/3.0/), which permits non-commercial reproduction and distribution of the work, in any medium, provided the original work is not altered or transformed in any way, and that the work is properly cited. For commercial re-use, please contact academic.permissions@oup.com 
more similarly unremunerative bank reserves. This simplifies the Bank of Japan's operations, which used a wide set of instruments and counter-parties, and the range of holders of bank reserves (which included holdings of foreign banks that had swapped dollars for yen), but it captures the disconnect between rapid growth of bank reserves and muted growth of the money supply that was observed in Japan.

A debt management operation can in principle have greater effect, at least in this simple financial system (Figure 9A, bottom left-hand panel). The Treasury sells bills to commercial banks and buys bonds from non-bank investors with the proceeds. The nonbank private sector holds less risky treasury bonds and more bank deposits (more money). (Bank reserves are assumed to be a non-binding constraint.)

A central bank that buys treasury bonds basically combines these two operations (bottom right-hand panel). The central bank credits the bank of the seller of the bond with bank reserves, and the bank credits the non-bank investor with a deposit. Money holdings increase, as with the debt swap of bills for bonds, but banks hold more excess bank reserves rather than bills.

In the real world, the results in this simplified financial system may not follow through. The non-bank private sector has in fact borrowed from the commercial banks. Thus, purchases of government bonds by the government or central bank might finance nonbanks' repayment of such bank debt rather than boosting broad money (UK House of Commons 2009). (In particular, an institutional investor might sell a government bond and purchase a newly issued corporate bond, and the issuer might repay a bank loan.) Finally, even if broad money can be increased, it is not clear that would necessarily increase spending by firms and households.

Until recently, the way monetary and debt management policies were implemented had narrowed the scope for their interaction. As noted, monetary policy entailed setting the overnight interest rate in response to inflation and growth forecasts. Though details differed, central banks operated at the short end in secondary markets or against collateral and thus left the mix of government bills and bonds in private hands unaffected. In this sense, monetary policy left debt management policy to the debt manager. For their part, debt managers had generally opted to 'regularize' debt by issuing steadily and predictably to minimize costs (Garbade 2007). Such debt management hardly enters into the central bank's forecast.

There is some mapping between institutional arrangements and the interactions of the two policies. A generation ago, the Bank of England and the Reserve Bank of India both served their governments as debt managers, consistent with a concept of monetary policy as embracing debt management. Subsequently, as the Bank of England focused on inflation targeting through short-term rate setting, debt management was moved to a separate dedicated office (Bleijer 1999). Many governments in the euro area have also set up debt management offices (Kalderen and Blommestein 2002), given Eurosystem monetary operations that advance against broad collateral rather than buying government debt outright. In the United States, where the central bank's 


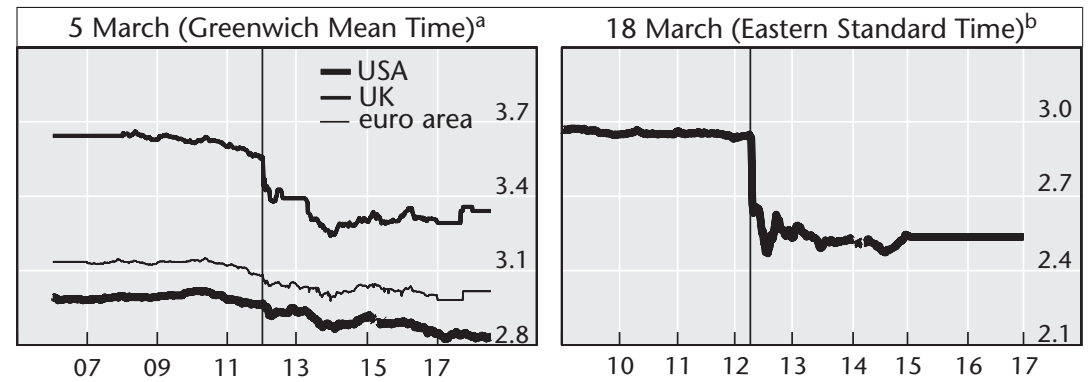

Figure 9.1. BoE and Fed buyback announcements: ten-year government bond yields (\%) a The vertical line marks the Bank of England's $£ 75$ billion asset purchase programme announcement.

b The vertical line marks the Federal Reserve's announcement of $\$ 300$ billion in purchases of Treasury coupon securities.

Sources: Bloomberg; BIS calculations.

mission remained broader, the Treasury and the Federal Reserve have continued to cooperate in debt management as principal and agent.

The scope for interaction between monetary policy and debt management has widened. In part, this is due to the tide of opinion, which has been running against the view that bond yields approximate the average of future short-term rates, rendering bills and bonds perfect substitutes.

The sceptics of this perfection point to the market reactions to the Bank of England's and the Federal Reserve's surprising announcements in March 2009, when yields fell by about 40 basis points in each case (Figure 9.1). Moreover, bond market anomalies during the financial crisis have heightened doubts about the power of arbitrage and speculation along the yield curve. ${ }^{2}$ To many other observers, however, these market reactions amounted to no more than a spasm of short covering subject to reversal over weeks.

More fundamentally, the scope for interaction has increased in three ways with the extraordinary policy responses to the crisis that began in 2008. First, short-term yields near the zero limit have led central banks to use their balance sheets to affect quantities and yields (BIS 2009: ch. VI). As the room for manœuvre with policy rates shrank, central banks advanced funds and bought assets in size, originally shedding government debt in some cases, but now including government debt. Domestic assets on central bank balance sheets have risen in some cases to double digit percentages of GDP, though still generally well below the government's domestic currency liabilities (Figure 9.2).

2 Anomalies include the inversion of swap yields below government yields at long maturities, implausible deflation indications from price gaps between benchmark bonds and illiquid inflationindexed bonds, and the pricing of floating rate notes in the JGB market (see below). 


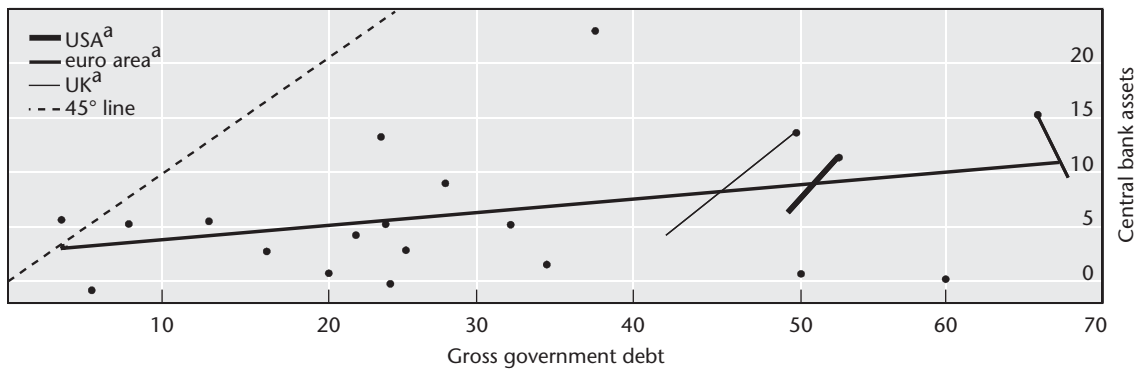

Figure 9.2. Gross government debt and central bank assets (domestic currencies, as a percentage of GDP in 2008)

${ }^{a}$ The line indicates the change from 2006 to the latest period.

Note: Countries represented are Argentina, Australia, Brazil, Chile, China, Chinese Taipei, the euro area, India, Indonesia, Korea, Mexico, the Philippines, Poland, South Africa, Sweden, Switzerland, Thailand, Turkey, the UK, and the USA. For central bank assets, 2007 figures for China; 2006 figures for the Philippines; for the euro area, 2007 figures and total debt instead of government debt. Gross government debt and central bank assets for Japan (not shown) are $180 \%$ and $21 \%$, respectively.

Sources: IMF; JPMorgan Chase; national data.

Second, as short-term interest rates approach zero, central bank liabilities and treasury bills become very close substitutes (Ueda 2001). ${ }^{3}$ As a result, when money yields nothing, central bank purchases of government bonds and the government debt manager's swapping of bills for bonds are 'indistinguishable' (King 2004: 11). Figure 9A in Box 9.1 traces graphically the similarity in terms of balance sheets and holdings of broad money.

Third, the central bank is often urged to take actions that are the province of the debt manager. For instance, Auerbach and Obstfeld (2005) suggest that the central bank reduce the net cost of government debt service by buying bonds at yields stuck at levels well above zero short-term rates. This proposal draws on the long-standing notion that debt management can be used to hedge macroeconomic risks and associated variation in tax receipts and expenditures (Missale 1999). In particular, reliance on short-term or floating rate debt will save on interest payments if the economy remains weak and subject to deflation, while higher taxes will offset higher interest payments in case of an economic rebound. Such proposals may be well taken or not, but there is no necessary central bank role unless debt management is on autopilot.

In sum, starting from a situation in which monetary and debt management remained in their respective corners, current circumstances have brought them closer. What can we learn from a review of two episodes in which the central bank bought government bonds even as the treasury managed the debt?

\footnotetext{
3 Payment of interest on excess reserves or issuance of interest-bearing central bank bills make central bank liabilities close substitutes for treasury bills even at positive yields.
}

This is an open access version of the publication distributed under the terms of the Creative Commons Attribution-NonCommercialNoDerivs licence (http://creativecommons.org/licenses/by-nc-nd/3.0/), which permits non-commercial reproduction and distribution of the work, in any medium, provided the original work is not altered or transformed in any way, and that the work is properly cited. For commercial re-use, please contact academic.permissions@oup.com 


\subsection{US debt management in the early 1930s and Federal Reserve bond purchases}

There are two accounts of the monetary policy mistakes of the early 1930s in the United States. They agree that bank deposits (the money supply) should have kept growing, but they differ on how this should have been done.

US monetarists say that the Federal Reserve erred in not buying more Treasury securities in order to increase bank reserves held at the Federal Reserve (Friedman and Schwartz 1963; Meltzer 2002). Large, sustained Treasury purchases, either bills or bonds, would have pushed short-term interest rates to zero and provided banks with large excess reserve. At some stage, they would have made loans and thereby sustained bank deposits. (In terms of Figure 9A in Box 9.1, these US monetarists leave it unclear whether their recommended policy is the top or bottom right-hand panel.)

Others say that the Treasury erred by not supplying bills in exchange for bonds in order to maintain bank assets and thus bank deposits (Culbertson 1957). After the collapse of share and commodity prices, private borrowers paid down securities credit and non-real estate loans, and banks thereby lost the bulk of their liquid assets. Banks could have replaced these private advances with holdings of Treasury bills, introduced in 1929 (Garbade 2008). Instead, the Treasury rolled over maturing First World War bonds with new bonds and left a vacuum on bank balance sheets. (In terms of Figure 9A in Box 9.1, this account corresponds to the bottom left-hand panel.)

These two arguments agree in their support for increased private-sector holdings of highly liquid claims, either excess reserves at the central bank or Treasury bills. They disagree in that the US monetarists see bills and bonds as perfect substitutes, and as a result do not specify whether the Federal Reserve should have purchased (or did purchase) one or the other. To them, bank reserves ('high-powered money') differ from Treasuries, and, in sufficient amounts, eventually lead to credit and broad money growth. On the other side, bills and bonds are considered as different and held in different portfolios so that a shift towards bills tends to boost broad money growth. In this view, when short-term interest rates are near zero, exchanging excess bank reserves for Treasury bills is seen as not helpful (as in the top right-hand panel of Figure 9A in Box 9.1).

In terms of price effects, at least some Federal Reserve officials at the time believed that their buying of Treasury bonds could raise their price and bring down their yields. For instance, in June 1930, Governor Harrison of the Federal Reserve Bank of New York argued to his fellow governors that purchases of 
Treasury bonds could 'lower long-term rates, increase loans to foreigners and thus stimulate exports' (Meltzer 2002: 307).

In terms of fiscal effects, if Treasury bills had been substituted for bonds (or the Federal Reserve had bought Treasury bonds in size), the immediate interest savings could have been substantial. It is remarkable how little long-term Treasury yields responded to the decline in Treasury bill rates through the first half of 1931 (Figure 9.3). Even if Treasury bond yields had not fallen owing to a shift from bonds to bills, interest costs could have been lower.

In the event, Federal Reserve purchases of Treasury securities barely reduced the amounts of bonds held by private investors through 1932 (Figure 9.4, lefthand panel). In particular, the bond purchases of the summer of 1930 are hardly visible. The Federal Reserve Bulletin reports Treasury debt in millions of dollars, but the Federal Reserve balance sheet in thousands. And, except in the summer of 1930, the Federal Reserve generally held more Treasury bills (and certificates) than bonds.

Broad money shrank as the decline in bank credit to private borrowers was not offset by increased holdings of Treasury securities. Even given the lack of an expansive fiscal policy that would have increased the supply of Treasury securities, the Treasury's choice to replace maturing bonds with new bonds failed to provide the banking system with safe and liquid assets. The result, hardly affected by Federal Reserve bond purchases, was that overall assets and bank deposits declined (Figure 9.5). Such was not the experience in Japan in the late 1990s and 2000s, where bank purchases of government securities kept broad money growing.
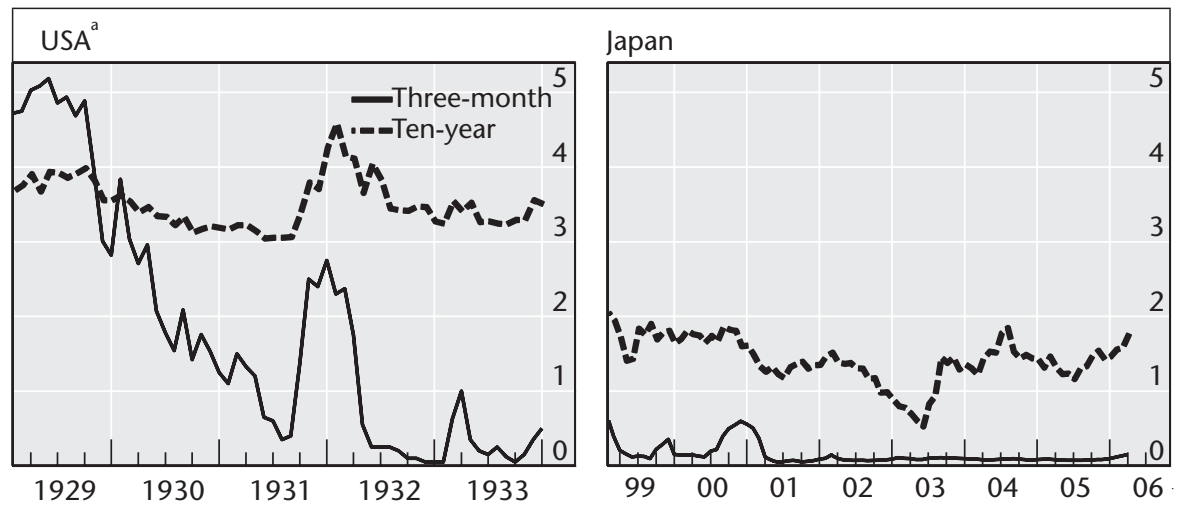

Figure 9.3. Three-month treasury bill and ten-year bond yields (\%)

${ }^{\text {a }}$ Option-adjusted Treasury bill rates calculated by Cecchetti (1988).

Sources: Cecchetti (1988); national data.

This is an open access version of the publication distributed under the terms of the Creative Commons Attribution-NonCommercialNoDerivs licence (http://creativecommons.org/licenses/by-nc-nd/3.0/), which permits non-commercial reproduction and distribution of the work, in any medium, provided the original work is not altered or transformed in any way, and that the work is properly cited. For commercial re-use, please contact academic.permissions@oup.com 


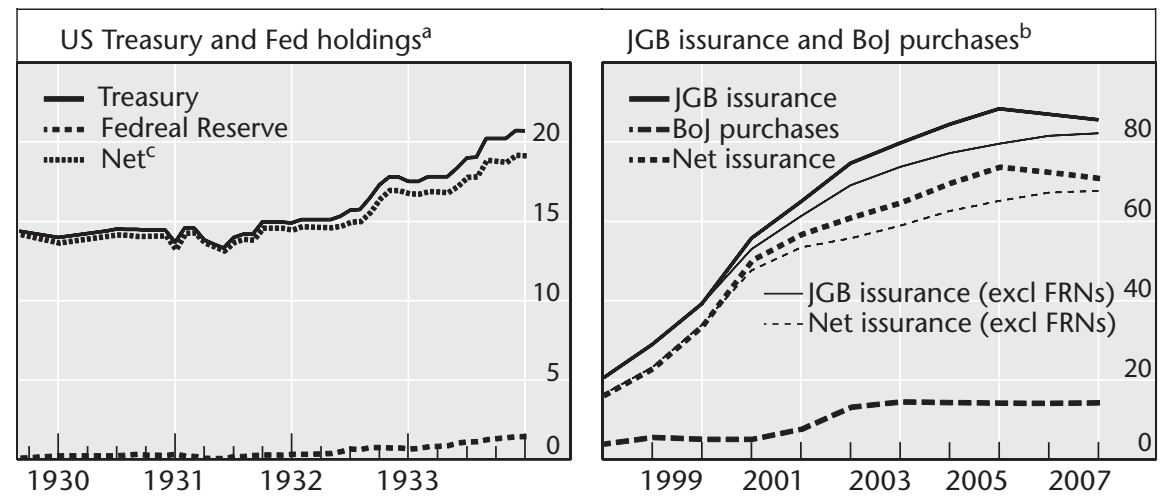

Figure 9.4. Holdings/issuance of government bonds and notes

${ }^{\text {a }}$ Outstanding amounts, in billions of US dollars.

${ }^{\mathrm{b}}$ In trillions of yen.

${ }^{\mathrm{c}}$ Treasury minus Federal Reserve holdings of bonds and notes.

Sources: Federal Reserve Bulletins; Ministry of Finance of Japan; authors' calculations.
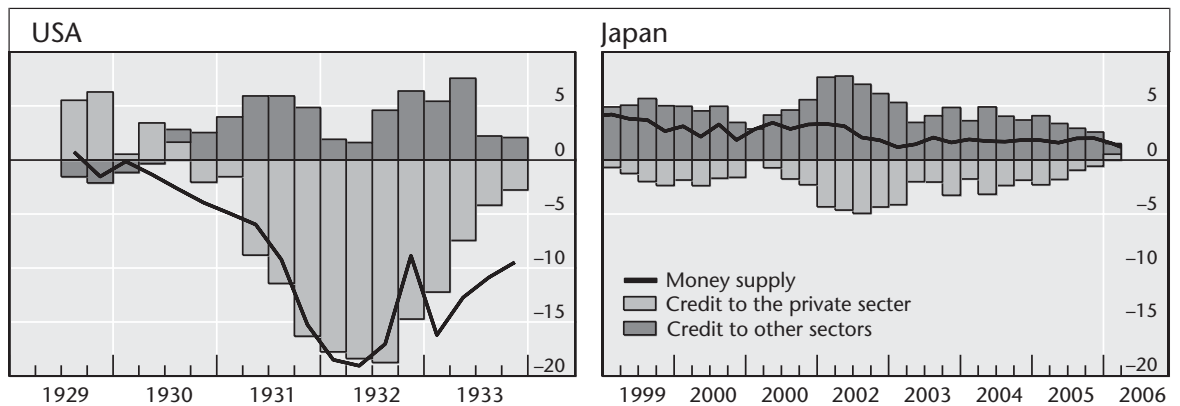

Figure 9.5. Bank credit and money growth (\%)

Notes: Annual growth rates for money supply; for credit, percentage point contribution, calculated as the year-on-year change in the level of the credit series divided by total bank assets of the corresponding period of the previous year. Money supply: For the USA, M1, calculated as currency held by the public plus demand and time deposits at commercial banks. For Japan, M2+CDs, calculated as cash currency in circulation plus deposit money, quasi-money and certificates of deposit. Credit to the private sector: For the USA, total bank assets minus investments in US dollar government securities of ninety leading member banks. For Japan, bank claims on the private sector plus net foreign assets. Credit to other sectors: For the USA, investments in US government securities of ninety leading member banks; for Japan, money supply minus credit to the private sector.

Sources: Bank of Japan; Federal Reserve; Friedman and Schwartz (1963); Koo (2008); authors' calculations.

This is an open access version of the publication distributed under the terms of the Creative Commons Attribution-NonCommercialNoDerivs licence (http://creativecommons.org/licenses/by-nc-nd/3.0/), which permits non-commercial reproduction and distribution of the work, in any medium, provided the original work is not altered or transformed in any way, and that the work is properly cited. For commercial re-use, please contact academic.permissions@oup.com 


\subsection{Japanese debt management since 2000 and Bol JGB purchases}

At the bottom of the Japanese recession in the early 2000s, there was discussion within the Ministry of Finance (MoF) on the possible contribution of debt management to macroeconomic stabilization. For example, Kuroda (2002), then the MoF's Vice Minister of Finance for International Affairs expressed his view that the scope of debt management could possibly be 'widened so as to pursue price stability more explicitly'. However, he recognized that this 'might mean a compromise with the traditional objective of debt management'. The stated general purpose of the MoF's debt management (2008) is to 'maintain markets' confidence in the capacity of the government to manage stable issuance of JGBs [Japanese government bonds] and Financing Bills and to repay its outstanding debt'. The report's Japanese-language version is more pointed: 'lowering interest payment cost on JGBs is a serious policy goal.' Given this, it might have been difficult to refrain from issuing long-dated debt at historically very low bond yields, albeit with a potential for tensions with monetary policy.

Some argued in the early 2000s that debt management might contribute to price stability by concentrating issuance at the short end, where yields would be held down by Bank of Japan (BoJ) policy. This would leave less issuance of JGBs at the long end and might allow longer-term bond yields to fall further. At its extreme, such an approach might have meant to 'target' bond yields in an attempt to lower them and to stimulate the economy. The idea did not become policy probably because of doubts about the practicality of controlling bond yields by merely changing the composition of debt.

Even in the pursuit of the goal of interest cost minimization, officials struggled to respond to the environment of near-zero short-term interest rates. This was the case especially after 1999, when the BoJ adopted the socalled zero interest rate policy (ZIRP). Some argued for much larger issuance of financing bills and short-term bonds, while others recognized the rollover and interest rate risks inherent in such a strategy. In the event, they adopted a middle-of-the-road approach. In the MoF's cost-at-risk analysis, an optimal debt issuance structure is determined by the trade-off between cost minimization and interest rate risks, especially when short-term rates are unusually low (Ministry of Finance of Japan 2008).

Thus, fiscal years 1999 and 2000 saw a shortening of the maturity of JGBs issued, perhaps in response to the ZIRP (Figure 9.6, left-hand panel). The next few years (2000-3) seem to have been a period in which the $\mathrm{MoF}$, in an attempt to maintain stable issuance of JGBs in the face of ballooning budget deficits, introduced various new types of debt instruments: 

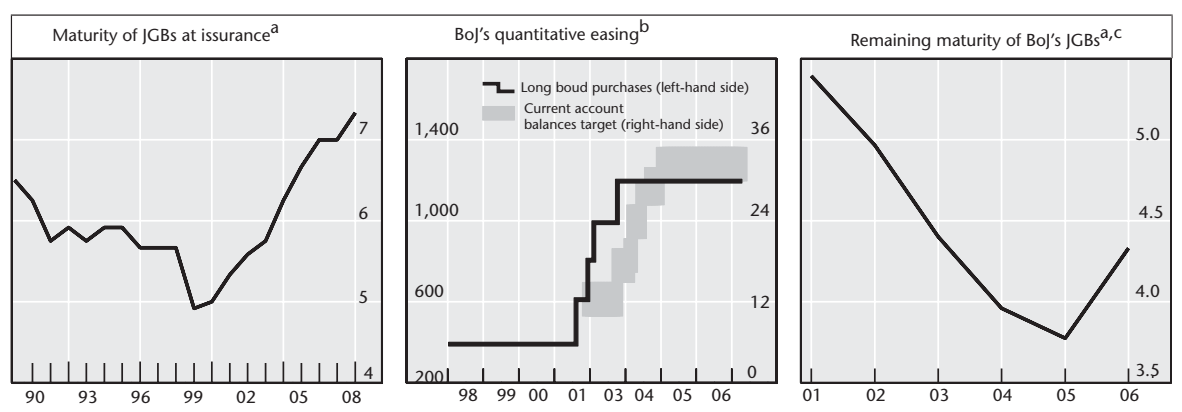

Figure 9.6. JGB issuance and BoJ purchases and holdings of JGBs

${ }^{a}$ Average, in years.

${ }^{\mathrm{b}}$ In trillions of yen.

${ }^{\mathrm{c}}$ Weighted average remaining maturity of fixed coupon JGBs held by the BoJ; June observations. The weights are based on the face value of the JGB series on the observation date.

Sources: Bank of Japan; Ministry of Finance of Japan, Finance Bureau (2008); BIS calculations.

fifteen-year floating rate notes (2000), three-year discount bonds and five-year coupon bonds (2000), and JGBs for individuals and inflation-indexed bonds (2003). These innovations helped to limit the tension with monetary policy. In 2003-4, however, the economy and tax revenue subsequently rebounded and the MoF's attention shifted to medium-term control of interest payments. Hence, the average maturity of issuance lengthened during this period. ${ }^{4}$

When long-term government bond yields began to rise sharply from the end of 1998, some politicians called for the BoJ to revert to the abandoned practice of underwriting government bonds (Tomita 2002: 5). As a means to achieve the step-ups in current-account balances that were at the centre of the quantitative easing starting in 2001, the BoJ ramped up its monthly outright purchases of JGBs from 400 billion yen to 1.2 trillion yen in four steps over fourteen months (Figure 9.6, centre panel). There was no reference to these purchases' affecting bond yields. In fact, the BoJ set a rule for buying JGBs, which, starting in June 2001, included medium-term (two-, four-, five-, and six-year) as well as ten-year JGBs, which resulted in its purchase of JGBs of fairly short remaining maturity. ${ }^{5}$ As a result, the remaining maturity of the BoJ portfolio declined from over five years in 2001 to under four years in 2005

4 The MoF has bought back large amounts of existing JGBs using funds from the special account of the Fiscal Investment and Loan Plan since 2002. It has carried out interest rate swap transactions since 2006, in common with many debt managers, which has certainly complicated the relationship between the maturity structure of debt and the yield curve.

5 In addition to the change in policy to purchase medium-term bonds, the expectation of persistently low policy rates may also have led to bonds of relatively short remaining maturity being tendered to the BoJ.

\section{4}

This is an open access version of the publication distributed under the terms of the Creative Commons Attribution-NonCommercialNoDerivs licence (http://creativecommons.org/licenses/by-nc-nd/3.0/), which permits non-commercial reproduction and distribution of the work, in any medium, provided the original work is not altered or transformed in any way, and that the work is properly cited. For commercial re-use, please contact academic.permissions@oup.com 
(Figure 9.6, right-hand panel). Broadly, the rule permitted market participants to choose which bonds to discount in price in order to sell to the central bank. In particular, on the day of the bond buying, the BoJ would accept JGBs with the widest gap between the offered yield and the yield curve at the end of the previous day.

In limiting its purchases of government bonds, the BoJ set a maximum at the note issue, which was seen as giving rise to a permanent need to supply funds; up to this limit JGBs could be held to maturity. Outside observers suggested risk management alternatives. Congdon (2003) urged that the government exchange bills for bonds in the market instead of central bank purchases of government bonds, which run the risk of central bank losses from a rise in bond yields. If the central bank were to purchase government bonds, he proposed that the government offer an indemnity against any losses (see UK policy below). When proposals for the BoJ to buy JGBs in quantity were met with the objection that the resulting holdings would risk central bank losses, Bernanke (2003) proposed that the government replace the fixed-rate bonds held by the BoJ with floating rate debt. Implicitly or explicitly, both proposals pointed to debt management.

In the event, how did the step-up in BoJ purchases of Japanese government bonds affect JGB holdings by private parties? First, recall that the central bank stepped up JGB purchases against the backdrop of a lengthening of issuance in 2001 and 2002 by the debt managers (Figure 9.6). This recalls the experience with Operation Twist in the United States in the 1960s (Box 9.2).

Second, despite the step-up in central bank purchases, JGB issuance to be absorbed by investors other than the central bank continued to grow. When government issuance is juxtaposed with central bank buying, the effect of BoJ purchases was only to decelerate the net supply of JGBs (Figure 9.4, right-hand panel). The introduction of floating rate notes helped, but did not change the outcome qualitatively (Box 9.3). In retrospect, although attention focused on the central bank purchases of JGBs, issuance policy determined the outcome.

Views on these purchases' effect on bond yields vary. Baba et al. (2005) and Oda and Ueda (2007) find that BoJ purchases had little effect on long-term yields. It is hard to distinguish the partial effect of central bank bond purchases from the powerful effect of the central bank's commitment essentially to keep the overnight rate at zero until the return of inflation (the so-called policy duration effect). Bernanke et al. (2004: 70-1) find that a few surprises (measured, inter alia, by a market participant's forecasts of BoJ bond-buying announcements) had a small but significant effect on JGB yields. Some JGB market participants put weight on the scale of purchases.

Notwithstanding their reliance on JGBs, debt managers' issuance of medium-term bonds sufficed to allow banks to maintain their assets in the face of debt repayment by businesses (Figure 9.5, right-hand panel). As a

This is an open access version of the publication distributed under the terms of the Creative Commons Attribution-NonCommercialNoDerivs licence (http://creativecommons.org/licenses/by-nc-nd/3.0/), which permits non-commercial reproduction and distribution of the work, in any medium, provided the original work is not altered or transformed in any way, and that the work is properly cited. For commercial re-use, please contact academic.permissions@oup.com 


\section{Box 9.2. OPERATION TWIST REVISITED}

In the early 1960s, the US economy was thought to need elevated short-term rates to defend the US dollar and lower bond yields to encourage investment. The Federal Reserve engaged in Operation Twist, departing from the earlier bills-only policy to buy Treasury bonds and to sell Treasury bills.

This policy experiment is often thought to have been a failure. In fact, the experiment never happened. The Treasury's extension of maturities overwhelmed the Federal Reserve sale of bills and purchase of bonds (Figure 9B). 'In the four years 1961-4, net purchases outside the 1-year area amounted to only $\$ 6.9$ billion, of which only $\$ 2.3$ billion represented over-5-year maturities. For every dollar of intermediate- and long-term bonds purchased by the System, the Treasury has sold many times that amount' (Beard 1965: 59). Moreover, the way that the Federal Reserve bought bonds minimized any impact on rates: 'Typically, the Manager did not solicit offerings from dealers, but only purchased some of the intermediate- and long-term securities offered at the dealers' initiative' (Beard 1965: 60).

As described by Roosa (1963), the Treasury's strategy was to boost issuance of Treasury bills in which central banks then invested their US dollars. At the same time, advance refundings of coupon securities approaching maturity reduced outstanding debt in the 'belly' of the curve-i.e. in the one- to five-year maturities. In current parlance, the Treasury was issuing in 'barbell' fashion-at three months and beyond five years. It is not clear that studies that related a ten-year Treasury bond yield to a threemonth bill rate took proper account of the Treasury strategy.
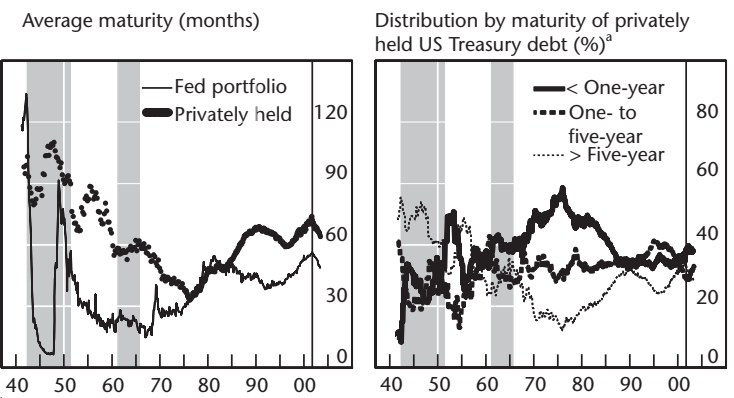

Distribution by maturity of Federal Reserve holdings (\%)

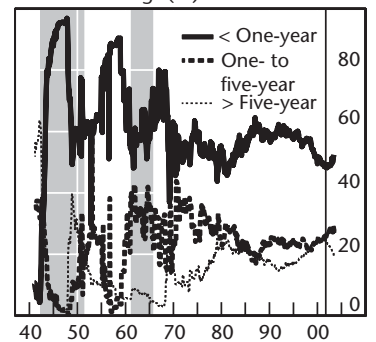

Figure 9B. Residual maturity of US Treasury debt and Federal Reserve holdings of Treasuries

${ }^{a}$ Includes foreign central banks.

Note: The shaded areas indicate Second World War and post-war interest rate caps (Mar. 1942-Feb. 1951) and the Operation Twist period (Feb.1961-June 1965). The vertical line indicates the cancellation of the 30-year bond (October 2001).

Source: Kuttner (2006).

result, M2 plus certificates of deposit continued to grow even as the private sector continued to deleverage by paying down bank debt (Shirakawa 2001). Moreover, because the BoJ commitment to keeping short-term interest rates near zero held down medium- to long-term interest rates, the opportunity cost of not selling more short-term or floating rate debt was limited (Figure 9.3,

This is an open access version of the publication distributed under the terms of the Creative Commons Attribution-NonCommercialNoDerivs licence (http://creativecommons.org/licenses/by-nc-nd/3.0/), which permits non-commercial reproduction and distribution of the work, in any medium, provided the original work is not altered or transformed in any way, and that the work is properly cited. For commercial re-use, please contact academic.permissions@oup.com 


\section{Box 9.3. JAPANESE FIFTEEN-YEAR FLOATING RATE NOTES}

An important innovation in debt management took place in Japan in this century. Debt managers hesitate to shorten the duration of government debt because it can increase rollover risk. This risk is usually neglected for top-rated sovereigns, but prudent debt managers cannot be indifferent to large financing requirements. Fitch (2009) recently warned that 'sizeable and sustained increases in governments' reliance on short-term funding would entail additional risks', recalling the downgrade of Belgium in the 1990s when financing requirements hit a third of GDP.

The Ministry of Finance (MoF) limited such rollover risks by introducing a fifteen-year bond (the CMT) in 2000. Its coupon, payable every half year, is set equal to half the average ten-year JGB auction yield over the prior six months less an issue-specific number of basis points (alpha). This ranged from 81 basis points in the first auction, to a peak of over 100 basis points in 2005 , to $40-50$ basis points in 2007 . The floating rate notes reduced the supply of fixed-rate debt significantly (Figure 9.4, right-hand panel). Nevertheless, like the central bank purchases, issuance of floating rate notes only slowed the growth of issuance of fixed-rate debt.

Since mid-2007, market pricing of these floating rate bonds has fallen below their 'theoretical' values, by as much as $10 \%$ in late 2008 , and the MoF cancelled issuance for the balance of the 2008-9 fiscal year. It is said that these bonds had come to be heavily held by hedge funds speculating on a convergence between the market price and the higher theoretical price (Bank of Japan 2008: 58-9; 2009: 45). The widening of the gap between the market and theoretical price is thought to reflect the shrinkage and deleveraging of hedge fund positions.

right-hand panel). On both counts, the experience in Japan in the 2000s compares favourably to that of the United States in the early 1930s.

Still, debt management in Japan may have missed opportunities in recent years in leaving much duration to be absorbed by the private sector. The debate over the role that the Bank of Japan could in effect play in debt management may have crowded out a broader debate over the course of debt management more generally.

\subsection{Debt management and monetary policy since 2008}

In March 2009, the UK, Japanese, and US central banks all announced or enlarged programmes to buy government debt. The context for these policies, and the policies themselves, showed some similarities and differences.

In all three cases, huge fiscal deficits and purchases of financial assets require financing. What maturity should the debt have? Apart from a debate in the United Kingdom (see, e.g., Booth et al. 2008), discussion of the contribution that debt management might make with interest rates very near zero has been notable by its absence. Instead, the three debt managers seem intent on

This is an open access version of the publication distributed under the terms of the Creative Commons Attribution-NonCommercialNoDerivs licence (http://creativecommons.org/licenses/by-nc-nd/3.0/), which permits non-commercial reproduction and distribution of the work, in any medium, provided the original work is not altered or transformed in any way, and that the work is properly cited. For commercial re-use, please contact academic.permissions@oup.com 
relying on longer-duration debt, as well-rated sovereigns tend to do (Figure 9.7). To be sure, the US Treasury shortened its debt when it sold bills in late 2008 to help the Federal Reserve sterilize the dollar funding extended to other central banks. However, following legislation allowing the Federal Reserve to pay interest on bank reserves, the US Treasury is stepping up long bond issuance.

Despite the similar timing of the policy changes in March, the goals of the central bank purchases of government bonds and their relationship to debt management show some differences (Table 9.1). The Bank of England's objectives include both quantity (faster money growth) and price (a lower bond yield) (Dale 2009). Indeed, the quantitative goal guided the choice of $£ 75$ billion in initial gilt purchases, which amounts to 5 per cent of broad money (UK House of Commons Treasury Committee 2009). The Bank of Japan's objective is to take the burden away from short-term operations. The Federal Reserve's goal in buying Treasury bonds is 'to help improve conditions in private credit markets' (Board of Governors of the Federal Reserve System 2009b).

The central bank bond purchases also interacted with debt management in different ways. The Bank of England acted before the Debt Management Office had announced its provisional plan of gilt sales for the new fiscal year. The Governor asked for and obtained a promise from the Chancellor that the Office would not alter its plan in the light of central bank decisions on the size, scope, and timing of gilt purchases (Bank of England 2009; UK Chancellor of the Exchequer 2009). In Japan, the government's large supplementary budget for 2009 implies an issuance of about 17 trillion yen of JGBs in addition to the amount already planned in the initial budget. This is expected to shift the focus of debt management policy back towards the

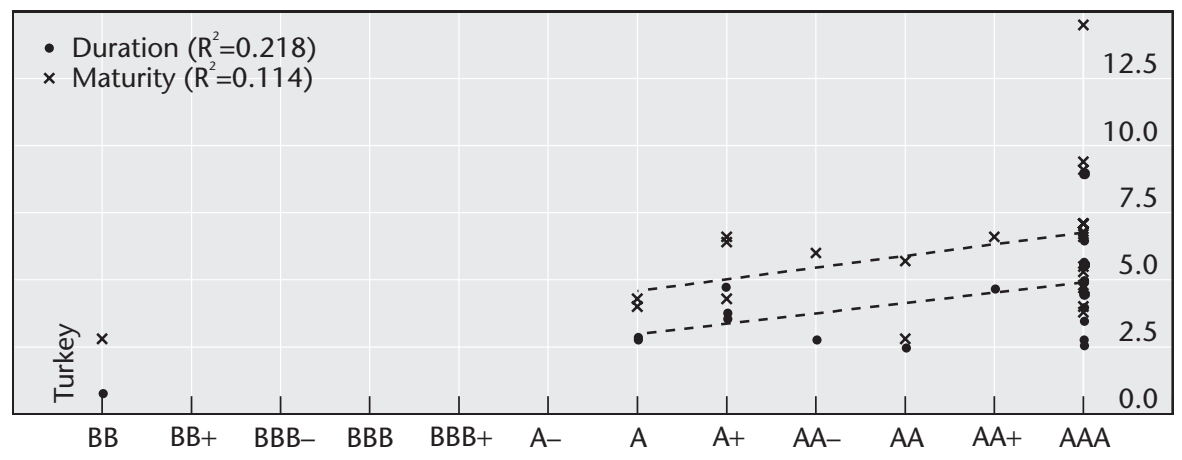

Figure 9.7. Rating, duration, and average term to maturity of OECD sovereign domestic debt, 2007

Notes: Duration-Macaulay or modified duration; average term to maturity—in years.

Source: OECD (2008b).

This is an open access version of the publication distributed under the terms of the Creative Commons Attribution-NonCommercialNoDerivs licence (http://creativecommons.org/licenses/by-nc-nd/3.0/), which permits non-commercial reproduction and distribution of the work, in any medium, provided the original work is not altered or transformed in any way, and that the work is properly cited. For commercial re-use, please contact academic.permissions@oup.com 
Table 9.1. Overview of three central bank policies to buy government bonds, 2009

\begin{tabular}{|c|c|c|c|}
\hline & Bank of England & Bank of Japan & Federal Reserve \\
\hline Date & 5 March, 7 May & 18 March & 18 March \\
\hline Action & $\begin{array}{l}\text { Initial purchase of } £ 75 \text { billion of gilts and } \\
\text { corporates over three months, to } £ 125 \\
\text { billion in May, } £ 52 \text { billion purchased by } \\
6 \text { May. }\end{array}$ & $\begin{array}{l}\text { Monthly purchases of JGBs raised } \\
\text { from } ¥ 1.4 \text { to } ¥ 1.8 \text { trillion }\end{array}$ & $\begin{array}{l}\text { Purchase of } \$ 300 \text { billion in Treasury bonds } \\
\text { over six months, } \$ 92 \text { billion bought as of } \\
6 \text { May }\end{array}$ \\
\hline $\begin{array}{l}\text { Relevant debt } \\
\text { stock/flow }\end{array}$ & $\begin{array}{l}£ 300 \text { billion outstanding in } 5 \text { - to } 25 \text {-year } \\
\text { bonds as of } 6 \text { May; issuance of } 7 \text { - to } \\
15 \text {-year gilts in April 2009-March 2010, } \\
£ 70 \text { billion }\end{array}$ & $¥ 679$ trillion at end-2007 & $\begin{array}{l}\$ 4.4 \text { trillion Treasury notes and bonds } \\
\text { outstanding on } 30 \text { April; borrowing } \\
\text { for current fiscal year estimated at } \\
\$ 1.3 \text { trillion }\end{array}$ \\
\hline Rationale & $\begin{array}{l}\text { Boost nominal demand by increasing broad } \\
\text { money (bank deposits), lowering gilt } \\
\text { yields and improving corporate credit } \\
\text { markets }\end{array}$ & $\begin{array}{l}\text { Take burden off short-term } \\
\text { operations }\end{array}$ & Improve the terms of private credit \\
\hline Market reaction & $\begin{array}{l}40-60 \text { basis points on gilt yield and } 30 \text { basis } \\
\text { points on corporate bond yield (Dale } \\
2009 \text { ) }\end{array}$ & $2-3$ basis points & 40 basis point immediate reaction \\
\hline Risk management & $\begin{array}{l}\text { Exchange of letters between Chancellor and } \\
\text { Governor; indemnity for any Bank of } \\
\text { England losses }\end{array}$ & $\begin{array}{l}\text { JGB holdings by BoJ limited to note } \\
\text { issue; JGBs to be purchased in } \\
\text { specific brackets of residual } \\
\text { maturity to control the maturity of } \\
\text { BoJ's portfolio }\end{array}$ & $\begin{array}{l}\text { No reference in Board of Governors of the } \\
\text { Federal Reserve System (2009b) }\end{array}$ \\
\hline
\end{tabular}

Sources: UK Debt Management Office (2009); US Treasury Office of Debt Management (2009); Bank of England; Bank of Japan: Federal Reserve. 
goal of stable issuance of JGBs. The Bank of Japan has not referred to any interaction with the government's debt plan in its own announcements. Similarly, the Federal Reserve, acting after the first Treasury refunding announcement in the first days of the new administration, made no reference to the government's funding plan.

\subsection{Conclusions and prospects}

Government debt management may have a role to play amid private deleveraging and very low policy rates. Some observers emphasize the potential to lower bond yields by swapping treasury bills for bonds in private hands, reinforcing the effect on bond yields of the prospect of sustained low policy rates. Monetarists emphasize that ample issuance of short- and medium-term government debt (including state-guaranteed bank debt) would allow banks to maintain deposit growth even as households and firms pay down their debt. Widespread deleveraging of financial firms' balance sheets may strengthen either argument. Despite the expansion of some central bank balance sheets, treasuries continue to enjoy more scope to alter the weight of bills and bonds held by private investors. For now, treasuries can issue longterm debt with interest rates tied to short-term bill rates in the confidence that monetary policy will keep bill yields low. In doing so, treasuries stand to benefit from interest cost savings as long as short-term rates remain low. When economic activity quickens and interest rates rise again, they stand to benefit from higher taxes in compensation for higher debt servicing costs.

This is an open access version of the publication distributed under the terms of the Creative Commons Attribution-NonCommercialNoDerivs licence (http://creativecommons.org/licenses/by-nc-nd/3.0/), which permits non-commercial reproduction and distribution of the work, in any medium, provided the original work is not altered or transformed in any way, and that the work is properly cited. For commercial re-use, please contact academic.permissions@oup.com 


\title{
The Effects of Fiscal Consolidation on Short-Term Growth: A Review and Implications for the UK
}

\author{
Katarzyna Anna Bilicka, Michael P. Devereux, and Clemens Fuest
}

\subsection{Introduction}

This chapter analyses the economic situation in the UK as it attempts to recover from the financial and economic crisis that began in 2008. In particular, we focus on the probability that the fiscal consolidation, introduced by the new coalition government in 2010, is likely to be either expansionary or contractionary. To analyse this we first briefly survey the large economic literature on the impact of government borrowing on economic growth. We identify the key factors that empirical evidence suggests affect the probability that a fiscal consolidation will be expansionary. We then examine these factors in the context of the UK to identify whether they are favourable or not towards the consolidation being expansionary.

The conventional 'Keynesian' view of a fiscal consolidation is that a decline in government expenditures or an increase in taxes will inevitably lead to a decline in demand relative to a baseline in which the consolidation did not take place. Other things being equal, this would depress the rate of growth of GDP. When the economy is fragile, fiscal consolidation could tip the economy into recession. This is certainly a view expressed in the UK. In 2011, the recovery from the recession induced by the financial crisis is weak. The prospect of significant cuts in public spending, combined with a rise in taxes, has led many to fear that the UK is poised to return to a recession.

However, the Keynesian view has been challenged by the empirical observation that some countries have managed to carry out significant programmes

This is an open access version of the publication distributed under the terms of the Creative Commons Attribution-NonCommercialNoDerivs licence (http://creativecommons.org/licenses/by-nc-nd/3.0/), which permits non-commercial reproduction and distribution of the work, in any medium, provided the original work is not altered or transformed in any way, and that the work is properly cited. For commercial re-use, please contact academic.permissions@oup.com 
of fiscal consolidation without a significant decline in GDP. For example, one widely cited example is the fiscal consolidation programme in Denmark in the early 1980s; this coincided with a strong increase in GDP growth, driven mainly by private investment demand, along with surprisingly stable growth in private consumption. The experience of Denmark and some other countries has given rise to a debate on the possibility that fiscal consolidations may be expansionary: that is, they may actually increase economic growth.

The arguments in favour of this view are based mainly on the impact of fiscal consolidation on expectations of consumers and investors about the future. While the Keynesian approach assumes that consumption and investment decisions are based on current income, more general macroeconomic models allow for intertemporal effects: economic agents make decisions based on the expectations of future income and wealth. In this context, a reduction in public spending, for example, could lead to expectations that taxes will be lower, and hence post-tax incomes will be higher, in the future. This could induce agents to increase demand in the short run.

We do not survey all theoretical and empirical research on these issues in this chapter. Instead, we focus primarily on the empirical literature that explicitly investigates the factors that are important for whether a consolidation may be expansionary. The key factors identified in that literature are that the probability of the consolidation being expansionary is higher if: the size of the consolidation is large; the composition of the consolidation is focused more on spending cuts than on tax increases; the initial level of public debt is high; interest rates are not at a lower bound; and there is a devaluation of the exchange rate. Not all studies find evidence that all of these factors are significant, and in some cases studies find some of these factors not to be significant. Nevertheless, there is some broad agreement in the literature that these are important factors.

We focus our empirical examination on the UK both because it is an important country, and because it is planning to undertake a very significant fiscal consolidation between 2010 and 2014. We consider data from the UK on each of the factors identified in the literature, with the aim of making an assessment of whether they are favourable for the prospects of economic growth in the UK.

The chapter is organized as follows. Section 10.2 briefly summarizes what macroeconomic theory has to say about the impact of fiscal consolidation. Section 10.3 turns to empirical studies. It discusses some conceptional issues and surveys the results of this literature. In Section 10.4 we discuss the implications of these results for the UK programme of fiscal consolidation. Section 10.5 concludes. 


\subsection{Effects of fiscal consolidation on short-term growth in macroeconomic theories}

According to the traditional, 'Keynesian' view of a fiscal consolidation, a decline in government expenditures or an increase in taxes lowers aggregate demand and, hence, GDP. When the economy is fragile, fiscal consolidation could, therefore, tip the economy back into recession. This view of fiscal consolidation is widespread, but it is based on strong assumptions regarding the impact of changes in fiscal policy on the economy, in particular the assumption that private consumption or investment is largely determined by current income.

Modern macroeconomic theory shows that there are many ways in which fiscal policy can affect aggregate demand and output (see, e.g., EEAG 2011: ch. 3). Such models put less emphasis on the link between current income and spending and instead emphasize the wealth and inter-temporal substitution effects of fiscal policy. For example, a permanent cut in public expenditure can be expected to lead to lower taxes in the future, and hence increase the perceived present value of lifetime income. This can boost current private consumption. This effect is reinforced if the decline in government borrowing reduces interest rates, in which case households will tend to bring consumption forward to the current period. In addition, in open economies, lower interest rates tend to reduce capital imports, so that net exports increase. A positive wealth effect may also arise if the costs of tax distortions are high, so that tax cuts generate efficiency gains.

The fact that private consumption and investment decisions may depend not just on current income but also on expectations for the future also has further implications. As Bertola and Drazen (1993) point out, 'a policy innovation that would be contractionary in a static model may be expansionary, if it induces sufficiently strong expectations of future policy in the opposite direction'. For example, if fiscal consolidation takes the form of higher taxes, the effect on demand will depend on the type of tax instrument used and the timing of the tax increase. The announcement of a future increase in value-added tax is likely to have an expansionary effect on demand in the short term because it creates incentives to purchase consumption goods, in particular durables, before the tax increase. In contrast, the announcement of a future increase in income tax is likely to reduce current consumption spending.

The credibility of fiscal consolidation is another factor that can affect current economic activity. If a fiscal consolidation plan is not perceived as credible, then private households and firms will have greater uncertainty over future economic conditions: they may therefore postpone consumption and 
investment decisions until they have more information about future policies. A more credible policy commitment would reduce such uncertainty, and hence reduce this dampening effect on the economy.

Some authors also argue that the impact of fiscal policy depends on the particular situation of the economy, including the exchange-rate regime, the current levels of interest rates, and the current level of government debt. For example, Sutherland (1997) shows that, in a model where consumers have finite lives, a decrease in spending (or increase in taxes) has contractionary effects at low debt levels but is expansionary at high debt levels. The IMF (2010a) emphasizes the interaction between fiscal and monetary policy and argues that fiscal consolidation is more likely to be harmful where interest rates are already low, so that the reduction in government borrowing can lead to only a minimal reduction in interest rates.

These considerations have led to a debate as to whether fiscal consolidations can be expansionary, and, if so, under what conditions. Alesina and Ardagna (2010) emphasize two channels through which expansionary effects may occur. On the demand side, the effect depends on expectations. If agents believe that the current fiscal policy eliminates the larger and more disruptive adjustments in spending cuts or tax increases in the future, as suggested by Blanchard (1990), then consolidation might generate a positive wealth effect. Consumers anticipate that their lifetime disposable income will increase and as a result may increase their current private consumption. For similar reasons firms may also increase their investment. Both effects would lead to higher aggregate demand. These effects may be reinforced by a reduction in interest rates: if the fiscal adjustment is credible, the probability of a default on government debt falls, and the rate of interest at which the government can borrow will also fall. If this affects the interest rate charged to consumers and firms, there could be a further positive effect on consumption and investment. Lower interest rates can also result in the appreciation of stocks and bonds, thus causing agents' financial wealth to increase and trigger still higher consumption and investment.

The second channel is the supply side, where expansionary effects might occur through the labour market. Here the composition of the fiscal adjustment can play a critical role. A reduction in government spending may result in lower public-sector employment and lower public-sector wages. Both of these will tend to reduce the wage rates in the private sector as well-through a higher supply of workers to the private sector as workers lose public-sector jobs, and by reducing the reservation wage of private-sector workers. This will tend to increase profits, and hence investment. However, a fiscal consolidation based on higher tax may induce private-sector employers to increase the 
wage rate to offset the higher tax at least partly; this would have the opposite effect. $^{1}$

In short, a brief review of macroeconomic theory suggests that the impact of fiscal consolidation programmes on short-term growth is ambiguous. The impact depends on several factors, including the type and credibility of the consolidation. In the light of this, we now turn to review empirical evidence on the conditions under which consolidations have been expansionary.

\subsection{Empirical studies on fiscal consolidations}

\subsubsection{Conceptual issues}

A large number of empirical studies have investigated the impact of fiscal policies on growth and employment. We do not attempt to provide a survey of this literature, but instead focus only on highlighting the key aspects, which allow us to assess the probability of a fiscal consolidation being expansionary. $^{2}$

One body of literature focuses on estimating the size of the fiscal multiplier. This is typically defined as the ratio of the change in output following a policy initiative, relative to the size of that initiative. For example, the multiplier would take the value of 1 if a rise in government expenditure of 1 per cent of GDP led to a rise in GDP of 1 per cent. A positive multiplier for government expenditure indicates that a reduction in spending leads to a reduction in GDP. In contrast, a negative multiplier for a rise in taxes would indicate a reduction in GDP. Identifying the size of the fiscal multiplier is difficult, since in principle it is necessary to identify the effects on GDP of some exogenous change in policy. If the change in policy is endogenous-for example, if the economy is hit by a shock that affects both the government deficit and GDPthen any resulting estimates of the fiscal multiplier are likely to be biased. The literature has attempted to devise several ways in which this problem of endogeneity can be overcome. For example, one example is the narrative approach used by Ramey and Shapiro (1998), among others. This attempts to identify an exogenous change in spending or taxation by identifying some exogenous event, in this case a build-up in military spending, or analysing the political discussion leading up to the change. A more detailed description of this and other approaches is provided in EEAG (2011). A drawback of much of

\footnotetext{
1 For more detailed theoretical analysis, see, e.g., Giavazzi and Pagano (1990), Alesina and Perotti (1996), Giavazzi and Pagano (1996), Alesina and Ardagna (1998), Perotti (1999), and Ardagna (2004), or the comprehensive summaries done by Nickel et al. (2010) or Rother et al. (2010). Additionally, Rzonca and Cizkowicz (2005) give a very detailed explanation of the mechanisms behind the non-Keynesian effects.

${ }^{2}$ For detailed surveys, see, e.g., Mahfouz et al. (2002) and Blanchard et al. (2009: app. II).
} 
this branch of the literature is that it typically does not explore heterogeneity in the size of the multiplier, but implicitly assumes that it does not vary with economic conditions.

By contrast, the second branch of the literature does focus on factors that may affect the size and sign of the multiplier. However, rather than estimating multipliers directly, this literature attempts to identify factors that determine whether a fiscal consolidation is expansionary or contractionary. This approach requires a judgement to be made about (a) whether a particular change in a budget deficit should be regarded as a fiscal consolidation, either ex-ante or ex-post, and $(b)$ whether the effect on GDP should be regarded as expansionary.

For the first issue, the most common approach used in the literature is to measure the cyclically adjusted primary budget balance (CAPB). ${ }^{3}$ The CAPB is calculated by taking the actual primary balance-revenue less spending, not including interest receipts or payments—and adjusting for the estimated effect of business cycle fluctuation. Correcting for cyclical adjustments may to some extent reduce endogeneity compared to using the raw primary balance. However, as the IMF (2010a) argues, it seems unlikely that this approach corrects for all endogeneity, for two reasons: the cyclical adjustment is likely to suffer from measurement error, and even then, as with the fiscal multiplier literature, shocks may be correlated both with the deficit and with GDP. By contrast, the IMF (2010a) uses a form of the narrative approach to identify fiscal consolidations, attempting to identify specific policy decisions on tax increases or spending cuts from IMF and OECD reports. However, the IMF (2010a) methodology is open to criticism as well. Alesina (2010a) argues that the approach involves too many judgemental calls, implying that endogeneity is not fully eliminated. The IMF report does not go into detail of policymakers' intentions, as do, for example, Romer and Romer (2010). Cos and Moral-Benito (2011) raise the issue of endogeneity in both the narrative and the CAPB approaches, and instead treat fiscal policy decisions as endogenous; they conclude that endogeneity biases are chiefly responsible for the nonKeynesian results previously found in the literature.

Leaving the broad approach to one side, the literature varies considerably as to what change in the CAPB constitutes a fiscal consolidation. For example Alesina and Ardagna (1998) identify a fiscal consolidation on the basis that the CAPB changes by more than 2 per cent of GDP in one year, or 1.5 per cent over two consecutive years. Alesina and Perotti (1996) use a cut-off of 1.5 per cent of GDP in one year and 1.25 per cent in two consecutive years. Others use

\footnotetext{
3 Studies using this method include, e.g., Alesina and Perotti (1995, 1996); McDermott and Westcott (1996); Alesina and Ardagna (1998, 2010); Alesina et al. (1998); Alesina et al. (2000); Guichard et al. (2007); and Broadbent and Daly (2010).
} 
a simple 1.5 percentage point threshold, ${ }^{4}$ and another uses a threshold of 1 per cent of GDP in one year or in two consecutive years with at least 0.5 per cent occurring in the first of the two years. ${ }^{5}$ The variations in these definitions mean that there is no commonly accepted set of events that are treated as fiscal consolidations in the literature.

The second issue is the definition of whether a consolidation is expansionary. The key problem here is the counterfactual: what would have happened to GDP in the absence of the fiscal consolidation? Two broad methods of identification of expansionary fiscal consolidations have been used:

- Alesina et al. (1998) and Alesina and Ardagna (2010) define an expansionary episode of fiscal consolidation as a period when the average growth rate of GDP in the first period of the episode and in the succeeding two years, less the G7 average over the same period, is greater than the value of 75th percentile (or average in case of Alesina et al. 1998) of the same variable empirical density in all episodes of fiscal adjustments.

- Alesina et al. (2002) defines a fiscal consolidation as follows: 'an episode of fiscal adjustment is expansionary if the average real GDP growth in each adjustment year and in the two years after is greater than the average real GDP growth in the two years before.' This definition has also been used by Giudice et al. (2007) and Cos and Moral-Benito (2011).

These two definitions are clearly very different. The first essentially identifies an expansionary outcome as being in the top 25 per cent of outcomes of fiscal consolidations (relative to the G7). Not only is this arbitrary, but it does not appear to capture any notion of expansion. For example, even if all consolidations led to dramatic falls in GDP, this approach would still identify 25 per cent of such consolidations as being expansionary. The second definition is also not convincing. For example, a period of fiscal consolidation typically follows a period of crisis: if so, the change in the growth rate since before the consolidation will depend heavily on the rate of economic growth in the crisis just before the consolidation. Fiscal episodes identified by the two methods described here are listed in Tables 10.1 and 10.2.

In sum, there are numerous reasons to be sceptical of the empirical literature used here. Nevertheless, this is the most promising approach to estimating the

${ }^{4}$ Alesina et al. (1998); Tavares (2004); Alesina and Ardagna (2010); and Broadbent and Daly (2010).

${ }^{5}$ See Guichard et al. (2007). In addition, McDermott and Westcott (1996) define 'aggressive fiscal impulse' as a tightening of the budget of at least 1.5 percentage points of GDP for at least two years. Giavazzi et al. (2000) define 'large and persistent fiscal impulse' as one in which the full employment surplus (as a per cent of potential output) changes by at least 1.5 percentage points per year over a two-year period, which is similar to Giavazzi and Pagano (1996).

This is an open access version of the publication distributed under the terms of the Creative Commons Attribution-NonCommercialNoDerivs licence (http://creativecommons.org/licenses/by-nc-nd/3.0/), which permits non-commercial reproduction and distribution of the work, in any medium, provided the original work is not altered or transformed in any way, and that the work is properly cited. For commercial re-use, please contact academic.permissions@oup.com 
Table 10.1. Episodes of fiscal consolidation using method defined in Alesina and Ardagna (2010)

\begin{tabular}{llllll}
\hline Austria & 1996 & 1997 & 2001 & 2005 \\
Belgium & 2006 & & & & \\
Canada & 1995 & 1996 & 1997 & \\
Czech Republic & 2004 & 2007 & & \\
Denmark & 2004 & 2005 & & & \\
Estonia & 2009 & & & & \\
Finland & 1994 & 1996 & 1998 & 2000 & \\
France & 1996 & & & & \\
Germany & 1996 & & & & \\
Greece & 1994 & 1996 & 2005 & 2009 & \\
Hungary & 1999 & 2003 & 2007 & 2009 & \\
lceland & 1995 & 2004 & 2005 & & \\
Italy & 1997 & 2007 & & & \\
Japan & 1999 & 2001 & 2006 & & \\
Luxembourg & 1994 & 1997 & & & \\
Netherlands & 1996 & 2004 & & & \\
New Zealand & 2000 & 2002 & 2006 & \\
Norway & 1994 & 1995 & 2000 & 2004 \\
Poland & 2012 & & & & \\
Portugal & 2002 & 2006 & & & \\
Spain & 1996 & & & & \\
Sweden & 1994 & 1996 & 1997 & 2000 & \\
Switzerland & 1999 & & & & \\
UK & 1996 & 1997 & 1998 & & \\
\hline
\end{tabular}

Note: Only episodes where CAPB improvement was greater than $1.5 \%$ of GDP are included.

likely effects of a particular consolidation, such as that initiated in the UK in 2010. We therefore turn to summarizing briefly the results of relevant studies.

\subsubsection{Results of empirical studies}

A large number of studies estimate the size of the fiscal multiplier, typically distinguishing between expenditure and tax multipliers. Most estimates of expenditure shocks find multipliers between zero and one, ${ }^{6}$ implying that the impact is positive, although not very large. If applied to cuts in expenditure, this would imply such a cut would tend to be contractionary, rather than expansionary. Estimates of tax multipliers are typically smaller than estimates of expenditure multipliers, but there is less agreement on the sign. An exception is the study by Romer and Romer (2010), which finds a large tax multiplier of -3 , implying that a tax increase of 1 per cent of GDP would reduce GDP by 3 per cent. Some papers analyse the impact of changes in government expenditures on different components of GDP. However, this literature does not tend to examine how different conditions might change the sign of the multiplier. An exception is Ilzetzki et al. (2010), who identifies varying sizes of

\footnotetext{
${ }^{6}$ See, e.g., the surveys in Hebous (2009) and Group (2010).
} 
Table 10.2. Episodes of fiscal consolidation using method defined in Guichard et al. (2007)

\begin{tabular}{lllllll}
\hline Australia & 1997 & 2002 & & & & \\
Austria & 1996 & 1997 & 2001 & 2005 & & \\
Belgium & 1998 & 2006 & & & & \\
Canada & 1995 & 1996 & 1997 & & & \\
Czech Republic & 2004 & 2007 & & & & \\
Denmark & 1999 & 2004 & 2005 & & & \\
Estonia & 2003 & 2009 & & & & \\
Finland & 1994 & 1996 & 1997 & 1998 & 2000 & \\
France & 1994 & 1996 & & & & \\
Germany & 1996 & 2007 & & & & \\
Greece & 1994 & 1996 & 1998 & 2005 & & \\
Hungary & 1999 & 2003 & 2007 & 2008 & 2009 & \\
Iceland & 1995 & 1999 & 2004 & 2005 & 2009 & \\
Ireland & 2000 & 2003 & & & & \\
Italy & 1997 & 2007 & & & & \\
Japan & 1999 & 2001 & 2004 & 2006 & & \\
Luxembourg & 1994 & 1995 & 1997 & 2007 & & \\
Netherlands & 1996 & 2004 & 2005 & & & \\
New Zealand & 1994 & 2000 & 2002 & & & \\
Norway & 1994 & 1995 & 1999 & 2000 & 2004 & 2005 \\
Poland & 2005 & & & & & \\
Portugal & 1995 & 2002 & 2006 & & & \\
Spain & 1994 & 1996 & & & & \\
Sweden & 1994 & 1996 & 1997 & 1998 & 2000 & 2005 \\
Switzerland & 1999 & & & & & \\
UK & 1995 & 1996 & 1997 & 1998 & & \\
\hline
\end{tabular}

Note: Only episodes where CAPB improvement was greater than $1 \%$ of GDP are included.

fiscal multipliers depending on the level of country development, degree of exchange-rate flexibility, degree of openness to trade, and the ratio of debt to GDP, and finds multipliers to be very small, sometime turning negative. The examples of negative fiscal multipliers occur for government spending in developing countries, flexible exchange-rate countries, open economies, and countries with a debt to GDP ratio above 60 per cent. Conditions for multipliers to change signs are also discussed by Mahfouz et al. (2002).

In the absence of many studies examining conditions under which multipliers may change signs, we focus more on the results of the second approach, in an attempt to identify the conditions under which fiscal consolidations are likely to be expansionary. Table 10.3 summarizes the key results. For each study listed, the table indicates whether it found empirical evidence of an effect of each of the factors listed in the columns. We discuss each of these factors in turn.

\subsubsection{THE MAGNITUDE OF FISCAL CONSOLIDATION PROGRAMMES}

Several studies find evidence that the response to fiscal consolidations is more likely to be expansionary the larger is the adjustment. Evidence for OECD

This is an open access version of the publication distributed under the terms of the Creative Commons Attribution-NonCommercialNoDerivs licence (http://creativecommons.org/licenses/by-nc-nd/3.0/), which permits non-commercial reproduction and distribution of the work, in any medium, provided the original work is not altered or transformed in any way, and that the work is properly cited. For commercial re-use, please contact academic.permissions@oup.com 
Table 10.3. Summary of the empirical literature findings on the effects of fiscal consolidation on growth

\begin{tabular}{|c|c|c|c|c|c|c|}
\hline Study & General & Magnitude & Composition & $\begin{array}{l}\text { Initial debt } \\
\text { level }\end{array}$ & $\begin{array}{l}\text { Monetary } \\
\text { policy }\end{array}$ & $\begin{array}{l}\text { Exchange } \\
\text { rate }\end{array}$ \\
\hline $\begin{array}{l}\text { Alesina and Ardagna } \\
\text { (1998) }\end{array}$ & + & $x$ & + & $x$ & $x$ & $x$ \\
\hline $\begin{array}{l}\text { Alesina and Ardagna } \\
\text { (2010) }\end{array}$ & + & & + & & & \\
\hline $\begin{array}{l}\text { Alesina and Perotti } \\
\text { (1995) }\end{array}$ & + & + & + & & & \\
\hline $\begin{array}{l}\text { Alesina and Perotti } \\
\text { (1996) }\end{array}$ & + & & + & & + & + \\
\hline Alesina et al. (2000) & + & $x$ & + & & & \\
\hline Alesina et al. (2002) & + & $x$ & + & & & \\
\hline Alesina et al. (1998) & + & & + & & & \\
\hline Ardagna (1999) & + & $x$ & & & & \\
\hline Ardagna (2004) & + & $x$ & + & & $x$ & $x$ \\
\hline $\begin{array}{l}\text { Broadbent and Daly } \\
\text { (2010) }\end{array}$ & + & & + & $x$ & & \\
\hline $\begin{array}{l}\text { Cos and Moral-Benito } \\
\text { (2011) }\end{array}$ & - & & $x$ & $x$ & + & $x$ \\
\hline $\begin{array}{l}\text { Giavazzi and Pagano } \\
\text { (1996) }\end{array}$ & + & + & + & & & \\
\hline Giavazzi et al. (2000) & + & + & + & $x$ & & \\
\hline Giudice et al. (2007) & + & & + & & $x$ & $x$ \\
\hline Guichard et al. (2007) & + & & & & & \\
\hline Ilzetzki et al. (2010) & + & & & + & & + \\
\hline IMF (2010a) & - & & + & & + & + \\
\hline $\begin{array}{l}\text { McDermott and } \\
\text { Westcott (1996) }\end{array}$ & + & + & & & & \\
\hline Perotti (1999) & + & & + & + & & \\
\hline Perotti (2005) & + & & $x$ & & & \\
\hline $\begin{array}{l}\text { Rzonca and Cizkowicz } \\
\text { (2005) }\end{array}$ & + & + & + & & + & \\
\hline Tavares (2004) & + & + & + & & & \\
\hline
\end{tabular}

Notes: For expansionary effects of fiscal consolidation: + if the paper finds positive effect, - if the paper finds negative effect, $x$ if no effect found, blank if it was not analysed. International environment is not included in the table, as the only evidence is provided by the simulation in the IMF (2010a) report. Credibility is also not included in the table, as there is no empirical evidence on the importance of that variable: almost all studies mention that credibility is an important factor determining whether the magnitude and composition matter, but none analyses it as an empirical variable.

countries is provided by Giavazzi and Pagano (1996); McDermott and Westcott (1996); Giavazzi et al. (2000); and Ardagna (2004). Giavazzi et al. (2000) focus on developing countries and find a non-linear relationship between fiscal contractions and the effects on GDP, with the effects on GDP increasing with the size of the consolidation. This chapter finds that expansion also tends to occur in periods in which debt is accumulating rapidly, regardless of its initial level. However, Alesina and Perotti (1996), Ardagna (1999), and Alesina et al. (2000) find no effect of the magnitude of the consolidation; in Alesina et al. (2000), after controlling for the composition of the fiscal impulse, there is no evidence that private investment reacts to large fiscal 
adjustments differently from normal times. Giavazzi and Pagano (1996) find that consolidations are more likely to be expansionary if they are not only large, but also persistent. They also point out that those effects can result from both changes in government spending and increase in taxes. Alesina et al. (2002) find that the magnitude of fiscal adjustments relying on tax increases is smaller than those on the expenditure side. Tavares (2004) finds that, the larger the decrease in public spending or public consumption, the larger the increase in output and its components.

\subsubsection{THE STRUCTURE OF THE FISCAL CONSOLIDATION PROGRAMME: HIGHER TAXES VERSUS EXPENDITURE CUTS}

Several papers-e.g. Alesina and Perotti (1996), Alesina et al. (2002), Alesina and Ardagna (2010), Broadbent and Daly (2010), IMF (2010a)—find that fiscal adjustments that rely primarily on tax increases and cuts in public investment are more likely to be contractionary. These papers also typically find that fiscal adjustments that rely primarily on cuts in current spending, in particular cuts of transfers and the public-sector wage bill, are more likely to be successful in reducing the deficit and less likely to be contractionary. Alesina and Ardagna (1998) also find that the probability that a fiscal consolidation is expansionary is highly positively correlated with cuts in transfers and government wages.

\subsubsection{THE INITIAL DEBT LEVEL}

The initial level of public debt is a factor that has been much less studied in the empirical literature. However, Perotti (1999) presents empirical evidence showing that, when public debt is high, deficit cuts are more likely to be expansionary. This is supported by OECD (2010b). However, as Table 10.3 indicates, several other studies have not found that the initial level of public debt is a significant factor in whether a consolidation is expansionary.

\subsubsection{THE ROLE OF MONETARY POLICY AND INTEREST RATES}

Ardagna (2004) argues that monetary policy and nominal interest rates play no major role in determining the effects of fiscal consolidations. On the other hand, Ahrend et al. (2006) find that consolidation efforts are more likely to be pursued and to succeed if the monetary policy stance is eased in the initial stages of the episode, thus contributing to offsetting the contractionary impact of fiscal tightening. Other authors point out that a contractionary effect of fiscal consolidation can be avoided only if monetary policy is expansionary (IMF 2010a; Krugman 2010b). In particular, these authors argue that fiscal consolidation is particularly contractionary in situations with low interest rates. One problem for the empirical investigation of this point is that there is only a limited number of cases where low interest rates and fiscal policy

This is an open access version of the publication distributed under the terms of the Creative Commons Attribution-NonCommercialNoDerivs licence (http://creativecommons.org/licenses/by-nc-nd/3.0/), which permits non-commercial reproduction and distribution of the work, in any medium, provided the original work is not altered or transformed in any way, and that the work is properly cited. For commercial re-use, please contact academic.permissions@oup.com 
action coincide. According to the IMF (2010a), the only episode with interest rates near zero since the 1990s occurred in Japan; all other episodes were associated with interest rate cuts. Therefore we cannot draw conclusions for zero interest rate countries from the basic analysis. To overcome this problem, the IMF (2010a) employs a simulation approach.

Additionally, in his critique of Alesina and Ardagna (2010), Krugman refers to work by Almunia et al. (2010), which uses data from 1930s-an era of low interest rates-and uses defence spending as an instrument to identify spending changes, similar to Blanchard and Perotti (2002), Barro and Redlick (2009), and Hall (2009). They find that fiscal stimulus was effective in a low interest rate environment, which is in contradiction to previous studies on that period. In addition to those studies, Corsetti et al. (2010) use a standard new Keynesian model with a zero bound on interest rates to show that anticipation of the medium-term spending cuts usually enhances the expansionary effects of a short-run fiscal stimulus. They advise not to withdraw stimulus too early in favour of spending cuts, as this may lower fiscal multipliers and lengthen the zero lower bound episode.

\subsubsection{EXCHANGE-RATE DEPRECIATION}

In countries with flexible exchange rates, depreciation can stabilize demand for domestically produced goods and services by increasing exports and reducing imports. The study by IMF (2010a) provides some evidence on the role of exchange rates, finding that depreciating exchange rates have a mitigating effect on the decline in GDP. They show that, in response to fiscal consolidation of 1 per cent of GDP, the exchange rate depreciates 1.1 per cent in real terms, increasing net exports by about 0.5 per cent of GDP, and reducing domestic demand by about 1 per cent of GDP. In this study, the mitigating effect of the exchange rate means that the negative effect of fiscal consolidation is cut in half. Alesina and Perotti (1996) suggest that devaluation may increase the probability of an expansion following a consolidation, but only if the composition of the adjustment had the other features that they discuss.

\subsubsection{THE FISCAL SITUATION OF OTHER COUNTRIES}

In the context of the current economic crisis, many observers have argued that fiscal consolidation will be less likely to be expansionary because many countries are switching to fiscal austerity at the same time. IMF (2010a) uses simulations with and without a zero interest rate floor to shed some light on the issue. It concludes that, with an interest rate floor, a fiscal consolidation of 1 per cent of GDP in a small open economy would generate a loss of output of about 1 per cent, whereas, if the rest of the world consolidates at the same time, the output cost increases to 2 per cent. Without the interest rate floor, the difference is smaller, but still present. However, none of the studies listed

This is an open access version of the publication distributed under the terms of the Creative Commons Attribution-NonCommercialNoDerivs licence (http://creativecommons.org/licenses/by-nc-nd/3.0/), which permits non-commercial reproduction and distribution of the work, in any medium, provided the original work is not altered or transformed in any way, and that the work is properly cited. For commercial re-use, please contact academic.permissions@oup.com 
in Table 10.3 provides any direct empirical evidence on this issue. We therefore do not discuss this issue further in Section 10.4.

\subsubsection{SUCCESSFUL FISCAL CONSOLIDATION}

The literature that deals with expansionary effects of fiscal adjustments also analyses determinants of 'successful' fiscal consolidations, where success is measured by a decline in public debt to GDP. For example Alesina and Ardagna (2010) define success as a period in which 'the cumulative reduction of the debt to GDP ratio three years after the beginning of a fiscal adjustment is greater than 4.5 percentage points'. There is evidence that the success of a fiscal consolidation affects whether it is expansionary. Alesina and Perotti (1996) and Alesina et al. (1998) find that rate of growth of GDP relative to the G7 countries increases during a successful adjustment but decreases during an unsuccessful one. They also find growth after successful adjustment comes mainly from the investment boom, with consumption contributing slightly less, though still being significant.

Since there is evidence that the success of fiscal adjustment affects growth, the determinants of successful fiscal consolidation may indirectly contribute to the possibility of expansionary fiscal adjustment. We therefore summarize the empirical results in the literature on how different factors contribute to successful fiscal adjustments. Table 10.4 summarizes the position, using the same factors as Table 10.3. We briefly consider each factor in turn.

- Magnitude of adjustment. McDermott and Westcott (1996) find that the greater the magnitude of the fiscal consolidation, the more likely it is to be successful. Ardagna (2004) finds that the success of fiscal adjustments depends more on the size of the fiscal contraction and less on its composition.

- Composition of adjustment. McDermott and Westcott (1996) and von Hagen and Strauch (2001) find that fiscal adjustments based on spending cuts are more likely to be successful in reducing the debt ratio. Moreover, Nickel et al. (2010) conclude that major debt reductions are driven mainly by decisive and lasting (rather than timid and short-lived) fiscal consolidation efforts focused on reducing government expenditure, in particular, cuts in social benefits and public wages. Alesina and Ardagna (1998) find that the probability of success depends on the composition on the adjustment but not on the size, with successful adjustments being more probable for cases of primary expenditure or cuts in wages and transfers.

- High initial deficit and debt relative to GDP. Alesina et al. (1998) show that successful fiscal adjustments tend to be undertaken when public debt as a share of GDP is relatively high. Von Hagen and Strauch (2001) show that

This is an open access version of the publication distributed under the terms of the Creative Commons Attribution-NonCommercialNoDerivs licence (http://creativecommons.org/licenses/by-nc-nd/3.0/), which permits non-commercial reproduction and distribution of the work, in any medium, provided the original work is not altered or transformed in any way, and that the work is properly cited. For commercial re-use, please contact academic.permissions@oup.com 
Table 10.4. Summary of the empirical literature findings on successful fiscal consolidations

\begin{tabular}{lllll}
\hline Study & Magnitude Composition & $\begin{array}{l}\text { Initial } \\
\text { debt level }\end{array}$ & $\begin{array}{l}\text { Monetary } \\
\text { policy }\end{array}$ & $\begin{array}{l}\text { Exchange } \\
\text { rate }\end{array}$
\end{tabular}

\begin{tabular}{|c|c|c|c|c|c|c|}
\hline Ahrend et al. (2006) & & + & & + & + & \\
\hline $\begin{array}{l}\text { Alesina and Argadna } \\
\text { (1998) }\end{array}$ & - & + & + & & - & \\
\hline $\begin{array}{l}\text { Alesina and Perotti } \\
\text { (1995) }\end{array}$ & + & + & & & & \\
\hline $\begin{array}{l}\text { Alesina and Perotti } \\
\text { (1996) }\end{array}$ & + & + & & & & \\
\hline Alesina et al. (1998) & & & + & & + & \\
\hline Ardagna (2004) & + & - & + & - & - & \\
\hline $\begin{array}{l}\text { Broadbent and Daly } \\
\text { (2010) }\end{array}$ & & + & & & & \\
\hline $\begin{array}{l}\text { Cos and Moral-Benito } \\
\text { (2011) }\end{array}$ & - & - & - & & & \\
\hline Giavazzi et al. (2000) & & + & & & & \\
\hline Guichard et al. (2007) & & + & + & + & & \\
\hline $\begin{array}{l}\text { Lambertini and } \\
\text { Tavares (2003) }\end{array}$ & + & + & - & - & + & \\
\hline $\begin{array}{l}\text { McDermott and } \\
\text { Westcott (1996) }\end{array}$ & + & + & & + & - & \\
\hline Nickel et al. (2010) & & + & + & & & \\
\hline OECD (2010b) & + & + & & & & \\
\hline Tavares (2004) & - & + & + & & & \\
\hline $\begin{array}{l}\text { von Hagen and } \\
\text { Strauch (2001) }\end{array}$ & & + & + & - & & + \\
\hline $\begin{array}{l}\text { von Hagen and } \\
\text { Strauch (2001) }\end{array}$ & & + & + & - & & + \\
\hline $\begin{array}{l}\text { von Hagen et al. } \\
\quad(2002)\end{array}$ & & + & + & - & & + \\
\hline
\end{tabular}

Notes: For success of fiscal consolidation: + if the paper finds positive effect, - if no effect found, blank if it was not analysed. All the above papers study the determinants of the successful fiscal consolidation, thus all find the consolidation to be successful under some set of conditions. Again credibility is not in the table, as there is no empirical evidence on the importance of that variable. Almost all studies mention it as an important factor determining whether the magnitude and composition matter, but none analyses it as an empirical variable.

a large debt-GDP ratio increases the probability of a consolidation being successful. Additionally, von Hagen et al. (2002) find that consolidations tend to last longer if they start from large debt-GDP ratios. They claim that these findings confirm the evidence found by Alesina and Ardagna (1998) for OECD countries, showing that the likelihood of a consolidation success increases in the debt level. Guichard et al. (2007) find that large initial deficits have been important in boosting the overall size and duration of consolidation.

- Monetary policy. Von Hagen and Strauch (2001)and Lambertini and Tavares (2003) argue that monetary policy does not affect the success of fiscal adjustments. Specifically, von Hagen et al. (2002) argue that domestic monetary conditions during a consolidation episode do not play a significant role in explaining the duration of consolidation 
episodes. However, Guichard et al. (2007) find that high interest rates have been important in prompting fiscal adjustment and also in boosting the overall size and duration of consolidation. Alesina and Perotti (1996) find that nominal long interest rates, relative to G7 rates, fall during successful adjustments, but increase during unsuccessful ones.

- Exchange rates. Lambertini and Tavares (2003) find a strong and robust association between depreciation of the exchange rate before the fiscal adjustment and the persistence of the adjustment. Additionally, they find that successful adjustments are almost always preceded by large nominal and real depreciations, with 1 per cent average depreciation in the two years preceding a fiscal adjustment leading to a roughly 1 per cent increase in the probability of success. Alesina et al. (1998) make the observation that both successful and unsuccessful adjustments tend to be accompanied by currency depreciation, though this is slightly larger before a successful adjustment.

- Fiscal situation in other countries. Von Hagen et al. (2002) find that fiscal tightening in OECD countries tends to increase the duration of a fiscal consolidation. Moreover, von Hagen and Strauch (2001) find that the stance of fiscal policy in OECD countries is an important determinant of a government's choice of fiscal consolidation strategy, making it an important determinant of the success of fiscal consolidation.

The link between successful and expansionary fiscal adjustment is two way, in that economic growth fosters successful fiscal consolidation. Specifically, Cos and Moral-Benito (2011) find that, in order to succeed in reducing budget deficits, economic growth is the only relevant ingredient. Nickel et al. (2010) find that robust real GDP growth increases the probability of a major debt reduction because it helps countries to 'grow their way out' of indebtedness.

Overall, the key insight emerging from research on the impact of fiscal policy on short-term growth suggests that this impact may be very different, depending on the design of the consolidation programme and the economic situation of the country where the fiscal policy change occurs. In the next section we discuss the current (2010-11) situation of the UK and use the insight of the literature on fiscal policy summarized so far to assess the likely impact of fiscal consolidation on the UK economy.

\subsection{Implications for the UK}

In the UK, both the public-sector deficit and the level of public-sector debt increased substantially during the recession, as indicated in Figures 10.1 and 10.2. The debt-GDP ratio nearly doubled from just over 40 per cent to over 


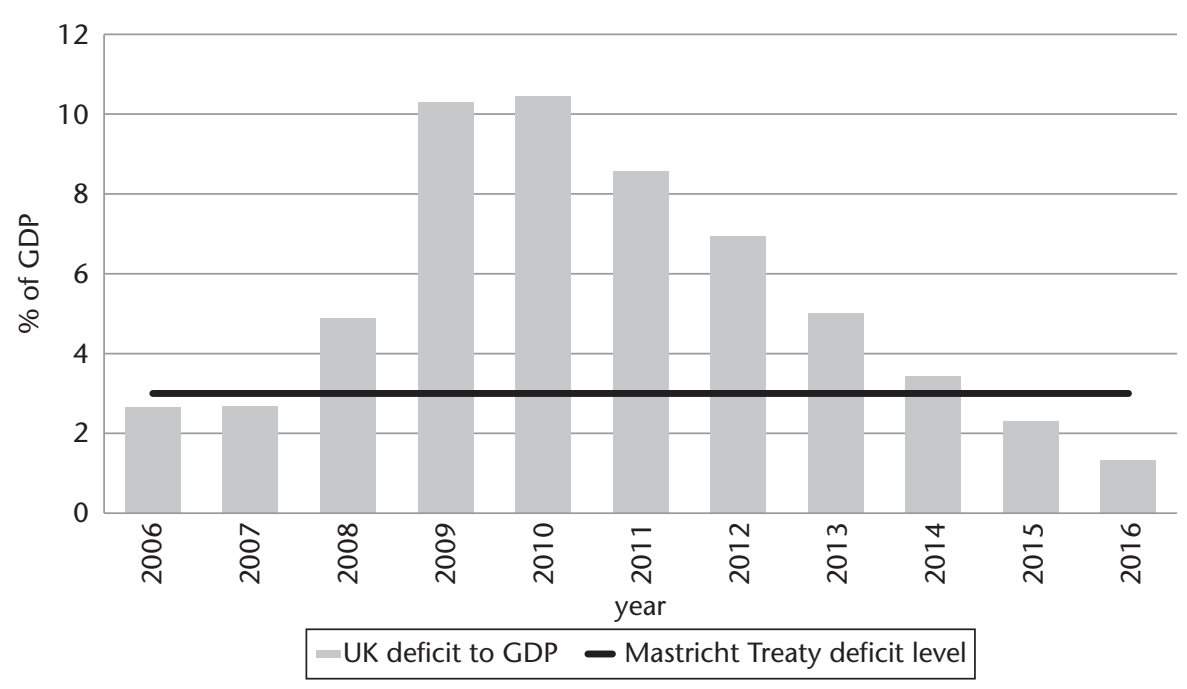

Figure 10.1. UK deficit to GDP level, 2006-16 Source: IMF World Economic Outlook Database.

80 per cent from 2006 to 2011, passing the 60 per cent threshold in the Maastricht Treaty in 2009. This rapid growth arose partly because of automatic adjustment, which was due in part to a reduction in revenues when spending continued according to plans set out in 2007. In addition, the government further deliberately increased the deficit as part of an attempt to stimulate the economy.

Figure 10.3 and 10.4 provide a comparison of the deficit and debt levels in the UK in 2011 with a number of other leading industrialized countries. Although the stock of public debt in the UK is not much higher than in other countries, the budget deficit is very high, and lies only behind Ireland and the USA in the ranking of the ratio of debt to GDP.

There is no doubt that the deficit faced by the UK in 2010-11 is unsustainable in the long term, and by 2010 there was a consensus that the large deficit needed to be reduced, although there was less of a consensus about the speed at which it should be reduced. The March 2011 plans for the deficit and the debt-GDP ratio are also shown in the figures. The government aims to reduce the deficit to zero by 2015 . However, under these plans, the debt-GDP ratio will continue to rise until 2013 before stabilizing.

This section attempts to examine the probability that the current UK programme of fiscal consolidation will be expansionary. We use the findings of the research surveyed in the preceding sections to provide guidance as to the relevant factors and we examine the position of these factors for the UK as of 2011. 


\section{The Effects of Fiscal Consolidation}

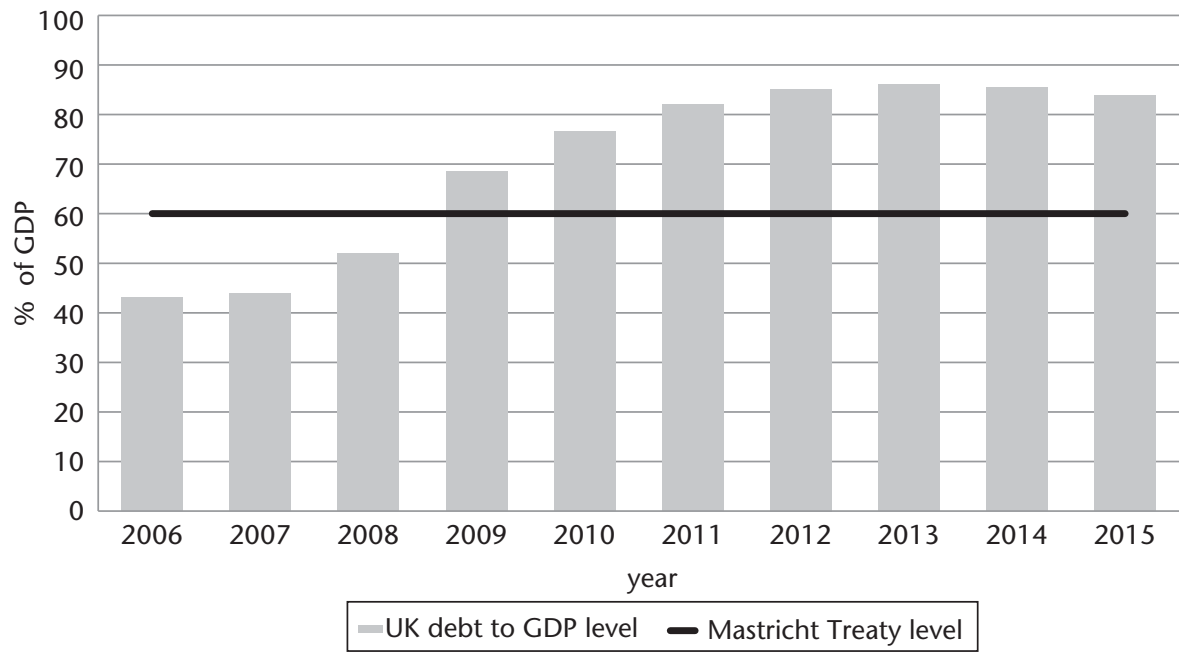

Figure 10.2. UK debt to GDP level, 2006-15

Source: IMF World Economic Outlook Database.

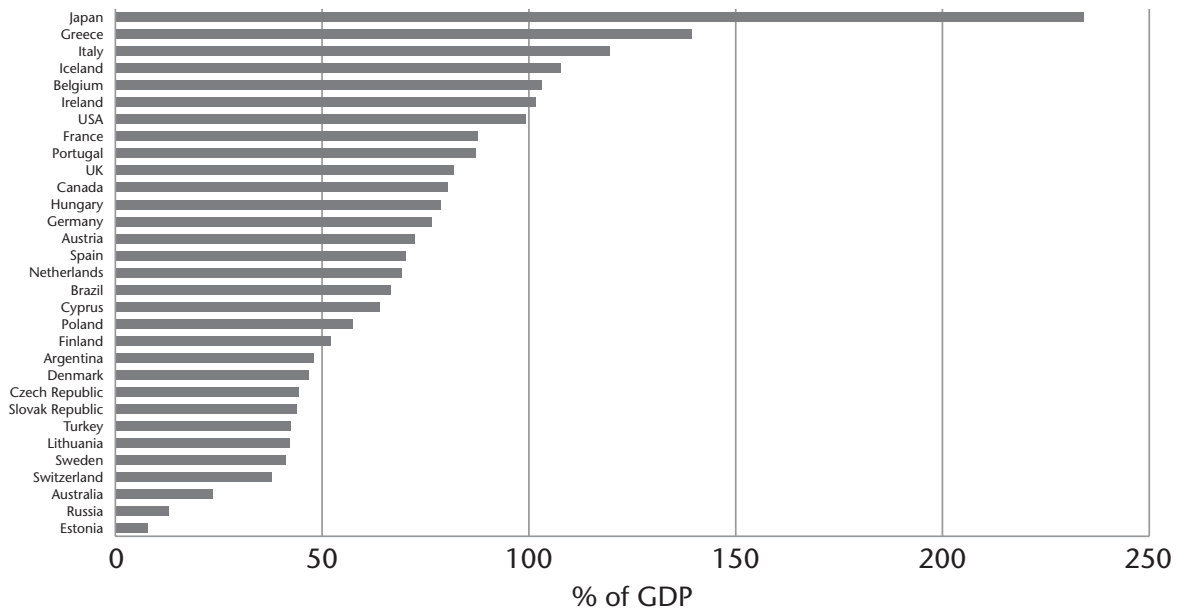

Figure 10.3. Debt-GDP ratio, country comparisons, 2011

Source: IMF World Economic Outlook Database.

Before undertaking that analysis, we consider what the growth forecasts of the UK Office for Budget Responsibility (OBR) imply for whether the current consolidation will be expansionary. The average growth rate in 2010 and in two years following that is forecast to be 1.8 per cent. The equivalent IMF World Economic Outlook forecast for the G7 weighted average over the same period is 2.5 per cent. The difference between these two forecasts is

This is an open access version of the publication distributed under the terms of the Creative Commons Attribution-NonCommercialNoDerivs licence (http://creativecommons.org/licenses/by-nc-nd/3.0/), which permits non-commercial reproduction and distribution of the work, in any medium, provided the original work is not altered or transformed in any way, and that the work is properly cited. For commercial re-use, please contact academic.permissions@oup.com 


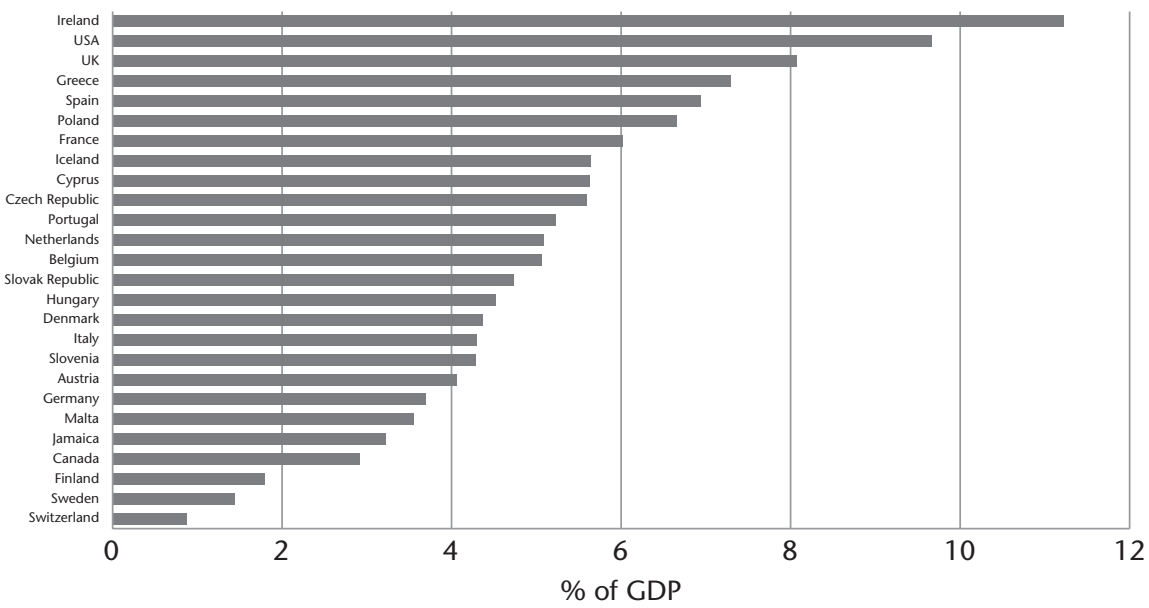

Figure 10.4. Deficit-GDP ratio, country comparisons, 2011 Source: IMF World Economic Outlook Database.

-0.6 per cent. Using the Alesina and Ardagna (2010) method of fiscal episodes identification and IMF World Economic Outlook growth rates, we calculated this difference for each past episode considered to be a fiscal consolidation. ${ }^{7}$ The 75th percentile of the distribution of these differences was 1.19 per cent. So, according to the Alesina and Ardagna (2010) method, the current UK consolidation is well below the cut-off point for describing the fiscal consolidation as expansionary.

In contrast, however, the identification method proposed by Alesina et al. (2002) gives a different picture. Average UK growth for 2008 and 2009 was -2.19 per cent. This clearly means that growth in 2010 and 2012 is expected to be considerably higher than prior to the consolidation. Based on this approach and the OBR forecast, the current UK consolidation would be identified as expansionary. Of course, the difference between these two approaches highlights one of the numerous problems in this literature.

What is more, using the definition of successful fiscal consolidation provided by Alesina and Ardagna (2010) and comparing it to the current OBR forecast, we can see that the UK is not expected to be a case of a successful fiscal consolidation either. The UK general government debt-GDP ratio will expand until 2013 before beginning to fall only in 2014. The ratio will not fall relative to the 2010-11 position over the following five years, as the forecast shows.

\footnotetext{
${ }^{7}$ For the list of all the episodes identified, see Table 10.1.
}

This is an open access version of the publication distributed under the terms of the Creative Commons Attribution-NonCommercialNoDerivs licence (http://creativecommons.org/licenses/by-nc-nd/3.0/), which permits non-commercial reproduction and distribution of the work, in any medium, provided the original work is not altered or transformed in any way, and that the work is properly cited. For commercial re-use, please contact academic.permissions@oup.com 
Leaving these different interpretations to one side, we now focus on the factors that the literature has identified as being significant for the growth outcome for the UK. For each of the main factors, we assess the situation in the UK.

\subsubsection{Magnitude of the consolidation}

As pointed out in the preceding section, research surprisingly indicates that larger consolidations are more likely to have an expansionary impact on growth. The OBR forecast, shown in Table 10.5, predicts that UK will reduce its CAPB substantially after 2009-10, with reductions of 2.3 per cent of GDP in 2010-11, 2.2 per cent of GDP from 2010-11 to 2011-12, and 1.5 per cent of GDP from 2012-13 to 2013-14. Based on the definitions in the literature, discussed above, these reductions clearly qualify this period as a case of fiscal consolidation.

However, it is useful to ask how large these cuts are, relative to those investigated in the literature. Figure 10.5 presents the projected reductions in CAPB for the UK in the context of historical consolidations; the data are taken from the OECD Economic Outlook 88 database. ${ }^{8}$ Because the literature typically draws conclusions for episodes of fiscal adjustments where the improvement in CAPB is larger than 1.5 per cent of GDP, with the lowest threshold analysed being 1 per cent (Guichard et al. 2007), we show only those episodes. ${ }^{9}$ The figure indicates that there has been a wide divergence in the size of past consolidations. A number of consolidations have been in excess of 3 per cent of GDP in a given year. However, about 85.5 per cent of

Table 10.5. Overview of OBR central fiscal forecast for UK, 2009-16 (\% of GDP)

\begin{tabular}{|c|c|c|c|c|c|c|c|}
\hline \multirow[b]{2}{*}{ Deficit measures } & \multicolumn{7}{|c|}{ Outturn Forecasts } \\
\hline & $\begin{array}{c}2009 / \\
10\end{array}$ & $\begin{array}{c}2010 / \\
11\end{array}$ & $\begin{array}{c}2011 / \\
12\end{array}$ & $\begin{array}{c}2012 / \\
13\end{array}$ & $\begin{array}{c}2013 / \\
14\end{array}$ & $\begin{array}{c}2014 / \\
15\end{array}$ & $\begin{array}{c}2015 / \\
16\end{array}$ \\
\hline Public-sector net borrowing & 11.1 & 9.9 & 7.9 & 6.2 & 4.1 & 2.5 & 1.5 \\
\hline Surplus on current budget & -7.6 & -7.1 & -5.8 & -4.5 & -2.7 & -1.2 & -0.2 \\
\hline Primary balance & -9.2 & -7.1 & -5 & -3.5 & -1.3 & 0.3 & 1.3 \\
\hline Cyclically adjusted net borrowing & 8.9 & 7.4 & 5.3 & 3.7 & 2 & 1 & 0.5 \\
\hline $\begin{array}{l}\text { Cyclically adjusted surplus on current } \\
\text { budget }\end{array}$ & -5.3 & -4.6 & -3.2 & -2 & -0.6 & 0.4 & 0.8 \\
\hline HM Treasury estimate of CAPB & -6.9 & -4.6 & -2.4 & -0.9 & 0.8 & 1.9 & 2.3 \\
\hline
\end{tabular}

${ }^{8}$ Here our measure of the CAPB is the sum of the general government cyclically adjusted balances and general government net debt interest payments.

${ }^{9}$ For the list of all the episodes with CAPB improvement higher than $1 \%$, see Table 10.2 .

This is an open access version of the publication distributed under the terms of the Creative Commons Attribution-NonCommercialNoDerivs licence (http://creativecommons.org/licenses/by-nc-nd/3.0/), which permits non-commercial reproduction and distribution of the work, in any medium, provided the original work is not altered or transformed in any way, and that the work is properly cited. For commercial re-use, please contact academic.permissions@oup.com 


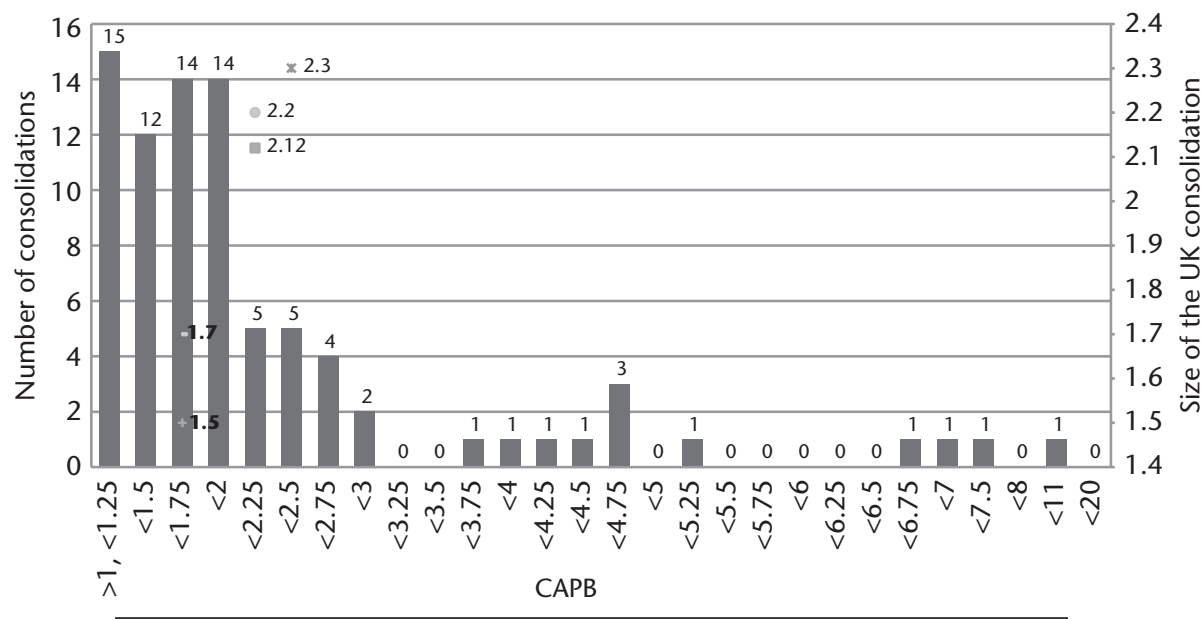

* UK OBR 2011 UK OBR 2012 TUK OBR 2013 =UK OBR 2014 UK 2010

Figure 10.5. Number of fiscal consolidations by size (CAPB measure) since 1994 Note: Projected reductions in CAPB for the UK are represented by dots.

Source: OECD Economic Outlook 88 database.

the observations have the size of the consolidation lower than 3 per cent of GDP and 66.3 per cent of observations smaller than 2 per cent of GDP.

The projected UK consolidation of a reduction in CAPB of more than 2 per cent for three consecutive years therefore ranks the UK consolidation as relatively large. To the extent that the literature is correct in identifying larger consolidations as being more likely to be expansionary, then this is a positive indication for the growth prospects of the UK.

\subsubsection{Composition of the consolidation}

There is a reasonable consensus in the literature that consolidations based primarily on cuts in public spending are more likely to be expansionary. The UK programme of fiscal consolidation includes both higher taxes and lower expenditure, but the government has placed emphasis on spending cuts. Table 10.6 shows the planned changes in tax receipts and public spending for the consolidation period in the UK. The spending share of the total discretionary consolidation is expected to be 59 per cent in 2010-11, rising to 76 per cent in 2015-16. The government's intention is, therefore, to reduce the deficit primarily through spending cuts.

Again we need to assess these plans against the past consolidations analysed in the literature. Table 10.7 shows estimates of the composition of fiscal 
Table 10.6. Total consolidation plans, UK, 2010-16

\begin{tabular}{|c|c|c|c|c|c|c|}
\hline Composition of consolidation & $\begin{array}{c}2010 / \\
11\end{array}$ & $\begin{array}{l}2011 / \\
12\end{array}$ & $\begin{array}{l}2012 / \\
13\end{array}$ & $\begin{array}{l}2013 / \\
14\end{array}$ & $\begin{array}{l}2014 / \\
15\end{array}$ & $\begin{array}{l}2015 / \\
16\end{array}$ \\
\hline $\begin{array}{l}\text { Total discretionary } \\
\text { consolidation ( } £ \text { bn) }\end{array}$ & 9.4 & 41 & 61 & 88 & 110 & 126 \\
\hline Spending $(£ b n)$ & 5.5 & 22 & 38 & 59 & 80 & 95 \\
\hline $\operatorname{Tax}(£ b n)$ & 3.8 & 20 & 23 & 29 & 30 & 30 \\
\hline $\begin{array}{l}\text { Spending share of } \\
\text { consolidation (\%) }\end{array}$ & 59 & 53 & 62 & 67 & 73 & 76 \\
\hline
\end{tabular}

Source: HM Treasury Budget, Mar. 2011.

Table 10.7. Contribution of primary expenditure and total revenue to fiscal consolidation, Alesina and Ardagna (2010)

\begin{tabular}{lcccc}
\hline $\begin{array}{l}\text { Contribution to fiscal } \\
\text { consolidation (cyclically } \\
\text { adjusted) }\end{array}$ & Successful & Expansionary & Unsuccessful & Contractionary \\
\hline Primary expenditure & 67.44 & 56.02 & 38.86 & \\
Total revenue & 32.56 & 43.98 & 61.14 & 62.67 \\
\hline
\end{tabular}

consolidations used in Alesina (2010b), based on Alesina and Ardagna (2010). The figures suggest that fiscal consolidations that are expansionary have been constituted by on average 56 per cent cuts in expenditure and 44 per cent increases in tax. The share accounted for by spending cuts is substantially higher than for consolidations that were contractionary. The medium-term aim for the UK clearly exceeds the average for expansionary consolidations. Based again on the results of the literature, this suggests that the UK's consolidation is more likely to be expansionary.

\subsubsection{Initial debt level}

There is only moderate evidence that an initially high ratio of debt to GDP improves the probability of a fiscal consolidation being expansionary, though there is more of a consensus that this may affect the probability of a successful fiscal consolidation. Table 10.8 gives some numerical examples from the literature, where it is clear that the debt-to-GDP ratio in expansionary fiscal consolidations was lower than in contractionary ones. However, in these examples, the proportions are reversed in comparing successful to unsuccessful consolidations.

In comparison to these examples, the debt-to-GDP ratio in UK in 2010 was 76.1 per cent. This exceeds almost all the examples in the table. It certainly

This is an open access version of the publication distributed under the terms of the Creative Commons Attribution-NonCommercialNoDerivs licence (http://creativecommons.org/licenses/by-nc-nd/3.0/), which permits non-commercial reproduction and distribution of the work, in any medium, provided the original work is not altered or transformed in any way, and that the work is properly cited. For commercial re-use, please contact academic.permissions@oup.com 
Table 10.8. Average debt to GDP levels during fiscal consolidation episodes

\begin{tabular}{|c|c|c|c|c|c|}
\hline \multirow[t]{2}{*}{ Method } & \multirow[t]{2}{*}{ Time span } & \multicolumn{4}{|c|}{ Average if } \\
\hline & & $\begin{array}{l}\text { expansionary } \\
\text { (\% of GDP) }\end{array}$ & $\begin{array}{l}\text { contractionary } \\
\text { (\% of GDP) }\end{array}$ & $\begin{array}{l}\text { successful } \\
\text { (\% of } \\
\text { GDP) }\end{array}$ & $\begin{array}{l}\text { unsuccessful } \\
\text { (\% of GDP) }\end{array}$ \\
\hline $\begin{array}{l}\text { Alesina and Ardagna } \\
\text { (1998)_IMF data }\end{array}$ & 1994-2012 & 49.27 & 80.13 & & \\
\hline $\begin{array}{l}\text { Alesina and Ardagna } \\
\text { (1998) }\end{array}$ & 1960-94 & 55.86 & 59.87 & 72.15 & 49.37 \\
\hline Alesina (2010b) & 1970-2007 & 57.53 & 71.8 & & \\
\hline Alesina et al. (1998) & $1965-92$ & & & 68.11 & 44.34 \\
\hline Giudice et al. (2007) & 1970-2002 & 75.1 & 67.4 & & \\
\hline Tavares (2004) & $1960-95$ & & & 68.63 & 44 \\
\hline
\end{tabular}

Note: Method of identifying fiscal episodes is CAPB, method of identifying expansionary fiscal episodes outlined in stub.

exceeds the examples of expansionary consolidations, as well as both successful and unsuccessful consolidations. The literature and these estimates provide only very weak evidence for the probability that UK consolidation can be expansionary.

\subsubsection{Credibility of the consolidation}

An important part of the case that a fiscal consolidation may be expansionary is that the planned cut in the deficit must be credible. The more credible it is, the lower the uncertainty surrounding future policy. Credibility is difficult to measure, and there have been no formal tests of the importance of credibility in the fiscal consolidation literature. Here we consider various measures that give some indication of the credibility of the UK consolidation.

A starting point is to compare the credit ratings of UK and other European countries; this is summarized in Table 10.9. The sovereign credit rating for the UK in 2011 is Aaa, a higher rating than most other countries currently engaged in a consolidation: for example, Ireland is at Baa1, Greece at Ba1, Spain at Aa1, and Portugal at A1. The CDS spread suggests a similar position. The UK spread in January 2011 was a little higher than that of Germany, but considerably lower than in a number of other countries, including all those with high deficit or debt levels. The CDS-IR Gap measures the gap between CDS Implied Ratings and Issuer Credit Ratings; this indicator is found to be strongly related to future rating actions and is often used to anticipate the rating agency actions. For the UK, this was -5 in January 2011, indicating some probability that the UK rating may be downgraded. However, overall, the information in Table 10.9 suggests that markets and ratings agencies believe that the probability of the UK government defaulting on its sovereign debt is very low. 
Table 10.9. European Sovereign Credit Ratings as of 11 January 2011

\begin{tabular}{lcccc}
\hline Country & Sovereign Credit Rating & CDS spread & CDS-IR & CDS-IR Gap \\
\hline Spain & Aa1 & 349 & B1 & -12 \\
Portugal & A1 & 540 & Caa1 & -12 \\
Belgium & Aa1 & 247 & Ba2 & -10 \\
Ireland & Baa1 & 666 & Caa2 & -10 \\
Greece & Ba1 & 1099 & C & -10 \\
Italy & Aa2 & 244 & Ba2 & -9 \\
France & Aaa & 108 & Baa2 & -8 \\
Austria & Aaa & 101 & Baa1 & -7 \\
UK & Aaa & 71 & A2 & -5 \\
Netherlands & Aaa & 60 & Aa2 & -2 \\
Denmark & Aaa & 48 & Aaa & 0 \\
Finland & Aaa & 37 & Aaa & 0 \\
Norway & Aaa & 23 & Aaa & 0 \\
Sweden & Aaa & 35 & Aaa & 0 \\
Switzerland & Aaa & 44 & Aaa & 0 \\
Germany & Aaa & 60 & Aa2 & -2 \\
USA & Aaa & 33 & Aaa & 0 \\
Average & Aa2 & 245 & Baa1 & -6 \\
\hline
\end{tabular}

Source: Moody's.

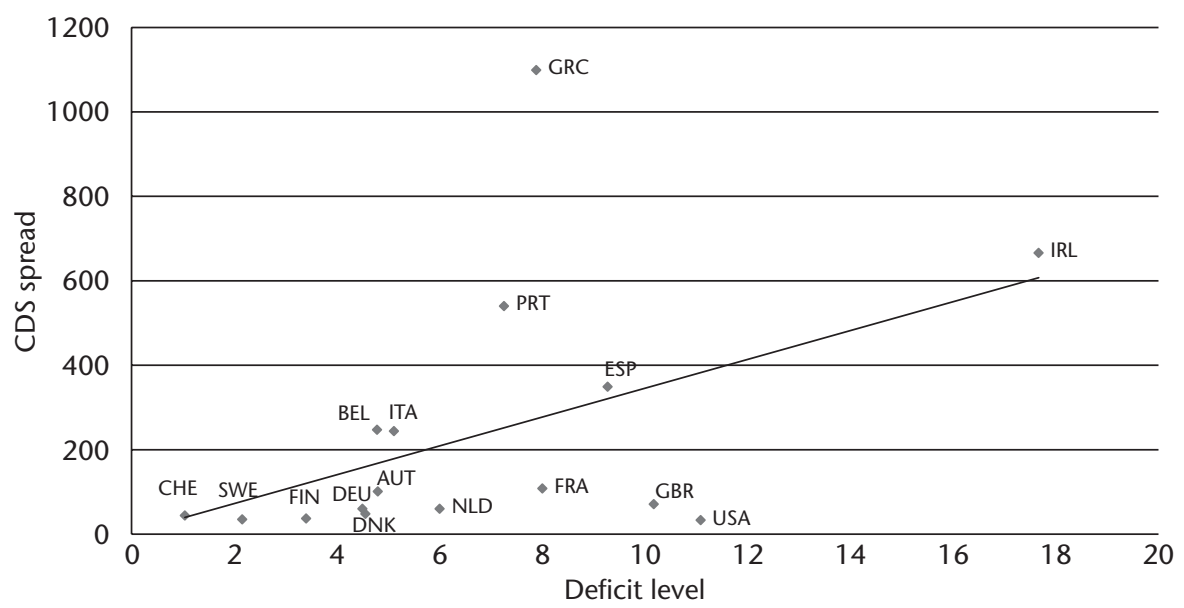

Figure 10.6. Deficit levels versus CDS spreads, 2011

Source: IMF World Economic Outlook Database and Moody's.

Figures 10.6 and 10.7 respectively take this analysis a little further, by plotting the CDS spread for each country against the deficit to GDP ratio and the debt to GDP ratio. These figures use the CDS spreads in Table 10.9 and the deficit and debt ratio from Section 10.4. As would be expected, in general the CDS spread depends positively on the size of the deficit and the size of the debt: this is shown by the trend line in each figure. However, one way of evaluating the

This is an open access version of the publication distributed under the terms of the Creative Commons Attribution-NonCommercialNoDerivs licence (http://creativecommons.org/licenses/by-nc-nd/3.0/), which permits non-commercial reproduction and distribution of the work, in any medium, provided the original work is not altered or transformed in any way, and that the work is properly cited. For commercial re-use, please contact academic.permissions@oup.com 


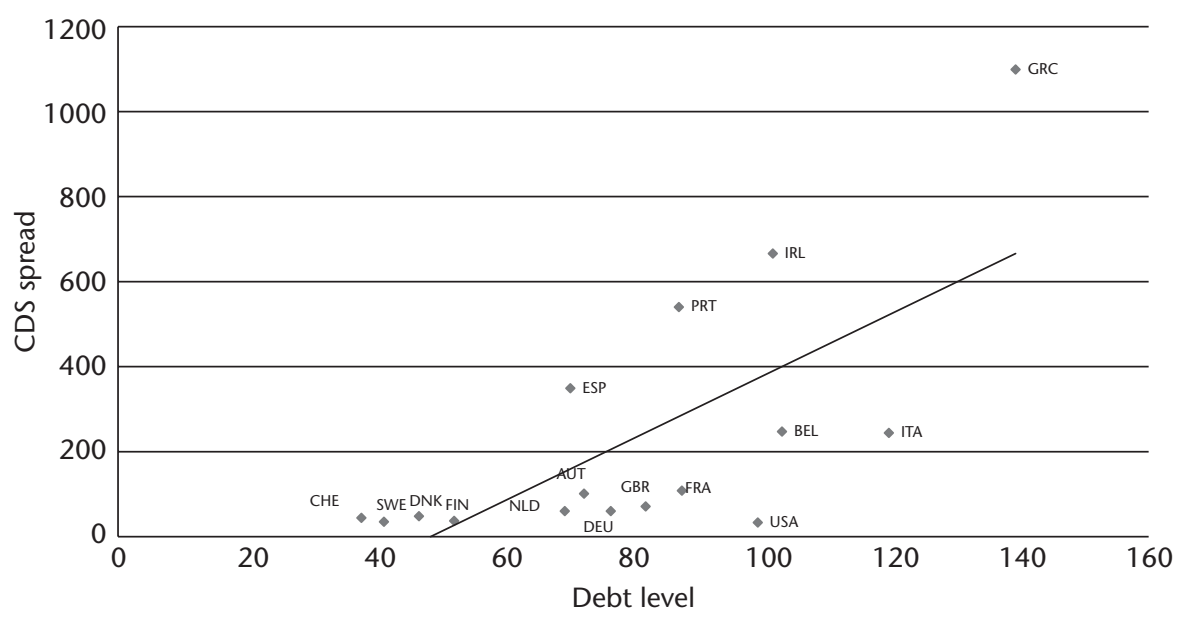

Figure 10.7. Debt levels versus CDS spreads, 2011

Source: IMF World Economic Outlook Database and Moody's.

credibility of the UK is to identify its specific position relative to the trend line. In both cases the UK is some way below the trend line. This suggests that the CDS spread for the UK is lower than would be expected, given the size of its deficit and debt. One important factor in generating such a low CDS spread is likely to be that markets believe that the announced fiscal consolidation in the UK is credible-and, indeed, more credible than in most other countries. Even in the absence of empirical evidence of the importance of credibility, it seems reasonable to suppose that this is a positive factor for the probability that the UK's consolidation will be expansionary.

\subsubsection{Monetary policy}

Although there is no overwhelming econometric evidence on the importance of the monetary policy for the expansionary fiscal consolidation, it does seem plausible that the part of the effects of a fiscal consolidation should depend on its effects on interest rates. For example, IMF (2010a) and Krugman (2010b) argue that fiscal consolidation is likely to be less contractionary in an environment with high interest rates; this is because in this case the consolidation can help to reduce interest rates, which in turn can help to stimulate the economy.

For the UK, however, Figure 10.8 clearly demonstrates that in 2011 the UK is in a low-interest environment. Interest rates decreased rapidly as part of the Bank of England's response to the financial crisis in mid-2009, and have not yet risen again. There is, therefore, little potential benefit from the consolidation via the channel of reducing interest rates.

This is an open access version of the publication distributed under the terms of the Creative Commons Attribution-NonCommercialNoDerivs licence (http://creativecommons.org/licenses/by-nc-nd/3.0/), which permits non-commercial reproduction and distribution of the work, in any medium, provided the original work is not altered or transformed in any way, and that the work is properly cited. For commercial re-use, please contact academic.permissions@oup.com 
The Effects of Fiscal Consolidation

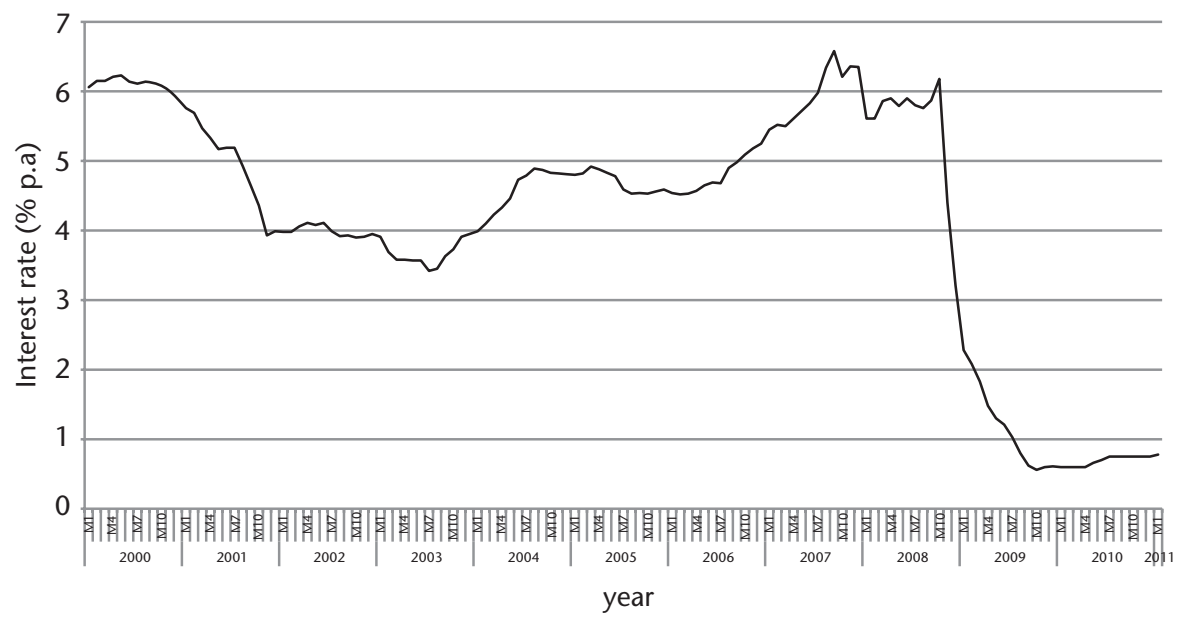

Figure 10.8. Monthly interbank three-month LIBOR, \% p.a., 2000-11, UK Source: Office for National Statistics.

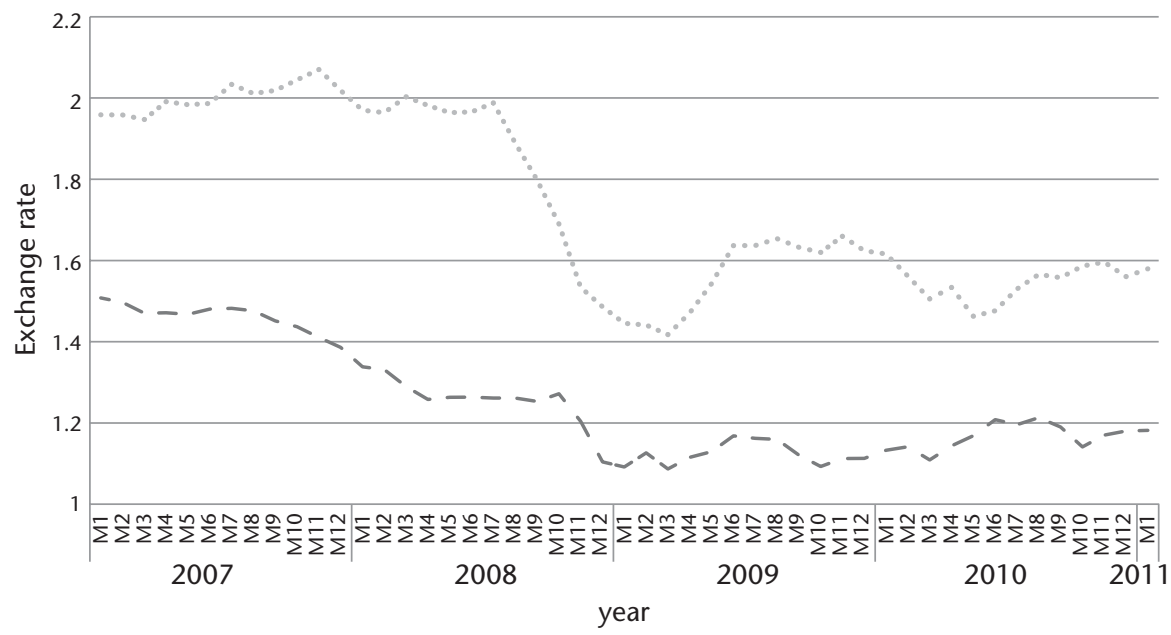

Figure 10.9. Exchange rates for sterling, 2007-11

Note: The dotted line indicates the exchange rate between British sterling and US\$. The dashed line indicates the exchange rate between British sterling and euro. Both cases show how much foreign currency $£ 1$ is worth.

Source: Office for National Statistics.

\subsubsection{Exchange-rate depreciation}

Sterling has depreciated considerably since the beginning of the financial crisis. This is illustrated by Figure 10.9, which shows the value of sterling relative to both the US dollar and the euro. It is plausible that depreciation of the currency improve the probability that a consolidation will be

This is an open access version of the publication distributed under the terms of the Creative Commons Attribution-NonCommercialNoDerivs licence (http://creativecommons.org/licenses/by-nc-nd/3.0/), which permits non-commercial reproduction and distribution of the work, in any medium, provided the original work is not altered or transformed in any way, and that the work is properly cited. For commercial re-use, please contact academic.permissions@oup.com 
expansionary-by boosting the demand for domestically produced goods. However, the econometric evidence discussed above does not in general suggest that this has a strong effect. We are therefore cautious about drawing any conclusions on whether the depreciation in sterling will have much effect on the possibility of the consolidation to be expansionary or contractionary.

\subsection{Conclusion}

This chapter attempts to evaluate factors in the UK that are important determinants of whether the UK fiscal consolidation announced in 2010 is likely to be expansionary or contractionary. Based on the empirical literature, we identify in particular five factors that are likely to be of significance. They are: the size of the consolidation; the composition of the consolidation between spending cuts and tax increases; the initial level of public debt; whether interest rates are at a lower bound; and whether there is a devaluation of the exchange rate.

Of these factors, there is rather more empirical support that the first two are important for whether a consolidation is likely to be expansionary. In comparison with consolidations studied in the empirical literature, and with other consolidations taking place alongside that of the UK, both of these factors are positive for the UK. The planned consolidation is relatively large, and relatively focused on spending cuts. Both of these factors are likely to make it more likely that the UK consolidation is expansionary. Other positive factors for the UK are that the initial debt level is relatively high, and that sterling has been devalued. In addition, there is evidence to suggest that the planned consolidation is credible. The only factor pointing in the opposite direction is that interest rates are very low, and hence cannot be reduced any further by the consolidation.

Based on the empirical literature, this suggests that the factors that are associated with a fiscal consolidation being expansionary are largely in place in the UK. Caveats are in order, however. Importantly, there are a number of weaknesses in the empirical literature. These include the lack of very clear identification of both fiscal consolidations and expansionary effects. Even putting this to one side, the favourable probability of the consolidation being expansionary is only relative to other consolidations. Despite the relatively good position of the UK, there must still be considerable doubt as to the eventual outcome. 


\title{
Regulation and Taxation: Economics and Politics
}

\author{
Donato Masciandaro and Francesco Passarelli
}

\subsection{Introduction}

The balance and interconnections between regulation and taxation of financial activities have come under closer scrutiny as a result of the crisis that began in 2008. The main reason is that both regulation and taxation represent policy tools for curbing systemic risk, a peculiar case of externality resulting from contagion in financial markets.

The possible failure of a financial intermediary can produce a generalized fear of counter-party credit risk, with potential domino effects spreading across markets. The externality arises because these potential effects are not completely internalized by the contracting parties. In a perfect Pigouvian world, taxation and regulation would be equivalent policy tools: both policies can achieve the first best outcome if well calibrated to deal with the externality. In the real world, dominated by uncertainty and asymmetric information, policy-makers usually choose financial regulation to produce progressive effects in economic agents' risk taking (IMF 2010c), while taxation is used to produce proportional effects, using flat tax schemes (Goodhart 2010).

Thus, from a normative viewpoint, the choice between regulation and taxation is made by looking at the shape of the externality and the distribution of costs. In this chapter we offer a positive perspective, based on a theoretical framework developed in Masciandaro and Passarelli (2011), which in turn is based on a political economy argument proposed for a general pollution problem by Alesina and Passarelli (2010).

In a nutshell the main argument is as follows. Suppose that regulation by its nature-as argued at length below-is structured to have a stronger impact on 
highly risk-polluting portfolios, while a tax is levied proportionally and hence on low-polluting portfolios as well. Furthermore let us assume that the choice between regulation and taxation is made by voting. Under these circumstances a majority of low-polluting portfolio owners may have a strategic incentive to choose regulation in order to charge the minority a larger share of the externality reduction burden. This may lead to a suboptimal instrument choice. This also explains why regulation is so frequent in financial markets, whereas taxation is rarely employed to cope with systemic risk problems.

J. M. Keynes (1936) was one of first proponents of a systemic risk tax. He identified security contracts as a source of financial instability. Thus he proposed to tax only those kinds of contracts. Subsequently many others took the same view (among them, Stiglitz, 1989). We claim that attention should be focused on the overall financial playing field, rather than on on a specific subset of financial transactions. The default of any specific financial contract may originate negative and amplifying effects not only on the lender's and/or the borrower's portfolios, but also on other interconnected operators' claims.

In principle, any financial contract can be characterized by its level of 'toxicity' in terms of system risk externality (SRE). In other words, any single financial portfolio produces a certain amount of systemic risk pollution, even an extremely small one. Therefore, curbing systemic risk represents a general interest policy task and any citizen's portfolio choice is potentially affected by that policy.

Our attention here is mainly focused on the 'political distortion' that occurs when the choice of policy instrument is made by voting. As in the political analysis of income taxation (Meltzer and Richard 1981), the distortion depends on the position of the median relative to the average voter. ${ }^{1}$

Taxes and rules, however, are different in the way they allocate the sacrifices of the externality reduction. In the case of regulation, most sacrifices are made by top risk producers. Thus, even when the median voter produces an amount of risk that is above the average, the majority prefers regulation that is too restrictive. By contrast, with a tax, low-risk producers bear a significant burden. Thus a low median is induced to prefer taxes that are too low. The two instruments are quite different in the political distortion: regulation is very likely to be too restrictive; taxation is likely to be too low.

This argument is based on the assumption that, independently of the toxicity measure adopted, regulation has a more than proportional impact on more toxic instruments-that is, it forces people to progressive toxicity reductions. For example, a full prohibition rule (such as, 'all instruments whose toxicity level is above a given level are banned') has a dramatically

1 For an excellent survey of political choices in several economic contexts, see Persson and Tabellini (2000).

This is an open access version of the publication distributed under the terms of the Creative Commons Attribution-NonCommercialNoDerivs licence (http://creativecommons.org/licenses/by-nc-nd/3.0/), which permits non-commercial reproduction and distribution of the work, in any medium, provided the original work is not altered or transformed in any way, and that the work is properly cited. For commercial re-use, please contact academic.permissions@oup.com 
progressive impact and it would resemble an extremely convex tax schedule (such as 'a 100 per cent toxicity tax is levied above a given level'). By its nature taxation tends to be less progressive, if not regressive.

Our assumption that regulation is more progressive than taxation is straightforward if regulation consists in full prohibition of toxic instruments. Apart from this extreme case, the assumption can be justified if one considers that usually lending institutions meet regulation on operational risk by drastic cuts in their most toxic activities. Vice versa, with a tax they may decide to keep some high-risk activities and pay taxes if they make high profits from those activities.

In addition, the idea that regulation is more progressive may be justified by a measurement problem. In principle, the base of both taxation and regulation should be a non-distorted toxicity measure. However, measuring toxicity may be quite costly, if not virtually impossible. In reality, rules and taxes are applied to differently distorted measures of toxicity.

Our idea is that rules may have progressive effects because they affect directly the supply of most toxic instrument, rather than the production of toxicity by any kind of instrument. Taxes are usually levied on non-linear measures of toxicity, with a regressive effect. For example, a fixed tax on financial transactions is independent of actual risk production and, hence, is regressive in SRE. Realistically, the measurement problem seems to be more severe with taxation. This possibly explains why both the political debate and the academic debate have paid relatively little attention to taxation.

A basic assumption of SRE taxation is that it is possible to evaluate the marginal systemic externality (Acharya et al. 2009; Adrian and Brunnermeier 2008) of each financial firm. In the presence of a measurement bias, taxation is highly suboptimal. Regulation is less subject to a measurement problem. Rules can be more detailed and easier to implement than taxation. Soft information is easier to use in regulation than in taxation (IMF 2010c). We argue here that, owing to a measurement bias, regulation is more progressive than taxation. As a consequence, a majority of low-risk portfolio owners prefers regulation.

The measurement bias may also explain why a proper SRE tax has not been among the proposed taxes on financial activity-that is, levies on banks on an ex post basis that are based on funding or profits, or banking bonuses (IMF 2010c). In general, financial activity taxation does not follow the SRE principle. There are, however, specific areas in which SRE principles have been applied, such as securities, currency, bank or real estate transactions, insurance premiums, and capital levies. Since 2000 several G20 countries have imposed different forms of financial transaction tax, although the current trend is a reduction in their application. ${ }^{2}$

\footnotetext{
2 See Matheson (2010) for a complete survey.
} 
Of course, taxation is not necessarily a substitute for regulation. In practice, regulation is the primary instrument to reduce systemic risk, while corrective taxation plays a complementary role (IMF 2010c). Taxation of the financial industry can also address goals that are different from externality reductions, such as the implementation of general taxation design (Lockwood 2010); ensuring that banks meet the direct financial costs of possible bailouts; the implementation of bankruptcy schemes (IMF 2010c), and macroeconomic policies in managing aggregate demand (Tobin 1978).

In this chapter we argue that regulation is more likely to be preferred to taxation in a direct democracy, in which citizens/voters are heterogeneous in their portfolio toxicity. One might object that a lobbying model, such as that of Stigler (1971), is possibly more appropriate to address politico-economic issues in financial markets. In this case, however, one would need to explain why banks would lobby for regulation rather than for taxation. Moreover, the idea that financial policies are specific interest policies is questionable. We rather think that any policy intervention in financial market is in principle a general interest policy. Any citizen is a potential portfolio owner. Thus anyone perceives the private consequences of any policy measure that may affect, directly or indirectly, the relative cost of alternative portfolio and the relative benefits from systemic risk reduction.

The remainder of this chapter is organized as follows. In Section 11.2 we outline a simple political economy model of the financial system with two types of agents. The following section examines how a median voter equilibrium leads to an inefficient level of regulation. The role of taxation in curbing systemic risk is discussed in Section 11.4. The remaining two sections compare regulation with taxation and provide some concluding remarks.

\subsection{Financial portfolios and systemic risk}

We consider a continuum of investors, which are at the same time voters. Each investor/voter makes a portfolio choice. A certain amount of systemic risk is associated to the financial instruments in any possible portfolio. Let $\tau_{i}$, be the risk produced by an investor of type $i$ when he chooses his most preferred portfolio. In a sense the type is a measure of the 'polluting' activity of the investor when his portfolio choice is not constrained whatsoever.

Types are measures in the unit line and represent the only source of heterogeneity among investors. We say that an investor is a 'low' type when the risk of his most preferred portfolio is low, and vice versa. A low-type investor chooses a portfolio with a small amount of 'toxic' instruments. Vice versa, high type means that the investor prefers highly polluting instruments. 
We can specify the distribution of types in the unit interval. This function describes how systemic risk is distributed across the population when investors choose their most preferred portfolios. For example, a rightward-slanted distribution means that there are relatively few big-risk producers, whereas the majority of investors prefer a low amount of toxic instruments in their portfolios.

Assume for simplicity that the population has unit measure. By definition, an investor maximizes his utility when his actual portfolio choice matches his type. Choosing a portfolio with a different amount of systemic risk entails a disutility that can be described as a cost function that is increasing in the distance between type and actual portfolio choice.

If an investor's actual choice is a portfolio with lower risk associated with respect to his type's choice, then he generates a social benefit that spreads over the population, but he bears a private burden given by the cost of making a choice that is different from his type.

Since individuals are infinitesimal in the population, the private benefit that an individual obtains from his own externality reduction is infinitesimal too. Hence, nobody has an incentive to reduce unilaterally his portfolio's systemic risk below his types. A free-riding problem eventually emerges as a result of the discrepancy between private and social benefits from externality reductions. Investors make portfolio choices with too much systemic risk production. There is scope for government intervention through either regulation or taxation.

\subsection{Regulation}

By financial regulation we denote a policy that tends directly to prevent financial institutions from issuing instruments having too much systemic risk. The supply of large SRE instruments is strongly limited; therefore investors with those kinds of instruments in their portfolios will have to make substantial changes. Arguably, this type of policy has a quite strong impact on 'highly polluting' portfolios, while it only moderately affects the lowpolluting ones.

We can describe this idea by assuming that a rule forces investors to more than proportional reductions in systemic risk production. We can also assume that the regulation level can be captured by a quantitative parameter, $\rho$.

When $\rho$ is enforced, individuals must choose a portfolio with a level of risk $\beta$ that decreases more than proportionally with respect to their types. Consider investor $i$ and assume that for any $i$ the relationship between risk produced and regulation is the following:

This is an open access version of the publication distributed under the terms of the Creative Commons Attribution-NonCommercialNoDerivs licence (http://creativecommons.org/licenses/by-nc-nd/3.0/), which permits non-commercial reproduction and distribution of the work, in any medium, provided the original work is not altered or transformed in any way, and that the work is properly cited. For commercial re-use, please contact academic.permissions@oup.com 


$$
\beta_{i}\left(\tau_{i}, \rho\right)=\left(1-\rho \tau_{i}\right) \tau_{i}
$$

As can be seen from this expression there is a more than proportional relationship between regulation and risk production. This captures the idea that regulation has a progressive impact on risk. For example, suppose that the risk produced before regulation by a low type, $l$, is given by $\tau_{l}=0.2$. With a regulation $\rho=0.5$ the investor is obliged to reduce risk production to $\beta_{l}=0.18$; thus risk is 10 per cent lower. For a high type, $\tau_{k}=0.8$, portfolio choice is lowered down to $\beta_{k}=0.48$, with actual risk production being lowered by 40 per cent.

Thus, for any level of the regulation parameter, risk production decreases more than proportionally with respect to risk before regulation.

The decision regarding the level of the regulation parameter is made by voting. The timing is the following: at time 1, given the distribution of types, individuals compute their preferences regarding the regulation parameter; at time 2, they select a Condorcet winner in pair-wise voting; at time 3, they choose their portfolios and their actual pollution levels.

Under regularity conditions, we can imagine that preferences for the policy parameter are concave. Thus each agent has a unique most-preferred level of regulation (a 'bliss' point) where the private benefit due to a marginal increase in the rule parameter equals the marginal private cost of complying with the rule.

The fact that all individuals are single peaked rules out strategic voting and allows for the existence of a Condorcet winner that is unique under the simple majority rule (Black 1948). Arguably, bliss points are negatively related to types: heterogeneity in policy preferences is due to differences in types.

An investor with highly polluting portfolio (a high type) wants a low rule; a low type prefers a high rule. The reason is simple. Private benefits are the same for all, but for any rule a higher type bears larger private costs. Since private costs are increasing, an individual's utility is maximized with a lower rule. The median voter theorem applies: under the bare majority, the voting outcome is the bliss point of the median type.

The efficiency of this policy outcome can be studied by comparing the median voter's choice with that of a Social Planner that maximizes total utility.

In a model in which the cost of complying with regulation is convex and the regulation has a progressive impact on risk reductions, a median that is lower than the average is a sufficient condition for the emergence of a toorestrictive rule. Restrictiveness can also occur if the median is slightly above the average. It is easy to see that, with more convex costs, the rule is too restrictive even if the median is consistently above the average. This result is not affected by the assumption about the shape of the externality function.

This is an open access version of the publication distributed under the terms of the Creative Commons Attribution-NonCommercialNoDerivs licence (http://creativecommons.org/licenses/by-nc-nd/3.0/), which permits non-commercial reproduction and distribution of the work, in any medium, provided the original work is not altered or transformed in any way, and that the work is properly cited. For commercial re-use, please contact academic.permissions@oup.com 
The main idea is that, when financial regulation is decided through voting, a too restrictive policy is rather easy to emerge. Even if the median voter pollutes more than the average, he opportunistically chooses a to-restrictive rule in order to force the minority of top polluters to substantial portfolio changes. The reason is that regulation impacts mostly on top-polluting investors, forcing them to large adjustments in their portfolio choices.

The median voter does not consider the cost incurred by top polluters. He rather looks at regulation as a way to charge them the main burden of the externality reduction. Therefore, voting on financial regulation is likely to yield rules that are socially too restrictive. Voting outcome inefficiency is larger when costs are more convex and when the median is in a relatively low position with respect to the highest types. It can be proved that this kind of inefficiency is larger if the impact of regulation on portfolio choices is even more progressive than the one assumed above (Masciandaro and Passarelli 2011).

\subsection{Taxation}

An SRE tax aims to increase the private cost of systemic risk production. The problem with this instrument is that risk is usually not easy to measure. Thus the tax is often levied on distorted SRE measures, as, for example, the monetary amount of financial transactions. Agents who make the same amount of financial transactions pay the same amount of tax, independently of actual systemic risk produced. We will see below that taxing a biased measure of the externality is not only socially inefficient; it also affects the political distortion.

\subsubsection{Tax on systemic risk}

Let us start by considering the policy benchmark. Suppose that the Social Planner is able to detect the true systemic risk in any portfolio-that is, the actual externality level produced by any single agent. A basic result in optimal taxation theory applies here: welfare is maximized if, for any agent, the after-tax private marginal cost equals the social marginal externality. An optimal tax must also ensure that marginal costs are the same for all agents.

Assume that preferences are quasi-linear. If the externality depends on the total risk produced, then the optimality condition is satisfied by a proportional tax with lump-sum refunds of proceeds. The idea is that the Social Planner sells the 'rights' to produce risk at a fixed unit price, and this can be done with a proportional taxation of risk. 
In fact, agents are induced to optimize their portfolio by choosing a risk level such that the marginal cost of decreasing risk equals the tax (or the price) per unit of risk. Thus, given the tax rate $\theta$, all agents reduce the systemic risk in their portfolios by the same amount:

$$
\beta_{i}=\tau_{i}-\frac{\vartheta}{2}
$$

At the margin, each agent pays a marginal cost that is equal to the marginal externality produced-that is, $\theta^{*}=1$. This first best condition is achieved thanks to the government's ability to detect and tax actual systemic risk production.

\subsubsection{Tax on financial transactions}

As pointed out earlier, the problem with a tax is that in reality it is levied on distorted measures of systemic risk, such as financial transactions. In order to study a transaction tax we have to specify how the tax is related to the risk produced.

Arguably, the systemic risk in a portfolio is due to two factors: first, the number of toxic instruments; second, the portfolio 'size' - that is, the number of transactions made by the investor. With a proportional transaction tax, however, an agent pays only according to the second factor. Somehow a proportional transaction tax does not bear on the full amount of the externality produced. Thus we can realistically assume that a tax that is proportional to financial transactions is de facto regressive with respect to the externality produced.

Applying taxes in this fashion results in an outcome that is second best. Taxing transactions forces the government to adopt a tax that is de facto regressive in the externality, whereas the first best instrument would be a proportional tax. Departures from the first best occur because the government taxes a distorted measure of risk. The difference between first and second best increases in the measurement bias.

If the ability to tax externalities through transactions is low such that only a low amount of externality is taxed, then it is better to have a low tax rate. Vice versa, as the measurement bias tends to zero, the socially optimal transaction tax approaches the first best.

Finally, observe that, with a regressive tax, the optimal rate must be higher when the average type is larger, because on average the marginal cost decreases. In synthesis, when the Social Planner adopts a tax on financial transactions, it chooses a too-low level. The reason is because a distorted measure of risk is adopted. Top-risk polluters do not pay enough taxes; their private marginal cost is too low, compared to marginal externalities, and vice versa low-risk polluters pay too much.

This is an open access version of the publication distributed under the terms of the Creative Commons Attribution-NonCommercialNoDerivs licence (http://creativecommons.org/licenses/by-nc-nd/3.0/), which permits non-commercial reproduction and distribution of the work, in any medium, provided the original work is not altered or transformed in any way, and that the work is properly cited. For commercial re-use, please contact academic.permissions@oup.com 


\subsubsection{Political distortions}

Let us now turn to the political distortion that may occur when the decision about taxes is made by voting. First, consider the case in which a proportional tax is levied on risk production directly and there is no measurement bias.

\subsubsection{TAX ON SYSTEMIC RISK}

In this situation the Social Planner chooses the first best tax rate. What does a majority choose in this case? Not surprisingly, the majority chooses a possibly different tax rate.

Recall that tax proceeds are redistributed on a lump-sum basis out of a balanced government budget. Any individual receives a refund that is equal to the average tax burden. It is easy to see that higher types want lower tax rates. They pay larger amounts of taxes because their after-tax risk production is higher. Since bliss points are inverse monotone in types, the majority chooses the median's bliss point. A distortion occurs in this case because the amount of taxes paid by, say, a low median is lower than the average.

A low median has an incentive to fix a high rate in order to have others pay for a larger share of the pollution reduction cost. Political distortion is avoided only if the median and average's risk production are equal.

When the government is able to tax systemic risk, the political distortion is determined only by the difference between median and average types. This result on externality taxation is similar to a well-known result in the public finance literature on income taxation (Roberts 1977; Meltzer and Richard 1981).

\subsubsection{TAX ON FINANCIAL TRANSACTIONS}

Consider now the political distortion when a tax is levied on financial transactions. A measurement bias occurs: systemic risk is not entirely taxed. In the voting stage, most preferred tax rates are decreasing in types. This means that in this case also agents with low-polluting portfolios want higher taxes. It also means that the transaction tax chosen by the majority is the one preferred by the median type. Political distortion is given by the sum of two factors.

The first factor is the relative position of the median. Because of regressivity, a high median wants too high a tax rate because the amount of taxes that he has to pay is relatively low compared to the risk produced. This lowers his marginal cost and induces him to prefer a socially too low tax rate.

The second factor is the 'usual' political distortion, which works in the opposite direction: a high median wants a low tax rate since he pays a large amount of taxes. Interestingly, the net political distortion depends on the measurement bias parameter. Suppose the median is lower than the average. In this case the 'usual' political distortion occurs only if the ability to tax 
systemic risk through a transaction tax is sufficiently high (that is, if the regressivity is low). In this case the second factor prevails. If this is not the case, a low median chooses a too-low tax because regressivity, rather than a low position, plays a major role.

\subsubsection{THE NATURE OF POLITICAL DISTORTION: REGULATION VERSUS TAXATION}

Let us compare the political distortion in the case of a transaction tax with that of a rule. Consider the most interesting case: transactions are a poor measure of risk. Suppose the median is lower than the average. A rule is always too restrictive: a low median uses the rule as a tool to charge a high-polluting portfolio the largest share of total cost, but this causes a social welfare loss.

By contrast, a tax is too low: because of tax regressivity, a low median must pay large amounts of tax and thus prefers too low a tax level. This relationship between political distortions and median's position is continuous. Thus, if the median is moderately above the average, the rule is too restrictive and a tax is too low. With a very high median both a rule and a tax are too restrictive.

Summing up, with both instruments, either taxation or regulation, majority voting produces a political distortion. This may cause large inefficiency losses. However, the distortion is considerably different when voting concerns a tax instead of a rule, especially if there is a problem of measurement bias.

Too restrictive rules are more likely to emerge than too restrictive taxes. The reason is that rules are a progressive mechanism, whereas taxes on transactions are regressive. Thus, on the one hand, a relatively low median voter, which is not necessarily below the average, prefers restrictive rules in order to force higher types to large risk reductions; on the other hand, the median voter prefers a low tax rate, because otherwise he would have to pay high taxes.

\subsection{Regulation or taxation?}

Suppose now that the majority determines not only the level of the policy, but also which instrument to adopt. We can realistically assume that voting takes place sequentially: first, the majority selects the instrument; then it chooses its level. ${ }^{3}$

\footnotetext{
${ }^{3}$ In general, with bi-dimensional policy issues the existence of a Condorcet winner cannot be taken for granted. However, with sequential voting in which the first issue is binary, this problem does not arise. Consider, however, that with bi-dimensional sequential voting the outcome is sensitive to the voting sequence. In our situation we do not have such a problem. An inverse sequence in which the majority decides the instrument after having decided the level of the policy is quite unnatural. For an exhaustive analysis of sequential bi-dimensional voting, see De Donder et al. (2010).
}

\section{6}

This is an open access version of the publication distributed under the terms of the Creative Commons Attribution-NonCommercialNoDerivs licence (http://creativecommons.org/licenses/by-nc-nd/3.0/), which permits non-commercial reproduction and distribution of the work, in any medium, provided the original work is not altered or transformed in any way, and that the work is properly cited. For commercial re-use, please contact academic.permissions@oup.com 
Voters know that, whatever the instrument, the level that will pass at the second stage is the one preferred by the median. Any voter compares his own utility in both cases, and chooses his most preferred instrument.

At the first stage, the majority behaves as a Stackelberg leader: it selects the instrument and it lets a possibly different majority choose the level at the second stage. There is no scope for a strategic vote.

When does the majority choose a rule at the first stage? A low-polluting investor has to make small adjustments with a rule, whereas with a tax he has to pay a relatively large amount, because of regressivity. Thus he prefers a rule. A top-polluting type has reversed preferences: a tax is better than a rule because, with a tax, the burden of systemic risk reduction is borne mostly by low-polluting investors.

A likely situation is that, if the number of low polluters is sufficiently large, then a majority on the rule will form. Observe that we do not require that the median is below the average in this case. If the rule is strongly progressive, then also moderately high types will prefer it.

Vice versa, a regressive tax is preferred by high-polluting investors. If regressivity is stronger, more moderate types prefer the tax. Thus a majority on a tax will form if it is strongly regressive with respect to the rule and the population of low polluters is relatively small.

Let us consider the normative characteristics of these positive results. In our model the social cost of systemic risk is linear. Thus, the Social Planner is not interested in who produces the externality; it is rather interested in choosing an instrument that shares costs evenly.

A rule is strongly progressive; the cost is concentrated on high-risk investors. Vice versa, a tax levied on a biased risk measure may be regressive; thus the cost is concentrated on low polluters. The socially optimal instrument is a tax if regressivity is not too high-that is, if the measurement bias is not too strong.

Consider, however, that, when the measurement bias causes strong regressivity or when the distribution is slanted towards top-polluting portfolios, a majority of voters prefer the rule. In this case a double political distortion occurs. First, the majority selects the wrong instrument: regulation instead of taxation. Second, the majority of low polluters choose a too-restrictive level of taxation.

\subsection{Conclusion}

The main point in this chapter is that, when policies to reduce financial systemic risk are made by voting, the political aspects of the decision are quite relevant and may cause significant distortions. These distortions are 
substantially different when taxation rather than regulation is under discussion.

We approached systemic risk contagion as an externality issue and we considered it as a general interest policy. In a sense, everybody is interested in reducing systemic risk; as a consequence of the selected policy, all investors must readjust their portfolio or bear a cost.

If regulation is adopted, most costs and adjustments are supported by highrisk producers; with taxation, sacrifices are more evenly distributed across population. Political distortions hinge on the distribution of sacrifices for the externality reduction. A majority of small portfolio owners with low-risk production will tend to choose regulation in order to concentrate sacrifices on high-risk producers. Even a median that is above the average might prefer regulation, provided it has a sufficiently progressive effect on risk adjustments.

We showed that regulation may be highly inefficient. In particular, majorities tend to choose too-restrictive rules. Loosely speaking, if 'risk is due to everybody' (as in the case where externalities are linearly related to risk), and the cost of complying with the rules grows at a fast rate, concentrating risk reduction on top-risk producers is not socially optimal. However, if the majority is made by low-risk producers, the decision will be harsh regulation.

With a tax, the political distortion is quite different. Systemic risk is reduced by taxing distorted measures of risk, such as transactions, intermediaries' profits, or their turnover. We argued that this is likely to yield a regressive effect: small-risk producers pay proportionally more than large-risk producers.

As a consequence, a majority of small-risk producers has less incentive to choose a tax; if this will be the case, it chooses too low a tax rate. This political economy argument is possibly helpful to understand reality in which taxes on risky financial instruments are usually rare and low, whereas financial regulation is much more frequent.

Of course, there might be many other circumstances, not considered in this chapter, that explain the frequency and efficiency of policies. For example, taxes can be better calibrated to financial activity, and produce more gradual externality reductions.

From a normative viewpoint, taxation is preferable when the contributions to system risk are more evenly distributed across financial instruments and investors. Vice versa, regulation is more effective when there are information concerns. If risk production is private information, a rule that limits specific financial activities is more effective than a tax on those activities.

Financial risk externalities may clearly be an international issue. In these circumstances, common decisions rely on the existence of institutions that ensure a sufficient degree of coordination among parties. Incentives and enforceability issues may severely limit the set of available policy options and distort common decisions. 
Finally, as already mentioned, financial intermediaries may find that engaging in lobbying activities is profitable in order to distort the political decision in a favourable direction. These are relevant aspects of the policymaking of systemic financial risk. They are not alternative, but rather complementary, to the points made in this chapter, and they may eventually suggest extensions of our approach.

This is an open access version of the publication distributed under the terms of the Creative Commons Attribution-NonCommercialNoDerivs licence (http://creativecommons.org/licenses/by-nc-nd/3.0/), which permits non-commercial reproduction and distribution of the work, in any medium, provided the original work is not altered or transformed in any way, and that the work is properly cited. For commercial re-use, please contact academic.permissions@oup.com 


\section{References}

Acharya, V. V., and Richardson, M. (2009). 'Causes of the Financial Crisis', Critical Review, 21/2-3: 195-210.

Acharya, V. V., Pedersen, L., Philippon, T., and Richardson, M. (2009). 'Regulating Systemic Risk', in V. Acharya and M. Richardson (eds), Restoring Financial Stability: How to Repair a Failed System. Hoboken, NJ: Wiley.

Acharya, V. V., Santos, J. A. C., and Yorulmazer, T. (2010). 'Systemic Risk and Deposit Insurance Premiums', Economic Policy Review (Aug.), 89-99. Federal Reserve Bank of New York.

Adelson, M. (2004). CDOs in Plain English: A Summer Intern's Letter Home. New York: Nomura Securities International.

Adrian, T., and Brunnermeier, M. K. (2008). 'CoVaR'. Staff Report, No. 348, Federal Reserve Bank of New York.

Agell, J., Englund, P., and Södersten, J. (1995). 'The Swedish Tax Reform: An Introduction', Swedish Economic Policy Review, 2: 219-28.

Ahrend, R., Catte, P., and Price, R. (2006). 'Interactions between Monetary and Fiscal Policy: How Monetary Conditions Affect Fiscal Consolidation'. OECD Economics Department, Working Paper 521, OECD Publishing.

Aldeweireldt, J. (2002). 'Tax Treatment of Employee Stock Options: An International Comparison', Tax Notes International, 27/8 (19 Aug.), 951-3.

Alesina, A. (2010a). 'Fiscal Adjustments and the Recession'. VOX policy comment $<$ http://www.voxeu.org/index.php?q=node/5776>.

Alesina, A. (2010b). 'Fiscal Adjustments: Lessons from Recent History'. Paper prepared for the Ecofin meeting in Madrid, 15 Apr.

Alesina, A., and Ardagna, S. (1998). 'Tales of Fiscal Adjustment', Economic Policy, 13/27: 487-545.

Alesina, A., and Ardagna, S. (2010). 'Large Changes in Fiscal Policy: Taxes versus Spending', in J. Brown (ed.), Tax Policy and the Economy, vol. 24. Chicago: University of Chicago Press, 35-68.

Alesina, A., and Passarelli, F. (2010). 'Regulation versus Taxation'. NBER Working Papers, No. 16413, National Bureau of Economic Research.

Alesina, A., and Perotti, R. (1995). 'Fiscal Expansions and Fiscal Adjustments in OECD Countries'. NBER Working Papers, No. 5214, National Bureau of Economic Research. Alesina, A., and Perotti, R. (1996). 'Fiscal Adjustments in OECD Countries: Composition and Macroeconomic Effects'. NBER Working Papers, No. 5730, National Bureau of Economic Research. 
Alesina, A., Ardagna, S., Perotti, R., and Schiantarelli, F. (2000). 'Fiscal Policy, Profits, and Investment'. Boston College Working Papers in Economics 504, Boston College Department of Economics.

Alesina, A., Ardagna, S., Perotti, R., and Schiantarelli, F. (2002). 'Fiscal Policy, Profits, and Investment', American Economic Review, 92/3: 571-89.

Alesina, A., Perotti, R., and Tavares, J. (1998). 'The Political Economy of Fiscal Adjustments'. Brookings Papers on Economic Activity, 1: 197-266.

Almunia, M., Bénétrix, A., Eichengreen, B. O., Rourke, K. H., and Rua, G. (2010). 'From Great Depression to Great Credit Crisis: Similarities, Differences and Lessons', Economic Policy, 25: 219-65.

Altshuler, R., Auerbach A. J., Cooper, M., and Knittel M. (2009). 'Understanding US Corporate Tax Losses', Tax Policy and the Economy, 23: 73-122.

Alworth, J. (1998). 'Taxation and Integrated Financial Markets: The Challenges of Derivatives and Other Financial Innovations', International Tax and Public Finance, 5/4: 507-34.

Alworth, J., and Lovisolo, S. (1998). 'La riforma della tassazione del reddito d'impresa', in F. Giavazzi, A. Penati, and G. Tabellini (eds), Politica economica in Italia: La constituzione fiscale. Bologna: Il Mulino.

Alworth, J., Arachi, G., and Hamaui, R. (2003). 'What's Come to Perfection Perishes: Adjusting Capital Gains Taxation in Italy', National Tax Journal, 56: 197-219.

Amromin, G., Harrison, P., and Sharpe S. (2006). 'How Did the 2003 Dividend Tax Cut Affect Stock Prices?', Federal Reserve Bank of Chicago, Working Paper No. 2006-17.

Anson, M. J., Fabozzi, F. J., Choudhry, M., and Chen, R. (2004). Credit Derivatives. Instruments, Applications, Pricing. Hoboken, NJ: Wiley.

Ardagna, S. (1999). 'Fiscal Ajustments: Expectations versus Supply Side'. Unpublished. Ardagna, S. (2004). 'Fiscal Stabilizations: When do they Work and Why', European Economic Review, 48/5: 1047-74.

Arulampalam, W., Devereux, M. P., and Maffini, G. (2008). 'The Direct Incidence of Corporate Income Tax on Wages'. Mimeo, Oxford University Centre for Business Taxation.

Auerbach, A. J. (1991). 'Retrospective Capital Gains Taxation', American Economic Review, Papers and Proceedings, 92: 167-78.

Auerbach, A. J. (2002). 'Taxation and Corporate Financial Policy', in A. Auerbach and M. Feldstein (eds), Handbook of Public Economics. Amsterdam: North Holland, iii. 1251-92.

Auerbach, A. J., and Bradford, D. F. (2004). 'Generalized Cash-Flow Taxation', Journal of Public Economics, 88: 957-80.

Auerbach, A. J., and Devereux, M. P. (2010). 'Consumption and Cash-Flow Taxes in an International Setting'. STICERD—Public Economics Programme Discussion Papers, London School of Economics.

Auerbach A. J., and Feldstein, M. (eds) (2002). Handbook of Public Economics, iv. Amsterdam: North Holland.

Auerbach, A. J., and Gale, W. G. (2009). 'The Economic Crisis and the Fiscal Crisis: 2009 and Beyond', Tax Notes, 125: 101-30.

This is an open access version of the publication distributed under the terms of the Creative Commons Attribution-NonCommercialNoDerivs licence (http://creativecommons.org/licenses/by-nc-nd/3.0/), which permits non-commercial reproduction and distribution of the work, in any medium, provided the original work is not altered or transformed in any way, and that the work is properly cited. For commercial re-use, please contact academic.permissions@oup.com 
Auerbach, A. J., and King, M. A. (1982). 'Corporate Financial Policy with Personal and Institutional Investors', Journal of Public Economics, 17: 259-85.

Auerbach, A. J., and Obstfeld, M. (2005). 'The Case for Open-Market Purchases in a Liquidity Trap', American Economic Review, 95/1: 110-37.

Ault, H. J., and Arnold, B. J. (2004). Comparative Income Taxation: A Structural Analysis. 2nd edn. New York: Aspen Publishers.

Baba, N., Nishioka, S., Oda, N., Shirakawa, M., Ueda, K., and Ugai, H. (2005). 'Japan's Deflation, Problems in the Banking System and Monetary Policy'. BIS Working Paper No. 188

Baily, M. N., Litan R. E., and Johnson, M. S. (2008). 'The Origins of the Financial Crisis', Fixing Finance Series Paper, vol. 3, Brookings Institution.

Bajaj, V., and Leonhardt, D. (2008). 'Tax Break May Have Helped Cause Housing Bubble', New York Times, 18 Dec.

Balsam, S., Halperin, R., and Mozes, H. (1997). 'Tax Costs and Nontax Benefits: The Case of Incentive Stock Options', Journal of the American Taxation Association, 19/2 (Fall), 19-37.

Baltagi, B. H., Li D., and Li Q. (2006). 'Transaction Tax and Stock Market Behavior: Evidence from an Emerging Market'. Empirical Economics, 31: 393-408.

Bank of England (2007). Financial Stability Review. Issue 21.

Bank of England (2008). Financial Stability Review. Issue 24.

Bank of England (2009). Letter from the Governor to the Chancellor of the Exchequer. 17 Feb.

Bank of Japan (2008). Financial Markets Report. Sept.

Bank of Japan (2009). Financial Markets Report. Mar.

Bankman, J. (2007). Testimony before the United States Senate Committee on Finance $<$ http://finance.senate.gov/imo/media/doc/073107testjb.pdf $>$.

Barro, R. J., and Redlick, C. J. (2009). 'Macroeconomic Effects from Government Purchases and Taxes'. NBER Working Papers, No. 15369, National Bureau of Economic Research.

Beard, T. (1965). US Treasury Advance Refunding. Washington, DC: Federal Reserve Board.

Bebchuk, L., and Fried, J. (2004). Pay without Performance: The Unfilled Promise of Executive Compensation. Cambridge, MA: Harvard University Press.

Beck, T., and Demirgüç-Kunt A. (2009). 'Financial Institutions and Markets across Countries and over Time: Data and Analysis'. World Bank Policy Research Working Paper No. 4943, May.

Beeman, R. E. (2009). 'A Compendium of Financial Crisis Tax Guidance', Bank Accounting \& Finance, 22/1 (Feb.-Mar.), 3-13.

Bernanke, B. (2003). 'Some Thoughts on Monetary Policy in Japan'. Remarks to the Japan Society for Monetary Economics, 31 May.

Bernanke, B., Reinhart, V., and Sack, B. (2004). 'Monetary Policy Alternatives at the Zero Bound: An Empirical Assessment', Brookings Papers on Economic Activity, 94/2: 1-78.

Bertola, G., and Drazen, A. (1993). 'Trigger Points and Budget Cuts: Explaining the Effects of Fiscal Austerity', American Economic Review, 83/1: 11-26. 
Biehl, A. M., and Hoyt, W. H. (2008). 'The Taxpayer Relief Act of 1997 and Homeownership: Is Smaller Now Better?' IFIR Working Paper No. 2009-04.

Bier, T., Maric, I., and Weizer, W. (2000). 'A Preliminary Assessment of the New Home Seller Capital Gains Law', Housing Policy Debate, 11/3: 645-73.

BIS (2005). Bank for International Settlements, 'Committee on the Global Financial System: The Role of Ratings in Structured Finance: Issues and Implications'. Jan.

BIS (2009). Bank for International Settlements, 79th Annual Report. June.

BIS (2010). Bank for International Settlements, 80th Annual Report. June

Black, D. (1948). 'On the Rationale of Group Decision-Making', Journal of Political Economy, 56: 23-34.

Blanchard, O. J. (1990). 'Comment on Giavazzi and Pagano', in NBER Macroeconomics Annual 1990, vol. 5. Cambridge, MA: National Bureau of Economic Research, 111-16. Blanchard, O. J., and Perotti, R. (2002). 'An Empirical Characterization of the Dynamic Effects of Changes in Government Spending and Taxes on Output', Quarterly Journal of Economics, 117/4: 1329-68.

Blanchard, O. J., Cottarelli, C., Spilimbergo, A., and Symansky, S. (2009). 'Fiscal Policy for the Crisis'. CEPR Discussion Paper No. 7130.

Bleijer, M. (1999). 'Public Debt Management and Monetary Policy: Macroeconomic and Institutional Interactions', in European Union Accession: The Challenges for Public Liability Management in Central Europe. Washington, DC: World Bank, 62-9.

Board of Governors of the Federal Reserve System (2008). 'Flow of Funds Accounts for United States', 11 Dec. <http://www.federalreserve.gov/releases/z1/>.

Board of Governors of the Federal Reserve System (2009a). 'Federal Open Market Committee Press Release', 18 Mar.

Board of Governors of the Federal Reserve System (2009b). 'The Role of the Federal Reserve in Preserving Financial and Monetary Stability', 23 Mar.

Board of Governors of the Federal Reserve System (2011). 'Assets and Liabilities of Commercial Banks in the United States-H.8, Interbank loans' <http://www. federalreserve.gov/releases/h8/current/default.htm>.

Bond, S. R., and Devereux, M. P. (1995). 'On the Design of a Neutral Business Tax under Uncertainty', Journal of Public Economics, 58/1: 57-71.

Bond, S. R., and Devereux, M. P. (2003). 'Generalised R-based and S-based taxes under Uncertainty', Journal of Public Economics, 87: 1291-1311.

Bond, S. R., Hawkins, M., and Klemm, A. (2005). 'Stamp Duty on Shares and its Effect on Share Prices', FinanzArchiv, 61: 275-97.

Booth, B., Congdon, T., Goodhart, C., Greenwood, J., Oliver, M., Pepper, G., Smith, D., and Ward, S. (2008). 'Government Must Borrow from Banks to Create Money', Financial Times, 31 Dec.

Bordignon, M., Giannini, S., and Panteghini, P. (2001). 'Reforming Business Taxation in Italy: Lessons from Italy', International Tax and Public Finance, 8/2: 191-210.

Borselli, F., Buoncompagni, A., and Manestra, S. (2010). 'Residential Real Estate Taxation in Europe: Actual Burden on Ownership and Investment', European Taxation, 50/10: 457-64.

Bradford, D. F. (1986). Untangling the Income Tax. Cambridge, MA: Harvard University Press.

This is an open access version of the publication distributed under the terms of the Creative Commons Attribution-NonCommercialNoDerivs licence (http://creativecommons.org/licenses/by-nc-nd/3.0/), which permits non-commercial reproduction and distribution of the work, in any medium, provided the original work is not altered or transformed in any way, and that the work is properly cited. For commercial re-use, please contact academic.permissions@oup.com 


\section{References}

Bradford, D. F. (2000). 'Blueprint for International Tax Reform', Brooklyn Journal of International Law, 26/4: 1449-63.

Bradford, D. F. (2004). 'The X Tax in the World Economy'. CESifo Working Paper No. 1264.

Brandes, A. J. (2008). 'Toward a New Framework and a Better Understanding of Credit Default Swaps', Derivatives and Financial Instruments, 10/3 (May/June), 75-91.

Broadbent, B., and Daly, K. (2010). 'Limiting the Fall-out from Fiscal Adjustment'. Global Economics Paper 195, Goldman Sachs.

Brooke, M., George, P., and Sharlene, G. (2010). 'Supertax Pulls in $£ 2.5 \mathrm{bn}$ for UK Treasury', Financial Times, 4 Mar.

Brunson, S. D. (2008). 'Elective Taxation of Risk-Based Financial Instruments: A Proposal', Houston Business and Tax Journal, 8/1 (2008), 1-36.

Bulow, J., and Shoven, J. B. (2005). 'Accounting for Stock Options', Journal of Economic Perspectives, 19/4 (Autumn), 115-34.

Burman, L. (2008). 'Did the Capital Gains Tax Break on Home Sales Help Inflate the Housing Bubble?', Tax Policy Center, Tax Vox, 22 Dec.

Büttner, T., Overesch, M., Schreiber, U., and Wamser, G. (2006). 'Taxation and Capital Structure Choice: Evidence from a Panel of German Multinationals'. CESifo Working Paper No. 1841.

Campbell, J. Y., and Froot, K. A. (1994). 'International Experiences with Securities Transaction Taxes', in Jeffrey A. Frankel (ed.), The Internationalization of Equity Markets. Chicago: University of Chicago Press, 277-308.

Cardarelli, R., Igan, D., and Rebucci, A. (2008), 'The Changing Housing Cycle and the Implications for Monetary Policy', in World Economic Outlook. Washington, DC: IMF, Apr.

Carter, M. E., Lynch, L. J., and Tuna, I. (2007). 'The Role of Accounting in the Design of CEO Equity Compensation', Accounting Review, 79/2 (Mar.), 251-75.

Case, K. E., and Shiller, R. J. (1988). 'The Behaviour of Home Buyers in Boom and PostBoom Markets', New England Economic Review (Nov.-Dec.), 29-46.

Case, K. E., and Shiller, R. J. (2004). 'Is there a Bubble in the Housing Market?'. Cowles Foundation Paper No. 1089.

Cecchetti, S. G. (1988). 'The Case of the Negative Nominal Interest Rates: New Estimates of the Term Structure of Interest Rates during the Great Depression', Journal of Political Economy, 96/6 (Dec.), 1111-41.

Chaboud, A., Chiquoine, B., Hjalmarsson, E., and Vega, C. (2009). 'Rise of the Machines: Algorithmic Trading in the Foreign Exchange Market'. Federal Reserve Board, International Finance Discussion Papers, 2009-980.

Cheng, Y. and Green, C. J. (2008). 'Taxes and Capital Structure: A Study of European Companies', Manchester School, 76 (supp. S1): 85-115.

Christiansen, V., and Smith, S. (2009). 'Externality-correcting Taxes and Regulation'. CESifo Working Paper No. 2793.

Clouse, J., Henderson, D., Orphanides, A., Small, D., and Tinsley, P. (2003). 'Monetary Policy when the Nominal Short-Term Interest Rate Is Zero', Topics in Macroeconomics, 3/1: 1088-22.

Cohen, F., Panteghini, P. M., and Valdameri, L. (2006). 'Employee Stock Options: Italy and the World', Tax Notes International, 44/12 (18 Dec.), 965-70.

This is an open access version of the publication distributed under the terms of the Creative Commons Attribution-NonCommercialNoDerivs licence (http://creativecommons.org/licenses/by-nc-nd/3.0/), which permits non-commercial reproduction and distribution of the work, in any medium, provided the original work is not altered or transformed in any way, and that the work is properly cited. For commercial re-use, please contact academic.permissions@oup.com 
Congdon, T. (2003). 'Debt Management and Deflation 1' and 'Debt Management and Deflation 2', Lombard Street Research, Monthly Economic Review, 165 (Mar.), 2-19; 166 (Apr.), 2-23.

Corsetti, G., Kuester, K., Meier, A., and Mueller, G. J. (2010). 'Debt Consolidation and Fiscal Stabilization of Deep Recessions'. Technical report.

Cos, P. H. de, and Moral-Benito, E. (2011). 'Endogenous Fiscal Consolidations'. Banco de España Working Papers 1102, Banco de España.

Cottarelli, C., and Viñals, J. (2009). 'A Strategy for Renormalizing Fiscal and Monetary Policies in Advanced Economies'. Staff Position Note SPN/09/22, IMF.

Culbertson, J. (1957). 'The Term Structure of Interest Rates', Quarterly Journal of Economics, 71/4 (Nov.), 485-517.

Cunningham, C. R., and Engelhardt, G. V. (2008). 'Housing Capital-Gains Taxation and Homeowner Mobility: Evidence from the Taxpayer Relief Act of 1997', Journal of Urban Economics, 63: 803-15.

Dale, S. (2009). 'Tough Times, Unconventional Measures'. Speech to the Association of British Insurers Economics and Research Conference, London, 27 Mar.

Davis, B. (2010). 'Global Divide Over a Bank Tax', Wall Street Journal, 26 Apr., C1.

Davis, P. E., and Stone, M. R. (2004). 'Corporate Financial Structure and Financial Stability', Journal of Financial Stability, 1: 65-91.

Dayal, R., Luther, L., Neu, P., and Tang, T. (2010). 'After the Storm: Creating Value in Banking 2010', Boston Consulting Group, Boston, Feb.

De Donder, P., Le Breton, M., and Peluso, E. (2010). 'Majority Voting in Multidimensional Policy Spaces: Kramer-Shepsle versus Stackelberg'. IDEI Working Papers, 593.

De la Feria, R., and Lockwood, B. (2009). 'Opting for Opting In? An Evaluation of the European Commission's Proposals for Reforming VAT on Financial Services'. Working Paper 0909, Oxford University Centre for Business Taxation.

De Long, J. B., Shleifer, A., Summers, L. H., and Waldmann, R. J. (1991). 'The Survival of Noise Traders in Financial Markets', Journal of Business, 94/1: 1-19.

De Meza, D., and Webb, D. (1987). 'Too Much Investment: A Problem of Asymmetric Iinformation', Quarterly Journal of Economics, 102: 281-92.

De Mooij, R., and Devereux, M. P. (2009). 'Alternative Systems of Business Tax in Europe: An Applied Analysis of ACE and CBIT Reforms'. Working Paper No. 17-2009, European Commission Directorate General for Taxation and Customs Union.

Demyanyk, Y., and Van Hemert, O. (2009). 'Understanding the Subprime Mortgage Crisis', Review of Financial Studies, 24/6: 1848-80.

Desai, M. A. (2005). 'The Degradation of Reported Corporate Profits', Journal of Economic Perspectives, 19: 171-92.

Desai, M. A., and Dharmapala, D. (2008). 'Tax and Corporate Governance: An Economic Approach', in Wolfgang Schon (ed.), Tax and Corporate Governance. Berlin: Springer, 13-30.

Desai, M. A., Fritz Foley, C., and Hines, J. R. (2004). 'A Multinational Perspective on Capital Structure Choice and Internal Capital Markets', Journal of Finance, 59: 2451-87.

This is an open access version of the publication distributed under the terms of the Creative Commons Attribution-NonCommercialNoDerivs licence (http://creativecommons.org/licenses/by-nc-nd/3.0/), which permits non-commercial reproduction and distribution of the work, in any medium, provided the original work is not altered or transformed in any way, and that the work is properly cited. For commercial re-use, please contact academic.permissions@oup.com 


\section{References}

Desai, M. A., Dyck, A., and Zingales, L. (2007). 'Theft and Taxes', Journal of Financial Economics, 84/3 (June ), 591-623.

Devereux, M. P., and Sørensen, P. B. (2006). 'The Corporate Income Tax: International Trends and Options for Fundamental Reform'. Economic Paper, European Commission, No. 264.

Devereux, M. P., Griffith, R., and Klemm, A. (2002). 'Corporate Income Tax Reforms and International Tax Competition', Economic Policy, 17/35: 451-95.

Devereux, M., Griffith, R., and Klemm, A. (2004). 'Why has the UK Corporation Tax Raised so Much Revenue?', Fiscal Studies, 25/4: 367-88.

Devereux, M. P., Mokkas, S., Pennock, J., and Wharrad, P. (2006). 'Interest Deductibility for UK Corporation Tax'. Mimeo, Oxford University Centre for Business Taxation.

Diamond, P. A., and Mirrlees, J. A., 1971, Optimal Taxation and Public Production, American Economic Review, 61/1: 8-27.

Domar, E. D., and Musgrave, R. A. (1944). 'Proportional Income Taxation and RiskTaking', Quarterly Journal of Economics, 58/3: 388-422.

Dooley, M. P. (1996). 'The Tobin Tax: Good Theory, Weak Evidence, Questionable Policy', in M. ul Haq, I. Kaul, and I. Grunberg (eds), The Tobin Tax: Coping with Financial Volatility. Oxford: Oxford University Press, 83-108.

Dow, J., and Gorton, G. (2006). 'Noise Traders'. NBER Working Paper Series 12256.

Drehmann, M., and Tarashev, N. (2011). 'Measuring the Systemic Importance of Interconnected Banks'. BIS Working Paper No 342.

Duarte, J., Longstaff, F. A., and Yu, F. (2005). 'Risk and Return in Fixed Income Arbitrage: Nickels in Front of a Steamroller?', Review of Financial Studies, 20/3: 769-811.

Duffie, D. (2008). 'Innovations in Credit Risk Transfer: Implications for Financial Stability'. BIS Working Paper No. 255, July.

Duffie, D., Jarrow, R. A., Purnanandam, A., and Yang, W. (2003). 'Market Pricing of Deposit Insurance', Journal of Financial Services Research, 24/2-3: 93-119.

Dunsky, R. M., and Follain, J. R. (2000). 'Tax-Induced Portfolio Reshuffling: The Case of the Mortgage Interest Deduction', Real Estate Economics, 28/4: 683-718.

ECB (2003). European Central Bank, Structural Factors in the EU Housing Markets. Mar.

ECB (2006). European Central Bank, Financial Stability Review. Dec.

Economic and Financial Committee (2011). 'Fnancial Levies and Taxes: State of Play'. Draft report to the Ecofin, Brussels.

The Economist (2005). 'The Global Housing Boom: In Come the Waves', 16 June.

Eddins, S. T. (2009). 'Tax Arbitrage Feedback Theory'. Mimeo, IronBridge Capital Management LP.

EEAG (2010). European Economic Advisory Group, 'Report on the European Economy'. Technical report, CESifo.

EEAG (2011). European Economic Advisory Group, The EEAG Report on the European Economy 2011. Munich: CESifo.

Eichengreen, B., Tobin, J., and Wyplosz, C. (1995). 'Two cases for Sand in the Wheels of International Finance', The Economic Journal, 105/428: 162-72. 
Elliott, D. J. (2010a). A Primer on Bank Capital. Washington: Brookings Institution <http://www.brookings.edu/papers/2010/ /media/A84D1C57A7CE4539BCD0FE6F66D1FB63.pdf>.

Elliott, D. J. (2010b). 'Tax Policy and Bank Regulation'. Manuscript, Brookings Institution, Washington, DC.

Elliott, L. (2010). 'Sachs Calls for Robin Hood Tax on "Smirking" Wall Street', Guardian, 9 Mar. <http://www.guardian.co.uk/business/2010/mar/09/jeffrey-sachs-robinhood-tax $>$.

Englund, P. (1999). 'The Swedish Banking Crisis: Roots and Consequences', Oxford Review of Economic Policy, 15/3: 80-96.

Englund, P., Hendershott, P. H., and Turner, B. (1995). 'The Tax Reform and the Housing Market', Swedish Economic Policy Review, 2: 319-56.

European Commission (2009a). 'Recommendation on Remuneration Policies in the Financial Services Sector'. C(2009), 3159, Brussels, 30 Apr.

European Commission (2009b). Recommendation Complementing Recommendations 004/913/EC and 2005/162/EC as Regards the Regime for the Remuneration of Directors of Listed Companies'. C(2009) 3177, Brussels, 30 Apr.

European Commission (2010a). State Aid Scoreboard: Report on Recent Developments on Crisis Aid to the Financial Sector. COM(2010)255.

European Commission (2010b). 'Public Finance in EMU 2010', European Economy, 4 (June).

European Commission (2010c). 'European Economic Forecast: Spring 2010', European Economy.

European Commission (2010d). 'Innovative Financial at a Global Level'. SEC(2010) 409, Taxation Paper 23.

European Commission (2010e). 'Communication on Taxation of the Financial Sector', COM(2010)549.

European Commission (2010f). 'Taxation of the Financial Sector'. Staff Working Document, SEC(2010)1166.

European Commission (2010g). 'Taxes in Europe Database' <http://ec.europa.eu/ tedb $>$.

European Council (2010). Conclusions of the 17 June European Council, Brussels.

Fama, E. (1970). 'Efficient Capital Markets: A Review of Theory and Empirical Work', Journal of Finance, 25/2: 383-417.

Fabozzi, F. J. (2005). The Handbook of Fixed Income Securities, 7th edn. New York: McGraw-Hill.

Fabozzi, F. J., and Khotari, V. (2007). 'Securitization: The Tool of Financial Transformation'. Yale ICF Working Paper No. 07-07, 2007 <http://ssrn.com/abstract=997079>.

Falkenheim, M., and Pennacchi, G. (2003). 'The Cost of Deposit Insurance for Privately Held Banks: A Market Comparable Approach', Journal of Financial Services Research, 24/2-3: 121-48.

Fehr, H., Knoll, L., and Mikus, L. (2004). 'Taxation of Stock Options: An International Comparison', Tax Notes International, 33/5 (2 Feb.), 463-72.

Financial Stability Board (2009). 'Improving Financial Regulation'. Report of the Financial Stability Board to G20 Leaders.

This is an open access version of the publication distributed under the terms of the Creative Commons Attribution-NonCommercialNoDerivs licence (http://creativecommons.org/licenses/by-nc-nd/3.0/), which permits non-commercial reproduction and distribution of the work, in any medium, provided the original work is not altered or transformed in any way, and that the work is properly cited. For commercial re-use, please contact academic.permissions@oup.com 


\section{References}

Financial Stability Forum (2009). 'Principles for Sound Compensation Practices', 2 Apr. Fitch Ratings (2009). 'Sovereigns: European Government Borrowing'. International Special Report, 26 Jan.

Fraser, R. (2002). 'An Evaluation of the Relative Performance of Alternatively Structured Resource Rent Taxes', Resources Policy, 28/1-2 (Mar.), 1-6. DOI: 10.1016/S0301-4207 (02)00012-0.

Friedman, M., and Schwartz, A. (1963). A Monetary History of the United States, 1867-1960. Princeton: University of Princeton Press.

FSA (2009). Financial Services Authority, The Turner Review: A Regulatory Response to the Global Banking Crisis. Mar. <http://www.fsa.gov.uk/pubs/other/turner_review.pdf>.

Gale, W. G., Gruber, J, and Stephens-Davidowitz, S. (2007). 'Encouraging Homeownership through the Tax Code', Tax Notes, 18 June, 1171-89.

Garbade, K. (2007). "The Emergence of "Regular And Predictable" as a Treasury Debt Management Strategy', Economic Policy Review, 13/1 (Mar.).

Garbade, K. (2008). 'Why the US Treasury Began Auctioning Treasury Bills in 1929', Economic Policy Review, 14/1 (July), 3147.

Garber, P., and Taylor, M. P. (1995). 'Sand in the Wheels of Foreign Exchange Markets: A Sceptical Note', Economic Journal, 105/428: 173-80.

Geithner, T. F. (2010). Testimony. 4 May. US Senate Committee on Finance, Washington, DC.

Genser, B., and Winker, P. (1997). 'Measuring the Fiscal Revenue Loss of VAT Exemption in Commercial Banking', Finanzarchiv, 54: 565-85.

George, P., and Megan, M. (2010). 'UK Fails to Alter Bank Bonus Culture', Financial Times, 6 Jan.

Giavazzi, F., and Pagano, M. (1990). 'Can Severe Fiscal Contractions Be Expansionary? Tales of Two Small European Countries', in NBER Macroeconomics Annual 1990, vol. 5. Cambridge, MA: National Bureau of Economic Research, 75-122.

Giavazzi, F., and Pagano, M. (1996). 'Non-Keynesian Effects of Fiscal Policy Changes: International Evidence and the Swedish Experience'. NBER Working Papers, No. 5332, National Bureau of Economic Research.

Giavazzi, F., Jappelli, T., and Pagano, M. (2000). 'Searching for Non-Linear Effects of Fiscal Policy: Evidence from Industrial and Developing Countries', European Economic Review, 44/7: 1259-89.

Giudice, G., Turrini, A., and in.t Veld, J. J. (2007). 'Non-Keynesian Fiscal Adjustments? A Close Look at Expansionary Fiscal Consolidations in the EU', Open Economies Review, 18/5: 613-30.

Gjerstad, S., and Smith, V. L. (2009). 'From Bubble to Depression?', Wall Street Journal Online, 6 Apr.

Glaeser, E. L. (2009). 'Killing (or Maiming) a Sacred Cow: Home Mortgage Deductions', New York Times, 24 Feb.

Glaeser, E. L., Gyourko, J., and Saks, R. E. (2005). 'Why Have Housing Prices Gone Up?'. Harvard Institute of Economic Research, Discussion Paper No. 2061, Feb.

Glaeser, E. L., and Shapiro, J. M. (2002). 'The Benefits of the Home Mortgage Interest Deduction'. NBER Working Papers, No. 9284, National Bureau of Economic Research. 
Goodhart, C. A. H. (2010). 'The New Emerging Architectures of Financial Regulation'. Mimeo.

Graham, J. R. (2003). 'Taxes and Corporate Finance: A Review', Review of Financial Studies, 16: 1075-129.

Graham, J. R., Raedy, J. S., and Shackelford, D. A. (2010). 'Research in Accounting for Income Taxes'. NBER Working Papers, No. 15665, National Bureau of Economic Research.

Griffith, R., Hines, J., and Sørensen, P. B. (2010). 'International Capital Taxation', in S. Adam, T. Besley, R. Blundell, S. Bond, R. Chote, M. Gammie, P. Johnson, G. Myles, and J. Poterba (eds), Dimensions of Tax Design: The Mirrlees Review. Oxford: Oxford University Press.

Grubert, H., and Newlon, T. S. (1997). Taxing Consumption in a Global Economy. Washington, DC: American Enterprise Institute.

Guichard, S., Kennedy, M., Wurzel, E., and André, C. (2007). 'What Promotes Fiscal Consolidation: OECD Country Experiences'. OECD Economics Department, Working Paper 553, OECD Publishing.

Hall, B., and Liebman, J. (2000), 'The Taxation of Executive Options', Tax Policy and the Economy, 20: 1-44.

Hall, B., and Murphy, K. (2003). 'The Trouble with Stock Options', Journal of Economic Perspectives, 17/3 (Summer), 49-70.

Hall, R. E. (2009). 'By How Much Does GDP Rise if the Government Buys More Output?' NBER Working Papers, No. 15496, National Bureau of Economic Research.

Han, J., Park, K., and Pennacchi, G. (2010). 'Corporate Taxes and Securitization'. Mimeo.

Hanke, M., Huber, J., Kirchler, M., and Sutter, M. (2007). 'The Economic Consequences of a Tobin Tax: An Experimental Analysis'. Working Papers in Economic and Statistics, University of Innsbruck, 2007-18.

Hanlon, M., LaPlante S., and Shevlin, T. (2005). 'Evidence for the Possible Information Loss of Conforming Book Income and Taxable Income', Journal of Law and Economics, 48: 407-42.

Hanson, S. G., Kashyap, A. K., and Stein, J. (2011). 'A Macroprudential Approach to Financial Regulation', Journal of Economic Perspectives, 25/1: 3-29.

Hassett, K. A., and Mathur, A. (2008). 'Taxes and Wages'. Mimeo, American Enterprise Institute.

Hau, H. (2006). 'The Role of Transaction Costs for Financial Volatility: Evidence from the Paris Bourse', Journal of the European Economic Association, 4/4: 862-90.

Haulotte, S., Valenduc, C., and Deloddere, E. (2010). 'Mémento fiscal 2010'. Service d'Etudes et de Documentation <http://docufin.fgov.be/intersalgfr/thema/publicaties//memento/memento.htm $>$.

Hay, J., and Paul, N. (1991). 'Regulation and Taxation of Commercial Banks during the International Debt Crisis'. World Bank Technical Paper No. 158.

Hayashida, M., and Ono, H. (2011). 'Tax Reforms and Stock Return Volatility: The Case of Japan'. Mimeo.

Hebous, S. (2009). 'The Effects of Discretionary Fiscal Policy on Macroeconomic Aggregates: A Reappraisal'. MPRA Paper 23300, University Library of Munich.

This is an open access version of the publication distributed under the terms of the Creative Commons Attribution-NonCommercialNoDerivs licence (http://creativecommons.org/licenses/by-nc-nd/3.0/), which permits non-commercial reproduction and distribution of the work, in any medium, provided the original work is not altered or transformed in any way, and that the work is properly cited. For commercial re-use, please contact academic.permissions@oup.com 


\section{References}

Hemmelgarn, T., and Nicodeme, G. (2010). 'The 2008 Financial Crisis and Taxation Policy'. Taxation Paper 20.

Hendershott, P., Price, G., and White, M. (2003). 'Household Leverage and the Deductibility of Home Mortgage Interest: Evidence from UK House Purchases', Journal of Housing Research, 14/1: 49-82.

High Level Group on Financial Supervision in the EU (2009). <http://ec.europa.eu/ internal_market/finances/docs/de_larosiere_report_en.pdf>.

Hilbers, A., Hoffmaister, A. W., Banerji, A., and Shi, A. (2008). 'House Price Developments in Europe: A Comparison'. IMF Working Paper 08/211.

Himmelberg, C., Mayer, C., and Sinai, T. (2005). 'Assessing High House Prices: Bubbles Fundamentals and Misperceptions', Journal of Economic Perspectives, 19/4: 67-92.

Hite, G. L., and Long, M. S. (1982). 'Taxes and Executive Stock Options', Journal of Accounting and Economics, 4/1 (July), 97-106.

Honohan, P., and Yoder, S. (2010). 'Financial Transactions Tax: Panacea, Threat, or Damp Squib?' World Bank Policy Research Working Paper No. 5230, Mar.

Huizinga, H. (2002). 'A European VAT on Financial Services?', Economic Policy, 17: 499-534.

Huizinga, H., Laeven, L., and Nicodeme, G. (2008). 'Capital Structure and International Debt Shifting', Journal of Financial Economics, 88: 80-118.

IAS (2002). International Accounting Standards, document, IAS 7.

IBFD (2009). International Bureau of Fiscal Documentation, European Tax Handbook 2009. Amsterdam: IBFD.

IBFD (2010). International Bureau of Fiscal Documentation, European Tax Handbook 2010: Ireland. Amsterdam: IBFD.

IBFD (2011). International Bureau of Fiscal Documentation, European Tax Handbook 2011: Germany. Amsterdam: IBFD.

Ilzetzki, E., Mendoza, E. G., and Végh, C. A. (2010). 'How Big (Small?) Are Fiscal Multipliers?'. NBER Working Papers, No. 16479, National Bureau of Economic Research.

IMF (2008). International Monetary Fund, 'Financial Stress and Economic Downturns', in World Economic Outlook. Washington, DC: IMF, ch. 4.

IMF (2009a). International Monetary Fund, 'Debt Bias and Other Distortions: CrisisRelated Issues in Tax Policy' <http://www.imf.org>.

IMF (2009b). International Monetary Fund, 'Lessons of the Financial Crisis for Future Regulation of Financial Institutions and Markets and for Liquidity Management' $<$ http://www.imf.org $>$.

IMF (2010a). International Monetary Fund, 'World Economic Outlook: Recovery, Risk and Rebalancing', in IMF Economic Outlook. Washington, DC: IMF.

IMF (2010b). International Monetary Fund, 'A Fair and Substantial Contribution by the Financial Sector'. Final report to the G20, June.

IMF (2010c). International Monetary Fund, Financial Sector Taxation: The IMF's Report to the G2O and Background Material, ed. S. Claessens, M. Keen, and C. Pazarbasioglu. Washington, DC: IMF.

IRS (2004). Internal Revenue Service, 'Request for Information about Credit Default Swaps', Notice, 52. 
Jacobs, O. H. (1997). 'The Allowance for Corporate Equity as a Method of Harmonizing Corporate Taxation in Europe?', Intertax, 25: 232-46.

Janeba, E., and Smart, M. (2003). 'Is Targeted Tax Competition Less Harmful than its Remedies?', International Tax and Public Finance, 10: 259-80.

Jaquette, S., Knittel, M., and Russo, K. (2003). 'Recent Trends in Stock Options'. Working Paper 89, Office of Tax Analysis, Department of Treasury, Washington, DC.

Johansson, A., Heady, C., Arnold, J., Brys, B., and Varita, L. (2008). 'Taxation and Economic Growth'. OECD Economics Department Working Paper No. 620.

Johnsen, K., and Eagan, M. (2003). 'Tax Treatment of Securitizations of Receivables', Derivatives and Financial Instruments, 5/6 (Nov.-Dec.), 232-40.

Joint Center for Housing Studies at Harvard University (2008). The State of the Nation's Housing 2008. Cambridge, MA: Harvard University.

Joint Center for Housing Studies at Harvard University (2009). The State of the Nation's Housing 2009. Cambridge, MA: Harvard University.

Jones, C. M., and Seguin, P. J. (1997). 'Transaction Costs and Price Volatility: Evidence from Commission Deregulation', American Economic Review, 87/4: 728-37.

Jorgenson, D. W., and Landau, R. (eds) (1993). Tax Reform and the Cost of Capital: An International Comparison. Washington, DC: Brookings Institution.

Kalderen, L., and Blommestein, H. (2002). 'The Role and Structure of Debt Management Offices', in Debt Management and Government Securities Markets in the 21st Century. Paris: OECD, 101-33.

Kaplow, L. (1994). 'Taxation and Risk Taking: A General Equilibrium Perspective', National Tax Journal, 47: 789-98.

Kaplow, L., and Shavell, S. (2002). 'On the Superiority of Corrective Taxes to Quantity Regulation', American Law and Economics Review, 4/1: 1-17.

Katz, A. (2009). Our Lot: How Real Estate Come To Own Us. New York: Bloomsbury USA. Kearl, J. (1979). 'Inflation, Mortgages, and Housing', Journal of Political Economy, 87: 1115-38.

Keen, M. (2001). 'Preferential Regimes Can Make Tax Competition Less Harmful', National Tax Journal, 54: 757-62.

Keen, M. (2008). 'Tax Competition', in Steven N. Durlauf and Lawrence E. Blume (eds), The New Palgrave Dictionary of Economics. 2nd edn. London: Palgrave Macmillan, 160-7.

Keen, M., and King, J. (2002). 'The Croatian Profits Tax: An ACE in Practice', Fiscal Studies, 23: 401-18.

Keen, M., and Syed, M. (2006). 'Domestic Taxes and International Trade: Some Evidence'. IMF Working Paper 06/47.

Keen, M., Klemm, A., and Perry, V. (2010). 'Tax and the Crisis', Fiscal Studies, 31/1: 43-79.

Keen, M., Krelove, R., and Norregaard, J. (2010). 'The Financial Activities Tax', in International Monetary Fund, Financial Sector Taxation, The IMF's Report to the G20 and Background Material. Washington, DC.

Kerrigan, A. (2010). 'The Elusiveness of Neutrality: Why Is It So Difficult to Apply VAT to Financial Services?', International VAT Monitor, 21/2 (Mar.-Apr.), 103-12.

Keynes, J. M. (1936). General Theory of Employment, Interest and Money. London: Macmillan St. Martin's Press.

This is an open access version of the publication distributed under the terms of the Creative Commons Attribution-NonCommercialNoDerivs licence (http://creativecommons.org/licenses/by-nc-nd/3.0/), which permits non-commercial reproduction and distribution of the work, in any medium, provided the original work is not altered or transformed in any way, and that the work is properly cited. For commercial re-use, please contact academic.permissions@oup.com 
King, M. (2004). 'The Institutions of Monetary Policy', American Economic Review, 94/2 (May), 1-13.

King, M. (2009). Interview with Stephanie Flanders, BBC, 5 Mar.

Kleinbard, E. D. (2003). 'Competitive Convergence in the Financial Services Market', Taxes, 81/3: 225-60.

Kleinbard, E. D. (2007a). Rehabilitating the Business Income Tax. Washington, DC: Brookings Institution.

Kleinbard, E. D. (2007b). 'Designing an Income Tax on Capital', in Henry J. Aaron, Leonard Burman, and Eugene Steuerle (eds), Taxing Capital Income. Washington, DC: Urban Institute Press, 165-210.

Kleinbard, E. D., and Edgar, T. (2010). 'The Financial Sector and the Crisis: Was Tax the Problem? Is It the Solution?'. Slides presented at a workshop on Rethinking the Taxation of the Financial Sector in Light of the Recent Crisis, 5 Feb., sponsored by the Office of Tax Policy Research and the UNC Tax Center, New York.

Klemm, A. (2007). 'Allowances for Corporate Equity in Practice', CESifo Economic Studies, 53: 229-62.

Kleven, H., Landais, C., and Saez, E. (2010). 'Taxation and International Migration of Superstars: Evidence from the European Football Market'. NBER Working Papers, No. 16545, National Bureau of Economic Research.

Koo, R. (2008). The Holy Grail of Macroeconomics: Lessons from Japan's Great Recession. Hoboken, NJ: Wiley.

Krugman, P. (2010a). 'Don't Cry for Wall Street', New York Times, 23 Apr., A27.

Krugman, P. (2010b). 'The Conscience of a Liberal', New York Times, blog column.

Kunieda, S. (2011). 'Speculative Bubbles and Tax Policy'. Mimeo.

Kuroda, H. (2002). 'Open Market Operations, Debt Management and Exchange Market Intervention: The General Case and the Japanese Case'. Speech to the Japan Project Meeting organized by NBER/CEPR/CIRJE/EIJS, 13 Sept.

Kuttner, K. (2006). 'Can Central Banks Target Bond Prices?'. NBER Working Papers, No. 12454, National Bureau of Economic Research.

Lambe, G. (2009). 'Top 1000 World Banks 2009', The Banker, 29 June.

Lambertini, L., and Tavares, J. (2003). 'Exchange Rates and Fiscal Adjustments: Evidence from the OECD and Implications for EMU'. Boston College Working Papers in Economics, No. 576, Boston College Department of Economics.

Lefebvre, F. (2010a). Mémento pratique fiscal: France. Levallois Perret: Éditions Francis Lefebvre.

Lefebvre, F. (2010b). Memento práctico fiscal: Spain. Levallois Perret: Éditions Francis Lefebvre.

Lent, G. E. (1951). 'Excess-Profits Taxation in the United States', Journal of Political Economy, 59/6: 481-97.

Levin, C. (2009). Senate Floor Statement on Introduction of the Ending Excessive Corporate Deductions for Stock Options Act' <http://levin.senate.gov/newsroom/ release.cfm?id=316068>.

Levine R. (1997). 'Financial Development and Economic Growth: Views and Agenda', Journal of Economic Literature, 35/2: 688-726.

This is an open access version of the publication distributed under the terms of the Creative Commons Attribution-NonCommercialNoDerivs licence (http://creativecommons.org/licenses/by-nc-nd/3.0/), which permits non-commercial reproduction and distribution of the work, in any medium, provided the original work is not altered or transformed in any way, and that the work is properly cited. For commercial re-use, please contact academic.permissions@oup.com 
Lindo, A. (2009). Speech at the Regulatory Accounting Update session of the AICPA 2009 National Conference on Banks and Savings Institutions, American Institute of CPAs, Washington, DC.

Liu, S., and Zhu, Z. (2009). 'Transaction Costs and Price Volatility: New Evidence from the Tokyo Stock Exchange', Journal of Financial Services Research, 36: 65-83.

Lockwood B. (2010). 'How Should Financial Intermediation Services be Taxed?'. CESifo Working Paper No. 3226.

Lucas, D. J., Goodman, L. S., and Fabozzi, F. J. (2007). 'Collateralized Debt Obligations and Credit Risk Transfer'. Yale ICF Working Paper No. 07-06 <http://ssrn.com/ abstract $=997276>$.

Lupo, T. B. (2008). 'Phantom Income', addendum to Peaslee and Nirenberg (2001) $<$ http://www.securitizationtax.com>.

McCauley, R., and Ueda, K. (2009). 'Government Debt Management at Low Interest Rates', BIS Quarterly Review, 35-51.

McDermott, C. J., and Westcott, R. F. (1996). 'An Empirical Analysis of Fiscal Adjustments'. IMF Working Paper 96/59.

MacKie-Mason, J. (1990). 'Do Taxes Affect Corporate Financing Decisions?', Journal of Finance, 45: 1471-93.

Madeo, S. A., and Omer, T. C. (1994). 'The Effect of Taxes on Switching Stock Option Plans: Evidence from the Tax Reform Act of 1969', Journal of the American Taxation Association, 16/2 (Fall), 24-42.

Mahfouz, S., Hemming, R., and Kell, M. (2002). 'The Effectiveness of Fiscal Policy in Stimulating Economic Activity: A Review of the Literature'. IMF Working Paper $02 / 208$.

Masciandaro, D., and Passarelli, F. (2011). 'Financial Systemic Risk: Taxation or Regulation?' Working Paper Series No. 91, Paolo Baffi Centre, Bocconi University.

Mason, J. R. (2009). 'Regulating for Financial System Development, Financial Institutions Stability, and Financial Innovation'. 17 Apr. <http://ssrn.com/abstract= 1393409>.

Mason J. R., and Rosner, J. (2007). 'Where Did the Risk Go? How Misapplied Bond Ratings Cause Mortgage Backed Securities and Collateralized Debt Obligation Market Disruptions'. 3 May <http://ssrn.com/abstract=1027475>.

Matheson, T. (2010). 'Taxing Financial Transactions: Issues and Evidence'. Working Paper, IMF, Washington, DC.

Mayer Brown (2006). 'Taxation of Investments into German Real Estate'. Rowe \& Maw LLP <http://www.mayerbrown.com>.

Meade, J. E. (1978). The Structure and Reform of Direct Taxation. Report of a Committee Chaired by Professor J. E. Meade. London: George Allen \& Unwin.

Meltzer, A. H. (2002). History of the Federal Reserve, i. 1913-51. Chicago: University of Chicago Press.

Meltzer, A. H., and Richard, S. F. (1981). 'A Rational Theory of the Size of Government', Journal of Political Economy, 89/5: 914-27.

Miller, D. S. (1998). 'An Overview of the Taxation of Credit Derivatives', in F. J. Fabozzi (ed.), The Use of Derivatives in Tax Planning. Hoboken, NJ: Wiley, 90-111.

Miller, M. H. (1977). 'Debt and Taxes', Journal of Finance, 32: 261-75.

This is an open access version of the publication distributed under the terms of the Creative Commons Attribution-NonCommercialNoDerivs licence (http://creativecommons.org/licenses/by-nc-nd/3.0/), which permits non-commercial reproduction and distribution of the work, in any medium, provided the original work is not altered or transformed in any way, and that the work is properly cited. For commercial re-use, please contact academic.permissions@oup.com 


\section{References}

Ministry of Finance of Japan, Finance Bureau (2004-8). Debt Management Report.Tokyo. Mintz, J. (2004). 'Conduit Entities: Implications of Indirect Tax-Efficient Financing Structures for Real Investment', International Tax and Public Finance, 11: 419-34.

Mintz, J., and Weichenrieder, A. (2005). 'Taxation and the Financial Structure of German Outbound FDI'. CESifo Working Paper No. 1612.

Missale, A. (1999). Public Debt Management. Oxford: Oxford University Press.

Morinobu, S. (2006). 'The Rise and Fall of the Land Myth in Japan: Some Implication to the Chinese Land Taxation'. Mimeo, Research Department Policy Research Institute, Ministry of Finance, Japan.

Mullins, P. (2006). 'Moving to Territoriality? Implications for the US and the Rest of the World', Tax Notes International, 4 Sept.

Munro, A. B. (2010). 'Revisiting Tax Considerations Regarding Credit Defaults Swaps', Derivatives and Financial Instruments, 12/1 (Jan.-Feb.), 9-15.

Murphy, K. (2002). 'Explaining Executive Compensation: Managerial Power versus the Perceived Cost of Stock Options', University of Chicago Law Review, 69/3 (Summer), 847-69.

New York State Bar Association Tax Section (2005). 'Credit Default Swap', Tax Notes International, 40/6 (7 Nov.), 545-89.

Nickel, C., Rother, P., and Zimmermann, L. (2010). 'Major Public Debt Reductions: Lessons from the Past, Lessons for the Future'. Working Paper Series 1241, European Central Bank.

Nomura (2006), MBS Basics.

Oda, N., and Ueda, K. (2007). 'The Effects of the Bank of Japan's Zero Interest Rate Commitment and Quantitative Monetary Easing on the Yield Curve: A MacroFinance Approach', Japanese Economic Review, 58/3 (Sept.), 303-28.

OECD (1998). Harmful Tax Competition: An Emerging Global Issue. Paris: OECD.

OECD (2000). Economic Survey: UK. Paris: OECD.

OECD (2005). 'The Taxation of Employee Stock Options'. OECD Tax Policy Study, No. 11.

OECD (2007a). Belgium. OECD Economic Survey. Paris: OECD.

OECD (2007b). Fundamental Reform of Corporate Income Tax. Paris: OECD.

OECD (2008a). Economic Outlook, 83 (June).

OECD (2008b). Central Government Debt: Statistical Yearbook. Paris: OECD.

OECD (2009a). Moving beyond the Crisis: Using Tax Policy to Support Financial Stability. June.

OECD (2009b). Economic Outlook, 86/2 (Nov.).

OECD (2010a). Addressing Tax Risks Involving Bank Losses. Sept. Paris: OECD.

OECD (2010b). Economic Outlook, 88/2 (Dec.).

OECD (2010c). 'Report on Attribution of Profits to Permanent Establishments'. OECD Publishing, July.

OECD (2010d). 'Transfer Pricing Guidelines for Multinational Enterprises and Tax Administrations'. OECD Publishing, Aug.

Office of the Press Secretary (2010). 'President Obama Proposes Financial Crisis Responsibility Fee to Recoup Every Last Penny for American Taxpayers'. Press Release, 14 Jan. The White House, Washington <http://www.whitehouse.gov/search/site/

This is an open access version of the publication distributed under the terms of the Creative Commons Attribution-NonCommercialNoDerivs licence (http://creativecommons.org/licenses/by-nc-nd/3.0/), which permits non-commercial reproduction and distribution of the work, in any medium, provided the original work is not altered or transformed in any way, and that the work is properly cited. For commercial re-use, please contact academic.permissions@oup.com 
president $\% 20$ obama $\% 20$ proposes $\% 20$ financial $\% 20$ crisis $\% 20$ responsibility $\% 20$ fee $\% 20$ recoup\%20every\%20last\%20penn>.

Office of Management and Budget (2011). Budget of the United States Government, Fiscal Year 2011.

O'Kane, D. (2005). 'Introduction to Credit Derivatives', in F. J. Fabozzi (ed.), The Handbook of Fixed Income Securities. 7th edn. New York: McGraw-Hill, 1337-70.

Onado, M. (2009). I nodi al pettine. Rome and Bari: Laterza.

Owens, J. (2005). 'The Intersection of Tax and Good Corporate Governance', Tax Notes International, 37/9 (28 Feb), 767-9.

Peaslee, J. M., and Nirenberg, D. Z. (2001). Federal Income Taxation of Securitization Transactions. 3rd edn. New Hope, PA: F. J. Fabozzi Associates. Updates available at $<$ http://www.securitizationtax.com>.

Pelizzari, P., and Westerhoff, F. (2007). 'Some Effects of Transaction Taxes under different Microstructures'. Quantitative Finance Research Centre Research Paper No. 212.

Pennacchi, G. (2009). 'Deposit Insurance'. Paper prepared for the AEI Conference on Private Markets and Public Insurance Programs, Mar.

Perotti, R. (1999). 'Fiscal Policy in Good Times and Bad', Quarterly Journal of Economics, 114/4: 1399-436.

Perotti, R. (2005). 'Estimating the Effects of Fiscal Policy in OECD Countries'. Proceedings, Federal Reserve Bank of San Francisco.

Perotti, E., and Suarez, J. (2009). 'Liquidity Risk Charges as a Macroprudential Tool'. Mimeo.

Persson, T., and Tabellini, G. (2000). Political Economics: Explaining Economic Policy. Cambridge, MA: MIT Press.

Peter, A. F. (2006). 'United States: Characterization of Credit Default Swaps for Tax Purposes', Derivatives and Financial Instruments, 8/1 (Jan.-Feb.), 1-12.

Philippon, T., and Reshef, A. (2009). 'Wages and Human Capital in the US Financial Industry: 1909-2006'. CEPR Discussion Paper No. 7282.

Pigou, A. C. (1928). A Study in Public Finance. London: MacMillan.

Pittsburgh Summit (2009), 'Leader's Statement', 24-5 Sept. 2009 <http://www.g20.org/ Documents/pittsburgh_summit_leaders_statement_250909.pdf >.

Poddar, S. (2003). 'Consumption Taxes: The Role of the Value-Added Tax', in P. Honohan (ed.), Taxation of Financial Intermediation. Oxford: Oxford University Press, 345-80.

Poterba, J. M. (1984). 'Tax Subsidies to Owner-Occupied Housing: An Asset-Market Approach', Quarterly Journal of Economics, 99/4: 729-52.

Poterba, J. M. (1991). 'House Price Dynamics: The Role of Tax Policy and Demography', Brooking Papers on Economic Activity, 2: 143-203.

Poterba, J. M. (1992). 'Taxation and Housing: Old Questions, New Answers', American Economic Review, 82: 237-42.

Poterba, J. M. (2004). 'Taxation and Corporate Payout Policy', American Economic Review, 94: 171-5.

This is an open access version of the publication distributed under the terms of the Creative Commons Attribution-NonCommercialNoDerivs licence (http://creativecommons.org/licenses/by-nc-nd/3.0/), which permits non-commercial reproduction and distribution of the work, in any medium, provided the original work is not altered or transformed in any way, and that the work is properly cited. For commercial re-use, please contact academic.permissions@oup.com 
Poterba, J. M. (2008). 'Tax Expenditures for Owner-Occupied Housing: Deductions for Property Taxes and Mortgage Interest and the Exclusion of Imputed Rental Income', American Economic Review: Papers \& Proceedings, 98/2: 84-9.

Poterba, J. M., and Sinai, T. M. (2008). 'Income Tax Provisions Affecting OwnerOccupied Housing: Revenue Costs and Incentive Effects'. NBER Working Papers, No. 14253.

Pozdena, R. J. (1988). The Modern Economics of Housing. New York, Westport, CT, and London: Quorum Books.

PricewaterhouseCoopers (2006). 'Economic Effects of the VAT Exemption for Financial and Insurance Services'. Report to the European Commission.

Quayes, S. (2010). 'The Impact of Capital Gains Tax Exemption on Housing Sales', Applied Economic Letters, 17: 213-16.

Radulescu, D. M. (2010). 'The Effects of a Bonus Tax on Manager Compensation and Welfare', CESifo Working Paper Series No. 3030, CESifo Group, Munich.

Rajan, R. (2008). 'Bankers' Pay is Deeply Flawed', Financial Times, 8 Jan., London <http://www.ft.com/cms/s/0/18895dea-be06-11dc-8bc9-0000779fd2ac.html\#axzz $1 \mathrm{eSxYWgdE}>$.

Ramey, V., and Shapiro, M. (1998). 'Costly Capital Reallocation and the Effects of Government Spending', in Carnegie-Rochester Conference Series on Public Policy, 48 (June),145-94.

Raskolnikov, A. (2008). 'Statement on the Tax Treatment of Derivatives at a Hearing of the House Committee on Ways and Means'. Subcommittee of Select Revenue Measures, 5 Mar.

Remolona, E. M., and Shim, I. (2008). 'Credit Derivatives and Structured Credit: The Nascent Markets of Asia and the Pacific', BIS Quarterly Review (June), 57-65.

Roberts, K. (1977). 'Voting over Income Tax Schedules', Journal of Public Economics, 8/3 (Dec.), 329-40.

Romer, C. D., and Romer, D. H. (2010). 'The Macroeconomic Effects of Tax Changes: Estimates Based on a New Measure of Fiscal Shocks', American Economic Review, 100/3: 763-801.

Roosa, R. (1963). 'The Management of the National Debt'. Lecture to the Industrial College of the Armed Forces, Washington, DC, 31 Oct.

Rother, P., Schuknecht, L., and Stark, J. (2010). 'The Benefits of Fiscal Consolidation in Uncharted Waters'. Occasional Paper Series No. 121, European Central Bank.

Rzonca, A., and Cizkowicz, P. (2005). 'Non-Keynesian Effects of Fiscal Contraction in New Member States'. Working Paper Series No. 519, European Central Bank.

Saporta, V., and Kan, K. (1997). 'The Effects of Stamp Duty on Level and Volatility of UK Equity Prices'. Issued by the Bank of England.

Schaefer, S., Gauthier, D., and Vaughan, M. (2009). 'France Joins UK Bonus Tax; Not Germany, US', Wall Street Journal, 14 Dec.

Schizer, D. M. (2000). 'Sticks and Snakes: Derivatives and Curtailing Aggressive Tax Planning', Southern California Law Review, 1348-406.

Scholes, M. S., Wolfson, M. A., Erickson, M. M., Maydew, E. L., and Shevlin, T. J. (2008). Taxes and Business Strategy. 4th edn. Upper Saddle River, NJ: Prentice Hall. 
Schulmeister, S., Schratzenstaller, M., and Picek, O. (2008). 'A General Financial Transaction Tax. Motives, Revenues, Feasibility and Effects'. Research Study WIFO, 3/2008.

Schwert, G. W., and Seguin, P. J. (1993). 'Security Transaction Taxes: An Overview of Costs and Benefits and Unresolved Questions', Financial Analysts Journal, 49/5: 27-35.

Scott, H. S. (2004). International Finance: Law and Regulation. 1st edn. London: Sweet \& Maxwell.

Shackelford, D. A., Shaviro, D. N., and Slemrod, J. (2010). 'Taxation and the Financial Sector', National Tax Journal, 63/4: 781-806.

Shan, H. (2008). 'The Effect of Capital Gains Taxation on Home Sales: Evidence from the Taxpayer Relief Act of 1997'. Finance and Economics Discussion Series 53, Board of Governors of the Federal Reserve System.

Shaviro, D. N. (2001). 'Does More Sophisticated Mean Better? A Critique of Alternative Approaches to Sourcing the Interest Expense of American Multinationals', Tax Law Review, 54: 353-419.

Shaviro, D. N. (2007). Taxes, Spending, and the US Government's March toward Bankruptcy. New York: Cambridge University Press.

Shaviro, D. N. (2008). 'Why the BEIT Proposal shouldn't be Discounted', Tax Notes, 100: 1048 (3 Mar.).

Shaviro, D. N. (2009a). Decoding the US Corporate Tax. Washington, DC: Urban Institute Press.

Shaviro, D. N. (2009b). 'Planning and Policy Issues Raised by the Structure of the US International Tax Rules'. Working Paper No. 0915, Oxford University Centre for Business Taxation, Oxford.

Shaviro, D. N. (2009c). 'The Optimal Relationship between Taxable Income and Financial Accounting Income', Georgetown Law Journal, 97: 423-84.

Shaviro, D. N. (2009d). 'Internationalization of Income Measures and the US Book-Tax Relationship', National Tax Journal, 62: 155-67.

Shaviro, D. N. (2009e). 'The 2008-09 Financial Crisis: Implications for Income Tax Reform'. New York University Law and Economics Working Paper No. 09-35, New York University, New York.

Shaviro, D. N. (forthcoming). Fixing the US International Tax Rules.

Shiller, R. J. (2005). Irrational Exuberance. Princeton: Princeton University Press.

Shin, H. S. (2009). 'Securitization and Financial Stability', Economic Journal, 119/536 (Mar.), 309-32.

Shirakawa, M. (2001). 'Monetary Policy under the Zero Interest Rate Constraint and Balance Sheet Adjustment', International Finance, 4: 463-89.

Shleifer, A., and Summers, L. H. (1990). 'The Noise Trader Approach to Finance', Journal of Economic Perspectives, 4/2: 19-33.

Shleifer, A., and Vishny, R. (2011). 'Fire Sales in Finance and Macroeconomics', Journal of Economic Perspectives, 25/1 (Winter), 29-48.

Sinn, H.W. (2008). 'What can be Learned from the Banking Crisis?', CESifo Forum, 9/4: 9-13.

Slemrod, J. (2009). 'Lessons for Tax Policy in the Great Recession', National Tax Journal, 62: 387-97.

This is an open access version of the publication distributed under the terms of the Creative Commons Attribution-NonCommercialNoDerivs licence (http://creativecommons.org/licenses/by-nc-nd/3.0/), which permits non-commercial reproduction and distribution of the work, in any medium, provided the original work is not altered or transformed in any way, and that the work is properly cited. For commercial re-use, please contact academic.permissions@oup.com 


\section{References}

Smith, V. L. (2007). 'The Clinton Housing Bubble', Wall Street Journal Online, 18 Dec.

Smith, T., and Huston, G. R. (2009). 'Do Taxes Matter? Evidence of Individual and Corporate Tax Incentives on the Choice to Hold Shares Acquired from Exercise of Employee Stock Options', 21 July <http://ssrn.com/abstract=1436967>.

Song, Frank M., and Zhang, J. (2005). 'Securities Transaction Tax and Market Volatility', Economic Journal, 115: 1103-20.

Staderini, A. (2001). 'Tax Reforms to Influence Corporate Financial Policy: The Case of the Italian Business Tax Reform of 1997-98'. Banca d'Italia Working Paper No. 423.

Stigler, G. J. (1971). 'The Theory of Economic Regulation', Bell Journal of Economics and Managements, 2/1: 3-21.

Stiglitz, J. (1989). 'Using Tax Policy to Curb Speculative Short-Term Trading', Journal of Financial Service Research, 3/2-3: 101-15.

Stiglitz, J., and Weiss, A. (1981). 'Credit Rationing in Markets with Imperfect Information', American Economic Review, 71: 393-410.

Stolz, S. M., and Wedow, M. (2010). 'Extraordinary Measures in Extraordinary Times: Public Measures in Support of the Financial Sector in the EU and the United States'. ECB Occasional Paper No. 117.

Subrahmanyam, A. (1998). 'Transaction Taxes and Financial Market Equilibrium', Journal of Business, 71/1: 81-117.

Sullivan, M. A. (2005). 'The Economics of the American Dream', Tax Notes, 24 Jan.

Sullivan, M. A. (2008). 'Deleveraging the Tax Code', Tax Notes, 120 (29 Sept.), 1241.

Summers, L. H., and Summers, V. P. (1989). 'When Financial Markets Work too Well: A Cautious Case for a Securities Transaction Tax', Journal of Financial Services Research, 3: $261-86$.

Surowiecki, J. (2009). 'The Debt Economy', New Yorker, 23 Nov.

Sutherland, A. (1997). 'Fiscal Crises and Aggregate Demand: Can High Public Debt Reverse the Effects of Fiscal Policy?', Journal of Public Economics, 65/2: 147-62.

Tavares, J. (2004). 'Does Right or Left Matter? Cabinets, Credibility and Fiscal Adjustments', Journal of Public Economics, 88/12: 2447-68.

Tobin, J. (1974). The New Economics One Decade Older. Princeton: Princeton University Press.

Tobin, J. (1978). 'A Proposal for International Monetary Reform', Eastern Economic Journal, 4/3-4 (July-Oct.), 153-9.

Tomita, T. (2002). 'The Need for Redefining Japan's Government Debt Policy'. NRI Papers, No. 42, 1 Feb.

Topel, R., and Rosen, S. (1988). 'Housing Investment in the United States', Journal of Political Economy, 96: 718-40.

Ueda, K. (2001). 'Japan's Liquidity Trap and Monetary Policy'. Speech to the Japan Society of Monetary Economics, Fukushima University, 29 Sept.

UK Chancellor of the Exchequer (2009). Letter to the Governor of the Bank of England. 3 Mar.

UK Debt Management Office (2009). 'Debt and Reserves Management Report 2009-10'. Apr.

UK House of Commons, Treasury Committee (2007). Private Equity: Tenth Report of Session 2006-07. London: Stationery Office.

This is an open access version of the publication distributed under the terms of the Creative Commons Attribution-NonCommercialNoDerivs licence (http://creativecommons.org/licenses/by-nc-nd/3.0/), which permits non-commercial reproduction and distribution of the work, in any medium, provided the original work is not altered or transformed in any way, and that the work is properly cited. For commercial re-use, please contact academic.permissions@oup.com 
UK House of Commons, Treasury Committee (2009). 'February Inflation Report: Evidence'. 24 Mar. (uncorrected text).

Umlauf, S. R. (1993). 'Transaction Taxes and the Behaviour of the Swedish Stock Market', Journal of Financial Economics, 33: 227-40.

US Department of Housing and Urban Development (2005). 'At HUD, Homeownership is on the Front Burner', Research Works, 2/6.

US Department of the Treasury (1992). Integration of the Individual and Corporate Tax Systems: Taxing Business Income Once. Washington, DC: US Government Printing Office.

US Government Accountability Office (2008). Private Equity: Recent Growth in Leveraged Buyouts Exposed Risks that Warrant Continued Attention. Washington, DC.

US Treasury Office of Debt Management (2009). Quarterly Refunding Charts, 27 Apr.

Valukas, A. (2010). Report by the Examiner of Lehman Brothers, United States Bankcruptcy Court, Southern District of New York <http://lehmanreport.jenner.com>.

Van den Noord, P. (2005). 'Tax Incentives and House Price Volatility in the Euro Area:

Theory and Evidence', Économie internationale, 101: 29-45.

Van den Noord, P., and Heady, C. (2001). 'Surveillance of Tax Policies: A Synthesis of Findings in Economic Surveys'. OECD Economics Department Working Paper No. 303.

Vink, D., and Thibeault, A. E. (2008). 'ABS, MBS and CDO Pricing Comparisons: An Empirical Analysis', Journal of Structured Finance, 14/2 (Aug.), 27-45.

Von Hagen, J., Hughes Hallett, A., and Strauch, R. (2002). 'Budgetary Consolidation in Europe: Quality, Economic Conditions, and Persistence', Journal of the Japanese and International Economies, 16/4: 512-35.

Von Hagen, J., and Strauch, R. R. (2001). 'Fiscal Consolidations: Quality, Economic Conditions, and Success', Public Choice, 109/3-4: 327-46.

Weder di Mauro, B. (2010). 'Taxing Systemic Risk: Proposal for a Systemic Risk Charge and a Systemic Risk Fund'. Working Paper, University of Mainz, Mainz, Germany.

Weichenrieder, A., and Klautke, T. (2008). 'Taxes and the Efficiency Costs of Capital Distortions'. CESifo Working Paper No. 2431.

Weisbach, D. A. (2008). 'The Taxation of Carried Interests in Private Equity', Virginia Law Review, 94/3 (May), 715-64.

Westerholm, J. (2003). 'The Impact of Transaction Costs on Turnover, Asset Prices and Volatility: The Case of Sweden's and Finland's Security Transaction Tax Reductions', Finnish Journal of Business Economics, 2: 213-41.

Wibaut, S. (2008). 'Quelles leçons tirer de la crise financière?', Regards économiques, 64 (Dec.).

Wilson, J. D. (1999). 'Theories of Tax Competition', National Tax Journal, 52: 269-304. Yakabuski, K. (2010). 'Under Fire, Wall Street Puts its Money to Work', Globe and Mail, 25 Jan., B-3 <http://www.globeadvisor.com/servlet/ArticleNews/story/gam/ 20100125/RYAKABUSKI25ART1932>.

This is an open access version of the publication distributed under the terms of the Creative Commons Attribution-NonCommercialNoDerivs licence (http://creativecommons.org/licenses/by-nc-nd/3.0/), which permits non-commercial reproduction and distribution of the work, in any medium, provided the original work is not altered or transformed in any way, and that the work is properly cited. For commercial re-use, please contact academic.permissions@oup.com 
This page intentionally left blank

This is an open access version of the publication distributed under the terms of the Creative Commons Attribution-NonCommercialNoDerivs licence (http://creativecommons.org/licenses/by-nc-nd/3.0/), which permits non-commercial reproduction and distribution of the work, in any medium, provided the original work is not altered or transformed in any way, and that the work is properly cited. For commercial re-use, please contact academic.permissions@oup.com 


\section{Author Index}

Acharya, V.V. 17, 18, 149, 154, 155, 259

Adelson, M. 105

Adrian, T. 18, 161, 259

Agell, J. 4, 63

Ahrend, R. 241, 244

Alesina, A. ix, 234, 235, 236, 237, 238, 240, 241, $242,243,244,245,248,251,252,257$

Almunia, M. 242

Altshuler, R. 183

Alworth, J.S. v, xi, 1, 8, 15, 42, 174

Amromin, G. 56

Arachi, G. v, xi, 1, 174

Ardagna, S. ix, 234, 235, 236, 237, 238, 240, $241,242,243,244,248,251,252$

Arnold, B.J. 176, 178

Arulampalam, W. 40

Auerbach, A. 28, 31, 33, 35, 42, 123, 161, 219

Ault, H.J. 176, 178

Baba, N. 214, 215

Baily, M.N. 70

Baltagi, B.H. 135

Bank of England 30, 228

Bankman, J. 10

Barro, R.J. 242

Beard, T. 226

Bebchuk, L. 185, 186

Beeman, R.E. 108

Bernanke, B. 215, 225

Bertola, G. 233

Biehl, A.M. 80

Bier, T. 80

Bilicka, A. vi, xi, 26, 231

Black, D. 262

Blanchard, O.J. 234, 235, 242

Bleijer, M. 217

Blommestein, H. 217

Bond, S.R. 39, 57, 123, 132

Booth, B. 227

Bordignon, M. 15, 39

Borio, C. 214

Borselli, F. 76, 85, 86

Bradford, D.F. 42, 123, 124

Brandes, A.J. 110
Broadbent, B. 236, 237, 240, 241, 244

Brooke, M. 14

Brown, B. 214

Brown, G. 1

Brunnermeier, M.K. 18, 161, 259

Brunson, S.D. 109

Bulow, J. 96

Burman, L. 81

Büttner, T. 35

Campbell, J.Y. 142

Cardarelli,R. 48

Carter, M.E. 97

Case, K.E. vii, 65, 66, 75, 79, 81

Cecchetti S.G. 221

Ceriani, V. v, xi, 9, 61, 88, 117

Chaboud, A. 133

Cheng, Y. 35

Chiquoine, B. 133

Christiansen, V. 160

Cizkowicz, P. 235, 240

Clouse, J. 215

Congdon, T. 216, 225

Corsetti, G. 242

Cos, P.H. 236, 237, 240, 244,245

Cottarelli, C. 28, 41

Cross, M. 214

Culbertson, J. 220

Cunningham, C.R. 80

Daly, K. 237, 240, 241, 244

Davis, B. 167

Davis, P.E. 6, 31, 38

Dayal, R. 207

De Donder, P. 266

De la Feria, R. 122

De Laet, J. 61

De Meza, D. 37

De Mooij, R. 40

Demyanyk, Y. 68

Desai, M.A. $8,35,186,187$

Devereux, M.P. vi, xi, 35, 36, 39, 40, 120, 123 , 124,231

This is an open access version of the publication distributed under the terms of the Creative Commons Attribution-NonCommercialNoDerivs licence (http://creativecommons.org/licenses/by-nc-nd/3.0/), which permits non-commercial reproduction and distribution of the work, in any medium, provided the original work is not altered or transformed in any way, and that the work is properly cited. For commercial re-use, please contact academic.permissions@oup.com 
Dharmapala, D. 186

Domar, E.D. 169

Dooley, M.P. 133

Drazen, A. 233

Drehmann, M. 19

Duarte, J. 154, 182

Duffie, D. 17, 103

Dunsky, R.M. 48

Durbin, R. 152

Eagan, M. 103, 104, 108

Eddins, S.T. 5, 8, 50, 107, 111, 112, 174, 185, 200, 201

Edgar, T. 15, 168, 169

Eichengreen, B. 132

Elliott, D.J. 156, 162

Elliott, L. 152

Engelhardt, G.V. 80

Englund, P. 4, 62, 63

European Commission 61, 98, 100, 116, 117, $118,119,130,131,133$

Fabozzi, F.J. 68, 70, 103, 106

Falkenheim, M. 17

Fehr, H. 93

Financial Service Authority, (FSA) 13, 42, 117

Follain, J.R. 48

Fraser, R. 15

Fried, J. 185, 186

Friedman, M. 219, 222

Froot, K.A. 142

Fuest, C. vi, xii, 231

Gale, W.G. 67, 161

Garbade, K. 217, 220

Garber, P. 133

Geithner, T.F. 171

Genser, B. 122

George, P. 14

Giavazzi, F. 235, 237, 240, 241, 244

Giudice, G. 237, 240, 252

Glaeser, E.L. 48, 79, 81, 82

Goodhart, C.A.H. 257

Graham, J.R. 35, 172

Green, C.J. 35

Griffith, R. 39, 120

Grubert, H. 123

Guichard, S. ix, 236, 237, 239, 240, 242, 245,249

Gyntelberg, J. 214

Hall, B. 55, 93, 94

Hall. R.E. 242

Han, J. 5, 108

Hanke, M. 135

Hanlon, M. 187

Hanson, S.G. 7, 12, 17, 18, 190

Harrison, G.L. 220
Hassett, K.A. 40

Hau, H. 134

Haulotte, S. 76

Hawkins, M. 132

Hay, J. 23

Hayashida, M. 135

Heady, C. 77

Hemmelgarn, T. v, xii, 5, 61, 88, 116, 117, 118, $148,150,165,188$

Hendershott, P. 48

Hilbers, A. 72, 74, 75, 83

Himmelberg, C. 79, 81

Hjalmarsson, E. 133

Honohan, P. 139, 165

Hoyt, W.H. 80

Huizinga, H. 35, 122

Huston, G.R. 94

Ilzetzki, E. 238, 240

International Monetary Fund (IMF) 1, 2, 6, 25 $28,38,42,62,77,78,79,80,81,83,88$, $100,118,119,122,126,127,128,130$, $131,149,150,164,168,169,171,219$, 234, 236, 240, 241, 242, 246, 247, 248, $252,253,254,257,259,260$

Jacobs, O.H. 180

Jaquette, S. 96

Johansson, A. 44

Johnsen, K. 103, 104, 108

Jones, C.M. 135

Jorgenson, D.V. 78

Kalderen, L. 217

Kan, K. 134

Kaplow, L. 15, 159

Katz, A. 80

Kearl, J. 74

Keen, M. v, xii, 7, 15, 28, 39, 52, 53, 174

Kerrigan, A. 121

Keynes, J.M. 19, 132, 133, 157, 258

Khotari, V. 103, 106

King, J. 39

King, M.A. 33, 216, 219

Klautke, T. 34, 35

Kleinbard, E.D. 15, 39, 151, 168, 169, 179

Klemm, A. v, xii, 28, 39, 120, 132, 180

Kleven, H. 180

Koo, R. 214, 222

Krugman, P. 162, 241, 242, 254

Kuroda, H. 223

Kuttner, K. 214, 215, 226

Lambe, G. 207

Lambertini, L. 244, 245

Landau, R. 78

Lefebvre, F. 85,86

292

This is an open access version of the publication distributed under the terms of the Creative Commons Attribution-NonCommercialNoDerivs licence (http://creativecommons.org/licenses/by-nc-nd/3.0/), which permits non-commercial reproduction and distribution of the work, in any medium, provided the original work is not altered or transformed in any way, and that the work is properly cited. For commercial re-use, please contact academic.permissions@oup.com 
Lent, G.E. 15

Levin, C. 97, 98

Levine, R. 16

Liebman, J. 55, 93

Lindo, A. 173

Liu, S. 135

Lloyd, G. v, xii, 8, 28, 67, 150, 174, 190

Lockwood, B. 122, 260

Lovisolo, S. 15

Lucas, D.J. 103, 105, 107

Lupo, T.B. 108

MacKie-Mason, J. 34

Mahfouz, S. 235, 239

Manestra, S. v, xiii, 61, 88

Margalioth, Y. 174

Masciandaro, D. vi, xiii, 257

Mason, J.R. 104

Matheson, T. 19, 20, 165, 259

Mathur, A. 40

McCauley, R. v, xiii, 26, 214

McCulley, P. 192

McDermott, C.J. 236, 237, 240, 243, 244

Meade, J.E. xiv, 38, 123

Megan, M. 14

Meltzer, A.H. 220, 221, 258, 265

Merkel, A. 167

Miller, M.H. 33, 176

Mintz, J. 31, 35

Missale, A. 219

Moral-Benito, E. 236, 237, 240, 244, 245

Morinobu, S. 57

Mullins, P. 53

Munro, A.B. 109

Murphy, K. 93, 94

Musgrave, R.A. 169

Myles, G. 28

Nakaso, H. 214

Newlon, T.S. 123

Nickel, C. 235, 243, 244, 245

Nicodeme, G. v, xiii, 61, 88, 116, 117, 118, 148, $150,165,188$

Nirenberg, D.Z. 106, 108

Norregaard, J. 28

O'Kane, D. 70

Obama, B. 11, 90, 98, 100, 103, 149, 152, 157, 167

Obstfeld, M. 219

Oda, N. 215, 225

Organization for Economic Cooperation and Development (OECD) 47, 52, 53, 73, 80, $83,90,93,105,123,196,207,212,213$, $228,241,244,250$

Onado, M. 103, 106

Ono, H. 135

Orszag, P. 102
Otani, A. 214

Owens, J. 28

Packer, F. 214

Pagano, M. 235, 237, 240, 241

Passarelli, F. xiv, 257

Paul, N. 23

Peaslee, J.M. 106, 107, 108

Pelizzari, P. 135

Pennacchi, G. 16, 17

Perotti, R. 18, 235, 236, 240, 241, 242, 243, 244,245

Perry, V. v, xiv,

Persson, T. 258

Peter, A.F. 112

Philippon, T. 121

Picek, O. 20

Pigou, A.C. 159

Pitaro, D. 61

Poddar, S. 122

Poterba, J.M. 4, 45, 56, 74, 82

Pozdena, R.J. 73

PricewaterhouseCoopers 121

Quayes, S. 80

Radulescu, D.M. 14

Ramey, V. 235

Raskolnikov, A. 174, 184

Redlick, C.J. 242

Remolona, E.M. 105

Reshef, A. 121

Richard, S.F. 258, 265

Richardson, M. 149, 154, 155

Ricotti, G. v, xiv, 61, 88

Roberts, K. 265

Romer, C.D. 236, 236, 238

Romer, D.H. 236, 236, 238

Roosa, R. 226

Rosen, S. 74

Rosner, J. 104

Rother, P. 235

Rzonca, A. 235, 240

Sachs, J. 152, 153

Sanelli, A. v, xiv, 61, 88

Saporta, V. 134

Schizer, D.M. 21

Scholes, M.S. 97

Schratzenstaller, M. 20

Schulmeister, S. 20, 137, 138, 139

Schwartz, A. 219, 222

Schwert, G.W. 134

Scott , H.S. 103

Seguin, P.J. 134, 135

Shackelford, D.A. v, xiv, xv, 148

Shan, H. 80

This is an open access version of the publication distributed under the terms of the Creative Commons Attribution-NonCommercialNoDerivs licence (http://creativecommons.org/licenses/by-nc-nd/3.0/), which permits non-commercial reproduction and distribution of the work, in any medium, provided the original work is not altered or transformed in any way, and that the work is properly cited. For commercial re-use, please contact academic.permissions@oup.com 


\section{Author Index}

Shapiro, M. 48, 81, 82, 235

Shavell, S. 152

Shaviro, D.N. v, 7, 8, 30, 36, 148, 150, 151, $161,174,177,179,180,181,184,187$

Shiller, R.J. vii, 65, 66, 75, 79, 81, 154

Shim, I. 105

Shirakawa, M. 226

Shleifer, A. 17

Shoven, J.B. 96

Sinai, T.M. 4, 45

Sinn, H.W. 53

Slemrod, J. v, xv, 9, 28, 41, 148, 150, 174

Smart, M. 53

Smith, S. 160

Smith, T. 94

Smith, V.L. 81

Sobrun, J. 214

Sørensen, P.B. 28,124

Staderini, A. 39

Stigler, G.J. 260

Stiglitz, J. 37, 133, 134, 135, 258

Stolz, S.M. 116

Stone, M.R. 6, 31, 38

Strauch, R. 243, 244, 245

Suarez, J. 18

Subrahmanyam, A. 134

Sullivan, M.A. 82, 83

Summers, L.H. 133, 135

Summers, V.P. 133, 135

Surowiecki, J. 83

Sutherland, A. 234

Syed, M. 52

Tabellini, G. 258

Tarashev, N. 19

Tavares, J. 237, 240, 241, 244, 245, 252

Taylor, M.P. 133
Tobin, J. 19, 20, 27, 74, 133, 146, 147, 260

Tomita, T. 224

Topel, R. 74

Ueda, K. v, xv, 26, 214, 215, 219, 225

Umlauf, S.R. 134, 142

Valukas, A. 2

van den Noord, P. 45, 74, 75, 77

Van Hemert, O. 68

Vega, C. 133

Vidal, G. 174

Viñals, J. 41

Vishny, R. 17

Volcker, P. 12

von Hagen J. 243, 244, 245

Webb, D. 37

Webb, J. 166

Weder Di Mauro, B. 19, 158

Wedow, M. 116

Weichenrieder, A. 34, 35

Weisbach, D. 10

Weiss, A. 37

Westcott, R.F. 236, 237, 240, 243,244

Westerhoff, F. 135

Westerholm, J. 57

Wibaut, S. 71

Wilson, J.D. 52

Winker, P. 122

Yakabuski, K. 152

Yoder, S. 139, 165

Zangari, E. v, xv, 61, 88, 118, 188

Zhu, Z. 135 


\section{Subject Index}

Adjustable rate mortgages (ARMs), 68, 69, 71, 108

Agency costs, see Moral hazard

Aggregate demand, 26, 233, 234, 260

Allowance for Corporate Equity (ACE), 15-16, 39-42, 88, 123, 125, 179-180

distributional and revenue impact, 40

American Dream Downpayment Act, 5, 67, 83

American International Group (AIG), 71, 154,182

Arbitrage

legal, 52

regulatory, 7,207

tax, 7-9, 11, 25, 33, 41, 50-54, 58, 84, 109, $111-115,151,159,185,191,195,197$, 199-203, 205, 206

Asset prices, 57, 58

Australia, 23, 33, 92, 119, 122, 167, 178, 196, 219,239

Austria, 13, 39, 91, 99, 180, 196, 238, 239, 248,253

Average voter, 258

Bank for International Settlements (BIS), 6, $103,106,119,120,191,193,218$, 222,224

Bank of America, 71

Bank of England, 71, 217, 228, 229

Bank of Japan (BoJ), 222-227, 229, 230

Bankruptcy, 71, 103, 195

costs, $5,6,30,37,151$

risks, 112,176

schemes, 260

Basle-II agreements, 68

Bear Stearns, 67, 71

Belgium, 39, 55, 73, 75-79, 85, 92, 180, 196, $227,238,239,253$

Bonds, 6, 9, 26, 70, 104, 105, 136-138, 143-145, 200-201, 214-222, 234

convertible, 36

Japanese government (JGBs), 218, 223-225, 227, 229

market anomalies, 218

mortgage-backed, 66

Bonus tax, see Tax, on bonuses

Book-tax conformity, 8, 21, 24, 27, 42, 97, 172
Brady debt relief initiative, 23

Brazil, 39, 46, 47, 119, 167, 180, 219, 247

Bretton Woods, 19, 132

Cadastral income, 76

Cadastral values, 85,87

Canada, 33, 34, 47, 91-93, 119, 120, 167, 196, 238, 239

Capital adequacy, 2, 14, 67, 150, 162, 172, 192, 194,196

ratio, 16

Capital gains tax (CGT), see Tax, capital gains

Capital inflows, 52, 58

Carried interest, 9, 10, 55, 56, 89, 101-103, 114, 202, 203

Carry-forwards, see Tax losses, carry-forwards

Carry-over, see Tax losses, carry-over

Case-Shiller price index, 65-66

Cash-flow tax, see Tax, cash-flow

Collateralized debt obligations (CDOs ), 8, 47, 70, 104-107, 112, 195, 201, 204, 207

Common consolidated corporate tax base (CCCTB ), 187

Community Reinvestment Act (CRA), 67

Compensation schemes, 9, 88, 98, 99, 155

Complex corporate structures, 51

Complex financial instruments, 28, 51, 59, 211

Compliance risk, 209-212

Comprehensive business income tax (CBIT), see Tax, comprehensive business income

Condorcet winner, 262, 266

Contagion, 18

Controlled foreign corporation (CFC), 51, 209

Corporate financial policies, 30

Corporate governance, 8, 24, 42, 90, 94, 98, 100, 101, 114, 175, 185-188, 192, 213

Corporate Income Tax (CIT); see also Tax, corporate income

exemption, 47

reduction in statutory rates, 33

reforms, 38

Corporate integration, 177, 180; see also Dividend taxation

Corporate leverage, see Leverage, corporate

This is an open access version of the publication distributed under the terms of the Creative Commons Attribution-NonCommercialNoDerivs licence (http://creativecommons.org/licenses/by-nc-nd/3.0/), which permits non-commercial reproduction and distribution of the work, in any medium, provided the original work is not altered or transformed in any way, and that the work is properly cited. For commercial re-use, please contact academic.permissions@oup.com 
Cost of capital, 32, 39, 45, 78, 106, 136, 197

Council tax, see Tax, Council

Credit default swaps (CDSs), 50, 70, 71, 105 106, 108-113, 115, 195, 201, 205, 252-254

CDS-IR Gap, 252, 253

spread, 252-254

Credit rating, 252, 253

Credit-scoring methods, 82

Croatia, 39, 40, 180

Cyclically adjusted primary budget balance (CAPB), 236, 238, 249, 250, 252

Cyprus, 14, 138

Debt

bias, $7,16,30,34,37,38,54,151,177,178$ $180,189,191$

level, 240, 241, 244, 251, 254, 256

management, 26, 214-218, 220, 223, 225, 227-230

Debt-equity

distinction, 36, 40, 175, 176

ratios, $6,30,35,38,39,48,58$

Deduction

double, 197, 198

itemized, 81

mortgage interest, $45,47,48$

Deduction pour habitation propre et unique, 76

Deferred tax assets, 172, 207

Denmark, 13, 43, 45, 47, 55, 91, 92, 99, 122, $130,192,196,238$

Deposit insurance, 16-18, 54, 155, 158

Depreciation allowances, $21,24,38,42,47$, 74,123

accelerated, 8, 24, 35, 42

true economic, 35,42

Derivatives, $5,8,13,19,21,70,103,109,110$, 131, 136-139, 142, 145, 146, 150, 151, $155,163,165,175,184,185,192,193$, $199,201,205,210$

Dividend taxation, 32, 56

exemption, 178, 179

imputation, 6, 32, 33, 60, 178, 196

split-rate, 196

Double-dip, 197, 198, 202, 205, 208

Dual income tax, see Tax, dual income

Effective average tax rate (EATR), 45, 46, 77-79, 83,87

Einheitswert, 85

European Community, 178, 187

European Council, 12, 117, 131

Excess-profits tax, see Tax, excess-profits

Exchange of information, 194, 205, 206

Exchange-rate depreciation, 232, 242, 245, 255

Exchange-rate regime, 234
Executive compensation, 29, 50, 54, 55, 84, 90, $94,95,98,99,155,186$

Exemption of foreign profits, 51, 53

Expectations, 62, 75, 81, 82, 84, 158, 232-234

Expenditure cuts, 232, 234, 236, 238, 242, 243, $250,251,256$

External imbalances, 37

Externality, 257, 258, 260, 263, 264, 268

from increased leverage, 6,38

Federal Deposit Insurance Corporation (FDIC), 12, 17, 18, 167

Federal Home Loan Mortgage Corporation (Freddie Mac), 66, 104, 166

Federal Housing Enterprises Financial Safety and Soundness Act, 67

Federal National Mortgage Association (Fannie Mae), 66

Federal Reserve, 31, 64, 70-72, 81, 173, 218, $220,221,226,228-230$

bulletin, 221

Financial Action Task Force (FATF), 25

Financial Asset Securitization Investment Trust, 50, 107

Financial Crisis Responsibility Fee (FCRF), 11, 15,100

Financial innovation, 36, 50, 51, 109, 190, 191, 195

Financial Stability Forum (FSF), 90, 98, 114, 194

Financial transaction tax (FTT), see Tax, financial transaction

Finland, 55, 62, 93, 196, 238, 239, 253

Fire sale, 18

Fiscal consolidation, 26, 119, 198, 202, 231-256

composition, 232, 243, 250, 256

credibility, 235, 252

expansionary, 237, 251

magnitude, 249

succesful, 243, 245

Fiscal multiplier, 235, 236, 238, 239, 242

expenditure, 238

$\operatorname{tax}, 238$

Fiscal stimulus, 61, 84, 183, 242

Forbearance, 18

France, 12, 13, 23, 34-36, 43, 45, 55, 72, 75-77, $79,85,87,91-93,99,100,122,129,166$, $178,196,238,239,247,248,253$

G7, 31, 33, 237, 243, 245, 247

G20, 1, 118, 119, 127, 131, 149, 164, 167, 194,259

General Motors A30 (GM), 185

German reunification, 62

Germany, 13, 23, 31, 33, 34, 36, 37, 55, $75-79,85,87,92,93,100,103,119,120$ $140,147,178,192,196,238,239,247$, 252,253 
Gilt purchases, 228

Glass-Steagall Act, 67

Global Forum on Transparency and Exchange of Information, 194, 206

GM, see General Motors A30 (GM)

Goldman Sachs, 67, 150

Government borrowing, 231, 233, 234

Government-sponsored enterprises (GSEs), 68, 69, 71

Gramm-Leach-Bliely Act (1999), 67

Greece, 92, 196, 238, 239, 252, 253

Grundsteuer, 85

Hard-to-tax areas, 24

Harmful tax practice, 52

Hedge funds, 9, 25, 31, 55, 71, 99, 101, 115, 191-194, 199, 201, 203, 204, 206, 227

High income individuals, 33, 176

High net worth individual (HNWI), 203

Household sector, 3, 4, 6, 37, 42-45, 56, 59, 73, $75,81,86,187,195,215-217,230,233$

Housing, 4-5, 42-49, 73-84, 149-151, 187-188

bubble (see United States, housing bubble)

equity, 44,62, 68, 69, 82, 104

market (see United States, housing market)

prices, 44

tax treatment, 42, 43, 59

user cost, 45

HSBC, 71

Hungary, 13, 92, 196, 238, 239

Hybrid entity, 53, 198

Hybrid mismatch arrangements, 211

Hybrid securities, 7, 37, 197

IBI, see Impuesto sobre bienes inmuebles (IBI)

Immovable withholding tax, see Tax, immovable withholding

Impuesto sobre bienes inmuebles (IBI), 86

Imputed rent, 4, 43, 45, 49, 74-79, 187

Incentive compensation, 155, 186, 188, 189

Income tax, see Tax, income

Inconsistencies in capital income taxation, 8, $52,151,159,185$

Inefficiencies of financial markets, 37

Inflation targeting, 217

Interest allocation rules for multinationals, 181

Interest deductibility, 4, 7, 30-32, 35-41, 43, 45-8, $51,54,62,74-75,80-83,123,178,180,202$

Interest rates, $3,23,26,62,64,66,68,70,75$, $156,191,195,209,214,216,219,220$, 223, 226, 227, 230, 232-234, 241, 242, $245,254,256$

Internal Revenue Code, see United States, internal revenue code
Internal Revenue Service (IRS), 54, 108, 112, 113,184

International Accounting Standards, 68

International Monetary Fund (IMF) 1, 2, 6, 25, $28,38,42,46,62,77-81,83,88,100$, $118,119,122,126-130,131,149,150$, $154,168,169,171,219,234,236$, 240-242, 246-248, 252-254, 257, 259,260

methodology, 77, 78, 80, 83

Investment, $8,10,24,35,37,38,40,42,43,45$, $47,53,67,68,71,73,74,78,83,102$, $125,132,136,142,146,171,176,177$, $179,181,187,190,198-203,205,226$, 232-234, 240, 241, 243

inward direct, 35

Ireland, 44-47, 55, 56, 72, 73, 75-79, 86, 91, $92,126,196,239,246,252,253$

Italy, 34, 36, 39, 42, 43, 45, 47, 55, 73, 76, 77, $79,86,91-93,99,131,180,196,238$, 239,253

Japanese Corporation, 33

Keynesian view/approach, 26, 231, 232

Korea, 23, 56, 92, 196, 219

Latin America, 19

Latvia, 6, 14, 37-39

Leasing, 54

Lehman Brothers, 2, 67, 71, 116

Leverage, 3-7, 12, 21, 29-31, 34, 35, 37, 38, $42,44,46,47,51,52,59,67,89,101$, $106,114,117,136,137,150,151,154$, $174,177,180-182,187,188,190-193$, 195, 196, 198, 202, 205, 207, 226 corporate, 30, 38, 150, 180, 191, 195

Leveraged buyouts (LBOs), 30, 31, 202

Limited partnership, 10

Liquidity runs, 18

Loan sales, 24

Lock-in effect, 31, 41

London Summit, 194

Low Income Housing Tax Credit, 67

Low-tax jurisdictions, 28, 34, 50-53

Maastricht Treaty, 246

Majority rule, 262

Malaysia, 23

Marginal tax rates effective, 35, 36, 125

non-linearity, 33

Market failure, 16, 20, 132, 136, 149

Marking to market, 21, 22, 24, 41, 42, 51

Median voter, 258, 260, 262, 263, 266

Merrill Lynch, 67, 71

Mexico, 23, 196, 219

This is an open access version of the publication distributed under the terms of the Creative Commons Attribution-NonCommercialNoDerivs licence (http://creativecommons.org/licenses/by-nc-nd/3.0/), which permits non-commercial reproduction and distribution of the work, in any medium, provided the original work is not altered or transformed in any way, and that the work is properly cited. For commercial re-use, please contact academic.permissions@oup.com 
Monetary policy, 20, 26, 45, 62, 64, 75, 84, $132,188,214,215,217,218,220,223$, $224,230,234,237,240,241,244,254$

Moral hazard, 16, 18, 117

agency costs, 177

Morgan Stanley, 67

Mortgage-backed securities, 69-71, 104, 108; see also Bonds, mortgage-backed

Mortgage interest, 3, 4, 43, 45-49, 56, 59, 74-77, 78-82, 84, 88, 187; see also Deduction, mortgage interest

tax relief, $4,43,48,49,76,77,84$

National Association of Realtors, 83

Netherlands, 23, 43, 72, 73, 76-79, 81, 82, 86, 87, 92, 99, 103, 196, 238, 239, 253

Net operating losses (NOLs), see Tax losses, net operating losses

New Century Financial, 71

New Community Reinvestment Act (1995), 67

Non-tax distortions to risk taking, 53

Northern Rock, 71

Norway, 62, 137, 196, 238, 239, 253

Note issuance, 225, 229

Obama proposal, 11, 98, 100, 149, 152, 167

Office for Budget Responsibility, 247

Onroerendezaakbelasting, 86

Opacity of financial arrangements, 36, 50

Operation Twist, 225, 226

Organization for Economic Cooperation and Development (OECD) 9, 34, 62, 79, 91, 92, 194, 206, 212, 228, 236, 239, 244, 245,249

Overnight rate, 225

Ownership/occupation tax, see Tax, ownership/occupation

Philippines, 23, 219

Pittsburgh Summit, 1, 149

Political distortions, 258, 263, 265-268

Portugal, 13, 92, 100, 196, 238, 239, 252, 253

Precompte immobilier, see Tax, immovable withholding

Price-to-rent ratio, 73

Private consumption, 232-234

Private equity funds, 31, 101, 102, 114, 193, 203, 204

Profit-shifting, 40, 51, 210

Property tax, see Tax, property

Provisioning for loan losses, 22

charge off method, 23

dynamic provisioning, 24, 42

general provisions, 22, 23

specific provisions, $22,23,42$

Public debt, 1, 25, 117, 232, 241, 243, 246, 256
Public deficit, 10, 25, 26, 117, 223, 227, 235, 236, 241, 243-246, 248, 249, 252-254 reduction, 26

Public sector employment, 234

wages, 234

Quantitative easing, 216, 224

Real depreciation, 245

Real estate investment trusts (REITs), 47

Real Estate Mortgage Investment Conduit (REMIC), 50, 107, 108, 199

Recharacterization of income, 9

Regulation, 2, 3, 5, 15, 16, 23, 27, 37, 107, $131,148,162-164,171,191-194,204$, 257-263, 266, 268

anti-money laundering, 25

banking, 15

financial, 257, 261, 263, 268

prudential, 16, 17, 23, 27

Remuneration plans, see Stock options, remuneration plans

Reserve Bank of India, 217

Residence-based tax system, 51

Retention finance, 32, 33, 60

Risk-free rate, 39,42

Risk score, 19

Risk taking, $15,23,28,50,53-56,61,63,67$, $82,84,89,90,98,101,102,114,117$, $123,125,126,132,159,162,164,169$, 175, 182, 183, 188-190, 205, 206, 257

Roosevelt administration, 66

Scandinavian banking crises, 62

Schedule relief, 196

Securitization, 3, 5, 9, 50, 59, 63, 70, 82, 89, $103,104,106-108,114,115,150,191$, 195, 199, 200, 205, 206

mortgages, 69, 104, 191

Shadow banking system, 103, 192, 193,206

Solvency, 16, 71, 154, 158, 161

Spain, 43, 45, 47, 55, 72, 73, 76-79, 86, 87, 91-93, 140, 196, 238, 239, 252, 253

Special levies on the financial sector, 11

Special purpose vehicles (SPVs), 25, 50, 104, 107, 204, 206

S\&P 500 Index, 71, 72

Stamp duty, 56, 57, 132, 140-142, 145,146

Stock options

employee, 9, 55, 95

remuneration plans, 9, 101, 114

Subprime mortgages, 68, 69, 106, 150, 207

Supply side, 234

\section{8}

This is an open access version of the publication distributed under the terms of the Creative Commons Attribution-NonCommercialNoDerivs licence (http://creativecommons.org/licenses/by-nc-nd/3.0/), which permits non-commercial reproduction and distribution of the work, in any medium, provided the original work is not altered or transformed in any way, and that the work is properly cited. For commercial re-use, please contact academic.permissions@oup.com 
Sweden, 13, 55, 62, 72, 92, 100, 126, 142, 143, $219,238,239,253$

Systemic risk, 16-18, 162, 167, 257, 258, 260, 261, 263-267

premium, 17

tax, 258, 263, 265

System risk externality (SRE), 258, 259, 261, 263

Tax

on bonuses, 15,166

capital gains (CGT), 31, 32, 42, 43, 45, 47, $51,56-58,62,65,74-76,80,81,91,93$, $95,99,102,103,107,135,143,191,200$, 203-205

cash-flow, 38

competition, 44, 52, 53, 180

comprehensive business income (CBIT), 38, $39,123,178,179$

corporate income (CIT), 5, 7, 24, 30-36, $38-42,47,52,53,55,60,92,108,111$, 118-125, 127

corporate-level, 33, 37, 59

Council, 76, 86, 87

distinction between debt and equity, 176

distortions, 28-30, 34, 35, 48, 51, 55, 58, 59, $175,197,206,233$

welfare costs, 35

dual income, 15, 41

excess-profits, 15

financial transaction (FTT), 19, 20, 84, $118,119,126,127,131-133,136$, $137,139,146,147,152,153$,

164-166, 254, 256, 259

immovable withholding (precompte immobilier), 76

income, 5, 10, 12, 15, 30, 38-41, 43, 45, 47, $49,53,56,74,76-79,82-83,85,86$, 91-92, 99, 102, 107-108, 110-111, $119,123,127,130,132,146,149-151$, $166,174,176-179,183,186,187,191$, 196, 200, 203-204, 233

ownership/occupation, 44

progressive, $33,53,56,126$

property, 56

proportional, 53

Taxation of housing, 14, 49, 75, 175, 187

Taxation on fair market value, 21,41

Taxe d'habitation, 85

Taxe foncière, 85

Tax-extempt investors, 33

Tax havens, 3, 25, 28, 52, 59, 89, 101, 115, 191, 193, 194, 204-206

Tax increases, 57, 232, 234, 236, 241, 256

Tax losses, 41, 43, 54, 109, 172, 183, 207, 208, $210,212,213$

bank loss recognition rules, 210 carry-forwards, 172, 182, 183

carry-over, 183, 208-210

double-dip reliefs for losses, 208

imperfect loss offset, 53

net operating losses (NOLs), 95, 182, 183, 289

Tax on financial transactions, 146, 259, 264, 265

Taxpayer Relief Act (TRA97), 67, 80, 96, 107

Tax planning, $8,106,172,179,181,184,185$, 208-213

aggressive, 34, 177, 209, 211-212

OECD Aggressive Tax Planning (ATP)

Directory, 212

Tax Reform Act (1986), 67, 96, 107

Tax shifting, 14, 145

TED spread, 71

Thin capitalization, 38, 180, 181, 202

Tier 1 capital, 7, 12, 13, 35-37, 39, 41, 42, 59, $172,173,197$

Tier 2 capital, 13, 37

Tobin taxes, 27

Toxic instruments, 258-261, 264

Transaction taxes, 19-20, 29, 44-46, 57, 132, $134,135,139,140,143-145,147,170$; see also Tax, financial transaction

Transfer prices, 51, 209

Treasury debt management, 26, 214

Trust preferred securities (TruPS), 7, 36-37

United Kingdom, 12, 13, 31, 33, 48, 49, 55, $72,76,77,79,83,86,91-93,99,100$, $102,103,119,120,123,128,132$, $140,141,143,145,146,178,182$, $219,231,238,239,245-248,250$, 251, 254, 256

United States, 3, 4, 7-9, 15, 17, 23, 24, 26, 30, $31,33,34,37,43,45,47,48,53,55,56$, 65, 73-84, 86, 87, 89, 91-93, 95, 96, 98, 100-103, 107, 112-114, 119-121, 132, $142,146,149,154,161,169,174,176$, $178,179,181,183,185-187,192,196$, $199,204,214,217,219,220,222,225$, 227,253

Capital and Financial Account, 64 housing bubble, 80

housing market, $61,62,72,79,80$, 83, 88

Internal Revenue Code, 95, 99, 176, 186

Primary Credit Discount Rate, 64

User charges, 16-18, 44

Valeur locative cadastrale, 85

Value-added tax (VAT), 11, 20, 25, 43, 49, $119,121-127,129,130,147,150$,

$156,169,233$

on first sales of residences, 43

status of financial institutions, 25

This is an open access version of the publication distributed under the terms of the Creative Commons Attribution-NonCommercialNoDerivs licence (http://creativecommons.org/licenses/by-nc-nd/3.0/), which permits non-commercial reproduction and distribution of the work, in any medium, provided the original work is not altered or transformed in any way, and that the work is properly cited. For commercial re-use, please contact academic.permissions@oup.com 
Wealth effect, 67, 233, 234

Welfare costs, see Tax distortions, welfare costs

Wells Fargo, 54

Wet waardering onroerende zaken (WOZ), 86
WOZ, see Wet waardering onroerende zaken (WOZ)

Zero interest rate floor, 242

Zero interest rate policy (ZIRP), 223

This is an open access version of the publication distributed under the terms of the Creative Commons Attribution-NonCommercialNoDerivs licence (http://creativecommons.org/licenses/by-nc-nd/3.0/), which permits non-commercial reproduction and distribution of the work, in any medium, provided the original work is not altered or transformed in any way, and that the work is properly cited. For commercial re-use, please contact academic.permissions@oup.com 